UNIVERSIDADE DE SÃO PAULO

MUSEU DE ARQUEOLOGIA E ETNOLOGIA

PROGRAMA DE PÓS-GRADUAÇÃO EM ARQUEOLOGIA

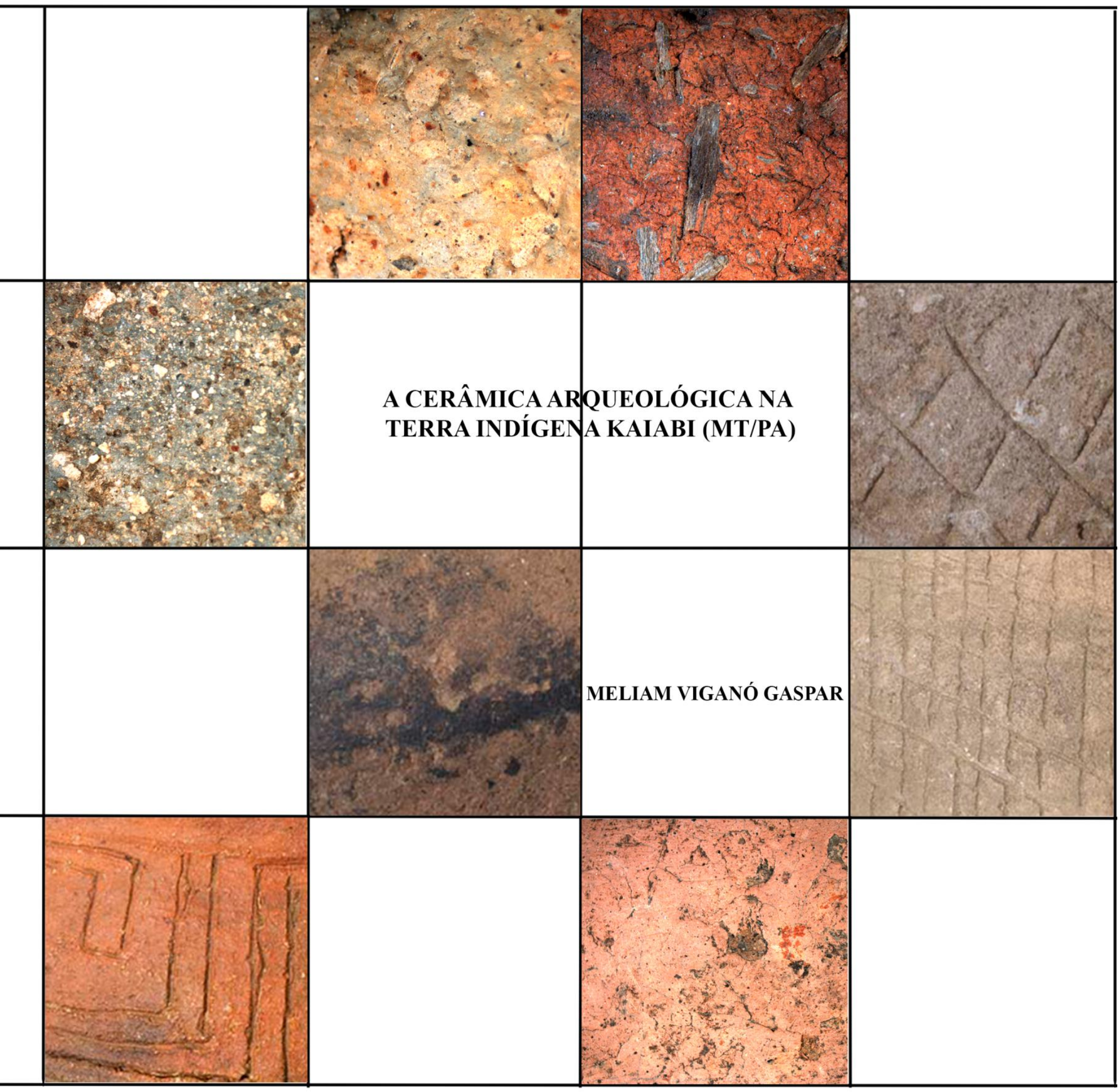


MELIAM VIGANÓ GASPAR

Versão corrigida

A versão original encontra-se na biblioteca do MAE

\section{A CERÂMICA ARQUEOLÓGICA NA TERRA INDÍGENA KAIABI (MT/PA)}

Dissertação apresentada ao

Programa de Pós-Graduação em

Arqueologia do Museu de

Arqueologia e Etnologia da

Universidade de São Paulo, para

obtenção do título de Mestre em

Arqueologia.

Área de Concentração:

Arqueologia

Orientadora: $\operatorname{Prof}^{\mathrm{a}}$. $\operatorname{Dr}^{\mathrm{a}}$.

Fabíola Andréa Silva

Linha de Pesquisa:

02 - Espaço, Sociedade e Processos de Formação do Registro Arqueológico

São Paulo

2014 


\section{AGRADECIMENTOS}

São muitos os agradecimentos que gostaria de fazer a todas as pessoas que contribuiram para a realização deste trabalho. Sem a ajuda, apoio e compreensão de todas elas durante este percurso de minha vida eu não poderia tê-lo completado.

Primeiramente, agradeço à Fabiola Silva por ter me acolhido na arqueologia e por sua excelente orientação em todos os momentos, assim como por todas as oportunidades e portas para serem abertas que ela me ofereceu. Agradeço também ao Francisco Noelli, por suas diversas sugestões, referências e diálogos.

Agradeço à Cristiana Barreto e Marisa Coutinho pelos comentários na qualificação, que ajudaram na melhoria da dissertação. Agradeço à Silvia Cunha Lima e Juliana Salles Machado Bueno pela arguição final.

Agradeço à todos os professores do Programa, especialmente à Veronica Wesolowski, pelo trabalho na organização da Semana de Arqueologia.

Agradeço aos funcionários, do MAE pelo apoio nas diversas etapas do trabalho: na biblioteca Alberto Bezerra e Helio Miranda; na seção acadêmica Cleberson Moura, Aline Dias Garcia, Karen Ribeiro e Regina Estela Leopoldo e Silva; na seção dos laboratórios e conservação Ader Gotardo (por todas as fotos e ajuda no Photoshop), Ana Carolina Vieira, Francisca Figols, José Paulo Jacob e Regivaldo da Silva; e nos demais setores Fábio Santos, Geraldo Miranda, Kleber Bianchi, Mauro da Silva e Regiane David.

Este trabalho é diretamente relacionado ao mestrado de Francisco Stuchi, a quem agradeço imensamente pela coleta do material analisado por mim e pelo lindo trabalho junto aos Kaiabi. Aos Kaiabi também expresso minha gratidão, mesmo que não tenha tido a oportunidade de conhecê-los pessoalmente. Espero sinceramente que este mestrado possa interessar-lhes e contribuir para que seu modo de vida seja respeitado.

Agradeço imensamente ao Eduardo Bespalez, por ter me apresentado ao mundo da arqueologia e me ensinado quase tudo que eu sei sobre a análise cerâmica, escavações e o trabalho com povos indígenas. Agradeço também aos outros colegas de laboratório, pelas conversas, ajudas e também por seus trabalhos: à Daniella Amaral, pelas dicas na análise; à Lorena Garcia, pelas análises e trabalho de campo; ao Ângelo Corrêa, por todas as dicas sobre cerâmica e imagens; ao Alexandre Robazzini, pelo diálogo com seu mestrado; à Milena Acha, pelas conversas; ao Fábio Guaraldo, pela companhia em campo; à Amanda Moraes, pela ajuda na curadoria do material e pelos desenhos; à Duane Mota, pelas análises 
arqueométricas; ao Wesley Rogério Pereira, pela ajuda na curadoria; à Lilian dos Anjos, pelo trabalho no laboratório.

Outras pessoas que também contribuíram para esse trabalho e que gostaria de agradecer foram: Daniela Sammia, pelos mapas; Márcia Rizzuto, coordenadora do Grupo de Física Aplicada com Aceleradores da USP, pelas análises arqueométricas e Jessica Fleury Curado, pelo tratamento dos resultados; Vitor Fossaluza e Talita Silva, do Centro de Estatística Aplicada da USP, pelas análises estatísticas; Helena, da loja de artesanatos indígenas Iandé, pelas imagens das vasilhas Munduruku; Katharina Kepplinger e Richard Haas, do Ethnologische Museum zu Berlin, pelas imagens das vasilhas Bakairi.

Também agradeço com carinho aos colegas do PPGArq que me acompanharam nesta trajetória acadêmica, cursando disciplinas, participando ativamente da vida discente no Museu e organizando a Semana de Arqueologia: Agda Sardinha, Ana Paula Tauhyl, Alessandro Gregori, Alex Martire, Breno Frijoles, Bruno Sanches, Camila Jácome, Carol Caromano, Débora Soares, Eduardo Kazuo, Erêndira Oliveira, Fernando Almeida, Guilherme Mongeló, João Carlos de Sousa, João Estevam, Laura Furquim, Leandro Cascon, Márcia Hattori, Maria Ester Franklin, Márjorie Lima, Maurício Silva, Pedro Damin, Roberto Perrota, Rafael Almeida, Rodrigo Angeles, Rodrigo Suñer, Silvio Cordeiro, Tatiana Bina, Tatiane Souza, Thiago Kater, Thiago Trindade. Dentre eles, agradeço especialmente aos que se tornaram amigos mais próximos, por todo o carinho e apoio nos momentos difíceis, e também por mostrarem que a Arqueologia pode ser um caminho para pensar em uma sociedade melhor. E um agradecimento mais que especial à Jaqueline Belletti, companheira de casa.

Não poderia também deixar de agradecer minha família, que sempre apoiou minhas decisões e incentivou os caminhos na vida acadêmica, especialmente minha mãe Regina (também pela leitura do texto), minha irmã Tainá, meu pai Gaspar, minha avó Myriam, Eduardo e Estevan (também por um dos desenhos). Agradeço também às amigas e amigos de São Xico, sempre presentes desde minha infância; e à todos os amigos e amigas que fiz, principalmente na Holanda, que é uma parte muito importante da minha vida.

Ainda gostaria de agradecer ao Renato, com muito amor, por estar junto de mim em alguns dos momentos mais difíceis e também nos mais felizes destes últimos anos.

Por fim, fica também registrado o agradecimento à CAPES, pela bolsa de estudos nos primeiros 2 anos; à FAPESP, pelo apoio ao Projeto Kaiabi-Lalima; e às Pró-Reitorias de Pesquisa (Prp), de Pós-Graduação (Prpg) e de Cultura e Extensão (Prceu) da USP, pelo apoio ao Programa de Pesquisa nos Acervos da USP. 


\section{"If you ever get close to a human and human behavior be ready be ready to get confused.}

There's definitely definitety definitely no logic to human behaviour but yet so yet so irresistible.

And there's no map to human behavior. and a compass wouldn't help at all." 


\section{RESUMO}

Este trabalho apresenta os resultados do estudo inicial das características tecnológicas do material cerâmico arqueológico coletado na Terra Indígena (T. I.) Kaiabi, localizada na região do baixo rio Teles Pires (Mato Grosso/Pará). Esta área ainda é bastante desconhecida do ponto de vista arqueológico, inserindo-se em um contexto que se relaciona tanto com o Brasil Central como com a Amazônia Meridional, tendo sido palco de ocupações e deslocamentos de diferentes populações indígenas ao longo do tempo. Para compreender melhor o que siginificam os conjuntos cerâmicos neste contexto, analisamos o material cerâmico com base na noção de cadeia operatória de produção cerâmica (Lemonnier) e nas características de performance dos materiais e objetos (Schiffer e Skibo), entendendo que para cada operação dentro da sequência de produção existe uma escolha feita pela ceramista que é determinada a partir de princípios culturalmente definidos, revelando diferentes modos de se fazer cerâmica, os chamados estilos tecnológicos.

Palavras-chave: Kaiabi, Tecnologia, Cerâmica, Características de Performance, Estilo Tecnológico

\section{ABSTRACT}

This paper presents the results of the initial study of the technological characteristics of the archaeological ceramic material colected in the Indigenous Land (T. I.) Kaiabi, located in the Lower Teles Pires River (Mato Grosso/Pará). This area is still largely unknown from the archaeological point of view, being part of the near context of both Central Brazil and Southern Amazon, which may have been the scene of occupations and displacements of different indigenous populations over time. To better understand the meanings of the ceramic sets within this context, we analyze the ceramic material based on the notion of chain operatoire (Lemonnier) and the performance characteristics of materials and objects (Schiffer and Skibo), understanding that for each operation within the production sequence there is a choice made by the potter which is determined by culturally defined principles, revealing different ways of making pottery, the so-called technological styles.

Keywords: Kaiabi, Technology, Ceramic, Performance Characteristics, Tecnhological Style 


\section{LISTA DE FIGURAS}

Figura 1: Mapa do Vale do Tapajós, mostrando a designação das áreas pesquisadas por Robazzini. (Mapa: Cheng Chi Cheng. Cf. ROBAZZINI, 2013: 46)

Figura 2: Terras Indígenas onde habitam atualmente os Kaiabi. A área do antigo território está circulada, entre a T. I. Kayabi e o PIX, englobando a T. I. Apiaká-Kayabi. (Cf. SILVA e STUCHI, 2010: 53).

Figura 3: Terras Indígenas no Vale do Tapajós atualmente (Mapa: adaptado de ISA, 2012;

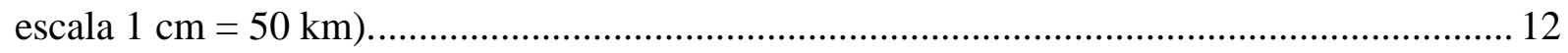

Figura 4: Mapa de localização da T. I. Kaiabi. (Cf: STUCHI, 2010: 52) .............................. 16

Figura 5: Localização dos sítios escavados na T. I. Kaiabi.(Mapa adaptado de STUCHI, 2010: $162)$

Figura 6: Diagrama resumindo as relações mais importantes que afetam as escolhas tecnológicas na produção cerâmica (Adaptado de SILLAR e TITE, 2000: 6). ........................ 36

Figura 7: Análise dos fragmentos cerâmicos no laboratório. (Foto: Duane Mota)...................55

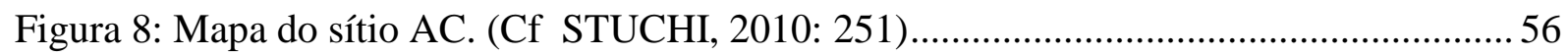

Figura 9: Perfil norte do PT1 no sítio AC. (Cf. STUCHI, 2010: 253).................................... 57

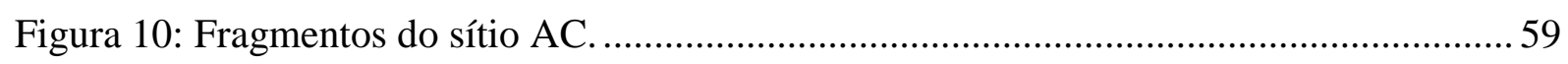

Figura 11: Fragmentos do sítio AC com banho, bordas alisadas, bolota de argila, base,

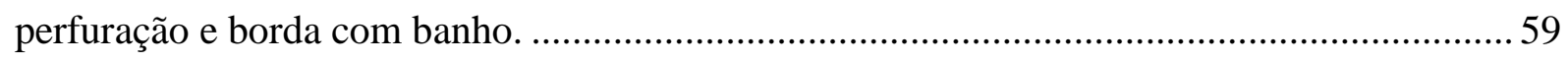

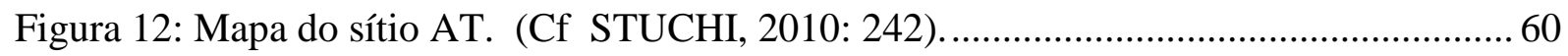

Figura 13: Perfil norte do PT1 no sítio AT. (Cf. STUCHI, 2010:249). .................................. 62

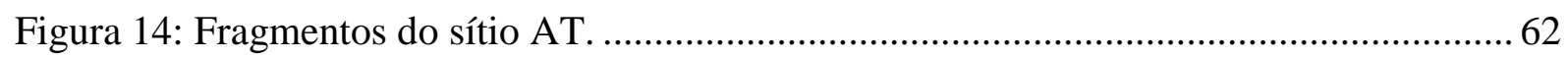

Figura 15: Fragmentos do sítio AT, com alisamento, banho, bolota de argila, objeto não

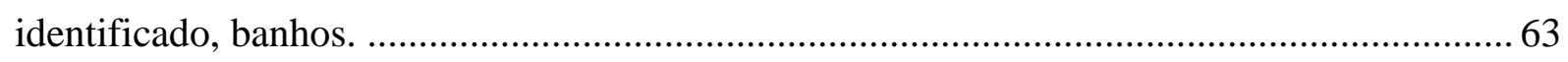

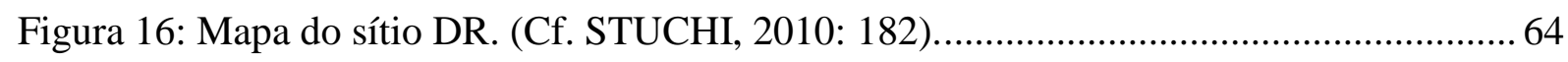

Figura 17: Perfil leste do PT1 no sítio DR. (Cf. STUCHI, 2010: 193).................................... 66

Figura 18: Perfil norte do PT2 no sítio DR. (Cf. STUCHI, 2010: 196).................................. 66

Figura 19: Borda fragmentada e base do nível 4 no PT3 no sítio DR. (Cf. STUCHI, 2010:

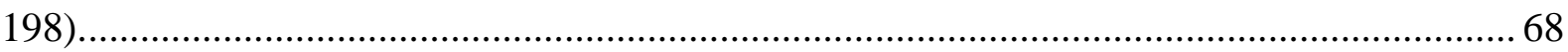

Figura 20: Perfil norte e croqui do nível 4 no PT3 no sítio DR. (Cf. STUCHI, 2010: 200).... 68

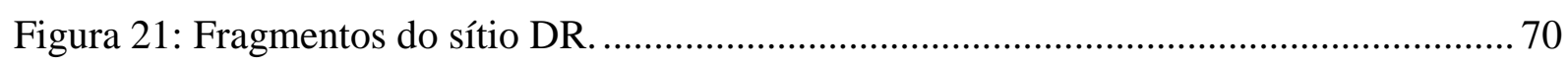

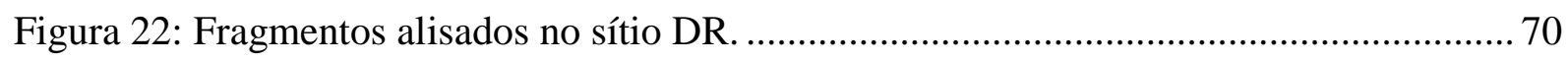

Figura 23: Mapa do sítio MC. (Cf. STUCHI, 2010: 202).................................................. 71 
Figura 24: Fragmento cerâmico no nível 2, enviado para datação. (Cf. STUCHI, 2010: 210).

Figura 25: Perfil norte do PT1 no sítio MC. (Cf. STUCHI, 2010: 211) .................................. 73

Figura 26: Fragmentos do sítio MC. .75

Figura 27: Fragmentos do sítio MC de base, com banho, depósito de carbono, incisos na face interna, banho e fuligem. .75

Figura 28: Mapa do sítio MI. (Cf. STUCHI, 2010: 225) ................................................... 76

Figura 29: Perfil norte do PT1 no sítio MI. (Cf. STUCHI, 2010: 227) .................................... 77

Figura 30: Perfil norte do PT2 no sítio MI. (Cf. STUCHI, 2010: 230)................................... 78

Figura 31: Fragmentos do sítio MI. .78

Figura 32: Fragmentos do sítio MI de ombros, com banho, base, apêndice, banho e engobo vermelho. .79

Figura 33: Mapa do sítio TT. (Cf. STUCHI, 2010: 213). ..................................................... 80

Figura 34: Perfil noroeste do PT1 no sítio TT. (Cf. STUCHI, 2010: 222). ............................. 82

Figura 35: Fragmentos do sítio TT

Figura 36: Fragmentos do sítio TT com fuligem, banho, polidor de sulco, engobo branco, polidor de sulco cruzado e fuligem. 84

Figura 37: Mapa do sítio YA. (Cf. STUCHI, 2010: 233). ..................................................... 85

Figura 38: Perfil norte do PT1 no sítio YA. (Cf. STUCHI, 2010: 240)................................. 87

Figura 39: Objetos não identificados de argila, com uma parte rugosa e outra alisada. .......... 88

Figura 40: a) forno Asurini e detalhe; b) casa Asurini com parede caída e detalhe................. 88

Figura 41: Fragmentos do sítio YA 90

Figura 42: Fragmentos do sítio YA, com impressão de corda, incisos, bases, banho e alisamento. .90

Figura 43: Pastas do Conjunto 1, aumento 10x na lupa binocular, escala em mm. a-c) diversos minerais, como quartzo e óxido de ferro, do sítio YA; d-f) quartzo, do sítio YA; g-i) pasta com minerais do sítio DR. 109

Figura 44: Perfis das bordas do Conjunto 1. a) sítio YA; b) sítio DR. (Desenhos: Amanda Moraes).

Figura 45: Formas do Conjunto 1. 1) YA-1034; 2) YA-18; 3) DR-159; 4) DR-157. (Desenhos: Amanda Moraes. Fotos: Ader Gotardo).

Figura 46: Fragmentos do Conjunto 1, sítio YA. a) bordas alisadas; b) bases alisadas; c) incisos formando losangulos; d) incisos cruzados; e) incisos variados; f) beliscado e 
impressão de corda, apêndice mamilonar; g) ungulado e impressão de corda,corrugado e impressão de corda; h) ungulados. (Fotos: Ader Gotardo).

Figura 47: Fragmentos do Conjunto 1, sítio YA. Impressão de corda. (Foto: Ader Gotardo).

Figura 48: Fragmentos do Conjunto 1, sítio DR. a) impressão de corda; b) inciso cruzado; c) corrugados; d) impressão de corda na face externa e na interna. (Fotos: Ader Gotardo). ..... 113 Figura 49: Pastas do Conjunto 2, sítio MC, aumento 10x na lupa binocular (exceto c e h: 2x), escala em mm. a-c) caraipé; d-f) caco moído; g-i) caco moído e caraipé. 115 Figura 50: Desenhos dos perfis das bordas do Conjunto 2, sítio MC. (Desenhos: Amanda Moraes).

Figura 51: Formas do Conjunto 2. 1) MC-201; 2) MC-204; 3) MC-207; 4) MC-64; 5) MC218. (Desenhos 1 a 4: Amanda Morae. Desenho 5: Stevan Rosa. Fotos: Ader Gotardo).

Figura 52: Paredes do Conjunto 2, sítio MC. a) paredes carenadas; b) parede carenada com banho e pintura branca, formando volutas; c) ombros com engobo rosa e fuligem; d) paredes carenadas com banho e engobo rosa. (Fotos: Ader Gotardo). 118

Figura 53: Acabamentos de superfície do Conjunto 2, sítio MC. a) incisão na face externa; b) inciso na face interna; c) banho e engobo rosa sobre incisão; d) incisos; e) bordas camabadas, uma com pintura branca triangular sobre banho; f) engobo rosa; g) alisamento; h) bases; i) bordas alisadas. (Fotos: Ader Gotardo).

Figura 54: Pastas do Conjunto 3, com caraipé e cauixi, aumento 3.2x na lupa binocular, escala em mm. a) sítio Aldeia Tukumã; b-d) sítio Dinossauro; e) sítio Minhocoçu; f) sítio Aldeia Coelho. 120

Figura 55: Perfis das bordas do Conunto 3. a) sítio DR; b) sítio MI; c) sítio TT; d) sítio AC.

Figura 56: Formas do Conjunto 3. 1) DR-2247; 2) DR-1811; 3) TT-1804; 4) DR-1186; 5) DR-2328. (Desenhos: Amanda Moraes. Fotos: Ader Gotardo).

Figura 57: Acabamentos de superfície do Conjunto 3, sítio DR. a) base em pedestal ou suporte de vasilha; b) incisos circulares; c) incisões e ponteado no lábio; d) borda; e) bordas alisadas; f) parede carenada; g) base circular; h) ombro. (Fotos: Ader Gotardo). 123 Figura 58: Acabamentos de superfície do Conjunto 3, sítio MI. a) base; b) parede angular; c) parede carenada; d) engobo vermelho. (Fotos: Ader Gotardo).

Figura 59: Acabamento de superfício do Conjunto 3, sítio AT, linha incisa e ponteado. ..... 124 Figura 60: Acabamentos de superfície do Conjunto 3, sítio TT. a) banho; b) engobo vermelho; c) engobo branco; d) polidor de sulco. (Fotos: Ader Gotardo). 125 
Figura 61: Pastas do Conjunto 4, com cauixi e caco moído, aumento 3.2x na lupa binocular (exceto 4: 2x), escala em mm. a-b) sítio Aldeia Coelho; c) sítio Aldeia Tukumã; d) sítio Dinossauro, aumento $2 \mathrm{x}$; e-f) sítio Taitetu.

Figura 62: Perfis das bordas do Conjunto 4. a) sítio TT; b) sítio DR. (Desenhos: Amanda Moraes). 126

Figura 63: Perfis das bordas do Conjunto 4. a) sítio AC; b) sítio AT. (Desenhos: Amanda Moraes). 127

Figura 64: Formas do Conjunto 4. 1) AC-813; 2) AC-45; 3) AC-47; 4) DR- 153. (Desenhos: Amanda Moraes. Fotos: Ader Gotardo). 128

Figura 65: Acabamentos de superfície, sítio AT. a) alisamento, com marca de erosão na face interna; b) inciso; c) acanalado. (Fotos: Ader Gotardo). 129

Figura 66: Acabamentos de superfície do Conjunto 4, sítio TT. a) alisamento; b) bases; c) ombro com fuligem; d) incisos; e) engobo vermelho e pintura vermelha; f) engobo branco; g) pintura vermelha sobre engobo branco. (Fotos: Ader Gotardo).

Figura 67: Acabamentos de superfície do Conjunto 4, sítio AC. a) alisamento; b) perfuração; c) inciso; d) engobo branco. (Fotos: Ader Gotardo).

Figura 68: Pasta de fragmentos não classificados, aumento 10x na lupa binocular (exceto f,h: aumento $4 \mathrm{x}$; i: aumento $3.2 \mathrm{x}$ ), escala em mm. a-b) diversos minerais, sítio TT; c) diversos minerais, sítio DR; d-e) caco moído, sítio DR; f) cauixi, sítio MI; g) caraipé, sítio DR; h) cauixi, caraipé e caco moído, sítio AT; i) carvão, sítio AT.

Figura 69: Perfis das bordas dos fragmentos não classificados. a) sítio DR; b) sítio AT; c) sítio MI; d) sítio TT. (Desenhos: Amanda Moraes).

Figura 70: Formas de fragmentos não classificados. 1) DR-154; 2) DR-14; 3) AT-705. (Desenhos: Amanda Moraes. Fotos: Ader Gotardo).

Figura 71: Acabamentos de superfície dos fragmentos não classificados. a) sítio DR, antiplástico cauixi, caraipé e caco moído, borda e ombro com banho e base com impressão de folha; b) sítio DR, antiplástico mineral, fragmentos com fuligem, ombro com engobo rosa e fuligem, borda alisada e fragmento com engobo vermelho; c) sítio TT, antiplástico cauixi, borda alisada e fragmento com engobo vermelho; d) sítio TT, antiplástico mineral, fragmentos com polidor de núcleo e fuligem, bordas acanaladas, inciso e engobo branco; e) sítio TT, antiplástico caco moído, borda com impressão de corda; f) sítio AT, antiplástico caco moído, borda com fuligem; g) sítio AT, antiplástico cauixi, caraipé e caco moído, borda alisada; h) sítio AT, antiplástico mineral, borda alisada; i) sítio MI, antiplástico mineral, borda alisada; j) sítio MI, antiplástico caraipé, bordas alisadas; k) sítio MI, antiplástico cauixi, apêndice 
mamilonar; sítio MI, antiplástico cauixi, caraipé e caco moído, inciso. (Fotos: Ader Gotardo).

Figura 72: Acabamentos de superfície de fragmentos coletados aleatoriamente em diferentes locais. a) Aldeia Kururuzinho, antiplástico cauixi e caco moído, inciso; b) Aldeia Kururuzinho, antiplástico mineral, ponteado e incisos ondulados; c) Roça João, antiplástico cauixi e caraipé, incisos losangulares; d) Tapera e pista, antiplástico cauixi, caraipé e caco moído, alisado; e) Capoeira e taipa, antiplástico mineral, alisamento; f) Saúva, antiplástico cauixi e caraipé, alisamento; g) Sauva, antiplástico cauixi, caraipé e caco moído, borda com incisos no lábio; h) Sauva, antiplástico cauixi e caco moído, alisamento; i) Roça Albertino, antiplástico mineral, alisamento, impressão de corda e corrugado; j) Roça Albertino, antiplástico cauixi e caraipé, alisamento; k) Roça Albertino, antiplástico caco moído, alisamento; 1) Roça Fernando e João, bases alisadas, a primeira antiplástico cauixi e caraipé, as outras duas antiplástico mineral; m) Roça Fernando e João, antiplástico mineral, incisos cruzados e losangulares; n) Roça Fernando e João, antiplástico mineral, ungulado na borda; o) Roça Fernando e João, antiplástico mineral, impressão de corda; p) Roça Fernando e João, antiplástico cauixi, caraipé e caco moído, alisamento; q) Roça Fernando e João, antiplástico mineral, alisamento. (Fotos: Ader Gotardo).

Figura 73: Cerâmica Capão do Canga, motivos incisos e pintados. (Adaptado de ERIG LIMA, 2012) 156

Figura 74: Cerâmica de Cocalino e Pajaú, respectivamente. (Adaptado de ROCHA, 2012). 159 Figura 75: Cerâmica de Terra Preta do Mangabal. (Adaptado de ROCHA, 2012). 159

Figura 76: Cerâmica de Terra Preta do Mangabal. (Adaptado de ROCHA, 2012). 160

Figura 77: Cerâmica de Parauá, com ponteado no lábio e incisos com motivos de espinha de peixe. (Cf. GOMES 2005: 240).

Figura 78: Vasilhas Kaiabi da coleção do Museu Paulista, agora no MAE-USP. 1: vasilha Kaiabi, coletada por Grünberg; 4: classificada como Waujá, mas tem a inscrição "Kajabi" em sua base; 2-3 e 4-6: classificadas como Waujá, mas acreditamos serem também Kaiabi. (Fotos: Ader Gotardo). 165

Figura 79: Grafismos na cestaria Kaiabi.1: motivo ifãe'ok; 2: Tanakuya, mulher-tanga e duas crianças-tanga; 3: sapos kururu com os ea (olhos); 4: i/wirapui, fileiras de cipó; 5: kwatsiarapa, muitos braços; 6: sapo kururu e fileiras de cipó. (Cf: RIBEIRO, 1986: 267 e GRÜNBERG, 2004: 131-133). 166

Figura 80: Maloca dos Apiaká, detalhes de vasilhas cerâmicas. (Cf: MONTEIRO, 1998: 338339). 167 
Figura 81: Os Apiaká e vasilhas cerâmicas. (Cf: FLORENCE, 1941). ................................. 168

Figura 82: Pintura corporal Apiaká. (Cf: FLORENCE, 1941). ........................................... 168

Figura 83: Interior de uma habitação Munduruku, com vasilhas cerâmicas. (Cf: FLORENCE, 1941)

Figura 84: Pintura corporal Munduruku, com motivos losangulares. (Cf: FLORENCE, 1941 e COUDREAU, 1977:110). 170

Figura 85: Vasilhas Munduruku. (Cf: ARARIBAH). 171

Figura 86: Vasilhas Munduruku. (Cf: IANDE). 171

Figura 87: Vasilhas coletada entre os Bakairi de Simão Lopes. (Cf: SCHMIDT, 1947: 87). 172 Figura 88: Ilustração de um dueto de flautas Bakairi, onde se observam vasilhas cerâmicas espalhadas pelo chão. (Cf: von den STEINEN, 1942: 202). 173

Figura 89: Vasilhas Bakairi, da coleção do Museu Etnográfico de Berlin. 173

Figura 90: Vasilha fragmentada Bakairi, do acervo Plínio Ayrosa do MAE-USP. (Foto: Ader Gotardo). 174

Figura 91: Comparação entre a) cerâmica do Capão do Canga (Cf. ERIG LIMA, 2012); b) cerâmica Terra Preta do Mandabal (Cf. ROCHA, 2012); c) cerâmica do Conjunto 1 (Foto: Ader Gotardo).

Figura 92: Comparação entre a) cerâmica Apiaká ilustrada por Florence (1941); b) cerâmica do Conjunto 2 (Desenho: Amanda Moraes. Foto: Ader Gotardo). 179 Figura 93: Comparação entre: a) cerâmica de Terra Preta do Mangabal (Cf. ROCHA, 2012); b) do sítio DR (Desenho: Amanda Moraes. Foto: Ader Gotardo). Comparação entre: c) cerâmica de Pajau e Cocalino (Cf. GOMES, 2005); d) cerâmica do sítio DR (Foto: Ader Gotardo). Comparação entre: e) cerâmica de Parauá (Cf. GOMES, 2005); f) cerâmica do sítio DR (Foto: Ader Gotardo). 180

Figura 94: Comparação entre a) cerâmica de Pajau e Cocalino (Cf. ROCHA, 2012); b) de Parauá (Cf. GOMES, 2005; c) do sítio DR (Foto: Ader Gotardo). 180 


\section{LISTA DE TABELAS}

Tabela 1: Relação de campo do material coletado na T. I. Kaiabi.......................................... 22

Tabela 2: Tabela de análise do material cerâmico. .................................................................. 43

Tabela 3: Relação dos sítios, siglas e materiais coletados após a curadoria no laboratório...... 54

Tabela 4: Distribuição dos fragmentos cerâmicos no sítio AC............................................... 57

Tabela 5: Distribuição dos fragmentos cerâmicos no sítio AT. ............................................... 61

Tabela 6: Distribuição dos fragmentos cerâmicos no sítio DR ................................................ 65

Tabela 7: Distribuição dos fragmentos cerâmicos no sítio MC. …………............................. 72

Tabela 8: Distribuição dos fragmentos cerâmicos no sítio MI.................................................. 77

Tabela 9: Distribuição dos fragmentos cerâmicos no sítio TT................................................ 81

Tabela 10: Distribuição dos fragmentos cerâmicos no sítio Ywantã. ...................................... 86

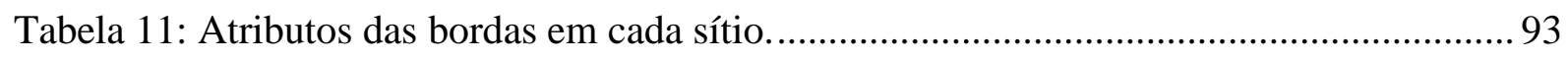

Tabela 12: Distribuição do acabamento de superfície da face externa dos fragmentos em cada sítio. .98

Tabela 13: Distribuição dos acabamentos de superfície da face interna dos fragmentos em cada sítio. 100

Tabela 14: Distribuição dos acabamentos de superfície do lábio nos fragmentos de cada sítio.

Tabela 15: Comparação dos 4 conjuntos finais com os 8 agrupamentos estatísticos. Os conjuntos e grupos similares estão marcados com as mesmas cores. 106

Tabela 16: Tabela com os agrupamentos arqueométricos, com os fragmentos analisados, sua classificação nos conjuntos, antiplástico, e acabamento de superfície das face externa e interna.

Tabela 17: Cadeia operatória e correlatos de performance dos 4 conjuntos. Legenda: + é uma boa performance, / é performance intermediária, - é performance ruim. (Fontes: SCHIFFER e SKIBO, 1987; MACHADO, 2005-2006; RYE, 1981).

Tabela 18: Indicações de relações entre forma e função de vasilhas cerâmicas (Cf. GARCIA, 2012: 154, apud AMARAL, 2008).

Tabela 19: Características e cadeia operatória dos 4 conjuntos propostos para a cerâmica na T.

I. Kaiabi. 151

Tabela 20: Características dos conjuntos cerâmicos arqueológicos no Brasil Central. 175

Tabela 21: Características dos conjuntos cerâmicos arqueológicos de outras regiões no Mato Grosso e Amazônia Meridional. 176 


\section{LISTA DE GRÁFICOS}

Gráfico 1: Distribuição de tipos de antiplásticos dos fragmentos em cada sítio. 91

Gráfico 2: Distribuição da categoria estrutural dos fragmentos em cada sítio 92

Gráfico 3: Distribuição das espessuras dos fragmentos em cada sítio. 94

Gráfico 4: Distribuição dos tipos de núcleo dos fragmentos em cada sítio. 95

Gráfico 5: Distribuição da coloração da face externa dos fragmentos em cada sítio. 96

Gráfico 6: Distribuição da coloração da face interna dos fragmentos em cada sítio. .97

Gráfico 7: Distribuição dos acabamentos de superfície da face externa não alisados nos fragmentos em cada sítio. .99

Gráfico 8: Distribuição dos acabamentos de superfície não alisados da face interna dos fragmentos de cada sítio. 100

Gráfico 9: Dendograma dos agrupamentos estatísticos. (Cf: SILVA e FOSSALUZA, 2013) 104

Gráfico 10: Análise de agrupamentos pela soma de quadrados. (Cf: SILVA e FOSSALUZA, 2013) 104

Gráfico 11: Rede bayesiana. (Cf: SILVA e FOSSALUZA, 2013) 105

Gráfico 12: Círculo de correlção PCA entre as variáveis identificadas. Em destaque está o grupo de elementos utilizado para a análise PCA. (Cf: RIZZUTT, CURADO e MOTA, 2014).

Gráfico 13: Gráfico de análise PCA para dados na análise XRF com sugestões de possível agrupamento. Os agrupados no círculo vermelho, no círculo azul, no circulo amarelo e no círculo verde (Cf.: RIZZUTT, CURADO e MOTA, 2014). 138

\section{LISTA DE ANEXOS}

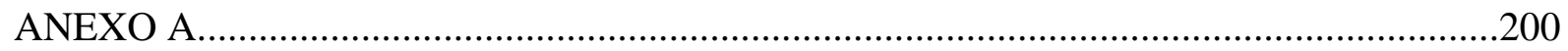

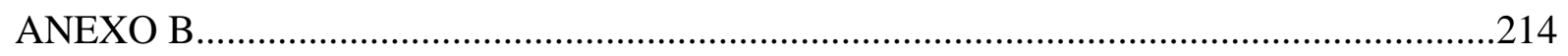

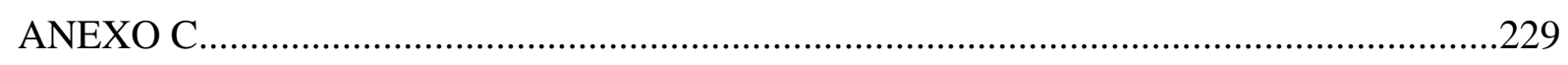

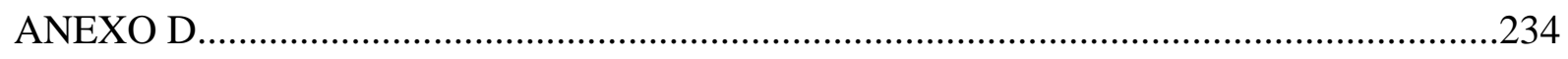

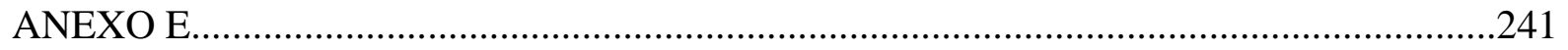




\section{SUMÁRIO}

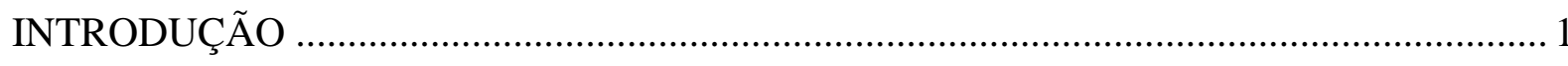

1. O VALE DO TAPAJÓS E ARQUEOLOGIA NA T. I. KAIABI ................................... 6

1.1. História e Arqueologia no Vale do Tapajós .............................................................. 6

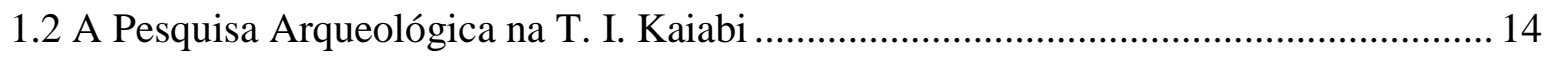

1.2.1. Coleta dos Conjuntos Cerâmicos Arqueológicos ............................................ 18

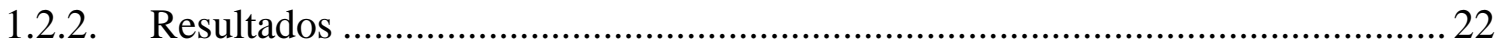

2. CERÂMICA, TECNOLOGIA E ESTILO TECNOLÓGICO ........................................ 24

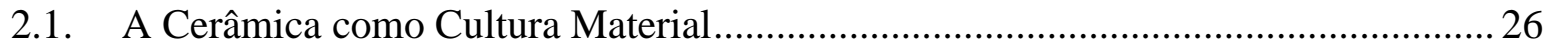

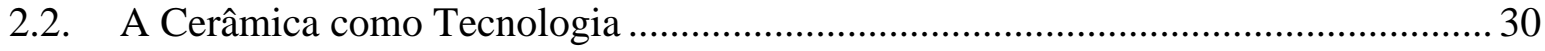

2.3. Cerâmica e Estilos Tecnológicos ....................................................................... 36

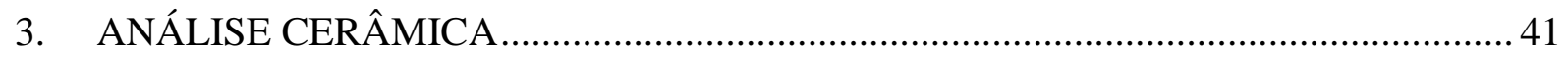

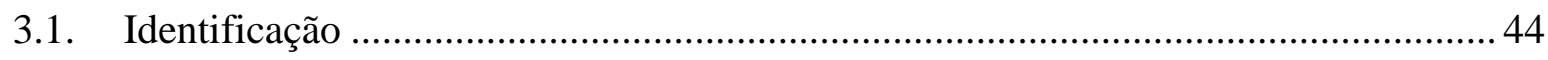

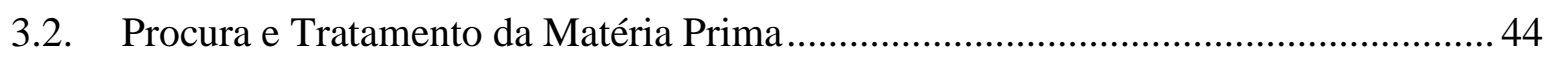

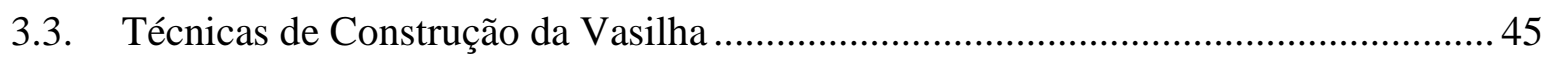

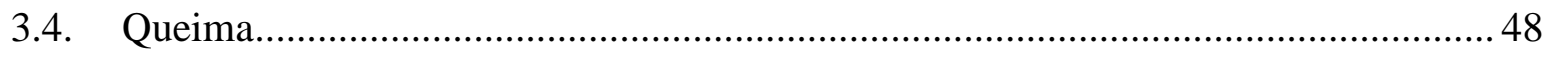

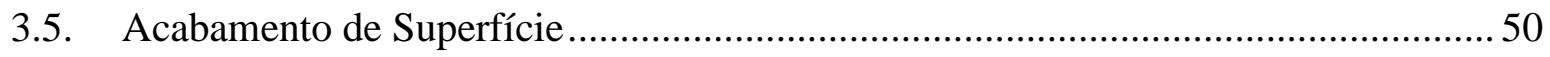

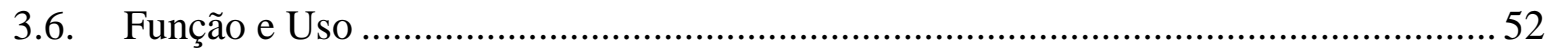

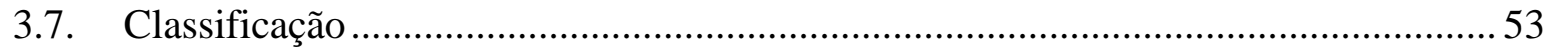

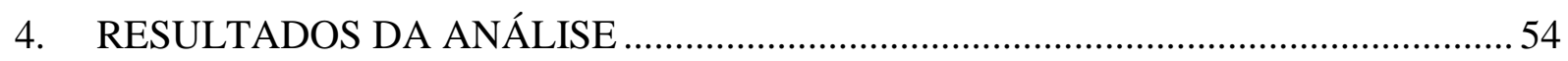

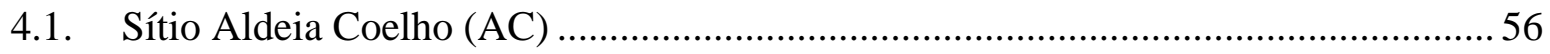

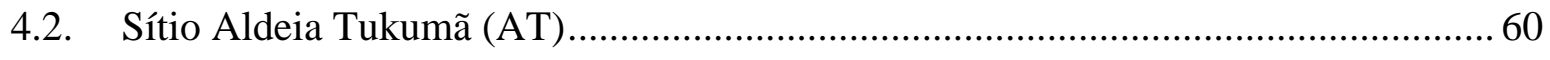

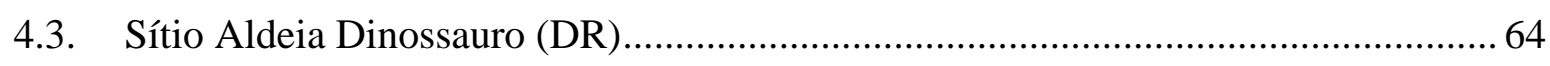

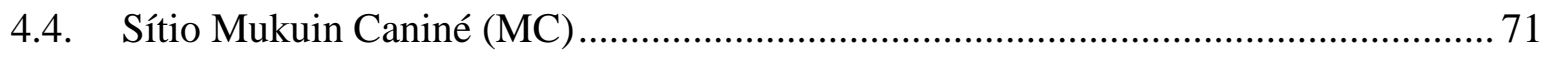

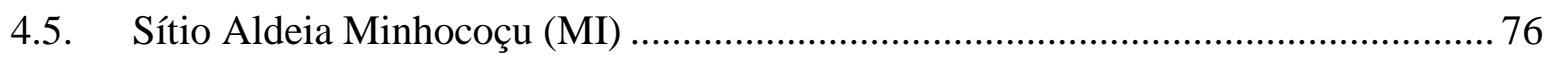

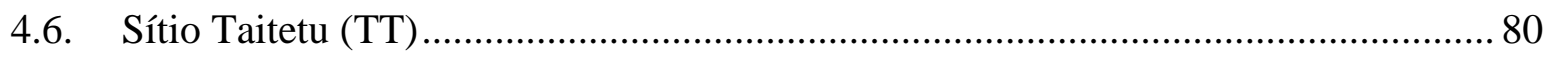

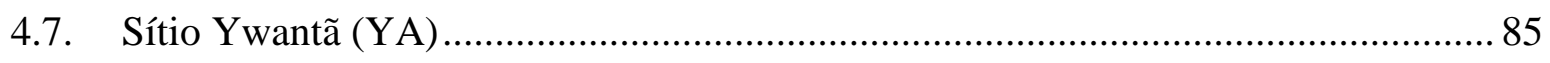


4.8. Estatística Descritiva da Análise Cerâmica ................................................................ 91

5. CONJUNTOS CERÂMICOS NA T. I. KAIABI ...................................................... 102

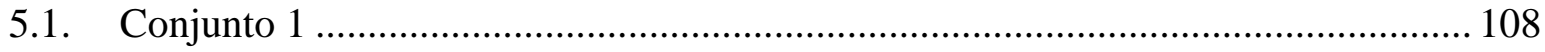

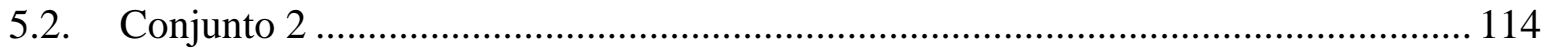

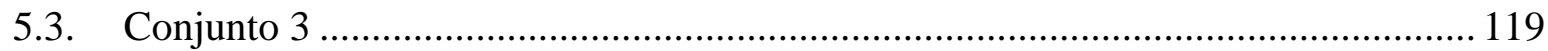

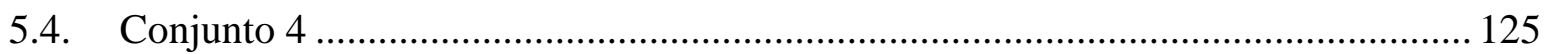

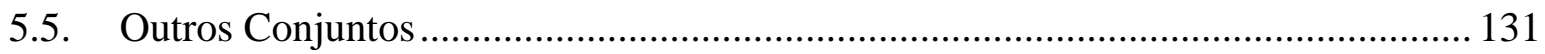

5.6. Considerações sobre os Estilos Tecnológicos ........................................................ 136

6. OS CONJUNTOS CERÂMICOS NO VALE DO TAPAJÓS ...................................... 153

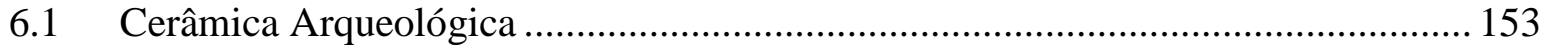

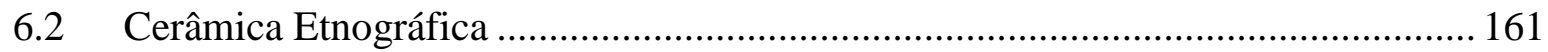

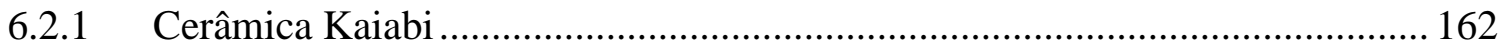

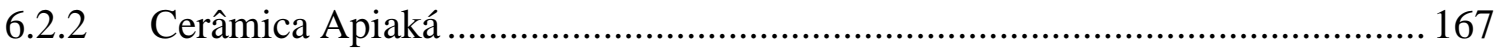

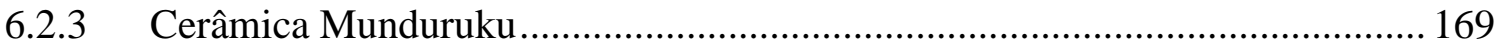

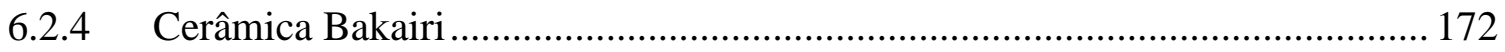

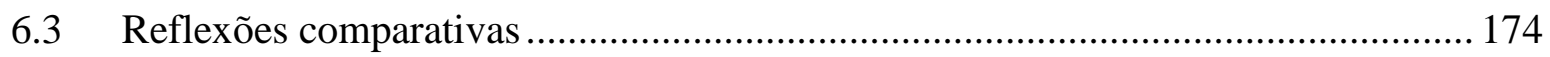

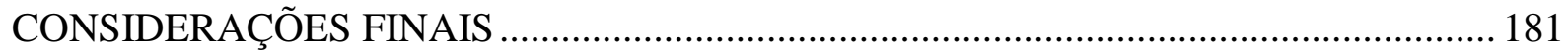

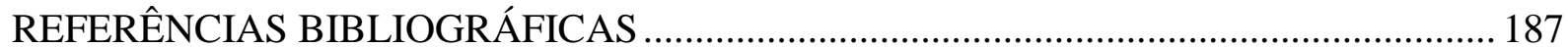




\title{
INTRODUÇÃO
}

\begin{abstract}
"When a pot becomes part of the ruin of time (...) revealed is the essential character of a material artifact - its duality of autonomy and dependency. The ruined fragment invites us to reconstruct, to exercise the work of imagination, making connections within and beyond the remnants. In this way the post-history of a pot is as indispensable as its pre-history. And the task is not to revive the dead (they are rotten and gone) or the original conditions from whose decay the pot remained, but to understand the pot as a ruined fragment. This is the fascination of archaeological interpretation".
\end{abstract}

(SHANKS, M. e HODDER, I. 1998: 91)

Tal como os autores desta epígrafe, acredito que um dos fascínios da interpretação arqueológica é justamente o estudo de fragmentos em ruínas para se alcançar o entendimento dos objetos completos que eles já foram um dia. Ao tentar reconstruir uma vasilha cerâmica a partir de seus fragmentos, estamos exercitando nossa imaginação como em um jogo de quebra-cabeças, tentando fazer conexões entre o passado e o presente, entre a história da produção deste objeto e sua história após o descarte definitivo. O objetivo deste exercício, como os autores acima escrevem, não é fazer reviver as populações que produziram as vasilhas em seu contexto original, mas sim entender esses objetos fragmentados e desgastados pelo tempo para podermos construir narrativas arqueológicas sobre o passado que nos permitam, também, compreender melhor nossas próprias narrativas no presente.

É assim que este mestrado se constitui, basicamente, de uma análise de fragmentos de vasilhas cerâmicas arqueológicas. No entanto, só é possível pensar na relevância de tal análise se considerarmos as vasilhas cerâmicas como produtos de comportamentos humanos (p. ex. cotidiano, ritual, simbólico e pragmático), mais especificamente no nosso caso, produtos dos modos de vida de povos indígenas no passado. Ou seja, uma análise de fragmentos cerâmicos em laboratório só faz sentido se puder contribuir para a história das populações que viveram e vivem na região em que foram coletados, nos revelando os 
caminhos percorridos por essas populações e mostrando sua continuidade e transformação cultural ao longo do tempo.

Nossa proposta é realizar uma análise tecnológica dos fragmentos cerâmicos arqueológicos, procurando visualizar estilos tecnológicos de produção cerâmica. Para isto, tentaremos descrever ao longo deste trabalho a cadeia operatória de produção destas cerâmicas, evidenciando as possíveis escolhas tecnológicas feitas pelas ceramistas durante o processo produtivo e entendendo estas escolhas como culturalmente estruturadas e responsáveis pela configuração do produto final: a vasilha cerâmica.

O material cerâmico aqui analisado foi coletado na Terra Indígena Kaiabi, no baixo Teles Pires, em Mato Grosso e Pará, como parte de uma pesquisa diretamente vinculada ao projeto “Arqueologia, Etnoarqueologia e História Indígena: um estudo sobre a trajetória de ocupação indígena em territórios do Mato Grosso e Mato Grosso do Sul: a terra indígena Kayabi e a aldeia Lalima”, coordenado pela Prof ${ }^{a} \operatorname{Dr}^{a}$ Fabíola Andrea Silva e realizado entre 2006 e $2010^{1}$. Este projeto, feito de maneira colaborativa com os indígenas, teve como principal objetivo contribuir para a recuperação das histórias de ocupação indígena dos territórios onde estão a T. I. Kaiabi (MT/PA) e a Aldeia Lalima (MS), assim como das trajetórias históricas e culturais das populações que ainda ocupam estes territórios nos dias de hoje (SILVA et al., 2006: 8). Outra preocupação do projeto foi explicitar o modo como as populações atuais se relacionam com as ocupações passadas, considerando sua interpretação sobre esse processo de ocupação territorial. Além disso, foi feita uma reflexão sobre a prática arqueológica em terras indígenas e suas implicações para as populações que nelas habitam, e que convivem e se relacionam com os vestígios arqueológicos (BESPALEZ, 2009; STUCHI, 2010; POUGET, 2010; SILVA, 2009; SILVA et al., 2010).

Em consonância com esse projeto, o mestrado de Francisco Forte Stuchi - intitulado “A Ocupação da Terra Indígena Kaiabi (MT/PA): História Indígena e Etnoarqueologia” foi realizado a partir dos parâmetros de uma Arqueologia Colaborativa e teve como objetivo específico identificar os processos envolvidos na trajetória de ocupação territorial da população Kaiabi. Esta pesquisa teve 2 mestrados como desdobramento: o de Alexandre Robazzini (2013), que realizou uma pesquisa bibliográfica sobre a dinâmica de ocupação territorial no Vale do Tapajós; e este mestrado, que analisou a cerâmica arqueológica coletada.

\footnotetext{
${ }^{1}$ (Processo FAPESP 2006/60241-8). O projeto contribuiu na realização das pesquisas de mestrado de Eduardo Bespalez (Processo FAPESP 05/57404-0), Frederic Pouget (Processo FAPESP 06/05470-1) e Francisco Forte Stuchi (Processo FAPESP 06/05466-4).
} 
Uma preocupação que perpassou todas as pesquisas acima citadas, inclusive esta, foi o fato de que quase sempre as trajetórias indígenas foram contadas de maneira fragmentada a partir de um viés colonialista que colocou esses povos em uma posição de figurantes passivos nas narrativas históricas, ou ainda de povos sem história até a chegada dos europeus. Ainda hoje eles são tratados dessa maneira por grande parte da sociedade brasileira, principalmente, pelos diversos interesses econômicos em seus territórios que os ameaçam constantemente.

É por isso que a pesquisa na T. I. Kaiabi foi elaborada a partir do pressuposto de que a arqueologia é um campo privilegiado que pode contribuir para o entendimento da "história de longa duração" de diferentes populações indígenas, pois tem a possibilidade de reconstruir suas trajetórias históricas até a atualidade, bem como compreender os processos de continuidade e transformação cultural das mesmas ao longo do tempo (HECKENBERGER, 2001; SILVA et al., 2006; STUCHI, 2010). Pesquisas arqueológicas em terras indígenas são muitas vezes fundamentais nos processos de delimitação dessas terras, o que torna ainda mais necessário o diálogo entre pesquisadores e indígenas tanto para a preservação do patrimônio que lá está como para o questionamento das interpretações produzidas pelos pesquisadores relativos à vida dos povos indígenas (SILVA, 2009; SILVA, 2011; SILVA et al., 2010; SILVA et al., 2011).

A arqueologia consegue visualizar parte dessas trajetórias a partir dos vestígios materiais deixados pelas populações no passado. A cerâmica é um dos vestígios materiais que podem ser estudados para conhecermos pedaços desta história, sendo que os processos de continuidades, mudanças e rupturas nas trajetórias históricas das populações passadas podem estar objetivados nos conjuntos cerâmicos (SILVA, 2000; SILVA, 2011). Este pressuposto está ancorado nos inúmeros trabalhos etnológicos, etnoarqueológicos e arqueológicos (com os quais trabalhamos ao longo da dissertação) que tratam da questão da variabilidade artefatual e da relação entre estilo (visual e tecnológico) e identidade (étnica, cultural, social, pessoal). É partindo dele que analisamos os conjuntos artefatuais cerâmicos coletados na T. I. Kaiabi.

Iniciamos a dissertação com um capítulo que procura mostrar um panorama da ocupação indígena no Vale do Tapajós, para então mostrar como são visualizados esses processos na T. I. Kaiabi. A primeira parte do Capítulo 1 resume a dissertação de Alexandre Robazzini (2013), que fez um levantamento das fontes bibliográficas históricas sobre a região, montando um panorama da dinâmica de ocupação indígena, e um levantamento de pesquisas e sítios arqueológicos. A segunda parte do capítulo descreve o trabalho de Francisco Stuchi (2010) na T. I. Kaiabi, detalhando como se desenrolou a pesquisa, os aportes teóricos 
utilizados, os procedimentos de escavação arqueológica e as conclusões sobre a ocupação da área.

No Capitulo 2, escrevemos sobre o objeto cerâmico, como ele pode ser estudado a partir de diferentes metodologias e interpretado de diferentes maneiras. Utilizamos as teorias da tecnologia de Lemonnier e Schiffer, tentando conectar essas diferentes perspectivas para guiar nossa análise. A partir destas teorias e do conceito de estilo tecnológico, conseguimos definir um modo de interpretar os resultados da análise.

Em seguida, mostramos a estrutura de nossa tabela de análise cerâmica e justificamos cada item ao longo do Capitulo 3. Apesar de se tratar de fragmentos, elaboramos a tabela pensando na vasilha completa, ordenando os itens de acordo com a cadeia operatória de produção para visualizarmos em cada etapa quais escolhas foram feitas pelas ceramistas, nos permitindo definir conjuntos cerâmicos.

Os resultados da análise de cada um dos 7 sítios escavados estão descritos no Capitulo 4, com os gráficos e tabelas ao final da descrição do último sítio. É no Capítulo 5 que explicamos como o banco de dados foi trabalhado estatisticamente para, juntamente com os resultados da análise do capítulo anterior, nos auxiliar na formação de conjuntos cerâmicos. A partir do reconhecimento desses conjuntos como diferentes estilos tecnológicos, sua descrição é feita do ponto de vista da cadeia operatória e das características de performance do artefato.

A partir dos resultados da análise cerâmica, no Capitulo 6 voltamos ao contexto descrito no primeiro capítulo e pesquisamos as características dos conjuntos cerâmicos arqueológicos e etnográficos já descritos para o Vale do Tapajós. Fazemos uma comparação entre estes conjuntos artefatuais e os nossos conjuntos cerâmicos arqueológicos, propondo algumas possíveis relações que poderiam ser pesquisadas com maior profundidade em trabalhos futuros.

Finalizamos esta pesquisa retomando a história indígena de longa duração a partir do contexto cerâmico na T. I. Kaiabi, esperando ter contribuído para o conhecimento do patrimônio arqueológico e cultural nesta área da Amazônia Meridional. Mesmo que a análise do material arqueológico tenha sido feita no laboratório em São Paulo, longe dos Kaiabi, as questões e pressupostos de uma Arqueologia Colaborativa estiveram sempre presentes na pesquisa, permitindo que um dos possíveis caminhos para o aprofundamento desta análise inclua, também, interpretações indígenas sobre o material.

Com as constantes ameaças e pressões aos povos indígenas e ao patrimônio arqueológico no Brasil (incluindo-se o Alto Tapajós) por causa de empreendimentos 
desenvolvimentistas, acreditamos ser cada vez mais importante que sejam feitas pesquisas de caráter colaborativo que permitam o conhecimento das trajetórias e dinâmicas, ao longo do tempo, dos povos indígenas para que sejam respeitados seus modos de vida, seus territórios e seus direitos enquanto povos com uma cultura diferenciada. Principalmente, esperamos ter adicionado ainda mais elementos para que os Kaiabi e demais povos que habitam esta região possam embasar suas reivindicações históricas por terra e proteção junto à sociedade brasileira, que tem cada vez mais retrocedido no reconhecimento do direito desses povos a manter seu modo de vida. 


\section{O VALE DO TAPAJÓS E ARQUEOLOGIA NA T. I. KAIABI}

“A Terra pro Kaiabi serve pra plantar mandioca, pra caçar, pra andar por aí, pra percurá comida e pra não perder a cultura da gente. Se a terra acabar a gente fica igual o branco mesmo.” (Atu Kaiabi apud OLIVEIRA, 2010: 247)

“Somos Kaiabi porque vivemos na nossa terra." (OLIVEIRA, 2010: 136)

A Terra Indígena Kaiabi está localizada no extremo norte do Mato Grosso e sul do Pará, no baixo curso do rio Teles Pires (ou São Manoel). Este rio tem uma extensão de 1.053.000 ha, banhando os municípios de Apiacás (MT) e Jacareacanga (PA), sendo que a T.I. Kaiabi se sobrepõe no limite territorial destes dois estados. É uma região com elevada biodiversidade e que faz parte dos corredores ecológicos ecótones sul amazônicos, com clima tropical chuvoso e regime de monções (STUCHI, 2010: 39-41).

O levantamento de fontes históricas e pesquisas arqueológicas no Vale do Tapajós feito por Alexandre Robazzini (2013) foi de fundamental importância para podermos vislumbrar a T. I. Kaiabi como parte de um cenário de deslocamentos populacionais na Amazônia e Brasil Central. A própria pesquisa de Francisco Stuchi (2010) já apontava para a importância desta área nos debates sobre as rotas de expansão e ocupação territorial dos povos Tupi, no período pré e pós-colonial, e de suas relações com outros povos que teriam ocupado estes territórios, revelando a importância desta área para os Kaiabi.

\subsection{História e Arqueologia no Vale do Tapajós}

Como destacado por Robazzini (2013: 9), a região do Vale do Tapajós (figura 1) foi ocupada por diversos povos indígenas ao longo do tempo, mas que foram desaparecendo e tendo seus territórios extremamente reduzidos por conta dos processos de colonização de 
portugueses e espanhóis (que por um tempo disputaram com os portugueses as terras na Amazônia), e de expansão da sociedade brasileira. A pesquisa nas fontes históricas procurou, nos relatos de viajantes, missionários e pesquisadores, a localização dos assentamentos indígenas e não indígenas, as datas que marcaram sua ocupação e abandono, e os deslocamentos das populações no território, comparando as informações dos diferentes autores por meio de tabelas e mapas (ROBAZZINI, 2013: 47).

Os primeiros relatos sobre a região foram feitos por missionários e funcionários coloniais no Rio Amazonas e seus afluentes, inclusive o Tapajós, nos séculos XVI e XVII. As expedições e relatos do padre Gaspar de Carvajal em 1542, Alonso de Rojas em 1633, Cristobál de Acuña em 1641 e Maurício Heriarte em 1662, nos mostram uma alta densidade populacional na foz do Tapajós com o domínio das populações Tupinambá e Tapajós ${ }^{2}$ (ROBAZZINI, 2013: 65).

Entre o final do século XVII e o XVIII, as missões jesuítas se estabeleceram na Amazônia, sendo os relatos deste período feitos basicamente por missionários, como Samuel Fritz em 1691, João Felipe Bettendorf em 1698, Bartolomeu Rodrigues em 1714, João de São José em 1763 e José Monteiro Noronha em 1768. Nesse período, os povos Tupinambá e Tapajós haviam sofrido um rápido declínio populacional, obrigando-os a fugirem cada vez mais para o interior e deixando a região mais desabitada. Por outro lado, abriu-se espaço para que as etnias que se encontravam sob o domínio desses povos se expandissem pela região. Além disso, os missionários conseguiram subir o Tapajós e descrever áreas mais acima da foz, incluindo também a região entre este rio e o Madeira. Os relatos de São José chegam mesmo até a confluência dos rios Arinos e Teles Pires, no alto curso do Tapajós, descrevendo diferentes etnias como os Apaunuariás, Marixitás, Apicurucús, Murivas, Muquiriás (ROBAZZINI, 2013: 75, 85).

Já no século XIX, contamos com relatos de expedições científicas que identificaram com maior precisão a localização e os nomes das diferentes etnias, apesar de seu número ter diminuído em relação aos séculos anteriores. Um pouco mais tarde, com a liberação dos impostos no comércio entre o Pará e Mato Grosso a partir do Rio Arinos, essas viagens foram ainda mais estimuladas (ROBAZZINI, 2013: 90 e 94).

O primeiro relato para este período é o de Almeida Serra, em 1797, que menciona os Apiacás na confluência do Arinos e Juruena, e os Munduruku (como Mondruci) no Tapajós.

\footnotetext{
${ }^{2}$ Deixamos em itálico os nomes de populações indígenas com a grafia das fontes históricas e dos povos que já não se encontram mais na região. Os nomes das populações atuais, com a grafia de acordo com o Instituto Socioambiental (ISA), estão com a letra normal.
} 


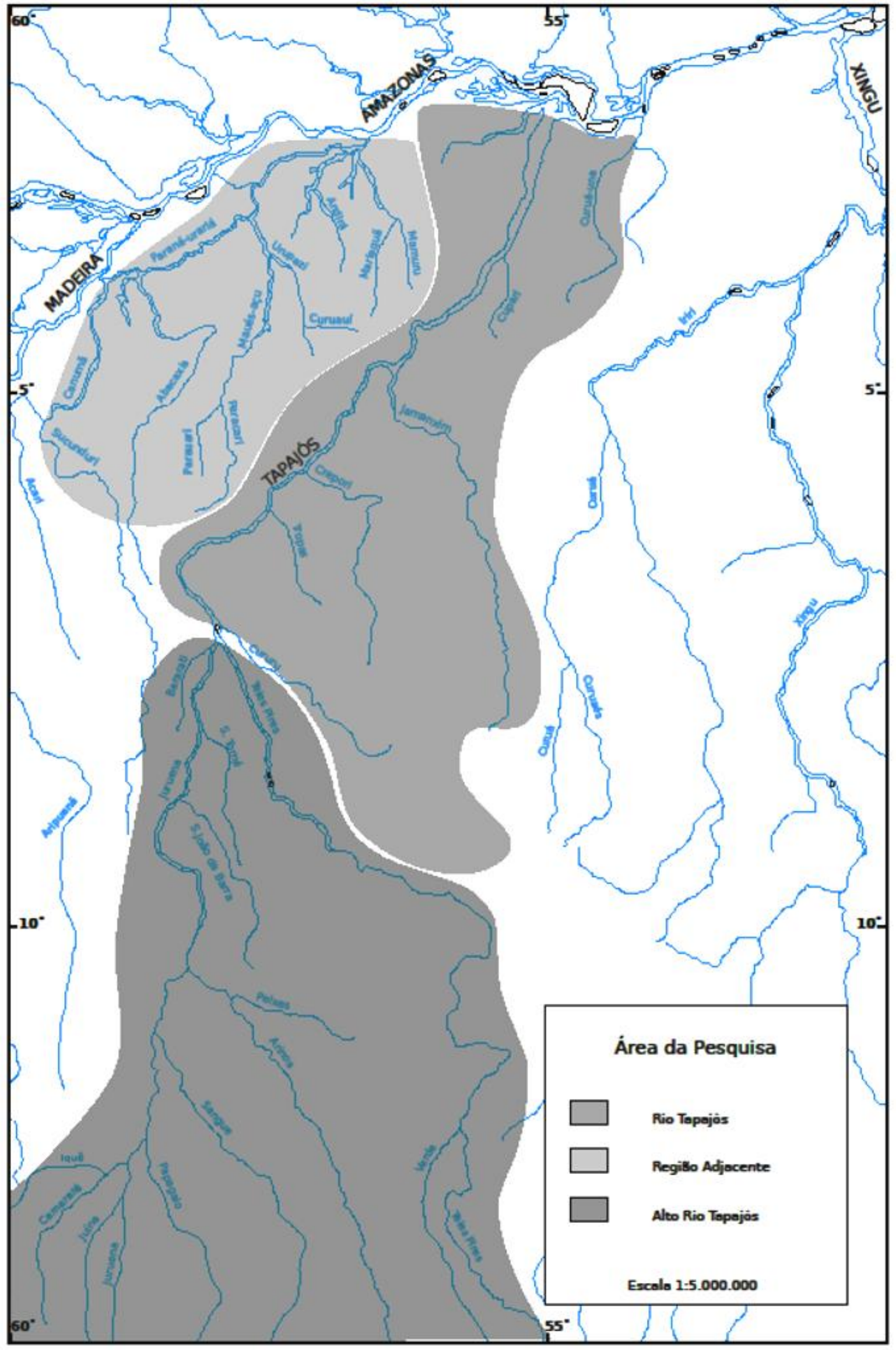

Figura 1: Mapa do Vale do Tapajós, mostrando a designação das áreas pesquisadas por Robazzini. (Mapa: Cheng Chi Cheng. Cf. ROBAZZINI, 2013: 46). 
Castro e França, em 1812, mencionam novamente os Apiacás no Arinos e os Munduruku e Maué no Tapajós. Spix e Martius, em 1817-1820, nos dão mais detalhes para o Alto Tapajós, mencionando os Munduruku espalhados por todo o rio; os Maués, Araras, Jumas, Parintintins e Yavaim entre o Tapajós e Madeira; os Guapindayas no Teles Pires; e os Apiacás no Arinos (ver mapa em ROBAZZINI, 2013: 97).

A expedição de Peixoto de Azevedo em 1819 foi a primeira a navegar pelo Teles Pires para chegar na foz do Tapajós. Ele constatou uma enorme densidade populacional na região a partir dos vestígios de grupos humanos (canoas, malocas, fogueiras, armadilhas para peixe, etc), no entanto só descreveu 3 grupos indígenas: os Muruná no alto Teles Pires, seguidos dos Parabi-tata e, então, os Munduruku, na confluência do Teles Pires, Arinos e Tapajós. Em 1825-1827, a expedição de Georg Heinrich von Langsdorff, que seguiu do Arinos ao Tapajós, contou com a presença de Hercules Florence, cujo relato acompanhado de pinturas e ilustrações é um documento muito valioso para a região, mencionando os Apiacás, Tapanhumas, Munduruku e Maués (ROBAZZINI, 2013: 99-100).

Em 1850, Castelnau menciona pela primeira vez os Bacaeris em guerra com os Cajaís (Kaiabi) nas nascentes do Arinos, assim como vários outros grupos até o Alto Tapajós. Mais relatos sobre os Kaiabi são colhidos pelas expedições de Karl von den Steinen ao Xingu, em 1884 e 1887, contados pelos Bacairis no Alto Teles Pires. Em 1895, Henri Coudreau viajou do Tapajós até o Baixo Juruena, mencionando os Munduruku, Cajabis e Bacairis (ROBAZZINI, 2013: 103, 106-107).

A partir destes relatos, foi possível compreender um pouco das dinâmicas de ocupação indígena no Vale do Tapajós. Robazzini elaborou um resumo desses deslocamentos partindo de noções de migração (ZEDEÑO, 1997) e expansão (NOELLI, 1996). Assim, os diversos grupos de Tupinambaranas (designação geral) foram migrando da Foz do Tapajós até o Alto Juruena (ver mapa em ROBAZZINI, 2013: 113). Os Parintintin migraram do médio Tapajós até quase o rio Arinos (ver mapa em ROBAZZINI, 2013: 115). Os Apiaká também passaram por um processo migratório: da margem esquerda do Arinos, foram para a confluência do Arinos com o Juruena e depois para as margens do rio dos Peixes, até chegarem ao Alto Juruena (ver mapas em ROBAZZINI, 2013: 114 e 118). Já os Munduruku passaram por um processo de expansão de seu território, do Alto Tapajós para o baixo Madeira e Tapajós, com incursões guerreiras para diferentes partes do Vale adjacentes ao seu território (ver ROBAZZINI, 2013: 122 a 125).

A pesquisa de Robazzini não chegou até os relatos do século $\mathrm{XX}$, quando encontramos mais referências para os Kaiabi e a área de nosso interesse específico, no baixo 
Teles Pires, mas complementamos esta história com relatos de outros autores, a partir do trabalho de Francisco Stuchi (2010).

Os Kaiabi são um povo de língua pertencente à família linguística Tupi-Guarani, do tronco Tupi. Segundo suas próprias histórias, o grupo teria se originado em uma lagoa nas proximidades do córrego Batelão, afluente da margem meridional do rio dos Peixes, onde disputavam com os Bakairi as pedras para fazer seus machados (STUCHI, 2010: 19). A área original dos Kaiabi se estendia por uma faixa entre os rios Arinos, Rio dos Peixes (denominado por eles como Tatuy) e médio Teles Pires (SENRA, 1999).

O contato com os Kaiabi foi feito pela primeira vez após 1900, quando eles já estavam se estabelecendo na área em que se encontram atualmente. Esses contatos se tornaram mais frequentes por conta do início do ciclo da borracha, até 1932, o que também ocasionou diversos conflitos entre os Kaiabi e seringueiros, além de conflitos pelas diversas tentativas do Serviço de Proteção ao Índio (SPI) e da Comissão Rondon para pacificá-los (MELIÁ, 1993: 495). Após o início do segundo ciclo da borracha, na década de 1940, a situação nesta área não tinha perspectivas de melhoras, já que o SPI não dava conta de assegurar o modo de vida dessa população na situação de conflito em que se encontrava. Assim, a proposta, em 1949, dos irmãos Villas Bôas de levá-los para o Xingu foi bem aceita por vários Kaiabi (SENRA, 1999). Até 1966, a maioria deles já havia sido transferida para lá com a "Operação Kayabi", que transportou de avião a maior parte dos índios do Tatuy (MELIÁ, 1993: 500-501; SENRA, 1999). Lá, os Kaiabi auxiliaram os Villas Bôas tanto na pacificação de outros povos indígenas como na adaptação de elementos da sociedade brasileira ao seu modo de vida.

No entanto, muitos Kaiabi começaram a lamentar-se por terem abandonado suas terras originais (SENRA, 1999). Aqueles que não se mudaram reocuparam duas aldeias, as quais se juntaram as famílias que retornaram do Xingu (STUCHI, 2010: 97-98). É nesse período que os Kaiabi do Teles Pires passaram a vender farinha para a mineradora local e em 1975 é reativado o posto Kaiabi pela FUNAI, dessa vez mais próximo de suas aldeias. Os garimpeiros só abandonaram a região no final da década de 1990, deixando para trás passivos ambientais e contaminação de mercúrio. Mais recentemente o conflito tem se dado com madeireiros, grandes fazendas, posseiros e projetos de construção de Pequenas Centrais Hidrelétricas (PCH). Outras aldeias foram construídas pelos Kaiabi no baixo Teles Pires, continuando esse processo de ocupação da área como parte de uma estratégia de demarcação e manutenção de seu território, contribuindo também para a revitalização de sua cultura (STUCHI, 2010: 98-100). 
Hoje, os Kaiabi vivem dispersos em três regiões (figura 2): no Parque Indígena do Xingu, na bacia do Rio Teles Pires e no Rio dos Peixes, ou Tatuy (MELIÁ, 1993: 489; STUCHI, 2010; SENRA, 1999). A maior parte deles encontra-se no PIX, mas ainda existem alguns na T. I. Apiaká-Kayabi, no Tatuy, e também na T. I. Kaiabi, no Teles Pires, que homologada em 2013. No entanto, o grupo ainda reivindica uma área próxima ao rio Batelão e uma área contígua ao PIX, que foi a primeira área de chegada dos Kaiabi ao Parque e a que tem maior semelhança com a sua região originária (STUCHI, 2010: 25).

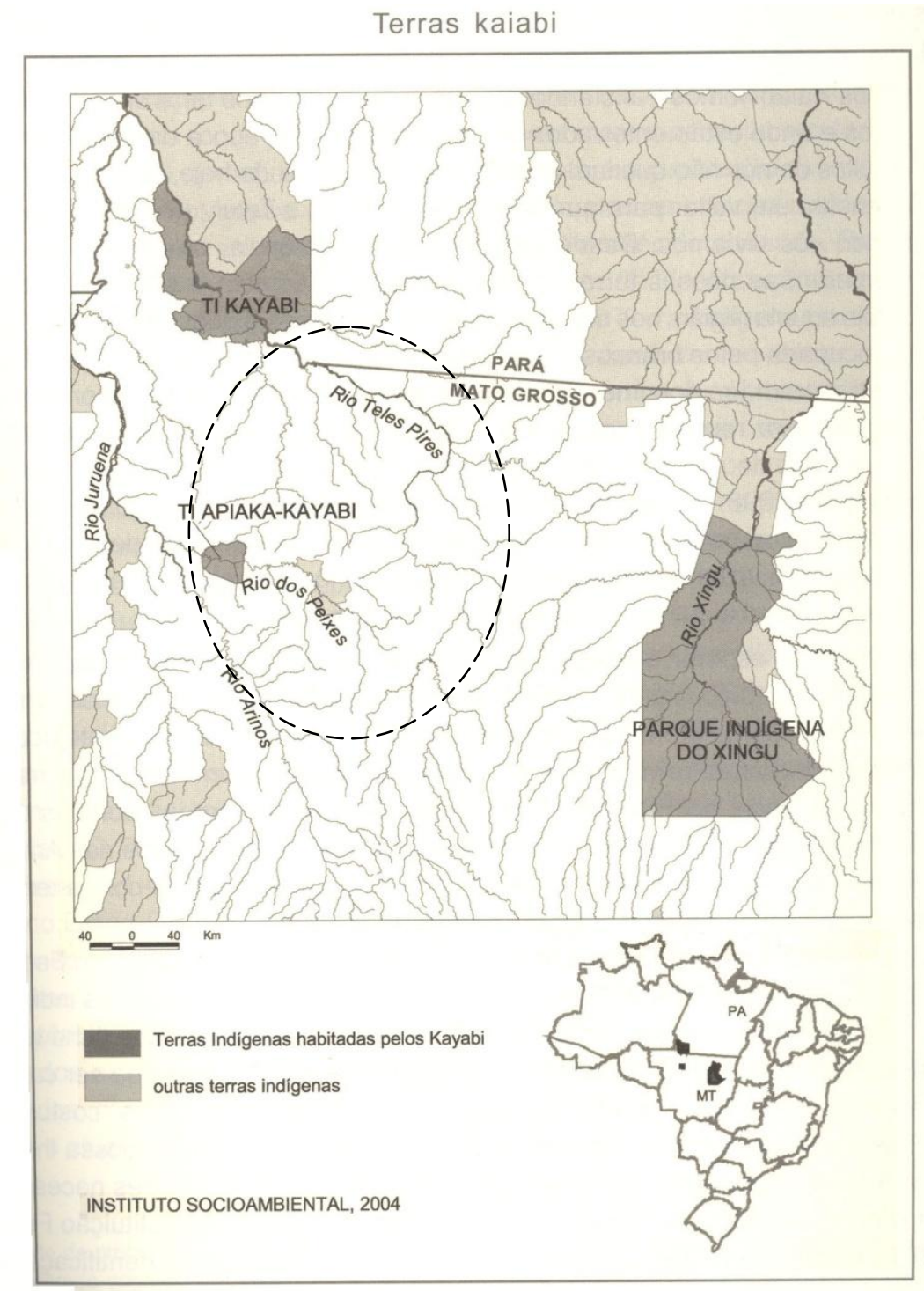

Figura 2: Terras Indígenas onde habitam atualmente os Kaiabi. A área do antigo território está circulada, entre a T. I. Kayabi e o PIX, englobando a T. I. Apiaká-Kayabi. (Cf. SILVA e STUCHI, 2010: 53).

Ao lado da T. I.Kaiabi, temos atualmente a T. I. Apiaká do Pontal e Isolados, a T. I. Mundurucu e a T. I. Sai Cinza. Existem outras terras indígenas demarcadas na região do Vale 
do Tapajós (figura 3), mas lembrando que esta região estava completamente ocupada por povos indígenas, podemos ver claramente como seus territórios foram drasticamente reduzidos desde o início do contato com os colonizadores (ver mapas em ROBAZZINI, 2013: 139 a 142).

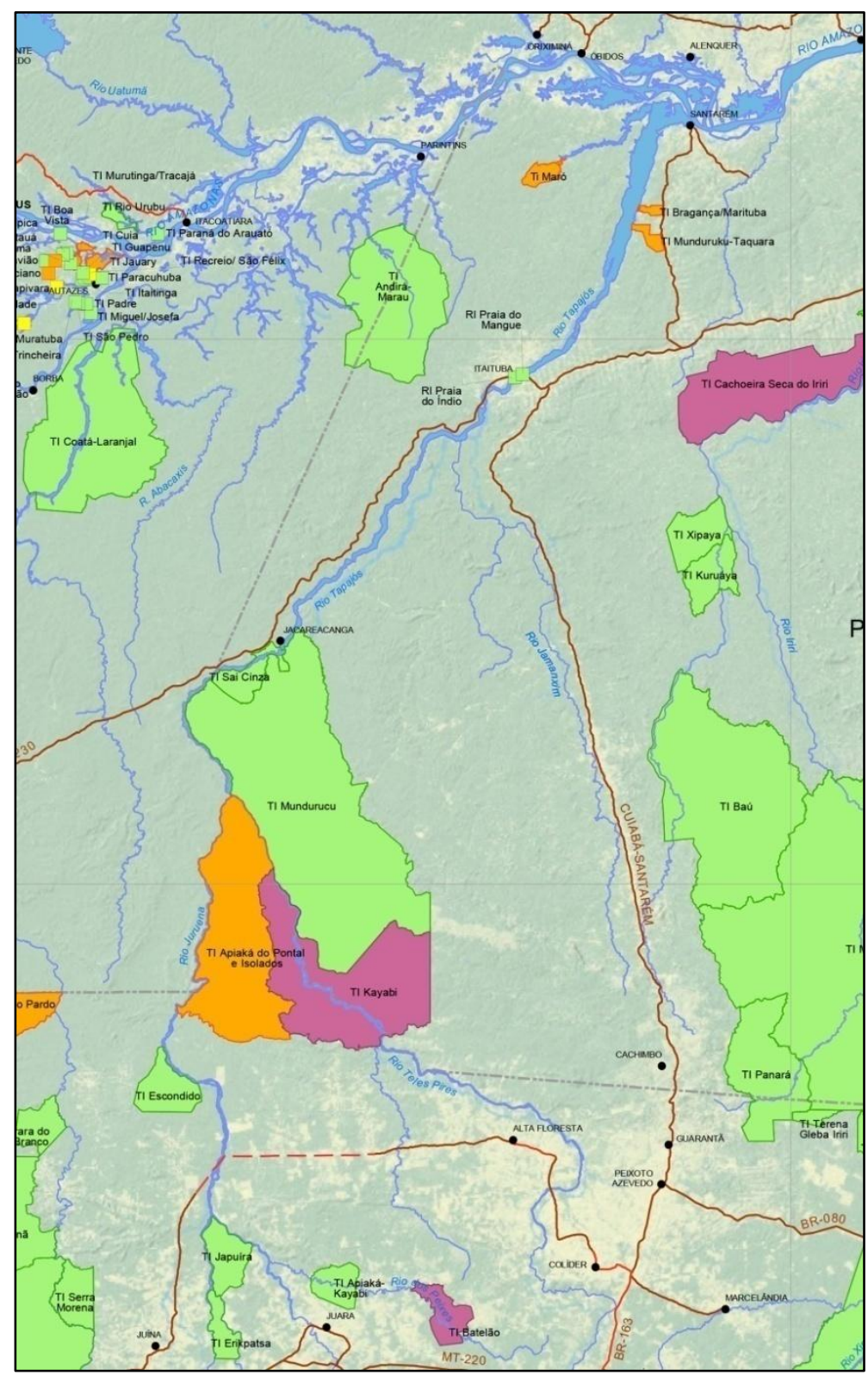

Figura 3: Terras Indígenas no Vale do Tapajós atualmente (Mapa: adaptado de ISA, 2012; escala $1 \mathrm{~cm}=50$ $\mathrm{km})$.

Apesar dos relatos históricos nos mostrarem uma região com um enorme potencial arqueológico, as pesquisas ali desenvolvidas são ainda bastante incipientes. Existem em torno de 600 sítios cadastrados na região do Vale do Tapajós, que foram listados com seus dados de localização e informações sobre sua caracterização por Robazzini (2013), no entanto são 
poucos os sítios que realmente tiveram seu material analisado mais profundamente e com seus resultados amplamente divulgados.

As primeiras escavações no Tapajós foram feitas em sua foz, no século XIX, pelo geólogo Frederick Hartt e pelo botânico Barbosa Rodrigues (ROBAZZINI, 2013: 159). Hartt relacionou áreas de terra preta com ocupações humanas, devido aos vestígios de fragmentos cerâmicos, escavando o sítio de Taperinha, que veio a ser pesquisado mais profundamente por Ana Roosevelt (1991). No começo do século XX, Nimuendajú chegou a registrar diversos sítios arqueológicos entre Santarém e Alter-do-Chão. Recentemente, muitas pesquisas foram feitas no baixo Tapajós, especialmente na região de Santarém, identificando cerâmicas da Tradição Tapajônica e da Tradição Borda Incisa (GOMES, 2005; 2008).

Já próximo a área que mais nos interessa, foram feitas algumas pesquisas vinculadas ao PRONAPABA por Celso Perota, das margens do Tapajós até a confluência do Juruena e Teles Pires (ROBAZZINI, 2013: 163). Apesar de não termos acesso aos relatórios completos dessas pesquisas, temos a informação dos relatórios parciais que identificam conjuntos cerâmicos pertencentes á Tradição Inciso-Ponteado e um conjunto de cerâmica sem decoração, que Perota sugere ser dos Munduruku que dominavam a região (PEROTA, 1979; 1982).

Recentemente, existem diversos trabalhos arqueológicos realizados por empresas de arqueologia de contrato, por causa dos projetos de construção das Pequenas Centrais Hidrelétricas ( $\mathrm{PCH})$. Esses estudos estão em andamento e ainda não temos acesso aos resultados dessas pesquisas.

Das pesquisas acadêmicas, destacamos primeiramente a pesquisa de Francisco Stuchi (2010), à qual estamos vinculadas e que iremos detalhar mais adiante. Também gostaríamos de destacar o trabalho de Bruna Rocha (2012), em uma área a 120 km de Itaituba, no Alto Tapajós, cujos resultados sobre a análise cerâmica serão detalhados no último capítulo.

Apesar deste enorme potencial de pesquisa e das inúmeras populações que ainda habitam essa região, muitos empreendimentos econômicos estão sendo implementados, ameaçando o patrimônio ambiental, cultural e arqueológico sem antes terem sido feitos estudos suficientes para sequer sabermos o que lá existe. Todas as pesquisas acadêmicas, desde Santarém até o Alto Tapajós, denunciaram as ameaças ao patrimônio arqueológico e cultural, muitas vezes em locais ainda não estudados adequadamente (ROBAZZINI, 2013). As populações indígenas que já perderam grande parte de seu território, ao longo dos séculos de contato, têm seu modo de vida mais uma vez ameaçado por esses empreendimentos, e é por isso que devemos nos preocupar com o modelo de desenvolvimento que o país continua 
adotando, totalmente "voltado para atender as necessidades do mercado externo, no qual os recursos naturais sofrem toda a sorte de pressão e no qual as diversidades culturais e étnicas do país são vistas como entrave à expansão dos lucros ou à elevação do saldo da balança comercial" (ROBAZZINI, 2013: 157).

\subsection{A Pesquisa Arqueológica na T. I. Kaiabi}

Dado este contexto do Vale do Tapajós, a pesquisa de Francisco Stuchi procurou compreender, especificamente, a trajetória de ocupação indígena na T. I. Kaiabi, com foco na trajetória dos próprios Kaiabi e os diferentes significados (sociais, políticos, econômicos e ambientais) de sua mobilidade em termos de ocupação territorial, percepções da paisagem e do seu território (SILVA e STUCHI, 2010: 50). Para isso, foi utilizada a noção de palimpsesto, que na Arqueologia refere-se a ideia de que

"um mesmo local ou sítio arqueológico pode ter sido ocupado diversas vezes por sociedades culturalmente diferenciadas através do tempo, ou ainda, de diversas maneiras diferentes pela mesma sociedade durante um determinado período, sendo que ambas as possibilidades podem resultar em conjuntos materiais arqueológicos diversos e dispostos espacialmente de modo muito complexo" (SILVA et al., 2006: 9).

Como ponto de partida para visualizar esse palimpsesto, foi utilizado, principalmente, o modelo de "história de formação territorial" concebido por Zedeño (1997), no qual ela pensa o território como “objetos agregados - constituídos por terra, recursos naturais e objetos feitos pelo homem - reunidos historicamente através de processos dinâmicos de interação sócio-ambiental” (ZEDEÑO, 1997: 73 apud SILVA et al., 2006: 11). Seria então possível reconstituir a história de um território por meio de correlatos materiais de atividades associadas às trajetórias de estabelecimento, manutenção e transformação territorial.

É importante ressaltar aqui o caráter colaborativo dessa pesquisa. Nos últimos anos, os arqueólogos têm refletido sobre a natureza colonialista de sua disciplina, o que provocou diversas transformações na prática arqueológica e abriu espaço para o desenvolvimento da 
Arqueologia Colaborativa, pautada em "práticas arqueológicas mais inclusivas, menos colonizadoras e, particularmente, nos contextos indígenas, de uma 'indigenização' da arqueologia" (SILVA et al., 2011: 36-37; SMITH e WOBST, 2005). O direito e o monopólio dos arqueólogos de controlar a produção do conhecimento sobre o passado e as interpretações sobre ele estão sendo amplamente questionados, dando espaço para a colaboração e o envolvimento de diferentes coletivos nas pesquisas e questões relativas à gestão do patrimônio cultural (SILVA et al., 2011: 37).

A realização de uma pesquisa nesses moldes pressupõe que os interesses e benefícios entre os cientistas e as comunidades a serem estudadas, ou que estão na área a ser investigada, estejam alinhados, mas não que haja consenso nas ideias e interpretações sobre os fenômenos estudados. O que se procura nessas pesquisas é justamente a multivocalidade, ou seja, a explicitação de perspectivas e conhecimentos dos indivíduos ou grupos que pertencem a diferentes contextos dos pesquisadores, sendo que no caso do trabalho com populações indígenas essas diferentes perspectivas são também multiculturais (SILVA et al., 2011: 37). O resultado dos trabalhos feitos entre os Kaiabi (STUCHI, 2010) e em outros trabalhos relacionados, como com os indígenas da Aldeia Lalima (BESPALEZ, 2009) e os Asurini (SILVA et al., 2011), foi o entendimento, por parte dos pesquisadores, de que um trabalho arqueológico/etnoarqueológico colaborativo em contextos indígenas só pode ser realizado se for pautado em uma relação de troca de conhecimentos, respeito e confiança (SILVA et al., 2011: 56).

Com poucas exceções (como o realizado por SILVA et al., 2011 na T. I. Koatinemu, dos Asurini do Xingu), a maioria das pesquisas arqueológicas em terras indígenas no Brasil é feita a partir da iniciativa de pesquisadores, não das populações indígenas.Essas pesquisas normalmente são feitas em contextos de demanda de trabalhos arqueológicos na demarcação, manutenção e reivindicação de territórios tradicionais pelos coletivos indígenas; na realização de empreendimentos que necessitam de trabalhos de arqueologia preventiva; nas pesquisas acadêmicas que tem foco na construção de uma história indígena de longa duração (SILVA et al., 2011: 38; ver também BESPALEZ, 2009; STUCHI, 2010; HECKENBERGER, 1996; NEVES, 1998; EREMITES DE OLIVEIRA, 1996).

No Projeto Kaiabi-Lalima, o diálogo entre pesquisadores e indígenas foi valorizado e procurado em todos os momentos. A grande preocupação dos Kaiabi em relação ao trabalho proposto pelos arqueólogos era a de que o mesmo fornecesse subsídios para a demarcação de sua área (figura 4), que ainda não havia sido homologada. Já haviam sido realizados diversos estudos na área com esse objetivo, inclusive governamentais, mas segundo os Kaiabi os dados 


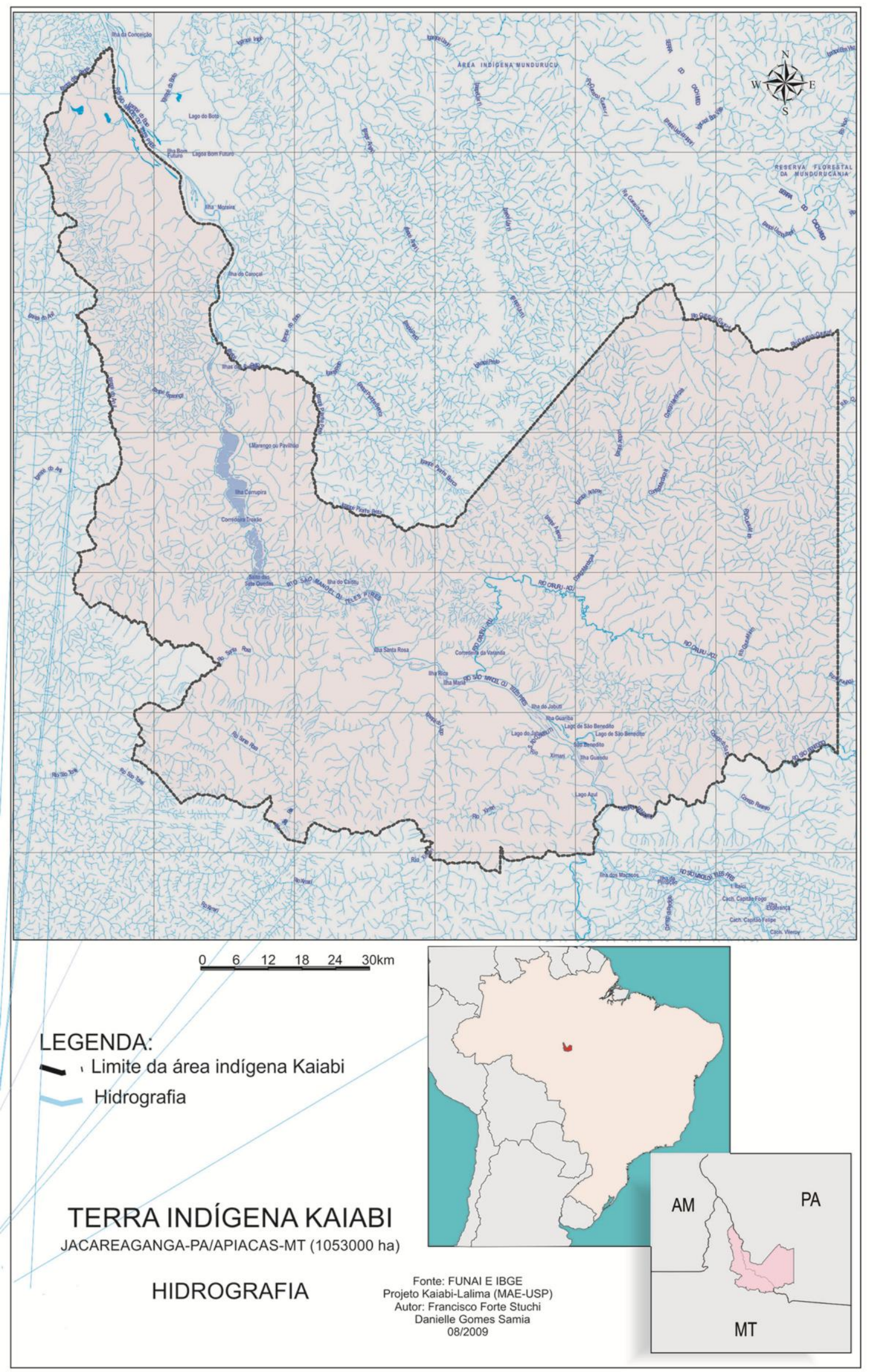

Figura 4: Mapa de localização da T. I. Kaiabi. (Cf: STUCHI, 2010: 52). 
coletados nunca foram vistos por eles e nunca geraram resultados concretos (SILVA e STUCHI, 2010: 51). Além disso, foi ressaltado que era preciso que os pesquisadores ficassem bastante tempo na área, o que não foi feito pelas pesquisas anteriores e que prejudicou as observações e coleta de informações. A pesquisa proposta por Stuchi, no entanto, não tinha os mesmos objetivos desses levantamentos feitos anteriormente e foi explicado aos indígenas que apesar disso os resultados dessa pesquisa seriam mostrados para eles e poderiam ser usados para embasar suas demandas.

Os arqueólogos foram vistos também como facilitadores das relações dos Kaiabi com os órgãos públicos, no sentido de poderem argumentar a seu favor de forma mais simétrica. Somente após um tempo do início da pesquisa é que os Kaiabi começaram a perceber outras nuances deste trabalho. Eles passaram a vê-lo como uma oportunidade de resgate cultural, utilizando da memória e tradição oral para significar os registros arqueológicos encontrados (SILVA, 2009; STUCHI, 2010). As visitas às aldeias antigas e outros lugares significativos foi uma oportunidade para que os anciãos relembrassem a história de ocupação dessa área, revelando também aos jovens parte dessa história desconhecida por eles, além de proporcionar novas formas de se aprender sobre o passado, combinando os relatos dos velhos e dos pesquisadores.

O desejo dos indígenas de que o material coletado permanecesse em sua área, ou pelo menos o mais próximo possível dela, foi levado em conta pelos pesquisadores, que se comprometeram a deixar o material próximo deles após sua análise no laboratório da USP ${ }^{3}$.

Para os pesquisadores, esse diálogo também foi muito enriquecedor, com a incorporação de dados relevantes para as reflexões sobre as histórias de formação territorial das áreas e reflexões sobre a própria prática arqueológica face aos diversos interesses políticos, sociais e culturais dos indígenas para a manutenção de seu modo de vida nas terras que ocupam (SILVA, 2009; BESPALEZ, 2009; STUCHI, 2010; POUGET, 2010). Estudar o modo de vida Kaiabi, seu modo de ocupação do espaço e da produção de cultura material ajudou bastante na identificação dos sítios arqueológicos (SILVA e STUCHI, 2010: 51). Esse projeto mostrou, também, como uma arqueologia norteada pelos princípios de uma arqueologia colaborativa pode "ser uma possibilidade de os indígenas terem voz e argumentos em relação aos seus direitos territoriais, autodeterminação e gerenciamento do patrimônio cultural de suas terras" (SILVA, 2009: 3).

\footnotetext{
${ }^{3} \mathrm{O}$ material arqueológico da T. I. Kaiabi será posteriormente armazenado no Instituto do Homem Brasileiro (Cuiabá-MT).
} 


\subsubsection{Coleta dos Conjuntos Cerâmicos Arqueológicos}

Ainda em concordância com o Projeto Kaiabi-Lalima, o estudo de Francisco Stuchi na T. I. Kaiabi combinou diferentes metodologias arqueológicas, etnográficas e etnoarqueológicas.

O material escavado foi coletado por Stuchi (2010) e colegas a partir de um total de 84 dias de permanência na T. I. Kaiabi, divididos em 6 etapas de campo que tiveram uma variação em sua duração de 5 a 27 dias. A primeira etapa da pesquisa foi a de negociação com os indígenas para a autorização da pesquisa. A segunda etapa foi a de living archaeology (GOULD, 1980), que seria uma etnografia conduzida com interesse arqueológico. Por último, foi feita a pesquisa arqueológica propriamente dita, mas cabe ressaltar que só foi possível realizá-la e desenvolvê-la a partir dos resultados das etapas anteriores.

A negociação da pesquisa arqueológica foi uma importante etapa da metodologia, pois é a partir da interação entre pesquisador e comunidade indígena que os objetivos e procedimentos da pesquisa podem ter continuidade e significação para ambas as partes (STUCHI, 2010). Além disso, existem diversas técnicas direcionadas para esse momento do trabalho de campo que foram tema de reflexão por antropólogos e etnólogos.

O que trabalhos similares têm demonstrado é que, para trabalhar em terras indígenas juntamente com os indígenas em um processo como o da Arqueologia Colaborativa, existem algumas estratégias fundamentais: 1) promover a interação social entre a equipe de pesquisa e a comunidade local; 2) manter a presença da equipe na área ao longo da pesquisa; 3) buscar recursos para beneficiar a comunidade local; 4) manter a comunidade inteirada sobre os procedimentos e andamento da pesquisa; 5) permitir o acesso fácil da comunidade aos vestígios arqueológicos coletados (SILVA et al., 2011: 37; MOSER, 2002; TULLY, 2007). Nesse sentido, o pesquisador precisa: 1) definir a população indígena; 2) obter permissão; 3) selecionar os interlocutores e colaboradores para orientar e auxiliar na pesquisa; 4) obter informações prévias sobre os registros arqueológicos; 5) receber aprovação dos indígenas para analisar e divulgar o material arqueológico; 6) construir o conhecimento e disseminar os resultados a partir de uma perspectiva intercultural (STUCHI, 2010: 11; SILVA et al., 2011).

Dentro destes princípios citados, a negociação com os Kaiabi foi conduzida em dois momentos, em 2005 e 2006, quando foi discutida a proposta de trabalho e a autorização necessária ao seu desenvolvimento (STUCHI, 2010: 14). A partir dessas conversas, os Kaiabi compreenderam que a natureza acadêmica da pesquisa não lhes traria benefícios imediatos e 
não esclareceria sua situação legal perante as autoridades, mas que, ao pesquisarem antigas aldeias, os arqueólogos estariam contribuindo para amparar suas demandas no processo de demarcação de suas terras. Assim, uma parceria foi estabelecida e a partir dos conhecimentos dos arqueólogos e dos indígenas o trabalho de campo foi realizado.

A pesquisa etnoarqueológica (feita a partir dos conceitos de POLITIS, 2002) foi a segunda etapa da pesquisa a ser desenvolvida, realizada ao longo de 25 dias, divididos em três momentos. A aldeia Kururuzinho (ver no mapa da Figura 5) foi escolhida como a base para a pesquisa por causa de sua localização estratégica em termos logísticos, além de ter sido o local de convergência deste grupo Kaiabi, ao final das décadas de 1980 e 1990, e de sua posterior dispersão para as demais aldeias (STUCHI, 2010: 109).

Foram feitas observações, anotações em cadernos de campo, registros fotográficos e desenvolvimento de entrevistas semi-estruturadas realizadas predominantemente com os chefes de família de cada aldeia. As entrevistas focaram na trajetória de vida dos interlocutores como um passo para entender a trajetória do próprio território (STUCHI, 2010: 110-111).

Foi então elaborado um diagrama da organização social do grupo, para conhecer melhor a população e sua distribuição nas aldeias, feito a partir das relações de parentesco, desde os anciãos das primeiras gerações que ocuparam a área até a $5^{a}$ geração de netos e bisnetos. Também elaboraram um mapa hidrográfico (figura 5) com a localização georeferenciada de cada aldeia, contendo informações sobre a ocupação e distribuição das casas, estruturas anexas, áreas de descarte de lixo, portos, pomares, antigas habitações, vestígios arqueológicos, etc., para se entender a organização e utilização do espaço (STUCHI, 2010: 109-110). No total, foram estudadas nesta etapa 9 aldeias ocupadas atualmente e 1 acampamento.

Não foi possível aos pesquisadores visitarem todos os locais de ocupação passada, mas com base nas informações dos Kaiabi e no levantamento etnográfico feito anteriormente por Medonça em 1994, foram elencados 41 locais considerados antigas aldeias ou outros tipos de ocupação. Deste conjunto de aldeias antigas somadas as 9 aldeias atuais, foram escavados 7 locais, seguindo alguns critérios que concordassem com os objetivos da pesquisa: 1) realizar uma amostragem que permitisse obter dados na maior extensão territorial da T. I. Kaiabi; 2) pesquisar contextos arqueológicos e históricos indicados pelos Kaiabi; 3) escolher aldeias atuais onde a presença dos pesquisadores tivesse receptividade, para divulgar e debater com os Kaiabi os objetivos e os resultados da pesquisa; 4) construir através do diálogo uma parceria com os Kaiabi (STUCHI, 2010: 179). 


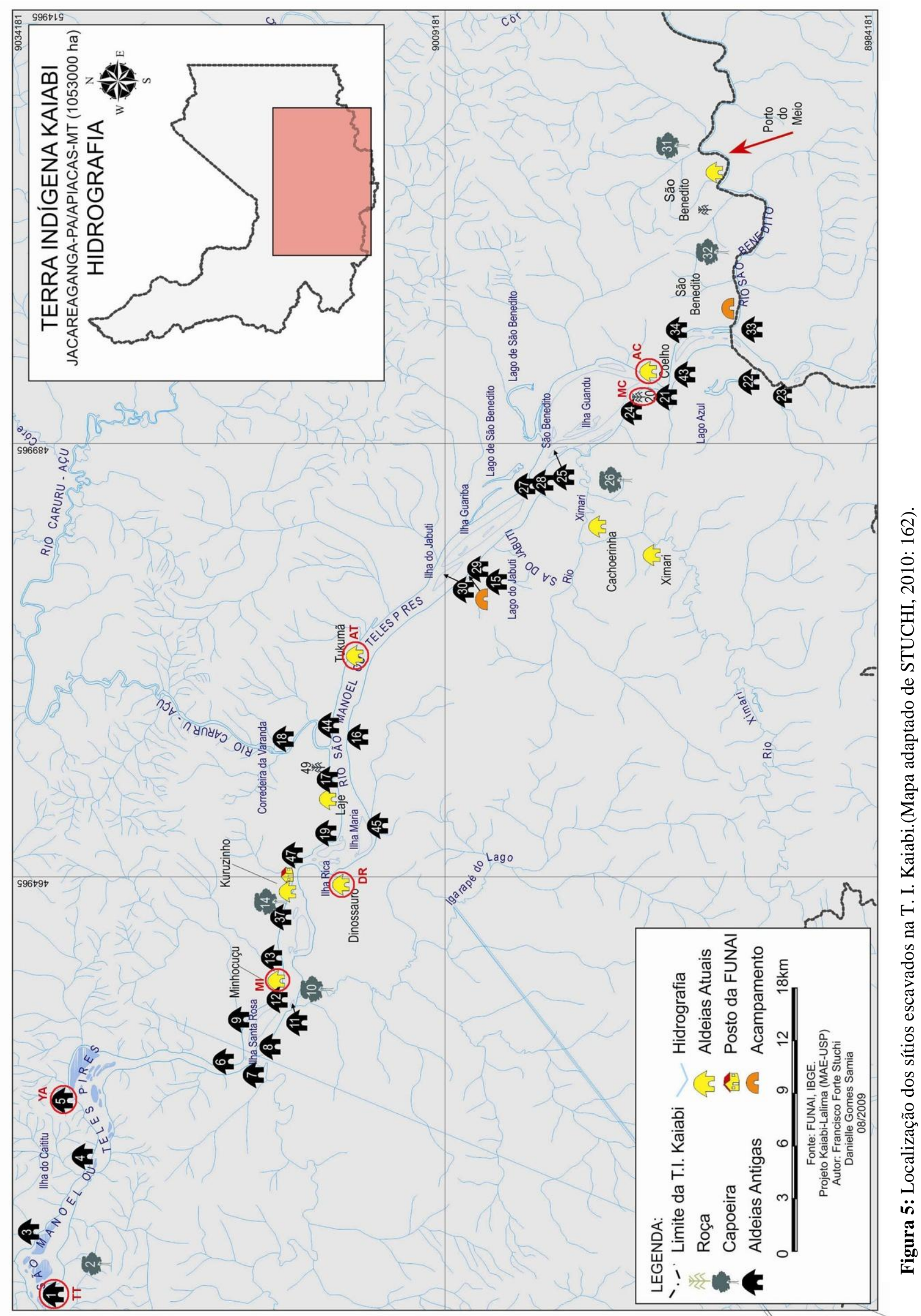


Os sítios arqueológicos escavados estão localizados em quatro aldeias atuais (Dinossauro - DR, Aldeia Tukumã - AT, Minhocoçu - MI e Aldeia Coelho - AC), duas aldeias antigas (Ywantã - YA e Taitetu - TT) e uma antiga área de roça (sítio Mukuin Caniné - MC). Os procedimentos realizados em cada sítio foram: 1) delimitação da área do sítio; 2) coletas assistemáticas e sistemáticas amostrais não-probabilísticas em superfície; 3) coletas sistemáticas amostrais não-probabilísticas em sub-superfície por meio de sondagens e poços testes (STUCHI, 2010:179).

Para a delimitação dos sítios, foram utilizados critérios distintos como: as linhas de sondagens, a presença de vestígios arqueológicos em superfície e subsuperficie e a orientação dos Kaiabi, que acompanharam os pesquisadores nas escavações e auxiliaram na identificação, delimitação e classificação dos sítios (STUCHI, 2010: 179-180). Na superfície a coleta sistemática foi realizada em quadrantes com área mínima de $10 \mathrm{~m}^{2}$, onde foram recolhidos os materiais diagnósticos dispersos. Os pesquisadores e os indígenas abriram picadas para estabelecer as linhas que orientaram as sondagens em busca dos limites da terra preta e da capoeira, bem como da distribuição horizontal de superfície dos vestígios arqueológicos. Essas atividades foram registradas em croqui para posterior definição em carta planialtimétrica confeccionada por topógrafo.

Ao longo das linhas estabelecidas foram efetuadas sondagens com cavadeira a cada $50 \mathrm{~m}$, tendo cada sondagem $30 \mathrm{~cm}$ de diâmetro e $1 \mathrm{~m}$ de profundidade, controlados por níveis artificiais de $10 \mathrm{~cm}$, permitindo assim verificar a distribuição vertical das evidências e a caracterização das camadas de solo (STUCHI, 2010: 179-180). Os solos escavados passaram pela peneira para que materiais menos visíveis pudessem ser recolhidos. Foram também escavados poços testes de $1 \mathrm{~m}^{2}$ dispostos a partir das informações obtidas nas sondagens, controladas também a partir de níveis artificiais de $10 \mathrm{~cm}$ (em alguns casos $20 \mathrm{~cm}$ ) e escavadas para verificar a disposição do contexto, obter evidências arqueológicas e materiais para datação de $\mathrm{C}^{14}$ e termoluminescência. Todo o material recolhido foi contabilizado e registrado em fichas, tabelas e diários de campo. Em cada poço-teste também foram coletadas amostras de solo de $10 \mathrm{~cm}^{3}$ do quadrante nordeste de cada nível escavado (AVC), para posteriores análises paleobotânicas e pedológicas.

Com os sítios delimitados e esboçados em croquis, foram obtidas informações dos Kaiabi, ainda em campo, sobre a etnoclassificação dos tipos de solo encontrados e a classificação da vegetação conforme a etnobotânica Kaiabi, para correlacionar essas informações com os resultados arqueológicos obtidos (STUCHI, 2010: 180).

O material coletado está descrito na tabela 1, abaixo: 


\begin{tabular}{|c|c|c|c|}
\hline Sítio & Material Cerâmico & Material lítico & Total por Sítio \\
\hline Aldeia Dinossauro & 2.558 & 283 & $\mathbf{2 . 8 4 9}$ \\
\hline Mukuin Caniné & 1.059 & 169 & $\mathbf{1 . 2 2 8}$ \\
\hline Taitetu & 2.051 & 195 & $\mathbf{2 . 2 4 6}$ \\
\hline Aldeia Minhocoçu & 368 & 56 & $\mathbf{4 2 4}$ \\
\hline Ywantã & 1.143 & 87 & $\mathbf{1 . 2 2 7}$ \\
\hline Aldeia Tukumã & 1.782 & 490 & $\mathbf{2 . 2 7 2}$ \\
\hline Aldeia Coelho & 1.003 & 19 & $\mathbf{1 . 0 2 2}$ \\
\hline Total Geral & $\mathbf{9 . 9 6 4}$ & $\mathbf{1 . 2 9 9}$ & $\mathbf{1 1 . 2 6 8}$ \\
\hline
\end{tabular}

Tabela 1: Relação de campo do material coletado na T. I. Kaiabi.

\subsubsection{Resultados}

Como resultado de sua dissertação de mestrado, Stuchi confirmou o entendimento da T. I. Kaiabi no baixo rio Teles Pires como um palimpsesto da trajetória de ocupação indígena e não indígena (SILVA e STUCHI, 2010: 56). Os processos envolvidos na trajetória de ocupação dessa região pelos Kaiabi também permitiram sua compreensão a partir do modelo de "história de formação territorial" de Zedeño (1997).

A área é ocupada pelos Kaiabi há pelo menos um século, privilegiando inicialmente os locais anteriormente ocupados, atestados pelos vestígios de objetos arqueológicos (cerâmica e lítico), possível terra preta antropogênica (TPA) e espécies vegetais manejadas (SILVA e STUCHI, 2010: 56). Em especial, a ocupação das TPAs insere-se em um debate maior sobre o processo de formação desse tipo de solo e da ocupação em geral na Amazônia (vide PETERSEN et al., 2001). Até hoje os Kaiabi reproduzem os padrões de ocupação de populações do passado, com as aldeias atuais situadas sobre as antigas aldeias, sítios arqueológicos, áreas de capoeira e antigos acampamentos de seringueiros e garimpeiros, além de grande parte das áreas de cultivo estarem situadas sobre as TPAs (SILVA e STUCHI, 2010: 56).

Os dados sobre o padrão de assentamento dos Kaiabi mostram-se muito interessantes para a discussão arqueológica (SILVA e STUCHI, 2010). Mesmo tendo roças e ranchos provisórios à beira de rios, os Kaiabi preferiam construir suas aldeias no interior, protegendose de possíveis ataques de seus inimigos Munduruku. Somente no contexto pós-contato é que 
os Kaiabi passaram a construir suas aldeias às margens dos rios, aproximando-se dos postos do SPI (STUCHI, 2010: 35-36). Como elemento determinante na escolha do local da aldeia, eles consideram as áreas de terra preta, geralmente terras férteis indispensáveis para a implantação de roças de policultivo (STUCHI, 2010:36). Não foi feita nenhuma análise específica para saber se tratava-se realmente da terra preta antropogênica (TPA), mas é uma possibilidade bastante plausível. A TPA é um tipo de solo muito comum na região Amazônica, provavelmente resultado de queimas de carvão e decomposição de matéria orgânica, sendo associado às antigas ocupações humanas, com alta fertilidade e que geralmente apresentam vestígios arqueológicos (NEVES, 2008; PETERSEN et al., 2001; ERICKSON, 2008).

É importante dizer que os Kaiabi reconhecem as ocupações anteriores a partir da memória deles, dos vestígios materiais deixados pelos moradores (sepultamentos, utensílios, esteios de construção), espécies vegetais manejadas e diferentes tipos de solo (SILVA e STUCHI, 2010: 56-57). A ocupação desses lugares é para eles um privilégio, pois é uma forma de garantir a obtenção de recursos para sua sobrevivência como a caça, pesca, áreas férteis para plantar, espécies vegetais manejadas e uma boa localização. Principalmente, após o contato com não índios eles intensificaram a formação de aldeias às margens do rio Teles Pires e seus afluentes, locais com grande diversidade ecológica, mas principalmente para facilitar as relações de troca, comércio, assistência governamental e proteção do território contra as invasões.

Ressaltamos ainda que os vestígios arqueológicos foram reconhecidos pelos Kaiabi em sua natureza e função, ou seja, como artefatos cerâmicos (vasilhas), líticos (machados, pilão, etc.) e outros, apesar de não terem sido reconhecidos como artefatos de sua própria cultura (STUCHI, 2010: 277). Um reconhecimento preliminar do material cerâmico coletado apontou para alguns vestígios com características Tupi, o que é muito provável, já que a área insere-se em um contexto histórico e cultural de ocupação Tupi (STUCHI, 2010: 275; ROBAZZINI, 2013). Considerando-se que os Kaiabi possuíam tradição oleira (STUCHI, 2010; GRÜNBERG, 2004), é possível encontrar fragmentos cerâmicos associados a eles, mas isso pode não ocorrer, pois a maior parte do material encontra-se em terras pretas, provavelmente formadas antes da ocupação Kaiabi (STUCHI, 2010: 275), além do que a ocupação destes locais pode ter sido feita depois que eles já não fabricavam mais cerâmica. 


\section{CERÂMICA, TECNOLOGIA E ESTILO TECNOLÓGICO}

"Ninguém hesitará em admitir que a argila para cerâmica se apresenta inicialmente em estado amorfo, e que o trabalho do oleiro ou da oleira consiste, justamente, em impor uma forma a uma matéria que anteriormente não tinha nenhuma." (LÉVI-STRAUSS, 1986:29)

Para analisar os fragmentos cerâmicos coletados na T. I. Kaiabi, primeiramente discutimos o objeto cerâmico, explicitando aqui as teorias que utilizamos para guiar nossa análise e interpretação dos resultados. Devido à enorme literatura sobre este assunto, escolhemos alguns artigos para aprofundar as leituras e auxiliar na construção deste trabalho.

Iniciamos este capítulo definindo cerâmica como um material feito de argila, queimado sob baixas temperaturas, não vitrificado e relativamente poroso com o qual se faz recipientes e outros objetos (RICE, 1987: 4-5). As argilas são formadas principalmente por silicato de alumínio $\left(\mathrm{Al}_{2} \mathrm{O}_{3} \mathrm{SiO}_{2} 2 \mathrm{H}_{2} \mathrm{O}\right)$ com diferentes graus de hidratação e de quantidade de impurezas (materiais orgânicos, ferro, manganês), sendo os tipos mais comuns a caulinita, montmorilonita e ilita (RICE, 1987; SHEPARD, 1971).

A importância da argila como matéria prima pode ser vista nos mitos de diferentes sociedades, sendo muitas vezes associado à origem dos próprios humanos (RICE, 1999: 2; LÉVI-STRAUSS, 1986; van VELTHEM, 2009). Argilas coloridas devem ter sido utilizadas para pintura desde tempos remotos, assim como para se fazer contas decorativas, revestimento de cestaria, ornamentos, figuras, construção, etc. (RICE, 1999; HURCOMBE, 2007). A origem da utilização da argila especificamente para a produção de vasilhas cerâmicas é incerta, mas é a partir de três princípios básicos que podemos pensar neste material com esse propósito: quando molhada ela é plástica e pode ser facilmente moldável em uma forma que permanecerá quando secar; o fogo a deixa permanentemente dura; e suas propriedades podem ser melhoradas ao ser combinada com outros materiais (RICE, 1987: 8). Como na epígrafe deste capítulo, trata-se de um material amorfo e extremamente moldável que adquire forma a partir do trabalho da ceramista. 
Uma das hipóteses para o início da fabricação de vasilhas cerâmicas é de que elas começaram a ser feitas por mulheres para cumprir funções associadas ao transporte, preparação, produção, consumo e armazenagem de alimentos, imitando a forma de recipientes de mesma função feitos com outros materiais, em contextos de sociedades agricultoras e sedentárias devido à dificuldade de transporte desses objetos, da disponibilidade de fontes próximas de argila e conflitos de calendário com outras atividades (RICE, 1999: 6-10; SKIBO e BLINMAN, 1999: 172). Essa hipótese tem sido questionada e dado lugar a outras explicações mais robustas, como a ampliação da utilização de recursos disponíveis, relacionada com aspectos demográficos, e à elaboração simbólica e social, colocando a cerâmica em um contexto ritual (RICE, 1999; VITELLI, 1999). Assim, podemos pensar em pelo menos 3 contextos diferentes de origem e adoção de vasilhas cerâmicas (SKIBO e BLINMAN, 1999: 173): 1) agricultores sedentários que usaram vasilhas cerâmicas para processar e cozinhar alimentos; 2) caçadores-coletores com assentamentos sazonais, que utilizaram as vasilhas para extrair nutrientes adicionais dos alimentos pelo aquecimento direto ou indireto; 3) agricultores ou caçadores-coletores que utilizaram as vasilhas primeiramente em contextos rituais.

Os objetos de argila mais antigos do mundo são as figuras de Dolní-Vǐstonice, na República Checa, datadas em 26.000 AP (SKIBO e BLINMAN, 1999: 171). Objetos de cerâmica antiga foram encontrados no Japão como, por exemplo, a cerâmica Jomon de 12.700 AP (RICE, 1999: 15). No Brasil, a cerâmica mais antiga foi encontrada em contextos amazônicos, no sítio Taperinha e na caverna Pedra Pintada, Pará, com aproximadamente 8.000 AP (ROOSEVELT et al., 1996).

Apesar de não haver um consenso sobre a origem da cerâmica, o que nos interessa neste trabalho é o fato de que ela é um importante material para os estudos arqueológicos, tanto por causa de sua presença em quase todo o mundo e de sua preservação praticamente indefinida, como também porque todo o processo de manufatura de uma peça cerâmica está inscrito no produto final, podendo ser observado pelo pesquisador mesmo milhares de anos depois de seu descarte (RICE, 1987:25).

Além disso, a produção de materiais cerâmicos não é somente uma atividade econômica, pois como parte da cultura material de uma sociedade ela pertence a um contexto social e político mais amplo dentro do qual as decisões de manufatura são feitas, sendo ligada aos padrões de distribuição e consumo (RICE, 1987: 168). A importância econômica, social e simbólica da cerâmica na vida das populações ceramistas está registrada em vários trabalhos antropológicos e etnoarqueológicos: além de fundamentais na preparação e consumo de 
alimentos, as vasilhas cerâmicas, através de suas técnicas de produção, formas e decorações, são também fontes de conhecimento sobre a organização social, a cosmologia e os processos de transformação cultural dos povos que os produziram (vide p.ex. ARNOLD, 1985 e 1993; LONGRACE [ed], 1991; LONGACRE e SKIBO [ed], 1994; SILVA, 2000; STARK [ed], 1998; KRAMER, 1985 e 1997; van VELTHEM, 2009; HODDER [ed], 1991; HODDER, 2009).

Os estudos sobre cerâmica levam em conta diferentes aspectos de seu processo de produção e de seus usos e significados, trazendo diferentes pontos de vista para a discussão. $\mathrm{O}$ objeto cerâmico pode ser entendido, assim, a partir de três diferentes áreas de estudo: arqueometria, arqueologia experimental, etnoarqueologia (GOSSELAIN, 1992: 559). A análise em laboratório de fragmentos cerâmicos arqueológicos é auxiliada pelos dados produzidos por essas áreas, caracterizando os conjuntos cerâmicos e frequentemente produzindo tipologias artefatuais. No entanto, para conectar as informações provenientes destes estudos e análises de modo que possamos fazer mais do que tipologias e realmente compreender os diferentes modos de se fazer cerâmica, ou seja, as escolhas e comportamentos dos indivíduos e povos que estão por trás de toda a sequência de produção, diferentes teorias podem ser utilizadas.

\subsection{A Cerâmica como Cultura Material}

Considerando que "um dos principais objetivos da pesquisa arqueológica (...) é promover a compreensão da relação entre escolhas tecnológicas e a padronização da cultura material e como estas refletem aspectos de fronteiras e identidades sociais no registro arqueológico" (DIAS, 2007: 60), os estudos da cultura material e sua relação com as sociedades que a produziram passaram por diversos enfoques, que acompanharam os desenvolvimentos teóricos da disciplina arqueológica.

Durante a primeira metade do século XX, no período conhecido como o da Arqueologia Histórico Cultural (WEBSTER, 2008), o conceito de cultura de Franz Boas influenciou a interpretação do registro arqueológico que é entendido como uma objetificação de normas sociais, sendo por isso possível reconstituir a cultura que o produziu a partir de seu estudo. As culturas arqueológicas reconstituídas pelos pesquisadores seriam análogas às culturas etnograficamente conhecidas (WEBSTER, 2008: 12-13). 
Em relação aos artefatos, os primeiros estudos tinham como preocupação central a descrição de suas características para a formação de tipologias, relacionando cada tipo a uma sociedade específica. Os pesquisadores Willey e Phillips (1958) sistematizaram uma terminologia muito utilizada por diversos pesquisadores. A unidade básica arqueológica era denominada componente, enquanto que o conjunto único e característico de componentes distribuídos espacial e temporalmente em nível local constitui a fase. A continuidade espacial de conjuntos de traços culturais é denominada horizonte. A tradição é a persistência desses traços no tempo, com longa duração, representada por configurações tecnológicas únicas, subentendendo fases relacionadas entre si. Componentes e fases são relacionados com horizontes e tradições (DIAS, 2007: 62; CHMYZ, 1969).

Com o desenvolvimento de técnicas de análises específicas e uma maior aproximação da arqueologia com outros conceitos da antropologia, os arqueólogos passaram a se preocupar com as explicações das mudanças e permanências no registro material, tentando criar generalizações sobre o comportamento humano e descobrir regularidades que pudessem ser transformadas em leis gerais (TRIGGER, 2004: 306). As tecnologias, incluindo a produção cerâmica, foram estudadas de modo que fossem compreendidas como resultado de estratégias adaptativas, relações entre o meio natural e a organização sócio-econômica das populações (DIAS, 2007: 63).

No âmbito do que foi chamado de Arqueologia Processual (WEBSTER, 2008: 31), na década de 60 e 70, foram desenvolvidos muitos trabalhos etnoarqueológicos e de arqueologia experimental com o intuito de se compreender como o comportamento cultural humano gerava os registros arqueológicos. Técnicas de análises físico-químicas foram aplicadas aos estudos arqueológicos, desenvolvendo a área da arqueometria. A arqueologia comportamental de Schiffer e a noção de ciclo de vida dos artefatos - uma adaptação de cadeia operatória de Leroi-Gourhan - surgiram dentro deste contexto.

Já na década de 80 , cresceram as pesquisas preocupadas com os aspectos relativos à construção simbólica e identitária da cultura material. As Arqueologias Pós-Processuais (SHANKS, 2008) passaram a considerar a variabilidade dos objetos como o resultado de diversos processos dinâmicos e intrincados de socialização, uso, distribuição, troca, descarte, etc., intra e intergrupos, de um mesmo contexto cultural ou da relação entre diferentes contextos culturais, ao invés do caráter exclusivamente empiricista atribuído à Arqueologia Processual. Mesmo que as técnicas e métodos não tenham mudado de uma corrente para outra, os enfoques no caráter simbólico da cultura material e de seu papel ativo e 
transformador nas sociedades humanas trouxeram inúmeras contribuições para a arqueologia (SHANKS, 2008; SILVA, 2000).

Para estudar a cultura material hoje, temos o acúmulo de diversos estudos e discussões e podemos entender um objeto, como a cerâmica, a partir de diferentes perspectivas com um olhar muito mais crítico. Nas últimas décadas houve muito investimento por parte dos arqueólogos e etnoarqueólogos nos estudos sobre cerâmica, focando sobre o papel das pessoas como os produtores dos objetos cerâmicos e seus usos e significados (HEGMON, 2000; STARK et al., 2008; HODDER [ed], 1991).

A arqueologia experimental, baseada no raciocínio analógico, foi desenvolvendo pesquisas com objetivos mais claros e delimitados (ver FERGUSON [ed.], 210) podendo ser definida como "a fabricação de materiais, comportamentos ou ambos de modo a observar um ou mais processos envolvidos na produção, uso, descarte, deterioração ou recuperação da cultura material" (SKIBO, 1992: 18). Podemos dividir essa área em experimentos de laboratório controlados (que prezam a replicabilidade) e experimentos de campo (pouco controle de variáveis para testes em condições mais naturais) (SKIBO, 1992b). Os objetivos de longo prazo de tais experimentos são a construção de um banco de dados robusto para inferências arqueológicas, pois as variáveis são tantas que nenhum experimento sozinho consegue dar conta de todas elas ao mesmo tempo (HARRY, 2010: 20).

Para um maior refinamento da caracterização do material cerâmico, é possível a utilização de algumas técnicas atômico-nucleares e moleculares não destrutivas ou microdestrutivas, que quando utilizadas por arqueólogos são chamadas técnicas arqueométricas. Existem diversas técnicas que variam desde a possibilidade de portabilidade até seu grau de definição ou tipo de elemento detectado. Muitos avanços foram feitos nessa área e essas técnicas são cada vez mais utilizadas no Brasil (p. ex.: SILVA, APPOLONI et al., 2004; FELICÍSSIMO et al, 2006; APPOLONI e PARREIRA, 2007; MILHEIRA et al., 2009; ALVES, 1997 e 2013; JÁCOME, 2006; RODRIGUES, 2011; LIMA, 2010).

O campo da etnoarqueologia, termo cunhado por Fewkes em torno de 1900 (SKIBO, 1992b), tornou-se uma sub-área ou subdisciplina da arqueologia que "estuda sociedades contemporâneas para testar hipóteses, formular modelos interpretativos e teorizações sobre a relação entre as pessoas e o mundo material" (SILVA, 2009b: 122). É uma estratégia ou campo de pesquisa (e não um método ou teoria), que tem como preocupação o entendimento da relação entre o comportamento humano e os vestígios materiais relacionados a ele, 
possibilitando a construção de "referenciais etnográficos que sirvam de subsídio às interpretações arqueológicas sobre o passado"4 (SILVA, 2009b: 131).

A etnoarqueologia focada na produção cerâmica trouxe muitos avanços para os estudos deste tipo de material (vide LONGACRE [ed.], 1991; STARK, 1998; STARK et al., 2008; SKIBO e FEINMAN [ed.], 1999). A observação em sociedades do presente da manufatura de objetos, suas características formais, os significados de sua variação estilística e seu contexto social de produção são aspectos que trazem informações bastante úteis para nos auxiliar na interpretação e análise de materiais arqueológicos. Como as mudanças do mundo globalizado tem afetado rapidamente as comunidades que ainda praticam técnicas tradicionais de produção de artefatos, os relatos etnoarqueológicos também são importantes por contribuírem para uma etnografia histórica (LANE, 2010: 412).

Apesar da diversidade das pesquisas, tanto em suas estratégias como nas abordagens e objetivos finais (SILVA, 2009b), existem alguns pontos em comum que definem essa subárea (LANE, 2010: 404):

- é conduzida entre sociedades vivas por indivíduos treinados arqueologicamente;

- envolve o uso combinado de métodos antropológicos de observação participante e procedimentos arqueológicos comuns para o registro de sítios, feições estruturais e artefatos;

- o propósito geral é juntar informações diretamente relevantes para auxiliar na interpretação de vestígios arqueológicos e para responder à perguntas arqueológicas;

- é desenvolvida particularmente para investigar e documentar:

○ o processo no qual a cultura material e resíduos entram no ou criam os registros arqueológicos;

- as causas da variabilidade na cultura material e sua organização espaço-temporal;

$\circ$ as relações entre tal variabilidade e ações/comportamentos humanos, sistemas de significado, organização social e/ou padrões de crenças.

\footnotetext{
${ }^{4}$ Para mais detalhes sobre a discussão da relação entre etnoarqueologia e analogia etnográfica, ver SILVA, 2009b:123-131.
} 
Partindo dessas três abordagens (arqueologia experimental, arqueomteria, etnoarqueologia), os estudos da cultura material levam em conta o fato de que ela é de fundamental importância "na transmissão e preservação de conhecimentos e na orientação das pessoas em seu ambiente natural e social” (SILVA, 2000: 20). Sua análise possibilita alcançar o entendimento de "seus diferentes papéis na vida social", sua importância na vida econômica e cotidiana das populações que o fabricaram e utilizaram, assim como da "organização social, vida ritual, cosmologia e estratégias de manutenção das identidades culturais" (SILVA, 2000: 21).

\subsection{A Cerâmica como Tecnologia}

Ultrapassando os estudos dos objetos em si, existem os estudos das tecnologias. Tecnologia pode ser, de modo geral, entendida como "o conjunto de artefatos, comportamentos e conhecimentos empregados pelo homem na transformação e utilização do mundo material" (SILVA, 2000: 21). Para entender a tecnologia de produção cerâmica, no contexto da T. I. Kaiabi, utilizamos as teorias de Lemonnier e Schiffer, as quais consideramos complementares.

As considerações de Mauss de que toda ação humana é aprendida culturalmente, desde o jeito de caminhar até a produção de um artefato cerâmico, os trabalhos comparativos de Leroi-Gourhan sobre os conjuntos tecnológicos e as considerações de Lévi-Strauss sobre o caráter sistêmico e contextual das técnicas, deram um novo impulso aos estudos das tecnologias (SILVA, 2000: 21). Pierre Lemonnier apoiou-se nestes autores para elaborar uma teoria da tecnologia que considera toda ação humana no mundo material como um produto social e, consequentemente, tentando compreender as tecnologias como o resultado de escolhas culturalmente definidas (LEMONNIER, 1992: 4).

Para Lemonnier, compreender uma tecnologia implica em considerar a noção de sistema tecnológico, que pode ser compreendido a partir de três níveis distintos: 1) das interações entre os cinco componentes das técnicas (matéria, energia, ferramentas, gestos e conhecimento específico) que formam uma tecnologia; 2) das interações entre as tecnologias de uma sociedade; e 3) da interação entre as tecnologias e outros fenômenos sociais (LEMONNIER, 1992: 8-9).

O primeiro nível do sistema tecnológico são as técnicas, definidas por Lemonnier a partir de Mauss como: uma ação que é efetiva e tradicional, percebida pelo ator como 
mecânica, física ou psico-química e perseguida com esse objetivo em vista (LEMONNIER, 1992: 5). Nesta definição, ação refere-se aos movimentos propositais do corpo; efetivo quer dizer que o resultado material obtido pela ação é aquele que é procurado; e tradicional é que esses movimentos são herdados do passado e aprendidos pelas pessoas. As técnicas podem ser compreendidas por meio de cinco componentes básicos relacionados entre si, que compõem as tecnologias (LEMONNIER, 1992: 5-6): 1) as matérias-primas utilizadas para a produção do artefato (na produção cerâmica seriam, por exemplo, a argila, água e pigmentos); 2) as fontes de energia para a produção (constituídas principalmente da força da ceramista); 3) as ferramentas que auxiliam a produção (as mãos da ceramista, pedras para alisar, instrumentos de incisão); 4) os gestos que organizam os três primeiros elementos em ações tecnológicas; 5) e os conhecimentos específicos (habilidades manuais, "know-how") que organizam as ações tecnológicas em sequências específicas, resultado de todas as possibilidades e escolhas percebidas que transformam as matérias-primas em um produto pronto para ser utilizado como está ou como parte de outra técnica.

O segundo nível de um sistema tecnológico é o da relação entre as tecnologias de uma sociedade. Como mencionado acima, o produto final de uma técnica pode ser utilizado como matéria-prima para outra. E não é somente o compartilhamento de ferramentas e matérias-primas que caracteriza as relações entre as tecnologias, mas também o de atores, lugares, artefatos, sequências de gestos, etc. (LEMONNIER, 1992: 8). Por exemplo, a tecnologia cerâmica está intimamente relacionada com a culinária, pois não só o produto final de uma é usado para a outra (as vasilhas) como as ceramistas são também as cozinheiras.

No terceiro nível do sistema tecnológico é preciso entender como ele se relaciona com outros sistemas da sociedade em que está inserido. Por exemplo, a cosmologia de uma sociedade pode influenciar no tipo e no modo de extraçào da matéria-prima a ser utilizada para a produção de uma vasilha cerâmica. Por exemplo, entre os Asurini o barro é propriedade das abelhas, que acompanham a personagem mítica ao local de extração, um espaço feminino que é proibido aos homens. Mesmo mulheres grávidas ou menstruadas não podem retirar a argila, senão as vasilhas podem quebrar durante a queima (SILVA, 2000). Entre os Wayana, o mito de criação das mulheres a partir da cera, argila e palha de arumã é diretamente relacionado à criação de tecnologias e a produção de artefatos utilizados por esse povo (van VELTHEM, 2009).

É esse caráter sistêmico das tecnologias que nos permite pensar que elas são mediações entre as leis naturais (p. ex. ciência dos materiais) e a infinita inventividade das culturas (LEMONNIER, 1993: 10), o que permite também entender os cinco componentes 
das técnicas como "áreas de escolha". Para a determinação de cada componente, estão envolvidas escolhas feitas pela artesã em relação às características que ela deseja obter do produto final, mas também em relação a uma grande variedade de fatores sociais, econômicos, ideológicos e culturais que formam sua própria percepção de quais opções estão disponíveis para que ela possa escolher (SILLAR e TITE, 2000: 4).

Essas escolhas são possíveis de observar durante toda a sequência de produção de uma vasilha cerâmica (LEMONNIER, 1993: 10; van der LEEUW, 1991) e são resultado da adesão a técnicas particulares durante a história da sociedade, mesmo havendo alternativas igualmente viáveis e que produzissem os mesmos resultados (LEMONNIER, 1992: 18). As técnicas podem não fazer sentido do ponto de vista de seu objetivo material, mas com certeza são coerentes do ponto de vista da lógica social, mesmo que na maioria dos casos envolva processos de escolhas inconscientes (LEMONNIER, 1993: 4). É importante ressaltar aqui que Lemonnier não nega as limitações impostas pelas propriedades físico-químicas dos materiais nas tecnologias, mas ele considera que essas limitações tem pouca influência em comparação com as de representações, crenças e ideias que pouco tem a ver com lógicas científicas, tecnológicas ou econômicas (LEMONNIER, 1992: 19), preocupando-se muito mais com as escolhas arbitrárias na cultura material.

Para compreender como se dão essas escolhas durante o processo de produção de um artefato, Lemonnier utiliza o conceito de chaîne opératoire (cadeia operatória), desenvolvido por Leroi-Gourhan desde a década de 1940. A análise da cadeia operatória é o estudo da série de operações feitas pela artesã para a transformação de matérias-primas em produtos (não necessariamente finais), considerando que para cada operação há uma escolha feita que é social e culturalmente enraizada (LEMONNIER, 1992). Os diferentes significados imbuídos nas escolhas feitas em cada etapa é que configuram cada sequência como diferentes modos de se fazer um artefato, registrando nessas sequências diferenças culturais.

A cadeia operatória de produção cerâmica segue, em linhas gerais, as seguintes etapas: procura da matéria-prima, seu transporte e tratamento; processo de formação da vasilha; secagem; acabamentos de superfície pré-queima; queima; acabamentos de superfície pós-queima; uso e consumo; distribuição; armazenagem; descarte; reutilização; e descarte final. O detalhamento dessa descrição tem como objetivo a compreensão da singularidade de cada cadeia operatória, entendendo porque foram feitas certas escolhas e como elas se relacionam com outros aspectos do sistema cultural, compreendendo assim as "associações entre o mundo material, o social e o universo simbólico de diferentes grupos humanos" (SILVA, 2000: 23-24). Mesmo na análise da cerâmica arqueológica, para a qual o processo de 
produção não está disponível com este nível de detalhamento, pode ser possível realizar uma análise de atributos que seja pensada em relação à cadeia operatória, como explicado no próximo capítulo.

A outra teoria da tecnologia que utilizamos neste trabalho foi desenvolvida no âmbito da Arqueologia Comportamental de Michael Schiffer, que tem como princípio a ideia de que as teorias do comportamento humano devem ser baseadas em artefatos, já que a vida humana consiste em inúmeras e incessáveis interações entre pessoas e diferentes objetos (SCHIFFER, 2010: 13).

A sequência operatória de produção de um artefato é entendida como cadeia comportamental, que compreende a sequência completa de atividades durante a história de vida do artefato, sendo cada atividade específica nomeada como escolha técnica (SCHIFFER e SKIBO, 1997: 29). Para Schiffer e Skibo, o termo escolha presume simplesmente que para cada atividade existe uma alternativa que não foi utilizada e/ou realizada. Apesar de também considerarem as tecnologias como produtos sociais, sua preocupação não é com as escolhas arbitrárias na cultura material e sua localização no sistema cultural. $\mathrm{O}$ foco destes autores está nas escolhas motivadas pelas propriedades físico-químicas dos materiais, para entender em que medida essas propriedades são fatores limitantes nas escolhas em relação às performances desejadas do produto final.

O detalhamento dessa sequência de produção tem por objetivo último a compreensão das causas da variabilidade artefatual, ou seja, os diferentes comportamentos que criaram diferentes artefatos. Essa variabilidade pode ser explicada de acordo com 4 dimensões (SCHIFFER, 2010: 19): 1) a variabilidade formal, que se refere às propriedades físicas e químicas mensuráveis de um artefato; 2) a variabilidade espacial, que se refere à localização ou lugar de achado do artefato; 3) a variabilidade frequencial ou quantitativa, que é o número de ocorrências de um tipo de artefato em uma unidade espacial, sua distribuição; e 4) a variabilidade relacional ou associacional, que compreende os padrões de coocorrência dentro de ou entre unidades espaciais.

Neste trabalho, focamos na variabilidade formal, já que não temos dados suficientes para elaborar uma interpretação nas outras dimensões. Para isso, as propriedades mensuráveis de fragmentos de vasilhas cerâmicas significantes em nosso estudo (que serão melhor explicadas no próximo capitulo) são: o tratamento da pasta, o processo de manufatura, a forma geral da vasilha, suas medidas (diâmetro, altura, espessura, capacidade volumétrica, etc.), atributos relativos à queima, acabamentos de superfície e atributos relativos ao uso. A causa da variabilidade nesses atributos são as escolhas feitas nas diferentes sequências de 
produção empregadas pelas artesãs e que configuram diferentes cadeias comportamentais (SCHIFFER e SKIBO, 1997: 28). Essas diferentes cadeias não necessariamente significam diferenças culturais, mas podem estar relacionadas às diferentes performances.

Cada propriedade dos materiais e cada técnica utilizada para a produção de uma vasilha cerâmica são fundamentais para a definição das características do produto final, chamadas características de performance. Uma característica de performance é a capacidade, competência ou habilidade que pode ser exercida por um determinado artefato em uma performance, sendo comportamentalmente relevante em uma interação específica (SCHIFFER, 2010: 90). Essas características podem ser de natureza física, química, térmica, elétrica ou mesmo sensorial, sendo fortemente influenciadas pelas propriedades formais do objeto, que por sua vez são determinadas pelas escolhas técnicas. Os resultados dessas performances garantem um retorno para a artesã, que pode então saber se suas escolhas obtiveram resultados satisfatórios.

Para que o pesquisador possa fazer a ponte entre as escolhas feitas e as performances das vasilhas, ele pode observar os resultados desta inter-relação a partir do princípio de correlatos (SCHIFFER e SKIBO, 1997: 32). Os correlatos são as leis experimentais e teorias de baixo alcance que os cientistas formulam para explicar esses efeitos, sendo que uma matriz de correlatos representaria os princípios relevantes para entendermos as interações em uma cadeia comportamental de um artefato. Assim, o pesquisador pode especificar quais escolhas técnicas estavam disponíveis para que a artesã resolvesse certos problemas de performance a partir dos materiais escolhidos e também delinear os efeitos delas, por meio de propriedades formais das características de performance.

Apesar de parecerem opostas em alguns sentidos, por causa da ênfase nas diferentes motivações das escolhas feitas durante a cadeia de produção do artefato, as teorias propostas por Lemonnier e Schiffer e Skibo podem ser utilizadas de modo complementar nos estudos da cultura material (SILVA, 2000; SILLAR e TITE, 2000). Se considerarmos a tecnologia como um fato social total (no sentido de Mauss, de que é um fenômeno simultaneamente material, social e simbólico), podemos perceber a criação e uso da tecnologia como modos de humanizar a natureza, que expressam diferentes visões sociais, engajando as pessoas em diferentes modos de vida (PFAFFENBERGER, 1988: 236).

Segundo Silva (2000: 29), é possível realizarmos o estudo de objetos de um modo que a dimensão material e os aspectos simbólicos possam ser vistos de maneira intimamente relacionada, sendo por isso mesmo muitas vezes difícil de distinguir os limites entre uma 
dimensão e outra. Assim, utilizaremos o termo escolha tecnológica, englobando tanto as escolhas motivadas pelos aspectos materiais como simbólicos.

O trabalho de Gosselain (1992) sobre os Bafia de Camarões mostra justamente como se dão as escolhas em cada etapa da cadeia operatória de produção cerâmica. Em todas as etapas é possível identificar restrições físico-químicas e ambientais que forçariam os ceramistas a trabalhar de certa maneira para obter uma vasilha cerâmica. No entanto, o autor nos mostra que dentro de cada grupo (e mesmo entre os indivíduos) são feitas escolhas (conscientes ou não) que fazem com que essas limitações sejam superadas como, por exemplo, a decisão de se adicionar um material antiplástico à argila de determinado depósito para que ela possa ser utilizada para a fabricação de vasilhas, ao invés de utilizar um depósito com argila que já contenha as qualidades desejadas. Gosselain também mostra que por trás de cada escolha aparentemente pragmática, existem elaborações culturais, simbólicas e sociais que justificam essas escolhas e que muitas vezes acabam diferenciando modos de se fazer cerâmica. Um exemplo deste tipo vem dos Luo no Quênia, que apesar dos diferentes grupos ceramistas utilizarem apenas um tipo de areia como antiplástico, um determinado grupo utiliza caco moído como forma de diferenciação, mesmo este antiplástico tendo as mesmas características da areia, que além de tudo é mais fácil de utilizar (DIETLER e HERBICH, 1989).

O propósito de investigar as escolhas tecnológicas é questionar as técnicas e materiais que a artesã escolheu usar e as consequências de sua escolha, visualizando o que ela queria ter conseguido com isso (SILLAR e TITE, 2000: 3). Como podemos observar na figura 6, a produção de uma vasilha cerâmica é totalmente interligada com diferentes elementos e cada um destes elementos é complexamente dependente de outro. 


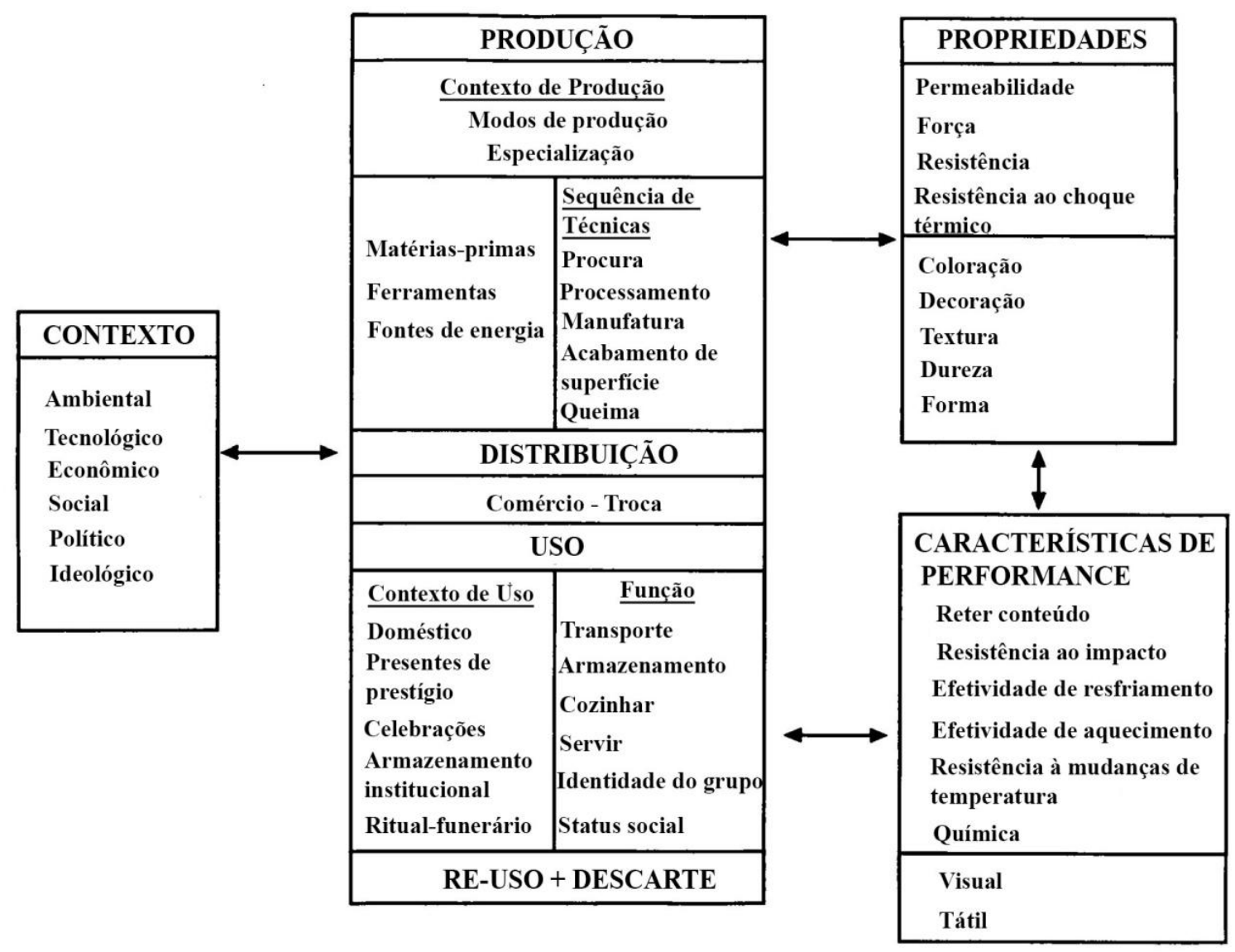

Figura 6: Diagrama resumindo as relações mais importantes que afetam as escolhas tecnológicas na produção cerâmica (Adaptado de SILLAR e TITE, 2000: 6).

\subsection{Cerâmica e Estilos Tecnológicos}

Para entender melhor como uma ceramista faz suas escolhas durante a cadeia de produção de uma vasilha e as transmite de geração em geração, de modo que essa sequência possa ser associada a um modo específico de se fazer cerâmica, precisamos compreender melhor como se dá o processo de ensino/aprendizagem das técnicas e como podemos diferenciá-las a ponto de conseguirmos enxergar diferentes modos de se fazer cerâmica como diferentes estilos tecnológicos.

Teorias sobre o aprendizado social iniciaram-se a partir do trabalho de Vigotsky, que observou a importância do aprendizado em determinados estágios da infância e situou os processos de ensino/aprendizagem dentro de contextos culturais específicos através de relações sociais (BOWSER e PATTON, 2008). Muitos trabalhos foram feitos sobre este 
assunto, tanto na antropologia como na arqueologia, mostrando sua complexidade e variedade em diferentes grupos culturais e contextos específicos.

$\mathrm{Na}$ produção cerâmica, este é o processo no qual a ceramista ensina/aprende as etapas de produção, podendo ser controlado por diversos graus de rigidez. A aprendizagem desta tecnologia vai determinar culturalmente as escolhas tecnológicas disponíveis para a ceramista, assim como muitos dos comportamentos socialmente aceitáveis no grupo (WALLAERT, 2008). O aprendizado vai depender do período de duração, a idade em que se começa a aprender, da relação entre aprendiz e instrutor, e também da contínua aprendizagem durante toda a vida da ceramista (WALLAERT, 2008). Pode ser de mãe para filha desde muito nova, de sogra para nora e aprendido após o casamento (HERBICH e DIETLER, 2008), pode ser controlado por uma classe específica de produtores de cerâmica com um rigor muito grande (WALLAERT, 2008) ou ser uma prática generalizada entre as mulheres do grupo (SILVA, 2000).

É um processo que envolve o ensino de gestos e habilidades manuais específicas, que vão sendo aprendidos pela observação, memória visual, fala e conhecimento teórico (WALLAERT, 2008). Segundo Ingold, a aprendizagem de uma habilidade (ou técnica) é feita não somente pela transmissão de fórmulas ou instruções, mas principalmente pela observação e imitação das práticas de artesãs mais habilidosas. É a prática de movimentos regulares e controlados que faz com que a artesã personifique os movimentos de uma técnica e a aprenda por meio de suas próprias percepções, sendo por isso que a execução de uma pessoa nunca será igual à de outra; a internalização dos movimentos é única para cada uma (INGOLD, 2001: 22-24). A persistência das técnicas como estilos ou tradições pode ser explicada pela reprodução de padrões de movimentos ao longo de sequências de produção, uma função da coordenação da percepção e da prática mimética (INGOLD, 2001: 25).

Assim, apesar da tecnologia ser aprendida dentro de um contexto cultural mais abrangente, ela também é um aprendizado individual e sua compreensão passa pela relação dialética entre indivíduo e sociedade. Essa relação não pode ser vista pelo viés ocidental moderno, mas sempre ponderada pelo contexto histórico e local, pela intenção individual de resistência ou incorporação de estruturas sociais particulares (DORNAN, 2002: 325). A opção da ceramista por reproduzir certos padrões nas vasilhas ou inventar novos padrões pode estar relacionado com diversos elementos da organização social do grupo, como, por exemplo, as relações políticas das mulheres ao longo de sua história de vida, que fazem com que as ceramistas mudem os motivos de pintura em cada fase de sua vida dependendo de sua atuação política e alianças no grupo (BOWSER e PATTON, 2008). 
Mesmo que o nível individual seja muito importante para compreender a transmissão das técnicas, é somente pensando no conjunto das escolhas culturais feitas dentro dos contextos ambientais, tecnológicos, econômicos, sociais, políticos e ideológicos que podemos pensar na transmissão de estilos tecnológicos ao longo de gerações e na diferenciação de identidades culturais.

Por muito tempo, os pesquisadores procuraram o estilo nos atributos de forma e decoração dos objetos, separando-o de seus aspectos funcionais e desprezando outros atributos e elementos da ação tecnológica. Estilo era estudado como um fenômeno passivo, delimitado no tempo e no espaço e diretamente relacionado com grupos sociais e culturais específicos (SILVA, 2000: 188). Esse entendimento pode estar relacionado com a separação entre os conceitos de arte e tecnologia, que originalmente, no grego, compunham uma só palavra que significava "artesanato habilidoso", sentido que ainda foi retido no francês “técnica”, como prática habilidosa (INGOLD, 2001: 17-19). Essa distinção entre os modos como os objetos funcionam e o papel que eles têm na comunicação de significados acaba negando a criatividade inerente ao processo tecnológico (SILLAR e TITE, 2000: 9). Diversos autores contribuíram para a integração dos aspectos funcionais e simbólicos dos objetos, criando uma visão mais abrangente de estilo, como por exemplo, o papel ativo dos objetos nas relações entre as pessoas, na comunicação de mensagens sociais e identidades (p. ex. WOBST, 1977; WIESSNER, 1991; CONKEY e HARSTOFF [Eds.], 1991).

O conceito de Sackett de estilo isocréstico foi bastante importante para o avanço dessa discussão. Sackett (1991) utiliza a noção de estilo isocréstico para descrever a existência de opções igualmente viáveis para se chegar a algum fim na produção e/ou uso de itens materiais. Assim, o estilo não reside apenas na forma dos objetos, mas em todas as partes da cadeia de produção onde o artesão escolheu apenas uma dentre todas as opções igualmente viáveis. E, o mais importante para nossa discussão, é o fato de que essas escolhas são culturalmente transmitidas (LEMONNIER, 1992: 89-90). Assim, podemos enchergar estilo em todas as etapas de produção de um artefato.

O estilo, portanto, é hoje estudado como um elemento ativo na relação entre grupos sociais e indivíduos com o mundo material (SILVA, 2000: 188), sendo a tecnologia também um fenômeno estilístico. Os sistemas tecnológicos estão relacionados com os sistemas de representação social e são também um local de manifestação estilística (DIAS e SILVA, 2001: 96). Por isso o estilo pode ser definido em qualquer estágio da cadeia operatória, pois cada escolha é feita de acordo com o contexto ambiental e cultural do artesão (SILVA, 2000: 191). 
Dias e Silva (2001: 101) elencaram alguns pontos que resumem as discussões sobre estilo tecnológico: 1) a variabilidade é resultado de escolhas tecnológicas, que são culturalmente determinadas e indissociáveis da função; 2) as escolhas tecnológicas refletem estilos tecnológicos, que podem estar presentes desde a seleção de materiais, técnicas e sequências de produção até a aparência final do artefato; 3) sendo o produto de uma tradição cultural, os estilos podem servir como indicadores de identidades sociais e culturais.

O estilo tecnológico pode ser definido, então, como a maneira a partir da qual os indivíduos realizam o seu trabalho, incluindo as escolhas feitas por eles no que se refere aos materiais e às técnicas de produção (REEDY e REEDY, 1994: 304, apud SILVA, 2000: 190). Ou seja, é o modo como é construída a cadeia de produção de um artefato, considerando que para cada etapa as escolhas feitas mostram a percepção cultural das artesãs das alternativas disponíveis para a fabricação do artefato. Um estilo não necessariamente é associado a um grupo cultural específico, podendo estar associado a diferentes funções dos artefatos, grupos sociais ou mesmo indivíduos.

O contato com outras técnicas, mudança na disponibilidade de matérias-primas e outros fatores, podem ser importantes fontes de mudanças em um estilo tecnológico. Mudanças na organização social também podem afetar a organização da produção cerâmica. Entretanto, a variabilidade interna também pode ser explicada na escala individual, pois erros na reprodução da técnica, criatividade individual e experimentos podem levar a uma diversidade interna do estilo tecnológico em questão.

Para Lemonnier, é preciso ir além e investigar "as bases sociais das escolhas tecnológicas das quais esta é resultante e que se verifique como estas escolhas se inserem em um sistema de significados" (DIAS e SILVA, 2001: 100). Mas para Schiffer e Skibo, não faz sentido questionar se a causa da variabilidade é estilística ou funcional, e sim investigar sistematicamente os processos de ordem comportamental, social e ambiental dos quais ela resulta, pois "a variabilidade artefatual é definida pelo conhecimento do artesão e aspectos situacionais e os conceitos de estilo e função não são explicativos para se entender os motivos das escolhas dos artesãos" (DIAS e SILVA, 2001: 100).

Segundo van der Leeuw (1993), é possível ordenar os fragmentos cerâmicos de acordo com os resultados da análise de atributos, de modo a ser possível pensar nesses grupos de fragmentos em relação às tradições tecnológicas. Para o autor, uma tradição tecnológica é caracterizada por um conjunto de características, observáveis no estudo da cadeia operatória, que se perpetuam no tempo e no espaço, podendo eventualmente estar relacionadas a grupos 
culturais específicos. Mudanças na cadeia operatória podem significar mudanças na disponibilidade de matéria-prima ou mudanças na própria tradição tecnológica.

Essas mudanças ocorrem constantemente, mas não afetam igualmente todas as etapas de produção. Como todas as etapas estão interligadas, a mudança em um dos elementos pode acarretar uma mudança na cadeia inteira, mas também pode não afetá-la completamente. Por exemplo, se mudar o tipo de argila utilizado por um outro com as mesmas propriedades, a cadeia operatória pode continuar a mesma. No entanto, se as propriedades da nova argila forem totalmente diferentes, é provável que toda a cadeia operatória se modifique para se adaptar a essa mudança (RYE, 1981: 5). As partes que parecem ser menos suscetíveis às mudanças são o processo de manufatura das vasilhas e a técnica de queima, por serem processos que exigem um controle muito grande por parte das ceramistas (RYE, 1981: 5; van der LEEUW, 1993). E é também por depender menos das restrições materiais que a forma é um dos principais atributos que definem tradições tecnológicas (GOSSELAIN, 1992).

No Brasil, por muito tempo foram utilizadas as definições propostas no Terminologia arqueológica brasileira para cerâmica (CHMYZ, 1966), propondo o agrupamento de conjuntos cerâmicos em Tradições, Subtradições e Fases ${ }^{5}$. Essas classificações têm sido aprofundadas em diversas pesquisas recentes, com uma caracterização mais específica dos conjuntos cerâmicos e sua relação com outros elementos do contexto arqueológico do qual fazem parte (p. ex.: LIMA et al., 2006; GARCIA, 2012).

Nosso objetivo neste trabalho não é tentar adequar os conjuntos cerâmicos analisados em tradições arqueológicas já definidas. O que propomos é uma análise dos fragmentos cerâmicos arqueológicos por meio de atributos que se relacionam diretamente com a cadeia operatória de produção de uma vasilha completa e com o papel de cada um deles nas características de performance do objeto final. Nossa questão fundamental é tentar compreender a cadeia operatória de produção destes conjuntos, evidenciando possíveis estilos tecnológicos e refletir sobre os significados das escolhas tecnológicas realizadas pelas artesãs. Depois disso vamos comparar nossos resultados com outros conjuntos descritos na bibliografia para a região, pensando na inserção da T. I. Kaiabi no contexto de deslocamentos e ocupações de diferentes populações nestas terras da Amazônia Meridional.

\footnotetext{
${ }^{5}$ Tradição: grupo de elementos ou técnicas, com persistência temporal. Subtradição: variedades dentro de uma mesma tradição. Fase: qualquer complexo (conjunto de elementos culturais associados entre si) de cerâmica, líticos, padrões de habitação, etc., relacionados no tempo e no espaço, em um ou mais sítios. (CHMYZ, 1966).
} 


\section{ANÁLISE CERÂMICA}

"Scientific awarness can become cultural bias if used uncritically. It will show us how we see past cultures, not how the people saw themselves." (RYE, 1981:2)

Para chegarmos nesta tabela de análise dos fragmentos cerâmicos, utilizamos diversas referências, tanto dos grandes livros sobre cerâmica (RYE, 1981; SHEPARD, 1971; RICE, 1986; SINOPOLI, 1991; ORTON et al.,1997; LA SALVIA e BROCHADO, 1989) como trabalhos de diversos colegas que também analisaram esse tipo de material, seja por meio de suas dissertações e teses ou conversas informais (BESPALEZ, 2009; CORRÊA, 2009; GARCIA, 2012; AMARAL, 2012; ZUSE, 2009; ALMEIDA, 2008; com. pessoal Márjorie Lima e Jaqueline Belletti). Procuramos ordenar a tabela de acordo com as etapas de produção de uma vasilha cerâmica, escolhendo atributos ${ }^{6}$ para serem analisados que pudessem nos revelar diferentes sequências de produção, nos permitindo pensar em diferentes estilos tecnológicos.

Optamos por realizar uma análise mais geral do conjunto artefatual cerâmico do que uma análise mais detalhada de cada fragmento, porque pouco conhecemos da cerâmica desta área e seria difícil classificar o que se encontra dentro da gama de variações que faz parte de um determinado estilo e o que estaria fora dessa variação, fazendo parte de outro estilo (RYE, 1981: 28). Por exemplo, as variações de tamanho ou distribuição de antiplásticos na pasta podem estar dentro de uma variação normal, muito mais do que serem elementos diferenciadores de conjuntos. Optamos também por analisar todos os tipos de fragmentos, não

\footnotetext{
${ }^{6}$ Atributos são os fenômenos físicos observáveis e repetíveis em um fragmento cerâmico, como o antiplástico, a forma do lábio, a decoração, marcas de técnicas de construção e de queima, etc. $\mathrm{O}$ resultado da análise desses atributos pode revelar as técnicas utilizadas na produção dos objetos, sendo as técnicas ações repetidas que produzem os atributos. A série de técnicas utilizadas é o que constitui a sequência de produção de uma vasilha inteira, e é essa sequência de produção que pode nos dar elementos para definir um estilo tecnológico (RYE, 1981: 4-7)
} 
somente os considerados diagnósticos ${ }^{7}$, no entanto conseguimos reduzir a amostra a ser analisada ao considerar somente os fragmentos cerâmicos maiores que $1,5 \mathrm{~cm}^{2}$, a não ser que apresentassem algum tipo de acabamento de superfície diferenciado ou que fossem classificados como borda, já que fragmentos tão diminutos não contribuiriam tanto para uma classificação geral do conjunto artefatual cerâmico.

Muitas etapas importantes da sequência de produção, como a secagem, deixam marcas muito sutis no produto final, não sendo possível identificar atributos que se relacionam a elas. Assim, os atributos que escolhemos identificar foram separados dentro das seguintes etapas de produção cerâmica: procura e tratamento da matéria-prima; técnicas de construção da vasilha (onde incluímos atributos relacionados à morfologia); indicativos de queima; acabamentos de superfície; uso e função. Conduzimos a análise pensando em cada fragmento como parte de uma vasilha inteira, por isso muitos dos atributos só são analisados quando conseguimos reconstituir a forma completa. Apresentamos a tabela de análise a seguir (tabela 2), mas a variabilidade dos atributos com ilustrações e fotos encontra-se no Anexo A e será melhor qualificada na descrição dos resultados da análise dos sítios.

\section{Tabela de Análise de Material Cerâmico}

\section{Identificação}

1. Sítio/Número do fragmento

2. Proveniência

3. Nível

\section{Preparação da Matéria-prima}

4. Antiplástico

\section{Técnicas de Construção da Vasilha}
5. Técnica de manufatura
6. Categoria estrutural
7. Variante de base
8. Variante de parede
9. Variante de borda
10. Variante de lábio
11. Variante de apêndice
12. Diâmetro da base
13. Diâmetro da boca
14. Diâmetro máximo

\footnotetext{
${ }^{7}$ Nas análises de laboratório, são usualmente considerados fragmentos cerâmicos diagnósticos aqueles com características relevantes em relação à morfologia da vasilha (como bordas, bases e paredes carenadas, infletidas, etc) ou ao acabamento de superfície (que não seja alisamento ou polimento).
} 
15. Altura

16. Espessura

17. Espessura (código)

18. Massa

19. Volume

20. Ângulo de inclinação

21. Relação boca/corpo

22. Contorno específico

23. Classe estrutural

24. Forma

\section{Indicativos de Queima}

25. Núcleo

26. Coloração da face externa

27. Coloração da face interna

28. Marca de Queima

V. Acabamento de superfície

29. Face externa

30. Face interna

31. Lábio

32. Apêndice

33. Posição

34. Grafismos

VI. Uso

35. Uso e Função

36. Marcas de uso

VII.Classificação

37. Classificação

Tabela 2: Tabela de análise do material cerâmico. 


\subsection{Identificação}

Cada fragmento foi identificado com a sigla de numeração de seu sítio, seguido de um número, iniciando em 1. No campo da proveniência, está discriminado se o fragmento foi coletado na superfície, nas sondagens ou nos poços teste. O nível refere-se à distribuição vertical do fragmento no sítio, se no nível 0 (superfície) ou nos níveis artificiais da escavação em subsuperfície (de 10 em $10 \mathrm{~cm})$.

\subsection{Procura e Tratamento da Matéria Prima}

O primeiro aspecto a ser levado em conta nas etapas de fabricação de uma vasilha cerâmica é a procura e seleção da matéria-prima, especialmente a argila. Muitas etapas deste processo não são possíveis de identificar no fragmento, por isso optamos por identificar o elemento antiplástico presente nos fragmentos e pensar na composição da pasta a partir da análise arqueométrica de alguns fragmentos.

Quando as características naturais da fonte de argila não são satisfatórias para a ceramista, ela pode adicionar outros materiais para mudá-las ou melhorá-las, o que resulta na pasta, que é a argila modificada para ser utilizada. Um componente da pasta que podemos observar na lupa binocular é o antiplástico, elemento que regula a plasticidade da argila, tornando possível seu manuseio e modelagem por meio de diferentes técnicas de manufatura (ORTON et al., 1997: 117). O antiplástico também é importante para regular o encolhimento excessivo do corpo cerâmico durante a secagem e queima, já que reduz a superfície absorvedora de água e sustenta o esqueleto da vasilha (SHEPARD, 1971: 24; ORTON et al., 1997: 117). Além disso, influencia as características físicas do produto final, pois pode ressaltar características térmicas, força mecânica e a porosidade da vasilha (ORTON et al., 1993: 117; CHILTON, 1998; SKIBO, 1992).

Até o momento, os antiplásticos encontrados nos conjuntos de fragmentos analisados foram mineral (usualmente quartzo, ferro, mica, feldispato), caco moído, cauixi, caraipé $e^{8}$, carvão, e diferentes combinações entre eles.

\footnotetext{
${ }^{8}$ Utilizamos a grafia caraipé seguindo CARNEIRO, 2009
} 
Para obter mais informações sobre a composição da pasta, realizamos análises arqueométricas que nos informaram mais sobre a argila e seu preparo. Essa análise foi conduzida pelo Grupo de Física Aplicada com Aceleradores da USP, sendo utilizado como método de análise a Fluorescência de Raios X (XRF - X Ray Fluorescence). Nesta técnica, a amostra é bombardeada por um feixe de fótons de alta energia que é absorvido pelos átomos, que por sua vez emitem um raio X característico de cada elemento que é medido (STUART, 2007: 234). Não é possível identificar a composição química dos elementos na amostra, somente os elementos constituentes (CURADO, RIZZUTT e MOTA, 2014).

Foram analisados 20 fragmentos cerâmicos, com um sistema portátil de Fluorescência de Raio X com filamento de prata e um detector SSD, modelo XR-100SSD de resolução 150eV@Mn Ka ambos da Amptek (CURADO, RIZZUTT e MOTA, 2014: 2). Foram medidos pelo menos 2 pontos em cada amostra, evitando-se os locais com inclusões minerais ou antiplásticos. A área irradiada um círculo de $4 \mathrm{~mm}$ de raio, a distância entre a amostra e o detector de raios $\mathrm{X}$ cerca de $1,3 \mathrm{~cm}$, com tensão de $30 \mathrm{kV}, 5 \mu \mathrm{A}$ e tempo de aquisição de 100 s. Foi utilizada a configuração horizontal do sistema, com o detector na frente da amostra e o tubo de raios X com ângulo de 45 graus. A calibração foi feita com uma amostra de Chumbo de espessura milimétrica (CURADO, RIZZUTT e MOTA, 2014: 2). Os resultados desta análises serão discutidos no Capítulo 5.

\subsection{Técnicas de Construção da Vasilha}

A técnica de manufatura da vasilha pode ser observada a olho nu, mas uma análise arqueométrica adequada, como a radiografia, poderia refinar nossa percepção sobre esse processo. Existem diversas técnicas para transformar uma quantia amorfa de argila em uma vasilha cerâmica com forma e função específica, técnicas essas que podem ser combinadas de diversas maneiras e com diferentes propósitos, dependendo das características do material utilizado e da forma e tamanho que se deseja obter. É um dos elementos mais importantes na classificação de vasilhas cerâmicas, já que na cadeia operatória seria o elemento mais difícil de ser modificado, sendo, portanto, central na caracterização de tradições tecnológicas (van der LEEUW, 1993) e na marcação de limites culturais (DEGOY, 2008). As técnicas de manufatura que pudemos identificar em nossa análise foram: roletado e modelado.

O roletado é uma técnica que se utiliza de roletes de argila sobrepostos de maneira circular ou em espiral, unidos posteriormente por diversas técnicas, como alisamento com 
dedo ou com instrumento, corrugado, etc. (SHEPARD, 1971: 57-59). A vantagem dessa técnica é que ela permite que se utilize uma argila menos plástica, portanto sem a necessidade de muito material antiplástico, além de garantir uma maior uniformidade de espessura da parede desde o começo, mas tem a desvantagem de ser uma técnica mais demorada e que tem a junção entre os roletes como uma potencial fonte de falhas posteriores, como rachaduras (SHEPARD, 1971: 57-59).

A técnica de modelagem é feita a partir de um bloco de argila, mais ou menos do tamanho que se quer a vasilha, que se vai moldando na forma desejada (SHEPARD, 1971: 5557). Para uniformizar a espessura e homogeneizar a superfície pode-se utilizar diversas técnicas, como pedras, pedaços de pau e a própria mão (SHEPARD, 1971: 55-57). Esta é uma técnica utilizada para vasilhas não muito grandes, apêndices e bases, além de outros artefatos cerâmicos com formas mais complexas, como estatuetas.

As duas técnicas são frequentemente combinadas. Por exemplo, pode-se modelar a base para depois adicionar os roletes para a construção do resto da vasilha; apêndices e outros apliques podem ser modelados e adicionados em vasilhas construídas por roletes; a vasilha modelada pode ter roletes colocados na borda para completá-la; etc.

As técnicas de construção vão definir os aspectos morfológicos da vasilha. Como trabalhamos basicamente com fragmentos, podemos dividir a vasilha em partes com diferentes nomenclaturas, as categorias estruturais. Vasilhas cerâmicas são, em diversas ocasiões, comparadas com o corpo humano (RICE, 1987: 212-215; DAVID et al., 1988; SILVA, 2000), por isso chamamos de corpo a vasilha toda, do orifício até a base, e suas partes às vezes têm nomes relacionados ao corpo humano: parede é qualquer fragmento do corpo da vasilha que não corresponde às partes específicas citadas na seqüência; a borda é a parte do orifício de abertura (boca) que contém o lábio, a margem desse orifício; base é a parte inferior da vasilha em contato com a superfície de apoio; a parte de restrição do orifício que começa acima do ponto de diâmetro máximo (ombro), é chamada de pescoço; um apêndice é uma projeção que se estende da vasilha, geralmente aplicado.Cada categoria estrutural pode ser classificada de várias maneiras, de acordo com sua posição em relação à vasilha e sua forma específica (Cf. RICE, 1987; SHEPARD, 1971).

Também foram classificados pedaços modelados de argila, queimada ou não, chamados bolota de argila que, apesar de não pertencerem a nenhuma categoria estrutural da vasilha, podem fazer parte de seu processo de produção.

A espessura do fragmento pode ser medida com um paquímetro. As medidas exatas em milímetros foram anotadas para cada fragmento, mas também classificamos as medidas 
em muito fino, para medidas menores que $5 \mathrm{~mm}$; fino, entre $6 \mathrm{~mm}$ e $10 \mathrm{~mm}$; médio, entre 11 $\mathrm{mm}$ e $15 \mathrm{~mm}$; grosso, entre $16 \mathrm{~mm}$ e $20 \mathrm{~mm}$; e muito grosso, para medidas maiores que 20 $\mathrm{mm}$.

Todos os fragmentos foram pesados em uma balança para a anotação da massa.

Dependendo do tamanho do fragmento da borda, podemos reconstituir a forma da vasilha inteira. Para isso, precisamos identificar seu ângulo de inclinação e seu diâmetro.A posição que o fragmento deveria ocupar na vasilha, vista lateralmente, é o ângulo. O método utilizado é o de orientar a borda apoiando o lábio sobre uma superfície plana, partindo do pressuposto de que o plano da boca das vasilhas se encontra em posição relativamente horizontal na posição de uso (BROCHADO et al., 1990: 727). O diâmetro da boca foi medido somente quando constituía $12 \%$ do diâmetro total, ou quando podíamos estimar essa medida a partir da medida de outro ponto da vasilha (como o ângulo de inflexão ou o diâmetro máximo), utilizando um medidor de curvas. $\mathrm{O}$ diâmetro pode ser calculado ao colocarmos o fragmento (ou a curva) "sobre um ábaco de círculos concêntricos divididos em intervalos de um ou dois centímetros" (BROCHADO et al., 1990: 728), partindo do pressuposto de que a boca (e demais medidas) é circular. O mesmo processo pode ser feito para medir o diâmetro da base. Somente a partir de uma reconstituição de formas inteiras é que podemos medir o diâmetro máximo,o volume ${ }^{9}$ e a altura da vasilha, assim como ter noção de sua forma.

A forma final pode estar relacionada com a funcionalidade e padrões estéticos, apesar de raramente serem relações fixas, podendo ser verificadas somente após um longo estudo (como para a cerâmica Guarani em LA SALVIA e BROCHADO, 1989), além de serem possíveis marcadores culturais. No entanto, a forma possui fatores limitantes, como os requerimentos para a estabilidade da vasilha em alguma superfície (geralmente plana) e algumas exigências específicas de cada função para a qual a vasilha foi feita (SHEPARD, 1971; SKIBO e BLINMAN, 1999). Aspectos estéticos valorizados pela cultura e pelo artista podem influenciar a forma, assim como a proporção, relação entre as partes, manuseio da curvatura e complexidade de contorno, ou seja, número e tipos de pontos característicos (SHEPARD, 1971: 251).

Para classificá-las, utilizamos a abordagem de Shepard, que considera a comparação com as formas geométricas para as vasilhas que tem simetria em relação a um eixo de revolução, o que exclui as vasilhas com formas de objetos naturais (SHEPARD, 1971: 228).

\footnotetext{
${ }^{9} \mathrm{O}$ volume foi calculado a partir de uma fórmula no excel utilizada em ALMEIDA, 2013.
} 
Isso não significa que as formas das vasilhas sejam matematicamente perfeitas, mas que elas podem ser definidas com referência às formas geométricas: esférica, semi-esférica, elíptica vertical, semi-elíptica vertical, elíptica horizontal, semi-elíptica horizontal, oval vertical, semi-oval vertical, oval invertido, semi-oval invertido, cilíndrica, cônica, hiperbólica, semihiperbólica (SHEPARD, 1971: 234).

Para auxiliar nessa reconstituição, podemos considerar os pontos característicos da vasilha: o ponto final, que indica o limite da vasilha na base e no lábio; o ponto de tangência vertical, que é o ponto de diâmetro máximo e mínimo; o ponto de quebra, onde a direção da tangente muda abruptamente; o ponto de inflexão, onde a curvatura muda de côncava para convexa e vice-versa (SHEPARD, 1971: 226). É por meio desses pontos que o contorno é classificado como simples, quando tem apenas pontos finais; infletido, caracterizado pelo ponto de inflexão; composto, que pode ou não ter pontos de tangência vertical, mas não tem pontos de inflexão; e complexo, com dois ou mais pontos de virada e de inflexão, ou com os dois pontos (SHEPARD, 1971: 232).

A relação do diâmetro da boca e do corpo pode ser tirada dessas medidas, e as vasilhas podem ser caracterizadas como abertas, se o diâmetro do orifício for maior que o diâmetro máximo, ou fechadas, se for o contrário. Paredes carenadas e infletidas podem ser uma evidência de que a vasilha é fechada. Outro atributo derivado dessas medidas é a classe estrutural da vasilha: não restringida, com diâmetro do orifício sendo maior ou igual ao diâmetro máximo da vasilha; restringida, com diâmetro do orifício menor que o diâmetro máximo da vasilha; restringida independente, com um ponto de virada ou de inflexão acima do diâmetro máximo (SHEPARD, 1971:229-231).

\subsection{Queima}

A queima é uma etapa fundamental na cadeia operatória, pois ela vai transformar os minerais da argila em cerâmica, um processo que começa a uma temperatura mais ou menos entre $550^{\circ} \mathrm{C}$ e $600^{\circ} \mathrm{C}$ e chegaria até $900^{\circ} \mathrm{C}$ em uma queima em ambiente aberto ou de atmofera oxidante (ORTON et al., 1997: 126), além de ser um teste final para as habilidades da ceramista e para a combinação das técnicas e materiais utilizados na manufatura da vasilha, sendo por isso mesmo objeto de diversos cuidados e restrições (SHEPARD, 1971: 74-75; SILVA, 2000; LÉVI-STRAUSS, 1986; GOSSELAIN, 1992). Podem acontecer muitos acidentes nesta etapa: impurezas ou partículas grandes que não foram removidas da argila 
podem causar rachaduras e fragmentação; ar preso entre as junções dos roletes ou em outros lugares pode expandir com o calor e quebrar a vasilha (SHEPARD, 1971: 91; SKIBO e BLINMAN, 1999). Defeitos podem ser causados também pelo contato direto com o combustível, como descoloração por deposição de fuligem ou redução local, as "fireclouds", como marcas de queima (SHEPARD, 1971: 76; SKIBO, 1992).

$\mathrm{O}$ processo de queima pode ser dividido em diferentes fases, de acordo com a temperatura e ambiente, o modo como a água vai se perdendo, a decomposição e sintetização dos minerais de argila, os componentes orgânicos e inorgânicos que são queimados (SHEPARD, 1971: 81; RYE, 1981). Os principais fatores que a ceramista deve controlar na queima são a taxa de aquecimento, a temperatura máxima e a atmosfera que circunda os objetos (RYE, 1981: 25). É importante ressaltar que a secagem anterior da vasilha, quando grande parte da água evapora da argila, é fundamental para o sucesso da queima; no entanto, não é possível observar essa etapa nos fragmentos.

Como no Brasil pré-colonial não se tem registro de uso de fornos (PROUS, 1992: 94), partimos do pressuposto de que a queima foi feita em atmosfera oxidante ou ambiente aberto. Com esta técnica, as vasilhas ficam em contato direto com o combustível, podendo ser dispostas em buracos no chão ou em armações improvisadas. A vantagem desse método é que podem ser queimadas poucas ou grandes quantidades de vasilhas (ORTON et al., 1997: 127), no entanto é preciso um maior controle sobre as correntes de ar e não se controla muito bem a temperatura e o ambiente de queima (SHEPARD, 1971: 75).

Podemos levantar hipóteses sobre o ambiente de queima a partir da configuração do núcleo do fragmento: uma atmosfera oxidante (com quantidade excessiva de ar para a queima do combustível) tende a deixar o núcleo com uma coloração mais clara, enquanto que uma atmosfera redutora (quantidade insuficiente de ar) tende a uma coloração mais escura. É importante observar também que o material orgânico tende a deixar a coloração do núcleo cinza, preta, marrom escura; o óxido de ferro a deixa vermelha, amarela, ou marrom, mas se for um ambiente redutor pode ficar cinza, preta ou azulada (RICE, 1987:333). Utilizamos as classificações de RYE (1981: 116): o núcleo de Tipo 1 é claro por inteiro, podendo significar que o ambiente da queima era oxidante ou que não havia material orgânico na pasta; o Tipo 3 é escuro por inteiro, sendo o ambiente e temperatura de queima insuficientes para completar a oxidação e queimar todo o material orgânico da pasta, podendo também ser uma marca de uso ou pós-deposicional; o Tipo 2 tem face interna e externa claras e núcleo escuro; o Tipo 4 tem a face interna clara e a externa escura; o Tipo 5 tem a face interna escura e a externa clara; o 
Tipo 6 tem alternância entre claro e escuro. Os tipos 2, 4, 5 e 6 seriam variações do 3 e do 1 , com diferenças na localização das partes claras e escuras.

Para complementar a análise da queima, podemos observar a coloração da superfície das faces externa e interna, que é definida após esse processo, e por isso foi incluída nesta etapa. Segundo RICE (1987:333), a cor é consequência de duas variáveis: uma é o tamanho, quantidade e distribuição de componentes da argila (ferro e material orgânico); outra é tempo, temperatura e atmosfera de queima. Para padronizar as cores observadas, um dos métodos utilizados é a comparação da cor da cerâmica com as cores do Código de Munsell, que organiza as cores de acordo com as variáveis tom, saturação e intensidade, devendo ser medido sempre pela mesma pessoa e na mesma luminosidade, para que a observação não seja tão discrepante (RICE, 1987:343).

Segundo Frankel (1994: 205), a descrição da coloração dos fragmentos pode servir para nos auxiliar em diferentes questões: 1) descrição básica (de indivíduos, tipos ou coleções); 2) investigação da tecnologia (técnicas de manufatura, controle de qualidade); 3) comparação inter-coleções (para explicações de cunho temporal, espacial e comportamental).

Classificamos a coloração observada pelo Código de Munsell (2000) da seguinte maneira: branco (7.5 YR 8/1, 7.5 YR 8/2, 7.5 YR 8/3), cinza claro (7.5 YR 6/1, 7.5 YR 6/2, 7.5 YR 6/3, 7.5 YR 6/4, 7.5 YR 7/1, 7.5 YR 7/2, 7.5 YR 7/3, 7.5 YR 7/4, 7.5 YR 8/4), cinza escuro (7.5 YR 4/3, 7.5 YR 5/1, 7.5 YR 5/2, 7.5 YR 5/3, 7.5 YR 5/4), marrom (7.5 YR 4/6, 7.5 YR 5/6, 7.5 YR 6/6, 7.5 YR 6/8, 7.5 YR 7/6; 7.5 YR 8/6), marrom avermelhado(5 YR 4/2, 5 YR 4/3, 5 YR 4/4, YR 4/6, 5 YR 5/3, 5 YR 5/4, 5YR 5/6, 5 YR 6/4, 5 YR 6/6, 5 YR 6/8, 5 YR 7/6, 5YR 7/8, 5 YR 6/3), vermelho (2.5 YR 4/4, 2.5 YR 4/6, 2.5 YR 5/4, 2.5 YR 5/6, 2.5 YR 5/8, 2.5 YR 6/4, 2.5 YR 6/6, 2.5 YR 6/8), rosa (5 YR 7/4, 2.5 YR 7/4, 2.5 YR 7/6), preto (7.5 YR 2.5/1, 7.5 YR 4/1).

\subsection{Acabamento de Superfície}

Consideramos acabamento de superfície qualquer característica da superfície que resulta do processo de igualação durante e depois da etapa de dar forma à vasilha (SHEPARD, 1971: 186) ou que produza efeitos decorativos. As superfícies cerâmicas podem ser manipuladas de diversas maneiras para se alterar a textura, cor e aparência geral (RICE, 1987:244) e também alterar diretamente a performance da vasilha (SKIBO, 1992). 
Não achamos muito interessante separar essa categoria de acordo com a intencionalidade, pois é quase impossível distinguir, sem uma boa base de comparação etnológica, se o acabamento foi feito por motivos funcionais (como um corrugado para fixar os roletes de argila entre si e aumentar a superfície de distribuição do calor) ou por motivos decorativos (geralmente associados com a estética). E às vezes essas intencionalidades se sobrepõe. O alisamento pode servir simplesmente para uniformizar as irregularidades da superfície, mas também como um importante aspecto da aparência estética final da vasilha (ORTON et al., 1997:126; SILVA, 2000).

A classificação das técnicas de acabamento de superfície pode ser confusa porque é difícil identificá-las apenas a partir da aparência do acabamento no fragmento cerâmico, às vezes tão pequeno, mesmo porque o uso de diferentes técnicas pode obter resultados similares. Optamos por analisar os acabamentos por sua aparência final, não pela técnica específica, pensando que após essa análise inicial seja possível refinar esse atributo. Classificamos tipos de acabamentos significativos para essa análise e os dividimos entre acabamentos plásticos e pintados.

Os acabamentos plásticos são alterações físicas que resultam na modificação tridimensional da superfície da vasilha, feitas com a argila ainda moldável ou no estágio de leather hard, antes da queima (LA SALVIA e BROCHADO, 1989:35; SHEPARD, 1971: 70,195). O principal tipo de acabamento plástico é o alisamento, que é feito com a própria mão ou outro material, para igualar a superfície, ainda na formação da peça e enquanto a pasta ainda está maleável e fácil de redistribuir (SHEPARD, 1971:66). Não classificamos nenhum acabamento com polimento por causa da dificuldade em especificar se a aparência de polimento resultava realmente desse processo ou se tratava de um pseudo-polimento, como qunado se adiciona mais argila à superfície no processo de alisamento (AMARAL, 2013: 277). Neste material encontramos também corrugado, ungulado, impressão de corda, perfurado, inciso, acanalado, ponteado, impressão de corda e acanalado, inciso e ponteado, impressão de corda e inciso, impressão de corda e beliscado.

Os acabamentos de pinturas utilizam pigmentos para mudar a coloração superficial. Normalmente, os pigmentos minerais podem ser aplicados antes da queima, pois sua transformação pelo calor é o que os deixa fixados na superfície, diferentemente dos pigmentos vegetais que são mais sensíveis e não resistem ao calor, sendo aplicados após a queima. Além dos diferentes tipod de pigmentos, as pinturas também podem ser diferenciadas de acordo com o modo como são aplicadas à superfície: com os dedos, pano, pincéis, algodão, varetas maleáveis, etc. Podem ser utilizadas para pintar faixas, linhas, pontos ou diferentes motivos 
geométricos, além de desenhos variados. Outra técnica muito comum de pintura é a do engobo.Com essa técnica, é aplicado um revestimento na superfície com uma camada de argila colorida (SHEPARD, 1971:67). La Salvia e Brochado (1989) descrevem a técnica da barbotina, muito parecida com a do engobo, feita com uma camada de argila não pigmentada mas fina, podendo ser a mesma argila utilizada na construção da vasilha ou uma argila

diferente. É muitas vezes difícil identificar a barbotina de um alisamento ou mesmo da própria pasta, por causa da pouca diferença na cor e de outros processos que deixam uma aparência parecida, de pseudo-barbotina (AMARAL, 2013: 277). Decidimos durante as análises identificar as camadas de argila como banho, para evitar a confusão do termo barbotina e sua associação com a descrição da cerâmica Guarani. Os acabamentos pintados foram classificados como engobo branco, engobo vermelho, banho, engobo rosa, pintura branca sobre engobo vermelho, pintura branca sobre banho, pintura vermelha sobre engobobranco, pintura branca sobre banho e faixa vermelha.

Há também combinações mistas entre acabamentos plásticos e de pintura, como inciso e pintura branca, inciso sobre engobo vermelho, engobo rosa sobre inciso, banho sobre inciso, impressão de corda e banho.

A descrição dos motivos decorativos foi feita quando possível e necessária, durante a análise qualitativa. Os desenhos e grafismos usados para a decoração da cerâmica podem estar carregados de significados cosmológicos, ideológicos, sociais ou mesmo pessoais. Podemos descrever como esses motivos são construídos, as figuras que formam e, quando possível, sua distribuição na vasilha e a relação de um motivo com outro (PAUKETAT e EMERSON, 1991; HEGMON, 1992; SHEPARD, 1971), já que relacioná-los com aspectos simbólicos seria muito difícil sem um contexto cultural conhecido. Outra observação importante é a de que os motivos decorativos fazem parte de um repertório cultural do grupo, por isso podem não ser exclusivos da cerâmica, mas ser representados também em outros suportes, como o próprio corpo, couro, madeira, etc. (VIDAL [org.], 1992).

\subsection{Função e Uso}

A cerâmica é um material mais durável e resistente aos roedores, insetos e umidade em comparação com outros materiais, como palha e tecidos. Ela pode conter líquidos, pode ser colocada diretamente ao fogo e, além disso, uma mesma vasilha pode ser utilizada para diferentes tarefas (RICE, 1987: 208-209). Inferir a função específica de uma vasilha cerâmica 
pode ser complicado sem uma base de comparação etnoarqueológica ou análises arqueométricas, de restos de alimentos e marcas de uso, já que o contexto de uso pode ser muito variado.

A variabilidade encontrada também vai depender da frequência de uso de determinados tipos de vasilhas, a quantidade em que cada tipo é produzido, o modo como são armazenados, reutilizados e descartados, podendo ser relacionada à variabilidade quantitativa de Schiffer e Skibo (1997).

As marcas de uso podem ser difíceis de enxergar sem uma base de dados para comparação, principalmente tratando-se de fragmentos, quando não temos uma ideia da vasilha como um todo. Comparando o material analisado com descrições feitas em outros trabalhos e o banco de dados da pesquisa de Silva (2000) entre os Asurini do Xingu, conseguimos identificar algumas marcas: fuligem, depósito de carbono, polidor de sulco, marcas de líquidos e combinações entre eles.

A partir dos resultados da análise e da descrição dos diferentes conjuntos, associados com os correlatos de performance de cada um deles, conseguimos pensar em funç̃̃es genéricas para os conjuntos artefatuais, mas raramente conseguimos atribuir uma função específica a um fragmento específico. Utilizamos a seguinte classificação (RICE, 1987; SILVA, 2000): vasilhas para cozinhar, para servir, para consumir, para transportar e armazenar líquidos, para rituais e outros.

\subsection{Classificação}

A partir dos resultados da análise cerâmica e da arqueometria combinados com o tratamento estatístico dos dados, conseguimos distinguir 4 conjuntos que configuram diferentes modos de se fazer vasilhas cerâmicas. Os elementos utilizados para a formação desses conjuntos e sua caracterização serão explicitados no Capítulo 5. 


\section{RESULTADOS DA ANÁLISE}

“(...) e vimos que a pesquisa (arqueológica) iria ser feita para nós mesmos: para mostrar para não-índio que ali existia índio.” (Liderança Kaiabi apud POUGET, 2010: 64)

O material cerâmico arqueológico coletado na T. I. Kaiabi foi lavado, numerado e analisado nesta etapa de curadoria. Na numeração, foi colocada a sigla do sítio (abreviada para este propósito) e o número do fragmento, seguindo a ordem: coletas de superfície, sondagens, poços teste, coletas aleatórias. O material lítico foi lavado e armazenado apropriadamente; no entanto, não foi analisado para este trabalho, sendo sua descrição bastante breve neste capítulo e no Anexo B. A tabela 3 evidencia o resultado desta primeira etapa de trabalho curatorial:

\begin{tabular}{|c|c|c|c|c|c|}
\hline Sítio & Sigla Original & Sigla N $^{\mathbf{0}}$ & Cerâmica & Lítico & Cerâmica Analisada \\
\hline Aldeia Coelho & PA-TP-04 & AC & 975 & 26 & $\mathbf{4 4 9}$ \\
\hline Aldeia Tukumã & PA-TP-03 & AT & 1.518 & 488 & $\mathbf{8 4 4}$ \\
\hline $\begin{array}{c}\text { Aldeia } \\
\text { Dinossauro }\end{array}$ & MT-TP-01 & DR & 2.594 & 226 & $\mathbf{1 . 5 7 7}$ \\
\hline Minhocoçu & PA-TP-01 & MI & 347 & 51 & $\mathbf{2 3 4}$ \\
\hline Mukuin Caniné & MT-TP-02 & MC & 1.041 & 180 & $\mathbf{5 5 5}$ \\
\hline Taitetu & MT-TP-03 & TT & 1.935 & 232 & $\mathbf{1 . 2 3 6}$ \\
\hline Ywantã & PA-TP-02 & YA & 1.066 & 84 & $\mathbf{7 4 0}$ \\
\hline Total Geral & - & - & $\mathbf{9 . 4 7 6}$ & $\mathbf{1 . 2 8 7}$ & $\mathbf{5 . 6 3 5}$ \\
\hline
\end{tabular}

Tabela 3: Relação dos sítios, siglas e materiais coletados após a curadoria no laboratório.

A análise do material cerâmico (figura 7) ocorreu no laboratório e os resultados iniciais dos 7 sítios estão descritos nos itens abaixo, com reflexões sobre a análise estatística e 
a classificação dos conjuntos ao final do capítulo. Os gráficos e tabelas relativos aos resultados da análise de todos os sítios encontram-se no item 4.8. (tabelas 11 à 14; gráficos 1 à 8), ao final deste capítulo. Uma discussão sobre os diferentes conjuntos definidos após a análise é feita no próximo capítulo, com considerações sobre os correlatos de performance das características de cada conjunto. As formas reconstituídas e a maior parte das fotos dos fragmentos são apresentadas com detalhe na descrição desses conjuntos, assim como uma discussão sobre as cronologias.

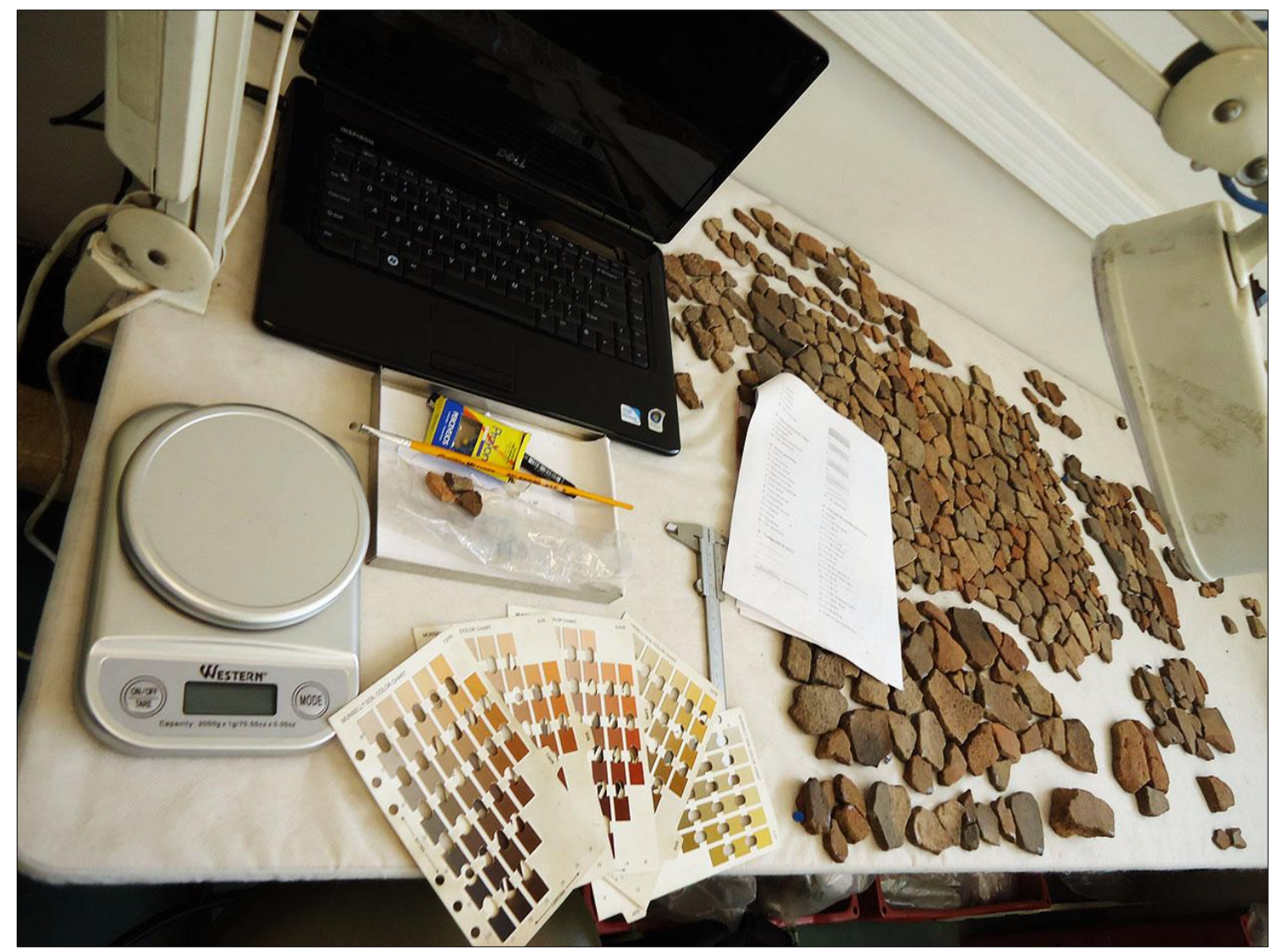

Figura 7: Análise dos fragmentos cerâmicos no laboratório. (Foto: Duane Mota). 
4.1. Sítio Aldeia Coelho (AC)

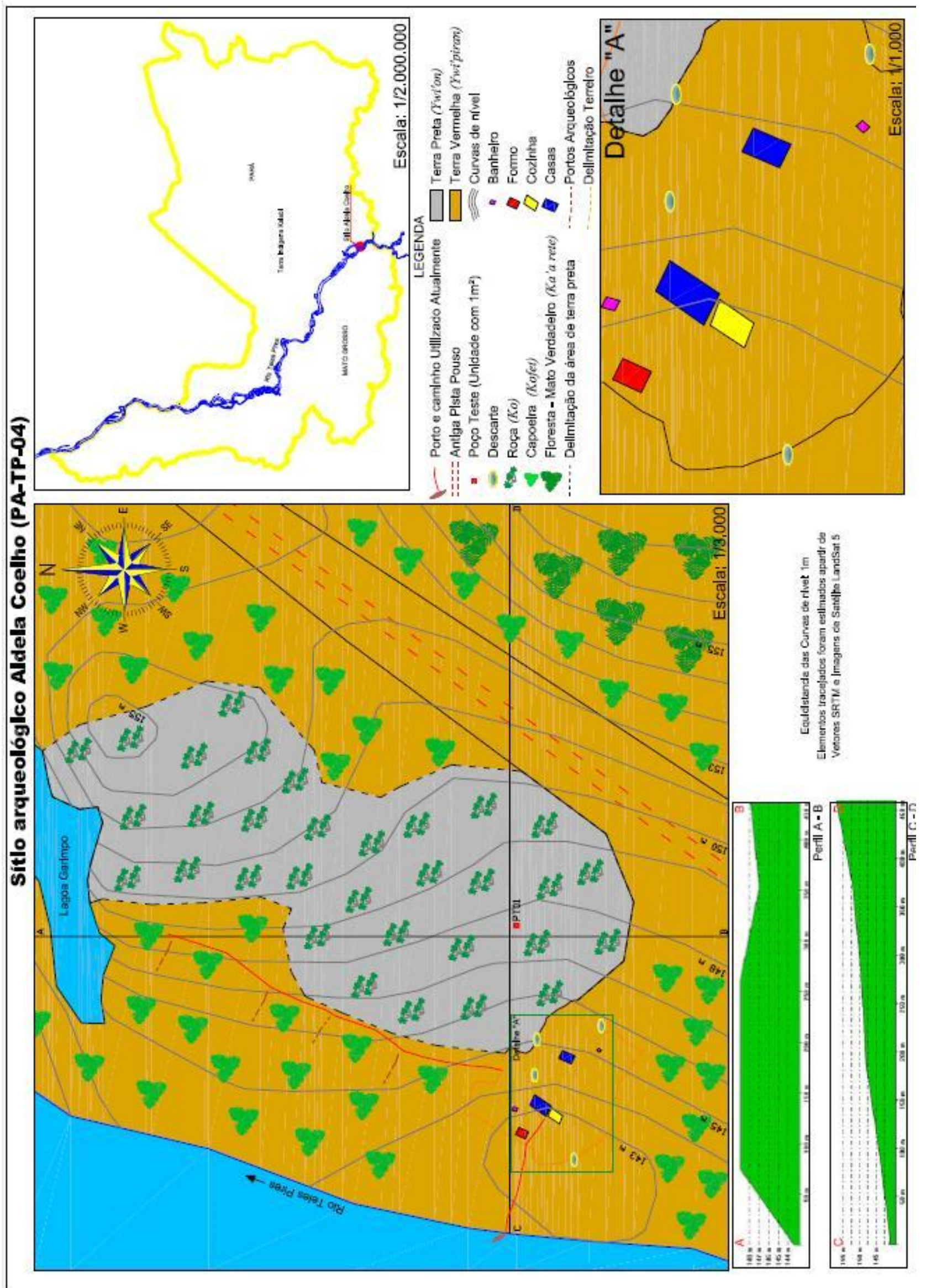

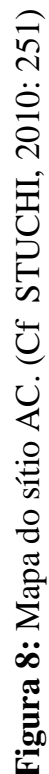


A Aldeia Coelho (figura 8) está localizada sobre um sítio arqueológico que recebeu o mesmo nome, caracterizado pelos fragmentos cerâmicos espalhados em superfície e subsuperfície por toda a extensão do terreiro até a área de roça em seu entorno (STUCHI, 2010: 250). O solo desta área tem coloração escura, reconhecida como terra preta ${ }^{10}$ por ser diferente do tipo de solo apontado para o local, que é o latossolo vermelho-amarelo. A área foi antigamente utilizada como roça pelos Kaiabi, estando coberta por capoeira antes da ocupação atual, que começou há 8 anos. A falta da correlação entre a vegetação, o solo e os vestígios arqueológicos, assim como o pouco tempo que restava para a conclusão da pesquisa, fez com que fossem realizadas apenas a coleta de superfície e a escavação de um poço-teste.

O material cerâmico encontrado soma 975 fragmentos, sendo distribuído no sítio como mostra a tabela 4 abaixo:

\begin{tabular}{|l|c|c|c|c|c|}
\hline $\mathbf{n = 9 7 5}$ & N0 & N1 & N3 & N4 & N5 \\
\hline Coleta aleatória & 32 & & & & \\
\hline Coleta de superfície & 588 & & & & \\
\hline PT1 & 39 & 153 & 137 & 20 & 6 \\
\hline Total & $\mathbf{6 5 9}$ & $\mathbf{1 5 3}$ & $\mathbf{1 3 7}$ & $\mathbf{2 0}$ & $\mathbf{6}$ \\
\hline
\end{tabular}

Tabela 4: Distribuição dos fragmentos cerâmicos no sítio AC.

No poço teste (PT1), foram escavados 6 níveis artificiais divididos em 4 camadas de solo, como mostra o esquema do perfil norte (figura 9).

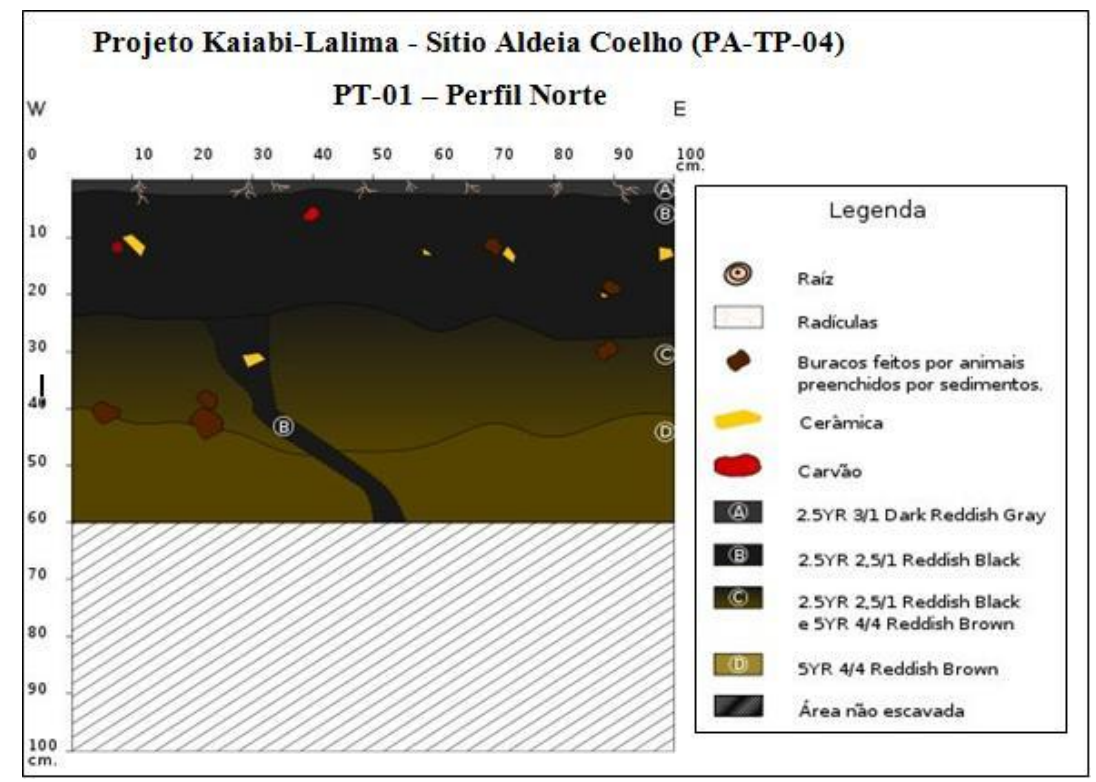

Figura 9: Perfil norte do PT1 no sítio AC. (Cf. STUCHI, 2010: 253).

\footnotetext{
${ }^{10}$ Ainda precisamos verificar se esse núcleo trata-se realmente de terra preta antropogênica (TPA), já que ainda não foi feita nenhuma análise de assinatura do solo.
} 
Além dos fragmentos de vasilhas, foi encontrada 1 bolota de argila (figura 11), talvez utilizada como matéria-prima para a construção das vasilhas.

Foram analisados 449 fragmentos de vasilhas cerâmicas neste sítio (figura 10).

Sobre o tratamento da matéria-prima, foi encontrada uma grande variedade de antiplásticos utilizados na composição da pasta cerâmica. No entanto, a combinação mais frequente de antiplásticos é caco moído e cauixi, somando 329 (73,3\%) fragmentos, seguida de caraipé e cauixi, com $68(15,1 \%)$ fragmentos.

Para a construção da vasilha, a técnica de manufatura roletada foi observada em $286(64 \%)$ fragmentos, sendo que no restante não foi possível identificar a técnica utilizada.

Em relação aos aspectos da morfologia da vasilha, dentre os 449 fragmentos, a maior parte foi classificada como paredes $(375 / 83,5 \%)$ das quais uma é infletida, depois bordas $(72 / 16 \%)$ e bases $(2 / 0,4 \%)$. A variabilidade das 72 bordas pode ser visualizada na tabela 11 , ao final do capítulo. A espessura mais comum é $6 \mathrm{~mm}$ e a maior parte dos fragmentos (343/76,4\%) encontra-se no intervalo entre $5 \mathrm{~mm}$ e $8 \mathrm{~mm}$.

Em relação aos indicativos de queima, foram observados 7 fragmentos com marca de firecloud. A configuração do núcleo mais comum foi a do tipo 3 (186/41,4\%). A coloração da face externa mostrou fragmentos majoritariamente com cores nos tons de cinza claro $(218 / 48,6 \%)$ e preto $(65 / 14,5 \%)$, este último provavelmente devido a marcas de uso ou pósdeposicionais. A face interna acompanhou essa tendência.

O acabamento de superfície da face externa, interna e do lábio é predominantemente alisado (438/98\%), com uma minoria (2\%) de fragmentos perfurados, incisos e com banho (figura 11).

Quanto ao uso, em apenas 16 (3,6\%) fragmentos foram identificadas marcas de fuligem, depósito de carbono e/ou de polidor de sulco. 


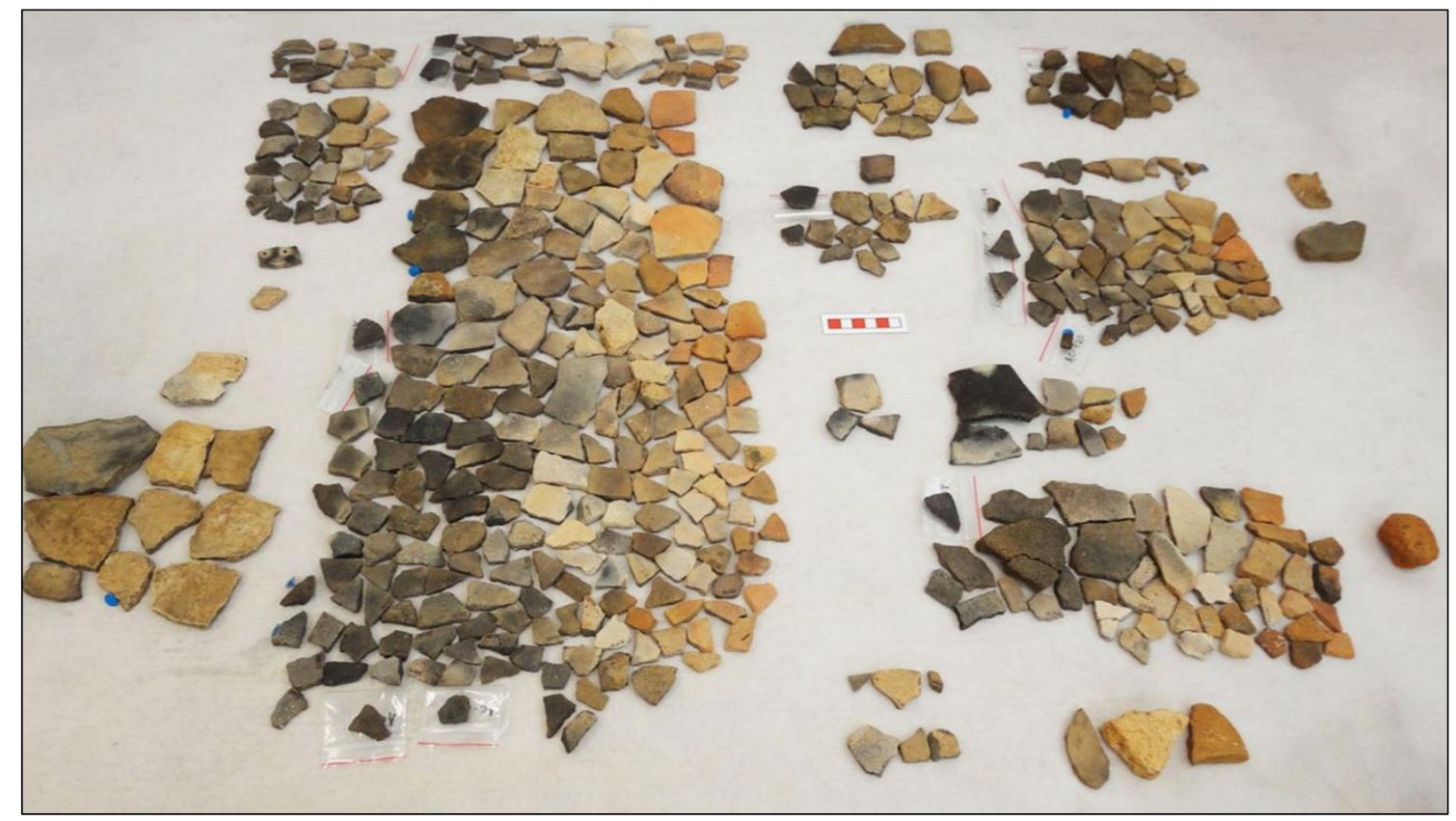

Figura 10: Fragmentos do sítio AC.
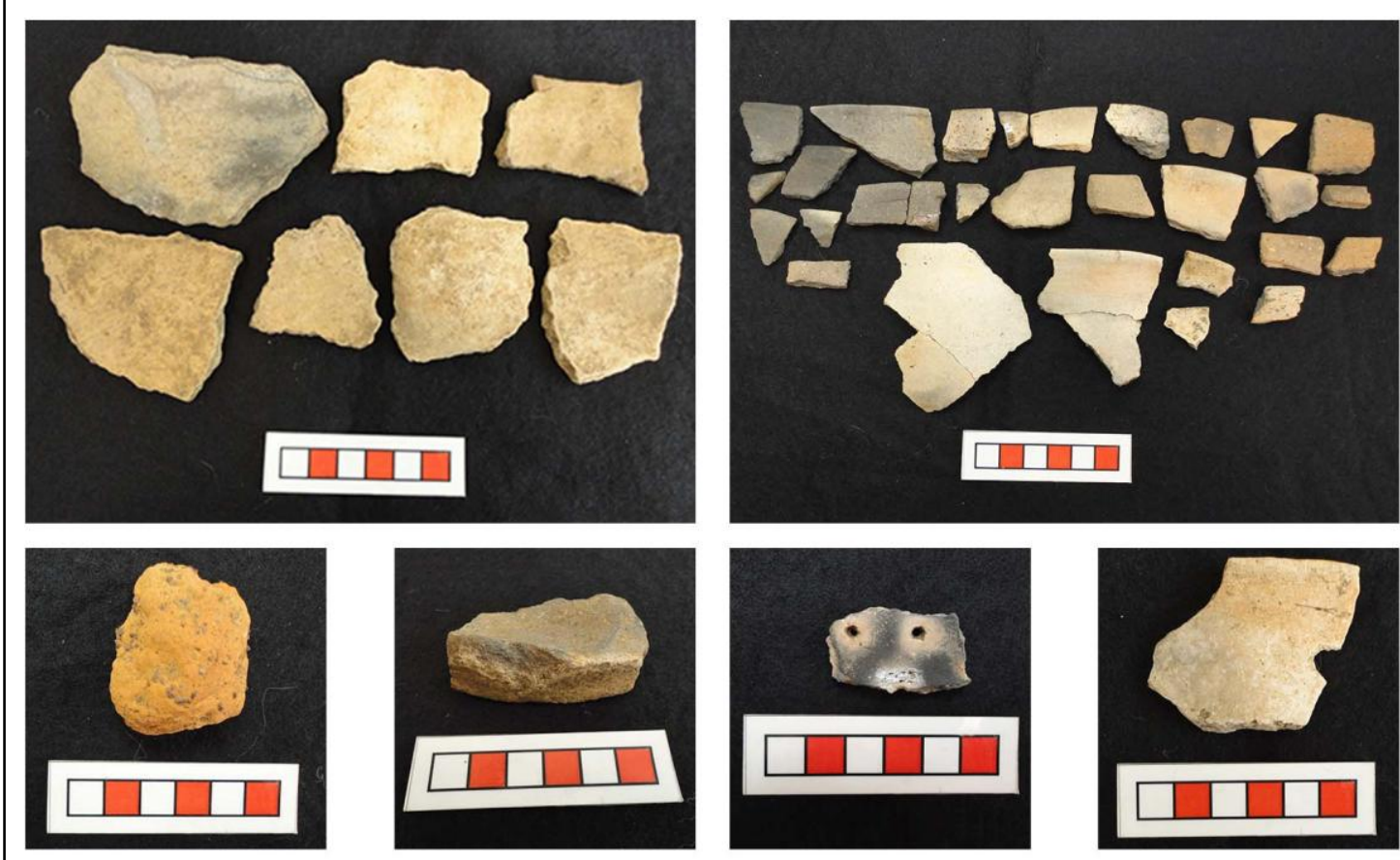

Figura 11: Fragmentos do sítio AC com banho, bordas alisadas, bolota de argila, base, perfuração e borda com banho. 


\subsection{Sítio Aldeia Tukumã (AT)}

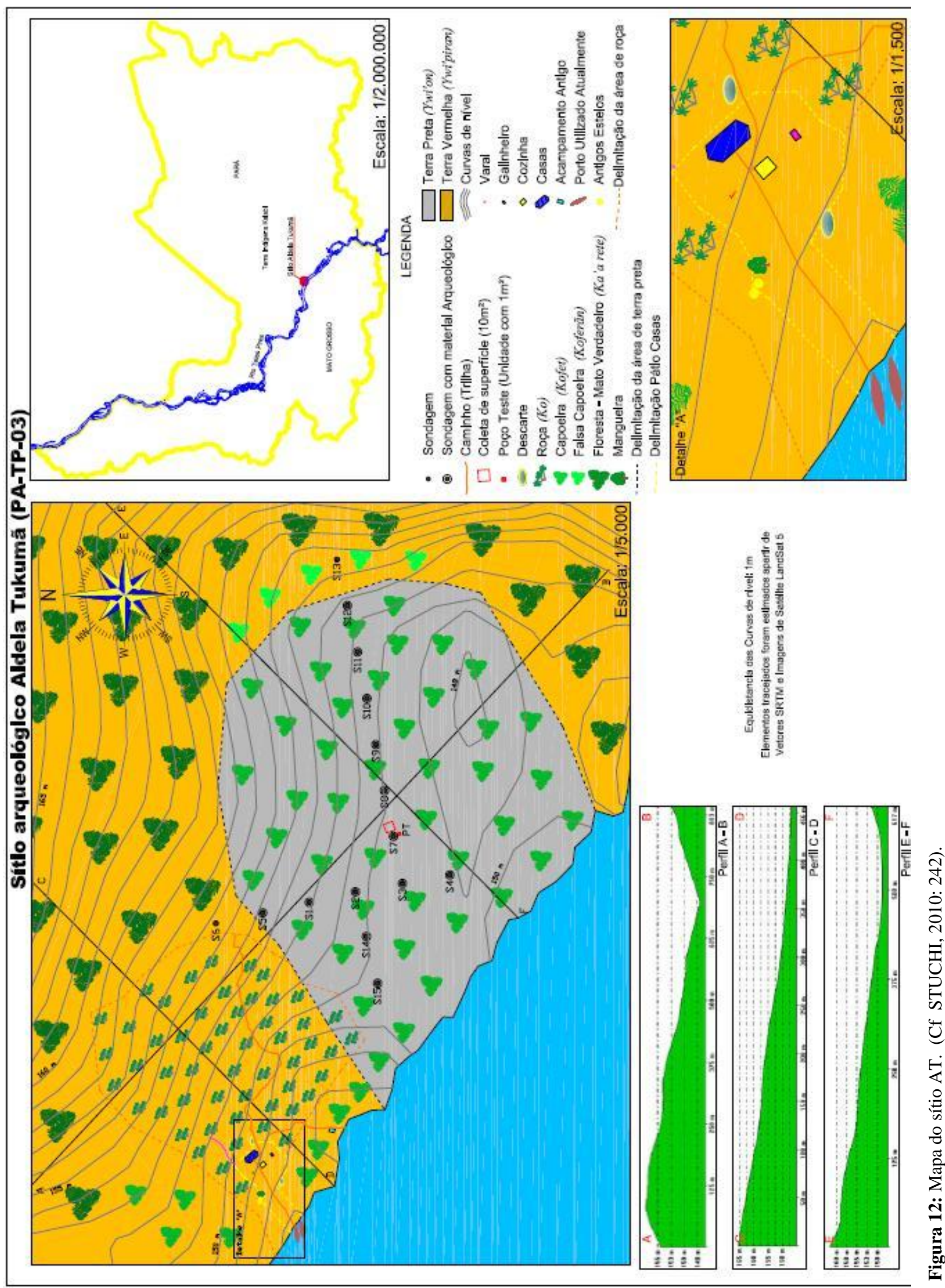


O trabalho arqueológico no sítio Aldeia Tukumã (figura 12) começou a ser feito por causa dos vestígios cerâmicos encontrados na superfície dessa área e áreas adjacentes, que é uma roça da aldeia de mesmo nome (STUCHI, 2010: 241). O sítio encontra-se em terra preta com vegetação de capoeira, na margem direita do Teles Pires.

$\mathrm{Na}$ superfície também foi encontrada uma faca de metal bastante oxidada (ver foto no Anexo B), sendo associada pelos interlocutores como pertencente à Kaipá Kaiabi, que antes morava no local (STUCHI, 2010: 241). Os 1.518 fragmentos cerâmicos coletados estão distribuídos como na tabela 5:

\begin{tabular}{|c|c|c|c|c|c|c|c|c|}
\hline $\mathrm{n}=1518$ & No & N 0-20 & $\mathbf{N 2}$ & N 20-40 & N 40-60 & N6 & N 60-80 & N 80-100 \\
\hline $\begin{array}{l}\text { Coleta de } \\
\text { superfície }\end{array}$ & 340 & & & & & & & \\
\hline S1 & & 4 & & & & & & \\
\hline $\mathbf{S 2}$ & & 10 & & & 2 & & 3 & \\
\hline $\mathbf{S 3}$ & & 25 & & & 16 & & 1 & \\
\hline S4 & & 7 & & 5 & & & & \\
\hline $\mathbf{S 5}$ & & 2 & & 2 & & & & \\
\hline S7 & & 23 & & 3 & & & & 1 \\
\hline S8 & & 7 & & 14 & & & 5 & \\
\hline S9 & & 20 & & 18 & 9 & & & \\
\hline S10 & & 21 & & 17 & 4 & & & \\
\hline S11 & & 15 & & 9 & & & & \\
\hline S12 & & 17 & & 3 & 1 & & & \\
\hline S13 & & 47 & & 2 & & & & \\
\hline S14 & & 6 & & & & & & \\
\hline $\begin{array}{lr}\text { S } & \text { não } \\
\text { identificada }\end{array}$ & & & & 7 & & & & \\
\hline PT1 & 21 & 276 & 332 & 148 & 65 & 10 & & \\
\hline Total & 361 & 480 & 332 & 228 & 97 & 10 & 9 & 1 \\
\hline
\end{tabular}

Tabela 5: Distribuição dos fragmentos cerâmicos no sítio AT.

Por conta do cronograma da escavação, a metodologia foi levemente alterada, sendo as sondagens escavadas em níveis artificiais de $20 \mathrm{~cm}$ (STUCHI, 2010: 241). Entre $5 \mathrm{~cm}$ e 70 $\mathrm{cm}$ de profundidade, o poço teste apresentou manchas de solo argiloso concrecionado de coloração amarelo avermelhado (5YR 6/8), que revelaram-se blocos de argila semiarticulados. Foram coletadas também 2 amostras de carvão. O perfil estratigráfico (figura 13) pode ser observado abaixo. 


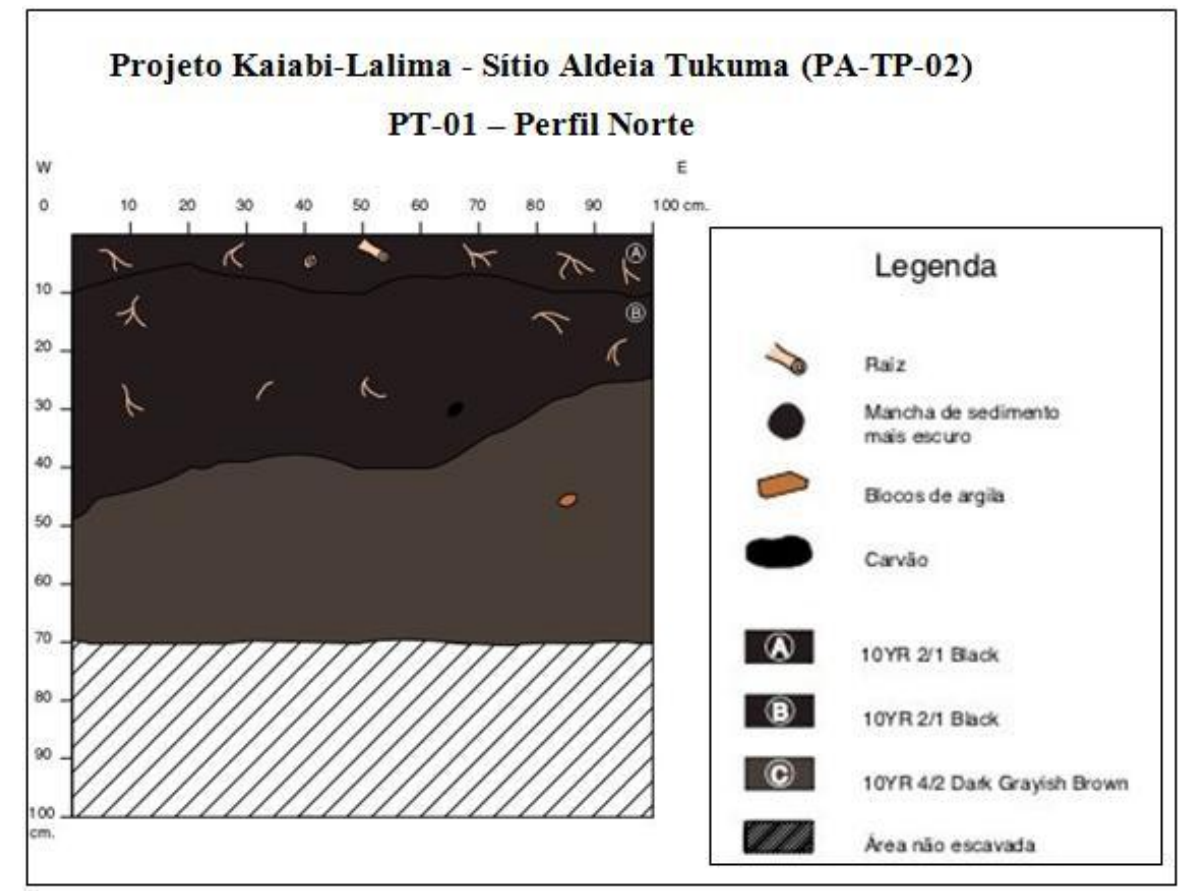

Figura 13: Perfil norte do PT1 no sítio AT. (Cf. STUCHI, 2010:249).

Foram encontradas 2 bolotas de argila (figura 15). Uma delas, de cor vermelha, possui antiplástico cauixi, sendo que a outra, de cor marrom avermelhado, possui antiplástico mineral. Foram encontrados também 2 fragmentos não identificados (figura 15), que podem ser o furo de um trempe para cozinhar ou a argila que é colocada nas estruturas de fogão ou casas, entre os bambus (ver descrição no item 4.6., sítio Ywantã).

Foram analisados neste sítio $\mathbf{8 4 4}$ fragmentos de vasilhas cerâmicas (figura 14).

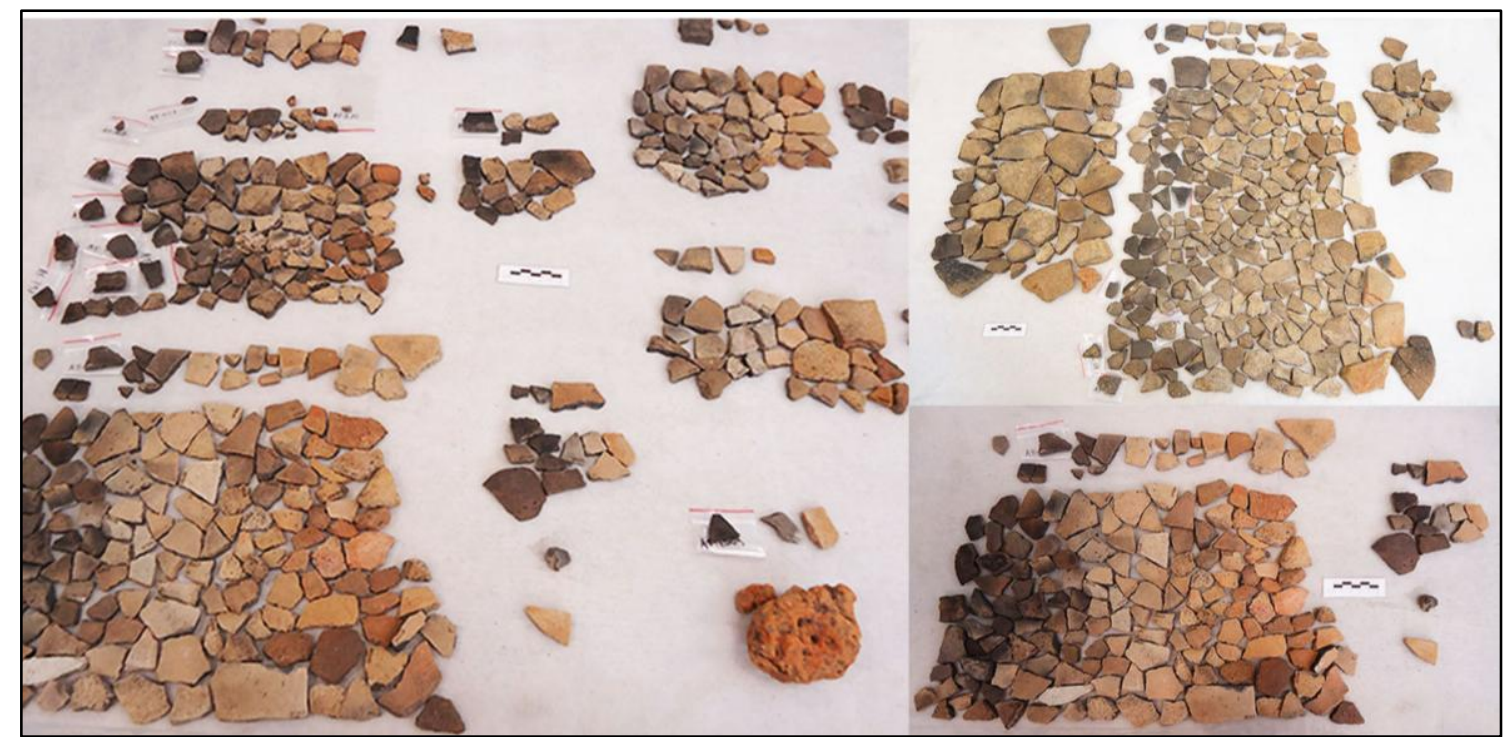

Figura 14: Fragmentos do sítio AT. 
Sobre o tratamento de matéria-prima, temos que o antiplástico mais utilizado na composição da pasta é uma combinação de caco moído e cauixi (465/55\%), seguido de caraipé e cauixi (183/21\%) e caco moído, caraipé e cauixi (132/15\%).

$\mathrm{Na}$ construção da vasilha, 560 fragmentos (66\%) foram identificados como tendo sido feitos pela técnica de roletagem.

Sobre a morfologia, 744 (88,2\%) fragmentos são paredes (das quais 1 é angular e 3 são ombro), $99(11,7 \%)$ são bordas e apenas $1(0,1 \%)$ é base. A variabilidade das 99 bordas pode ser vista na tabela 11, do item 4.8. A espessura dos fragmentos está majoritariamente entre $6 \mathrm{~mm}$ e $10 \mathrm{~mm}(568 / 67,3 \%)$, sendo a mais comum $8 \mathrm{~mm}$.

Dos indicativos de queima, mostram marcas de firecloud 6 dos 844 fragmentos. Os tipos de núcleo mais comuns são o 1 (245/29\%), $3(233 / 27,6 \%)$ e o 2 (179/21,2\%). A coloração da face externa é predominantemente cinza claro $(431 / 51,1 \%)$, assim como da face interna $(413 / 48,9 \%)$. No entanto, vale destacar que $181(21,4 \%)$ fragmentos tem coloração marrom e marrom-avermelhada na face externa e $98(11,6 \%)$ na face interna.

O acabamento de superfície mais comum é novamente o alisado, tanto na face externa como na face interna e no lábio (ver figura 15). Na face externa, 18 (2\%) fragmentos tem engobo vermelho e banho, enquanto apenas 1 tem incisão e 1 é inciso e ponteado. Na face interna, $6(1 \%)$ fragmentos tem engobo vermelho e banho e apenas 1 fragmento é acanalado.

Quanto ao uso, $40(4,7 \%)$ fragmentos apresentam marca de fuligem, depósito de carbono e/ou de polidor de sulco.

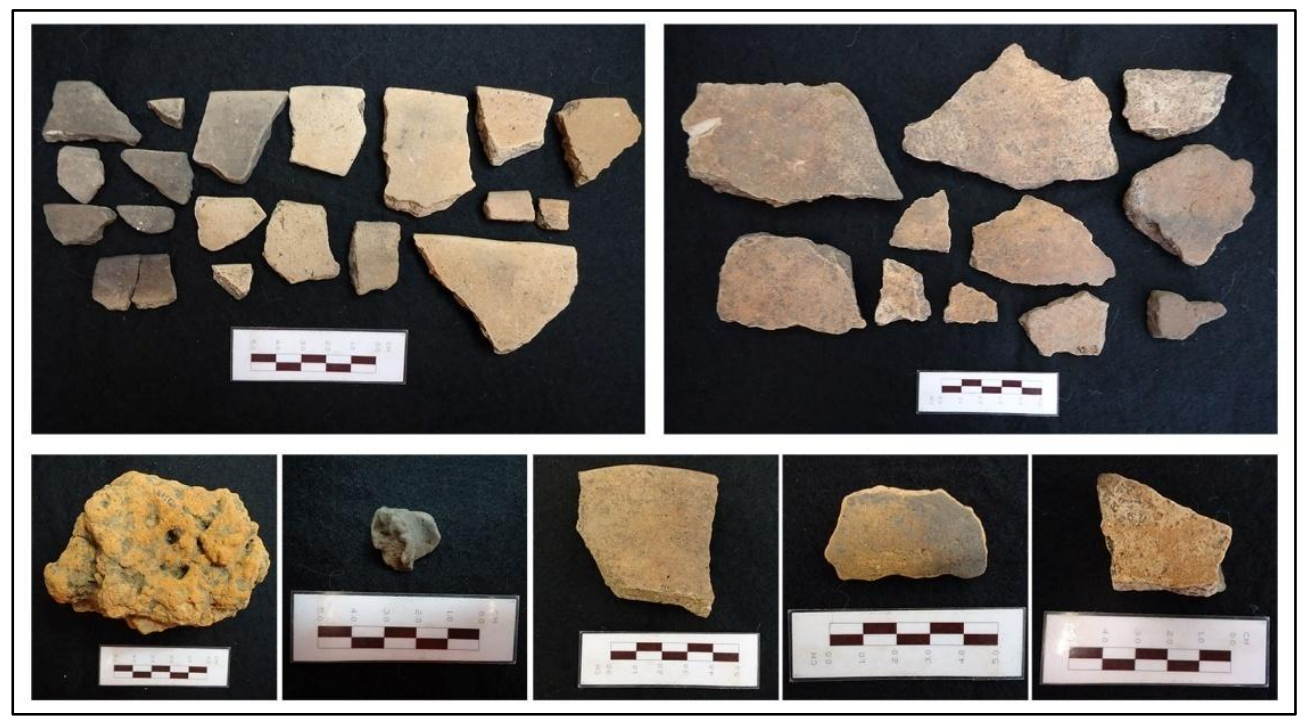

Figura 15: Fragmentos do sítio AT, com alisamento, banho, bolota de argila, objeto não identificado, banhos. 
4.3. Sítio Aldeia Dinossauro (DR)

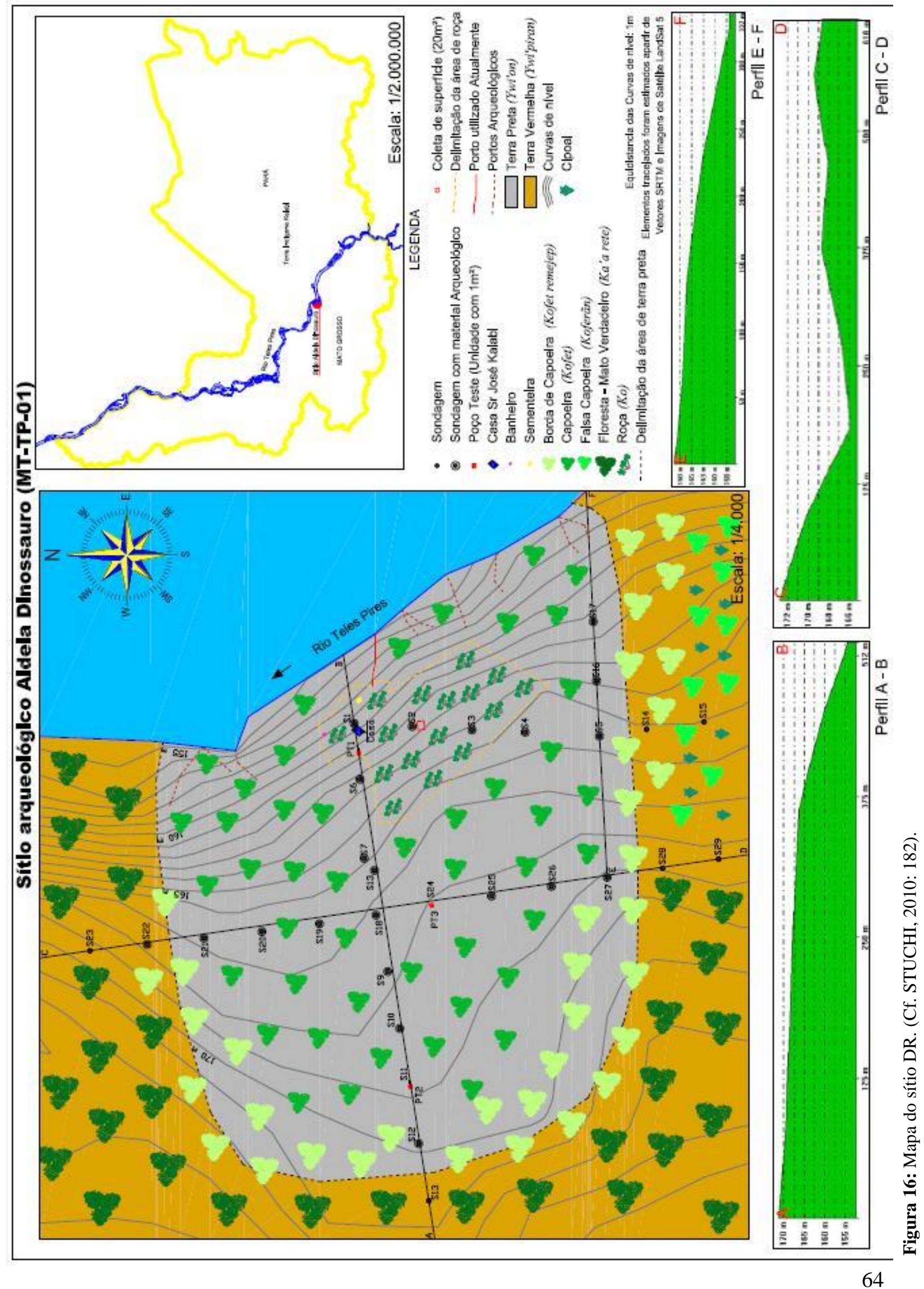


A Aldeia Dinossauro encontra-se em um terreno fluvial na margem esquerda do Teles Pires (figura 16). É uma área de ocupação ainda inicial pela família de José Kayabi e recebeu esse nome por causa de fósseis de megafauna associados aos dinossauros que foram encontrados no local. Devido a grande quantidade de vestígios arqueológicos na área do terreiro e na roça do entorno da área da aldeia, foi escavada a parte de terra preta abrangendo a área de capoeira adjacente (STUCHI, 2010: 181).

Foram coletados 2.594 fragmentos cerâmicos, cuja distribuição em superfície e subsuperfície é mostrada na tabela 6, abaixo.

\begin{tabular}{|c|c|c|c|c|c|c|c|c|c|c|c|c|c|}
\hline $\mathrm{n}=2594$ & No & N1 & $\mathbf{N 2}$ & N3 & N4 & N5 & N6 & N7 & N8 & N9 & N10 & N11 & NI \\
\hline $\begin{array}{l}\text { Coleta de } \\
\text { superfície }\end{array}$ & 193 & & & & & & & & & & & & \\
\hline Ocorrência & 8 & & & & & & & & & & & & \\
\hline S1 & & 43 & 16 & 1 & & 37 & 36 & & & & & & 2 \\
\hline S2 & & 11 & & 6 & & 5 & 5 & & 2 & & 1 & 2 & \\
\hline $\mathbf{S 3}$ & & 8 & 21 & 3 & & 3 & 2 & 1 & & & 1 & & \\
\hline $\mathbf{S 4}$ & & 14 & 10 & 10 & 18 & 9 & 3 & 1 & & & & & \\
\hline S5 & & & 1 & 6 & 2 & & & & & & & & \\
\hline S6 & 1 & 10 & 15 & & 8 & 3 & 3 & & 2 & & & & \\
\hline S7 & & 4 & 7 & 9 & 1 & & & & & & & & \\
\hline S8 & & & 2 & & & & & & & & & & \\
\hline $\mathbf{S 1 0}$ & & 3 & & & & & & & & & & & \\
\hline S11 & & 1 & 2 & & 5 & 6 & 14 & 4 & 10 & & 5 & 3 & \\
\hline S12 & & & 1 & & & & & & & & & & \\
\hline S16 & & & & 3 & 1 & 2 & 2 & & & 3 & & & \\
\hline S17 & & 4 & 11 & 2 & & & & & & & & & \\
\hline S18 & & 14 & 9 & & 2 & 4 & 3 & 2 & 5 & 2 & 1 & & \\
\hline S19 & & 9 & 15 & 3 & 3 & & 2 & & & & & & \\
\hline S21 & & 6 & 9 & 2 & & & 5 & & & & & & \\
\hline S22 & 1 & & 2 & & & & & & & & & & \\
\hline S25 & & 14 & 8 & 2 & & & & & & & & & \\
\hline S26 & & 5 & 4 & & & 1 & 1 & & & & & & \\
\hline S27 & & 1 & 3 & & & & & & & & & & \\
\hline S28 & & 2 & & & & & & & & & & & \\
\hline PT1 & & 135 & 425 & 312 & 170 & & & & & & & & \\
\hline PT2 & & 311 & 132 & 40 & 33 & 4 & 1 & & & & & & \\
\hline PT3 & & 177 & & 28 & 58 & & & & & & & & \\
\hline Total & 203 & 772 & 693 & 427 & 301 & 74 & 77 & 8 & 19 & 5 & 8 & 5 & 2 \\
\hline
\end{tabular}

Tabela 6: Distribuição dos fragmentos cerâmicos no sítio DR. 
No nível 4 do poço teste 1 (perfil estratigráfico na figura 17), foram encontrados 2 fragmentos cerâmicos associados a carvão na matriz preta, que foram coletados com a perspectiva de se obter uma datação, sendo coletados outros fragmentos de carvão nessa camada.

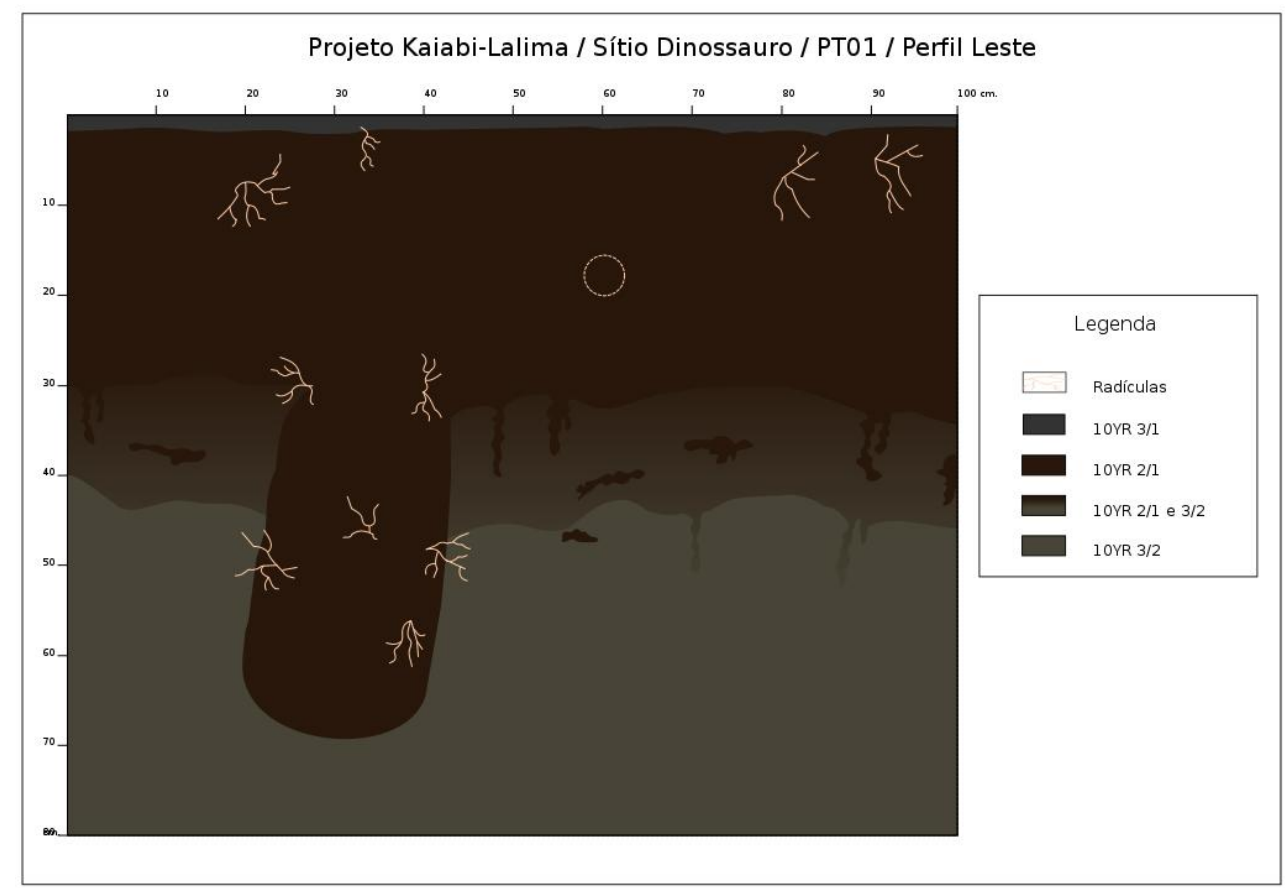

Figura 17: Perfil leste do PT1 no sítio DR. (Cf. STUCHI, 2010: 193).

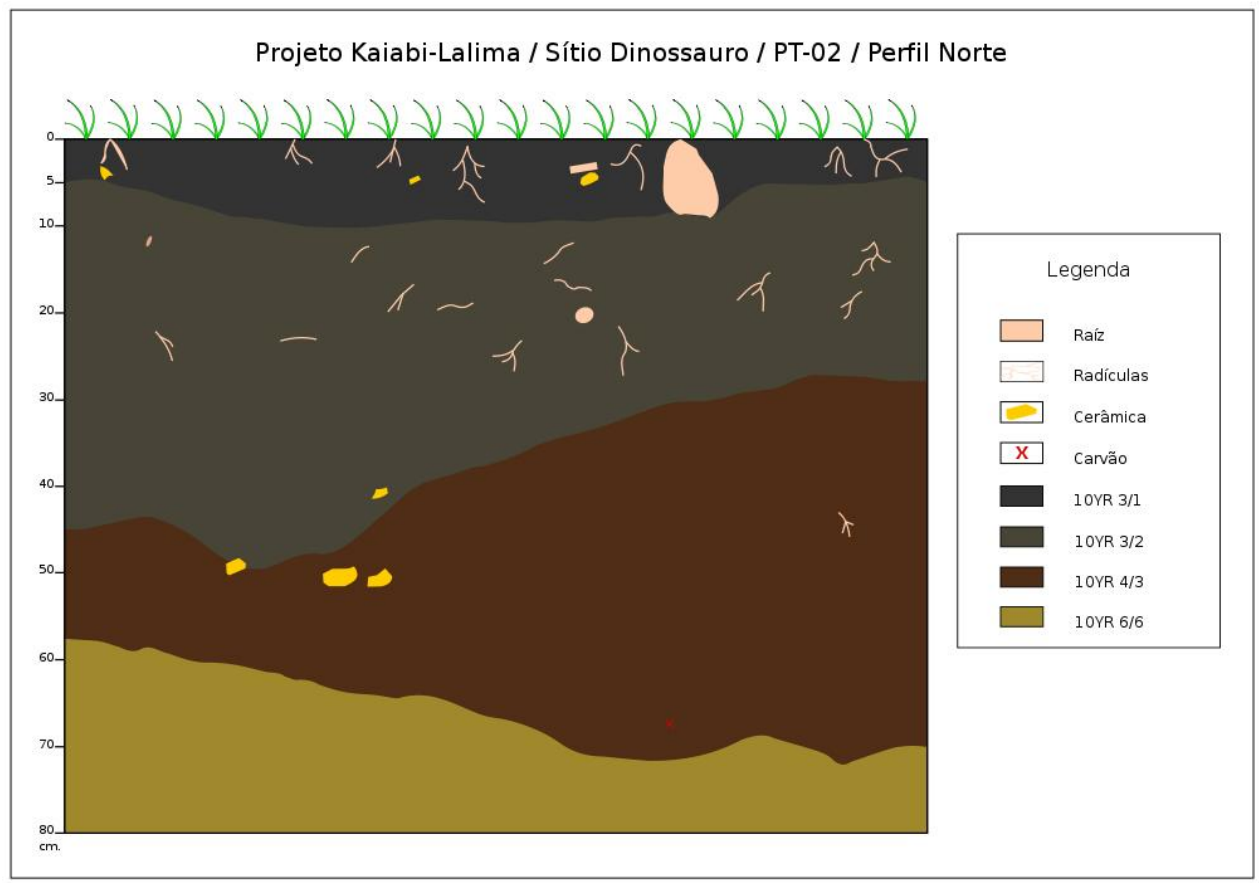

Figura 18: Perfil norte do PT2 no sítio DR. (Cf. STUCHI, 2010: 196). 
No poço teste 2 foi coletado, no nível 3, um fragmento de carvão associado com um fragmento cerâmico que foi reservado para datação posterior. No nível 4 também coletaram 2 amostras de carvão para datação radiocarbônica e 2 fragmentos cerâmicos no perfil norte com uma porção do solo para uma posterior datação por termoluminescência. O perfil estratigráfico pode ser visto na figura 18 , abaixo.

Já no poço teste 3 , foram escavadas 3 camadas de solo. Na superfície, o solo é argiloarenoso preto, sendo a camada A constituída de solo argiloso cinza muito escuro, nos primeiros $5 \mathrm{~cm}$. Logo nesse nível, durante as sondagens, foram coletados fragmentos que podem ter sido parte de uma mesma vasilha e que foram realmente colados um no outro, formando uma borda (figura 19). A camada B, de solo argiloso cinza escuro (10YR 4/1), chegou a $30 \mathrm{~cm}$. A última camada C, de solo argiloso marrom escuro acinzentado (10YR 4/2), compreendeu o intervalo de 30 a $40 \mathrm{~cm}$. Na base do nível 4 foi encontrada uma concentração de grandes fragmentos cerâmicos, pequenos fragmentos de carvão e blocos líticos, sendo o carvão coletado para posterior datação. Os pesquisadores comentaram em campo que alguns fragmentos cerâmicos pudessem pertencer a uma mesma vasilha, talvez um torrador ou assador, e que o solo compactado fosse o piso de uma habitação (figura 19). O carvão encontrado no nível 4 do PT3 e associado à cerâmica foi enviado para datação pela Beta Analytics Inc $^{11}$ (ver Anexo C), resultando em uma data de $1680 \pm 30$ A.P. (Cal d.C. 260 a 300).

No entanto, a escavação foi interrompida neste ponto, sendo decidido que continuariam em um momento mais oportuno para não atrapalhar o cronograma da pesquisa e a escavação de outros sítios. O perfil estratigráfico e o croqui do piso podem ser vistos na figura 20.

\footnotetext{
${ }^{11}$ Para mais informações sobre a empresa, acessar: http://www.radiocarbon.com/
} 

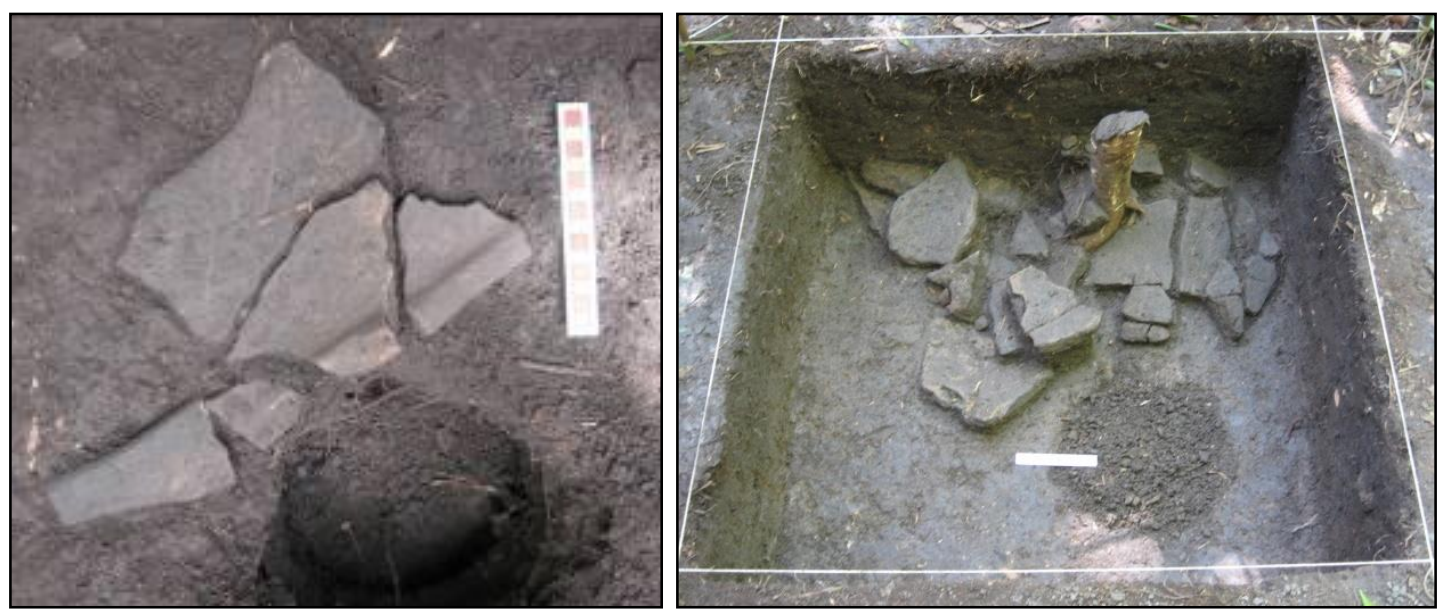

Figura 19: Borda fragmentada e base do nível 4 no PT3 no sítio DR. (Cf. STUCHI, 2010: 198).

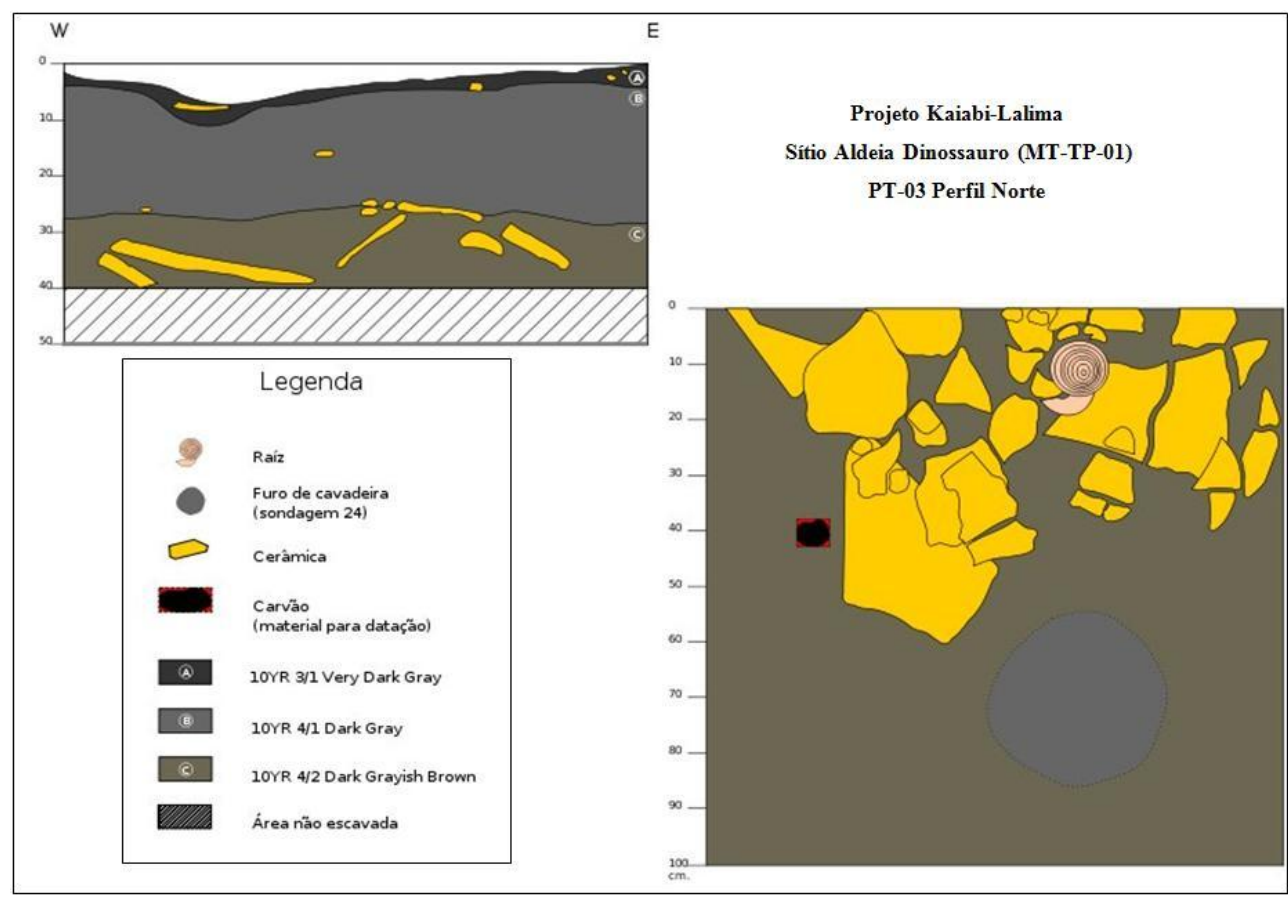

Figura 20: Perfil norte e croqui do nível 4 no PT3 no sítio DR. (Cf. STUCHI, 2010: 200).

A análise inicial identificou 14 bolotas de argila de coloração vermelha e marrom avermelhada, sendo que 12 tinham antiplástico mineral, 1 caraipé e 1 cauixi. Foi também encontrado um objeto não identificado, mas que parece ser uma base em pedestal ou suporte para vasilhas.

Foram analisados $\mathbf{1 . 5 7 7}$ fragmentos de vasilha cerâmica (figura 21). 
Sobre o tratamento da matéria-prima, a combinação predominante de antiplásticos é cauixi e caraipé (825/52,3\%), seguida da combinação caco moído, caraipé e cauixi (218/13,8\%), caco moído e/ou caraipé $(216 / 13,7 \%)$ e caco moído e cauixi $(161 / 10,2 \%)$.

Em relação a construção da vasilha, a técnica roletada foi identificada em 1190 (75\%) fragmentos.

A análise da morfologia revelou $7(0,4 \%)$ bases, sendo apenas 1 identificada como circular plana e $6 \mathrm{~cm}$ de diâmetro. A maior parte dos fragmentos é de paredes $(1.344 / 85,2 \%)$, das quais 9 ombros, 6 angulares, 3 infletidas, 1 cambada e 1 do segmento inferior. A variabilidade das $226(14,3 \%)$ bordas está descrita na tabela 11, no item 4.8. A maior parte dos fragmentos tem espessura entre $5 \mathrm{~mm}$ e $10 \mathrm{~mm}(1311 / 83,1 \%)$, sendo a mais comum 7 $\mathrm{mm}$.

Em relação aos indicativos de queima, 33 fragmentos apresentam marca de firecloud. A configuração do núcleo predominante é o tipo 1 (738/46,8\%), seguida do tipo 2 (417/26,4\%). O cinza claro é a coloração predominante na face externa $(840 / 53,3 \%)$ e na face interna (787/49,9\%), sendo marrom e marrom avermelhado presentes na face externa de 323 $(20,5 \%)$ fragmentos e na face interna de $228(14,5 \%)$.

Em relação ao acabamento de superfície, a maior parte é alisada na face externa, interna e lábio (figura 22). No entanto, nos 6\% de fragmentos com outros acabamentos de superfície existe uma maior variabilidade, como corrugado, impressão de corda, perfurado, inciso, ponteado e acanalado/impressão de corda. Entre os acabamentos cromáticos, temos engobo vermelho, rosa e banho.

Quanto ao uso, $213(13,5 \%)$ fragmentos apresenta fuligem, depósito de carbono e marcas de polidor de sulco. 


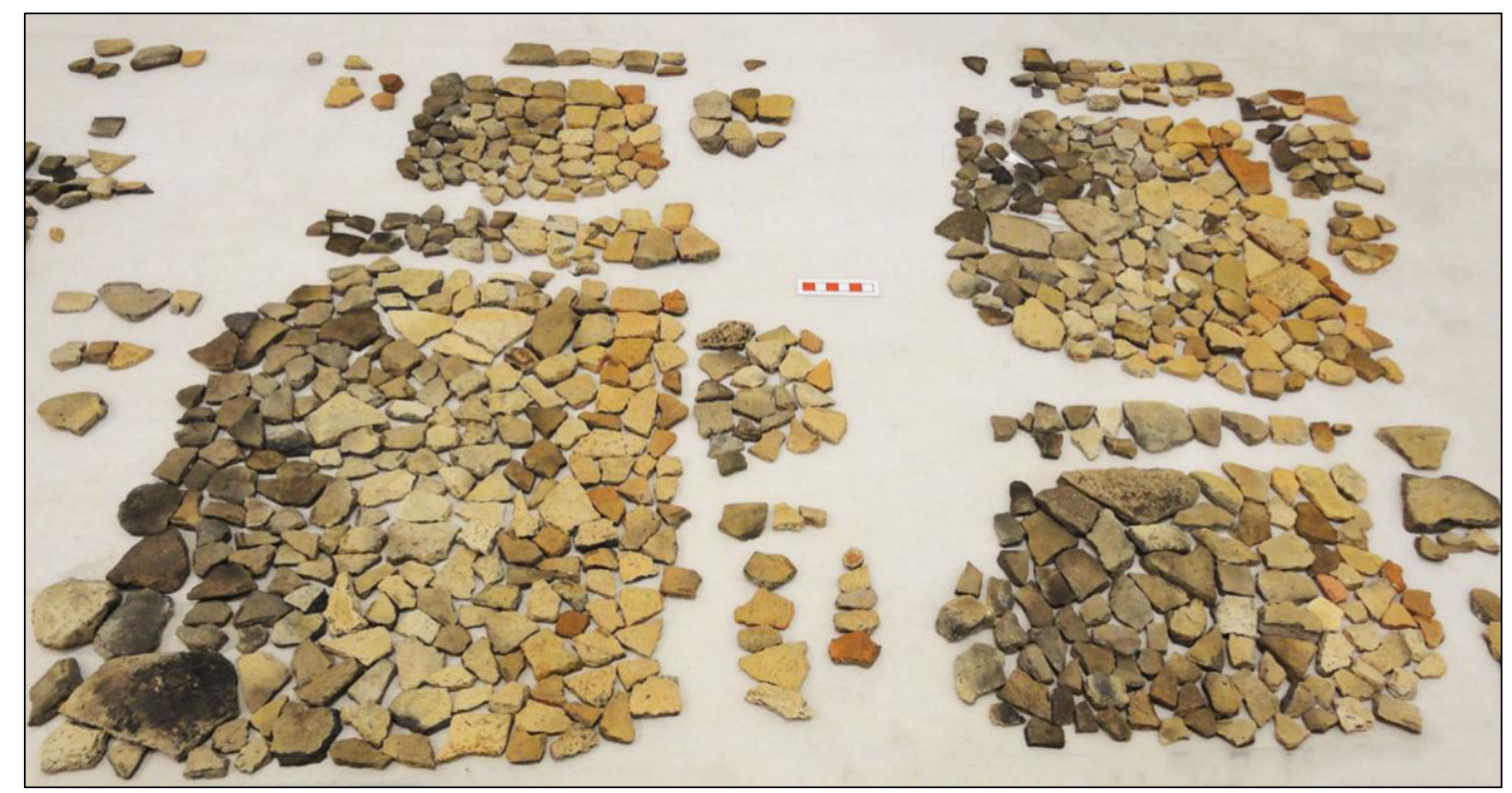

Figura 21: Fragmentos do sítio DR.

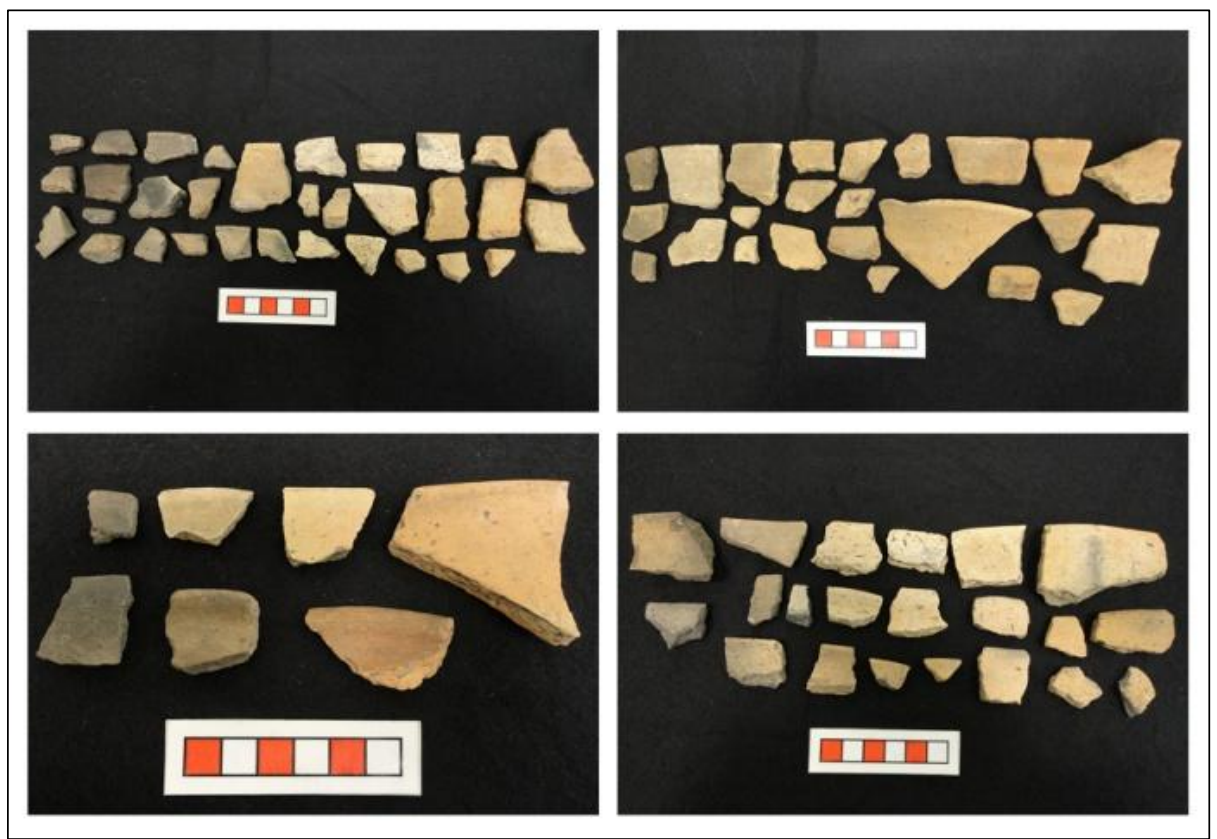

Figura 22: Fragmentos alisados no sítio DR. 
4.4. Sítio Mukuin Caniné (MC)

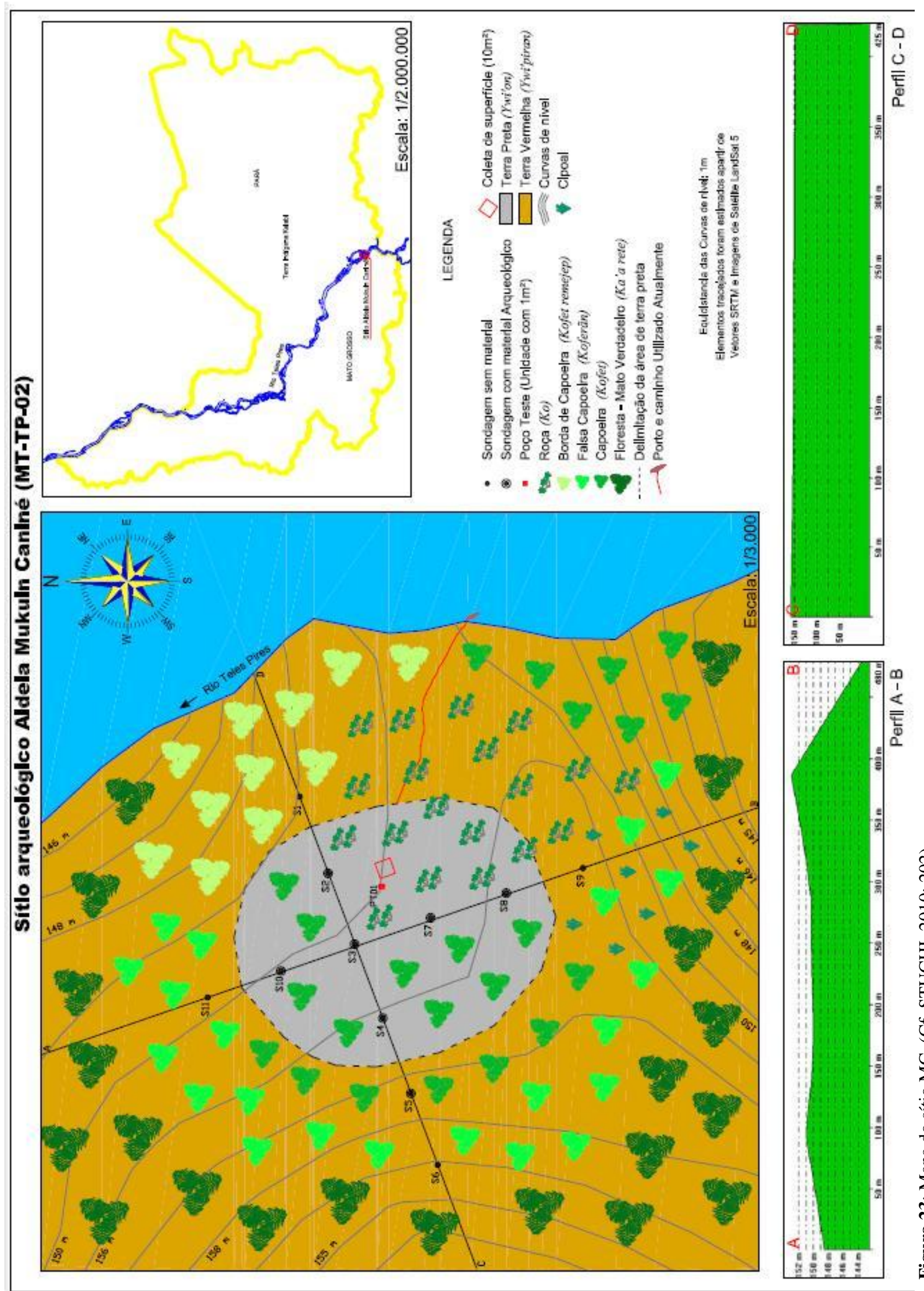

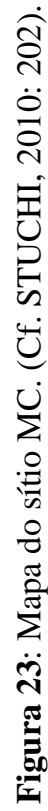


O sítio Mukuin Caniné está localizado nas encostas baixa e média de uma colina suave na margem esquerda do rio Teles Pires (figura 23). A área que continha material arqueológico estava sobre um núcleo de terra preta, com uma vegetação caracterizada como capoeira.

O sítio, em geral, possui fragmentos cerâmicos bem conservados quanto a sua superfície interna e externa, apesar de estar bastante fragmentado, sendo quase metade dos fragmentos menores que $1,5 \mathrm{~cm}^{2}$ (469 fragmentos do total de 1.056). A distribuição horizontal e vertical dos 1.056 fragmentos cerâmicos no sítio pode ser visualizada na tabela 7 , abaixo.

\begin{tabular}{|l|l|l|l|l|l|l|l|l|}
\hline $\mathrm{n}=1056$ & N0 & N1 & N2 & N3 & N4 & N5 & N6 & N7 \\
\hline Coleta de superfície & 235 & & & & & & & \\
\hline S2 & & 30 & 10 & & & & & \\
\hline S3 & & 37 & 3 & & & & & \\
\hline S4 & & 24 & 2 & & & & & \\
\hline S5 & & 44 & & & & & & \\
\hline S6 & 1 & 1 & & & & & \\
\hline S7 & & 31 & 24 & 7 & 3 & & & \\
\hline S8 & & 12 & 6 & & 2 & & 1 & \\
\hline S9 & & 2 & 1 & & 1 & & & \\
\hline S10 & & 58 & 12 & & & & & \\
\hline S11 & & 214 & 186 & 74 & 12 & 7 & 10 & 4 \\
\hline PT1 & $\mathbf{2 3 5}$ & $\mathbf{4 5 5}$ & $\mathbf{2 4 5}$ & $\mathbf{8 1}$ & $\mathbf{1 8}$ & $\mathbf{7}$ & $\mathbf{1 1}$ & $\mathbf{4}$ \\
\hline Total
\end{tabular}

Tabela 7: Distribuição dos fragmentos cerâmicos no sítio MC.

A escavação do poço teste foi feita em 9 níveis artificiais, revelando 4 camadas de solo diferenciado. A camada A são os primeiros $5 \mathrm{~cm}$, com solo argilo arenoso de coloração marrom escuro acinzentado (10YR 4/2), presença de material arqueológico e fragmentos de carvões recentes, por causa da queima no preparo da roça. A camada B continua no restante do nível até a metade do nível 4, com solo argilo arenoso marrom escuro (7.5YR 3/2), possuindo a maior quantidade de material arqueológico. Nesta camada, foram encontradas bolotas de argila de coloração avermelhada (10R 5/8), entre $6 \mathrm{~cm}$ e $35 \mathrm{~cm}$ de profundidade, que foram reconhecidas por Vitorino Krixi Munduruku como a matéria-prima utilizada pelos Munduruku na preparação de tintas para pintura e manufatura da cerâmica como tempero (STUCHI, 2010: 209). Essas 18 bolotas de argila foram analisadas e parecem mesmo ser matéria-prima, sendo todas modeladas, alisadas e de coloração avermelhada, 16 delas tem antiplástico mineral e 2 caco moído. 
Também na mesma camada, mais precisamente na base do nível $2(20 \mathrm{~cm})$, foi coletado um fragmento cerâmico (figura 24), que foi enviado para datação por termoluminescência (TL), com a empresa Datação ${ }^{12}$. O resultado foi uma data de $870 \pm 120$ A.P. (ver Anexo C).
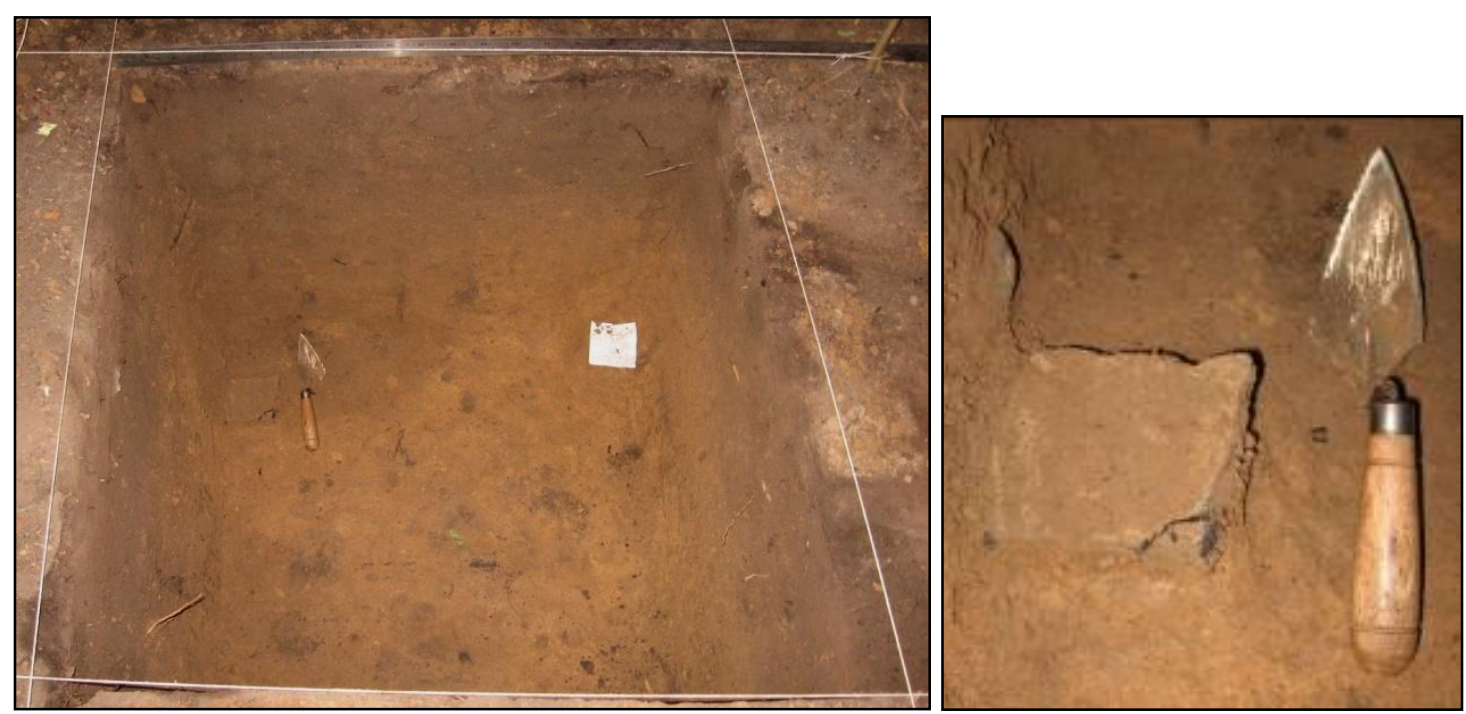

Figura 24: Fragmento cerâmico no nível 2, enviado para datação. (Cf. STUCHI, 2010: 210).

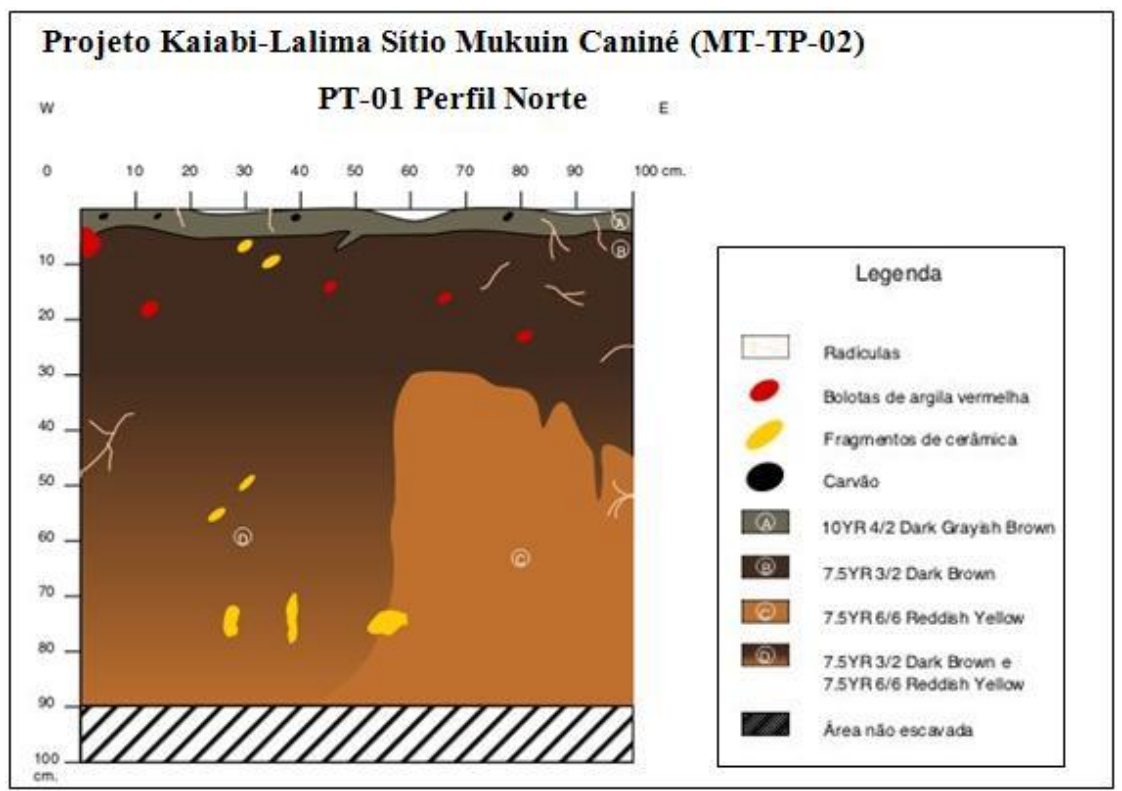

Figura 25: Perfil norte do PT1 no sítio MC. (Cf. STUCHI, 2010: 211).

As últimas camadas do poço teste, $\mathrm{C}$ e D, não são sobrepostas horizontalmente, mas são paralelas verticalmente, de 50 à $90 \mathrm{~cm}$ de profundidade. A camada $\mathrm{C}$ encontra-se na

\footnotetext{
${ }^{12}$ Para mais informações sobre a empresa, acessar: http://www.datacao.com.br/
} 
porção nordeste do perfil, com granulação fina e amarelo avermelhado (7.5YR 6/6). A camada D está na porção noroeste do perfil, com solo variegado entre o amarelo avermelhado e o marrom escuro (perfil estratigráfico na figura 25).

Ao todo, foram analisados $\mathbf{5 5 5}$ fragmentos (figura 26).

Em relação ao tratamento da matéria-prima, os materiais antiplásticos mais comuns são o caco moído (254/45,8\%) e o caraipé $(178 / 32,1 \%)$, além do mineral $(84 / 15,1 \%)$ e uma combinação de caco moído e caraipé $(37 / 6,7 \%)$.

Sobre a construção da vasilha, em alguns fragmentos foi possível identificar a técnica de manufatura, havendo 162 (29\%) fragmentos produzidos pela técnica de roletes.

Em relação à morfologia, a maior parte foi classificada na categoria estrutural como sendo a parede das vasilhas $(469 / 84,5 \%)$, mas também foram encontradas bordas $(84 / 15,1 \%)$ e bases $(2 / 0,4 \%)$. As 2 bases encontradas foram classificadas como circular plana e uma delas possui diâmetro de $4 \mathrm{~cm}$. Das paredes, 7 são ombros, 11 são infletidas, 5 são carenadas, 1 angular e 3 são cambadas. A variabilidade das 84 bordas é mostrada na tabela 11, no item 4.8. A maior parte dos fragmentos possui espessura entre $5 \mathrm{~mm}$ e $9 \mathrm{~mm}(478 / 86,1 \%)$, sendo as mais comuns $6 \mathrm{~mm}$ e $7 \mathrm{~mm}$.

Em relação aos indicativos de queima, apenas 3 fragmentos apresentaram marca de queima, a firecloud. Os tipos de núcleos observados foram principalmente do tipo 1 (291/52,4\%), sendo que o restante dividiu-se praticamente entre os tipos 2 (90/16,2\%), 3 $(87 / 15,7 \%)$ e $5(77 / 13,9 \%)$. Já a coloração dos fragmentos é bastante diversificada. Na face externa, a coloração predominante é o marrom $(156 / 28,1 \%)$, seguida de cinza claro (114/20,5\%), marrom avermelhado $(106 / 19,1 \%)$ e cinza escuro $(102 / 18,4 \%)$. Já na face interna, a maior parte é cinza claro $(145 / 26,1 \%)$, mas as outras cores seguem a mesma tendência da face externa.

Apesar de o alisamento ser o acabamento de superfície mais comum na face externa, interna e lábio, notamos neste sítio uma maior porcentagem de outros tipos de acabamento, predominantemente pintados (figura 27). Na face externa, $28 \%$ dos fragmentos apresenta acabamentos como banho, engobo vermelho, engobo rosa e branco. Pinturas sobre engobo e combinações de incisos com pinturas também foram encontrados. Na face interna a porcentagem de outros acabamentos foi menor, $11 \%$, mas também variada.

Quanto ao uso, em 11 (2\%) fragmentos foi encontrada fuligem, depósito de carbono e marcas de polidor de sulco (figura 27). Foi encontrado 1 fragmento de borda que parece ter sido de um assador, o único fragmento que tivemos alguma segurança em classificar quanto a sua função. 


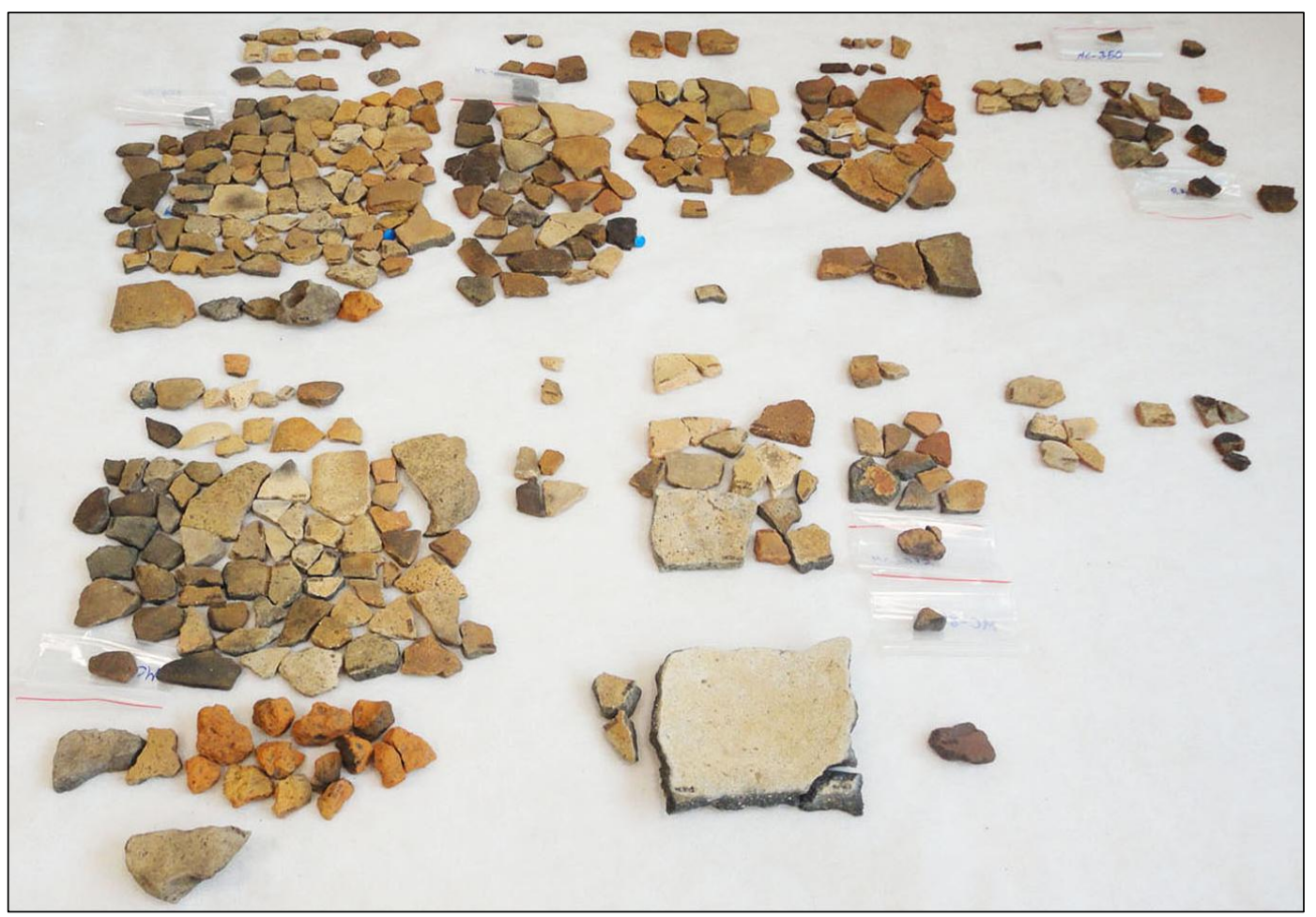

Figura 26: Fragmentos do sítio MC.

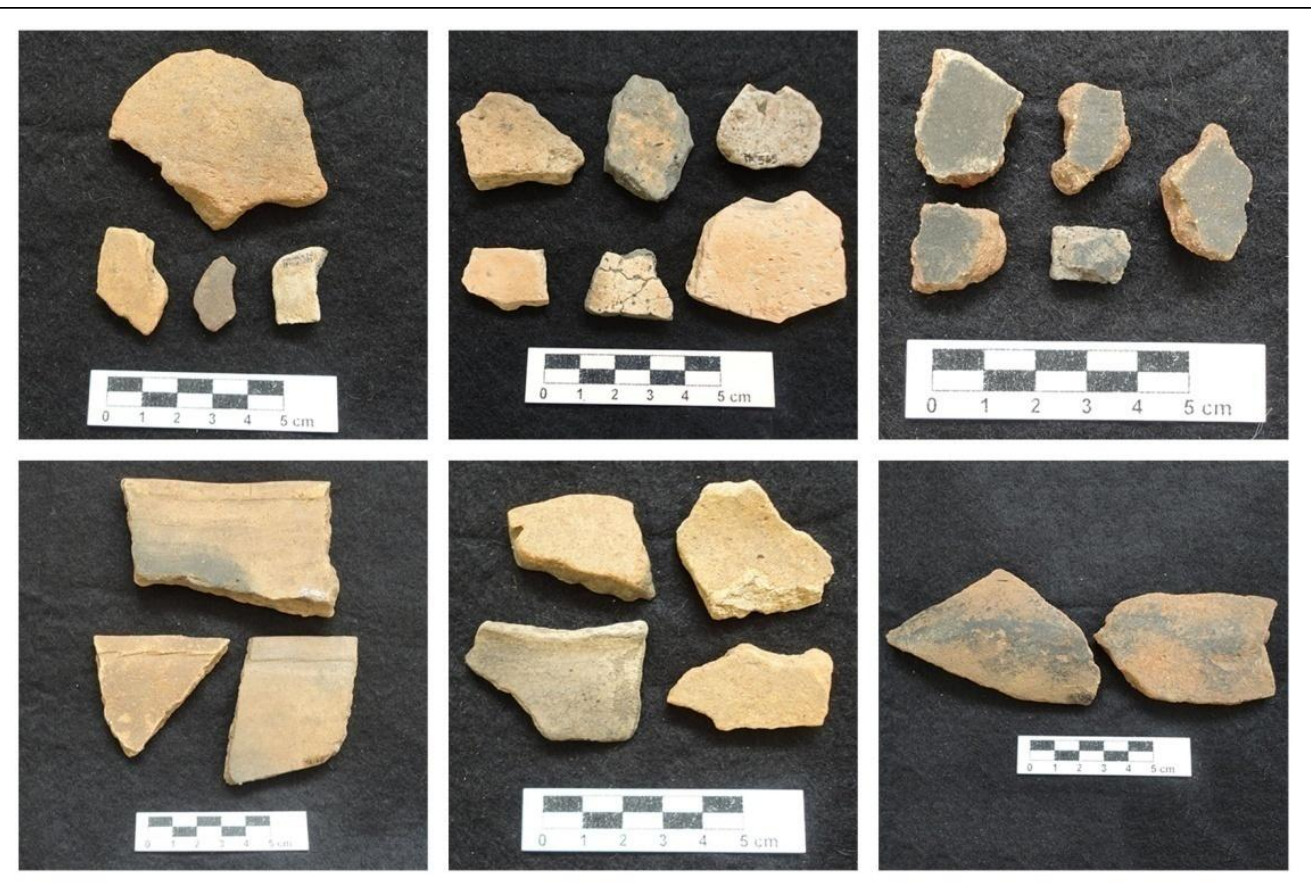

Figura 27: Fragmentos do sítio MC de base, com banho, depósito de carbono, incisos na face interna, banho e fuligem. 
4.5. Sítio Aldeia Minhocoçu (MI)

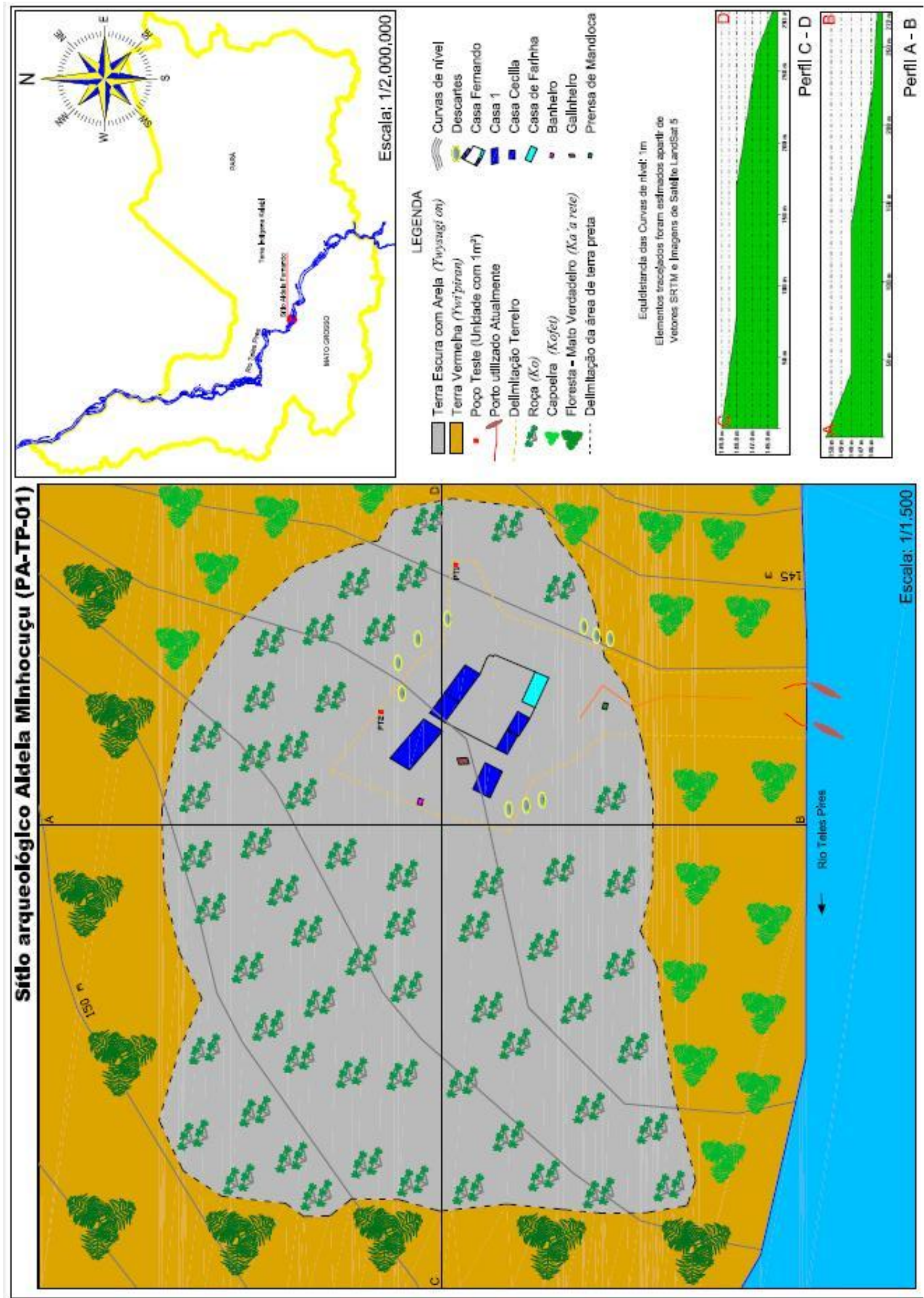

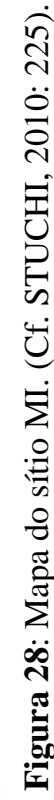


O trabalho arqueológico no sítio Aldeia Minhocoçu (figura 28) começou pela identificação do sítio a partir da presença de fragmentos cerâmicos distribuídos pela superfície do terreiro ao redor do espaço doméstico de Fernando Apiaká, para onde o material teria sido varrido, chegando até a área de roça próxima (STUCHI, 2010: 224). Segundo os relatos dos índios, este local era antes ocupado por uma vegetação de capoeira em solo arenoso (STUCHI, 2010: 224). A área foi, e ainda é, utilizada como área de roça pelos Kaiabi, tendo a capoeira sido derrubada dando lugar à roças em solo de coloração pouco escura, com baixa ocorrência de vestígios arqueológicos (STUCHI, 2010: 224).

Foram coletados 347 fragmentos cerâmicos, distribuídos como na tabela 8, abaixo.

\begin{tabular}{|l|l|l|l|l|l|l|}
\hline $\mathrm{n}=347$ & N0 & N1 & N2 & N3 & N4 & N5 \\
\hline Coleta de superfície & 110 & & & & & \\
\hline PT1 & & 90 & 45 & 14 & 4 & 2 \\
\hline PT2 & & 15 & 23 & 23 & 16 & 5 \\
\hline Total & $\mathbf{1 1 0}$ & $\mathbf{1 0 5}$ & $\mathbf{6 8}$ & $\mathbf{3 7}$ & $\mathbf{2 0}$ & $\mathbf{7}$ \\
\hline
\end{tabular}

Tabela 8: Distribuição dos fragmentos cerâmicos no sítio MI.

Foi encontrado no poço-teste um fragmento de carvão associado a um fragmento de cerâmica, há $50 \mathrm{~cm}$ de profundidade. O perfil estratigráfico dos poços teste são mostrados abaixo (figuras 29 e 30).

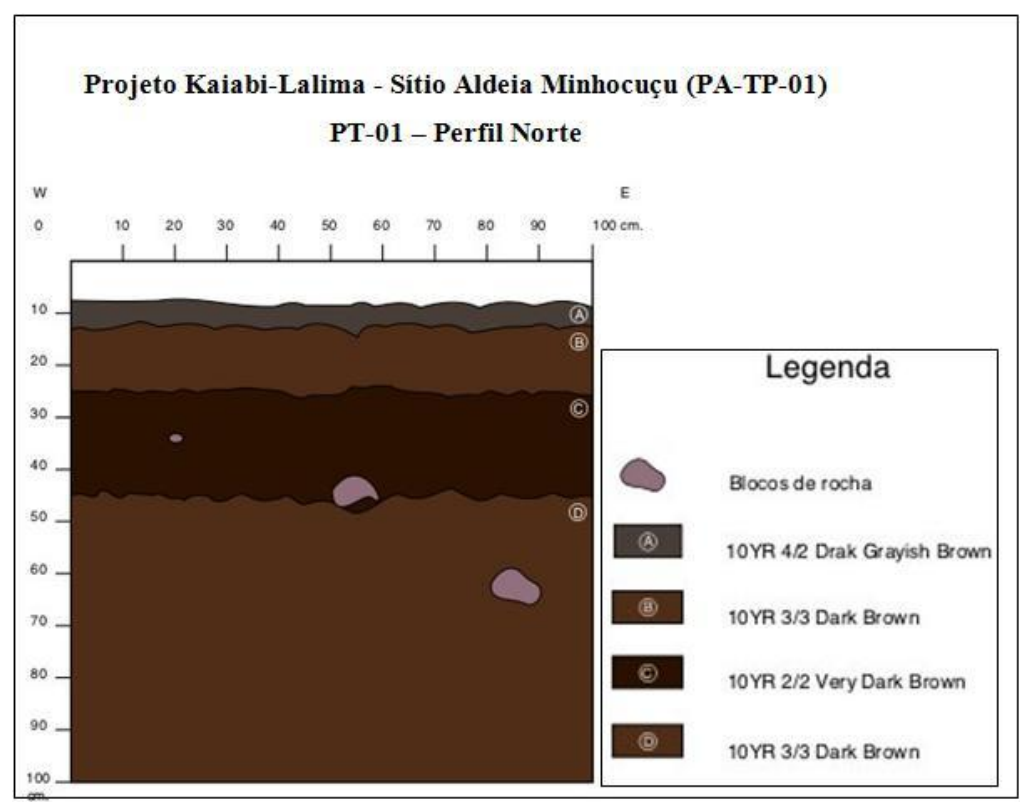

Figura 29: Perfil norte do PT1 no sítio MI. (Cf. STUCHI, 2010: 227). 


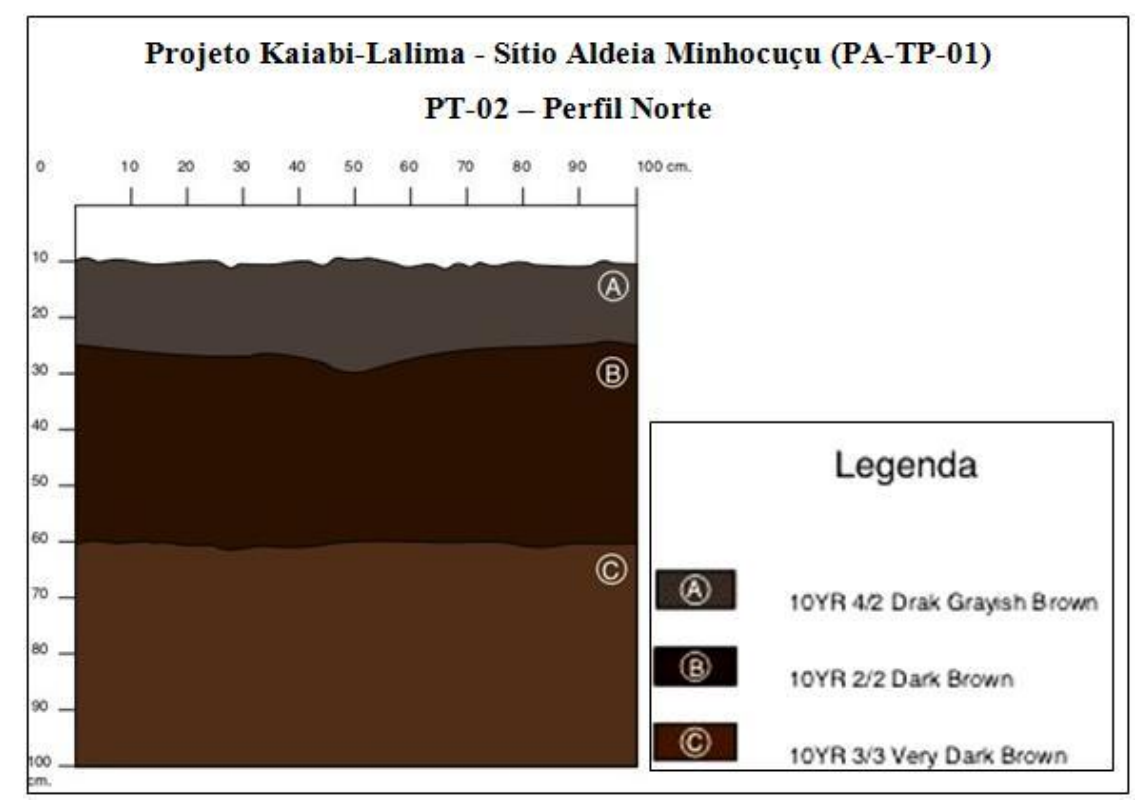

Figura 30: Perfil norte do PT2 no sítio MI. (Cf. STUCHI, 2010: 230).

Foi também encontrada 1 bolota de argila, com antiplástico mineral e coloração avermelhada.

Foram analisados $\mathbf{2 3 4}$ fragmentos de vasilhas cerâmicas (figura 31).

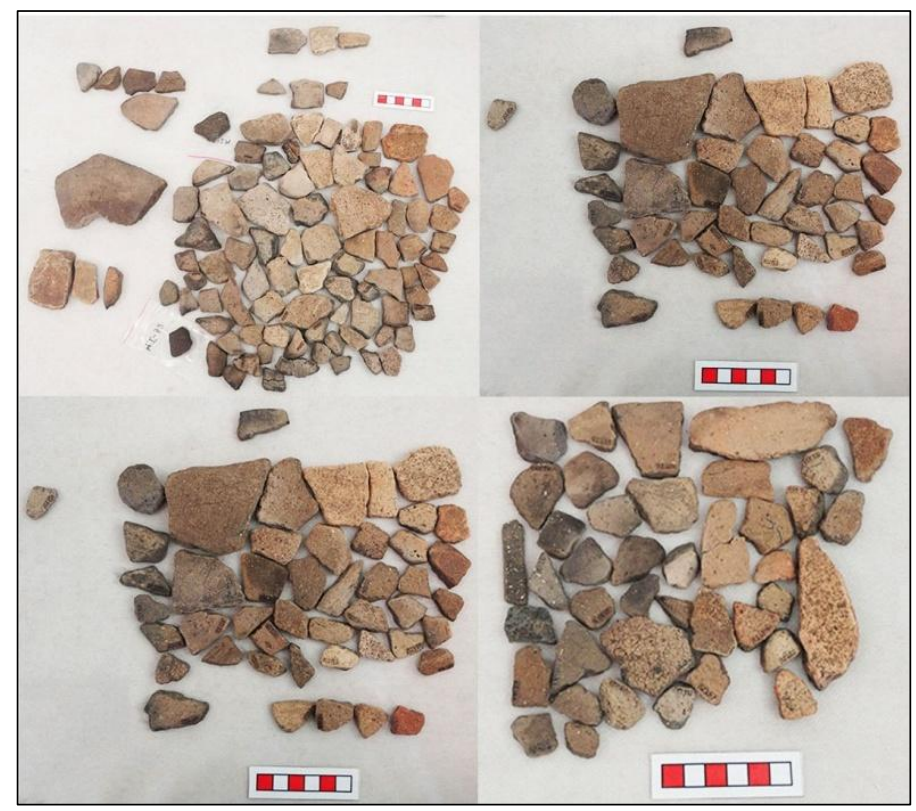

Figura 31: Fragmentos do sítio MI.

Sobre o tratamento da matéria-prima, a maior parte dos fragmentos possui antiplástico cauixi e caraipé (204/87,2\%), sendo o restante mineral, caraipé, cauixi e uma combinações entre eles. 
Em $124(53 \%)$ fragmentos foi possível identificar o roletado como técnica de manufatura, relacionado à construção da vasilha.

Em relação à morfologia, foi encontrada $1(0,4 \%)$ base (circular plana), $221(94,4 \%)$ paredes (sendo 3 ombros e 2 carenadas) e $12(5,1 \%)$ bordas, cuja variabilidade está descrita na tabela 11, no item 4.8. Na maior parte dos fragmentos não foi possível identificar a espessura, pois a face externa ou interna estava muito deteriorada, impossibilitando a medição. Nos fragmentos em que a espessura foi medida, a maior parte ficou entre $6 \mathrm{~mm}$ e $11 \mathrm{~mm}$ (122/52,1\%), principalmente $7 \mathrm{~mm}$.

Em relação aos indicativos de queima, 3 fragmentos apresentaram a firecloud como marca de queima. Os tipos de núcleos observados foram principalmente do tipo 3 (97/41,5\%), seguido do tipo $1(60 / 25,6 \%)$ e $5(52 / 22,2 \%)$. Em relação à coloração da face externa, a maior parte é cinza claro (129/55,1\%), seguida de marrom $(29 / 12,4 \%)$ e cinza escuro $(28 / 12 \%)$. Para a face interna, grande parte não pode ser identificada $(83 / 35,5 \%)$ por estar ausente, mas das identificadas a coloração majoritária é o cinza claro $(93 / 39,7 \%)$.

O acabamentos de superfície da face externa, interna e do lábio mais comum foi o alisamento, com raríssimo fragmentos com engobo vermelho, banho e inciso (figura 32).

Quanto ao uso, 22 (9,4\%) fragmentos apresentou marca de fuligem, depósito de carbono e polidor de sulco.

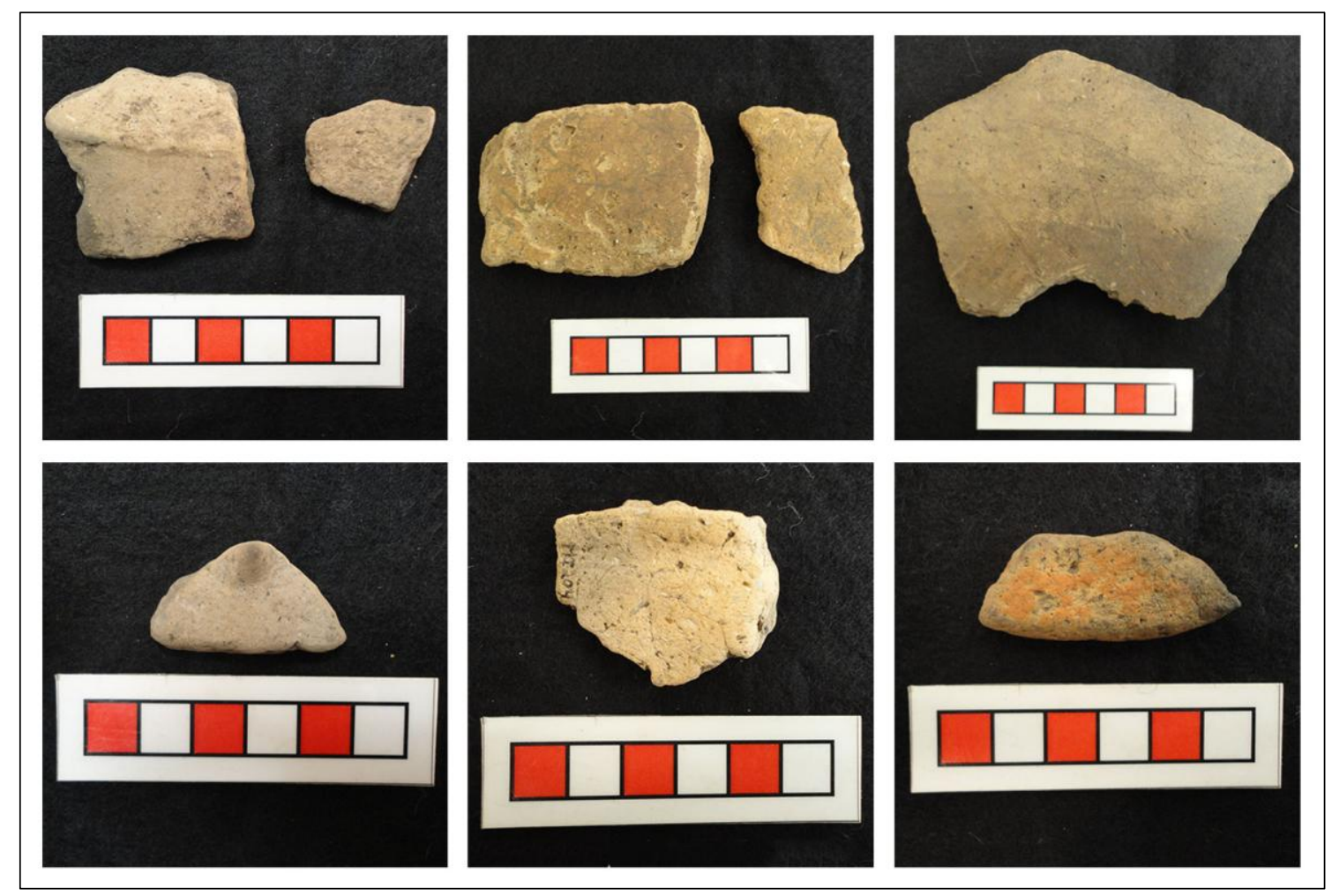

Figura 32: Fragmentos do sítio MI de ombros, com banho, base, apêndice, banho e engobo vermelho. 
4.6. Sítio Taitetu (TT)

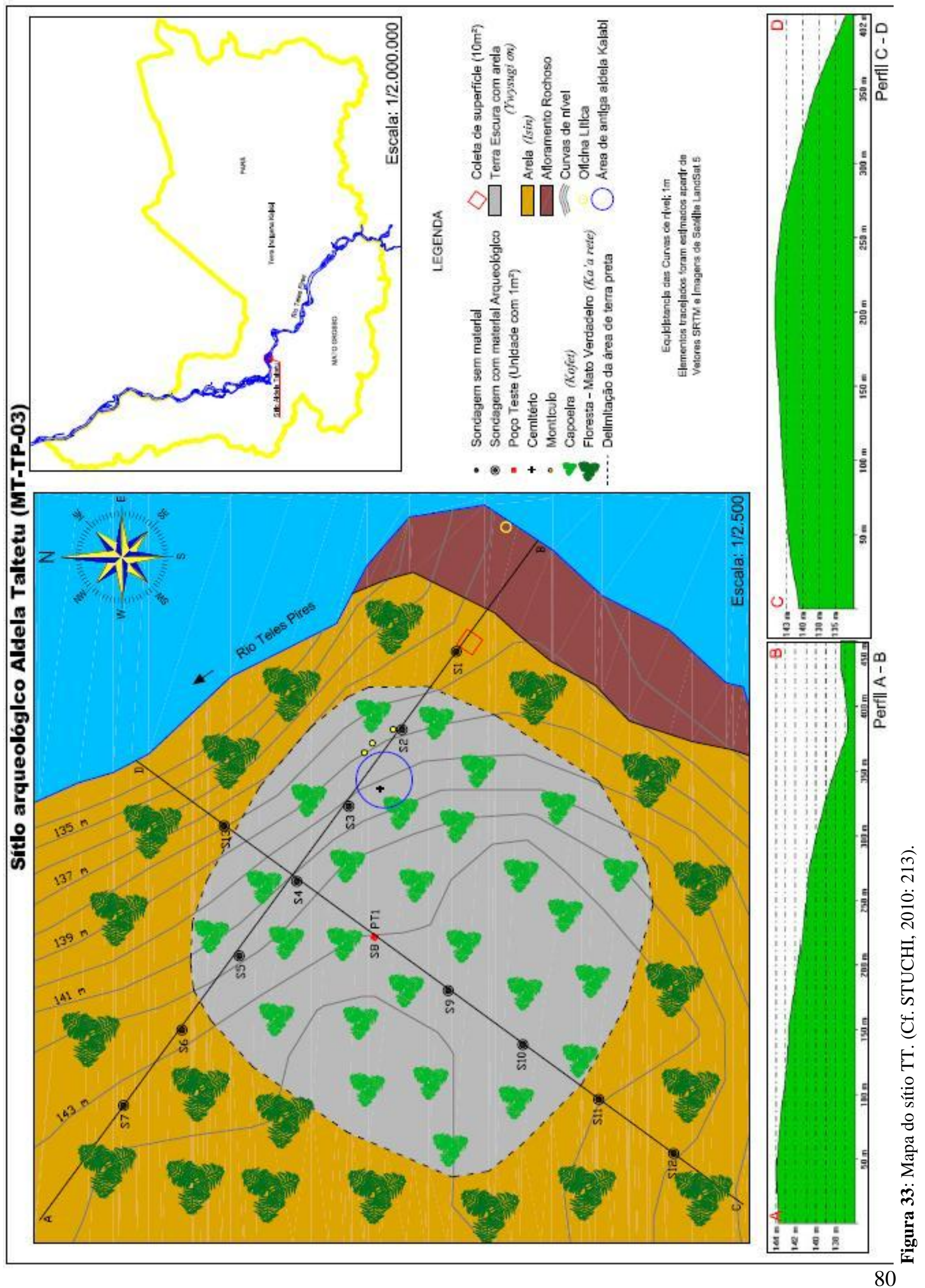


O sítio Taitetu está localizado em uma ilha fluvial de mesmo nome, no rio Teles Pires, aproximadamente duas horas e meia a jusante da aldeia Kururuzinho (figura 33). Na porção leste da ilha existe um grande lajedo que emerge na estiagem, onde observa-se uma oficina lítica constituída de polidores em canaleta, sendo que o sítio escavado encontra-se no interior da ilha em solo arenoso de coloração escura e vegetação de capoeira (STUCHI, 2010: 212).

Este sítio foi ocupado diversas vezes, tanto por índios na época pré-colonial como pelos Kaiabi em duas ocasiões e também por não índios (STUCHI, 2010: 212). A primeira ocupação Kaiabi foi muito antiga, lembrada pelos relatos de seus antepassados de quando os Kaiabi chegaram ao Teles Pires; a segunda ocupação ocorreu na década de 70, com uma aldeia da família extensa de Kupekain Kaiabi da qual ainda pode-se ver um esteio de madeira deteriorado e um sepultamento (STUCHI, 2010: 212-214). Além dos fragmentos cerâmicos e líticos arqueológicos foram encontrados bens industrializados, podendo estar associados tanto a segunda ocupação Kaiabi como a ocupação posterior dos garimpeiros, que construíram uma pista de pouso passando por cima da antiga aldeia (STUCHI, 2010: 214).

A distribuição horizontal e vertical dos fragmentos no sítio está descrita na tabela 9 abaixo:

\begin{tabular}{|l|l|l|l|l|l|l|l|l|l|l|l|l|l|l|}
\hline $\mathrm{n}=1935$ & N0 & N1 & N2 & N3 & N4 & N5 & N6 & N7 & N8 & N9 & N10 & N11 & N12 & NI \\
\hline $\begin{array}{l}\text { Coleta de } \\
\text { superfície }\end{array}$ & 751 & & & & & & & & & & & & & \\
\hline S1 & & & 1 & & 4 & & 4 & 4 & 5 & 1 & & & & \\
\hline S2 & & & 2 & 8 & & 49 & & & & & & & & \\
\hline S3 & & & 2 & 3 & 10 & 6 & 6 & & & & & & & \\
\hline S4 & & 1 & 4 & 6 & 1 & 8 & 15 & 3 & 5 & 1 & 4 & & & \\
\hline S5 & & & 5 & & 21 & & & & & & & & & \\
\hline S6 & & & & & & & & & & & & & & 10 \\
\hline S7 & & & 2 & & 3 & & & & & & & & & \\
\hline S8 & & & 4 & & 23 & & & & 7 & & 5 & & & \\
\hline S9 & & & 1 & & 4 & 22 & & & 14 & & 3 & & 1 & \\
\hline S10 & & & 3 & & 6 & & 2 & & & & & & & \\
\hline S11 & & & 6 & & 2 & & 5 & & & & & & & \\
\hline S12 & & & 9 & & 2 & & & & & & & & & \\
\hline S13 & & & 2 & & 4 & & 1 & & & & & & & \\
\hline PT1 & & 7 & 165 & 203 & 227 & 132 & & 88 & 12 & 16 & 14 & & & \\
\hline Total & $\mathbf{7 5 1}$ & $\mathbf{8}$ & $\mathbf{2 0 6}$ & $\mathbf{2 2 0}$ & $\mathbf{3 0 7}$ & $\mathbf{2 1 7}$ & $\mathbf{3 3}$ & $\mathbf{9 5}$ & $\mathbf{4 3}$ & $\mathbf{1 8}$ & $\mathbf{2 6}$ & $\mathbf{0}$ & $\mathbf{1}$ & $\mathbf{1 0}$ \\
\hline
\end{tabular}

Tabela 9: Distribuição dos fragmentos cerâmicos no sítio TT. 
Os fragmentos cerâmicos coletados neste sítio encontram-se bastante deteriorados nas superfícies externa e interna, estando também bastante fragmentados. A deterioração deste material pode estar associada ao fato de que o sítio localiza-se em uma ilha de terreno arenoso sujeita à inundações periódicas. .

Devido à redução da equipe de escavação e ao difícil acesso à esse sítio, a metodologia de escavação teve que ser alterada para que fosse possível aos pesquisadores terminar o trabalho em tempo. Em muitas sondagens e no poço teste, foram escavados níveis artificiais de $20 \mathrm{~cm}$, ao invés de $10 \mathrm{~cm}$.

$\mathrm{Na}$ escavação do poço teste, foi encontrado um buraco causado por bioperturbação de $90 \mathrm{~cm}$ até $120 \mathrm{~cm}$ de profundidade, o que pode ter sido responsável pelo transporte do material cerâmico até a profundidade de $120 \mathrm{~cm}$ (STUCHI, 2010: 222). O perfil estratigráfico é mostrado aqui (figura 34).

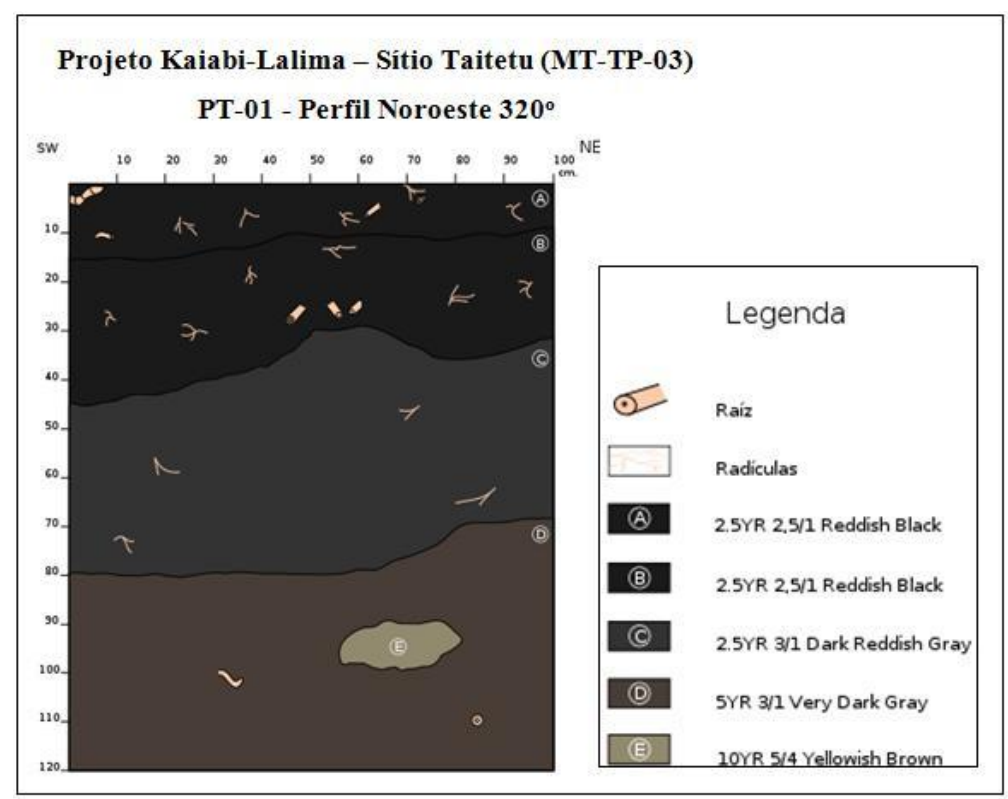

Figura 34: Perfil noroeste do PT1 no sítio TT. (Cf. STUCHI, 2010: 222).

Foram escavados 12 níveis artificiais, com 4 camadas de solo. A primeira camada, A, é composta de solo arenoso e preto (2.5YR 2.5/1), chegando até um pouco mais do que 10 $\mathrm{cm}$, com baixa quantidade de material arqueológico. A camada B vai do nível 2 até quase metade do 5, com o mesmo solo da camada anterior, mas uma maior quantidade de material até os $30 \mathrm{~cm}$, diminuindo novamente até $50 \mathrm{~cm}$. Enviamos para datação por termoluminescência, com a empresa Datação, uma cerâmica encontrada no nível 4, resultando em uma data de $380 \pm 50$ A.P. (ver Anexo C). 
A camada C é ainda de um solo arenoso, mas com coloração cinza escuro avermelhado (2.5YR 3/1), estendendo-se até o nível 8. A última cada, D, começa no nível 9 até o fim da escavação em $110 \mathrm{~cm}$, apresentando um solo arenoso de coloração cinza muito escuro (5YR 3/1), e um buraco que possivelmente é resultado de biopertubação, o que possivelmente transportou um fragmento de cerâmico até o último nível encontrado na sondagem.

Foram encontradas 3 bolotas de argila, com antiplástico mineral e coloração avermelhada.

Foram analisados 1236 fragmentos de vasilhas cerâmicas (figura 35).

O resultado inicial da análise encontrou, sobre o tratamento da matéria-prima, que o antiplástico mais comum é a combinação de cauixi e caco moído (671/54,3\%). Também estão presentes em maior quantidade o mineral (197/15,9\%), cauixi $(135 / 10,9 \%)$, e outros como caco moído, caraipé e combinações entre esses elementos.

Sobre a construção da vasilha, em alguns fragmentos foi possível identificar a técnica de manufatura, havendo 565 (46\%) fragmentos produzidos por roletes.

Em relação à morfologia, a maior parte foi classificada na categoria estrutural como sendo a parede das vasilhas (1088/88\%), mas também foram encontradas bordas $(141 / 11,4 \%)$ e bases $(7 / 0,6 \%)$. Das 7 bases encontradas, 5 foram classificadas como circular plana, uma com $6 \mathrm{~cm}$ diâmetro. Das 1.088 paredes, 1 é do segmento inferior, 2 são ombros, 5 são infletidas e 1 angular. A análise das 141 bordas está descrita na tabela 11, no item 4.8. A maior parte dos fragmentos possui espessura entre $5 \mathrm{~cm}$ e $10 \mathrm{~cm}(1000 / 80,9 \%)$, com maior concentração em $8 \mathrm{~mm}$.

Em relação aos indicativos de queima, 33 fragmentos apresentaram a firecloud como marca de queima. Os tipos de núcleos observados foram principalmente do tipo 1 $(486 / 39,3 \%), 2(340 / 27,5 \%)$ e $3(248 / 20,1 \%)$. Em relação à coloração da face externa, 437 $(35,4 \%)$ foi classificada como cinza claro, 239 (19,3\%) marrom avermelhado e $169(13,7 \%)$ cinza escuro. Na face interna, a coloração seguiu o mesmo padrão, com $537(43,4 \%)$ cinza claro, 203 (16,4\%) marrom avermelhado e $164(13,3 \%)$ cinza escuro.

O acabamento de superfície da face externa, interna e do lábio mais comum foi o alisamento (figura 36). Encontramos outros acabamentos na face externa de 58 (5\%) fragmentos e na face interna de 28 (2\%) fragmentos. Os acabamentos plásticos incluem impressão de corda, inciso e acanalado e os acabamentos cromáticos o engobo branco, vermelho, rosa e banho, com combinações entre eles. 
Quanto ao uso, em 8,3\% dos fragmentos foi encontrada fuligem, depósito de carbono e marcas de polidor de sulco (figura 36).

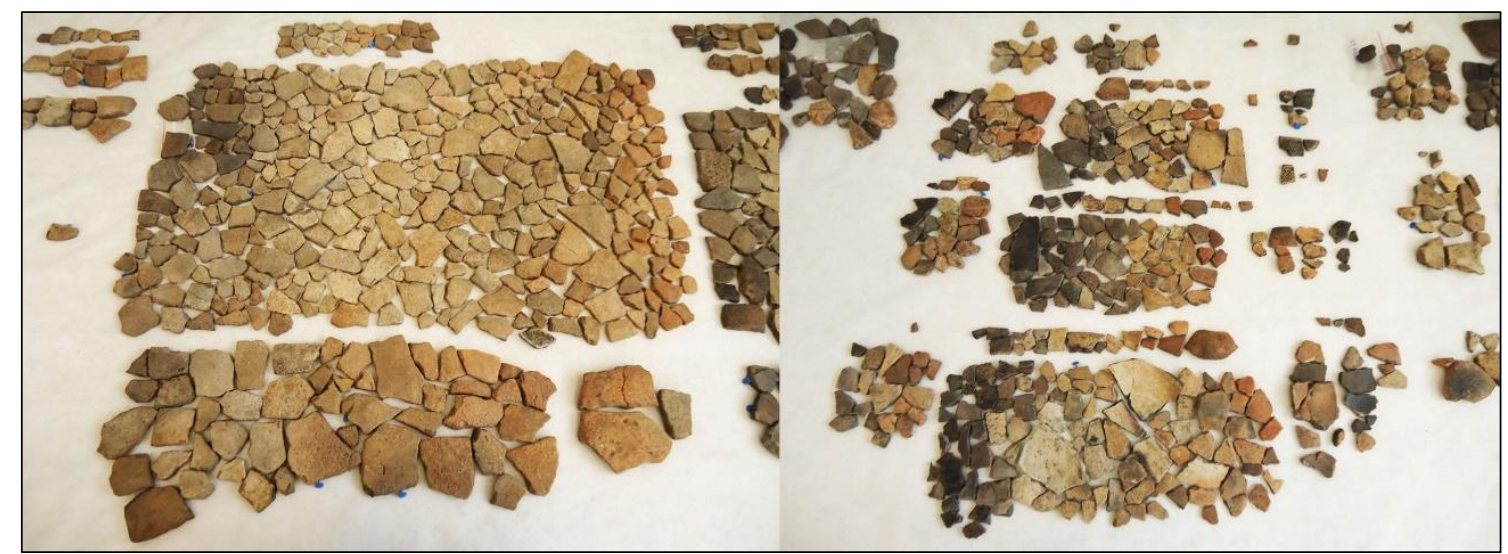

Figura 35: Fragmentos do sítio TT.

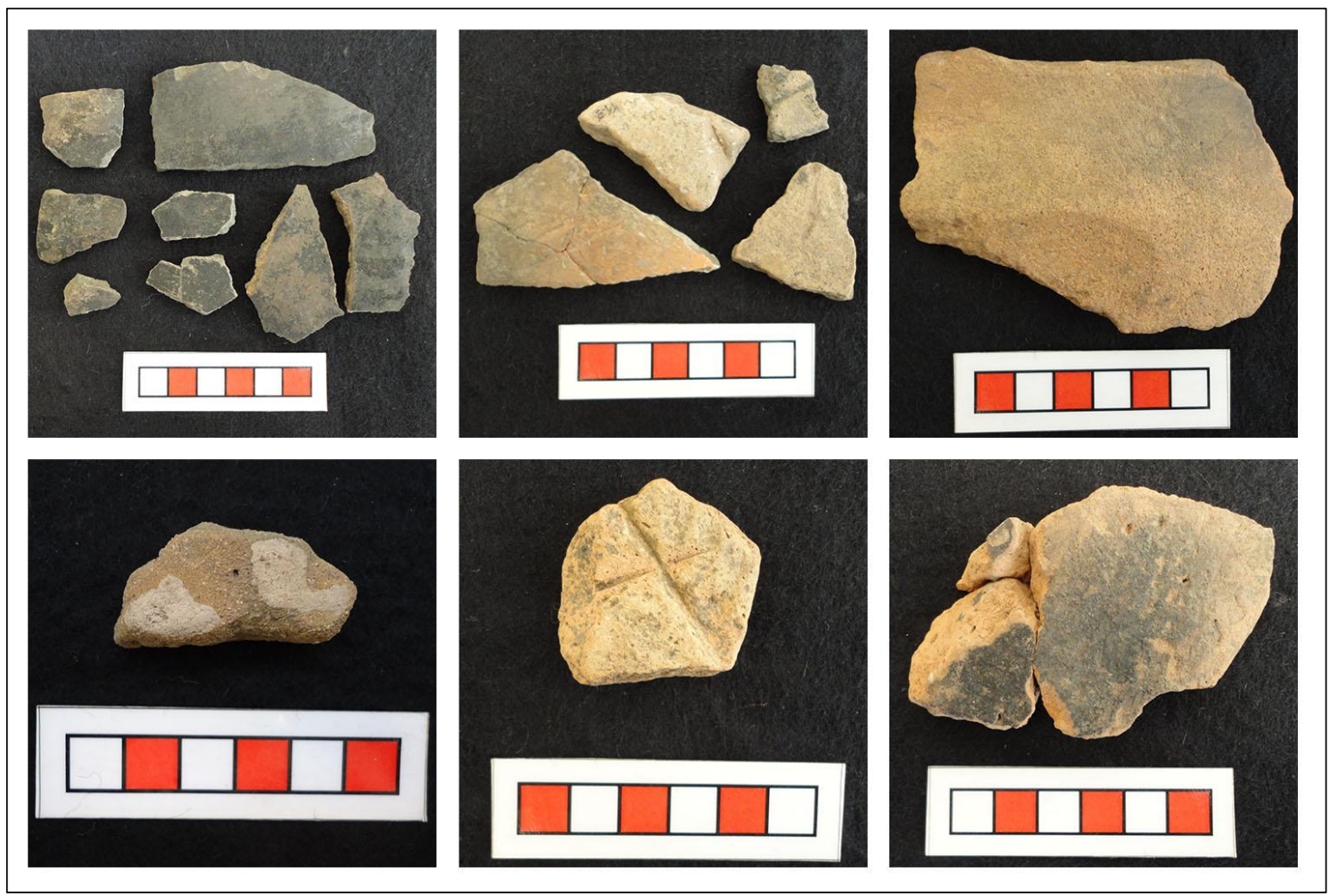

Figura 36: Fragmentos do sítio TT com fuligem, banho, polidor de sulco, engobo branco, polidor de sulco cruzado e fuligem. 
4.7. Sítio Ywantã (YA)

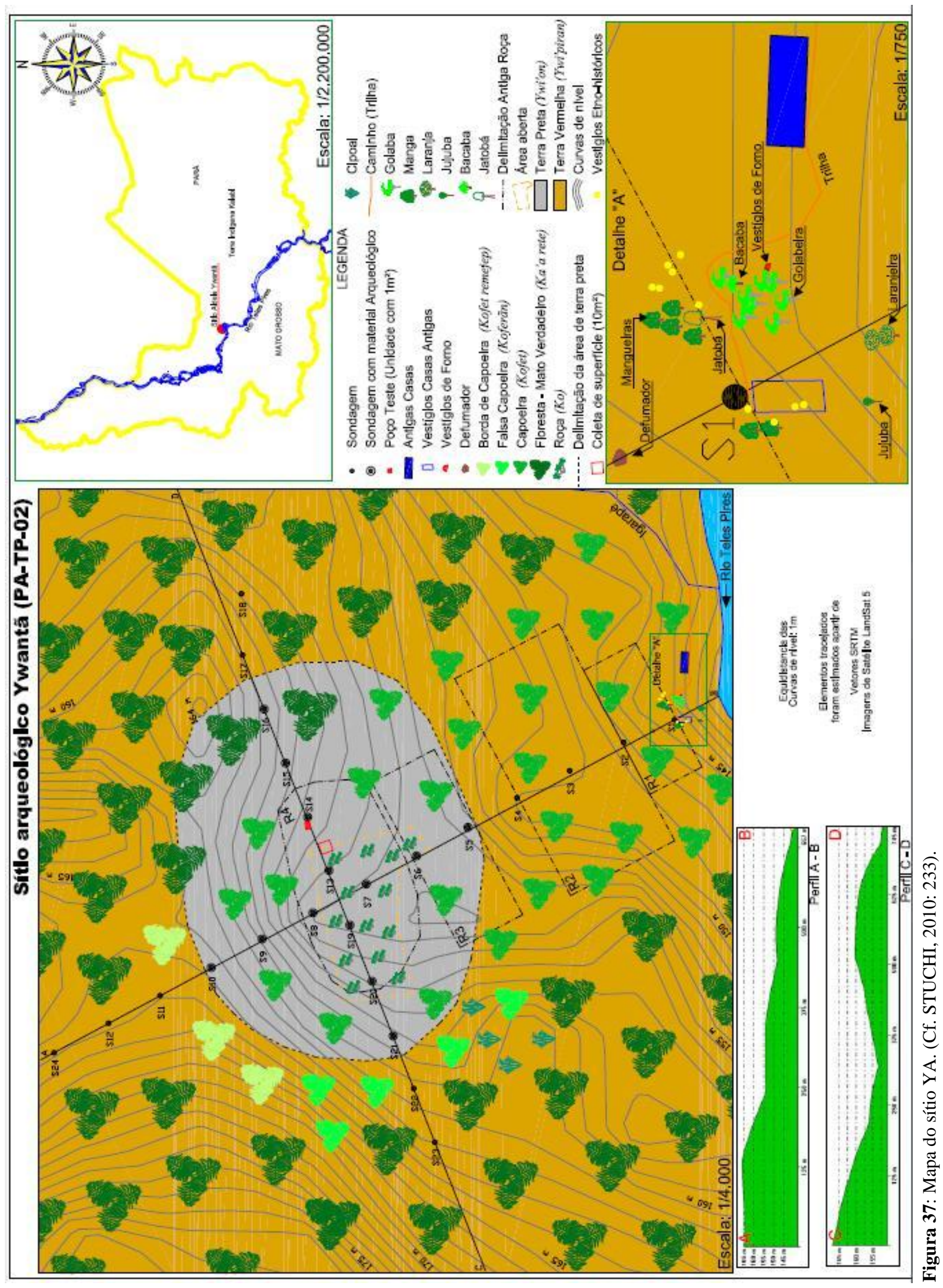


Este sítio está localizado a jusante da aldeia Kururuzinho, nas encostas baixa e média de uma colina suave, entre a confluência da margem direita de um pequeno igarapé com a margem direita do baixo curso do Teles Pires (figura 38). Ywantã é um sítio pré-colonial e etno-histórico, sendo que a última ocupação foi feita pela família de Fernando Paleci Apiaká, há mais ou menos 10 anos (STUCHI, 2010: 231). Ainda pode-se observar as estruturas de duas casas, vestígios de um forno de torrar farinha e outro de defumar seringa, além de restos de bens industrializados. À noroeste da área de habitação estão as antigas roças de Fernando Apiaká, implantadas sobre capoeiras mais antigas que continham vestígios da ocupação précolonial em um núcleo de terra preta (STUCHI, 2010: 232).

Foram coletados 1.066 fragmentos cerâmicos, distribuídos no sítio como na tabela 10, abaixo.

\begin{tabular}{|c|c|c|c|c|c|c|c|}
\hline$n=1066$ & NI & No & N1 & $\mathbf{N 2}$ & N3 & N4 & N5 \\
\hline NI & 44 & & & & & & \\
\hline Coleta de superfície & & 326 & & & & & \\
\hline S5 & & & & 4 & 1 & & 1 \\
\hline S7 & & & 4 & 4 & 3 & 1 & 1 \\
\hline S8 & & & 12 & 18 & 3 & 1 & 1 \\
\hline S10 & & & 8 & & & & \\
\hline $\mathbf{S 1 3}$ & & & 3 & 1 & 1 & & \\
\hline S14 & & & 19 & 8 & 2 & & \\
\hline S15 & & & 5 & 2 & & & \\
\hline S16 & & & 2 & & & & \\
\hline S17 & & & 5 & 3 & & & \\
\hline S19 & & & 2 & 6 & & 1 & \\
\hline S20 & & & 13 & 4 & 1 & & \\
\hline S21 & & 9 & 6 & 2 & & & \\
\hline $\mathbf{S 2 2}$ & & & 4 & 1 & 2 & & \\
\hline PT1 & & & 280 & 225 & & 12 & 6 \\
\hline Buraco & & 9 & & & & & \\
\hline Total & 44 & 344 & 363 & 278 & 13 & 15 & 9 \\
\hline
\end{tabular}

Tabela 10: Distribuição dos fragmentos cerâmicos no sítio Ywantã.

A cerâmica deste sitio chamou a atenção dos pesquisadores por sua decoração pintada, ungulada, corrugada, com incisos geométricos e impressões de corda, sendo as unguladas e corrugadas bastante semelhantes às cerâmicas Guarani do sul e sudeste do Brasil (STUCHI, 2010: 234). No entanto, apesar da similaridade inicial, essa comparação com a cerâmica Guarani não foi confirmada após a análise. 
A escavação do poço teste foi feita em uma área de capoeira, atingindo $60 \mathrm{~cm}$ de profundidade e evidenciando 5 camadas de solo. As camadas A e B são constituídas de um solo argilo-arenoso marrom escuro (10YR 2/2), compreendendo a maior quantidade de vestígios arqueológicos. A camada $\mathrm{C}$ abrange $65 \%$ do nível 2 e chegou até metade do terceiro nível, clareando a coloração do solo (10YR 3/1) e diminuindo a quantidade de material arqueológico. A camada D chegou até o fim do nível 4, com um solo mais argiloso e variegado (7.5YR 3/4), tendo sido coletada uma amostra de carvão no fím do nível 3. A última camada, E, abrange os níveis 5 e 6 , predominando o solo argiloso marrom escuro com pontos marrom amarelados (10YR 5/6). O perfil estratigráfico está mostrado na figura 38.

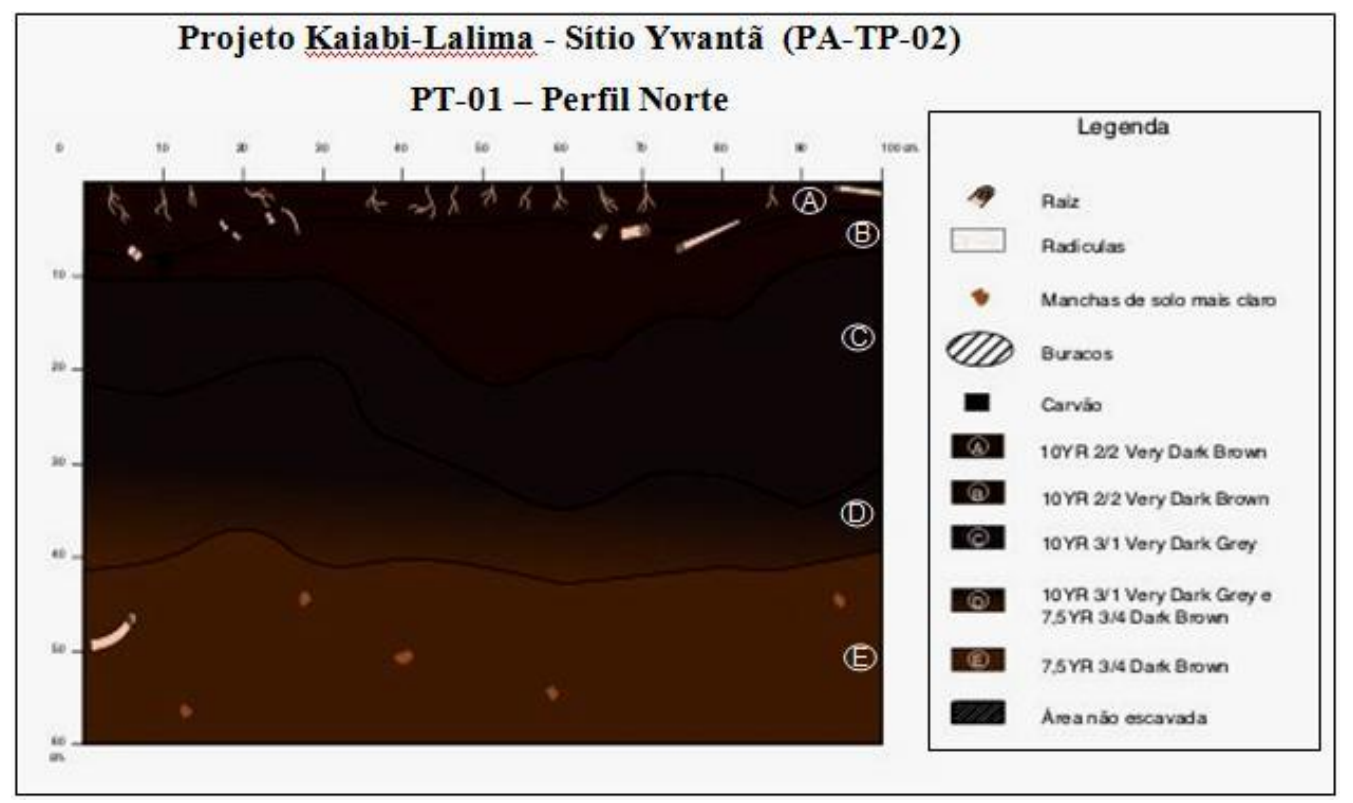

Figura 38: Perfil norte do PT1 no sítio YA. (Cf. STUCHI, 2010: 240).

Foi coletada uma amostra de carvão para datação no nível 3, enviada à Beta Analytic Inc. (ver Anexo C), revelando uma data de $4.920 \pm 30$ A.P. (Cal a.C. 3760 a 3720). Além disso, foi enviada uma amostra de cerâmica do nível 2 para datação por termoluminescência, pela empresa Datação, com resultado bastante diferente de $420 \pm 40$ A.P..

Foram encontradas 13 bolotas de argila e 19 objetos de argila não identificados. As bolotas de argila são provavelmente matéria-prima para a fabricação de vasilhas, mas podem ter sido utilizadas de outra maneira. Os materiais não identificados (figura 39) assemelham-se a bolotas de argila, no entanto possuem uma parte extremamente alisada, parecendo terem sido feitas pelo contato com um instrumento cilíndrico. Temos algumas sugestões para sua utilização (com. pessoal de Silvia Cunha Lima, Claide Moraes, Francisco Noelli, 2013): 
podem ter composto a parte central de um trempe, onde foi feito o furo no meio da massa de argila; podem ter sido pedaços de argila colocados em estruturas de fornos. Ao observar estruturas de forno etnográficas dos Asurini do Xingu (figura 40), nos sentimos incliandos a olhar para estes fragmentos dessa maneira. Outra hipótese é que sejam fragmentos de estruturas de casas, que também observamos entre os Asurini (figura 40). Já que no sítio foram encontradas estruturas de forno (talvez da ocupação anterior mais recente, de Fernando Apiaká) próximas à sondagem 1 e 2 (de onde vem esses fragmentos), pode ser que esses materiais tenham realmente pertencido a elas.

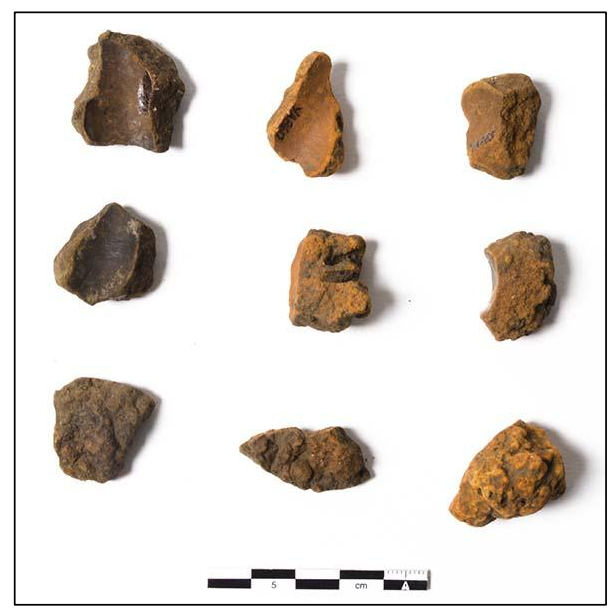

Figura 39: Objetos não identificados de argila, com uma parte rugosa e outra alisada.

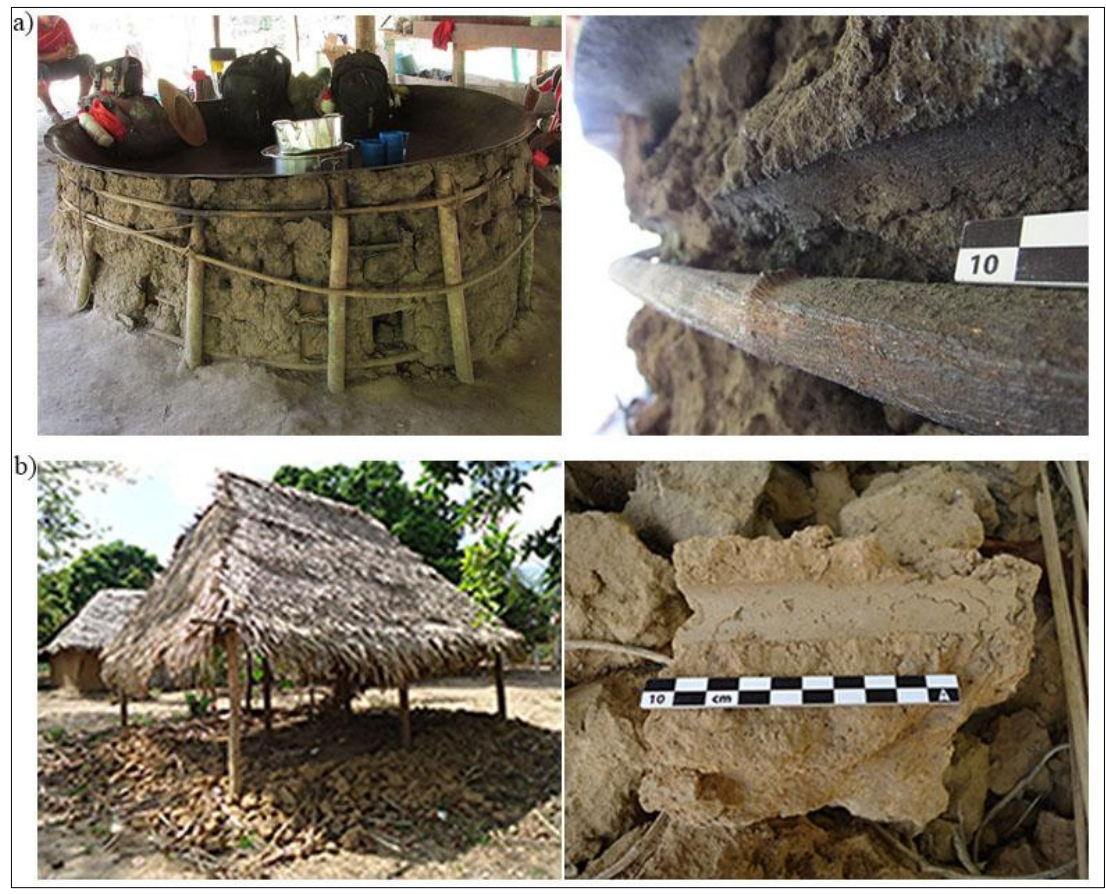

Figura 40: a) forno Asurini e detalhe; b) casa Asurini com parede caída e detalhe. 
Foram analisados $\mathbf{7 4 0}$ fragmentos de vasilha cerâmica (figura 41).

Sobre o tratamento da matéria-prima, o material antiplástico predominante é o mineral em 704 fragmentos (95\%), sendo outros tipos (caco moído, caraipé e cauixi) presentes em apenas $36(5 \%)$ fragmentos.

Sobre a construção da vasilha, em 532 (72\%) fragmentos foi possível observar a técnica de manufatura roletada.

Quanto aos aspectos da morfologia, foram encontradas 3 bases circulares planas, com $8 \mathrm{~cm}, 10 \mathrm{~cm}$ e $16 \mathrm{~cm}$ de diâmetro. As 636 paredes contam com 2 ombros e 2 paredes infletidas. A variabilidade das 100 bordas está descrita na tabela 11, no item 4.8. A maior parte dos fragmentos $(656 / 88 \%)$ tem espessura entre $5 \mathrm{~mm}$ e $9 \mathrm{~mm}$, com concentração em 7 $\mathrm{mm}$.

Em relação aos indicativos de queima, 14 fragmentos apresentam firecloud. A maior parte apresenta a configuração do núcleo do tipo 3 (278/37,6\%), seguida do 1 $(247 / 33,4 \%)$ e $2(141 / 19,1 \%)$. A coloração da face externa é predominantemente cinza claro e escuro (454/61,4\% e 107/14,5\%), sendo que a da face interna segue o mesmo padrão.

O acabamento de superfície da face externa é predominantemente alisado (648/88\%), no entanto chamam a atenção os $11 \%$ de acabamentos plásticos feitos com motivos incisos, de impressão de corda e ungulado, sendo apenas $1 \%$ pintados com engobo (figura 42). Na face interna e no lábio são raros os fragmentos com algum tipo de acabamento que não o alisado.

Quanto ao uso, 14,2\% apresenta marca de fuligem, depósito de carbono e de polidor de sulco. 


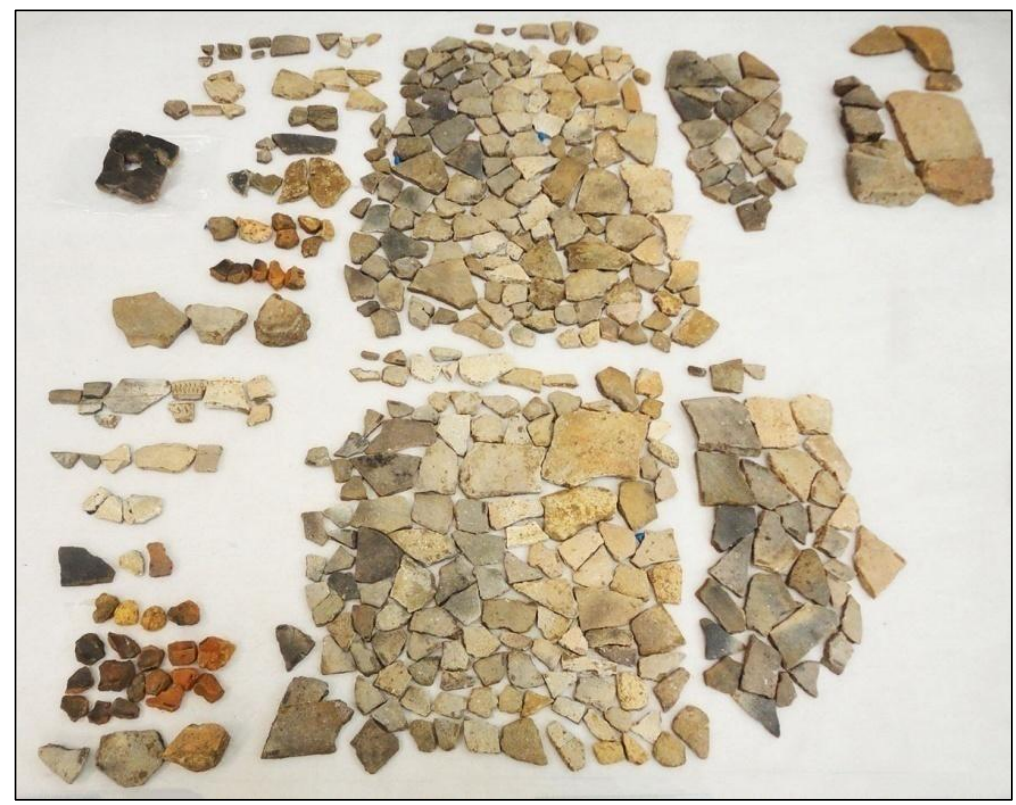

Figura 41: Fragmentos do sítio YA.
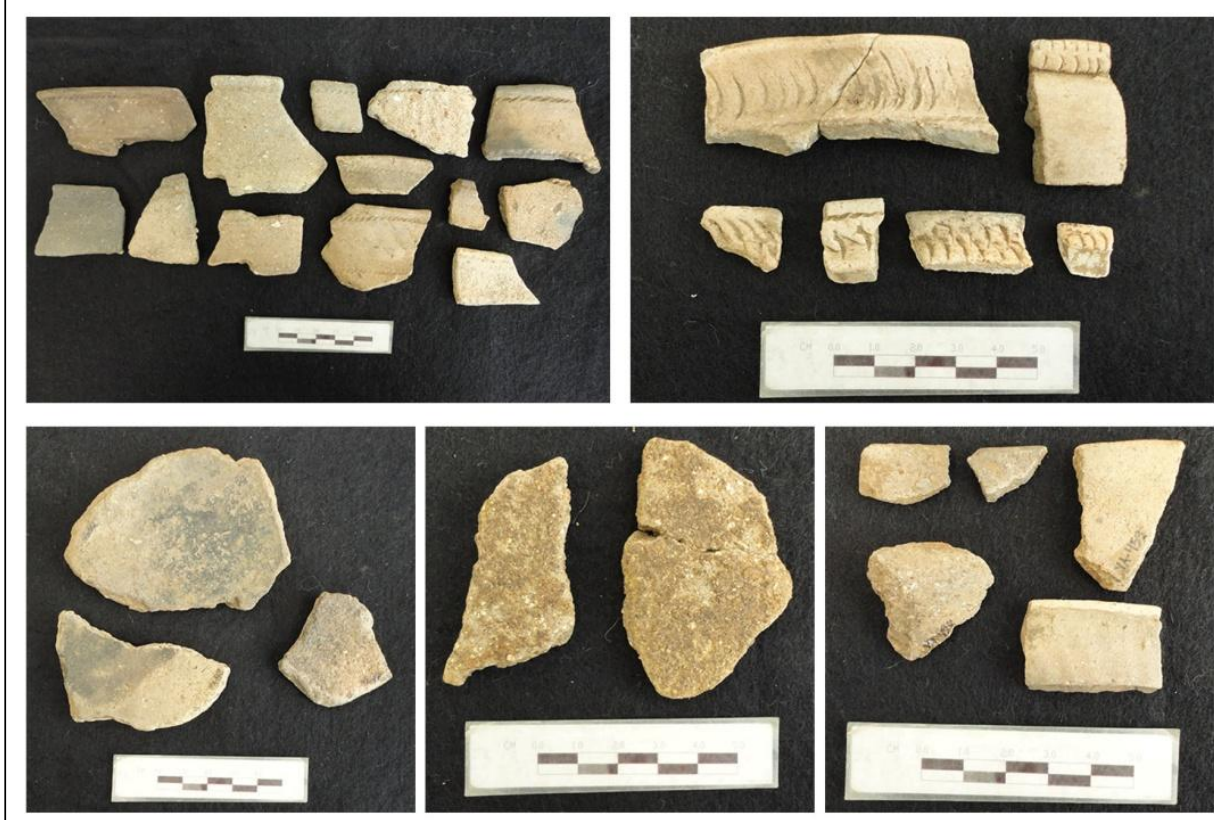

Figura 42: Fragmentos do sítio YA, com impressão de corda, incisos, bases, banho e alisamento. 
4.8. Estatística Descritiva da Análise Cerâmica
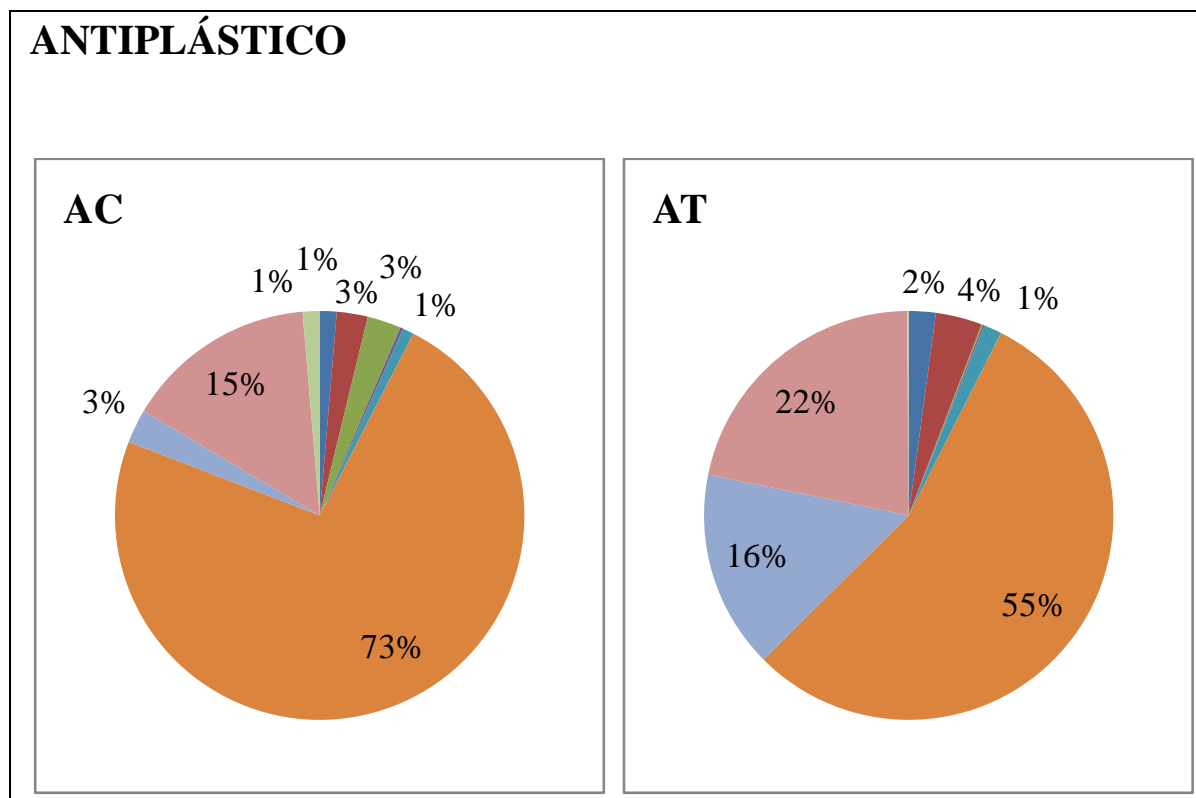

\section{DR}
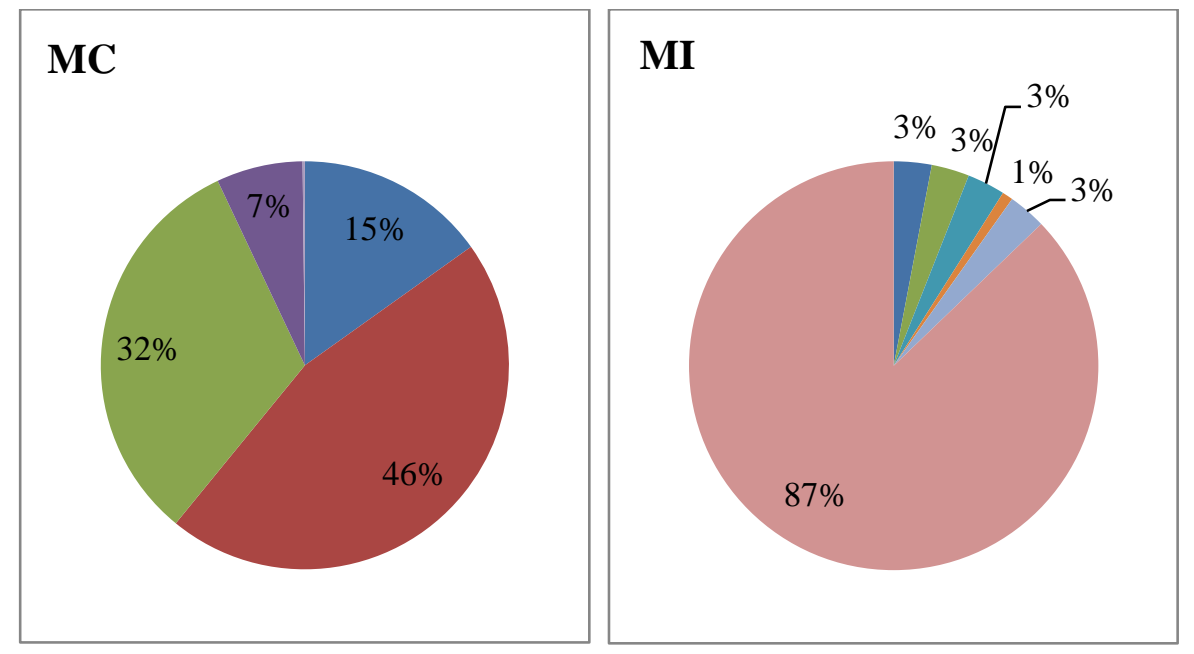

TT
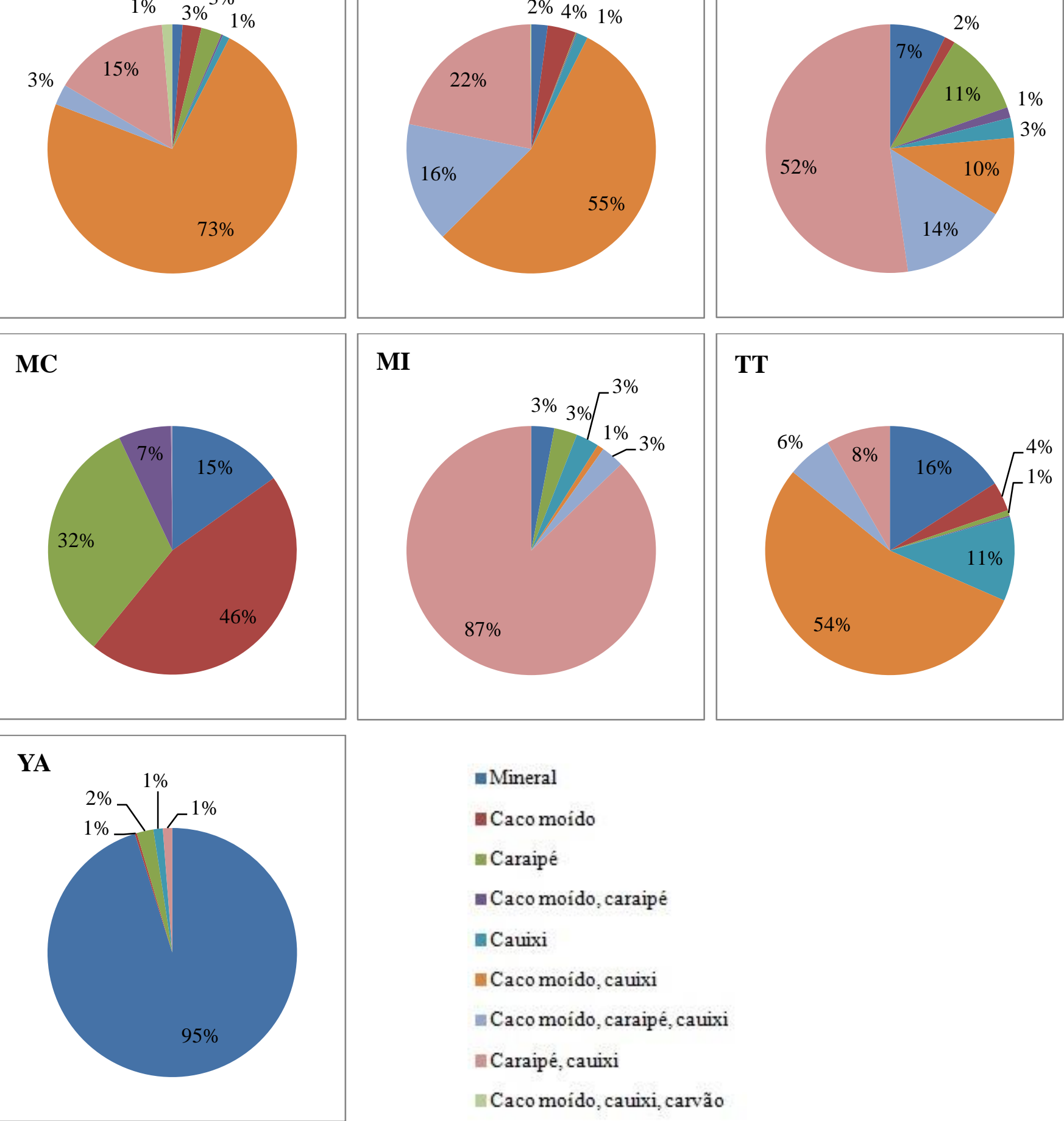

- Mineral

Caco moído

- Caraipé

- Caco moído, caraipé

Cauixi

Caco moido, cauixi

- Caco moido, caraipé, cauixi

Caraipé, cauixi

Caco moído, cauixi, carvão

Gráfico 1: Distribuição de tipos de antiplásticos dos fragmentos em cada sítio. 


\section{CATEGORIA ESTRUTURAL}
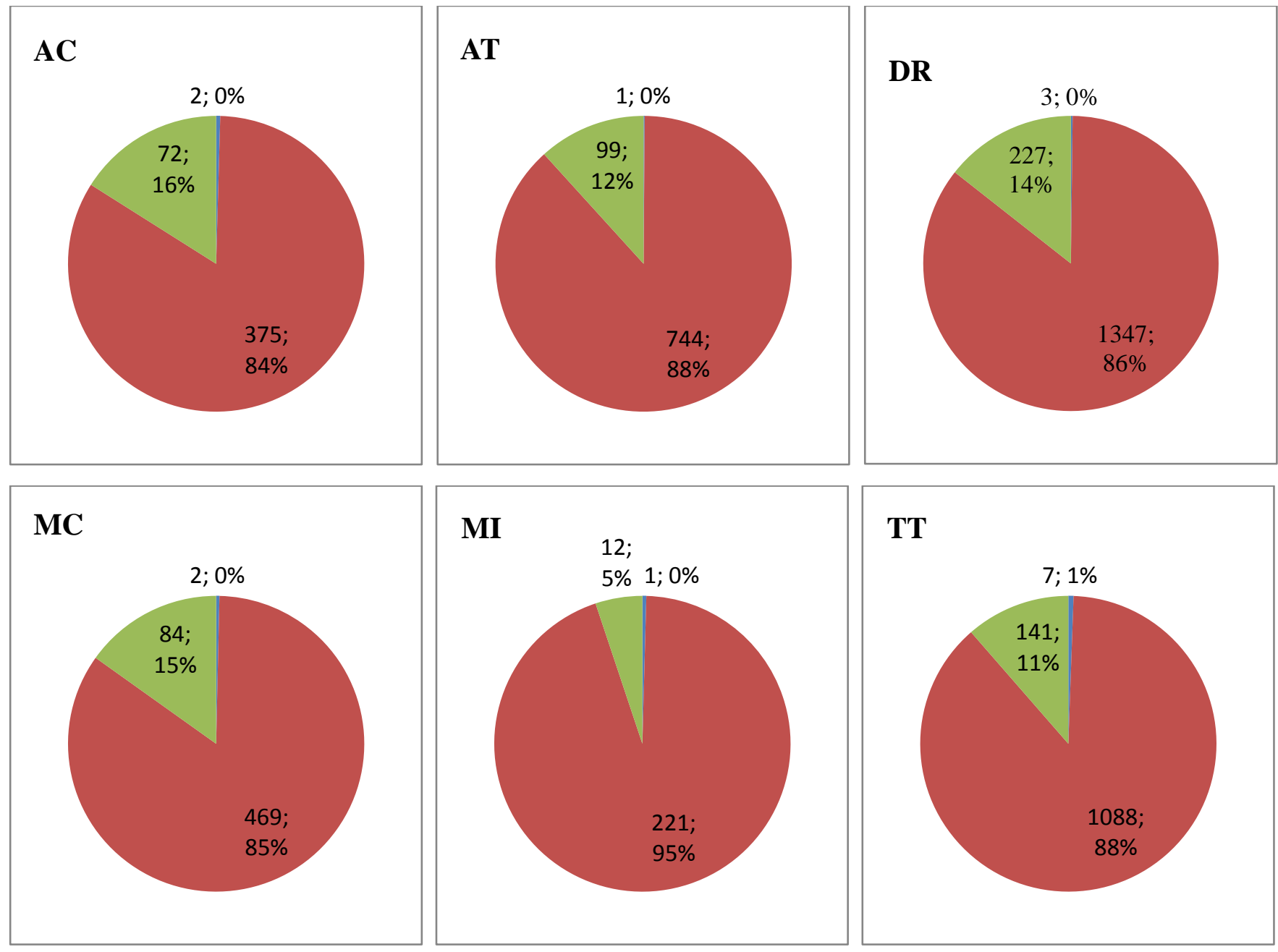

TT

YA
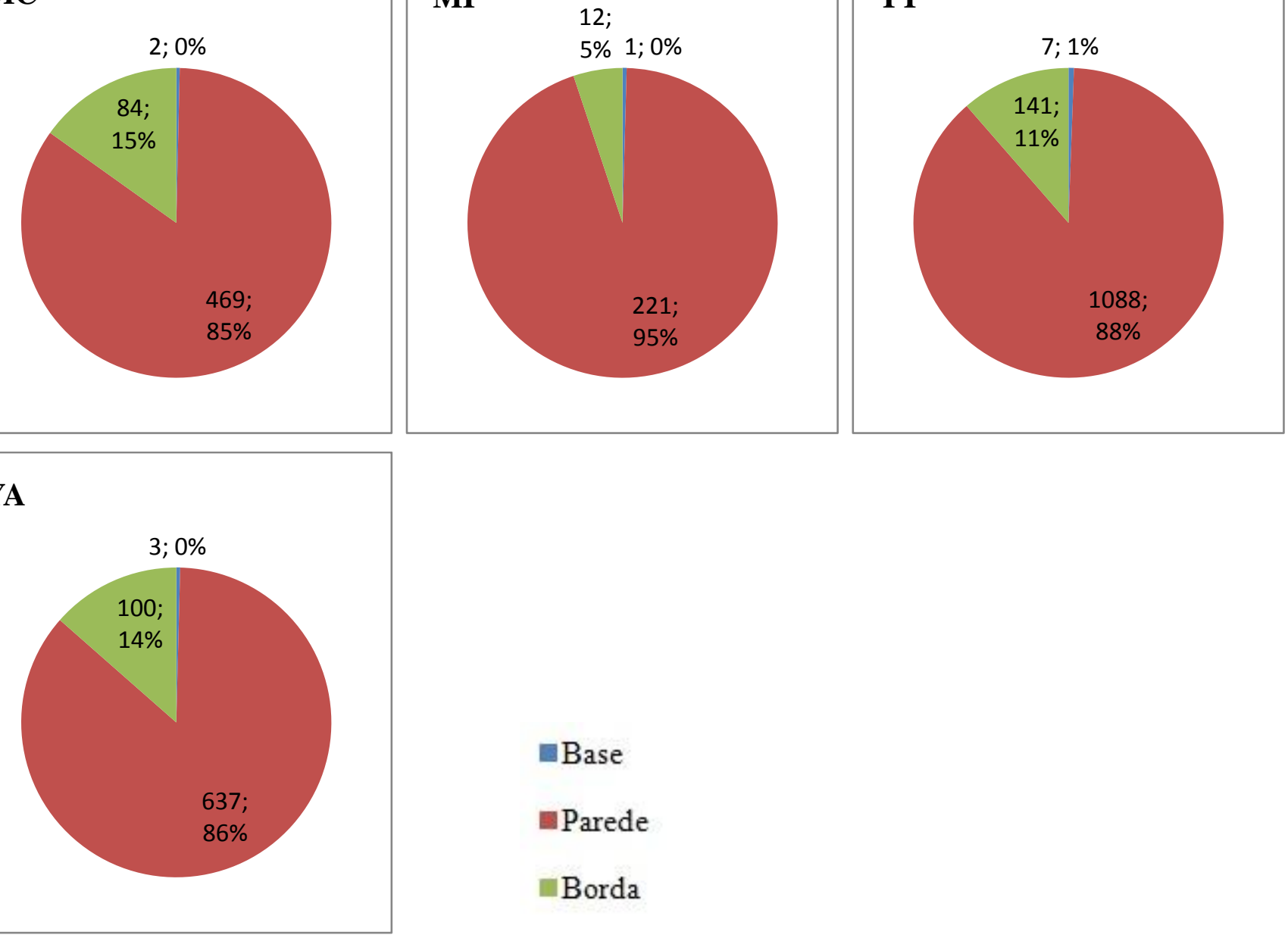

Gráfico 2: Distribuição da categoria estrutural dos fragmentos em cada sítio. 
VARIANTES DE BORDA

\begin{tabular}{|l|c|c|c|c|c|c|c|}
\hline Variante de borda & AC & AT & DR & MC & MI & TT & YA \\
\hline Direta vertical & 4 & 3 & 52 & 11 & 2 & 8 & 10 \\
\hline Direta inclinada externa & 7 & 6 & 15 & 4 & 2 & 8 & 14 \\
\hline Direta inclinada interna & - & 2 & 8 & 8 & 1 & - & 5 \\
\hline Extrovertida & - & - & 12 & 3 & 1 & 1 & - \\
\hline Carenada & - & - & 1 & - & - & - & - \\
\hline Cambada & - & - & - & 2 & - & - & - \\
\hline Residual & - & - & - & 1 & - & - & - \\
\hline Horizontal & - & - & 1 & - & - & - & - \\
\hline NI & 61 & 88 & 138 & 55 & 6 & 121 & 71 \\
\hline Total & $\mathbf{7 2}$ & $\mathbf{9 9}$ & $\mathbf{2 2 7}$ & $\mathbf{8 4}$ & $\mathbf{1 2}$ & $\mathbf{1 4 1}$ & $\mathbf{1 0 0}$ \\
\hline
\end{tabular}

\begin{tabular}{|l|c|c|c|c|c|c|c|}
\hline Ângulo de inclinação & AC & AT & DR & MC & MI & TT & YA \\
\hline Vertical & 4 & 3 & 52 & 13 & 2 & 8 & 10 \\
\hline Ligeiramente aberto & 7 & 3 & 10 & 4 & 1 & 8 & 14 \\
\hline Aberto & - & 3 & 16 & 4 & 2 & 1 & 1 \\
\hline Ligeiramente fechado & - & 2 & 8 & 8 & 1 & - & 4 \\
\hline Fechado & - & - & 1 & - & - & - & - \\
\hline Horizontal & - & - & 1 & - & - & - & - \\
\hline Muito aberto & - & - & 1 & - & - & - & - \\
\hline NI & 61 & 88 & 138 & 55 & 6 & 121 & 71 \\
\hline Total & $\mathbf{7 2}$ & $\mathbf{9 9}$ & $\mathbf{2 2 7}$ & $\mathbf{8 4}$ & $\mathbf{1 2}$ & $\mathbf{1 4 1}$ & $\mathbf{1 0 0}$ \\
\hline
\end{tabular}

\begin{tabular}{|l|c|c|c|c|c|c|c|}
\hline Variante de lábio & AC & AT & DR & MC & MI & TT & YA \\
\hline Ausente & - & - & - & 6 & - & 4 & 3 \\
\hline Arredondado & 64 & 72 & 145 & 68 & 9 & 86 & 69 \\
\hline Apontado & - & 14 & 25 & 3 & 2 & 21 & 11 \\
\hline Aplanado & 3 & 6 & 31 & 4 & 1 & 10 & 13 \\
\hline Biselado & 2 & 5 & 17 & - & - & 11 & 2 \\
\hline Reforçado & 2 & 1 & 2 & 1 & - & - & 1 \\
\hline Rebarbado & - & 1 & - & - & - & 1 & 1 \\
\hline Ondulado & - & - & 1 & - & - & - & - \\
\hline NI & 1 & - & 4 & 2 & - & - & - \\
\hline Total & $\mathbf{7 2}$ & $\mathbf{9 9}$ & $\mathbf{2 2 7}$ & $\mathbf{8 5}$ & $\mathbf{1 2}$ & $\mathbf{1 4 1}$ & $\mathbf{1 0 0}$ \\
\hline
\end{tabular}

Tabela 11: Atributos das bordas em cada sítio. 


\section{ESPESSURA (MM)}
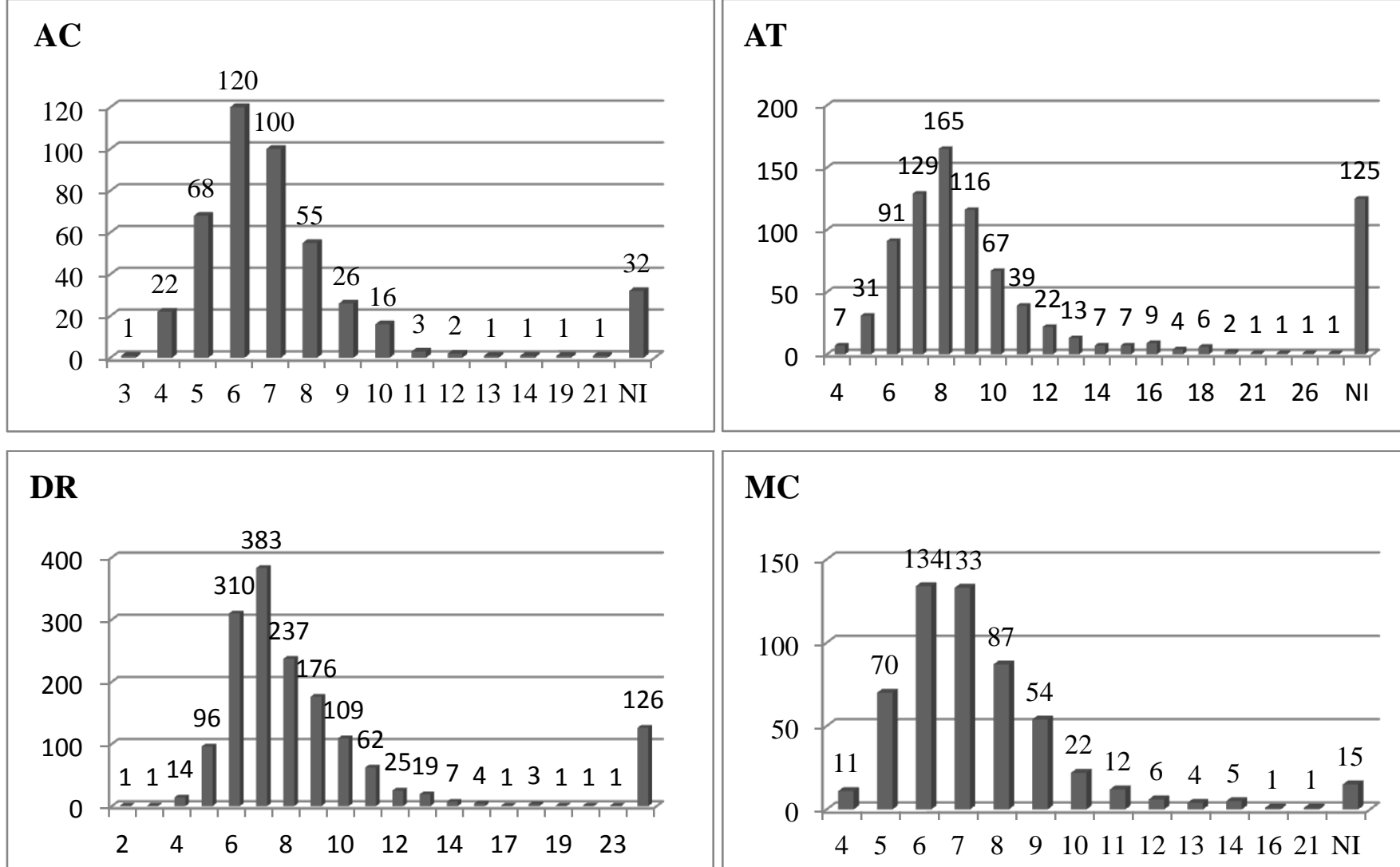

\section{MC}
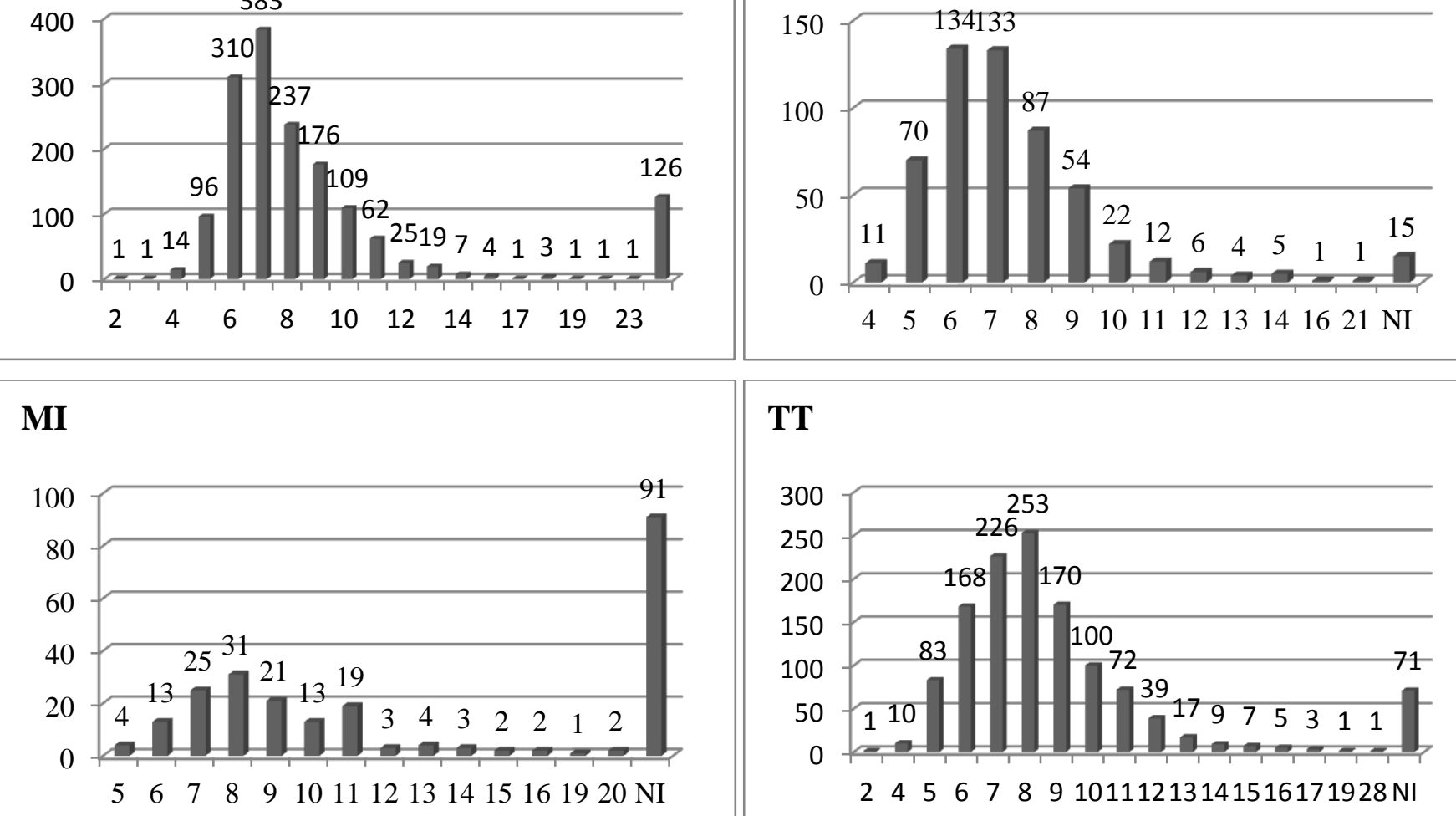

\section{TT}
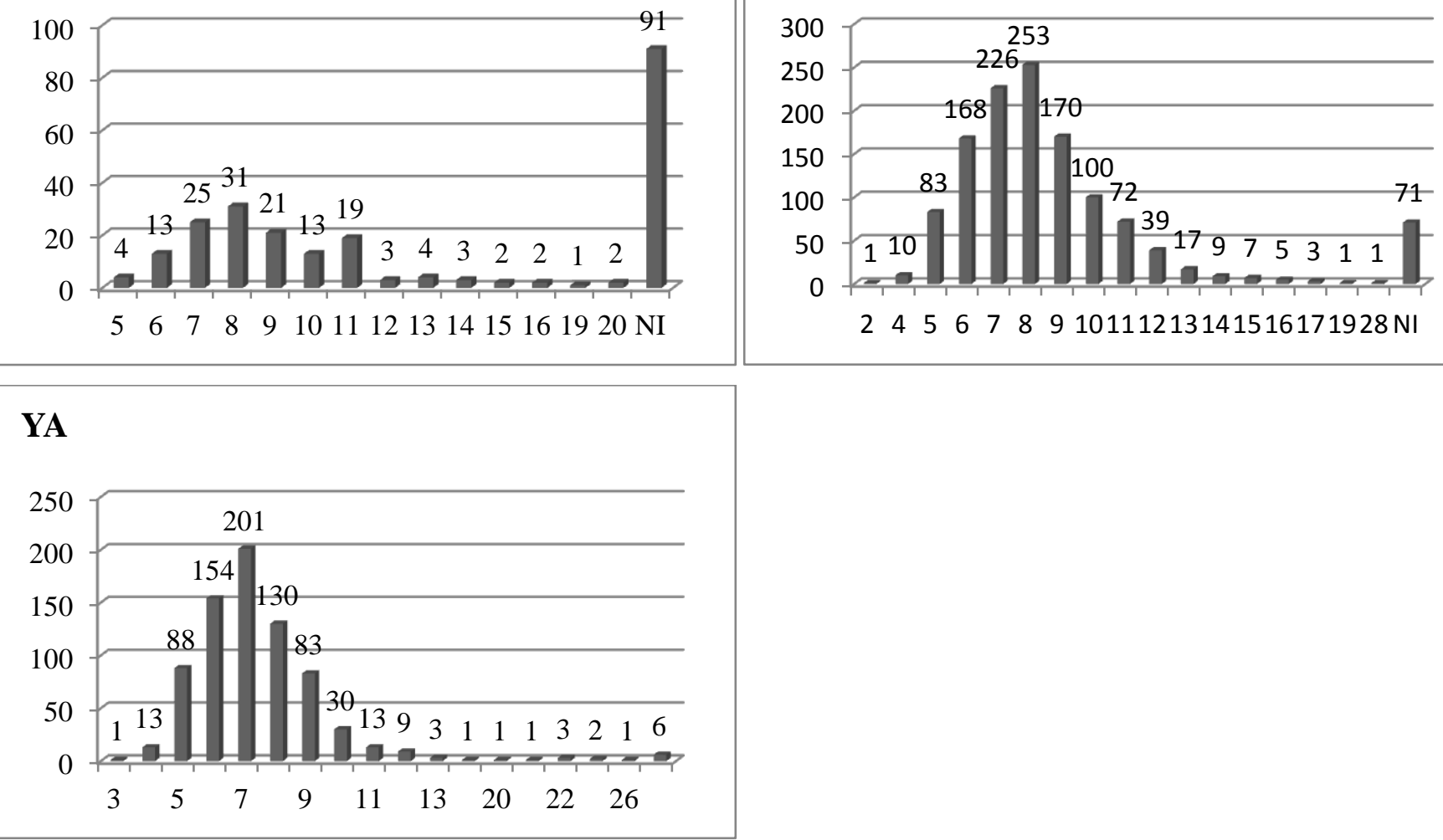

Gráfico 3: Distribuição das espessuras dos fragmentos em cada sítio. 


\section{TIPO DE NÚCLEO}
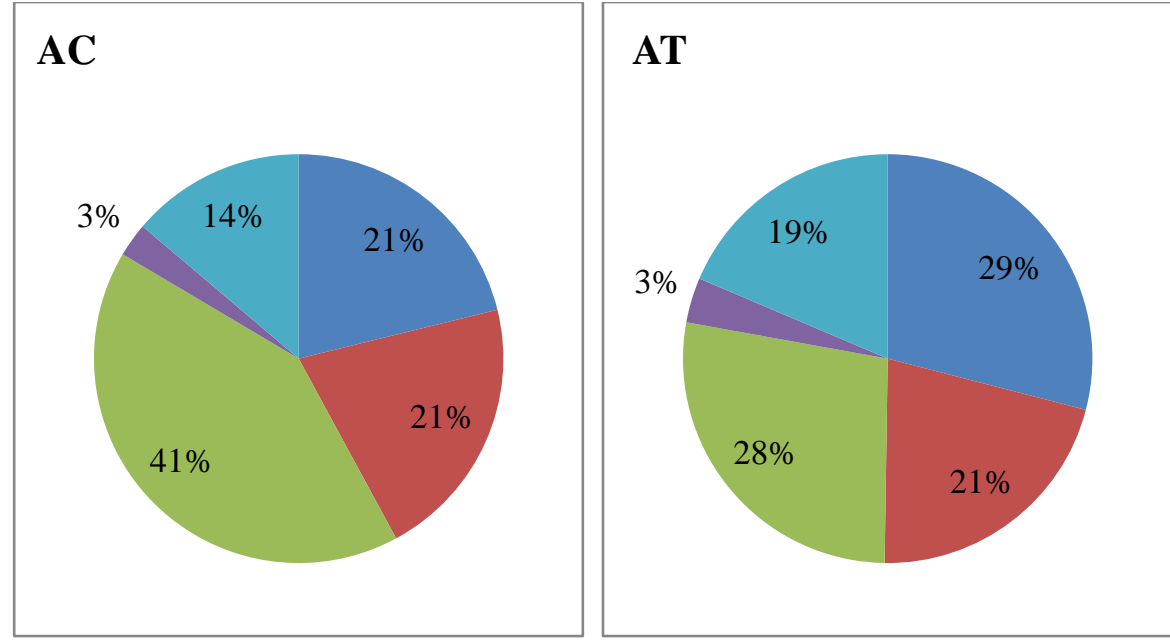

\section{DR}

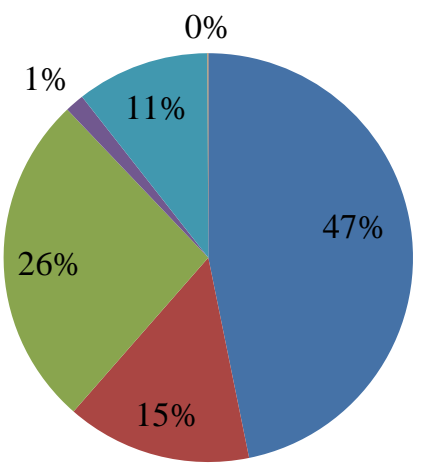

\section{MC}

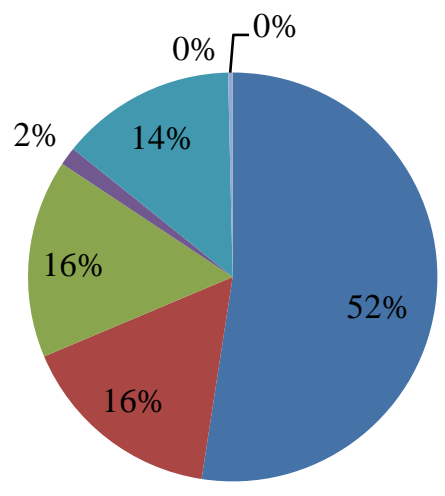

MI

TT
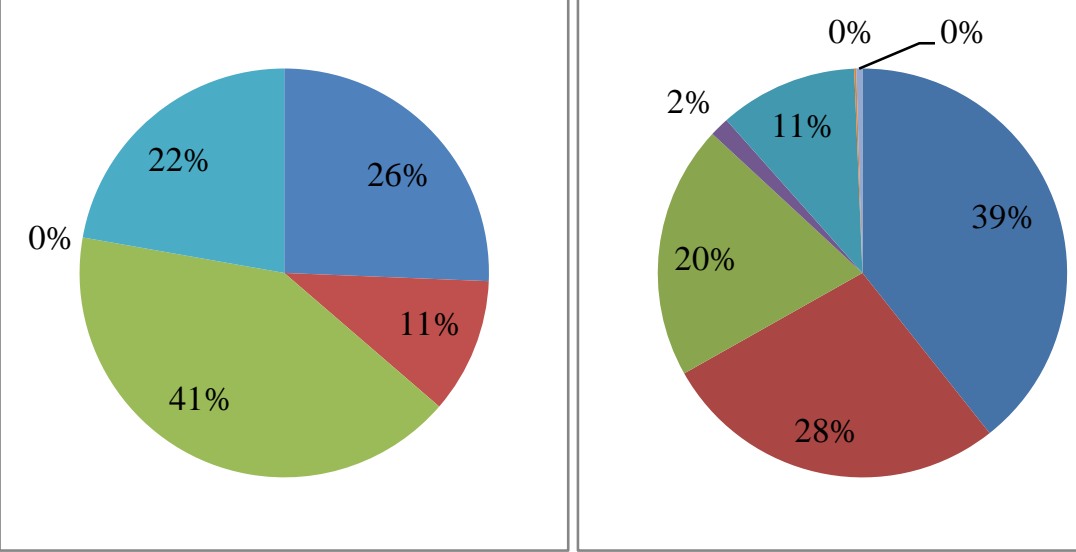

YA

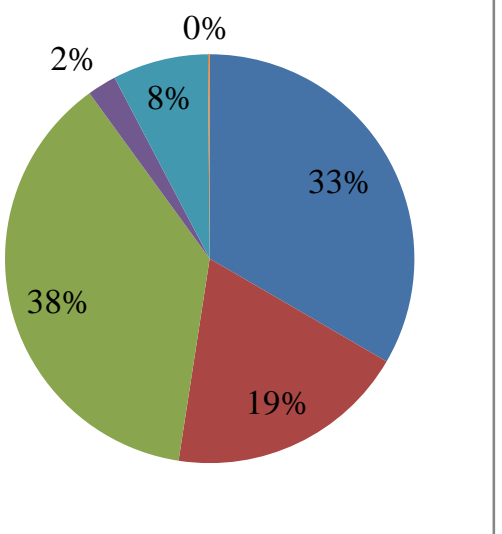

$$
\begin{aligned}
& \text { = Tipo } 1 \\
& \text { = Tipo } 2 \\
& \text { = Tipo } 3 \\
& \text { = Tipo } 4 \\
& =\text { Tipo } 5 \\
& =\text { Tipo } 6 \\
& =\text { NI }
\end{aligned}
$$

Gráfico 4: Distribuição dos tipos de núcleo dos fragmentos em cada sítio. 


\section{COLORAÇÃO FACE EXTERNA}
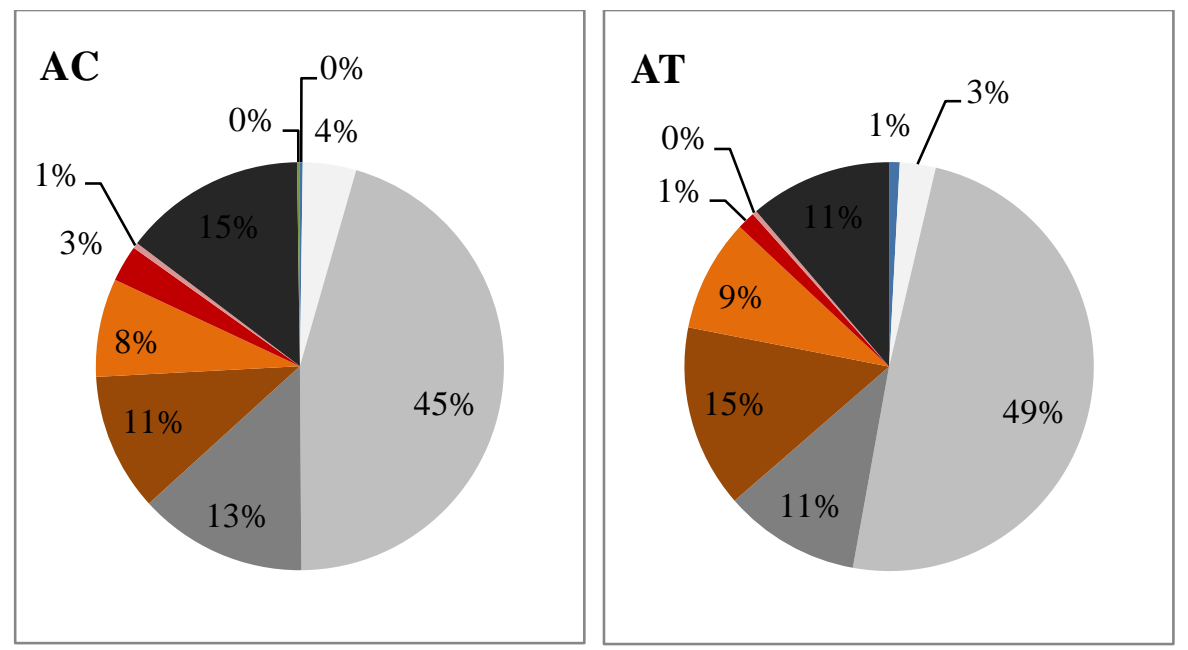

\section{DR}
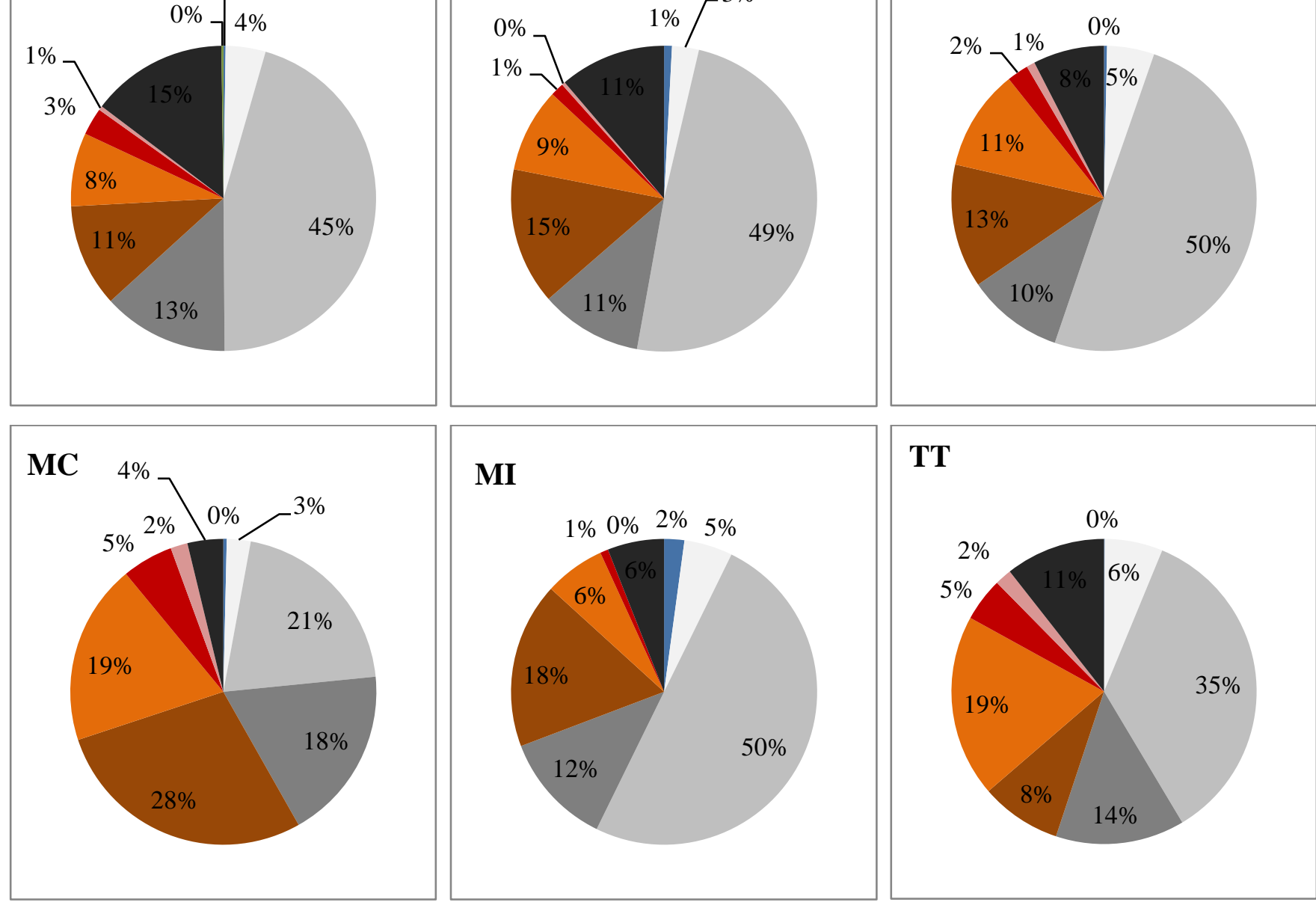

TT

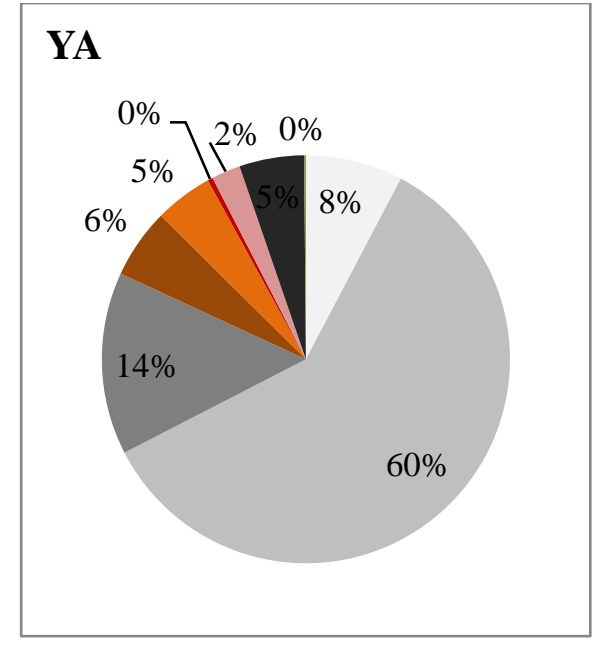

\section{Ausente \\ Branco \\ - Cinza claro \\ ninza escuro \\ -Marrom \\ - Marrom avermelhado \\ -Vermelho \\ Rosa \\ - Preto \\ inI}

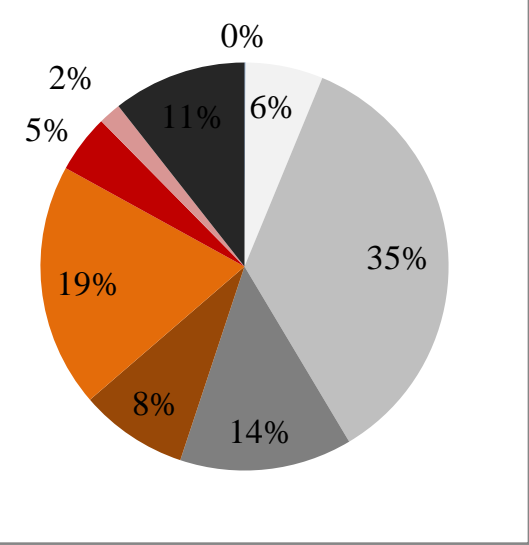

Gráfico 5: Distribuição da coloração da face externa dos fragmentos em cada sítio. 


\section{COLORAÇÃO FACE INTERNA}
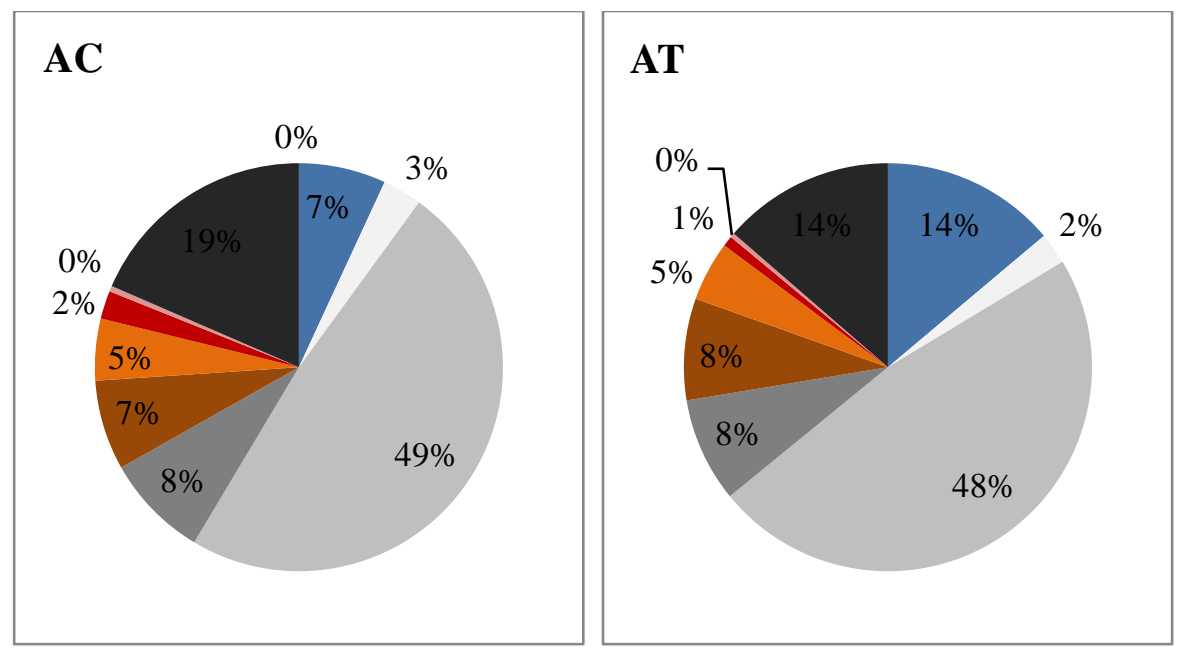

\section{DR}

\section{MC}
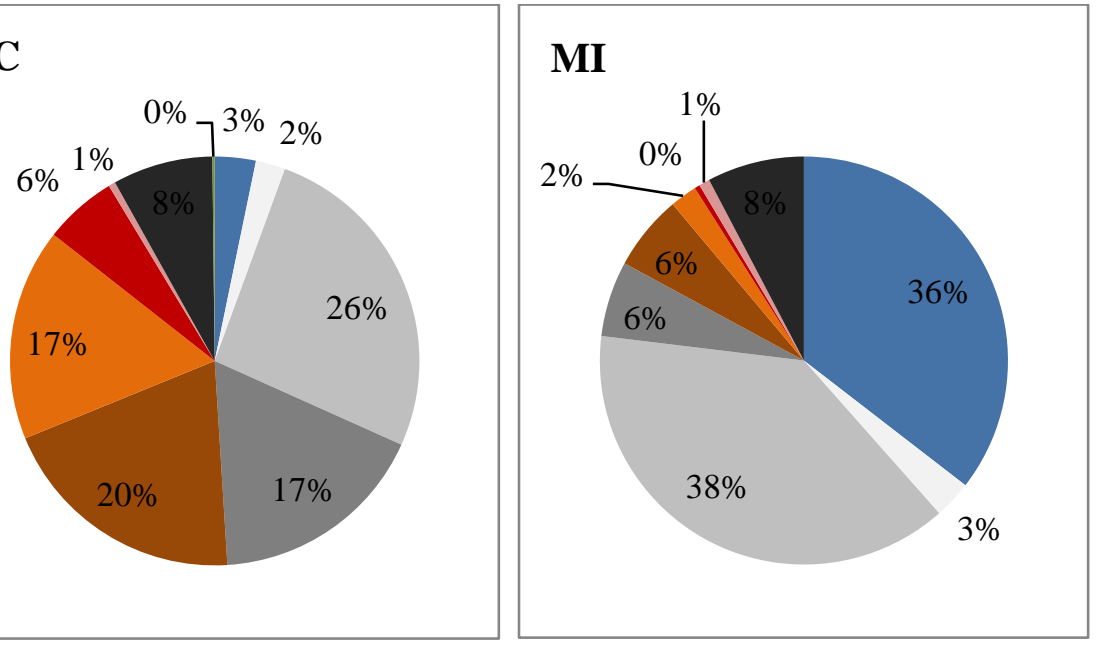

YA

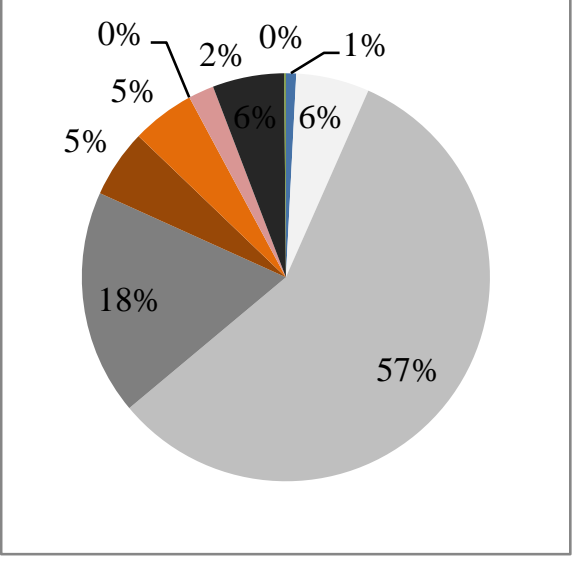

TT
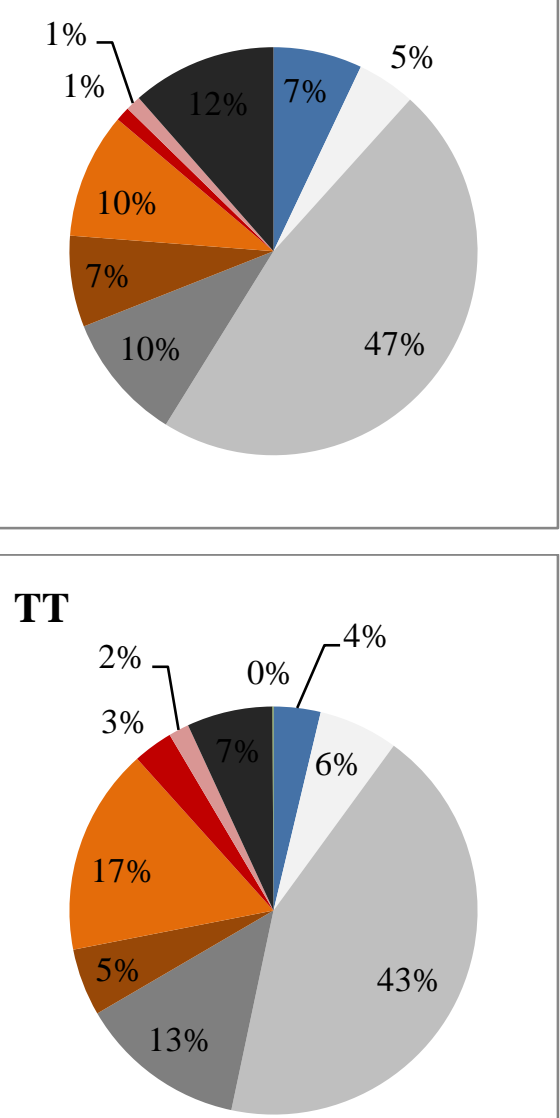

Gráfico 6: Distribuição da coloração da face interna dos fragmentos em cada sítio. 
ACABAMENTO DE SUPERFÍCIE FACE EXTERNA

\begin{tabular}{|c|c|c|c|c|c|c|c|}
\hline & $\mathrm{AC}$ & AT & DR & MC & MI & TT & YA \\
\hline Ausente & 1 & 8 & 7 & 4 & 5 & 7 & - \\
\hline Alisamento & 437 & 816 & 1478 & 403 & 226 & 1156 & 648 \\
\hline Corrugado & - & - & 3 & - & - & - & 2 \\
\hline Ungulado & - & - & - & - & - & - & 16 \\
\hline Impressão de corda & - & - & 13 & - & - & 1 & 41 \\
\hline Perfurado & 1 & - & 3 & - & - & - & - \\
\hline Inciso & 2 & 1 & 11 & 5 & 1 & 2 & 17 \\
\hline Acanalado & - & - & - & - & - & 3 & - \\
\hline Ponteado & - & - & - & - & - & - & 1 \\
\hline Inciso e impressão de corda & - & - & - & - & - & - & 5 \\
\hline $\begin{array}{l}\text { Impressão de corda e } \\
\text { beliscado }\end{array}$ & - & - & - & - & - & - & 1 \\
\hline $\begin{array}{l}\text { Impressão de corda e } \\
\text { acanalado }\end{array}$ & - & - & 1 & - & - & - & - \\
\hline Inciso e ponteado & - & 1 & - & - & - & - & - \\
\hline Engobo branco & - & - & - & 3 & - & 1 & - \\
\hline Engobo vermelho & - & 13 & 24 & 42 & 1 & 34 & 2 \\
\hline Banho & 8 & 5 & 36 & 77 & 1 & 13 & 6 \\
\hline Engobo rosa & - & - & 1 & 8 & - & 2 & - \\
\hline $\begin{array}{l}\text { Pintura branca sob engobo } \\
\text { vermelho }\end{array}$ & - & - & - & 1 & - & 1 & - \\
\hline Pintura branca sobre banho & - & - & - & 2 & - & - & - \\
\hline $\begin{array}{l}\text { Pintura vermelha sob engobo } \\
\text { branco }\end{array}$ & - & - & - & - & - & 1 & - \\
\hline $\begin{array}{l}\text { Pintura branca sobre banho e } \\
\text { faixa vermelha }\end{array}$ & - & - & - & 1 & - & - & - \\
\hline Inciso e pintura branca & - & - & - & 1 & - & - & - \\
\hline Inciso sobre engobo vermelho & - & - & - & 1 & - & - & - \\
\hline Engobo rosa sobre inciso & - & - & - & 3 & - & - & - \\
\hline Banho sobre inciso & - & - & - & 1 & - & - & - \\
\hline $\mathrm{NI}$ & - & - & - & 3 & - & 15 & 1 \\
\hline Total & 449 & 844 & 1577 & 555 & 234 & 1236 & 740 \\
\hline
\end{tabular}

Tabela 12: Distribuição do acabamento de superfície da face externa dos fragmentos em cada sítio. 


\section{OUTROS ACABAMENTOS DE SUPERFÍCIE FACE EXTERNA}

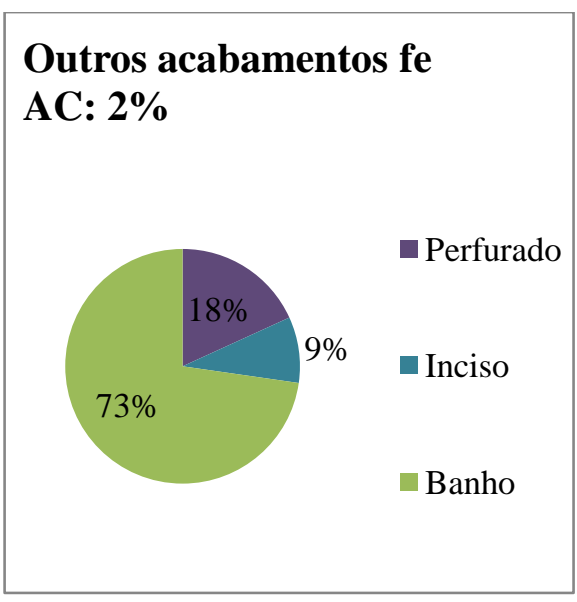

Outros acabamentos fe

$\mathrm{AC}: 2 \%$

Outros acabamentos fe

DR: $6 \%$

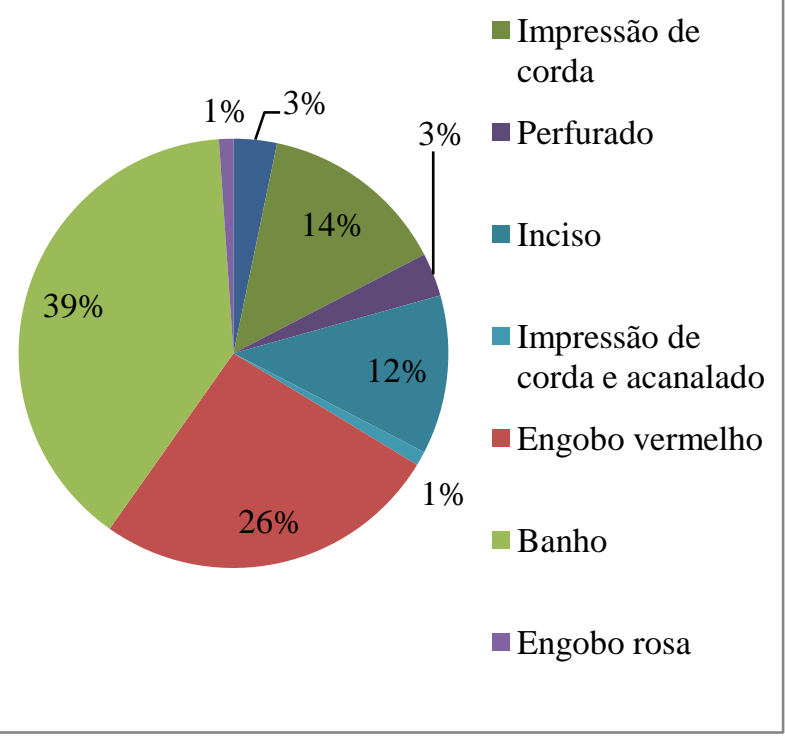

\section{Outros acabamentos fe}

TT: 5\%

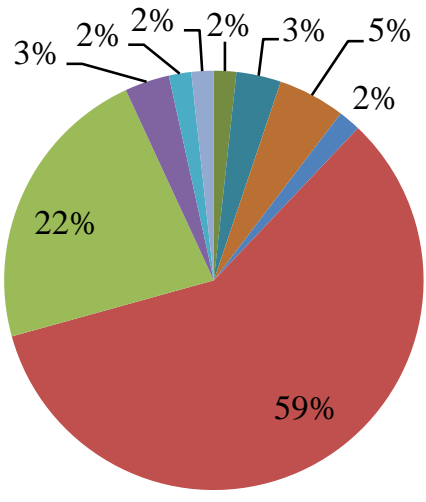

- Impressão de corda

Inciso

- Acanalado

Engobo branco

Engobo vermelho

Banho

Engobo rosa

- Pintura branca sob engobo vermelho

Pintura vermelha sob engobo branco
Outros acabamentos fe

AT: $2 \%$

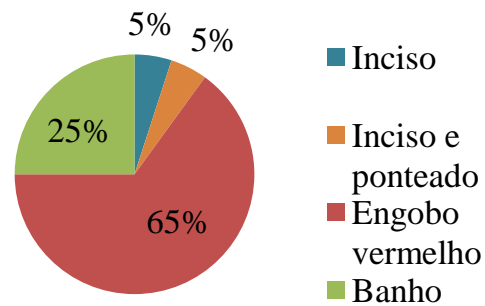

Outros acabamentos fe MI: 1\%

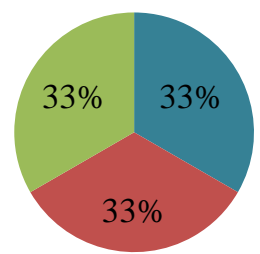

Inciso

Engobo vermelho

- Banho
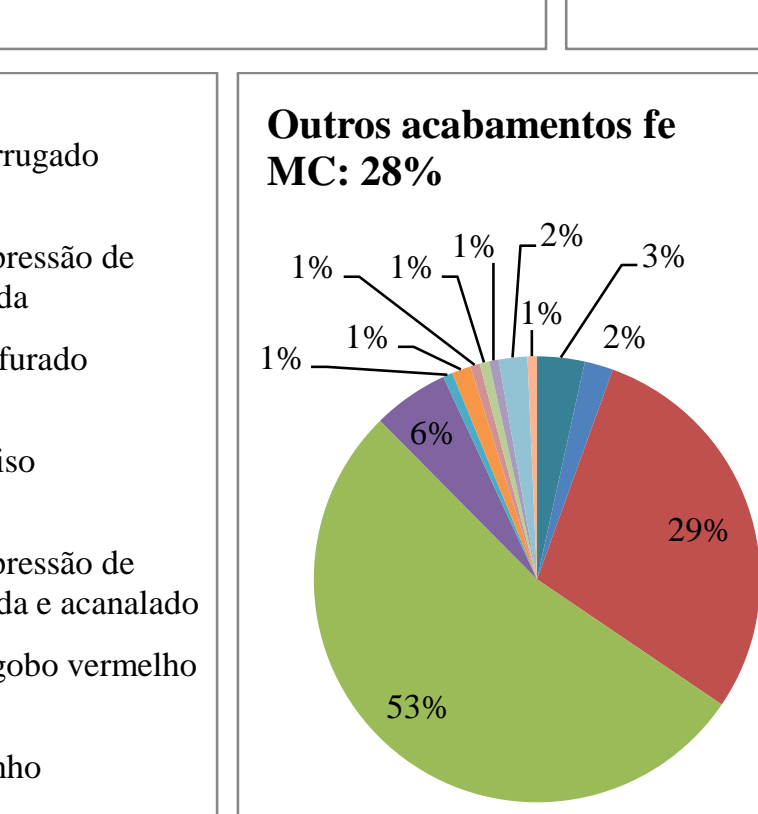

- Inciso

Engobo branco

Engobo vermelho

Banho

- Engobo rosa

- Pintura branca sob engobo vermelho

Pintura branca sobre

banho

Pintura branca sobre

banho e faixa vermelha

Inciso e pintura branca

Inciso sobre engobo vermelho

Engobo rosa sobre inciso

Banho sobre inciso

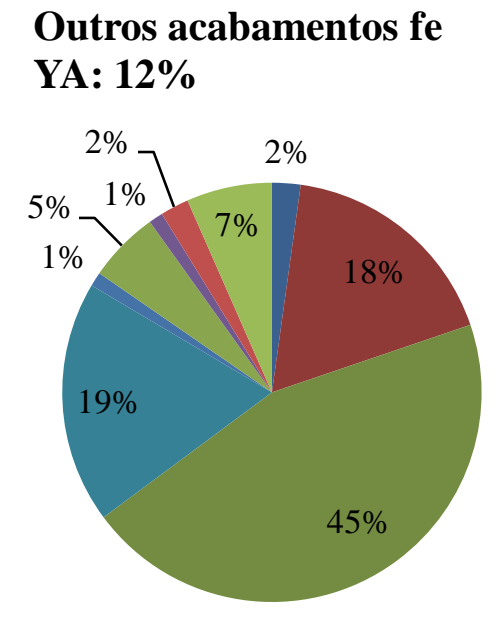

- Corrugado

- Ungulado

- Impressão de corda

Inciso

Ponteado

Inciso e impressão de corda

- Impressão de corda e beliscado Engobo vermelho

Banho

Gráfico 7: Distribuição dos acabamentos de superfície da face externa não alisados nos fragmentos em cada sítio. 
ACABAMENTO DE SUPERFÍCIE FACE INTERNA

\begin{tabular}{|l|c|c|c|c|c|c|c|}
\hline & AC & AT & DR & MC & MI & TT & YA \\
\hline Ausente & 30 & 113 & 105 & 17 & 78 & 57 & 6 \\
\hline Alisamento & 409 & 724 & 1442 & 462 & 155 & 1135 & 728 \\
\hline Impressão de corda & - & - & 1 & - & - & - & - \\
\hline Perfurado & 1 & - & 3 & - & - & - & - \\
\hline Inciso & - & - & 3 & 4 & - & - & 1 \\
\hline Acanalado & - & 1 & - & - & - & - & - \\
\hline Engobo vermelho & - & 4 & 11 & 34 & - & 18 & 1 \\
\hline Banho & 9 & 2 & 14 & 30 & 1 & 13 & 2 \\
\hline Engobo rosa & - & - & - & 7 & - & - & - \\
\hline NI & - & - & - & 1 & - & - & 2 \\
\hline Total & $\mathbf{4 4 9}$ & $\mathbf{8 4 4}$ & $\mathbf{1 5 7 7}$ & $\mathbf{5 5 5}$ & $\mathbf{2 3 4}$ & $\mathbf{1 2 3 6}$ & $\mathbf{7 4 0}$ \\
\hline
\end{tabular}

Tabela 13: Distribuição dos acabamentos de superfície da face interna dos fragmentos em cada sítio.

\section{OUTROS ACABAMENTOS DE SUPERFÍCIE FACE INTERNA}

\section{Outros acabamentos fi}

AC: $2 \%$

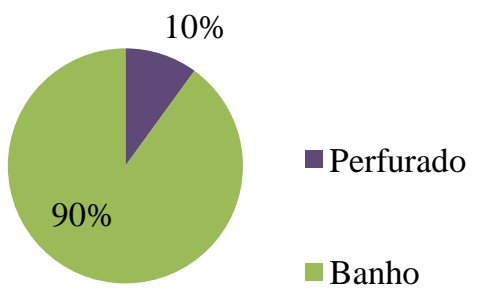

\section{Outros acabamentos fi}

MC: $14 \%$

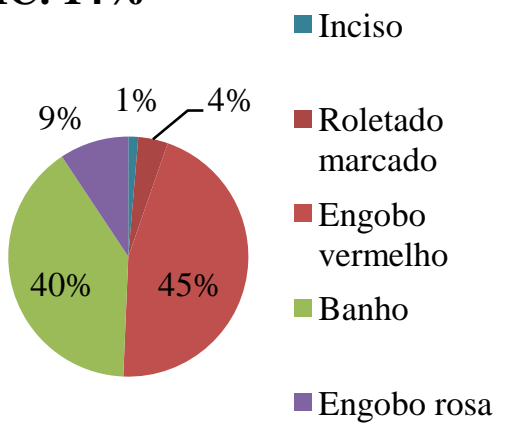

Outros acabamentos fi

AT: $1 \%$

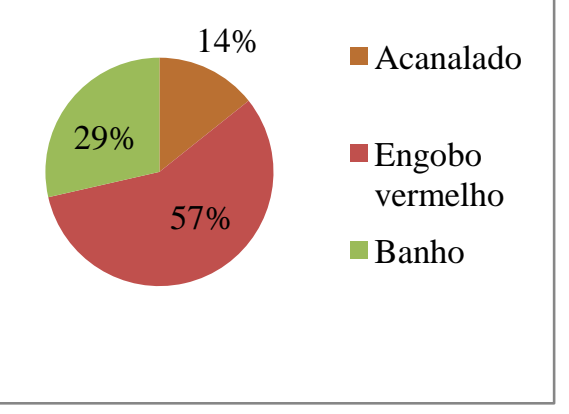

Outros acabamentos fi

TT: $2 \%$

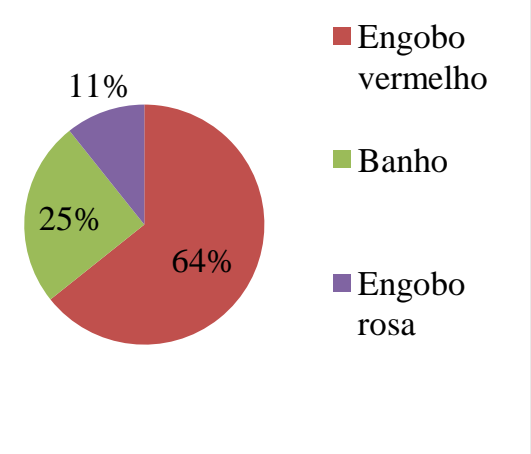

\section{Outros acabamentos fi}

DR: $2 \%$

Impressão de corda

- Perfurado

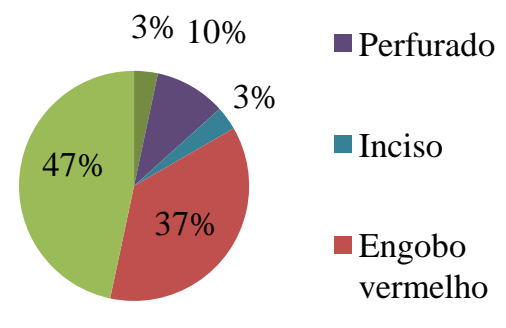

- Banho

Gráfico 8: Distribuição dos acabamentos de superfície não alisados da face interna dos fragmentos de cada sítio. 


\section{ACABAMENTO DE SUPERFÍCIE DO LÁBIO}

\begin{tabular}{|l|c|c|c|c|c|c|c|}
\hline & AC & AT & DR & MC & MI & TT & YA \\
\hline Ausente & 2 & 1 & 5 & 10 & 1 & 8 & 7 \\
\hline Alisamento & 68 & 98 & 207 & 66 & 11 & 125 & 91 \\
\hline Ungulado & - & - & - & - & - & - & 1 \\
\hline Inciso & - & - & 6 & - & - & 2 & - \\
\hline Ponteado & - & - & 2 & - & - & - & - \\
\hline Engobo vermelho & - & - & 2 & 3 & - & 2 & \\
\hline Banho & 1 & - & 5 & 3 & & & 1 \\
\hline Engobo rosa & - & - & - & 1 & - & 1 & - \\
\hline Engobo rosa sobre inciso & - & - & - & 1 & - & - & - \\
\hline NI & 1 & - & - & 1 & - & 3 & - \\
\hline Total & $\mathbf{7 2}$ & $\mathbf{9 9}$ & $\mathbf{2 2 7}$ & $\mathbf{8 5}$ & $\mathbf{1 2}$ & $\mathbf{1 4 1}$ & $\mathbf{1 0 0}$ \\
\hline
\end{tabular}

Tabela 14: Distribuição dos acabamentos de superfície do lábio nos fragmentos de cada sítio. 


\section{CONJUNTOS CERÂMICOS NA T. I. KAIABI}

“Aquilo ali era panela dos antigamente, aí ele quebra né aí jogar fora, dizia o pessoal que a terra cresce né aí joga ali, aí fica lá, aí a terra cobre por cima, diz que fica lá dentro né, fica lá enfiado, aqui também tem muito aqui, terra preta, eu acho que é lugar de antigamente né, que vira terra preta né.” (Fernando Apiaká apud STUCHI, 2010: 132)

Após o trabalho de escavação e coleta de material arqueológico nos sítios escolhidos, não foi possível continuar o trabalho da análise do material junto aos Kaiabi. No entanto, durante as etapas de campo foram registrado alguns depoimentos e comentários sobre a percepção dos Kaiabi em relação a este material.

Inicialmente, muitos Kaiabi tiveram receio de mexer com o material das escavações. Segundo eles, era comum nos rituais quebrar as panelas dos inimigos Apiaká e Munduruku que eles venciam nas guerras, por isso poderiam lhes causar mal quando desenterradas (POUGET, 2010: 80-81). Esse receio passou rapidamente no momento em que eles passaram a associar esses fragmentos às ocupações ainda mais antigas. A epígrafe deste capítulo resume a opinião de Fernando Apiaká, da Aldeia Minhocoçu, sobre o assunto, descartando a associação da cerâmica com os Munduruku ou Apiaká.

Na Aldeia Kururuzinho, Ryip Kayabi reconheceu um fragmento cerâmico encontrado no porto da aldeia como um pedaço de um filtro de barro, lembrando que em uma ilha próxima à travessia da balsa havia uma boa fonte de barro para fazer cerâmica. Já Judite Kayabi mencionou outra fonte de argila, na desembocadura do rio Santa Rosa no Teles Pires. Ela também comentou que os fragmentos cerâmicos deveriam pertencer aos Munduruku, ou outro povo, já que na pista de pouso já foi encontrada uma grande panela de formato globular com ossos dentro, associada aos Munduruku (STUCHI, 2010: 118).

Na Aldeia Laje, Albertino Munduruku associou a terra preta como sendo um lugar onde os antigos moraram e os fragmentos cerâmicos, as "panelas veias dos antigos", teriam 
sido abandonadas pelos índios que ali moravam e que fugiam dos ataques dos Munduruku (STUCHI, 2010: 123-124). Vitorino Munduruku, da Aldeia Coelho, também deu a mesma explicação para os fragmentos cerâmicos: abandono pelo conflito com os Munduruku (STUCHI, 2010: 129). Já na Aldeia São Benedito, a cerâmica encontrada durante a escavação de uma fossa foi associada a uma ocupação antiga dos próprios Kaiabi, especificamente no acampamento São Benedito que é relacionado à Eroit, da primeira ocupação Kaiabi da área.

Feitas essas considerações, procuramos elaborar a nossa interpretação sobre os conjuntos cerâmicos na T. I. Kaiabi. Após a análise dos fragmentos de vasilhas cerâmicas de todos os sítios procuramos uma maneira de interpretar os resultados e as análises estatísticas descritivas, visando o agrupamento dos fragmentos de vasilhas cerâmicas em conjuntos que pertenceriam a estilos tecnológicos diferenciados, à exemplo de Chilton (1998).

O banco de dados da análise cerâmica foi enviado ao Centro de Estatística Aplicada (CEA) da USP e a análise estatística foi conduzida pela estudante Talita Carvalho da Mota e Silva, sob orientação do Prof. Dr. Victor Fossaluza, durante o segundo semestre de 2013.

Primeiramente, foram feitas análises descritivas a partir de tabelas e gráficos (tal como os apresentados nas descrições dos sítios anteriormente) com o objetivo de identificar as possíveis associações entre variáveis (SILVA e FOSSALUZA, 2013: 12). Para verificar a associação das variáveis entre si foi utilizado o coeficiente de Goodman-Kruskal (Lambda -

$\lambda)$, que é dado por

$$
\lambda=\frac{\sum_{i \in L} \max _{j \in C} \theta_{i j}+\sum_{j \in C} \max _{i \in L} \theta_{i j}-\max _{i \in L} \theta_{i \cdot-}-\max _{j \in C} \theta_{j}}{2-\max _{i \in L} \theta_{i \cdot}-\max _{j \in C} \theta_{\cdot j}}
$$

fragmento pertencer a i-ésima categoria da $1^{\mathrm{a}}$ variável e a j-ésima categoria da $2^{\mathrm{a}}$ variável (SILVA e FOSSALUZA, 2013: 27). Para interpretar o lambda foi utilizada a abordagem bayesiana e para verificar a significância da associação foi analisado o e-value. As associações feitas (a partir de 0,10) foram entre sítio, antiplástico, espessura, acabamento de superfície da face externa e interna, coloração da face externa e interna.

Em seguida, foi feita uma análise de agrupamento (cluster) para juntar as observações semelhantes (gráfico 9). As variáveis consideradas mais relevantes para dar origem aos grupos foram: sítio, antiplástico, acabamento de superfície da face externa, coloração da face externa. Foi feito um dendograma para representar as uniões de grupos e subgrupos, agrupados de acordo com o método hierárquico que uniu os subgrupos considerados mais semelhantes (SILVA e FOSSALUZA, 2013: 32). Notamos pelo dendograma que seria possível realizar diferentes cortes para a obtenção de grupos, por isso foram feitos vários testes e comparações a partir das interpretações da análise cerâmica. 


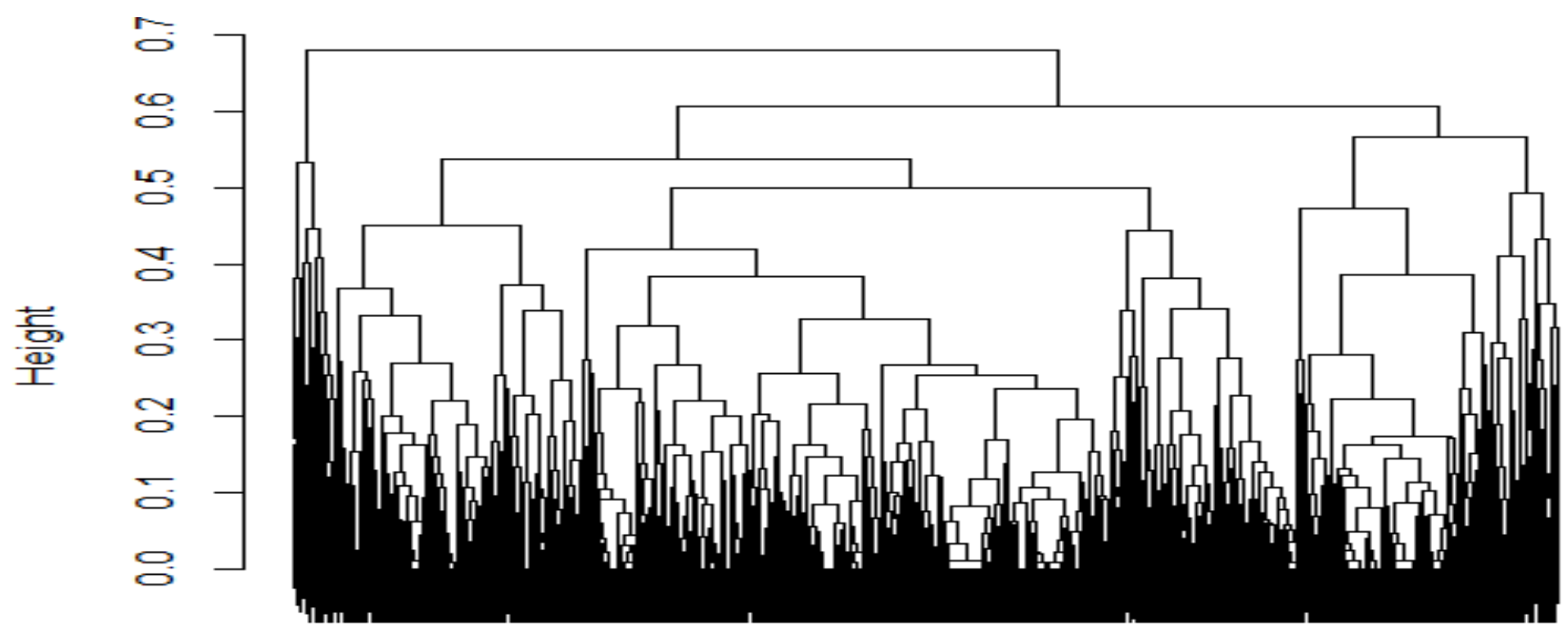

Gráfico 9: Dendograma dos agrupamentos estatísticos. (Cf: SILVA e FOSSALUZA, 2013)

Durante as análises dos fragmentos, notamos principalmente 4 conjuntos bem definidos e 1 mais difuso, mas não conseguimos identificar variações menores que formariam outros conjuntos. Com os resultados da análise estatística, comparamos esses 5 conjuntos com diferentes cortes no dendograma: 5, 8 e 10 grupos. Notamos que em todos os cortes havia certa correspondência entre os primeiros 4 conjuntos da análise cerâmica e os diferentes grupos estabelecidos pela estatística (ver Anexo D), apesar de o sítio Taitetu não parecer se comportar de maneira coerente entre a análise cerâmica e a análise estatística. Decidimos, então, fazer o corte quando os grupos se estabilizavam e que poderiam mostrar melhor a variabilidade dos conjuntos de fragmentos, a partir da soma de quadrados ${ }^{13}$, criando 8 grupos (gráfico 10).

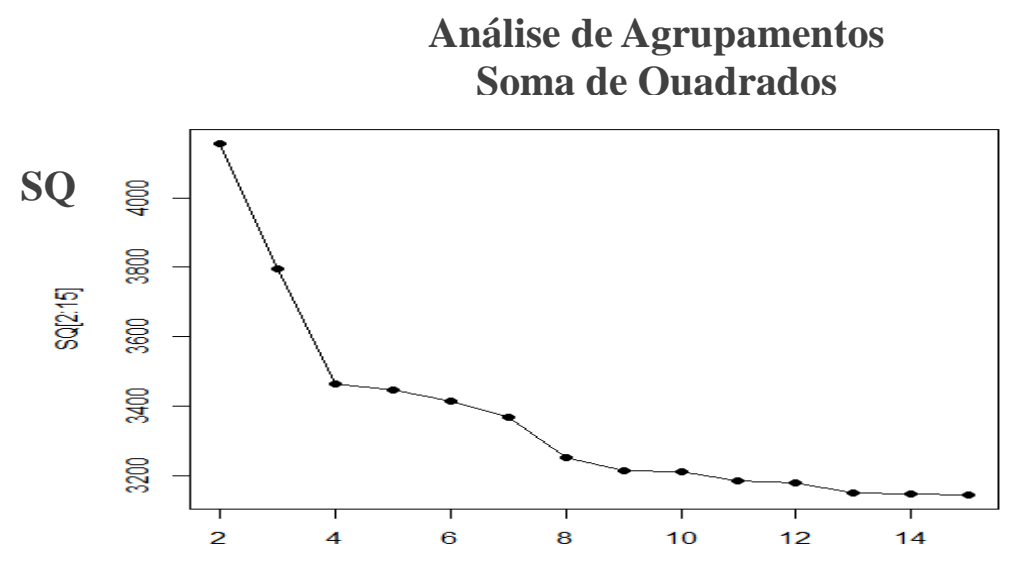

Número de amostras

Gráfico 10: Análise de agrupamentos pela soma de quadrados. (Cf: SILVA e FOSSALUZA, 2013)

${ }^{13} S Q D=\sum_{l=1}^{p} \sum_{j=1}^{k} \sum_{i=1}^{n_{j}}\left(Y_{i j l}-\bar{Y}_{j l}\right)^{2}$ em que $Y_{i j l}$ é o valor na l-ésima variável do $i$-ésimo indivíduo do $j$-ésimo grupo e $\bar{Y}_{j l}$ é a média da l-ésima variável no $j$-ésimo grupo (SILVA e FOSSALUZA, 2013: 33). 
É importante ressaltar que também foi desenvolvida uma rede bayesiana (gráfico 11) para classificar novas peças dentro destes mesmos conjuntos (SILVA e FOSSALIZA, 2013: 37), além de mostrar a relação entre os atributos na formação deles. A rede considerou que a distribuição do sítio depende principalmente do antiplástico e que a distribuição do acabamento de face externa depende do sítio.

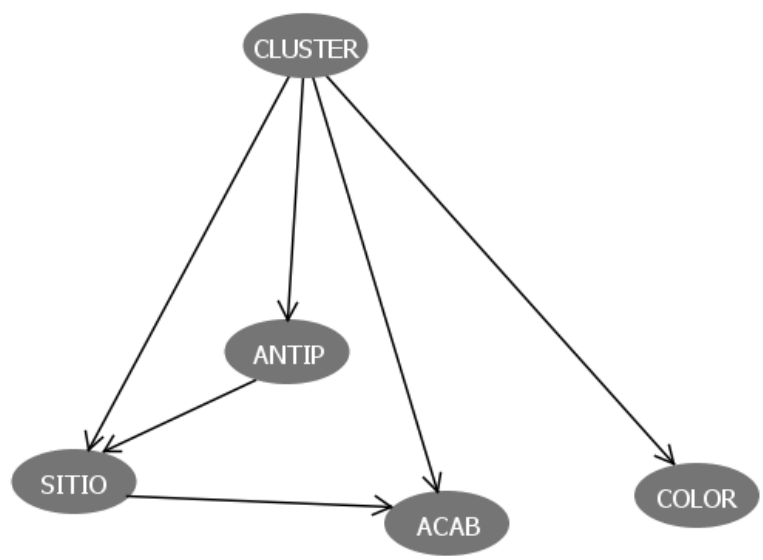

Gráfico 11: Rede bayesiana. (Cf: SILVA e FOSSALUZA, 2013)

Em todas as diferentes classificações, o antiplástico mostrou-se realmente como um grande elemento separador de conjuntos, além de ser um dos únicos atributos possíveis de ser observado em todos os fragmentos. Consideramos também sua importância na formação de conjuntos a partir da relevância que tem como "indicador de uma série de escolhas tecnológicas decorrentes das etapas iniciais da cadeia operatória" (MACHADO, 2005-2006: 92), que são a escolha das fontes de argila e a forma de preparo da pasta. A coloração também auxiliou nesta caracterização.

Após a comparação dessas diferentes tipologias - a estatística e a intuitiva (durante a análise) - decidimos apresentar 4 conjuntos (bastante distintos no dendograma), seguindo um sistema de classificação de variedade-tipo ${ }^{14}$, baseado nos traços que se revelaram diagnósticos (tabela 15): antiplástico, composição da pasta, coloração da face externa e interna, acabamentos de superfície da face externa, interna e do lábio. Apesar dos poucos fragmentos diagnósticos de aspectos morfológicos, este atributo também apontou para uma caracterização interessante de alguns conjuntos.

\footnotetext{
${ }^{14}$ Consideramos a divisão de diferentes sistemas de classificação e tipologias feita por Sinopoli (1991: 50-53): Tipologia Intuitiva/Tradicional que é baseada na capacidade humana de ver padrões complexos, durante a análise; Sistema de Variedade-Tipo, onde tipo é a classe ampla de cerâmicas definida com base em um pequeno número de traços diagnósticos e as variedades diferem do tipo amplo ao qual elas se relacionam em alguns aspectos; Tipologias Quantitativas ou Estatísticas que são construídas com métodos estatísticos na análise de duas ou mais variáveis.
} 
Conjuntos Finais

\begin{tabular}{|l|l|l|l|l|}
\hline & Conjunto 1 & Conjunto 2 & Conjunto 3 & Conjunto 4 \\
\hline Antiplástico & Mineral & $\begin{array}{l}\text { Caco moído e/ou } \\
\text { caraipé }\end{array}$ & Caraipé e cauixi & Caco moído e cauixi \\
\hline Sítios & YA, DR* & MC & DR, MI, AT**, AC & AC, AT, TT, DR \\
\hline $\begin{array}{l}\text { Acabamento } \\
\text { de superfície } \\
\text { face externa }\end{array}$ & $\begin{array}{l}\text { Plástica } \\
\text { (impressão de } \\
\text { corda, ungulado, } \\
\text { inciso) } \\
\text { Pintura (banho, } \\
\text { engobo } \\
\text { vermelho*) }\end{array}$ & $\begin{array}{l}\text { Pintada (banho, } \\
\text { engobo vermelho, } \\
\text { rosa, pinturas) } \\
\text { Plástica (inciso) }\end{array}$ & $\begin{array}{l}\text { Liso } \\
\text { Poucos banho, } \\
\text { engobo vermelho, } \\
\text { inciso } \\
\text { Raros impressão de } \\
\text { corda, inciso e } \\
\text { ponteado** }\end{array}$ & $\begin{array}{l}\text { Liso } \\
\text { Poucos engobo } \\
\text { vermelho, banho, } \\
\text { pinturas } \\
\text { Raros impressão de } \\
\text { corda, inciso, } \\
\text { perfurado }\end{array}$ \\
\hline $\begin{array}{l}\text { Coloração face } \\
\text { externa }\end{array}$ & Cinza & $\begin{array}{l}\text { Cinza, marrom, } \\
\text { marrom } \\
\text { avermelhado }\end{array}$ & $\begin{array}{l}\text { Cinza, marrom, } \\
\text { marrom avermelhado }\end{array}$ & $\begin{array}{l}\text { Cinza, marrom } \\
\text { avermelhado }\end{array}$ \\
\hline
\end{tabular}

Agrupamentos Estatísticos

\begin{tabular}{|c|c|c|c|c|c|c|c|c|}
\hline & Grupo 1 & Grupo 2 & Grupo 3 & Grupo 4 & Grupo 5 & Grupo 6 & Grupo 7 & Grupo 8 \\
\hline Antiplástico & $\begin{array}{l}\text { Caraipé, } \\
\text { caco, } \\
\text { mineral }\end{array}$ & $\begin{array}{l}\text { Caco e } \\
\text { cauixi, } \\
\text { cauixi e } \\
\text { caraipé, } \\
\text { todos }\end{array}$ & $\begin{array}{l}\text { Caco, } \\
\text { mineral, } \\
\text { caraipé }\end{array}$ & $\begin{array}{l}\text { Mineral, } \\
\text { caco, } \\
\text { caraipé }\end{array}$ & $\begin{array}{l}\text { Caco e } \\
\text { cauixi, } \\
\text { cauixi, } \\
\text { cauixi e } \\
\text { caraipé }\end{array}$ & $\begin{array}{l}\text { Cauixi e } \\
\text { caraipé, } \\
\text { caco e } \\
\text { cauixi, } \\
\text { todos }\end{array}$ & $\begin{array}{l}\text { Caco e } \\
\text { cauixi, } \\
\text { caraipé e } \\
\text { cauixi, } \\
\text { cauixi }\end{array}$ & Mineral \\
\hline Sítios & $M C, D R$ & $A T, A C, D R$ & $M C, D R$ & $\begin{array}{l}\text { YA, TT, } \\
\text { MC, DR }\end{array}$ & & $\mathrm{DR}, \mathrm{TT}, \mathrm{MI}$ & TT, MI & YA, TT \\
\hline $\begin{array}{l}\text { Acabamento } \\
\text { de } \\
\text { superfície } \\
\text { face externa }\end{array}$ & $\begin{array}{l}\text { Liso } \\
\text { Impressão } \\
\text { de corda, } \\
\text { plásticos }\end{array}$ & $\begin{array}{l}\text { Liso } \\
\text { Banho, } \\
\text { engobo } \\
\text { vermelho, } \\
\text { plásticos }\end{array}$ & $\begin{array}{l}\text { Banho, } \\
\text { engobo } \\
\text { vermelho } \\
\text { pinturas, } \\
\text { mistos }\end{array}$ & $\begin{array}{l}\text { Liso } \\
\text { Inciso, } \\
\text { impressã } \\
\text { o de } \\
\text { corda, } \\
\text { ungulado }\end{array}$ & $\begin{array}{l}\mathrm{NI} \\
\text { pinturas, } \\
\text { mistos }\end{array}$ & $\begin{array}{l}\text { Liso } \\
\text { Plásticos }\end{array}$ & $\begin{array}{l}\text { Liso } \\
\text { Engobo } \\
\text { vermelho } \\
\text { /rosa, } \\
\text { banho, } \\
\text { inciso }\end{array}$ & $\begin{array}{l}\text { Liso } \\
\text { Inciso, } \\
\text { impressã } \\
\text { o de } \\
\text { corda, } \\
\text { ungulado } \\
\text {, banho }\end{array}$ \\
\hline $\begin{array}{l}\text { Coloração } \\
\text { face externa }\end{array}$ & $\begin{array}{l}\text { Cinza, } \\
\text { marrom, } \\
\text { marrom } \\
\text { avermelh } \\
\text { ado }\end{array}$ & $\begin{array}{l}\text { Cinza, } \\
\text { preto, } \\
\text { marrom } \\
\text { avermelha } \\
\text { do }\end{array}$ & $\begin{array}{l}\text { Marrom, } \\
\text { marrom } \\
\text { avermelha } \\
\text { do, cinza }\end{array}$ & $\begin{array}{l}\text { Preto, } \\
\text { rosa }\end{array}$ & $\begin{array}{l}\text { Branco, } \\
\text { preto, } \\
\text { cinza }\end{array}$ & Cinza & $\begin{array}{l}\text { Marrom } \\
\text { avermelh } \\
\text { ado, } \\
\text { preto, } \\
\text { marrom }\end{array}$ & Cinza \\
\hline
\end{tabular}

Tabela 15: Comparação dos 4 conjuntos finais com os 8 agrupamentos estatísticos. Os conjuntos e grupos similares estão marcados com as mesmas cores.

Foram feitas tentativas de relacionar os dados da análise com os dados das escavações, comparando a distribuição dos conjuntos propostos com a distribuição nos sítios dos fragmentos em superfície e subsuperfície. No entanto, essas comparações não foram adiante pois os dados coletados nas escavações foram insuficientes, já que foi um trabalho 
preliminar cujo principal objetivo era delimitar os sítios e coletar amostras do material neles presentes, sem saber que tipo de material ou agrupamento se encontraria nos sítios. Em nossos testes, os diferentes conjuntos presentes em um mesmo sítio estavam misturados em todos os níveis artificiais, além de não estarem separados em diferentes áreas do sítio. São necessários trabalhos de escavação mais aprofundados, agora com os dados das análises, para que essa correlação possa ser feita de maneira apropriada.

Assim, estamos aqui refletindo se as diferenças observadas nos conjuntos são comportalmente significativas a ponto de justificar essa separação, levantando hipóteses de porque esses conjuntos se diferenciam (SCHIFFER e SKIBO, 1987). Existem inúmeras possibilidades de escolhas ao longo de qualquer cadeia de produção que podem obter resultados semelhantes, mas é somente a partir das escolhas realmente feitas que podemos definir os conjuntos como estilos tecnológicos diferentes. Os conjuntos foram pensados a partir das características de performance dos atributos identificados, para o que utilizamos como principal referência o artigo de Machado (2005-2006). Assim como esta autora, e apesar de usarmos as mesmas categorias tradicionais de análise de atributos, acreditamos que a forma de análise e interpretação dos resultados que utilizamos é que tornam possível um diálogo mais interessante com "os processos dinâmicos por trás do objeto analisado" (MACHADO, 2005-2006: 88).

Sabemos que as escolhas iniciais da fabricação cerâmica podem afetar a sequência de produção e as diversas características de performances das vasilhas, no entanto também sabemos que outras escolhas podem ser feitas durante a cadeia operatória para complementar ou compensar os efeitos das características da pasta, como a morfologia da vasilha ou a utilização de outros materiais para o acabamento de superfície (SCHIFFER e SKIBO, 1987). Além disso, uma performance não necessariamente anula a outra, já que por exemplo, como aponta Rye (1981), todas as vasilhas possuem um certo nível de capacidade de aquecimento e todas tem uma certa resistência ao impacto e abrasão, entre outras características. No entanto, podemos colocar esses níveis em uma escala para pensar quais foram as prioridades da ceramista em detrimento de outras, pensando nas performances como um todo.

Feitas essas observações iniciais esperamos que os conjuntos apresentados a seguir possam servir de base para outros questionamentos mais profundos e análises mais específicas, refinando sua caracterização e interpretação em trabalhos futuros. 


\subsection{Conjunto 1}

Este conjunto esteve claramente presente em todos os cortes estatísticos, sempre relacionados ao sítio Ywantã, correspondendo aos grupos 4 e 8 do agrupamento estatístico. É característico do sítio Ywantã $(95,1 \%)$, tendo sido identificado ainda durante a análise deste sítio, mas também está presente em pequena quantidade (mas de forma bastante distinta) no sítio Dinossauro (7,3\%). As datas do sítio Ywantã $4920 \pm 30$ A.P. (radiocarbônica) e $420 \pm 40$ A.P. (termoluminescência) são associadas a este conjunto.

A principal característica do Conjunto 1 é o antiplástico exclusivamente mineral, principalmente o quartzo ${ }^{15}$ (figura 43). Normalmente se associa a forma angulosa dos componentes minerais à adição intencional destes na argila, por terem sido triturados anteriormente. No entanto, uma forma arredondada do mineral não é suficiente para se confirmar que ele já se encontrava na argila, pois ele poderia fazer parte de uma areia que foi adicionada (CUOMO di CAPRIO, 1985), por isso não nos preocupamos tanto em descrever com detalhes o antiplástico neste momento.

As faces externa e interna tem coloração predominantemente cinza, tanto claro como escuro. Uma parte deste conjunto foi dividida na estatística por conta da coloração predominantemente preta e rosa (grupo 4). Acreditamos que os fragmentos pretos possuem essa coloração devido a marcas de uso, reutilização ou processos pós-deposicionais. Os de coloração rosa podem estar relacionados a uma fonte de argila diferenciada, já que não encontramos engobo com esta coloração neste conjunto. No entanto, essa hipótese não foi testada com análises arqueométricas ainda.

\footnotetext{
${ }^{15}$ No sítio Ywantã, reparamos que o principal componente mineral é o quartzo, presente em $63 \%$ da amostra deste sítio. Em $32 \%$ dos fragmentos foram identificados outros minerais junto com o quartzo, como ferro, além de outros que não conseguimos identificar com certeza. Uma análise arqueométrica adequada pode identificar com mais precisão os componentes minerais presentes neste conjunto.
} 


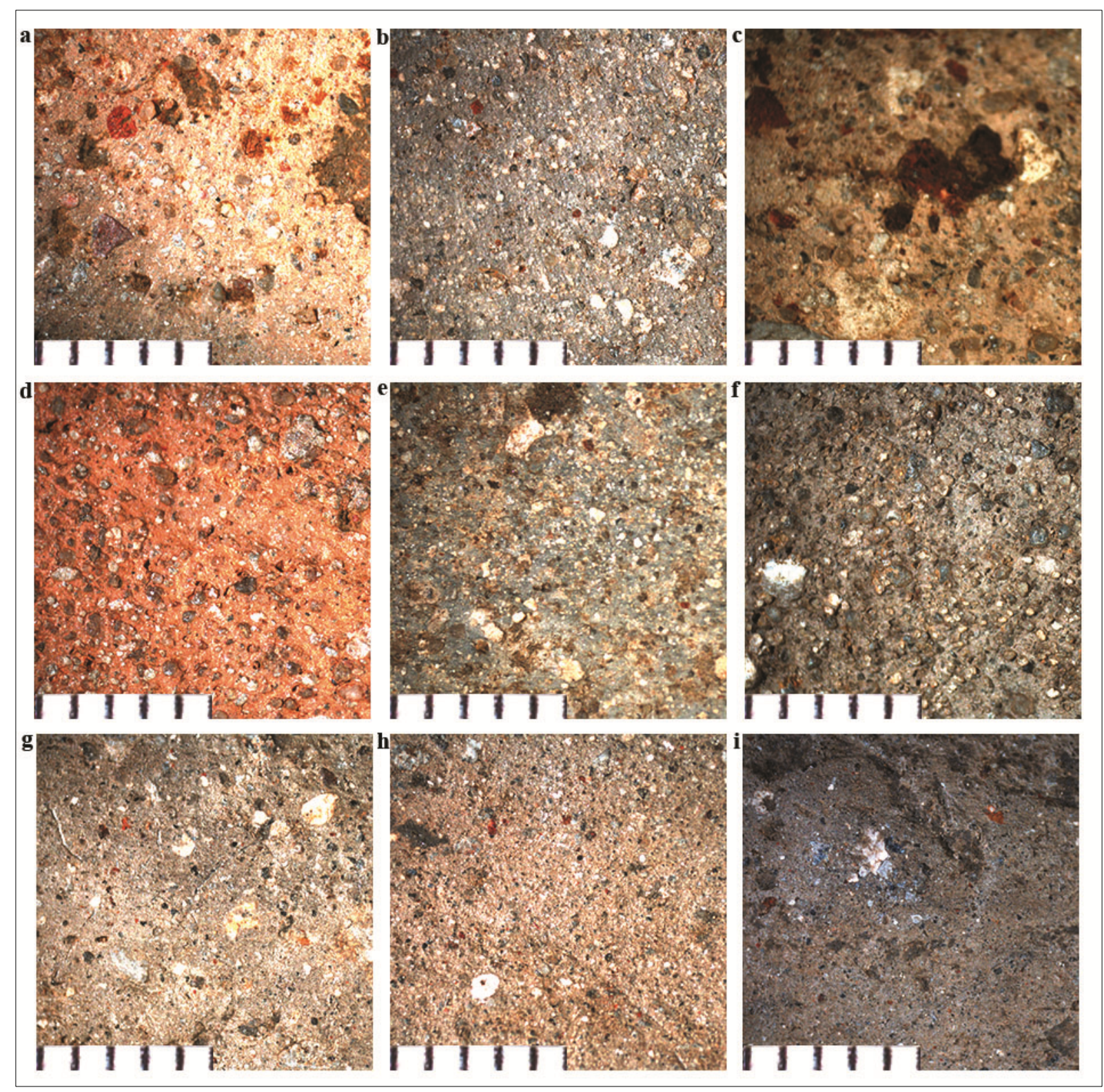

Figura 43: Pastas do Conjunto 1, aumento 10x na lupa binocular, escala em mm. a-c) diversos minerais, como quartzo e óxido de ferro, do sítio YA; d-f) quartzo, do sítio YA; g-i) pasta com minerais do sítio DR.

Para as bordas que conseguimos identificar o ângulo de inclinação, desenhamos os perfis para ilustrar sua variabilidade (figura 44). 


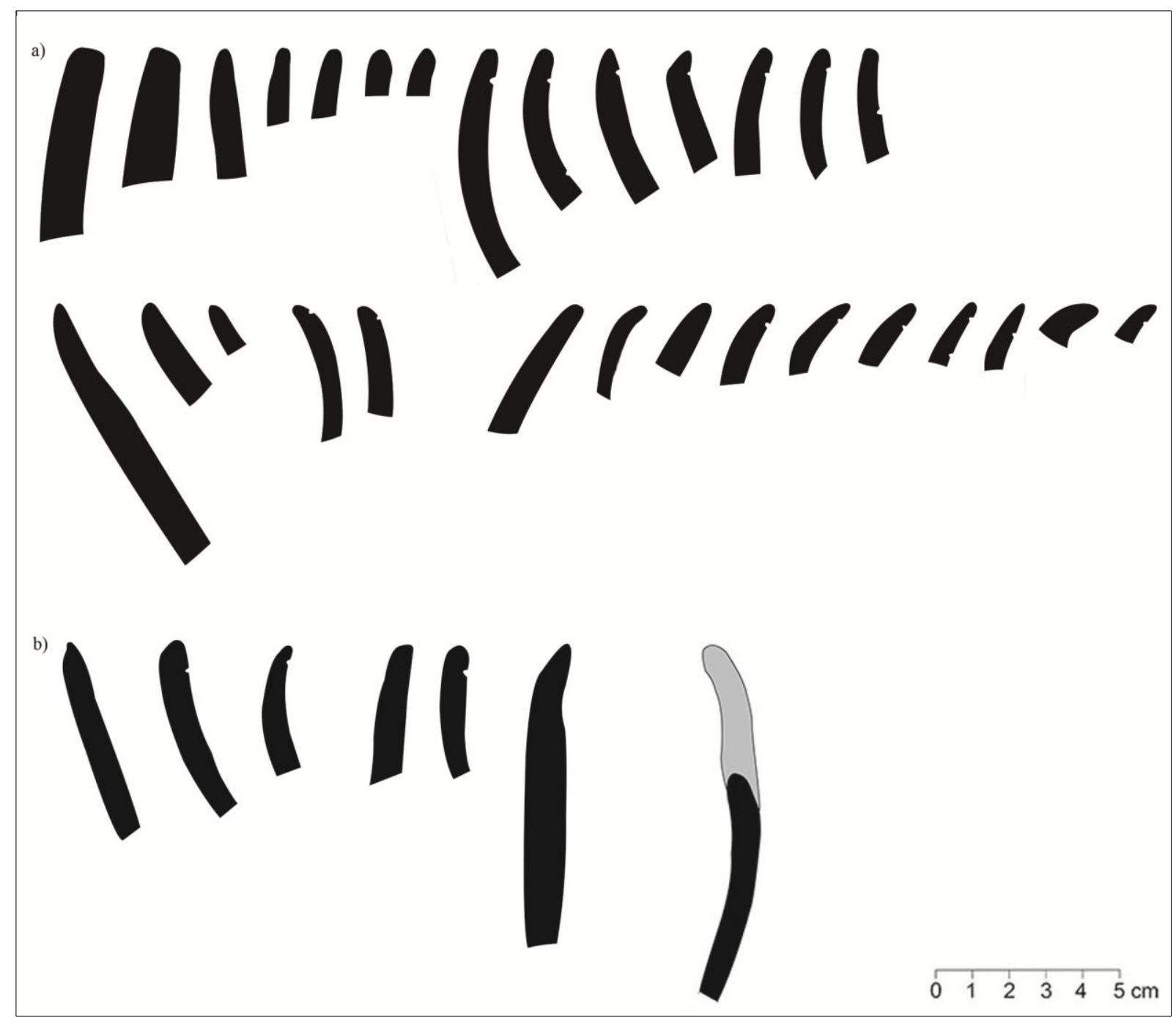

Figura 44: Perfis das bordas do Conjunto 1. a) sítio YA; b) sítio DR. (Desenhos: Amanda Moraes).

Foi possível reconstituir duas formas do sítio Ywantã (figura 45), ambas com linhas de impressão de corda na face externa da borda. A forma 1 (YA-1034) é esférica, fechada, restringida e de contorno simples; o diâmetro da boca é $16 \mathrm{~cm}$, espessura $0,6 \mathrm{~cm}$, tendo sido calculadas na reconstituição a altura como $18 \mathrm{~cm}$ e o volume 6,18 1. A forma 2 (YA-18) é semi-esférica, aberta, não restringida e de contorno simples; o diâmetro da boca é de $6 \mathrm{~cm}$, espessura 0,6 cm, calculando-se a altura $5 \mathrm{~cm}$ e o volume 0,131 . Temos também duas formas do sítio Dinossauro (figura 44), também com impressão de corda. A forma 3 (DR-159) é oval, aberta, restringida e de contorno simples; o diâmetro da boca é de $12 \mathrm{~cm}$, espessura $0,6 \mathrm{~cm}$, com estimação de $13 \mathrm{~cm}$ de altura e 2,12 1 de volume. A forma 4 (DR-157) é esférica, aberta, não restringida, de contorno simples e possui um apêndice (como uma orelha) no lábio; diâmetro da boca $18 \mathrm{~cm}$, espessura $0,7 \mathrm{~cm}$, estimando-se a altura $10 \mathrm{~cm}$ e o volume 2,24 1 . 


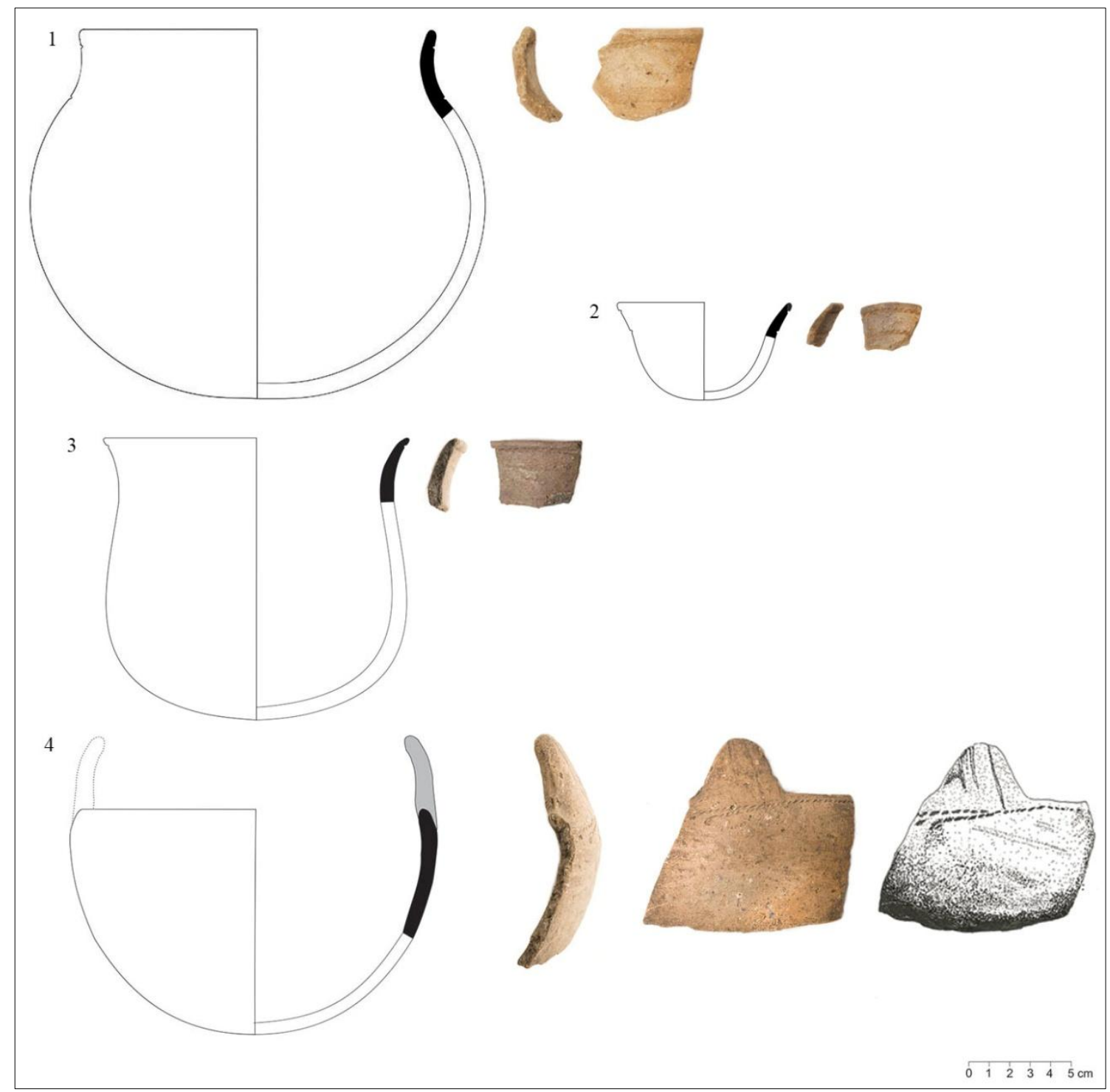

Figura 45: Formas do Conjunto 1. 1) YA-1034; 2) YA-18; 3) DR-159; 4) DR-157. (Desenhos: Amanda Moraes. Fotos: Ader Gotardo).

A espessura dos fragmentos varia entre 3 e $26 \mathrm{~mm}$, estando a maioria predominantemente entre 5 e $7 \mathrm{~mm}$. Existem 8 fragmentos lisos com espessura entre 20 e 26 mm que podem corresponder a fragmentos de vasilhas planas e grandes, como assadores/torradores.

$\mathrm{Na}$ face externa, $86 \%$ dos fragmentos são alisados e, apesar de não termos qualificado os tipos de alisamento, neste conjunto a superfície parece ser muito bem alisada, às vezes até parecendo um polimento (figura 46). Ainda assim, são os outros acabamentos de superfície que auxiliam enormemente na caracterização deste conjunto. São os acabamentos plásticos da face externa, principalmente impressão de corda, ungulado, inciso e corrugado (figuras 46 a 48). A face interna é acabada com alisamento, no entanto temos uma exceção que é um pequeno fragmento de borda com impressão de corda tanto na face externa como na 
face interna (figura 48). Uma pequena parte de fragmentos classificados neste conjunto possui banho e engobo vermelho, nas duas faces. Os lábios também são predominantemente alisados, com exceção dos fragmentos com engobo e banho.

As impressões de corda são lineares, imediatamente abaixo do lábio ou um pouco mais abaixo na borda ou pescoço, no entanto não temos certeza se elas se restringiam a esse local da vasilha. Alguns fragmentos apresentam até três linhas paralelas, mas o mais comum é uma linha. $\mathrm{O}$ ungulado também ocorre em faixas paralelas, próximas à borda na face externa, mas novamente não temos certeza se sua localização é exclusiva nesta região. Os incisos muitas vezes imitam o ungulado, formando meias-luas. Outro tipo de inciso forma motivos quadriculados, provavelmente feitos em toda a parede externa da vasilha: linhas paralelas e perpendiculares em diferentes inclinações, sendo que às vezes um dos conjuntos de linhas paralelas não é contínuo.
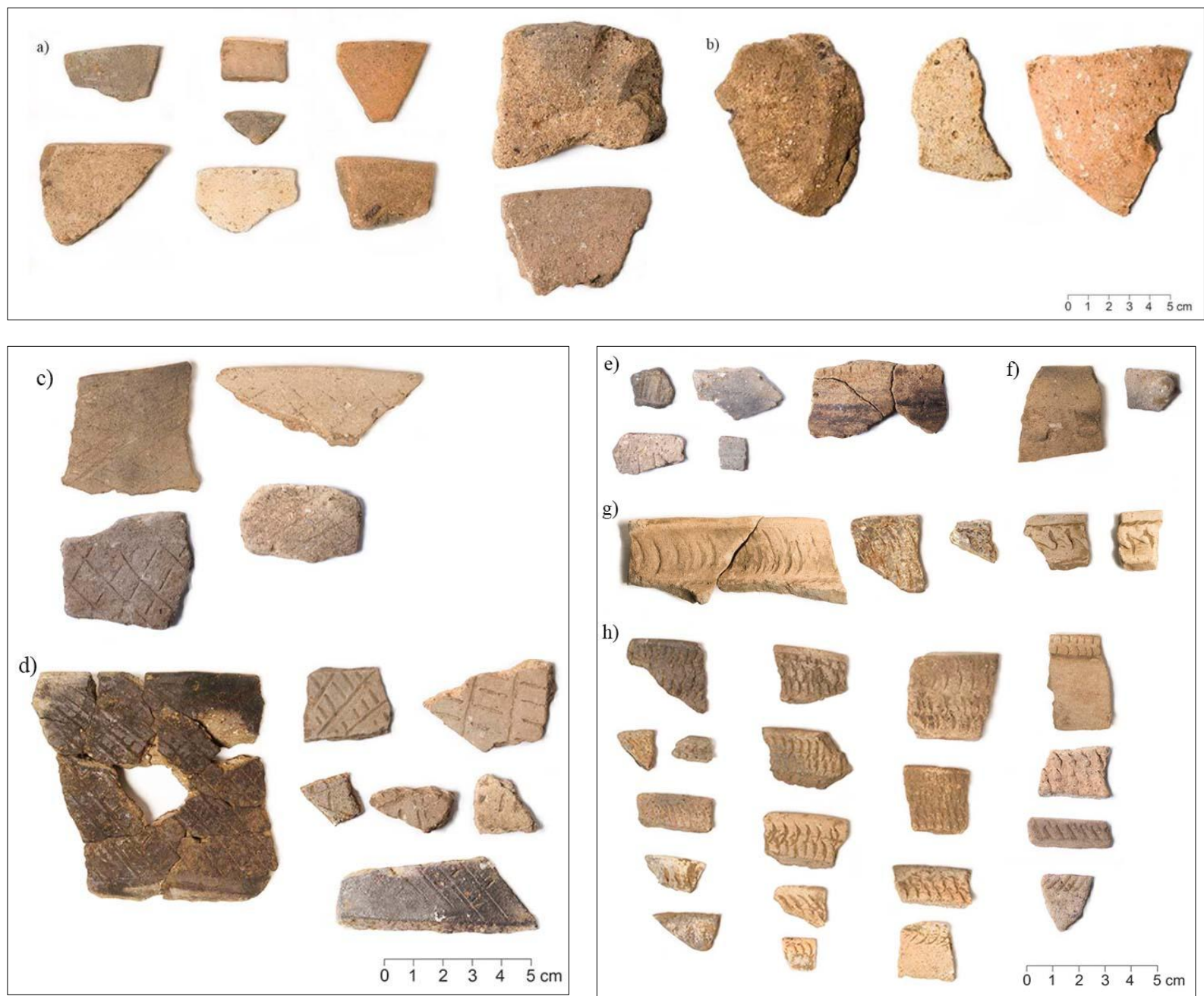

Figura 46: Fragmentos do Conjunto 1, sítio YA. a) bordas alisadas; b) bases alisadas; c) incisos formando losangulos; d) incisos cruzados; e) incisos variados; f) beliscado e impressão de corda, apêndice mamilonar; g) ungulado e impressão de corda,corrugado e impressão de corda; h) ungulados. (Fotos: Ader Gotardo). 


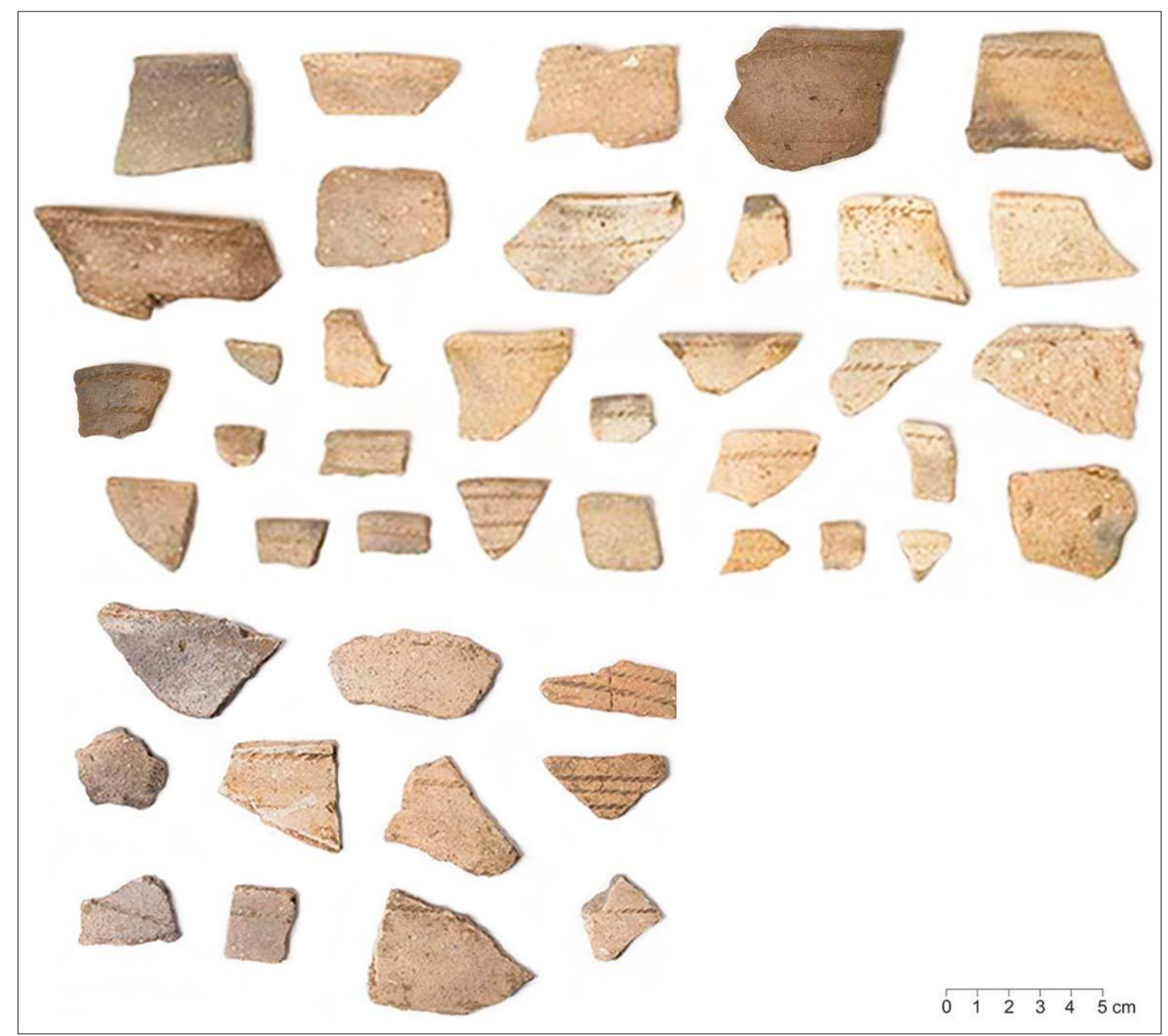

Figura 47: Fragmentos do Conjunto 1, sítio YA. Impressão de corda. (Foto: Ader Gotardo).

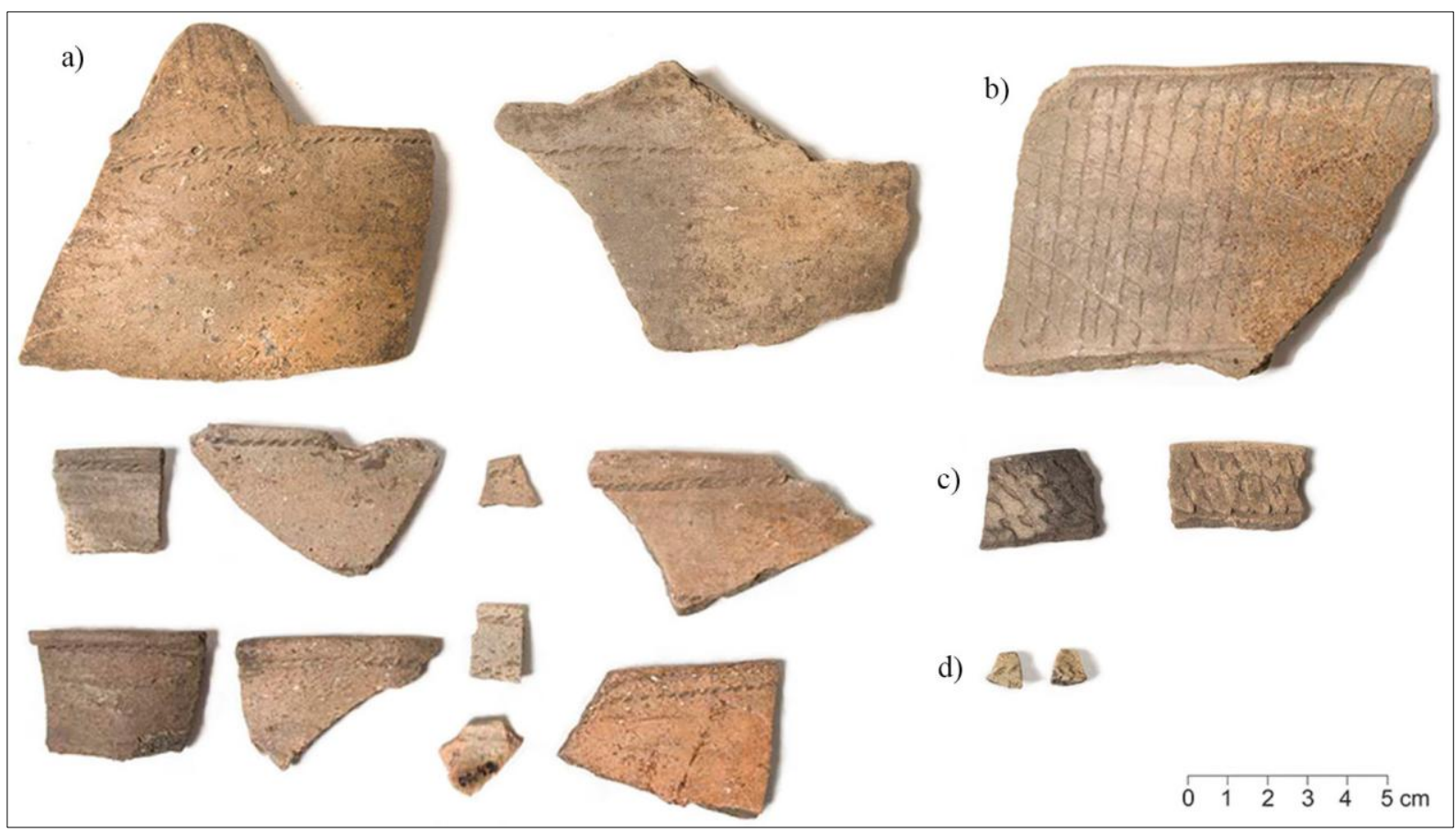

Figura 48: Fragmentos do Conjunto 1, sítio DR. a) impressão de corda; b) inciso cruzado; c) corrugados; d) impressão de corda na face externa e na interna. (Fotos: Ader Gotardo). 


\subsection{Conjunto 2}

Este conjunto foi identificado ainda durante a análise pois possui características bastante distintas associadas ao sítio Mukuin Caniné, que parece ser unicomponencial. Apareceu em todos os cortes do dendograma, correspondendo aos grupos 1 e 3 da estatística. Pela estatística, alguns fragmentos do sítio Dinossauro foram classificados neste conjunto, no entanto não temos certeza desta classificação, pois algumas características podem ser confundidas com a dos outros conjuntos descritos adiante. Assim, consideramos como pertencentes a este conjunto somente os fragmentos do sítio MC, sendo a data de $870 \pm 120$ A.P. (termoluminescência) associada a ele.

Os antiplásticos utilizados neste conjunto (figura 49) são principalmente o caco moído e o caraipé, frequentemente ocorrendo uma combinação entre eles, além de haver uma porcentagem de antiplástico exclusivamente mineral. A divisão dos grupos estatísticos parece ter sido justamente por conta do caraipé e caco moído, que, como veremos mais adiante, possuem propriedades bastante diferentes em termos de performance.

Quase metade dos fragmentos possui coloração da face externa e interna cinza (claro e escuro), a outra metade tem coloração marrom e marrom-avermelhada. A coloração cinza está associada ao caraipé, enquanto que a coloração marrom está associada ao caco moído. Pode ser que cada antiplástico tivesse sido usado com um tipo de argila diferente, no entanto não fizemos análises arqueométricas suficientes para testar esta hipótese. A coloração acinzentada pode ser por causa da queima do material orgânico, caraipé. 


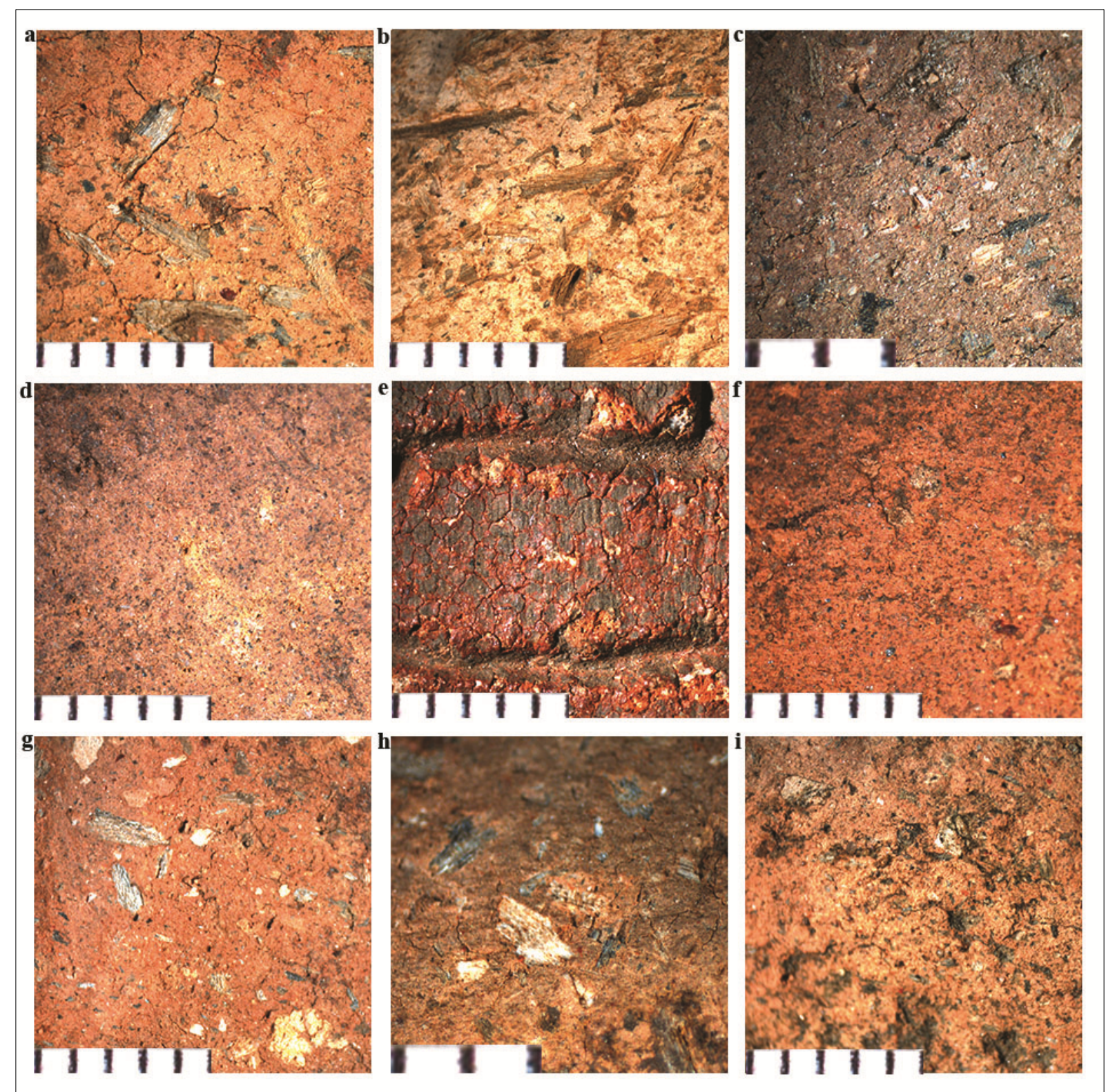

Figura 49: Pastas do Conjunto 2, sítio MC, aumento 10x na lupa binocular (exceto c e h: 2x), escala em mm. ac) caraipé; d-f) caco moído; g-i) caco moído e caraipé.

Abaixo, temos as ilustrações dos perfis das bordas das quais pudemos identificar o ângulo de inclinação (figura 50). 


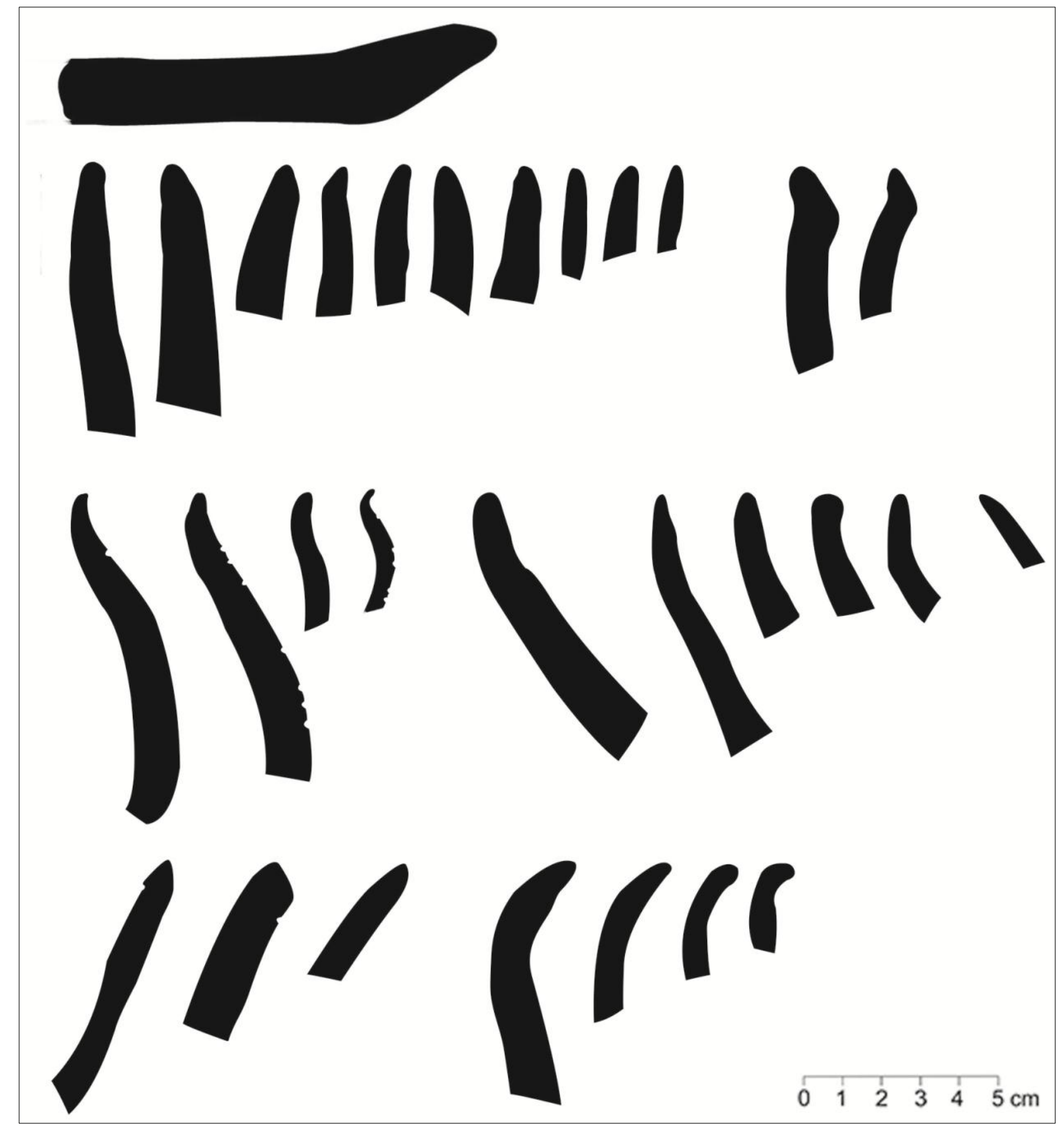

Figura 50: Desenhos dos perfis das bordas do Conjunto 2, sítio MC. (Desenhos: Amanda Moraes).

Foram reconstituídas cinco formas do sítio Mukuin Caniné (figura 51). A forma 1 (MC-201) é de um fragmento com incisões de motivos escalonados sobre engobo vermelho, tendo forma bicônica, restringida, fechada e de contorno composto; o diâmetro da boca é 22 $\mathrm{cm}$, espessura $0,7 \mathrm{~cm}$, com cálculo de altura $14 \mathrm{~cm}$ e volume 7,27 1. A forma 2 (MC-204) foi feita a partir do diâmetro máximo de $22 \mathrm{~cm}$, sendo então o diâmetro da boca $20 \mathrm{~cm}$, espessura $1 \mathrm{~cm}$, estimação da altura $14 \mathrm{~cm}$ e volume 5,19 1; a forma também é bicônica, restringida, fechada e de contorno composto. A terceira forma parece ser uma miniatura (MC-207), alisada, com forma esférica, restringida, fechada e de contorno infletido, sendo o diâmetro da 
boca $6 \mathrm{~cm}$, espessura $0,7 \mathrm{~cm}$, calculando-se altura $5 \mathrm{~cm}$ e volume 0,21 1. Ela parece ter sido feita por alguém em fase de aprendizado, pois se observamos o pefil dos dois lados do fragmento vemos uma grande diferença na espessura e morfologia. A forma 4 (MC-64) também parece ser uma miniatura, com incisões de linhas e volutas com pintura branca na face externa, com diâmetro da boca $4 \mathrm{~cm}$, espessura $0,5 \mathrm{~cm}$, estimando-se altura $4 \mathrm{~cm} \mathrm{e}$ volume 0,07 1; sua forma é esférica, restringida, fechada e de contorno infletido. A última forma 5 (MC-218) parece corresponder a um assador ou torrador, sendo aberta, não restringida, de contorno simples e forma hiperbólica horizontal; a espessura é de 1,6 cm, o diâmetro da base é de $30 \mathrm{~cm}$, diâmetro da boca $34 \mathrm{~cm}$, altura 2,8 cm, volume 1,07 1 .
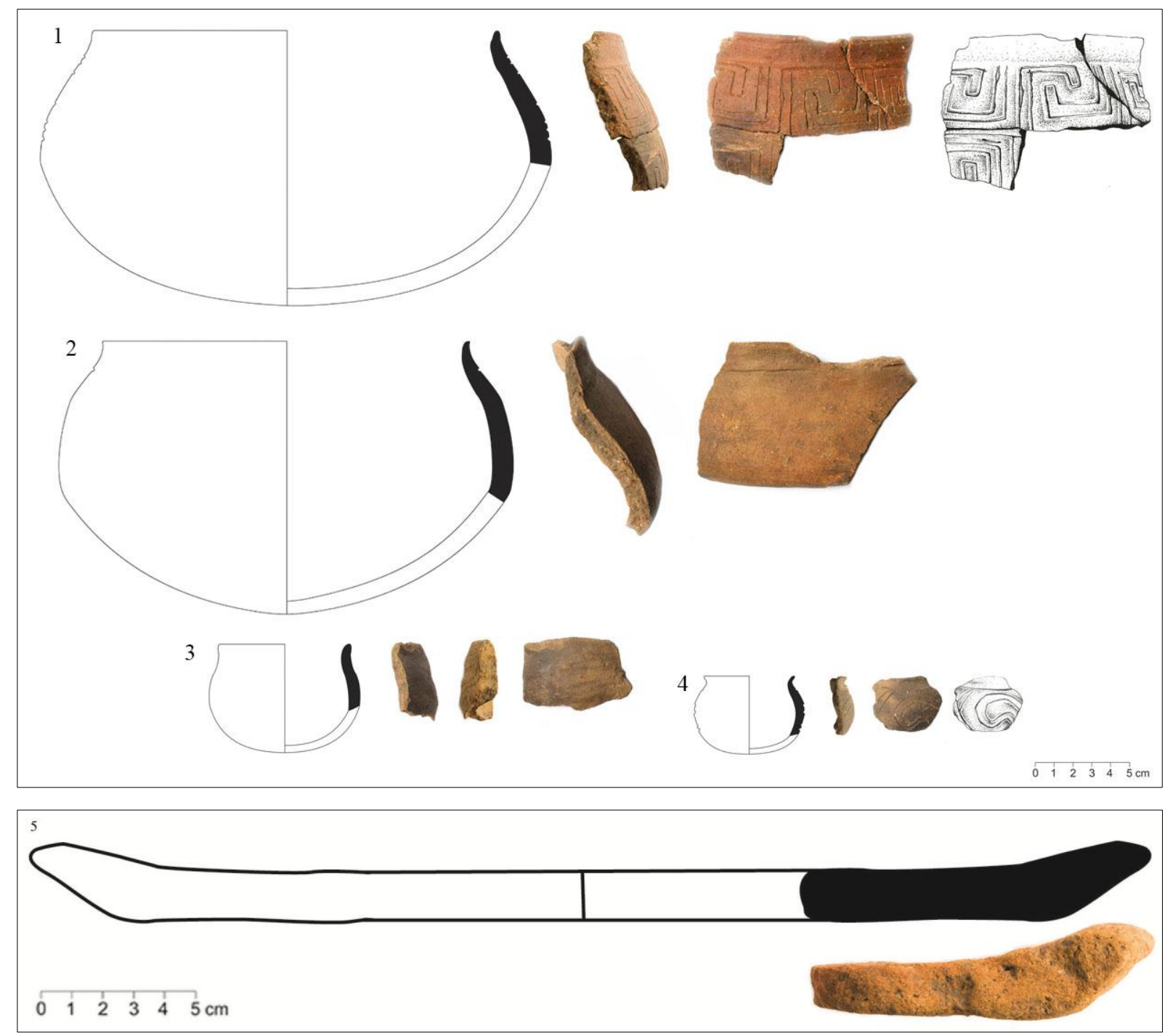

Figura 51: Formas do Conjunto 2. 1) MC-201; 2) MC-204; 3) MC-207; 4) MC-64; 5) MC-218. (Desenhos 1 a 4 : Amanda Morae. Desenho 5: Stevan Rosa. Fotos: Ader Gotardo). 
A espessura dos fragmentos deste conjunto variam de 4 a $21 \mathrm{~mm}$, com maior concentração entre 6 e $9 \mathrm{~mm}$. Existem também muitas paredes classificadas como ombros, carenadas e infletidas, apontando para uma maior quantidade de formas angulares (figura 52), como as duas formas bicônicas descritas a cima. Uma parede angular tem um acabamento de banho com uma pintura branca formando volutas (figura 52-b).

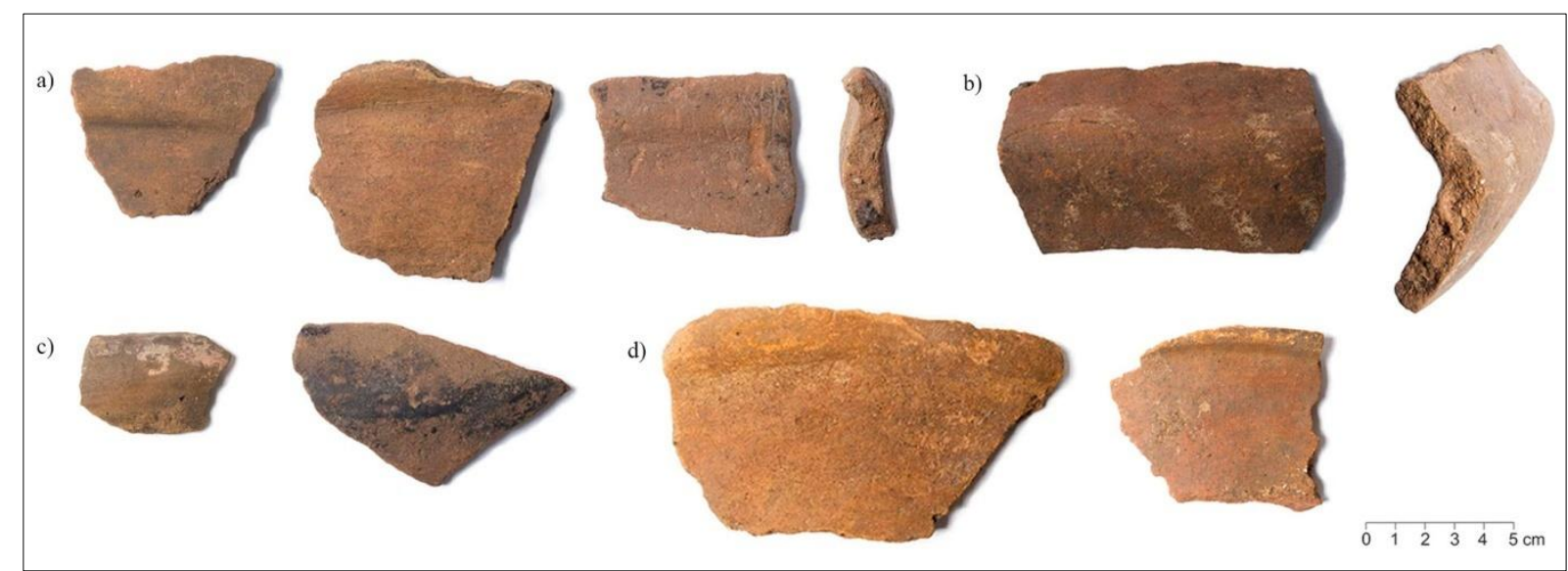

Figura 52: Paredes do Conjunto 2, sítio MC. a) paredes carenadas; b) parede carenada com banho e pintura branca, formando volutas; c) ombros com engobo rosa e fuligem; d) paredes carenadas com banho e engobo rosa. (Fotos: Ader Gotardo).

O alisamento (não tão fino quanto o do conjunto anterior) corresponde a $79 \%$ dos acabamentos de superfície, mas destacam-se neste conjunto os acabamentos pintados. Os engobos (branco, vermelho e rosa) e banho somam $17 \%$, havendo diversas combinações de pinturas sobre banho ou engobo vermelho, além de acabamentos plásticos (inciso) combinados com pintados (figuras 53).

Um tipo de incisão bastante comum neste conjunto é feita formando uma linha que demarca a região da borda ou do lábio, na parte externa ou na interna (figura 53-a e 53-b). É muitas vezes combinado com engobos e banho (figura 53-c). Tanto as pinturas como os outros tipos de incisos formam motivos geométricos: triangulares, volutas e gregas. Uma borda cambada possui, também sobre o banho, uma pintura branca de triângulos concêntricos (figura 53-e). As bordas com motivos incisos de volutas e gregas foram descritas anteriormente (ver figua 51-1 e 51-4). Classificamos um engobo de coloração rosa (figura 53c e 53-f) por ser bastante diferente da coloração do engobo vermelho (figura 53-d). Ainda não sabemos se ele é formado por uma combinação de pigmento branco e vermelho, ou se é realmente um pigmento diferente. 


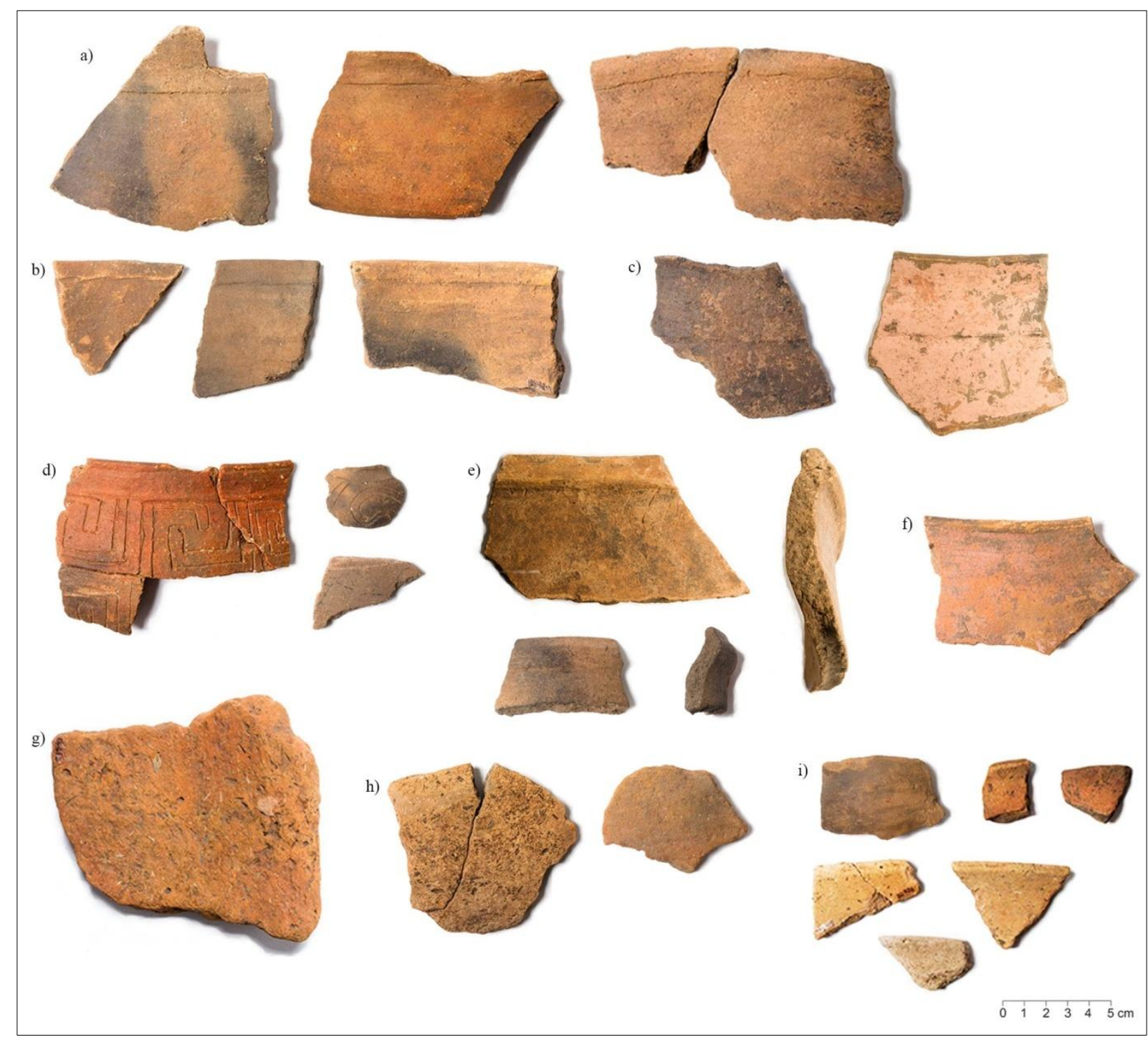

Figura 53: Acabamentos de superfície do Conjunto 2, sítio MC. a) incisão na face externa; b) inciso na face interna; c) banho e engobo rosa sobre incisão; d) incisos; e) bordas camabadas, uma com pintura branca triangular sobre banho; f) engobo rosa; g) alisamento; h) bases; i) bordas alisadas. (Fotos: Ader Gotardo).

\subsection{Conjunto 3}

É o conjunto predominante do sítio Dinossauro (52,3\%) e do Minhocoçu (87,18\%), mas também está presente na Aldeia Coelho (15,1\%), Aldeia Tukumã $(21,7 \%)$ e Taitetu (8,3\%). É claramente o grupo 6 na estatística. A data de $1680 \pm 30$ A.P. (radiocarbônica) está em um contexto do Dinossauro associado à esse conjunto, assim como a data de $380 \pm 50$ A.P. (termoluminescência) do Taitetu. 
O Conjunto 3 é caracterizado principalmente pela combinação de caraipé e cauixi como antiplástico (figura 54), mas também encontramos fragmentos somente com cauxi ou caraipé e às vezes uma combinação deles também com caco moído.

A coloração da face externa dos fragmentos é predominantemente cinza claro, mas também existe uma porcentagem significativa de fragmentos com coloração marrom e marrom-avermelhado. A coloração da face interna segue esses padrões, apesar de ter uma alta porcentagem de fragmentos com a face interna ausente por conta de sua deterioração (não podemos afirmar se pelo uso ou ações pós-deposicionais), principalmente no sítio Minhocoçu..

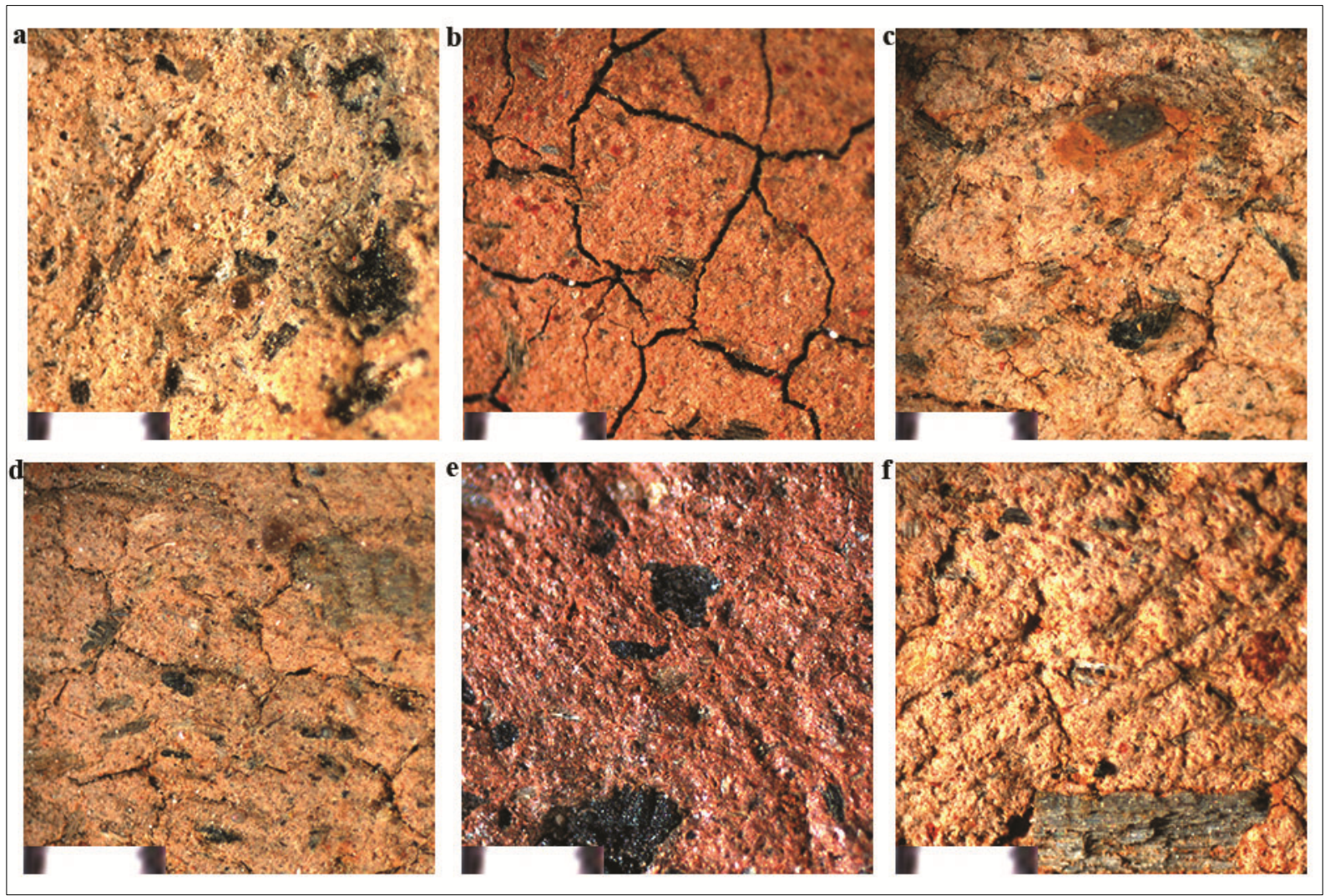

Figura 54: Pastas do Conjunto 3, com caraipé e cauixi, aumento 3.2x na lupa binocular, escala em mm. a) sítio Aldeia Tukumã; b-d) sítio Dinossauro; e) sítio Minhocoçu; f) sítio Aldeia Coelho.

Os perfis das bordas que pudemos observar o ângulo de inclinação estão mostrados na figura 55, abaixo. 


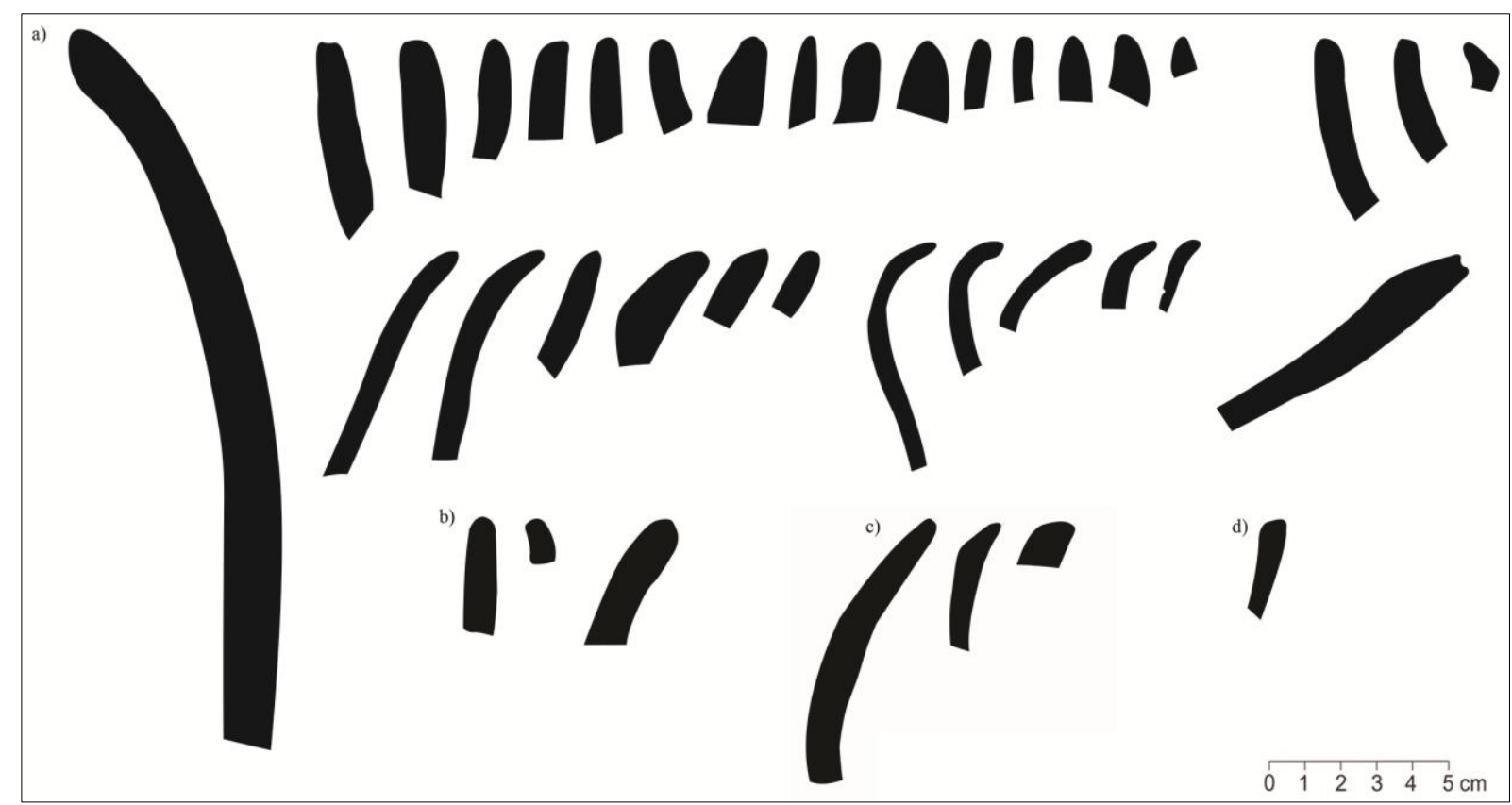

Figura 55: Perfis das bordas do Conunto 3. a) sítio DR; b) sítio MI; c) sítio TT; d) sítio AC.

As formas reconstituídas para este conjunto são basicamente do sítio Dinossauro (figura 56). A reconstituição 1 (DR-2247) tem forma oval invertida, restringida, fechada e de contorno infletido; o diâmetro da boca é $16 \mathrm{~cm}$, espessura $0,5 \mathrm{~cm}$, com estimação da altura 25 cm e volume 11,49 1. A forma 2 (DR-1811) é também uma forma oval invertida, restringida, fechada e de contorno infletido; diâmetro da boca $18 \mathrm{~cm}$, espessura 0,7 cm, calculando-se a altura $22 \mathrm{~cm}$ e volume 11,48 1. A reconstituição 3 desse conjunto é do sítio Taitetu (TT-1804), uma forma semi-esférica, aberta, não restringida e de contorno simples, com diâmetro da boca $12 \mathrm{~cm}$, espessura $0,7 \mathrm{~cm}$, calculando-se a altura $9 \mathrm{~cm}$ e volume 1,22 1. A reconstituição 4 (DR-1186), com incisão na face interna e no lábio (dando um efeito serrilhado), tem forma semi-esférica, aberta, não restringida e de contorno simples, com diâmetro da boca $9 \mathrm{~cm}$, espessura 0,4 cm, estimando-se altura $4 \mathrm{~cm}$ e volume 0,151 , que consideramos uma miniatura. A última forma 5 (DR-2328) é bastante grande. Ela é esférica, fechada, não restringida e de contorno simples; o diâmetro da boca é $56 \mathrm{~cm}$, espessura $1,2 \mathrm{~cm}$, calculando-se altura $33 \mathrm{~cm}$ e volume 36,561 . 

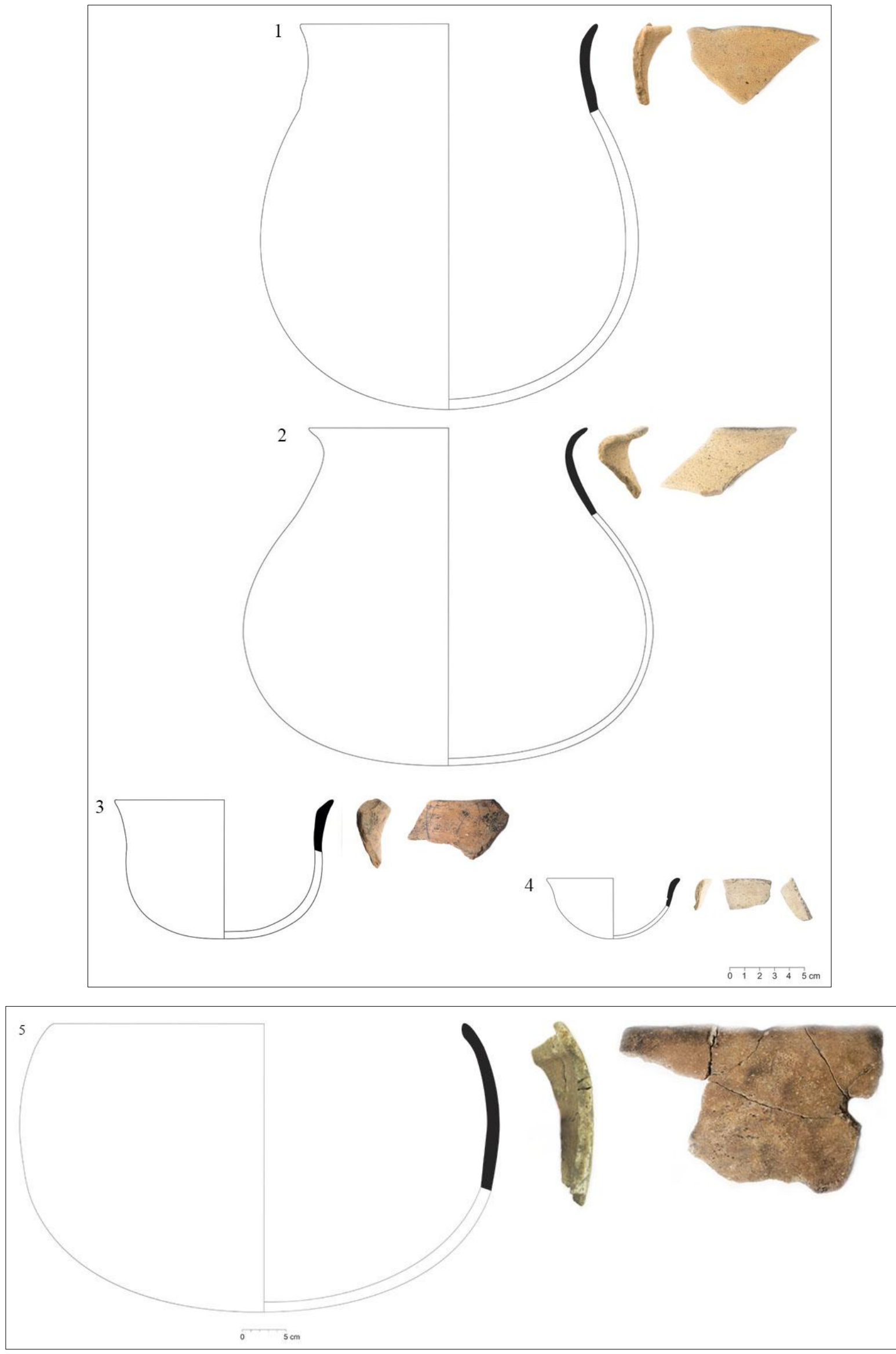

Figura 56: Formas do Conjunto 3. 1) DR-2247; 2) DR-1811; 3) TT-1804; 4) DR-1186; 5) DR-2328. (Desenhos: Amanda Moraes. Fotos: Ader Gotardo). 
A espessura dos fragmentos varia entre 2 e $26 \mathrm{~mm}$, sendo a faixa com maior concentração de fragmentos entre 6 e $9 \mathrm{~mm}$, especialmente em $7 \mathrm{~mm}$. Encontramos neste conjunto algumas paredes angulares, mas não foi possível reconstituir nenhuma forma com essas características.

O acabamento de superfície da face externa e interna é o alisamento em $96 \%$ dos fragmentos, sendo os restantes $4 \%$ divididos entre fragmentos com banho, engobo vermelho e alguns únicos fragmentos com acabamentos plásticos. Raras bordas possuem acabamento inciso ou ponteado no lábio. Esses acabamentos diferentes são tão poucos que merecem ser descritos individualmente.

No sítio Dinossauro (figura 57), temos um fragmento bastante diferente que dá a impressão de ser uma base em pedestal, mas também pode ser um suporte para vasilha (figuras 57-a). Um fragmento apresenta incisões de círculos concêntricos na face externa (figura 57-b). Temos também três fragmentos com incisões no lábio que apresentam um efeito serrilhado (figura 57-c).

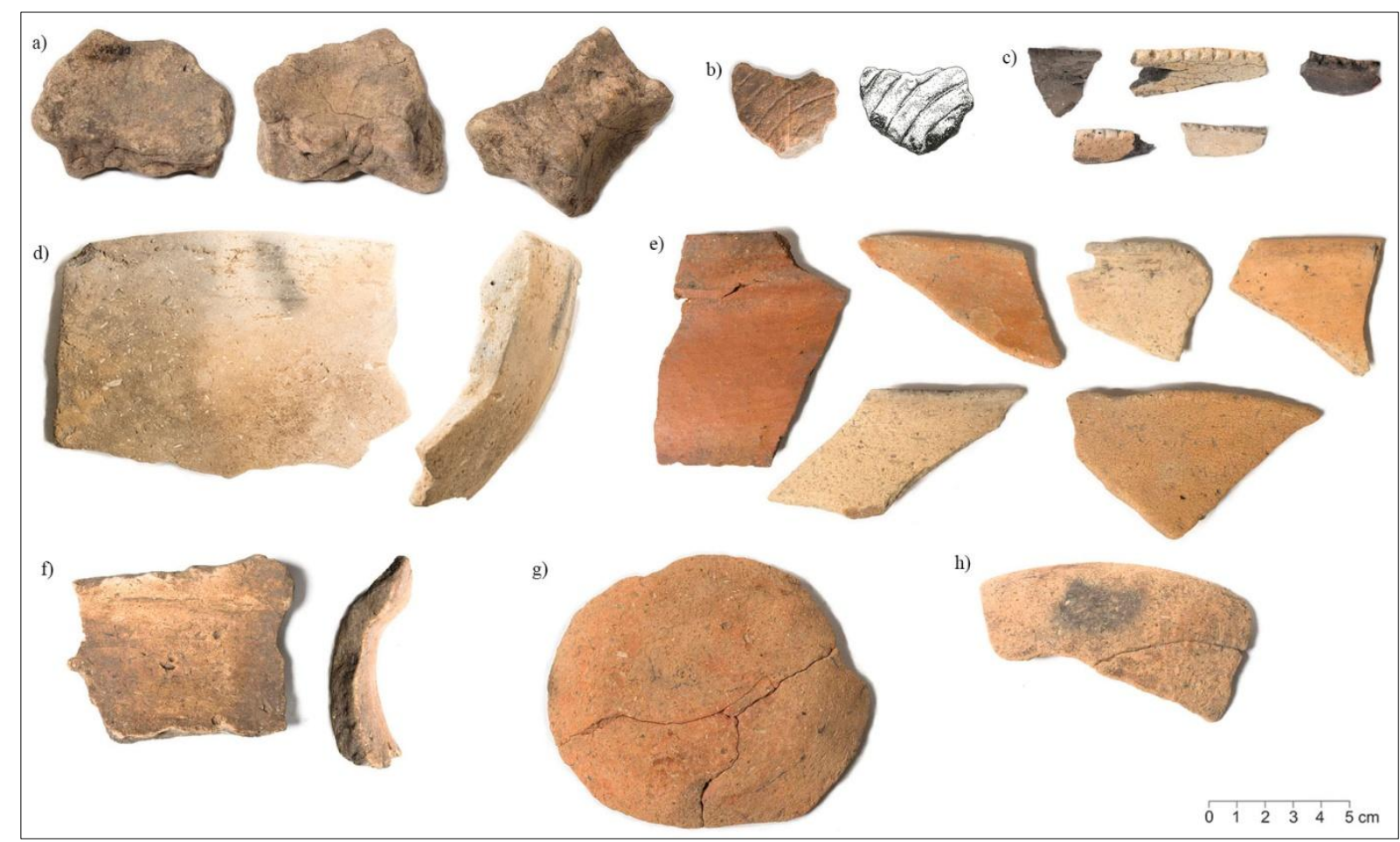

Figura 57: Acabamentos de superfície do Conjunto 3, sítio DR. a) base em pedestal ou suporte de vasilha; b) incisos circulares; c) incisões e ponteado no lábio; d) borda; e) bordas alisadas; f) parede carenada; g) base circular; h) ombro. (Fotos: Ader Gotardo). 
O sítio Minhocoçu (figura 58) tem fragmentos predominantemente alisados, com alguns banhos e engobos vermelhos (figura 58-d). Temos dois fragmentos de base (figura 58a), além de um fragmento com ângulo saliente (figura 58-c).

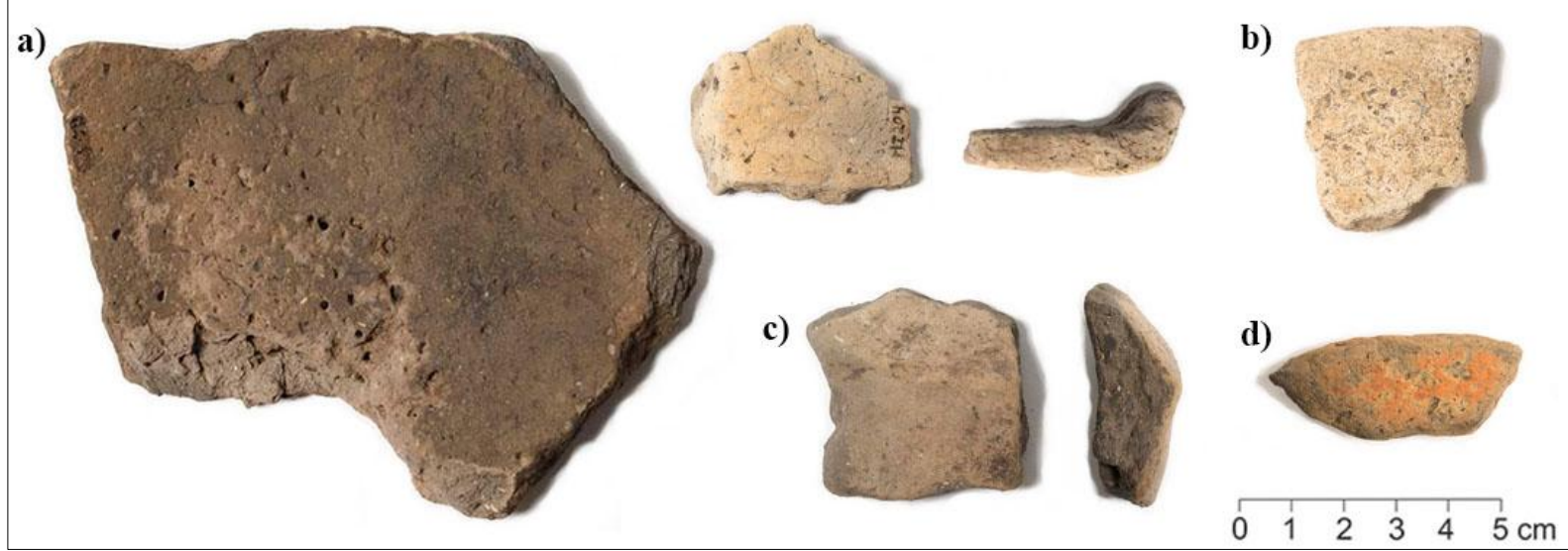

Figura 58: Acabamentos de superfície do Conjunto 3, sítio MI. a) base; b) parede angular; c) parede carenada; d) engobo vermelho. (Fotos: Ader Gotardo).

No sítio Aldeia Tukumã (figura 59), encontramos um único fragmento com acabamento diferenciado: uma linha incisa e três fileiras de ponteado.

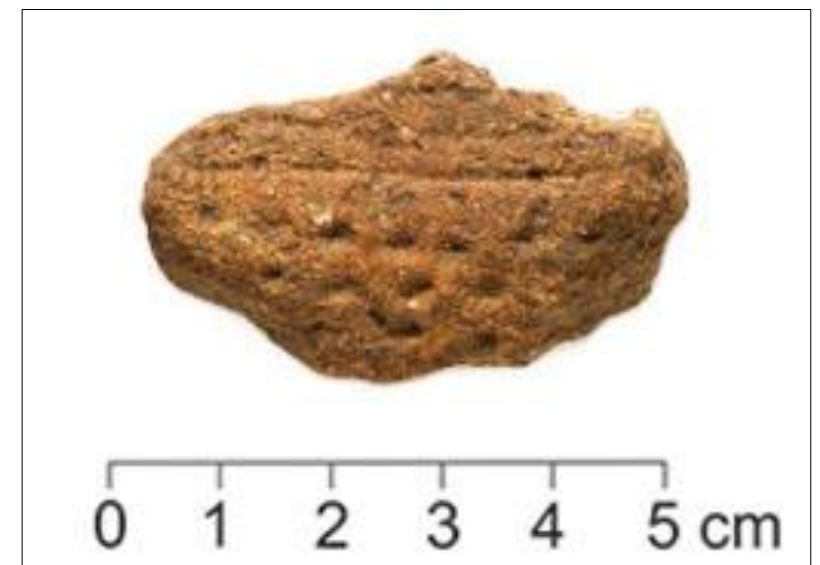

Figura 59: Acabamento de superfício do Conjunto 3, sítio AT, linha incisa e ponteado.

No sítio Taitetu, destacam-se os fragmentos com engobo vermelho (figura 60-b). Além deles, temos também um engobo branco (figura 60- c) e um fragmento com marcas de polidor de sulco (figura 60-d). 


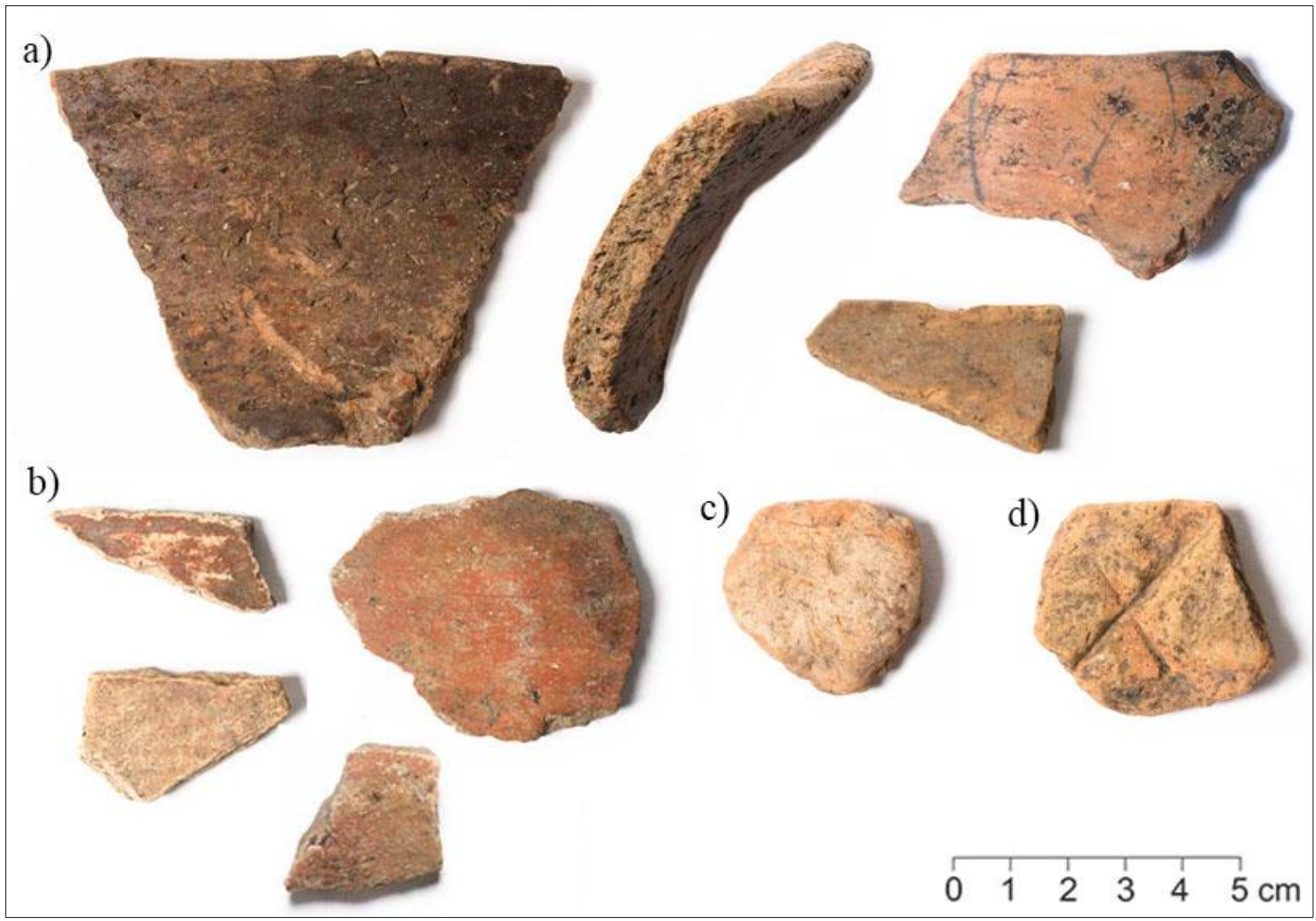

Figura 60: Acabamentos de superfície do Conjunto 3, sítio TT. a) banho; b) engobo vermelho; c) engobo branco; d) polidor de sulco. (Fotos: Ader Gotardo).

\subsection{Conjunto 4}

É o conjunto predonimante nos sítios Aldeia Coelho (73,3\%), Aldeia Tukumã $(55,1 \%)$ e Tatitetu $(54,3 \%)$, estando presente em pequena quantidade também no sítio Dinossauro $(10,2 \%)$.

O Conjunto 4 se caracteriza principalmente pela combinação de caco moído e cauixi como antiplástico (figura 61), mas também apresenta os dois antiplásticos separadamente ou ainda combinados com caraipé.

A coloração predominante da face externa e interna é o cinza claro e escuro, seguido de marrom avermelhado. A face interna segue o mesmo padrão. 


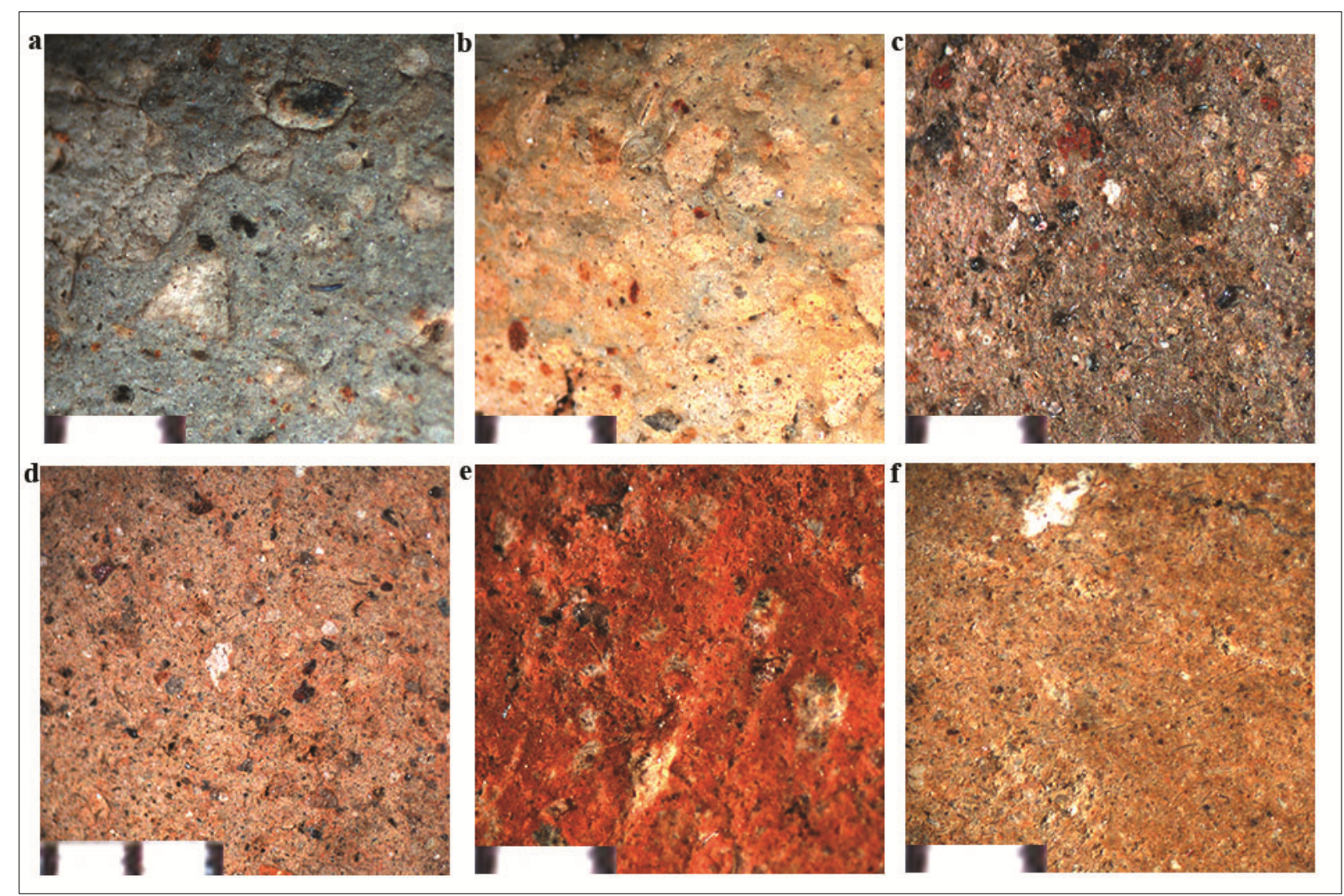

Figura 61: Pastas do Conjunto 4, com cauixi e caco moído, aumento 3.2x na lupa binocular (exceto 4: 2x), escala em mm. a-b) sítio Aldeia Coelho; c) sítio Aldeia Tukumã; d) sítio Dinossauro, aumento 2x; e-f) sítio Taitetu.

Os perfis das bordas com ângulo de inclinação identificado estão mostrados nas figuras 62 e 63 abaixo.

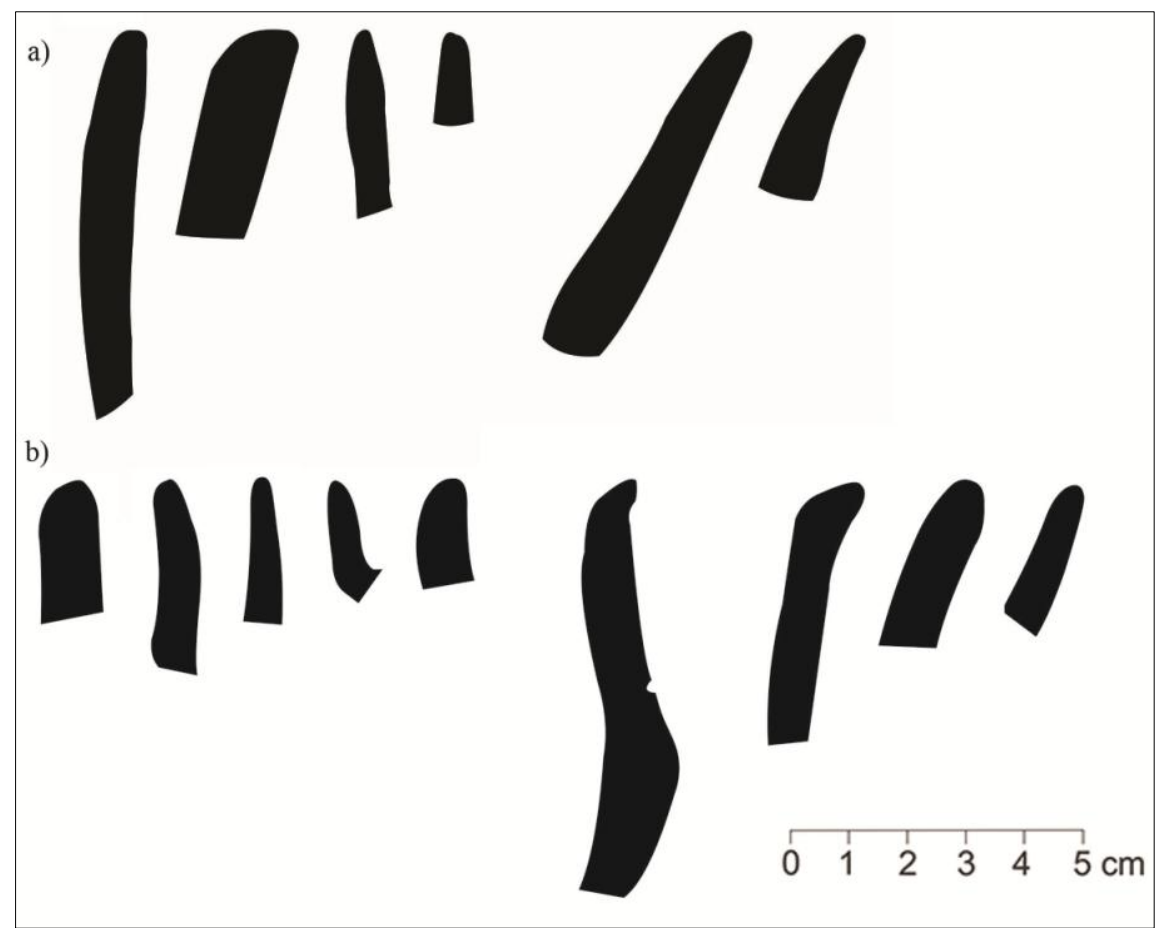

Figura 62: Perfis das bordas do Conjunto 4. a) sítio TT; b) sítio DR. (Desenhos: Amanda Moraes). 


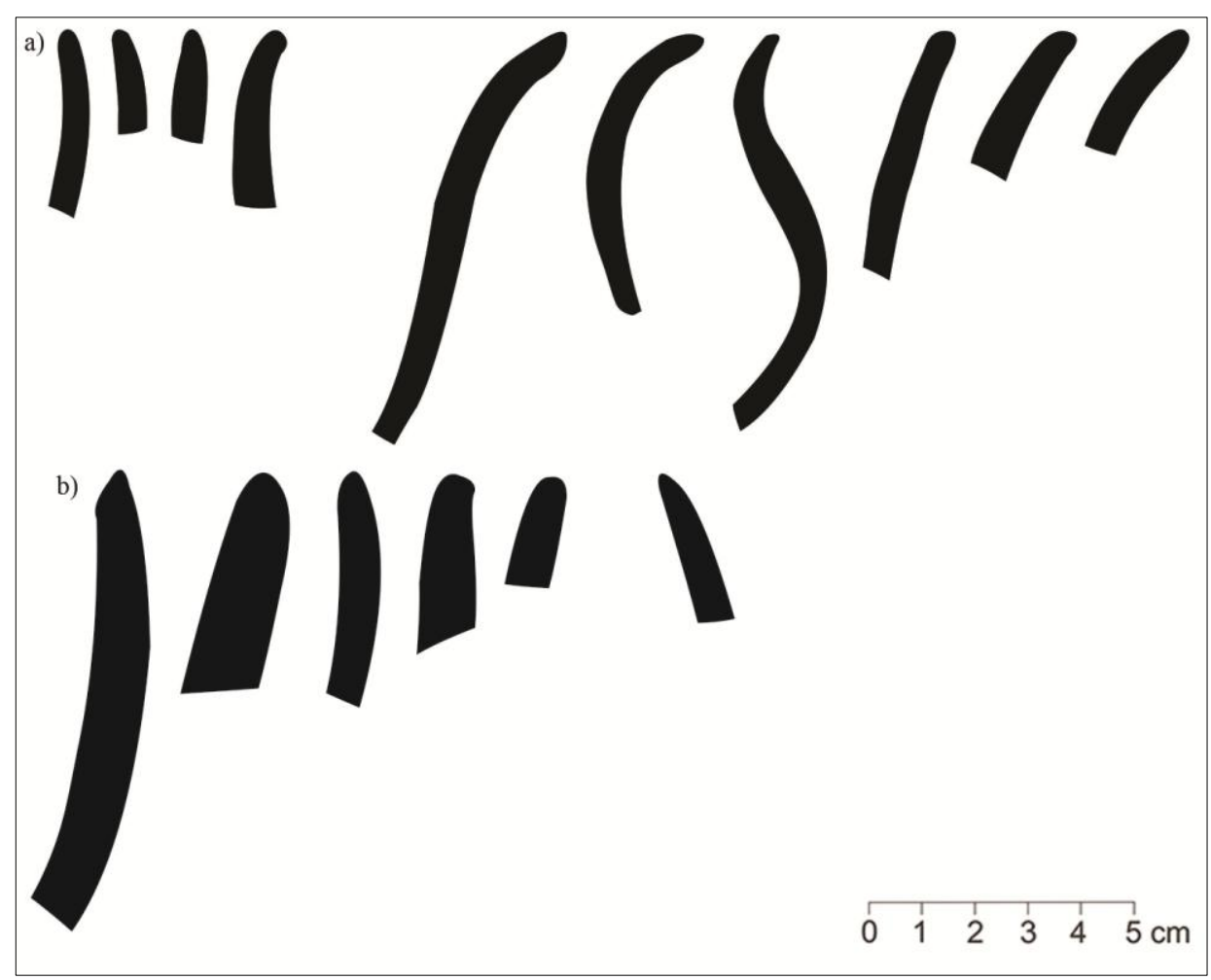

Figura 63: Perfis das bordas do Conjunto 4. a) sítio AC; b) sítio AT. (Desenhos: Amanda Moraes).

As formas reconstituídas deste conjunto são na maior parte do sítio Aldeia Coelho (figura 64). São todas formas esféricas, restringidas, fechadas e de contorno infletido. A forma 1 (AC-813) tem como medida do diâmetro da boca $16 \mathrm{~cm}$, espessura 0,6 cm, estimando-se altura $16 \mathrm{~cm}$ e volume 4,33 litros. A forma 2 (AC-45) tem diâmetro da boca $10 \mathrm{~cm}$, espessura $0,5 \mathrm{~cm}$, estimando-se altura $13 \mathrm{~cm}$ e volume 1,81 1. A forma 3 (AC-47) tem diâmetro da boca $11 \mathrm{~cm}$, espessura $0,6 \mathrm{~cm}$, calculando-se altura $9 \mathrm{~cm}$ e volume 0,77 litros. A forma 4 é do sítio Dinossauro (DR-153), semi-esférica, restringida, fechada e de contorno infletido, com diâmetro da boca $12 \mathrm{~cm}$, espessura $0,8 \mathrm{~cm}$, calculando-se altura $10 \mathrm{~cm}$ e volume 1,48 1 . 


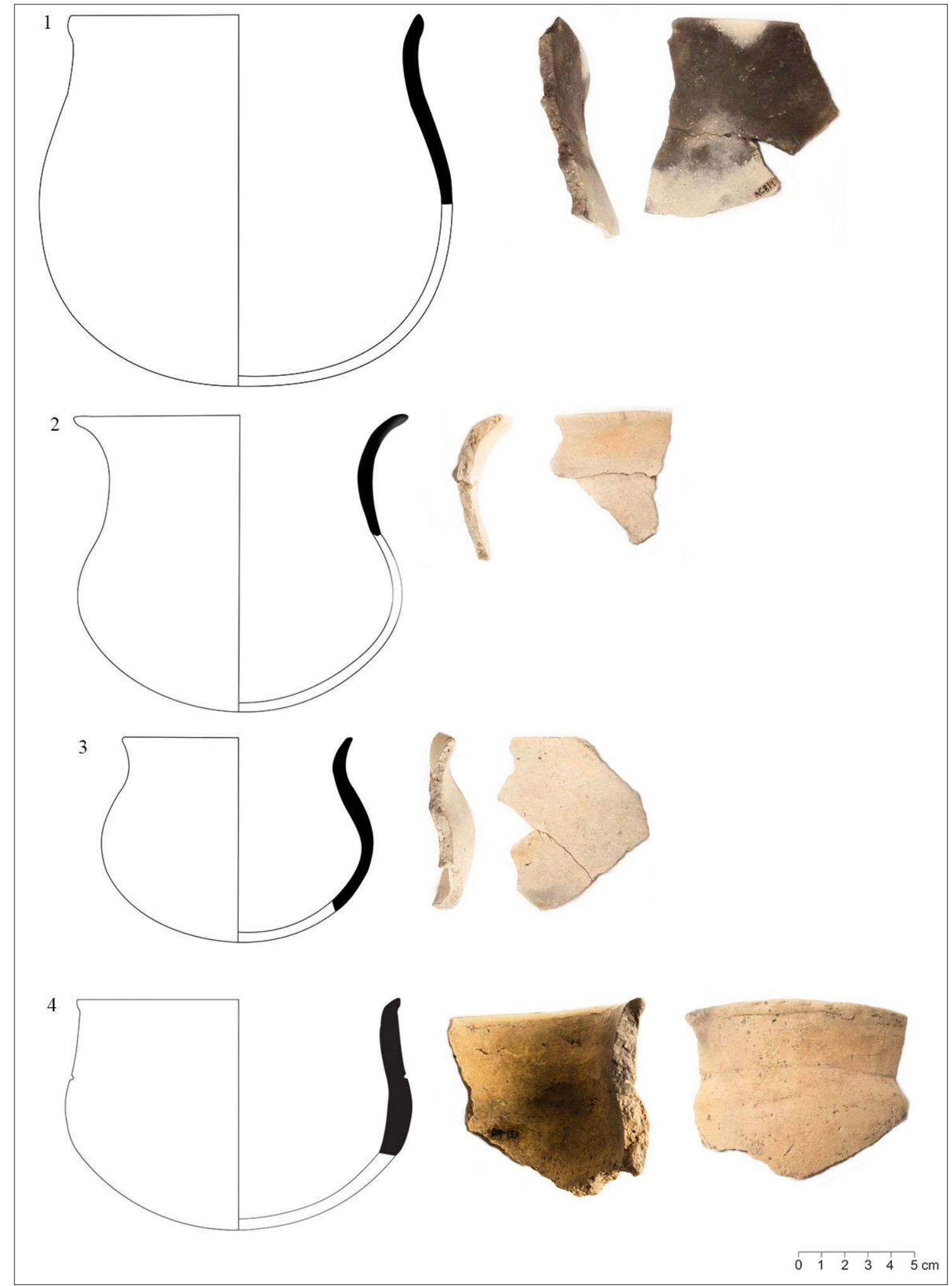

Figura 64: Formas do Conjunto 4. 1) AC-813; 2) AC-45; 3) AC-47; 4) DR- 153. (Desenhos: Amanda Moraes. Fotos: Ader Gotardo).

A espessura varia de 2 a $29 \mathrm{~mm}$, com maior concentração entre 6 e 9 mm. Foram encontradas pouquíssimas paredes infletidas e ombros. 
O acabamento de superfície da face externa dos fragmentos é majoritariamente alisado (96\%), com apenas 4\% de fragmentos com acabamentos pintados (engobo vermelho, banho) e raros acabamentos plásticos. A face interna é predominantemente alisada. O lábio de algumas bordas tem acabamento inciso, banho e engobo. Como no conjunto anterior, os raros fragmentos com um acabamento diferente merecem ser descritos individualmente.

No sítio Aldeia Tukumã, temos uma borda lisa (figura 65-a), que é interessante por apredentar marcas de erosão na face interna que podem ter sido causadas por alimentos fervendo ou fermentação. Existe um fragmento inciso (figura 65-b) e um com uma linha acanalada na face interna (figuras 65-c).

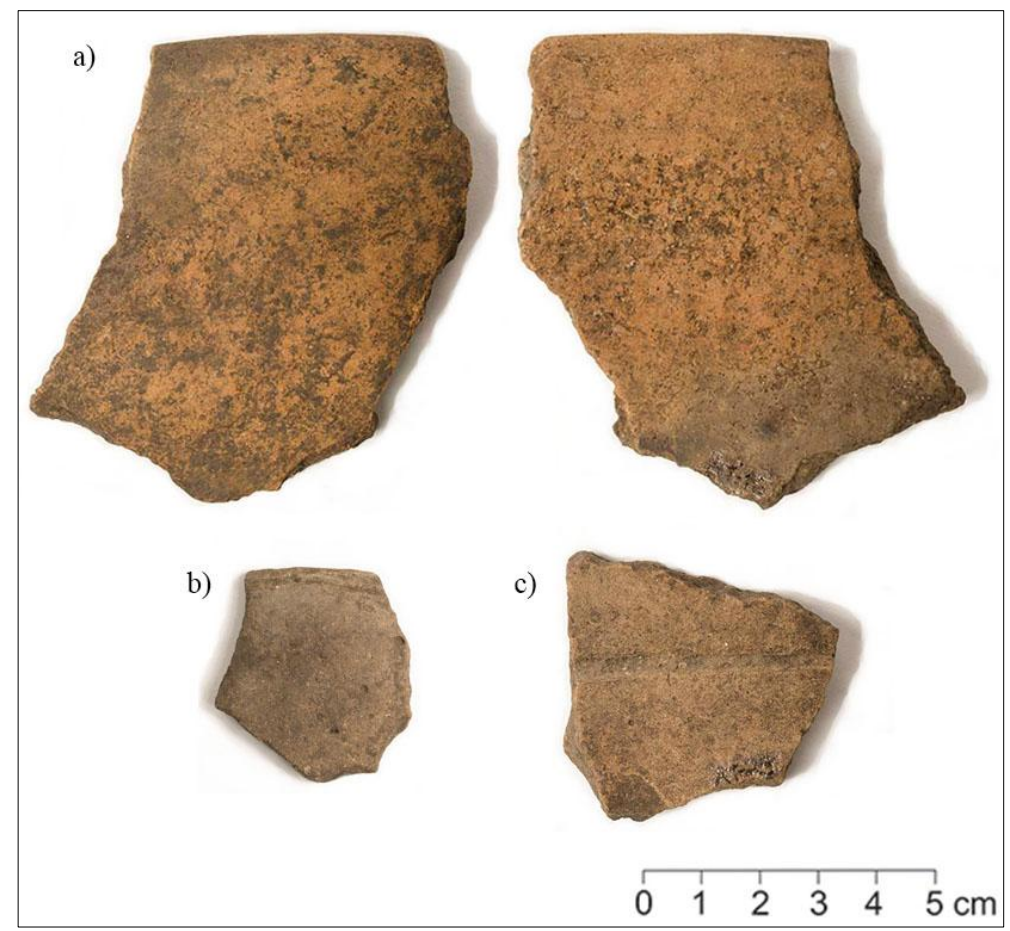

Figura 65: Acabamentos de superfície, sítio AT. a) alisamento, com marca de erosão na face interna; b) inciso; c) acanalado. (Fotos: Ader Gotardo).

No sítio Taitetu (figura 66), existem fragmentos que parecem ser bases de assadores, devido à espessura e morfologia (figura 66-b). Um fragmento de ombro tem uma marca bastante acentuada de fuligem (figura 66-c). Os engobos também são um acabamento que aparece bastante neste sítio (figura 66-e, 66-f e 66-g). Além disso, temos três outros com incisões nos lábios (figura 66-d), mas que não formam o efeito serrungulado como no sítio Dinossauro. 


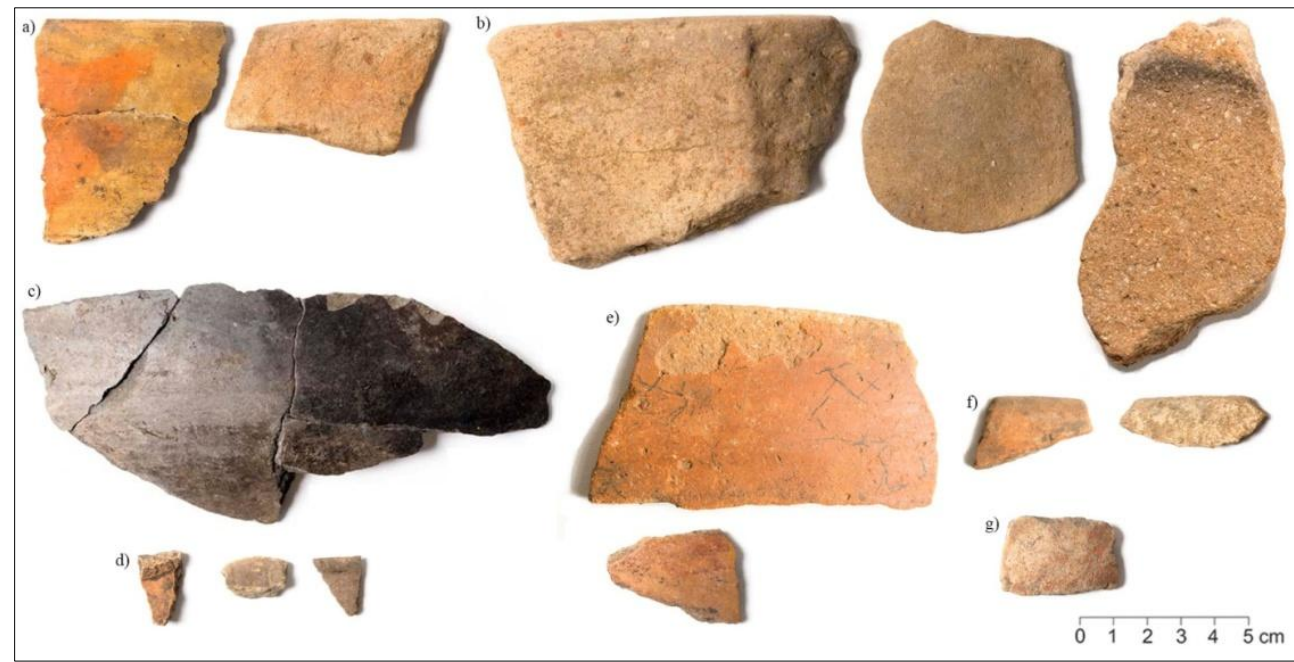

Figura 66: Acabamentos de superfície do Conjunto 4, sítio TT. a) alisamento; b) bases; c) ombro com fuligem; d) incisos; e) engobo vermelho e pintura vermelha; f) engobo branco; g) pintura vermelha sobre engobo branco. (Fotos: Ader Gotardo).

$\mathrm{Na}$ Aldeia Coelho, além das formas reconstituídas temos um fragmento perfurado, que pode ser de uma base (figura 67-b). As perfurações parecem ter sido feitas com a pasta mais dura, pois são um pouco irregulares e não vemos rebarbas nos limites dos furos. Temos também um fragmento com incisões de linhas paralelas na face externa (figura 67-c) e uma borda com engobo branco (figura 67-d).

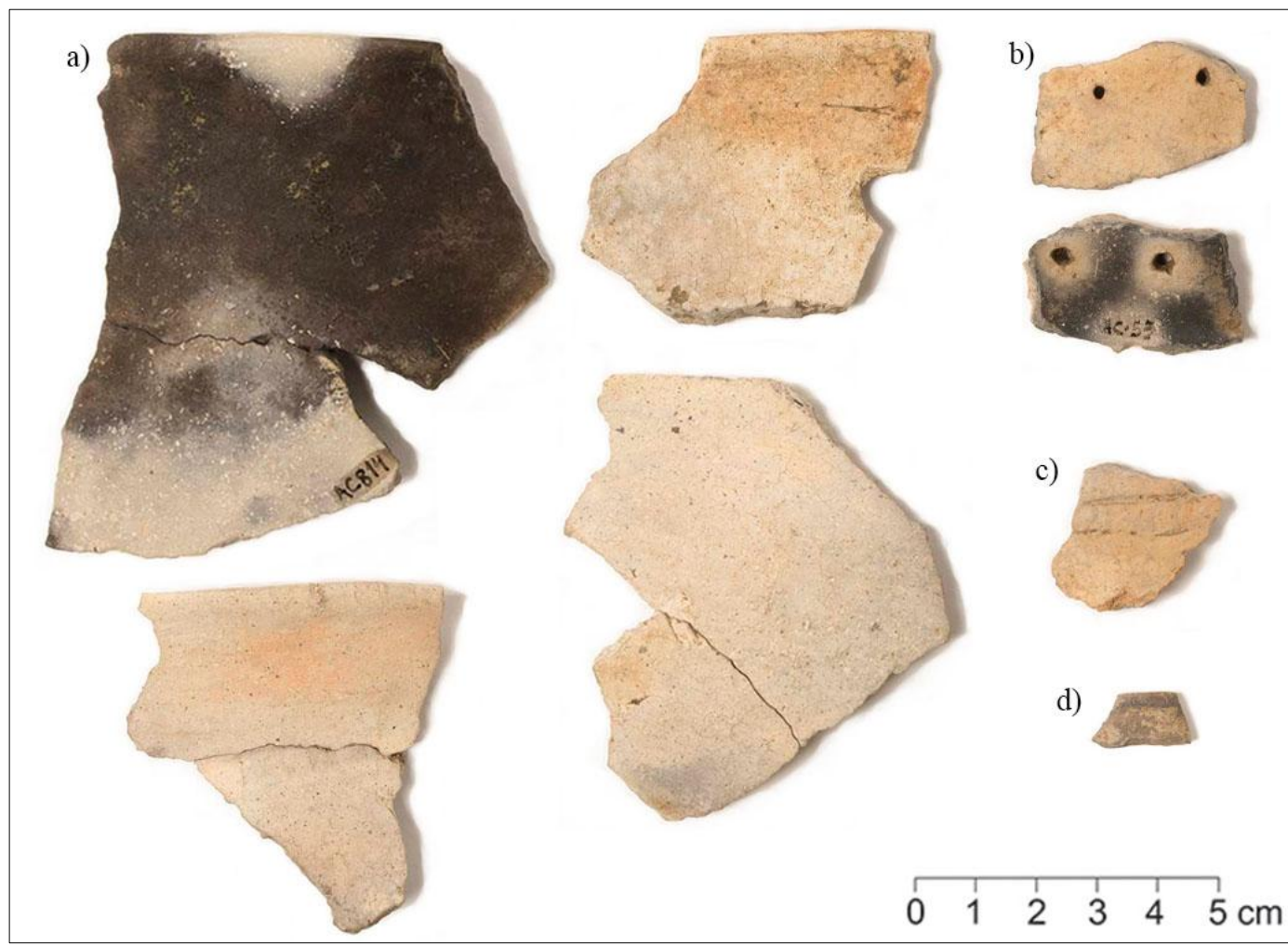

Figura 67: Acabamentos de superfície do Conjunto 4, sítio AC. a) alisamento; b) perfuração; c) inciso; d) engobo branco. (Fotos: Ader Gotardo). 


\subsection{Outros Conjuntos}

Existem diversos fragmentos de diferentes sítios que não se encaixaram exatamente em nenhum dos conjuntos propostos a cima, nem nos agrupamentos estatísticos. Somente com trabalhos de escavação e análise mais aprofundados é que podemos chegar a uma melhor caracterização dos conjuntos e classificar com mais segurança esses outros fragmentos.

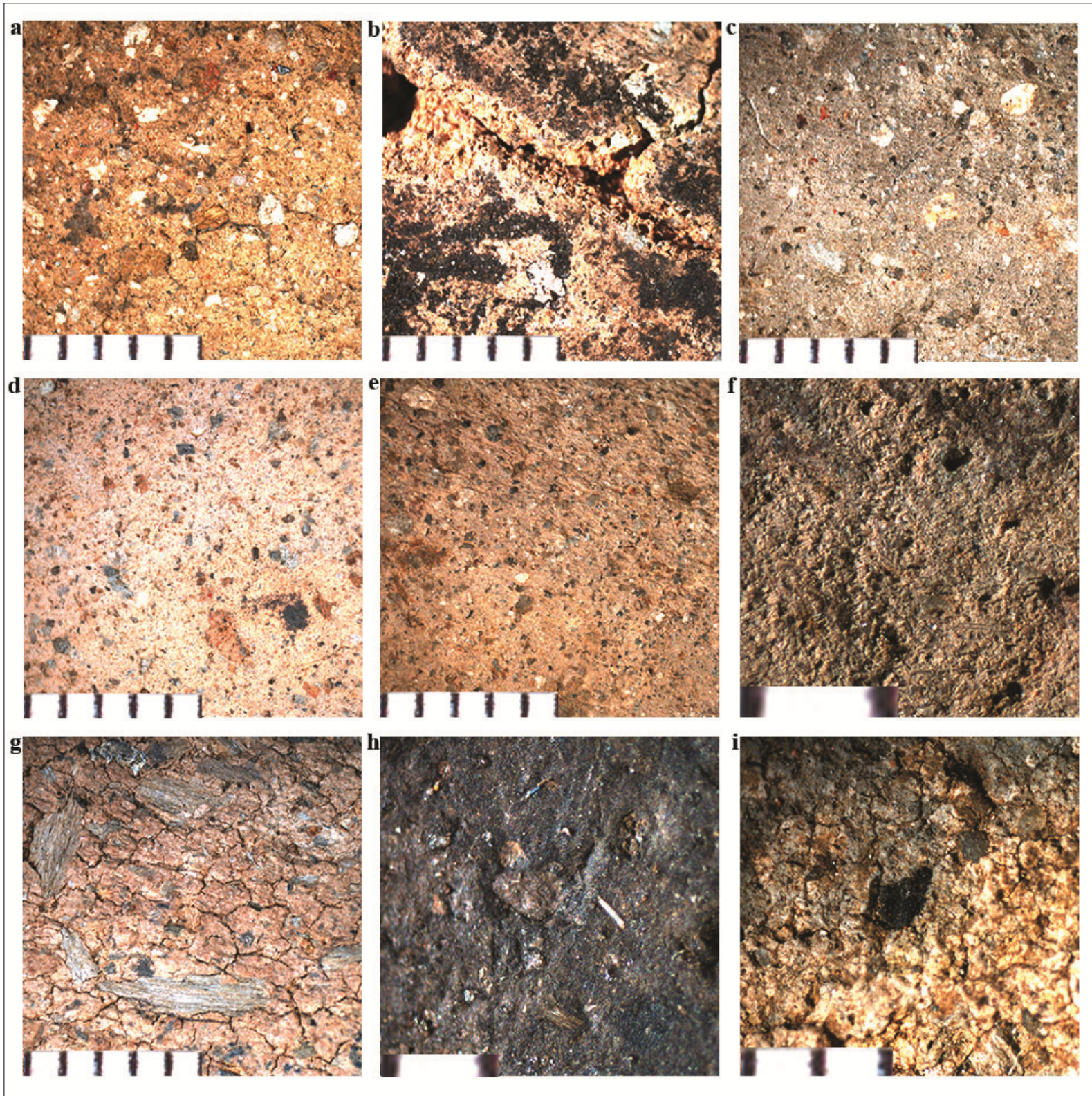

Figura 68: Pasta de fragmentos não classificados, aumento 10x na lupa binocular (exceto f,h: aumento $4 \mathrm{x}$; i: aumento 3.2x), escala em mm. a-b) diversos minerais, sítio TT; c) diversos minerais, sítio DR; d-e) caco moído, sítio DR; f) cauixi, sítio MI; g) caraipé, sítio DR; h) cauixi, caraipé e caco moído, sítio AT; i) carvão, sítio AT. 
Uma parte dos fragmentos de cada sítio possui uma combinação de antiplásticos diferente das descritas nos 4 Conjuntos, ou mesmo que sejam os mesmos materiais, as outras características dos fragmentos não nos permitiram classificá-los dessa maneira. A variabilidade dos antiplásticos é mostrada na figura 68.

Os perfis das bordas com ângulo de inclinação identificado são mostrados abaixo na figura 69.

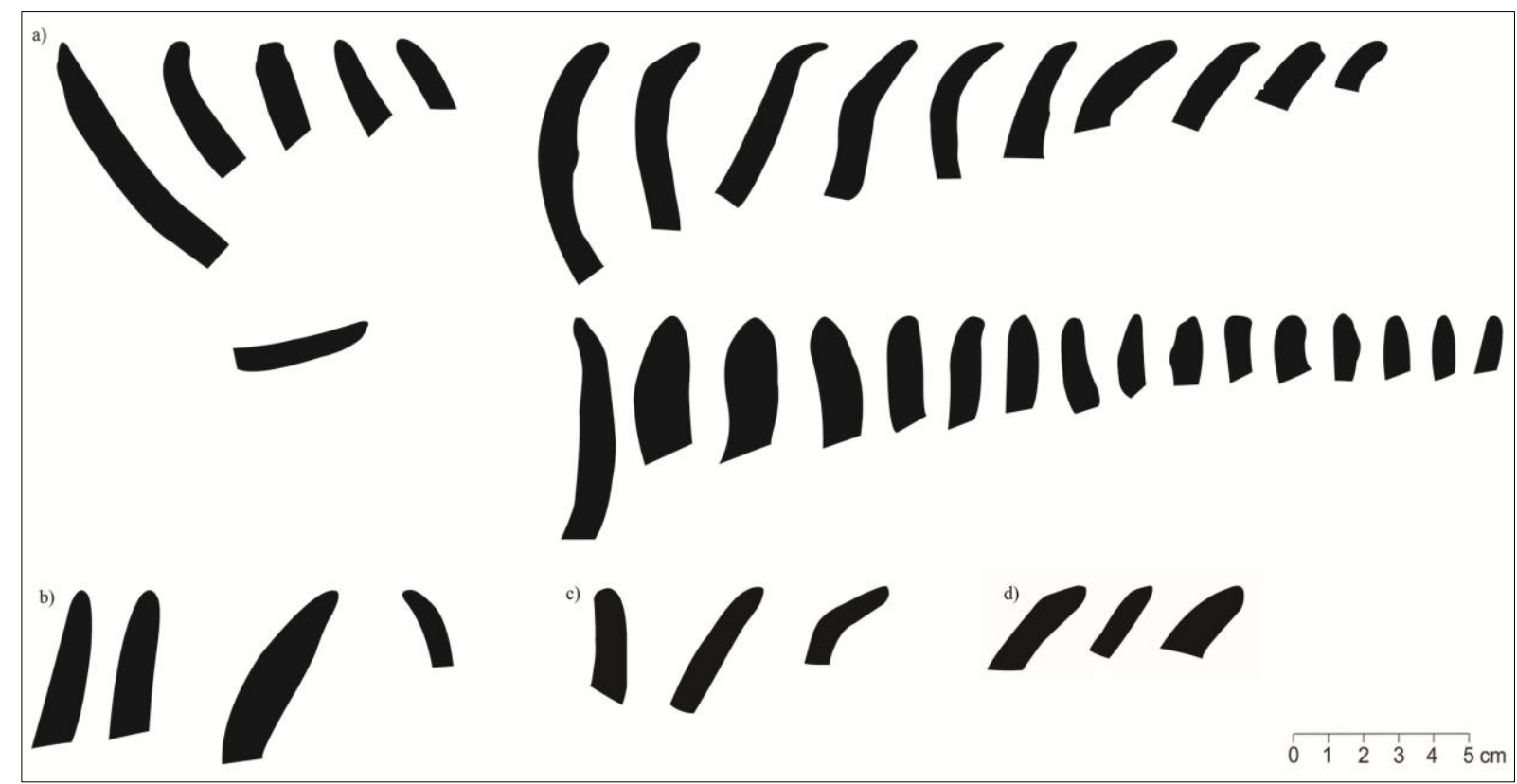

Figura 69: Perfis das bordas dos fragmentos não classificados. a) sítio DR; b) sítio AT; c) sítio MI; d) sítio TT. (Desenhos: Amanda Moraes).

Alguns fragmentos que possibilitaram a reconstituição de formas também não puderam ser classificados em nossos conjuntos (figura 70). A forma 1 (DR-154) foi feita com duas possibilidades, ambas descrevendo vasilhas esféricas, restringidas e fechadas, mas com bases diferentes. $\mathrm{O}$ diâmetro da boca é $24 \mathrm{~cm}$, a espessura $0,7 \mathrm{~cm}$, calculando-se a altura entre 25 e 29 cm, o diâmetro máximo entre 30 e 32 cm e o volume entre 19,02 e 20,83 1. A forma 2 (DR-14) é semi-esférica, aberta, não restringida, com $12 \mathrm{~cm}$ de diâmetro da boca, $0,7 \mathrm{~cm}$ de espessura, estimação de $5 \mathrm{~cm}$ de altura, e 0,27 1 de volume, considerada uma miniatura. A 3 (AT-705) é uma forma esférica, não restringida, fechada, com diâmetro da boca $6 \mathrm{~cm}$, espessura $0,5 \mathrm{~cm}$, estimando-se altura $5 \mathrm{~cm}$, volume 0,231 , outra miniatura. 


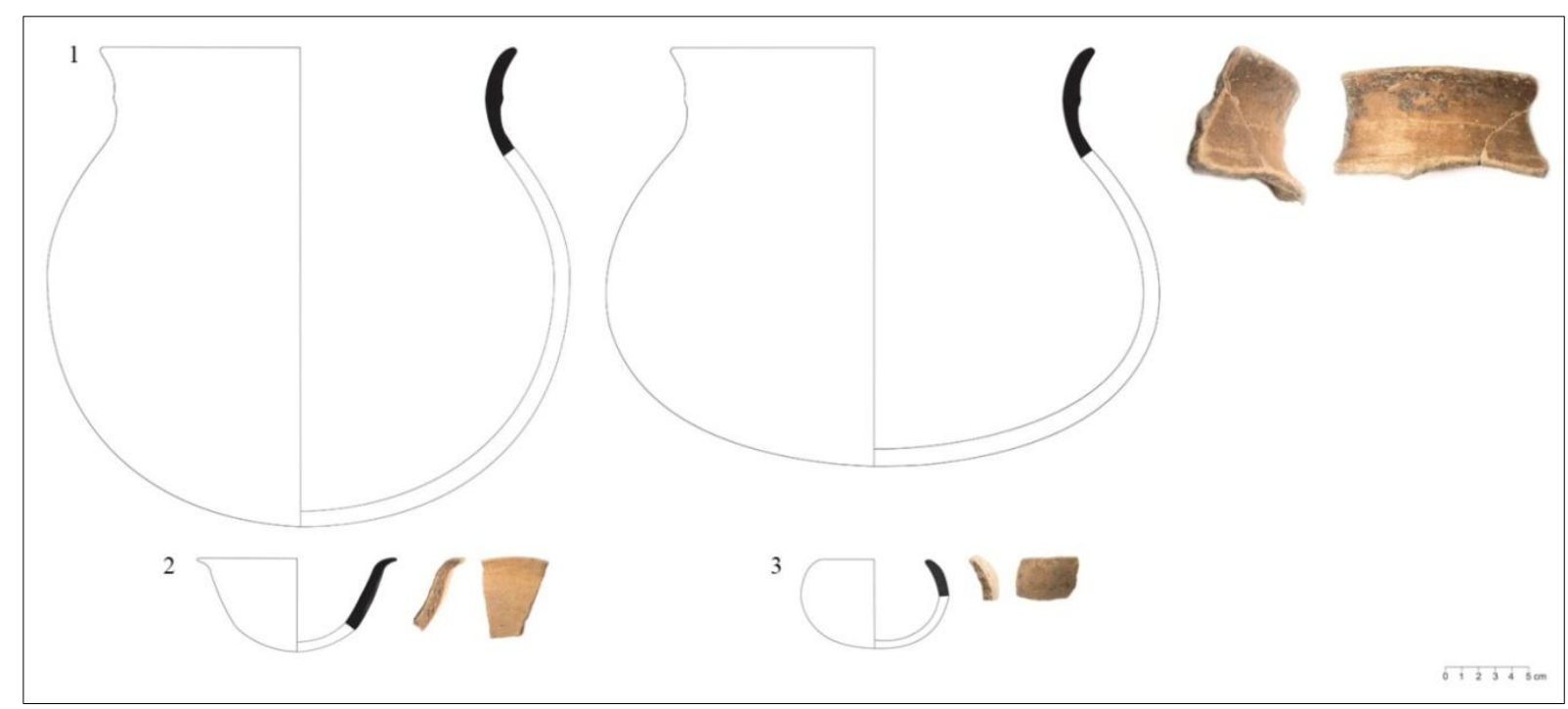

Figura 70: Formas de fragmentos não classificados. 1) DR-154; 2) DR-14; 3) AT-705. (Desenhos: Amanda Moraes. Fotos: Ader Gotardo).

Vários desses fragmentos poderiam ser encaixados em um dos conjuntos devido às características do acabamento de superfície (figura 71), no entanto como as outras características são diferentes não os classificamos dessa maneira. O ombro com engobo rosa do item b poderia ser do Conjunto 2, enquanto que os demais poderiam ser de qualquer um dos conjuntos. Os fragmentos com acanalados do item d nos deixam dúvidas se fazem parte dos Conjuntos 3 ou 4, ou do Conjunto 1, ou ainda de algum subconjunto do sítio Taitetu.

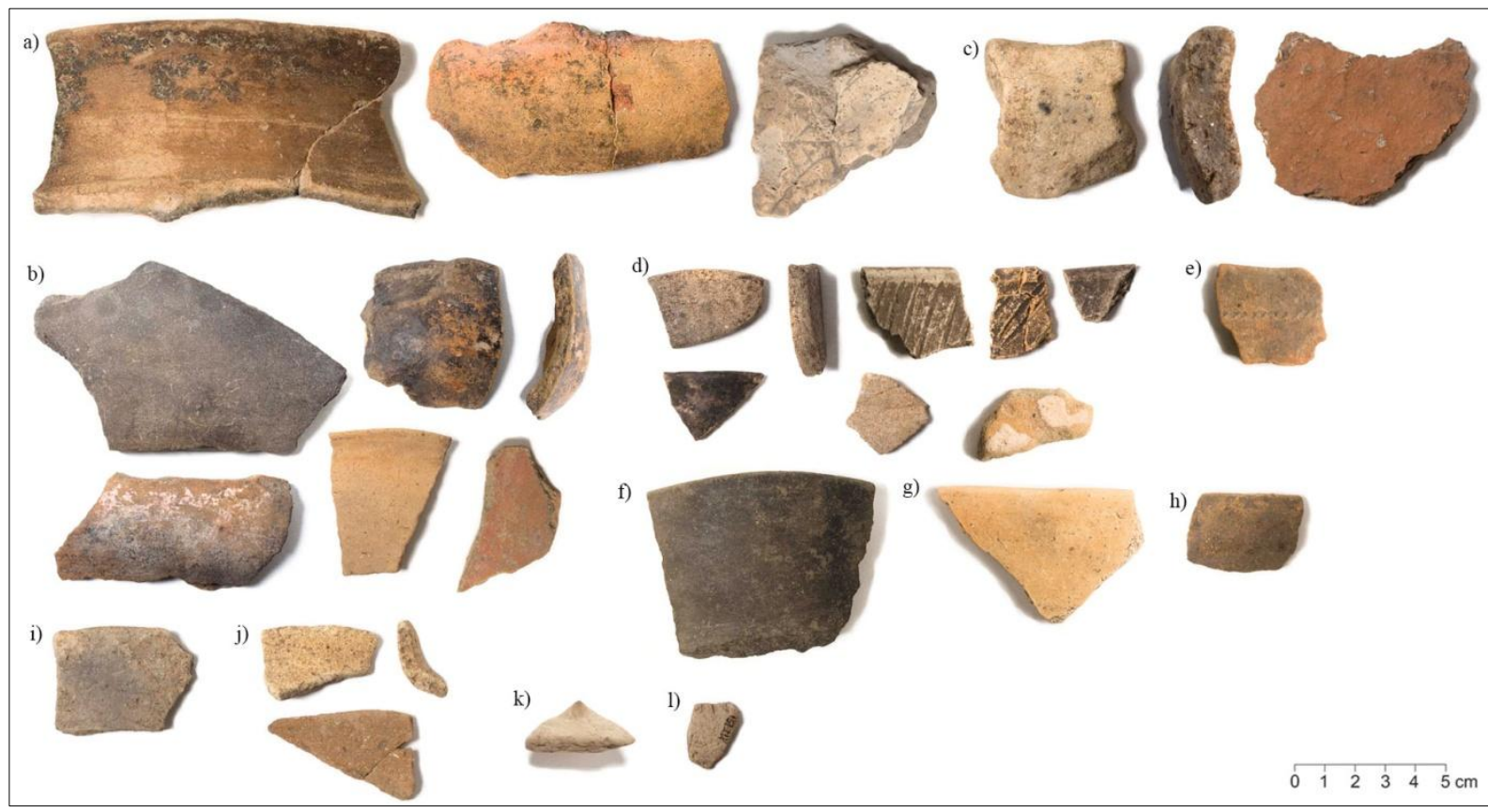

Figura 71: Acabamentos de superfície dos fragmentos não classificados. a) sítio DR, antiplástico cauixi, caraipé e caco moído, borda e ombro com banho e base com impressão de folha; b) sítio DR, antiplástico mineral, fragmentos com fuligem, ombro com engobo rosa e fuligem, borda alisada e fragmento com engobo vermelho; 
c) sítio TT, antiplástico cauixi, borda alisada e fragmento com engobo vermelho; d) sítio TT, antiplástico mineral, fragmentos com polidor de núcleo e fuligem, bordas acanaladas, inciso e engobo branco; e) sítio TT, antiplástico caco moído, borda com impressão de corda; f) sítio AT, antiplástico caco moído, borda com fuligem; g) sítio AT, antiplástico cauixi, caraipé e caco moído, borda alisada; h) sítio AT, antiplástico mineral, borda alisada; i) sítio MI, antiplástico mineral, borda alisada; j) sítio MI, antiplástico caraipé, bordas alisadas; k) sítio MI, antiplástico cauixi, apêndice mamilonar; sítio MI, antiplástico cauixi, caraipé e caco moído, inciso. (Fotos: Ader Gotardo).

O sítio Dinossauro é o que apresenta mais fragmentos diferentes, muitas vezes mais semelhantes ao Conjunto 3 do que ao 4 . Isso nos faz pensar que estes conjuntos talvez sejam relacionados entre si, mas constituem vasilhas com funcionalidades diferentes. Ou então, que no caso do Dinossauro e Minhocoçu eles formem um conjunto só, e que os fragmentos do Taitetu, Aldeia Tukumã e Aldeia Coelho formem outro conjunto.

O sítio Taitetu parece ser o mais problemático em relação a nossa classificação, pois apesar de a maior parte dos fragmentos se encaixar no Conjunto 4, nas análises estatísticas ele sempre esteve mais próximo dos sítios Dinossauro e Minhocoçu, ou seja, do Conjunto 3. Essa confusão pode também estar relacionada ao fato de que esses conjuntos estão muito próximos entre si. Além disso, vários fragmentos deste sítio não parecem se encaixar em nenhum conjunto.

Além deles, temos uma amostra de alguns fragmentos coletados aleatoriamente em alguns locais que não foram escavados (figura 72). Como são poucos, não os incluímos nas análises, mas gostaríamos de destacar alguns deles por terem acabamentos e morfologias bastante interessantes para pensarmos os conjuntos propostos a cima. Os fragmentos do item c, m, n e o tem características muito semelhantes ao Conjunto 1, enquanto que os demais poderiam fazer parte tanto do Conjunto 3 como do 4. 


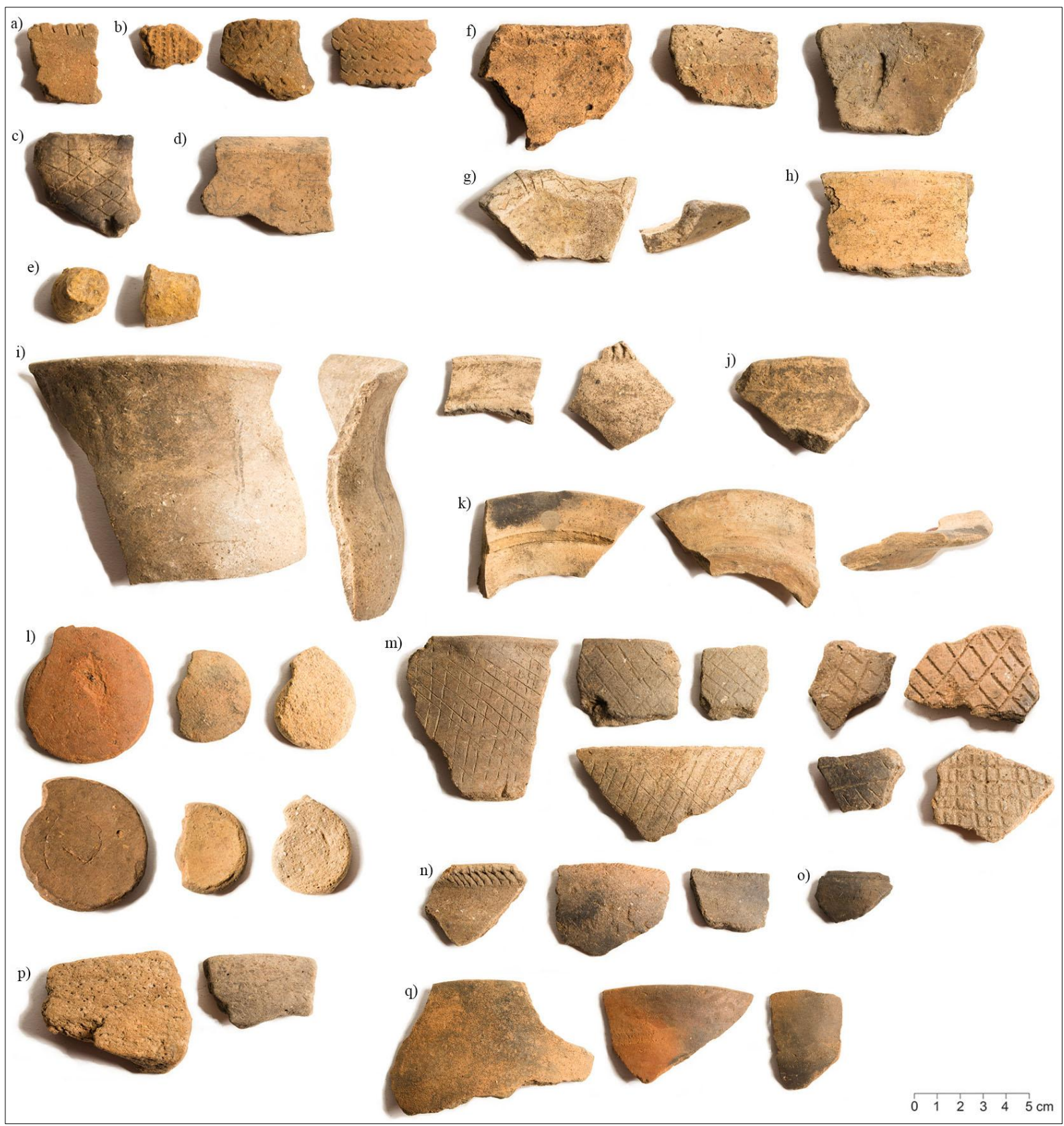

Figura 72: Acabamentos de superfície de fragmentos coletados aleatoriamente em diferentes locais. a) Aldeia Kururuzinho, antiplástico cauixi e caco moído, inciso; b) Aldeia Kururuzinho, antiplástico mineral, ponteado e incisos ondulados; c) Roça João, antiplástico cauixi e caraipé, incisos losangulares; d) Tapera e pista, antiplástico cauixi, caraipé e caco moído, alisado; e) Capoeira e taipa, antiplástico mineral, alisamento; f) Saúva, antiplástico cauixi e caraipé, alisamento; g) Sauva, antiplástico cauixi, caraipé e caco moído, borda com incisos no lábio; h) Sauva, antiplástico cauixi e caco moído, alisamento; i) Roça Albertino, antiplástico mineral, alisamento, impressão de corda e corrugado; j) Roça Albertino, antiplástico cauixi e caraipé, alisamento; k) Roça Albertino, antiplástico caco moído, alisamento; 1) Roça Fernando e João, bases alisadas, a primeira antiplástico cauixi e caraipé, as outras duas antiplástico mineral; m) Roça Fernando e João, antiplástico mineral, incisos cruzados e losangulares; n) Roça Fernando e João, antiplástico mineral, ungulado na borda; o) Roça Fernando e João, antiplástico mineral, impressão de corda; p) Roça Fernando e João, antiplástico cauixi, caraipé e caco moído, alisamento; q) Roça Fernando e João, antiplástico mineral, alisamento. (Fotos: Ader Gotardo). 


\subsection{Considerações sobre os Estilos Tecnológicos}

Acreditamos que os 4 conjuntos descritos aqui configuram estilos tecnológicos diferentes. No entanto, é preciso aprofundar sua análise e caracterização para melhor compreender em que medida eles realmente se separam associando-se a: 1) grupos culturais produzindo cerâmicas de modo diferente; 2) diferentes segmentos de um grupo cultural produzindo cerâmica de modos diferentes; 3) divisões temporais; 4) funcionalidade das vasilhas; 5) outras possibilidades.

A primeira escolha feita pelas ceramistas na produção cerâmica que pudemos observar em nossos conjuntos, é a escolha da fonte de argila, a base da composição da pasta. O critério mais importante para essa escolha é a plasticidade da argila, que engloba questões pragmáticas que devem ser resolvidas durante a preparação da pasta e o processo de manufatura. É preciso saber: 1) se a argila é fácil de manipular, mas também se é firme o suficiente para manter a forma durante a manufatura; 2) como a argila reage à perda de água durante a secagem e queima; 3) que aparência ela dá ao produto final; entre outras preocupações (SINOPOLI, 1991: 11).

Existem diversos trabalhos etnoarqueológicos que mostram como diferentes populações ceramistas escolhem suas fontes de argila. Arnold (1985; 2000) esboçou um modelo sobre a procura de matéria-prima que considera a logística do transporte, propondo que as ceramistas não viajariam mais do que $7 \mathrm{~km}$ para encontrar essas fontes, sendo que normalmente utilizam fontes em um raio de 3 a 4 km. Ainda segundo Arnold (2000), a variabilidade da pasta cerâmica depende muito mais de fatores ambientais (variabilidade geológica), tecnológicos (processos de procura, seleção e tratamento da matéria prima) e sociais (acesso às fontes de argila) do que da organização da produção (especialização). Podem ser utilizadas fontes similares de argila, ou então podem ser exploradas diferentes fontes com diferentes propriedades, combinadas entre si ou trabalhadas de diferentes maneiras, como entre os Luo, no Quênia (DIETLER e HERBICH, 1989). Uma análise da composição da argila de diferentes cerâmicas pode revelar padrões de distribuição de vasilhas e mudanças na utilização de fontes, como mostrado em uma comparação de vasilhas etnográficas e arqueológicas entre os Banda, em Gana (STAHL et al. 2008).

A partir da coloração, já arriscamos uma sugestão de que pelo menos 3 argilas diferentes foram utilizadas: uma argila mais acinzentada no Conjunto 1; no Conjunto 2 um ou dois tipos de argila, já que a coloração cinza pode estar relacionada à queima do material 
orgânico e não às fontes diferentes; e uma argila entre o cinza e marrom, utilizada nos Conjuntos 3 e 4.

Não foi realizado nenhum trabalho de reconhecimento das fontes de argila na T. I. Kaiabi, mas analisamos arqueometricamente alguns fragmentos cerâmicos (por fluorescência de raio X, ver item 3.2 do capítulo 3) para observar a composição da pasta. Esses fragmentos foram selecionados após a definição dos conjuntos, procurando um fragmento representativo de cada conjunto e alguns que geraram dúvidas quanto à sua classificação. Os gráficos para exemplificar estas análises podem ser vistos no Anexo E.

Nas medidas dos fragmentos, foram identificados, ao todo, os seguintes elementos: Al, Si, P, S, K, Ca, Ti, Mn, Fe, Zn, Rb, Sr, Y, Zr, Cl, Ni, Cu e Cr. Nem todos os elementos estavam presentes em todos os fragmentos, sendo o resultado utilizado para cada fragmento composto pela média das 2 medidas feitas nele (RIZZUTT, CURADO e MOTA, 2014). Para testar algumas possibilidades de agrupamentos, foram feitos gráficos de elementos versus elementos, sendo observadas algumas separações relacionadas a alguns deles. Esses resultados foram analisados estatisticamente a partir da técnica de PCA (Principal Components and Classification Analysis), utilizada para reduzir as variáveis e classificar os casos estudados (RIZZUTT, CURADO e MOTA, 2014). Foram utilizados os elementos Al, K, Si, Ti e Fe para a projeção do caos no plano, como mostra o gráfico 12 abaixo:

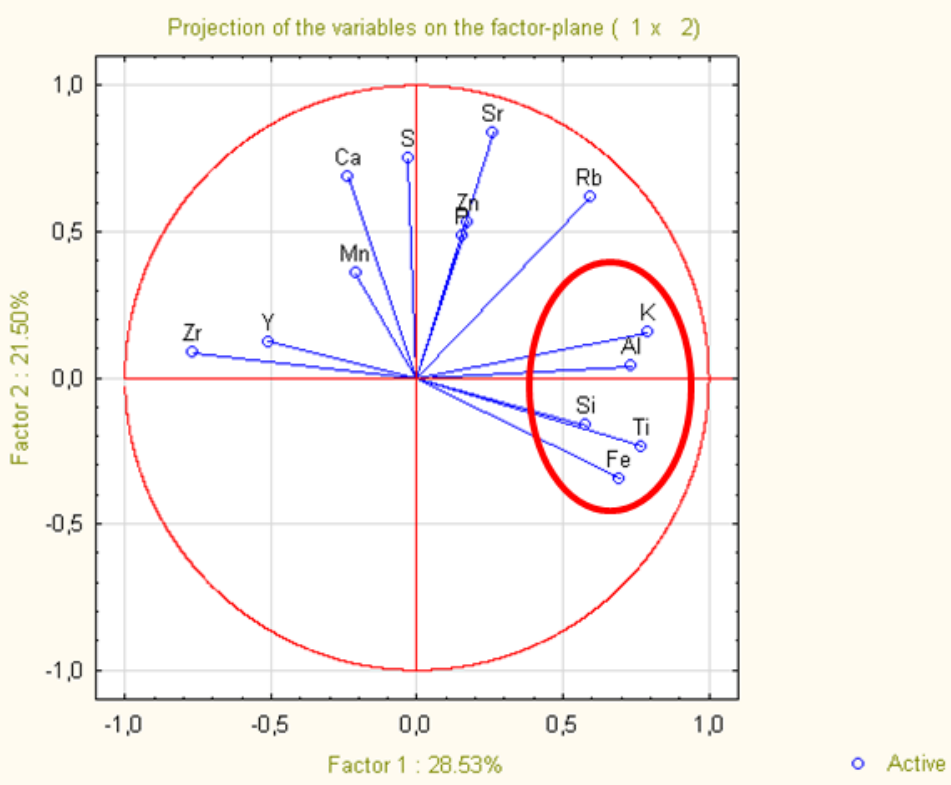

Gráfico 12: Círculo de correlção PCA entre as variáveis identificadas. Em destaque está o grupo de elementos utilizado para a análise PCA. (Cf: RIZZUTT, CURADO e MOTA, 2014). 
Utilizando os elementos $\mathrm{Al}, \mathrm{K}, \mathrm{Ti}, \mathrm{Fe}, \mathrm{Sr}$ e $\mathrm{Y}$ como parâmetro, os fragmentos puderam ser agrupados em 4 conjuntos, como mostra o gráfico 13 abaixo:

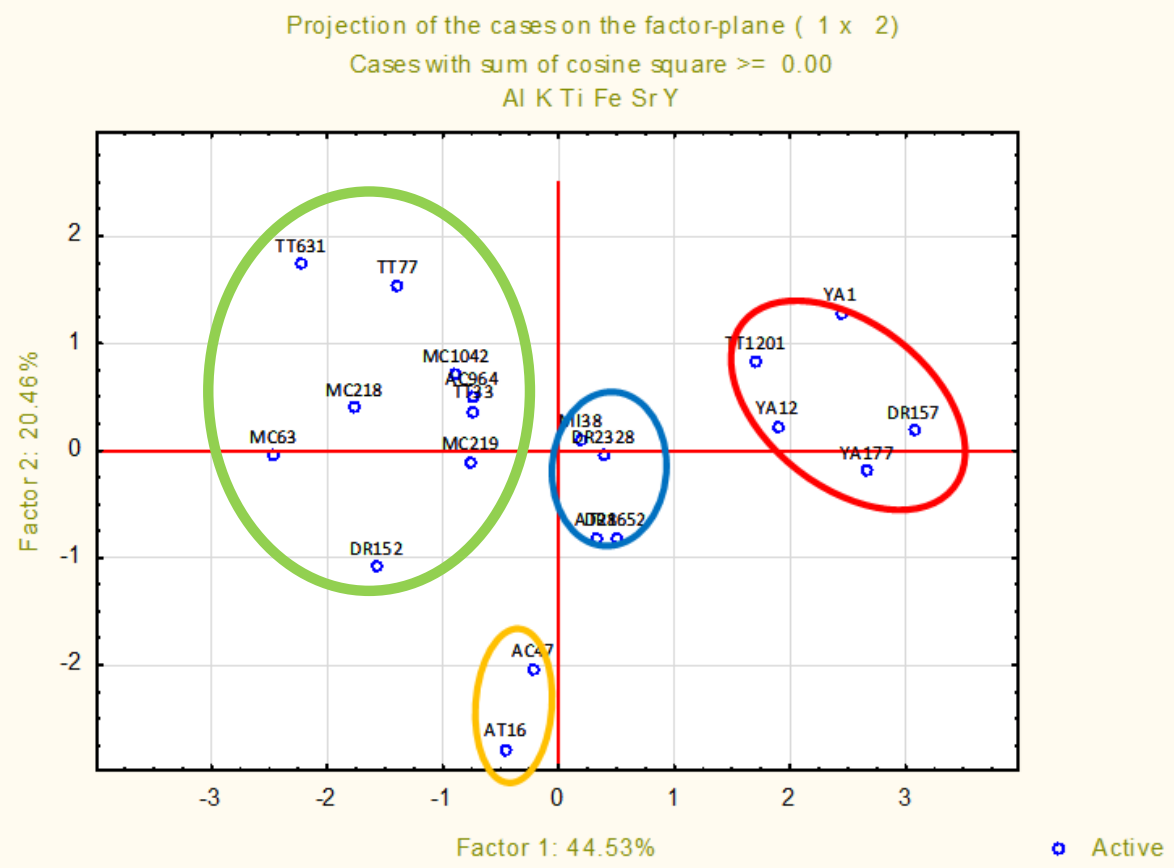

Gráfico 13: Gráfico de análise PCA para dados na análise XRF com sugestões de possível agrupamento. Os agrupados no círculo vermelho, no círculo azul, no circulo amarelo e no círculo verde (Cf.: RIZZUTT, CURADO e MOTA, 2014).

O agrupamento dos fragmentos feito dessa maneira (tabela 16) foi interessante para pensar algumas questões sobre a utilização de fontes de argila.

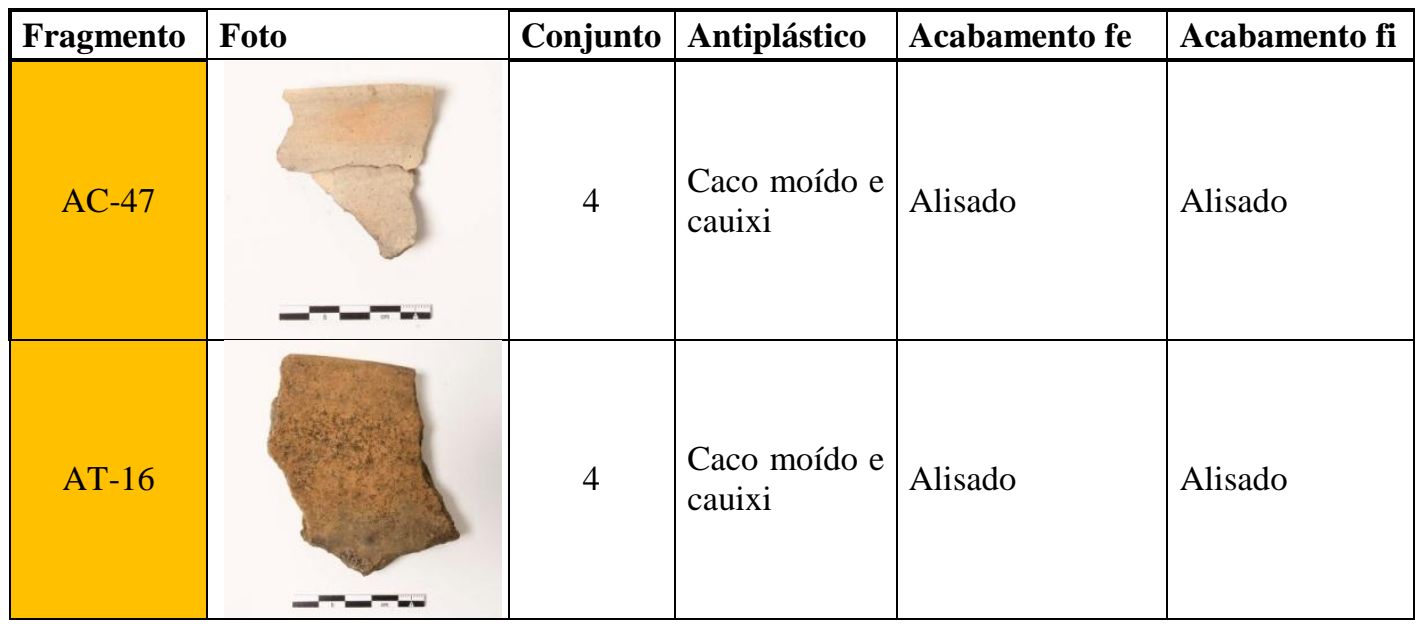




\begin{tabular}{|c|c|c|c|c|c|}
\hline Fragmento & Foto & Conjunto & Antiplástico & Acabamento fe & Acabamento fi \\
\hline DR-157 & & 1 & Mineral & $\begin{array}{l}\text { Impressão de } \\
\text { corda e inciso }\end{array}$ & Alisado \\
\hline YA-1 & & 1 & Caco moído & $\begin{array}{l}\text { Impressão de } \\
\text { corda e inciso }\end{array}$ & Alisado \\
\hline YA-12 & & 1 & Cauixi & $\begin{array}{l}\text { Impressão de } \\
\text { corda e inciso }\end{array}$ & Alisado \\
\hline YA-177 & & 1 & Mineral & $\begin{array}{l}\text { Impressão de } \\
\text { corda }\end{array}$ & Alisado \\
\hline TT-1201 & & - & Mineral & Acanalado & Alisado \\
\hline
\end{tabular}

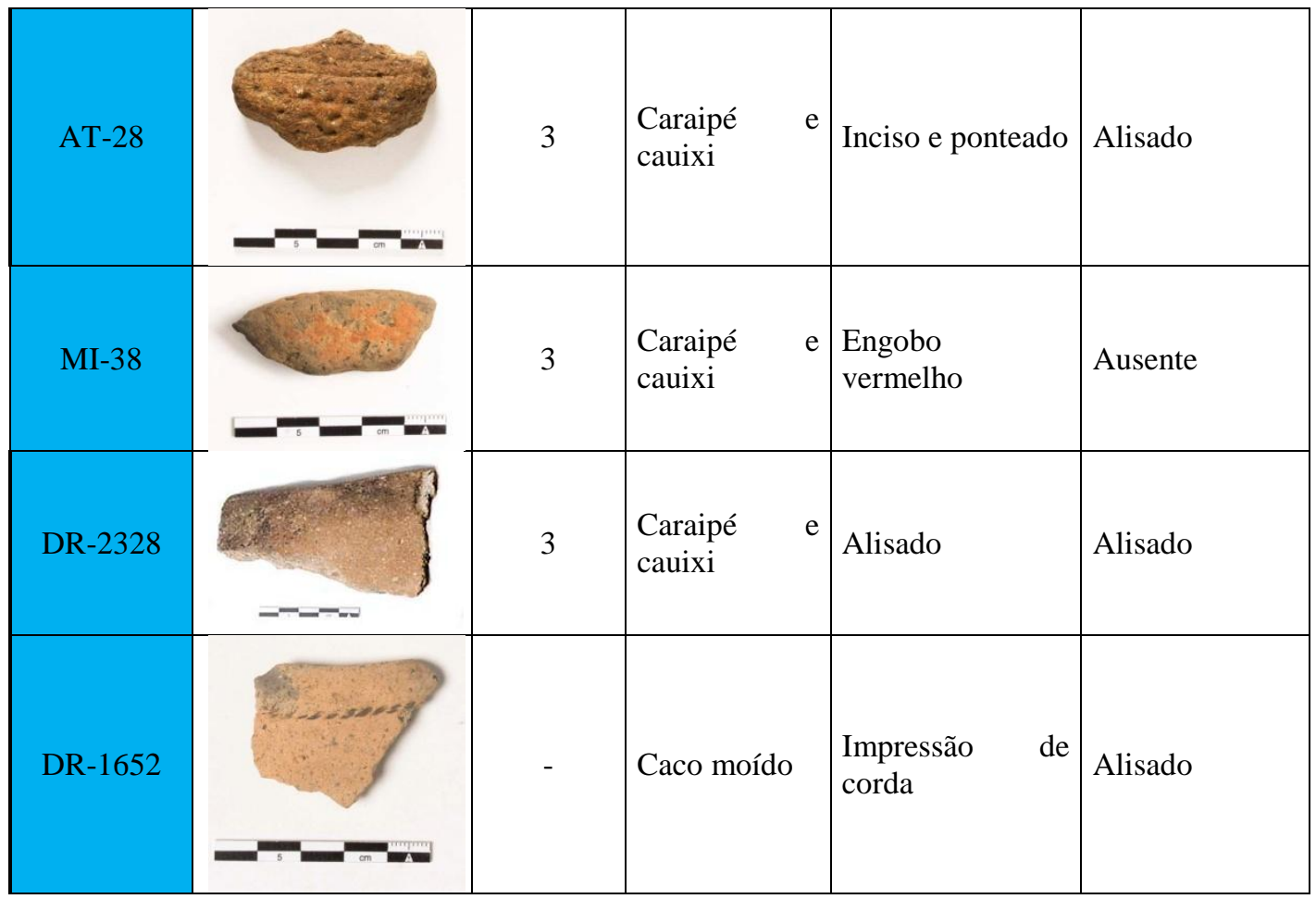




\begin{tabular}{|c|c|c|c|c|c|}
\hline Fragmento & Foto & Conjunto & Antiplástico & Acabamento fe & Acabamento fi \\
\hline AC-964 & & 3 & $\begin{array}{l}\text { Caraipé e } \\
\text { cauixi }\end{array}$ & Alisado & Alisado \\
\hline DR-152 & & 4 & $\begin{array}{l}\text { Caco moído e } \\
\text { cauixi }\end{array}$ & Inciso & Alisado \\
\hline TT-33 & & - & Caco moído & $\begin{array}{l}\text { Impressão de } \\
\text { corda }\end{array}$ & Alisado \\
\hline TT-77 & & - & Mineral & Engobo branco & Alisado \\
\hline TT-631 & & 4 & $\begin{array}{l}\text { Caco moído e } \\
\text { cauixi }\end{array}$ & $\begin{array}{l}\text { Engobo } \\
\text { vermelho }\end{array}$ & $\begin{array}{l}\text { Engobo } \\
\text { vermelho }\end{array}$ \\
\hline MC-63 & & 2 & Mineral & $\begin{array}{l}\text { Pintura branca, } \\
\text { faixa vermelha } \\
\text { sobre banho }\end{array}$ & Alisado \\
\hline MC-218 & & 2 & Caraipé & Alisado & Alisado \\
\hline MC-219 & & 2 & Caco moído & $\begin{array}{l}\text { Pintura branca } \\
\text { sobre banho }\end{array}$ & Alisado \\
\hline MC-1042 & & 2 & Caco moído & $\begin{array}{l}\text { Engobo rosa } \\
\text { sobre inciso }\end{array}$ & Alisado \\
\hline
\end{tabular}

Tabela 16: Tabela com os agrupamentos arqueométricos, com os fragmentos analisados, sua classificação nos conjuntos, antiplástico, e acabamento de superfície das face externa e interna. 
No agrupamento circulado em laranja (argila tipo 1), ficaram dois fragmentos alisados do Conjunto 4, um do sítio Aldeia Coelho e outro do Aldeia Tukumã.

No agrupamento circulado em vermelho (argila tipo 2), ficaram juntos os fragmentos do sítio Ywantã, Conjunto 1, mesmo os que tinham antiplásticos diferentes do mineral, típico deste conjunto. Esse resultado nos fez incluir os fragmentos YA-1 e YA-12 neste conjunto, já que além disso o acabamento de superfície deles é coerente com os acabamento típicos do Conjunto1. Um fragmento do sítio Dinossauro, classificado neste mesmo conjunto, também ficou agrupado com os fragmentos do Ywantã. Além deles, foi agrupado um fragmento do sítio Taitetu, de antiplástico mineral e acabamento acanalado, que não havia sido classificado em nenhum dos nossos conjuntos mas que poderia pertencer a um conjunto 5, que não conseguimos separar claramente.

No agrupamento circulado em azul (argila tipo 3), estão três fragmentos do Conjunto 3, dos sítios Aldeia Tukumã, Minhocoçu e Dinossauro. O fragmento do DR-1652 nos deixou em dúvida quanto a sua classificação, pois apesar de ter como acabamento uma linha de impressão de corda, condizente com o Conjunto 1, seu antiplástico é o caco moído e a pasta é bastante diferente. O agrupamento desse fragmento com os do Conjunto 3 nos fizeram descartar essa possibilidade, sem no entanto nos permitir encaixa-lo em outro conjunto.

Os outros fragmentos no círculo verde formam o último agrupamento (argila tipo 4), com fragmentos de diversos sítios e conjuntos diferentes. $\mathrm{O}$ interessante dele é que todos os fragmentos do Mukuin Caniné ficaram juntos, representando o Conjunto 2. Infelizmente, não foi possível testar a hipótese das diferentes colorações de argila relacionadas ora com caco moído ora com caraipé, mas esse resultado já nos dá uma pista de que talvez não seja esse o caso. Além deles, está um fragmento do Aldeia Coelho, do Conjunto 3; dois fragmentos do Conjunto 4, um do Dinossauro e outro do Taitetu; e dois fragmentos não classificados, do sítio Taitetu. O caso do fragmento TT-33 é o mesmo do DR-1652, mas como eles não foram agrupados juntos continuamos com dúvidas sobre sua classficação.

Assim, temos uma segunda sugestão de que foram exploradas pelo menos 4 fontes de argila. Certamente a fonte explorada para a cerâmica do Conjunto 1 é bem diferente da do Conjunto 2. Para o Conjunto 3, parecem ter sido exploradas ao menos 2 fontes diferentes, o mesmo ocorrendo para o Conjunto 4, sendo que ambos compartilham uma das fontes com o Conjunto 2. Os agrupamentos da análise arqueométrica também foram interessantes para nos fazer pensar mais sobre alguns dos fragmentos que não conseguimos classificar. 
Selecionada a argila, as próximas escolhas das ceramistas estão relacionadas com o preparo da pasta para a produção das vasilhas, como sua limpeza, armazenamento antes do uso, adição de água e materiais antiplásticos. A segunda escolha que visualizamos foi a dos antiplásticos, que são bastante significativos para a separação dos conjuntos, nos mostrando como eles parecem ser realmente elementos diferenciadores de modos de se fazer vasilhas cerâmicas. As informações sobre as performances de diferentes antiplásticos são muitas, nos possibilitando organizar os dados na tabela 17:

\begin{tabular}{|c|l|c|c|c|c|}
\hline Cadeia operatória & $\begin{array}{l}\text { Matriz de Correlatos de } \\
\text { Performance }\end{array}$ & Mineral & $\begin{array}{c}\text { Caco } \\
\text { moído }\end{array}$ & Caraipé & Cauixi \\
\hline \multirow{2}{*}{$\begin{array}{c}\text { Técnicas de } \\
\text { construção }\end{array}$} & Rapidez na secagem & $/$ & $/$ & + & $/$ \\
\cline { 2 - 6 } Queima & Formas angulares & - & - & + & + \\
\hline \multirow{2}{*}{ Uso } & $\begin{array}{l}\text { Resistência ao choque } \\
\text { térmico }\end{array}$ & + & + & $/$ & + \\
\cline { 2 - 7 } & Aumento de porosidade & - & - & + & + \\
\hline & Condução térmica & + & + & $/$ & - \\
\cline { 2 - 7 } & Resistência ao impacto & - & - & + & + \\
\hline
\end{tabular}

Tabela 17: Cadeia operatória e correlatos de performance dos 4 conjuntos. Legenda: + é uma boa performance, / é performance intermediária, - é performance ruim. (Fontes: SCHIFFER e SKIBO, 1987; MACHADO, 20052006; RYE, 1981).

O Conjunto 1 tem antiplástico mineral, que auxilia na secagem da argila, mas não tanto quanto os antiplásticos orgânicos. Ele diminui a força da "argila verde" (da argila não queimada, greenware strenght, in: SCHIFFER e SKIBO, 1987:35) durante a manufatura, dificultando a construção de formas mais angulares por não sustentar bem o corpo da vasilha. O mineral é também um ótimo condutor térmico, aquecendo as vasilhas muito facilmente e aumentando sua resistência a choques térmicos, como os que ocorrem durante a queima. Em relação ao quartzo, no entanto, sua taxa de expansão é maior que a da cerâmica, podendo causar rachaduras durante os aquecimentos da vasilha para cozinhar. A grande desvantagem do mineral é que ele diminui a resistência ao impacto, além de deixar a vasilha mais pesada (SCHIFFER e SKIBO, 1987; MACHADO, 2005-2006; CHILTON, 1998).

No Conjunto 2, temos dois subconjuntos formados pela escolha de diferentes antiplásticos. O caco moído é um material que pode ser bastante vantajoso para ser utilizado como antiplástico por diversos motivos (RYE, 1981): sua presença no próprio local de manufatura; é um modo de utilizar cacos de vasilhas quebradas no processo de produção e durante o uso; é mais fácil de quebrar que minerais; é estável durante a queima; e por ser 
também cerâmica tem as mesmas propriedades que a pasta a que se incorpora. Seu comportamento é bastante parecido com o mineral: auxilia na diminuição da plasticidade da argila, mas diminui a força da "argila verde"; é um bom condutor térmico e resistente aos choques térmicos, mas diminui a resistência ao impacto (SCHIFFER e SKIBO, 1987; MACHADO, 2005-2006).

Já o caraipé, como um elemento orgânico e fibroso formado basicamente por sílica, possui correlatos de performance bastante diferentes. O caraipé melhora muito a plasticidade da argila, absorvendo a água a ponto de deixar a argila imediatamente pronta para uso. Aumenta a força da "argila verde" e das paredes curvas, permitindo a construção de formas mais angulares. Ele diminui a redução da argila durante a secagem e queima, reduzindo riscos de falhas nesses processos, a não ser no caso de o aquecimento se dar de forma muito rápida. Apesar de não ser um bom condutor térmico, por ser um material orgânico, sua forma agregada permite que ele tenha uma performance intermediária nesta característica. A queima do caraipé deixa poros na pasta, aumentando a permeabilidade da cerâmica, auxiliando no resfriamento e aumentando a resistência ao impacto, já que as rachaduras tendem a parar nos vazios dos poros, não se propagando pela vasilha. Ele também deixa as vasilhas mais leves (SCHIFFER e SKIBO, 1987; MACHADO, 2005-2006).

No Conjunto 3 é utilizada uma combinação de antiplásticos orgânicos, o cauixi e o caraipé, mas que tem algumas propriedades diferentes. O cauixi, uma espícula esponginária, é também composto de sílica, no entanto sua estrutura, oca por dentro, faz com que tenha características um pouco diferentes do caraipé. Por formar uma rede pela pasta, o cauixi ajuda a garantir uma uniformidade na queima e aumenta a resistência ao choque térmico, no entanto, por ser oco, não é um bom condutor térmico. Mas como o caraipé, o cauixi aumenta levemente a rapidez na secagem da argila, aumenta a resistência nas paredes curvas por ajudar na estruturação do corpo da vasilha (com. pessoal Silvia Cunha Lima, 2013) e a resistência ao impacto, deixando a cerâmica mais leve (MACHADO, 2005-2006; CAPDEPONT et al., 2013). A combinação entre esses dois antiplásticos faz com que a argila possa ser trabalhada facilmente, por acelerar a secagem e permitir a construção de formas angulares, apesar de essas formas não serem características deste conjunto. Nenhum dos antiplásticos é particularmente resistente aos choques térmicos, mas auxiliam bastante na resistência ao impacto e dão leveza às vasilhas. Além disso, a porosidade dada pelos antiplásticos orgânicos permite também uma maior permeabilidade da pasta, auxiliando na manutenção da temperatura fresca dos líquidos armazenados em seu interior, por exemplo (SHCHIFFER e SKIBO, 1987; MACHADO, 2005-2006). 
Já no Conjunto 4, a combinação é de cauixi e caco moído, também com algumas propriedades diferentes um do outro. Uma combinação entre eles pode promover um leve aumento na rapidez da secagem e uma performance intermediária na construção de paredes angulares. A capacidade de aquecimento do caco moído pode ser diminuída pela ação contrária do cauixi, um péssimo condutor térmico. No entanto, ambos dão uma resistência maior ao choque térmico, o caco moído por ter um coeficiente de dilatação próximo ao da pasta e o cauixi por formar uma rede por ela. Do mesmo modo, a pouca resistência ao impacto do caco moído pode ser compensada pelo cauixi, que além disso pode deixar a vasilha um pouco mais leve.

O processamento da argila e adição de outros materiais a ela são basicamente uma questão de aprendizado da ceramista, de como ela aprendeu a manipular a matéria-prima. A percepção da ceramista é muito importante neste momento, pois se ela é acostumada a não adicionar materiais antiplásticos em uma argila que já o contêm, quando utiliza uma argila que não tem essas propriedades não vai saber usá-la (ARNOLD, 1985: 22). No entanto, cada material possui propriedades que influenciam na performance da vasilha, o que também é levado em conta pelas ceramistas (SCHIFFER e SKIBO, 1997; BRONITSKY e HAMER, 1986).

Alguns grupos utilizam fontes de argila que já contém quantidades consideradas suficientes de antiplástico, como os Asurini do Xingu (SILVA, 2000) e os Kalinga nas Filipinas (STARK et al., 2000). Outros, como os Bafia de Camarões (GOSSELAIN, 1992), não adicionam antiplásticos, mas batem e amassam a argila até que ela fique homogênea e adequada para ser utilizada, um tipo de técnica que infelizmente não podemos verificar arqueologicamente. Os Luo, no Quênia, utilizam areia como antiplástico, mas um grupo local utiliza o caco moído, com propriedades similares, simplesmente como uma marca de distinção (DIETLER e HERBICH, 1989).

É importante lembrar novamente que o preparo da pasta não envolve somente a adição ou não de antiplásticos, mas também a adição de água, armazenagem da argila, técnicas de preparo (peneirar, bater/amassar), etc. Nos Camarões, mesmo utilizando a mesma fonte, ceramistas podem preparar a argila de diferentes maneiras (SMITH, 2000; GOSSELAIN, 1992).

No Conjunto 1, pode ser que as ceramistas tenham escolhido uma fonte de argila já com aquela quantidade de minerais, considerando-a adequada para o preparo das vasilhas. No caso dos Conjuntos 2, 3 e 4, tanto o caco moído como o caraipé foram muito provavelmente adicionados, já que não são materiais naturalmente disponíveis na argila. 
Já a presença do cauixi na pasta dos Conjuntos 3 e 4 pode ser explicada de duas maneiras: pode ter sido adicionado por suas características de performance ou marca distintiva; ou pode já estar presente na fonte de argila, provavelmente localizadas na beira de rios ou lagos que já tivessem as espículas de cauixi. Apesar deste material provocar diversas irritações na pele e coceiras, o uso proposital do cauixi na fabricação cerâmica foi documentado entre alguns grupos indígenas, como os Karajá (VOLKMER-RIBEIRO e BATISTA, 2007). Outros trabalhos aventaram a possibilidade de o cauixi já estar presente na fonte de argila (RODRIGUES, 2011). Esta última hipótese é levada em conta por causa de informações etnográficas de alguns grupos indígenas, como os Kaiabi (GRÜNBERG, 2004), que utilizam depósitos da beira de rios, os quais poderiam conter essas espículas. Além disso, outros trabalhos mencionam que a argila do fundo de lagos com bastante cauixi é de uma qualidade excelente para a fabricação cerâmica moderna, como telhas e tijolos (VIANA et al, 2011). As duas possibilidades são plausíveis e já foram descritas para a cerâmica do vale do rio Manso (Mato Grosso) e Araguaia (Tocantins) (VIANA et al., 2011).

Mesmo que o uso do cauixi não tenha sido proposital em nossos casos, a escolha pela utilização de uma argila com este material mostra um reconhecimento das propriedades do cauixi na fabricação cerâmica. Ou, ainda, a escolha pela utilização de uma pasta com cauixi (adicionado ou não) pode ter sido uma questão relacionada a fatores culturais, já que a coceira e dermatites causadas por essa espícula seriam fatores não atraentes para seu uso (VIANA et al., 2011).

Apesar de em todos os conjuntos mais da metade dos fragmentos apresentarem marcas de roletes sobrepostos, indicando a técnica roletada de construção da vasilha, foram raros os fragmentos que nos permitiram visualizar a forma geral da vasilha, muito menos a sequência de sua construção. No entanto, sabemos o quão importante são essas técnicas para a caracterização de um conjunto cerâmico (van der LEEUW, 1993). Sobre este aspecto, pudemos fazer algumas observações sobre o que seria uma terceira escolha das ceramistas, relacionada aos aspectos da morfologia, que podem nos informar também sobre uma quarta escolha, relacionada à função das vasilhas.

No Brasil, o trabalho mais completo sobre a relação entre forma e função de vasilhas cerâmicas foi feito para a cerâmica Guarani, por La Salvia e Brochado (1989), uma obra de referência. Essa relação só foi possível após uma extensa pesquisa dos autores, envolvendo fontes históricas, etnográficas e análise de vasilhas arqueológicas inteiras. Outros autores que escreveram sobre análises de cerâmica também propuseram relações entre forma e função, 
baseando-se em algumas características de performance das formas (ex.: RICE, 1987; SCHIFFER e SKIBO, 1987).

É importante ressaltar a diferença entre função e uso. Mesmo que uma vasilha tenha sido feita com a expectativa de cumprir uma determinada função, sua utilização pode acabar sendo outra ou mesmo ir se modificando ao longo da vida do artefato, até seu descarte final. É por isso que as marcas de uso que identificamos nos fragmentos cerâmicos podem muitas vezes ser resultado de uma reutilização desses fragmentos, e não de seu uso original. Ainda, muitas marcas só são possíveis de serem identificadas com certeza quando examinamos a vasilha inteira (ex.: SKIBO, 1992).

Para pensar de uma maneira mais genérica sobre esta relação, utilizamos um quadro (tabela 18) elaborado por Amaral (GARCIA, 2012: 154, apud AMARAL, 2008), que procura resumir algumas tendências de funções e formas:

Indicação funcional das formas cerâmicas proposta por Amaral (2008), baseando-se nas proposições de Rice $(1987,226-242$ ) (in SCIENTIA, 2008, p.403-404):

Vasilhas para armazenamento: formas esféricas, com boca constrita (para facilitar o fechamento, despejar líquidos e restringir o acesso ao seu conteúdo), grande capacidade volumétrica (em geral maior do que 10 litros), em alguns casos, presença de engobo, polimento ou outros tratamentos de superfície (para diminuir a porosidade e a permeabilidade), e paredes mais espessas. Apresentam apêndices para auxiliar na suspensão. São usadas para guardar água, bebidas ou alimentos secos (e.g. grãos de milho). Possuem baixa freqüência de reposição.

Vasilhas para transporte: formas esféricas, com boca constrita (para evitar o derramamento durante o transporte), capacidade volumétrica variável (grandes volumes para o transporte em pequenas distâncias e pequenos volumes para grandes distâncias); podem apresentar tratamento de superfície, polimento ou engobo (para reduzir a permeabilidade), são leves, porém densas (para facilitar a resistência ao estresse mecânico provocado pelo deslocamento), [podem possuir] alças [...] São utilizadas para transporte especialmente de líquidos (água e bebidas), bem como de gêneros alimentícios secos.

Vasilhas para cocção: formas esféricas ou semi-esféricas, (consideradas melhores para cozinhar (Silva, 2000: 15), boca aberta, sem ângulos (para facilitar o acesso ao interior das vasilhas, permitindo a manipulação do alimento, com objetos como colheres, durante ao processo de cocção), pasta grossa e porosa e paredes finas (que melhora a resistência ao choque térmico), sem tratamentos de superfície mais elaborados, engobos ou decorações (visto que este tipo de vasilha entra em contato direto com o fogo, o que compromete qualquer tipo de investimento decorativo), superfície áspera (que permite segurar a vasilha), e presença de marcas de fuligem (na face externa) e de restos de alimentos queimados (na face interna), e, às vezes, marcas de raspar, melhor observadas em peças inteiras [...] 0 volume varia de pequeno a médio, porém sempre maiores do que as vasilhas utilizadas para servir. São utilizadas para cozinhar mingaus, ensopados, entre outros. Possuem alta freqüência de reposição em virtude de seu uso diário. Possuem freqüência moderada de reposição.

Vasilhas para preparo: formas esféricas, semi-esféricas e calotas esféricas, com boca aberta (para permitir o acesso e a manipulação dos alimentos), pasta grossa e densa (que permite melhor resistência ao estresse mecânico). A capacidade volumétrica é pequena, visto que as vasilhas são geralmente rasas. Não possui decorações ou tratamentos de superfície mais elaborados, no entanto, em alguns casos apresenta a superfície externa com marcas de cestaria ou decoração corrugada ou roletada (que neste caso não seriam atributos decorativos, porém funcionais, pois facilitam a condução térmica). Podem apresentar abrasão na face interna, devido ao atrito com instrumentos na manipulação de alimentos. Utilizadas para preparação de alimentos sem aquecimento (como moer e ralar, entre outros), com exceção dos assadores. Possuem frequêtncia moderada de reposição. 
Vasilhas para serviço: formas esféricas, semi-esféricas ou calotas esféricas, geralmente com a boca aberta (para permitir o acesso aos alimentos), ou constrita (especialmente quando utilizada para servir líquidos), bases mais planas (para permitir estabilidade), [podem apresentar] alças [...]. As paredes são mais finas e há a presença de tratamentos de superfície mais aprimorados, bem como engobo, decorações plásticas e pintadas, a apêndices, denotando uma preocupação estética e simbólica maior. Foram agrupadas nesta categoria funcional vasilhas com estas características e capacidade volumétrica maior do que 1 litro, associando estes recipientes ao serviço coletivo dos alimentos ou bebidas. Possuem alta freqüência de reposição devido ao alto índice de utilização das mesmas.

Vasilhas para consumo: possuem as mesmas características das vasilhas utilizadas para servir alimentos e bebidas, no entanto as capacidades volumétricas estão entre 0,100 litros e 1 litro, e estão associadas ao consumo individual de alimentos e bebidas. Possuem alta freqüência de reposição.

Miniaturas: formas esféricas, semi-esféricas e calotas esféricas, com boca aberta ou constrita, paredes de espessura bem fina, porém geralmente densas, ausência de decorações, polimentos ou engobos, embora, em geral, sejam bem alisadas. A capacidade volumétrica é menor do que 0,100 litros. Compreendem boa parte das formas estabelecidas para os sítios, embora em tamanho reduzido. [...]

Tabela 18: Indicações de relações entre forma e função de vasilhas cerâmicas (Cf. GARCIA, 2012: 154, apud AMARAL, 2008).

Tanto os fragmentos diagnósticos de formas (bordas e alguns tipos de paredes) como as formas que reconstituímos não foram suficientes para nos mostrar toda a variabilidade de vasilhas de cada conjunto. Contudo, alguns comentários gerais podem ser feitos levando em conta a tabela acima e com o auxílio das características de performance dos materiais antiplásticos escolhidos para a confecção das vasilhas.

As 4 formas reconstituídas para o Conjunto 1 são todas de contorno simples, de formato esférico, semi-esférico e oval, sendo apenas uma fechada (ver figura 45). Seriam formas adequadas para cozinhar, ainda mais associadas a espessura fina e o antiplástico mineral. O acabamento de superfície de impressão de corda próximo à borda não cria impedimentos para essa atividade. Por outro lado, tanto a espessura quanto o antiplástico tendem a diminuir a resistência ao impacto. A forma 2 deste conjunto é pequena para a atividade de cozinhar, adequando-se mais ao perfil de uma vasilha para servir ou de uma miniatura. Além das formas reconstituídas, existem 8 fragmentos de bordas e bases planas com espessura entre 20 e $26 \mathrm{~mm}$ que poderiam ser fragmentos de assadores ou torradores. A ausência de paredes carenadas e angulares pode estar relacionada ao processo de construção da vasilha, já que a pasta com mineral não se sustenta muito bem enquanto úmida.

As 5 reconstituições do Conjunto 2 apresentam uma variedade maior de formas (figura 51). As duas primeiras são formas bicônicas, associadas ao caco moído, espessuras intermediárias, acabamentos de incisões, engobo vermelho e banho. Podem ser vasilhas utilizadas para cozinhar, mas vemos que a preocupação da sustentação na construção da 
vasilha com ângulos salientes não foi levada em conta com a escolha do caco moído como antiplástico. O engobo e o banho podem ter auxiliado na impermeabilização da superfície. As duas formas esféricas e pequenas parecem ser miniaturas, sendo que a forma 3 pode ter sido feita durante a fase de aprendizado, devido a diferença dos perfis de cada lado do fragmento. Já a última forma é bastante coerente com um assador ou torrador, que serviria especificamente para cozinhar, apesar de ser associada ao caraipé, que não auxilia nesta função.

O Conjunto 3 também apresenta uma variedade de formas reconstituídas (figura 56). As formas 3 e 4, abertas, pequenas e rasas, combinadas com as características de leveza e resistência ao impacto dada pelos antiplásticos cauixi e caraipé, parecem ser pensadas para servir ou consumir. A 4 também poderia ser pensada como uma miniatura. Já as formas 1 e 2 , restringidas, maiores e fundas, podem estar associadas ao armazenamento ou transporte de líquidos, função auxiliada pelo aumento da porosidade proporcionado pela combinação de antiplásticos. A última forma é bastante grande, esférica e aberta, podendo ser realmente uma vasilha para cozinhar. No entanto, a combinação de caraipé e cauixi como antiplástico não é boa para essa função, o que poderia ser de algum modo compensado pela aplicação do banho na superfície. Por outro lado, eles podem dar leveza e resistência ao impacto maiores, características talvez mais desejáveis para aumentar o tempo de vida da vasilha.

Em relação ao Conjunto 4 (figura 64), as formas 2, 3 e 4, esféricas, pequenas, restringidas e fechadas parecem favorecer características de performance para servir, mais especificamente servir líquidos. O pouco volume que comportam e as bordas extrovertidas com pequeno pescoço favorecem essa função. A forma 1, maior que as outras e um pouco menos fechada, poderia servir também para cozinhar. O caco moído e o cauxi tem propriedades por vezes opostas, promovendo performances intermediárias em quase todas as características.

A maior variabilidade na cadeia operatória é encontrada na etapa dos acabamentos de superfície, principalmente entre aqueles relacionados a características estéticas, ou decorações, que são onde visualizamos uma quinta escolha. Qualquer que seja a motivação da escolha de determinados acabamentos (p. ex. funcional, estética, identitária, etc.), inúmeros trabalhos etnoarqueológicos e etnográficos nos mostram as mais diversas relações entre esta etapa da produção cerâmica e elementos da cosmologia e identidade de diferentes grupos, além dos aspectos pragmáticos. 
Os tipos de acabamentos e sua posição podem também estar relacionados com funções das vasilhas. Diversos tipos de engobos ou resinas podem ser aplicados à superfície para reduzir sua permeabilidade (RICE, 1987), auxiliando o cozimento (SCHIFFER e SKIBO, 1987). No entanto, alguns tipos de pigmentos não podem ser expostos ao fogo, por isso não são aplicados às vasilhas para cozinhar. A escolha do local do acabamento também pode estar relacionada a sua visibilidade durante o uso da vasilha.

Schiffer e Skibo (1997: 30) também comentam sobre a perfomance visual dos artefatos, que pode incluir sua capacidade de se destacar de seu meio, de captar ou dirigir o olhar de um observador, de ser visto à distância, etc. Essas características dependem muito do arcabouço cultural do observador, que pode distinguir elementos visuais (forma e acabamento) presentes no objeto e interpretando-os como mensagens culturais ou de outra natureza. Em muitos grupos, a associação com padrões decorativos é muito ligada com a identidade cultural. Em outros, essa é uma questão muito mais fluida, que leva em conta não só o grupo cultural, mas a posição social, idade, gênero, cosmologia, etc. (ver CARR e NEITZEL [orgs.], 1991).

Podem existir micro estilos, que caracterizam grupos locais/comunidades de uma determinada etnia. Em casos de produção especializada, pode até ser que ceramistas produzam vasilhas "ao gosto do cliente", para vender em mercados específicos, como os Luo para os Kiisi (DIETLER e HERBICH, 1994).

Entre os Mafa e Bulahay, dos Camarões, decorar uma vasilha é, em muitos aspectos, como decorar o próprio corpo, pois os potes "são" pessoas (DAVID et al., 1988). Entre os Asurini no Xingu, o alisamento da superfície cerâmica deve ser feito de tal modo que fique parecido com a pele, sendo a vasilha também considerada um corpo e adornada com grafismos também utilizados na pintura corporal (SILVA, 2000). Na cerâmica Marajoara, Pará, as urnas funerárias também representam corpos, tendo desenhos na superfície externa que nos remetem a diferentes animais (BARRETO, 2005).

A maior parte dos fragmentos de todos os conjuntos é alisada, ou por uma escolha por este acabamento ou por uma erosão das superfícies que nos impediram de identificar outros tipos de acabamento. No entanto, os poucos fragmentos com acabamentos diferentes de alisamento em cada conjunto foram interessantes para nos auxiliar na separação destes conjuntos.

O Conjunto 1 tem acabamentos plásticos bastante distintos, que são as impressões de corda, ungulados e incisos entrecruzados, todos motivos lineares. O Conjunto 2 utiliza muito mais engobos para cobrir toda a superfície da vasilha, além de motivos incisos ou de pintura 
que formam motivos geométricos distintos, como gregas, volutas e triângulos. Já os Conjuntos 3 e 4 não apresentam traços que os distingam claramente um do outro nem em relação aos conjuntos anteriores. Neles predomina o alisamento, com apenas alguns fragmentos com características bastante diferentes: lábio serrilhado, círculos concêntricos, incisos de triângulos concêntricos, inciso e ponteado, etc.

Apesar de não termos uma quantidade siginificativa de formas de cada conjunto, nem sua associação com funções e usos específicos, podemos, a partir das considerações acima, pensar em algumas hipóteses sobre as escolhas feitas em cada conjunto como alternativas para produzir diferentes tipos de vasilhas, considerando pelo menos as três propostas por Rye (1981: 26): 1) usar diferentes materiais e processos de queima para cada tipo; 2) usar materiais mais apropriados para determinada função e reconhecer que não terão a mesma eficácia para outros propósitos; 3) usar o mesmo material pra todos os tipos, escolhendo o que tem qualidades intermediárias para todas as funções.

A alternativa utilizada no Conjunto 1 parece ter sido a segunda, de escolher os mesmos materiais para fabricar todos os tipos de vasilhas, priorizando as características relacionadas à resistência ao choque térmico na queima e em repetidos aquecimentos e resfriamentos (como nas vasilhas de cozinhar), enquanto pouca atenção foi dada à resistência ao impacto e leveza da vasilha, importantes para outras funções como servir e transportar.

Já no Conjunto 2, as ceramistas parecem ter escolhidos materiais diferentes para diferentes tipos de vasilhas, utilizando a primeira alternativa. Ainda não sabemos se são utilizadas uma ou mais argilas na confecção das vasilhas deste conjunto, no entanto podemos observar que de qualquer modo foram feitas opções de utilização de antiplásticos com performances diferentes: uma mais associada à resistência térmica e atividades de cozinhar (caco moído, grupo 3 na estatística), e outra mais associada à portabilidade e resistência a rachaduras (caraipé, grupo 1 na estatística). Neste caso, essas performances parecem ter sido mais decisivas para a escolha do antiplástico do que para a facilidade de construção da vasilha, já que as formas angulares estão associadas ao caco moído e não ao caraipé. No entanto, o fragmento de assador/torrador, com antiplástico de caraipé, não parece ter sido pensado dessa maneira, já que este material não auxilia no cozimento. Assim, a alternativa utilizada parece ser muito mais fluida.

Quanto aos Conjuntos 3 e 4, temos a impressão de que foi feita uma opção combinada da terceira e da primeira alternativa: usando um material com performance intermediária em todos os atributos, que é o cauixi, para depois acrescentar um segundo 
antiplástico que ressaltasse ora características relacionadas a servir e transportar (caraipé), ora relacionadas à resistência e condutividade térmica (caco moído). No entanto, não conseguimos testar essa associação por causa da insuficiência de formas reconstituídas e funções associadas a elas.

De qualquer forma, é possível visualizar claramente que existem diferenças muito significativas entre as escolhas feitas para o Conjunto 1 e o Conjunto 2, com agrupamentos sempre distintos na estatística e mesmo na arqueometria, e para os Conjuntos 3 e 4, que apresentam algumas características comuns entre si. Parece-nos, neste primeiro momento de análise, que existem três estilos que podem estar relacionados a três grupos diferentes de ceramistas, sendo que para o terceiro grupo podemos distinguir dois outros, mais relacionados a diferentes funcionalidades.

Para finalizar essa descrição, organizamos os dados dos 4 conjuntos na tabela 19, para facilitar a visualização de suas características. A partir disso e das relações que fizemos com exemplos etnoarqueológicos, poderemos também comparar essas informações com a de outros conjuntos cerâmicos descritos na bibliografia para a região do Vale do Tapajós, pensando em possíveis relações entre eles.

\begin{tabular}{|c|c|c|c|c|c|}
\hline Classificação & Classificação & Conjunto 1 & Conjunto 2 & Conjunto 3 & Conjunto 4 \\
\hline \multirow[b]{2}{*}{$\begin{array}{l}\text { Preparação da } \\
\text { matéria-prima }\end{array}$} & Argila & Tipo 2 & Tipo 4 & Tipo 3, Tipo 4 & Tipo 1, Tipo 4 \\
\hline & Antiplástico & Mineral. & $\begin{array}{l}\text { Caco moído e/ou } \\
\text { caraipé. } \quad \text { Menor } \\
\text { quantidade mineral. }\end{array}$ & Caraipé e cauixi. & Caco moído e cauixi. \\
\hline \multirow{3}{*}{$\begin{array}{l}\text { Construção da } \\
\text { Vasilha }\end{array}$} & Manufatura & Roletado. & Roletado. & Roletado. & Roletado. \\
\hline & Espessura & 3 a 26 mm. & 4 a $21 \mathrm{~mm}$. & 2 a $26 \mathrm{~mm}$ & 2 a $29 \mathrm{~mm}$. \\
\hline & Morfologia & Esféricas, simples. & Bicônicas e esféricas. & $\begin{array}{c}\text { Abertas, pequenas. } \\
\text { Fundas e restringidas. }\end{array}$ & Esféricas, pequenas \\
\hline Queima & Coloração & Cinza. & $\begin{array}{l}\text { Cinza, marrom, } \\
\text { marrom avermelhado. }\end{array}$ & \begin{tabular}{|lr} 
Cinza, & marrom, \\
marrom avermelhado.
\end{tabular} & $\begin{array}{l}\text { Cinza, marrom } \\
\text { avermelhado. }\end{array}$ \\
\hline $\begin{array}{l}\text { Acabamento } \\
\text { de superfície }\end{array}$ & $\begin{array}{l}\text { Acabamento } \\
\text { de } \\
\text { fe }\end{array}$ & $\begin{array}{l}\text { Acabamento } \\
\text { plástico: impressão } \\
\text { de corda, ungulado, } \\
\text { inciso. } \\
\text { Acabamento } \\
\text { pintado: banho, } \\
\text { engobo vermelho*. }\end{array}$ & 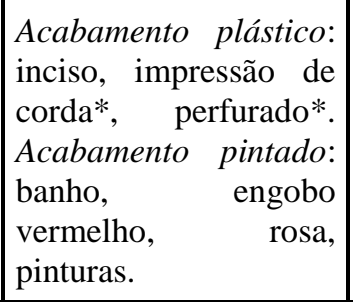 & 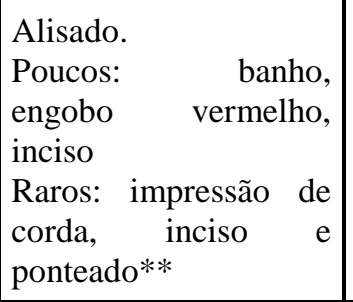 & $\begin{array}{l}\text { Alisado. } \\
\text { Poucos: } \\
\text { vermelho, } \quad \text { bangobo } \\
\text { pinturas. } \\
\text { Raros: impressão de } \\
\text { corda, inciso, } \\
\text { perfurado. }\end{array}$ \\
\hline \multirow[t]{4}{*}{ Função e Uso } & Função e Uso & Cozinhar & Cozinhar & Cozinhar e servir & Cozinhar e servir. \\
\hline & Data & $\begin{array}{l}4920 \pm 30 \mathrm{AP} \\
420 \pm 40 \mathrm{AP}\end{array}$ & $870 \pm 120 \mathrm{AP}$ & $\begin{array}{l}1680 \pm 30 \mathrm{AP} \\
380 \pm 50 \mathrm{AP}\end{array}$ & \\
\hline & Sítios & YA, DR* & $\mathrm{MC}, \mathrm{DR}^{*}$ & $\mathrm{DR}, \mathrm{MI}, \mathrm{AT}^{* *}, \mathrm{AC}$ & $\mathrm{AC}, \mathrm{AT}, \mathrm{TT}, \mathrm{DR}$ \\
\hline & Observações & & & & \\
\hline
\end{tabular}

Tabela 19: Características e cadeia operatória dos 4 conjuntos propostos para a cerâmica na T. I. Kaiabi. 
Um último aspecto a ser levado em conta nas considerações sobre esses conjuntos é a cronologia, para a qual levamos em conta tanto as datas realizadas pelo método de $\mathrm{C}^{14}$ como pelo de Termoluminescência ${ }^{16}$.

O Conjunto 1 apresenta duas datas discrepantes entre si, as duas do sítio Ywantã: a primeira, de $\mathrm{C}^{14}$, é de $4920 \pm 30$ A.P. (período entre 3760 e 3720 a.C.); a segunda, de termoluminescência, é de $420 \pm 40$ A.P. (período entre 1554 e 1634 d.C.). Apesar de a datação de $\mathrm{C}^{14}$ ter sido feita com um carvão a $30 \mathrm{~cm}$ de profundidade, o resultado é antigo demais para o pouco que se sabe da região. A datação do fragmento cerâmico entre 10 e 20 $\mathrm{cm}$ de profundidade nos revelou uma data mais coerente, sendo um fragmento coletado no mesmo poço teste que o carvão datado. Para o Conjunto 2, temos uma data de termoluminescência para o sítio Mukuin Caniné: $870 \pm 120$ A.P. (período entre 1024 e 1264 d.C). O fragmento cerâmico datado ecnontrava-se exatamente a $20 \mathrm{~cm}$ de profundidade, revelando um período pré-colonial de ocupação. Por último, para o Conjunto 3, temos duas datas. A primeira foi feita por $\mathrm{C}^{14}$, datando um carvão do sítio Dinossauro em $1680 \pm 30$ A.P. (período entre 260 e 300 d.C.). O carvão encontrava-se no nível 4, associado aos fragmentos da forma 5 deste conjunto. Apesar de também ser uma data antiga, ainda pode ser comparada com algumas datas da região, como veremos no próximo capítulo. A outra data foi feita por termoluminescência para um fragmento de cerâmica do nível 4 do sítio Taitetu, classificado neste conjunto. O resultado de $380 \pm 50$ A.P. (período entre 1584 e 1684 d.C.) é bem mais recente que a data de carvão do sítio Dinossauro, além de ser contemporânea à data de termoluminescência do sítio Ywantã. Esta data é mais um elemento para nos fazer pensar na problemática do sítio Tatitetu, que não se encaixou bem nas nossas classificaçõe e nem nos agrupamentos estatísticos, além de apresentar uma variedade de pastas, como mostrou a análise arqueométrica.

\footnotetext{
${ }^{16}$ A desconfiança pelas datas de TL não é justificada, como aponto Corrêa (2014: 194-199). Pelo contrário, é um metodo que tem se aperfeiçoado cada vez mais e que é bastante utilizado pelo mundo, tomando-se os devido cuidados de seleção da amostra, assim como o $\mathrm{C}^{14}$.
} 


\title{
6. OS CONJUNTOS CERÂMICOS NO VALE DO TAPAJÓS
}

\begin{abstract}
"Only through detailed study of temporally controlled archaeological assemblages can we assess the extent to which technological practices and the consumption of resulting products varied through time." (STAHL et al., 2008: 377)
\end{abstract}

Apesar de não ser a intenção principal deste trabalho, concordamos que para melhor compreender os processos de continuidades e mudanças nos conjuntos cerâmicos arqueológicos, bem como as relações sociais e culturais entre os diferentes grupos que os produziram, é preciso um estudo aprofundado e temporal de conjuntos arqueológicos e, acrescentamos, etnográficos. É por isso que neste capítulo damos um passo inicial nesta direção, realizando uma pesquisa bibliográfica sobre a cerâmica arqueológica e etnográfica no contexto regional da T. I. Kaiabi, a partir de um panorama geral da distribuição de conjuntos arqueológicos no Mato Grosso e Pará e dos deslocamentos e ocupações indígenas na região do Vale do Tapajós. Procuramos, com isso, realizar algumas comparações com os conjuntos que separamos em nossa análise, sugerindo possíveis relações entre eles.

\subsection{Cerâmica Arqueológica}

Os levantamentos arqueológicos feitos por Pardi (1995-96) nos municípios de Alta Floresta, Apiacás e Jacareacanga e na margem paraense do Teles Pires, identificaram 20 sítios arqueológicos: 2 rupestres, 2 com material e/ou vestígios de fabricação de artefatos líticos polidos e 15 cerâmicos a céu aberto, dentre os quais 12 teriam sido caracterizados como de terra preta. A pesquisadora nota que essa região "constitui um enorme 'vazio' arqueológico" (PARDI, 1995-96: 6), dificultando as explicações sobre sua ocupação pré-colonial e mesmo a caracterização do material cerâmico encontrado. 
Assim mesmo, ela nos sugere algumas relações iniciais dos conjuntos cerâmicos coletados com Tradições Cerâmicas do Brasil Central (PARDI, 1995-96). Um conjunto seria relacionado à Tradição Uru, sendo caracterizado pela presença de caraipé como antiplástico, espessura entre 4 e $14 \mathrm{~mm}$, acabamento de superfície alisado e um de incisões cruzadas, formas infletidas (abertas e fechadas). O segundo conjunto teria relações com a Tradição Tupiguarani, caracterizado por antiplástico caco moído e mineral, espessura entre 4 e 16 mm, ombros indicando formas complexas, vasilhas grandes; acabamentos ungulado, escovado, ponteado, incisões paralelas ou cruzadas (superfície externa ou lábio). Já o terceiro conjunto, de características da Tradição Aratu, possui antiplástico mineral, espessura de 4 a $16 \mathrm{~mm}$, alisamento e incisões serrunguladas, com formas diretas e infletidas e uma borda com pequena orelha. Por último, um conjunto com traços das Tradições Uru e Tupiguarani, sinalizando uma situação de contato ou nova unidade cultural ainda não identificada, caracterizada pelos antiplásticos caco moído, caraipé e mineral, espessuras de 5 a $15 \mathrm{~mm}$, formas globulares e semiglobulares às vezes infletidas; acabamento na superfície externa e interna de engobo vermelho, motivos plásticos ungulado, ponteado e corrugado.

Essas Tradições, semelhantes ao quadro mais amplo de ocupação do Brasil Central, permitem a inserção da T. I. Kaiabi como uma área de ocupação e/ou caminhos para os deslocamentos de diversos grupos ceramistas (STUCHI, 2010: 80). Para alguns pesquisadores, a região do Mato Grosso poderia ter sido uma área de confluência e deslocamento (mais do que a ideia de um corredor de passagem) de diversos grupos ceramistas, com a constatação da presença de pelo menos 5 tradições cerâmicas arqueológicas: Una, Aratu, Uru, Tupiguarani e Bororo (EREMITES DE OLIVEIRA e VIANA, 1999-2000; ROBRAHN-GONZÁLEZ, 1996; WÜST e BARRETO, 1999).

A Tradição Una, apesar de ser datada em outras regiões em mais de 3 mil anos, é datada em dois momentos no Mato Grosso: entre os últimos séculos a. C. e o início da Era Cristã, no alto Araguaia e médio Tocantins; e entre 720 a 1.020 d. C., no Tocantins, calha do Rio Vermelho e baixo Paranaíba (EREMITES DE OLIVEIRA e VIANA, 1999-2000: 160). As ocupações Una precederam as ocupações mais tardias de aldeias circulares, mas podem ser parcialmente contemporâneas (WÜST e BARRETO, 1999: 5), praticando ainda uma agricultura incipiente de milho e mandioca (WÜST, 1990). Essa tradição consiste principalmente de vasilhas com antiplástico mineral e caraipé; colorações escuras de superfície (preto, marrom e cinza); espessura fina (4 a $10 \mathrm{~mm}$ ); tamanho pequeno e formas globulares e cônicas, tigelas rasas e potes com gargalo; bem alisadas, com poucos engobos vermelhos (ROBRAHN-GONZÁLEZ, 1996:26; WÜST, 1990). 
A Tradição Aratu é associada aos grupos de grandes aldeias, iniciando no século IX d. C. e chegando até pouco antes da colonização portuguesa, localizada principalmente nas partes central e oriental do Mato Grosso (WÜST e BARRETO, 1999: 8-9). Esses povos já possuíam um sistema agrícola mais organizado, plantando milho e diferentes tubérculos, mas não mandioca (WÜST, 1990). A cerâmica Aratu pode ter antiplástico mineral e, em períodos posteriores, caraipé; a espessura varia de 5 a $15 \mathrm{~mm}$, chegando a $30 \mathrm{~mm}$; são vasilhas grandes e cônicas (muitas vezes utilizadas como urnas funerárias) e vasilhas globulares ou semi globulares com bordas diretas e extrovertidas; o acabamento é basicamente de alças modeladas, linhas duplas e simples incisas paralelas à borda, impressões digitais, ungulados, apliques e raramente engobo vermelho; as bases podem ter impressões de folhas ou furos (WÜST e BARRETO, 1999: 8-9; ROBRAHN-GONZÁLEZ, 1996: 30).

No vale do Araguaia até o sudeste do Mato Grosso está localizada a Tradição Uru, também associada às grandes aldeias circulares, no período do século VIII d. C., podendo alguns sítios estarem associados aos Karajá (EREMITES DE OLIVEIRA e VIANA, 19992000). As vasilhas cerâmicas mais comuns dessa tradição tem como antiplástico o caraipé; a espessura está entre 10 e 15 mm, são grandes jarras com pescoço e tigelas com base plana, com bordas extrovertidas e reforçadas; o acabamento é alisado, com poucos apêndices, faixas aplicadas e incisão ponteada (WÜST e BARRETO, 1999: 10; ROBRAHN-GONZÁLEZ, 1996:37). As vasilhas desta tradição parecem estar mais relacionadas ao processamento de farinha (WÜST, 1990).

Já os sítios Bororo estão relacionados à fusão de diversas matrizes e culturas étnicas, como a Uru e Tupiguarani, no alto e médio Vermelho (EREMITES DE OLIVEIRA e VIANA, 1999-2000: 161), diretamente associados ao grupo étnico Bororo (WÜST, 1990).

É somente na porção sudeste do Mato Grosso que se encontra uma concentração de material cerâmico relacionado à Tradição Tupiguarani (subtradição Pintada e Corrugada), datado entre 860 d.C. e 1.440 d.C., mas que podem ter tido contatos com povos de outras tradições, como a Una e Aratu, sugerindo-se que estes sítios sejam na verdade classificados como intra-componenciais (WÜST e BARRETO, 1999). Neste Estado, a cerâmica Tupiguarani é caracterizada pelo antiplástico de caco moído, mineral e pouco caraipé; por grandes jarros com ombro, vasilhas rasas com bordas reforçadas e semiglobulares com bases convexas ou planas; acabamento em policromia (vermelho, marrom ou preto sobre engobo branco ou vermelho), corrugado e inciso (ROBRAHN-GONZÁLEZ, 1996: 46; WÜST, 1990). 
Além do contexto descrito a cima, uma pesquisa recente no alto rio Guaporé, sudoeste do Mato Grosso, revelou uma cerâmica não descrita anteriormente (figura 73), com horizonte de ocupação entre 800 e 1.300 AD, chamada de cerâmica Capão do Canga (ERIG LIMA, 2012). O antiplástico predominante é o mineral, associado às vezes com cauixi e caco moído, e uma baixa porcentagem de caraipé; as bases são modeladas mas a vasilha é acordelado; a espessura varia de 2 a $25 \mathrm{~mm}$; as formas são usualmente fechadas, extrovertidas (com diâmetros de 6 a $26 \mathrm{~cm}$ ), seguida de diretas (com diâmetros de 5 a $36 \mathrm{~cm}$ ); as bordas são inclinadas internas e externas, verticais; lábios arredondados, planos e apontados; bases planas com face externa rugosa ou digitada, convexas e anelares; o acabamento mais comum é o alisamento, com poucos engobos vermelhos, enegrecimento e brunidura; o acabamento plástico é predominantemente inciso, com outros acordelados, corrugados, escovados, estocados, ponteados, raspados e ungulados (ERIG LIMA, 2012: 196-197).

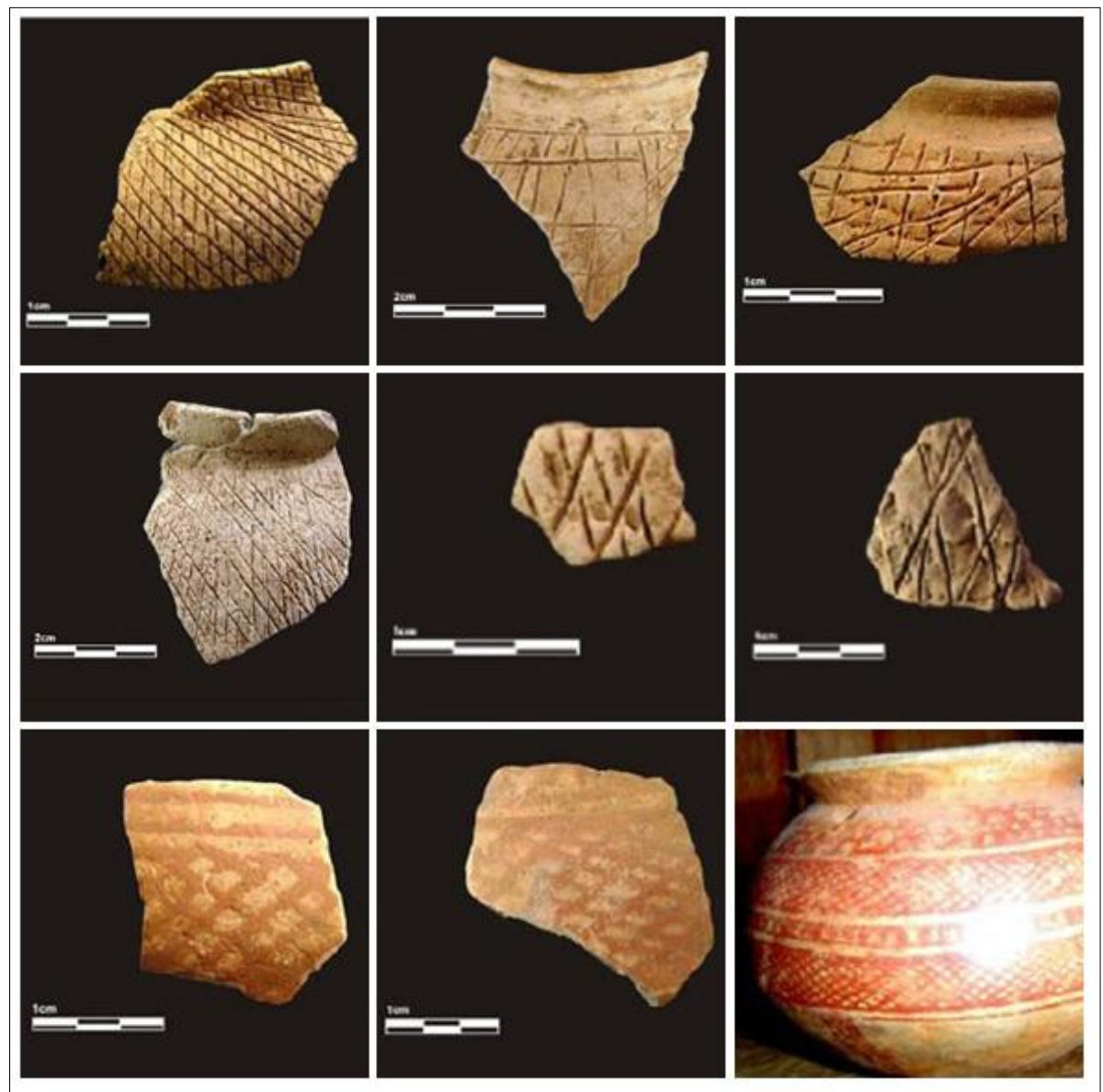

Figura 73: Cerâmica Capão do Canga, motivos incisos e pintados. (Adaptado de ERIG LIMA, 2012).

No entanto, não descartamos a possibilidade de que também existam conjuntos cerâmicos da Amazônia Meridional na T. I. Kaiabi, já que pesquisas realizadas ao longo do 
rio Tapajós (até a confluência dos rios Juruena e Teles Pires) encontraram um material cerâmico similar a este contexto.

Os trabalhos de Meggers e Evans na Amazônia, a partir da década de 1960, classificaram os conjuntos cerâmicos amazônicos em quatro Horizontes de ocupação, utilizando-se os atributos da pasta e acabamento de superfície para esse agrupamento: Zonado-Hachurado, Borda Incisa, Polícroma e Inciso-Ponteado (NEVES, 2008: 365-367). Ainda hoje existem debates sobre a cronologia, origem, dispersão e correlação cultural desses agrupamentos iniciais, gerando trabalhos que se propõe a rever estas classificações. Por exemplo, após a revisão cronológica, essa nomenclatura agora se refere à Tradições, não à Horizontes, mostrando conjuntos ainda mais antigos que esses (a cerâmica da fase Mina e a de Taperinha, indicadas por ROOSEVELT, 1991 e ROOSEVELT et al., 1996). Ao contrário das premissas anteriores, de que essas tradições teriam surgido nos Andes ou norte da América do Sul, pesquisas recentes sugerem diferentes centros independentes de produção cerâmica nas terras baixas da Amazônia (NEVES, 2008: 365-367). O significado da variabilidade artefatual destes conjuntos também tem sido revisto (p. ex. LIMA et al, 2006; GARCIA, 2012). Concentramos-nos em definir brevemente as três últimas tradições cerâmicas, que foram mencionadas para a região que nos interessa.

A Tradição Borda Incisa (em concordância com as hipóteses de Meggers e Evans e ao contrário das sugestões posteriores de Lathrap e Oliver) provavelmente é derivada de centros de produção no norte da Colômbia, assim como as séries Barrancóides da bacia do Orinoco (NEVES, 2008: 367). Esta Tradição tem datas no período entre 100 e 800 d. C., caracterizando-se pelo antiplástico cauixi (ao menos nas fases Manacapuru e Paredão); bordas largas, com o topo achatado e silhueta seccional triangular; acabamentos incisos nas bordas, às vezes pintura ou engobo vermelho na face externa e interna (LIMA, 2008: 32). Essa cerâmica chegou a ser associada por Lathrap aos povos falantes de línguas Arawak (NEVES, 2011: 33), sendo relacionada à Tradição Barancóide, vinda da Bacia do Orinoco (GOMES, 2005: 233; 2008).

A cerâmica encontrada após a Borda Incisa é pertencente à Tradição Polícroma, caracterizada por seus acabamentos pintados com motivos em vermelho e/ou preto sobre engobo branco; acabamentos plásticos (inciso, corrugado, modelado); tempero de caraipé no alto Amazonas e caco moído no Marajó. Esta Tradição está distribuída desde o baixo Amazonas até o piemonte andino na Colômbia, Equador e Peru. As hipóteses iniciais de Meggers e Evans de uma origem Andina ou circum-Caribe para a cerâmica Polícroma foram refutadas por Brochado e Lathrap, na década de 1980, sugerindo uma origem na Amazônia 
Central para esta cerâmica, além de sua associação com povos falantes de línguas Tupi (NEVES, 2008: 368).

Já a Tradição Inciso-Ponteado se encontra na região mais próxima de nossa área de pesquisa, no baixo Tapajós, Nhamundá e Trombetas. São cerâmicas elaboradas, com acabamentos de pinturas e incisões, modelados zoo e antropomorfos; antiplástico cauixi; e associação com estátuas de pedra antropomorfas e amuletos líticos zoomorfos (muraiquitãs). As datas mais antigas para essa cerâmica são mais tardias que as da cerâmica Polícroma, a não ser na área de Santarém, que se sobrepõe com os sítios Pocó de 100 a.C. à 200 d.C.. Há uma sugestão de que essa cerâmica esteja relacionada com povos de língua Karib, que teriam se expandido a partir da bacia do Orinoco (NEVES, 2008: 369-370; ROCHA, 2012: 52).

Nos 33 sítios localizados ao longo do Tapajós por Perota em 1979, foi encontrado pouco material cerâmico da Tradição Tapajônica, mas muitos fragmentos com pintura polícroma e excisões, sepultamentos secundários, terra preta e machados de pedra. $\mathrm{Na}$ segunda expedição, em 1982, foram encontrados fragmentos cerâmicos atribuídos à Tradição Inciso-Ponteado e uma cerâmica lisa, sem decoração, que poderia pertencer aos Munduruku. A partir desses dados, Perota propõe que essa região seja um divisor geográfico natural entre os grupos portadores da cerâmica Inciso-Ponteado e os grupos associados a contextos do Brasil Central (PEROTA, 1982; ROBAZZINI, 2013).

Mais recentemente, a pesquisa de Bruna Rocha (2012) no Tapajós, a 120 km de Itaituba, identificou uma cerâmica parecida com a cerâmica de Nhamundá-Trombetas, relacionada a Tradição Inciso-Ponteado. Em 2 sítios escavados (Pajaú e Cocalino, figura 74), a pesquisadora descreveu um material com antiplástico mineral (quartzo e areia de quartzo) às vezes associado com cauixi; espessura entre 4 a $16 \mathrm{~mm}$, com média em 7 e $8 \mathrm{~mm}$; lábios aplanados ou arredondados; acabamento predominantemente alisado, destacando-se o acabamento plástico de incisões com motivos de espinha de peixe ou linhas paralelas, de triângulos isósceles ou linhas cruzadas; apliques de filetes de argila com ponteado em cima, lábios entalhados com efeito serrilhado ou com ponteado no interior. 


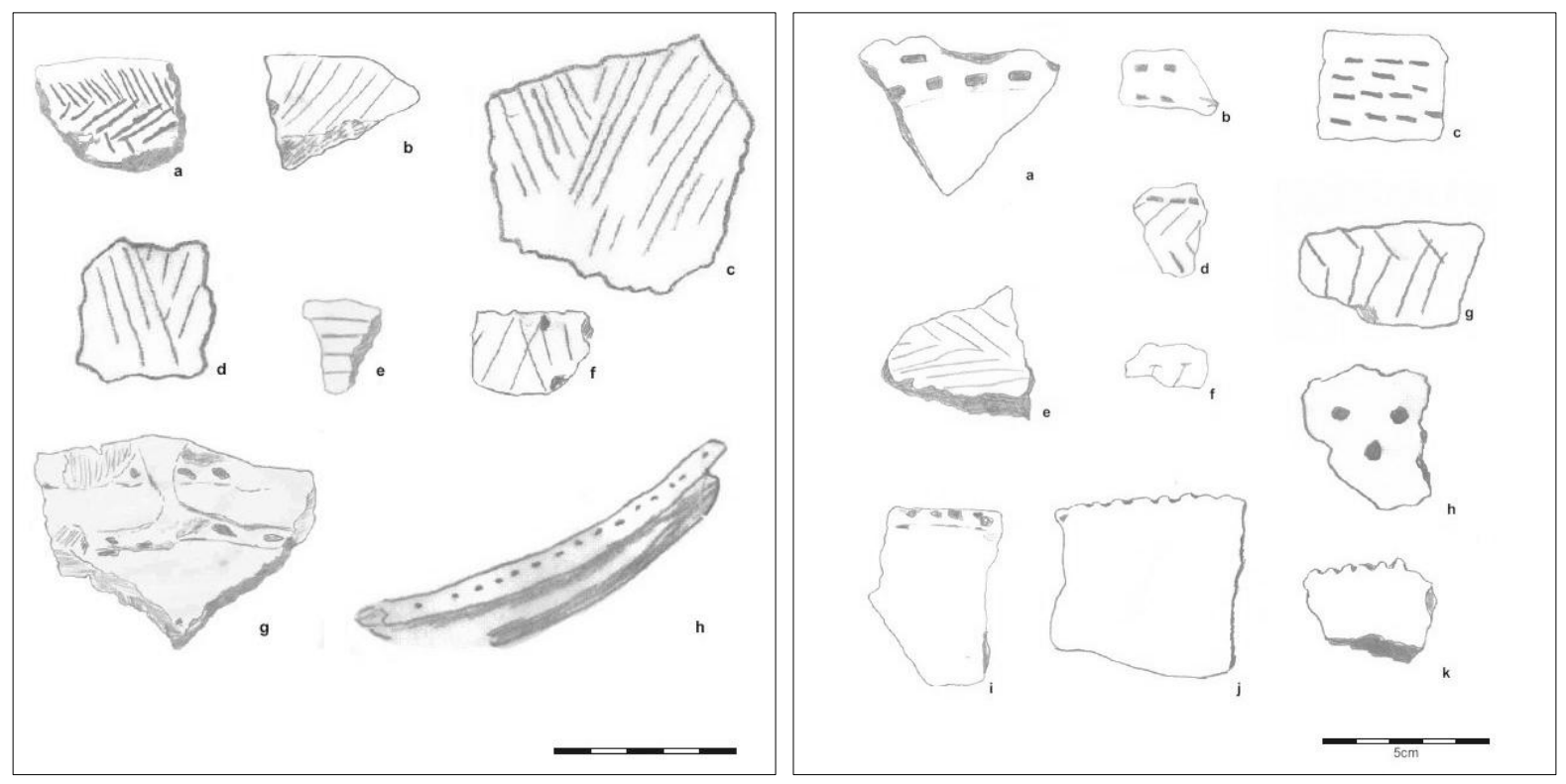

Figura 74: Cerâmica de Cocalino e Pajaú, respectivamente. (Adaptado de ROCHA, 2012).

O outro sítio escavado, Terra Preta do Mangabal (figuras 75 e 76), apresenta antiplástico de quartzo e cauixi; espessura entre 4 a $15 \mathrm{~mm}$, com média em $5 \mathrm{~mm}$; o acabamento alisado, mas também incisos, modelado, ungulado e apliques. Um motivo que se destaca é de linhas incisas cruzadas em ângulos agudos, formando losangos ou diamantes. Sabendo que a área deste sítio já havia sido ocupada pelos Munduruku, a pesquisadora indicou uma possível associação entre estes motivos de losangos incisos nos fragmentos cerâmicos e estes mesmos motivos na pintura corporal Munduruku.

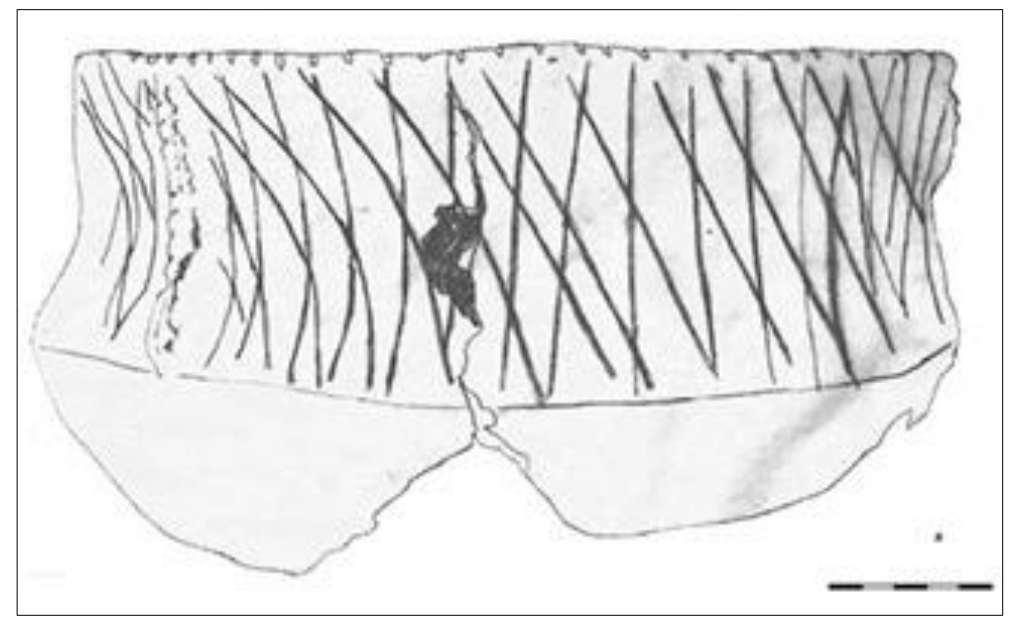

Figura 75: Cerâmica de Terra Preta do Mangabal. (Adaptado de ROCHA, 2012). 


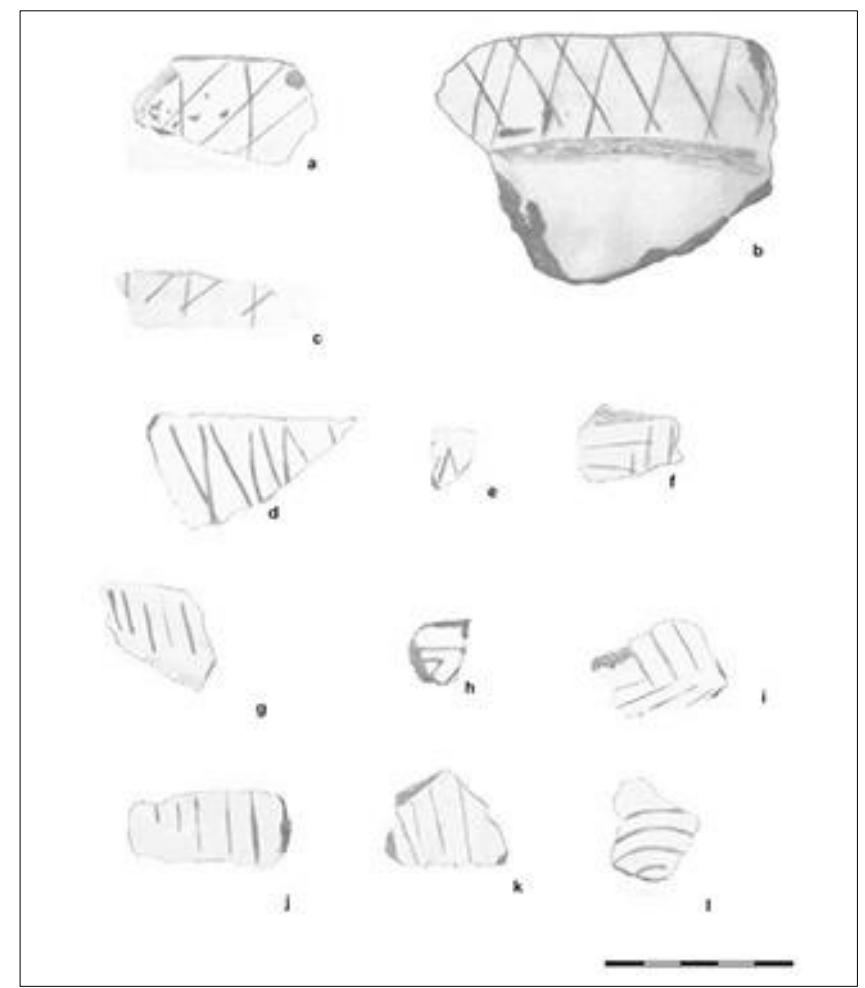

Figura 76: Cerâmica de Terra Preta do Mangabal. (Adaptado de ROCHA, 2012).

Em Parauá, próximo a Santarém, Denise Gomes (2008) descreve uma cerâmica (figura 77) que pode ter similaridades com a Tradição Borda Incisa. A manufatura é feita pela técnica de acordelamento, utilizando como antiplástico o cauixi e uma associação dele com outros materiais (quartzo, caco moído, caraipé). Predominam as vasilhas de formato esférico, contorno infletido, borda inclinada interna, lábio arredondado ou plano; vasilhas com formato de calota esférica, borda inclinada externa, lábio plano ou arredondado. As bases planas são mais frequentes, mas também encontra-se base em pedestal, convexa e de pés cônicos. A capacidade volumétrica foi calculada para algumas vasilhas, sendo as mais frequentes de 1,1 a 4 litros e de 4,2 a 12 litros, com algumas vasilhas pequenas, entre 0,5 a 1 litro. A maior parte dos fragmentos é alisada, mas a decoração diagnóstica do conjunto são incisões transversais e verticais, colocadas em bandas abaixo das bordas. Também se encontra ponteado na parte interna das bordas extrovertidas, em fileira única sobre os lábios, e raros apêndices zoomorfos. A pintura vermelha (Münsell 7.5 YR 5/8) é rara. A pesquisadora observa que esses elementos também são indicativos de uma afinidade desta cerâmica com a Tradição Uru e outros conjuntos amazônicos sendo possível que ela tenha uma origem amazônica (GOMES, 2008: 7; 2005). 


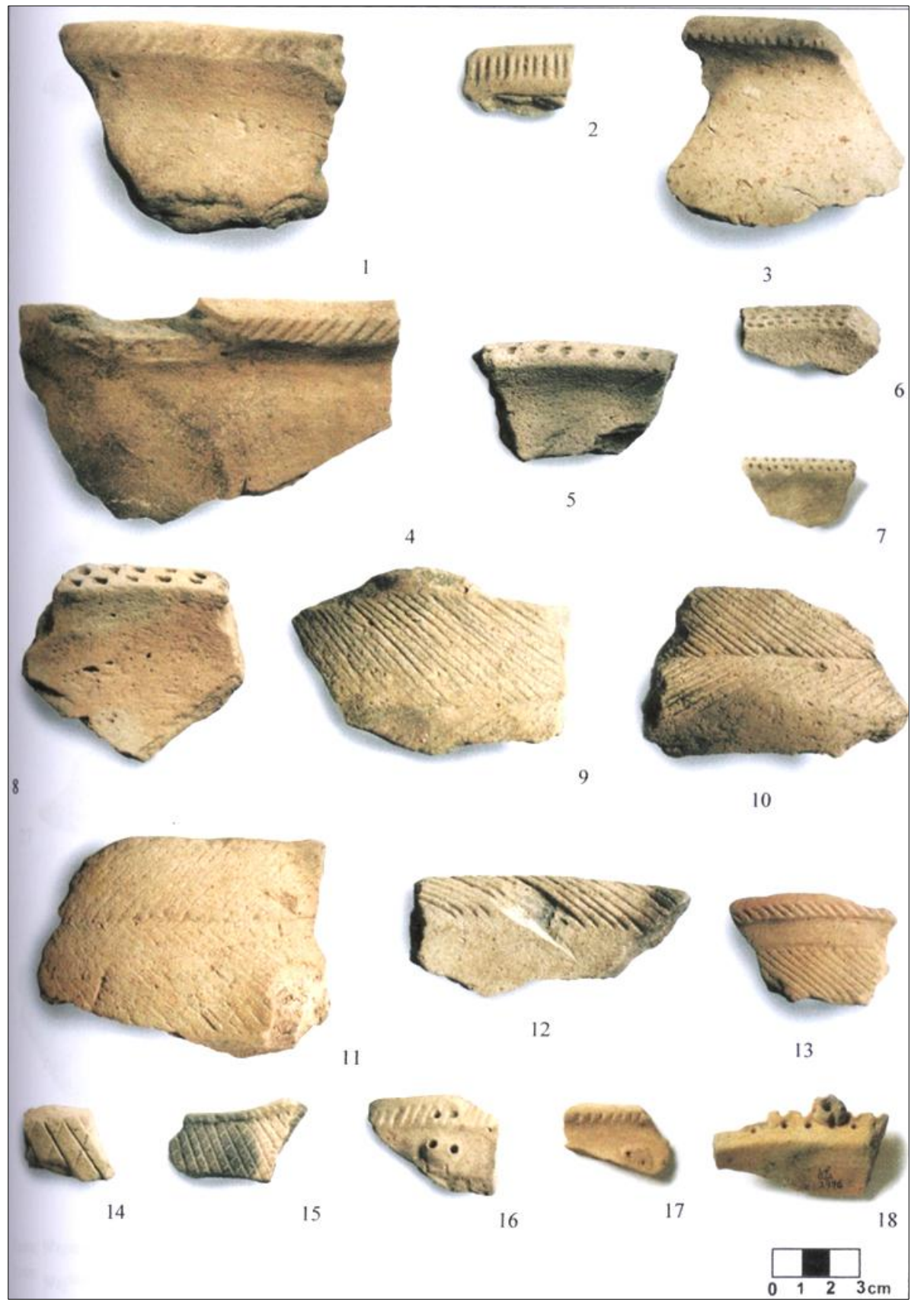

Figura 77: Cerâmica de Parauá, com ponteado no lábio e incisos com motivos de espinha de peixe. (Cf. GOMES 2005: 240).

\subsection{Cerâmica Etnográfica}

Existe também a possibilidade de que os conjuntos cerâmicos escavados na T. I. Kaiabi sejam similares ou mesmo pertençam às populações indígenas que historicamente habitaram e habitam a região. Relatos históricos sugerem que essa região foi predominantemente ocupada por povos Tupi, sendo ainda hoje ocupada por esses povos, 
como os Munduruku, Apiaká e Kaiabi. No entanto, como a Tradição Inciso-Ponteado pode estar relacionada a povos de língua Karib e a região do Alto Teles Pires é habitada pelos Bakairi (povo Karib, que tem relações históricas de inimizade com os Kaiabi), não descartamos a possibilidade de que povos Karib também ocupassem essa região.

Apesar de existirem relatos históricos sobre esses povos, são poucas as informações e imagens sobre sua produção cerâmica, mas o que encontramos sobre esse assunto descrevemos aqui. Além disso, já faz algum tempo que nenhum deles fabrica mais vasilhas cerâmicas, tendo-as substituído gradualmente por panelas de alumínio. É por isso que raramente encontramos informações sobre esses objetos nas pesquisas etnográficas mais recentes.

\subsubsection{Cerâmica Kaiabi}

A produção cerâmica entre os Kaiabi é uma atividade que foi diminuindo ao longo do tempo devido a sua substituição por vasilhas de alumínio (VILLAS BÔAS, 1989; GRÜNBERG, 2004; STUCHI, 2010). Além do mais, com a transferência dos Kaiabi do Tatuy para o Parque Indígena do Xingu, as mulheres foram deixando de produzir vasilhas, pois já não dispunham mais do barro que utilizavam e precisavam adicionar outros tipos de materiais à argila, como o cauixi, produzindo resultados não satisfatórios para elas (GRÜNBERG, 2004: 288).

Os irmãos Villas Bôas (1989: 60) registraram o processo de fabricação de vasilhas cerâmicas entre os Kaiabi do rio São Manuel, ou Teles Pires. As mulheres escolhiam o barro apropriado para a confecção das vasilhas, misturando-o com o pó do carvão de uma casca de árvore determinada, sendo amassado com as mãos até adquirir a uniformidade desejada. Cada vasilha era feita com a sobreposição de roletes que eram depois alisados com um caramujo, estando a vasilha em uma cova rasa e circular aberta no chão. Após a secagem da peça, ela é retirada da cova e colocada com a abertura para baixo sobre um monte de cinza quente, para então ser queimada em uma estrutura feita com a cascas de árvore. O acabamento final é dado por uma resina na superfície da vasilha, feita de seiva vegetal. Na ocasião, os Villas Bôas (1989: 60-61) encontraram os seguintes tipos de vasilhas:

- Iapepó-ú: para a preparação de diversos tipos de mingau. Com mais ou menos $70 \mathrm{~cm}$ de diâmetro e $50 \mathrm{~cm}$ de altura; 
- Iapepó-ivicú: como um caldeirão, medindo $50 \mathrm{~cm}$ de diâmetro e $60 \mathrm{~cm}$ de altura;

- Iapepó-iurú-em: panela grande de forma afunilada, com o diâmetro da boca maior que o do fundo;

- Iapepó-uá: panela de forma alongada, oblonga (mais comprida do que larga);

- Iapepó-Ugát: idêntica à anterior, mas com o formato de uma canoa;

- Iapepó-urú-í: um caldeirão com a boca mais estreita do que o fundo;

- Iapepó-ií: panela rasa e pequena;

- Iapepó-namim: panela pequena, com um apêndice de apoio para as mãos, em forma de "orelha";

- Iapepó-muiáp: uma travessa rasa com duas divisões, separadas por um ressalte transversal;

- Iamép: uma chapa circular com as bordas levemente levantadas;

- Iamé-ií: idêntico ao anterior, mas de tamanho pequeno e utilizado para a preparação de beijus;

- Iamé-uú: idêntico ao anterior, mas de tamanho grande e utilizado para torrar farinha.

Também temos algumas informações esparsas sobre a produção cerâmica Kaiabi ao longo do panorama geral sobre cerâmica de povos indígenas no Brasil de Tânia Andrade Lima (1986: 174 a 177). Segundo a autora, os Kaiabi (provavelmente os que habitam no Parque Indígena do Xingu) se deslocam por vários dias em expedições para buscar argila, que é depois amassada e socada em um pilão com água, misturando-se a casca queimada da árvore takupip. Para a queima, usam como trempe (apoio para as vasilhas) pedras ou fragmentos de termiteiras, enchendo de brasa o interior das vasilhas, sendo proibido às mulheres falar, defecar ou urinar durante esse processo. Como acabamento, passam uma resina de simaneiro no interior e exterior das vasilhas.

O relato mais completo é o de Georg Grünberg, para os Kaiabi do Teles Pires (2004: 139-140). As mulheres fazem panelas de barro para o preparo da chicha e o cozimento de carne, peixe, feijão, cogumelos e diversos outros produtos alimentícios. A argila utilizada era 
branca, obtida pelos homens na estação seca, nas margens do rio a três dias de viagem acima da aldeia de Temeoni (antigo chefe dso Kaiabi). Os torrões eram armazenados dentro de casa, sendo triturados depois de secos com um pilão e um pouco de água. A argila era misturada com o carvão peneirado da queima da casca de uma árvore, takupe $i / p$, resultando em uma massa preta. A vasilha era manufaturada sobre um suporte de terra laterítica, seca e peneirada, sendo a base modelada no formato de uma tigelinha para então sobreporem-se os roletes, formando a parede. A parede era alisada com uma concha fluvial (Unio sp) e polida com uma pedra-sabão lisa. Apesar de trabalhar ao sol, para a secagem as peças eram primeiramente postas sob a sombra, voltando ao sol após algumas horas e completando sua secagem perto do fogo, com cinzas dentro da vasilha, até $1 / 4$ de altura. As peças, então de coloração cinza escuro, são colocadas sobre pedaços de pedra e cupinzeiro, bem juntas mas sem se tocarem, recheadas de cinzas e cobertas com cascas de takupe $i / p$ para serem queimadas. Essa estrutura forma um cone e em seu topo são colocadas folhas secas de palmeira, retiradas dos telhados das casas, queimando as cascas de cima para baixo durante uma meia hora. Durante a queima, é proibido falar, urinar e defecar para que a cerâmica não quebre. Finalmente, as vasilhas queimadas e frias ficam com uma coloração preta com manchas vermelhas, sendo impermeabilizadas por dentro e por fora com a seiva da casca de simaneiro, morii/p.

Grünberg (2004: 139) retirou a medida de 3 vasilhas cerâmicas: 10,8 cm de altura e $12 \mathrm{~cm}$ de diâmetro; $13 \mathrm{~cm}$ de altura e $16 \mathrm{~cm}$ de diâmetro; e $18 \mathrm{~cm}$ de altura e $25 \mathrm{~cm}$ de diâmetro. Ele também menciona que Schmidt (1929: 95, in GRÜNBERG, 2004: 140) trouxe em sua coleção duas panelas simples de barro.

No acervo do Museu de Arqueologia e Etnologia da USP, existe uma vasilha Kaiabi coletada pelo próprio Grünberg, com $14,5 \mathrm{~cm}$ de altura, $17,5 \mathrm{~cm}$ de diâmetro da boca, 0,6 cm de espessura e uma resina na superfície externa e interna. Além desta vasilha, acreditamos que outras 5 possam também ser Kaiabi (figura 78). Elas foram coletadas no Parque Indígena do Xingu e classificadas como Waujá, mas não se parecem com as vasilhas tradicionais deste povo. Uma delas, inclusive, tem a inscrição “Kajabi” em sua base.

No acervo do Museu Paraense Emílio Goeldi também há uma vasilha classificada como Kaiabi, que no entanto parece ser uma vasilha Juruna (CORRÊA, 2014: 163 e 220). 


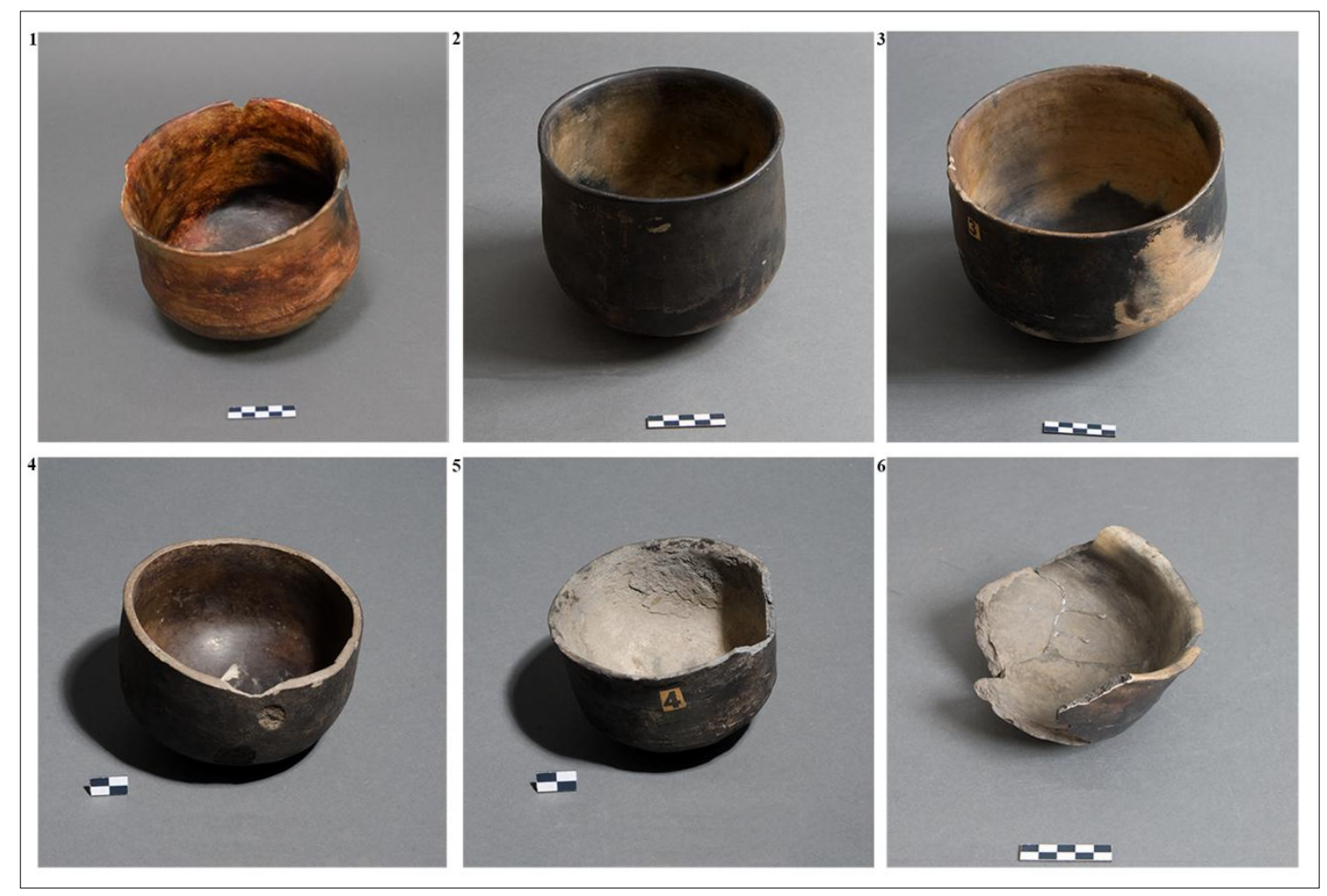

Figura 78: Vasilhas Kaiabi da coleção do Museu Paulista, agora no MAE-USP. 1: vasilha Kaiabi, coletada por Grünberg; 4: classificada como Waujá, mas tem a inscrição "Kajabi" em sua base; 2-3 e 4-6: classificadas como Waujá, mas acreditamos serem também Kaiabi. (Fotos: Ader Gotardo).

Apesar de as informações sobre as vasilhas Kaiabi serem esparsas, temos um estudo bastante detalhado sobre os grafismos Kaiabi, utilizados principalmente na cestaria, mas também na pintura corporal. Se considerarmos (assim como ROCHA, 2012) os "desenhos simbólicos de um grupo indígena" como "representações iconográficas, profundamente enraizadas nas suas vivências e na sua mitologia e, em virtude disso, emblemas de identidade étnica" (RIBEIRO, 1986: 266), essa relação entre os grafismos de diferentes suportes pode ser seriamente considerada. Diversos autores ressaltam como os mesmos motivos gráficos utilizados por um grupo são colocados em diferentes suportes materiais, desde a pintura corporal até a cestaria, couro, madeira e cerâmica (ver artigos em VIDAL [org.], 1992; DAVID et al. 1988).

Berta Ribeiro (1986: 266) descreve um dos principais grafismos Kaiabi, que é uma representação de um personagem mítico, tana ou tanga, semelhante ao $\mathrm{H}$ maiúsculo, com prolongamentos bifurcados dos membros como dedos esticados e separados. Segundo os próprios Kaiabi, esse motivo foi emprestado dos Apiaká, cujas mulheres são consideradas ótimas parceiras de casamento, pois consideram os Apiaká “como parentes, como nós, falam a mesma língua, têm as mesmas tatuagens e pertencem a nós" (RIBEIRO, 1986: 268; 
GRÜNBERG, 2004: 179). Grünberg (2004: 144) também descreve a semelhança das pinturas corporais Kaiabi e Apiaká, observada também nos relatos de Schmidt e Florence. Outra referência sobre a relação entre esses dois povos vem do mito Kaiabi de criação: o herói mítico Tuiararé cria os Apiaká a partir de cacos de cerâmica (OLIVEIRA, 2010: 46). No entanto, o relato de Grünberg (2004: 225) sobre este mito relata que Tuyararé criou os Apiaká a partir do carvão, tendo os Bakairi e Waujá sido criados a partir de cacos de cerâmica.

$\mathrm{O}$ motivo tana/tanga tem diversas variações, representando mulheres, crianças ou homens, ou representando somente braços e pernas. Ribeiro comenta, inclusive, sobre a semelhança deste motivo com o grafismo Asurini do taingawa, sendo que os Kaiabi também comentam terem uma proximidade muito grande com este grupo, separados deles pelos JêKayapó (RIBEIRO, 1986: 274). Outro motivo de grafismo similar é o do sapo kururu, associado às muitos olhos e fileiras de cipó. Todos esses motivos são utilizados na cestaria (figura 79).

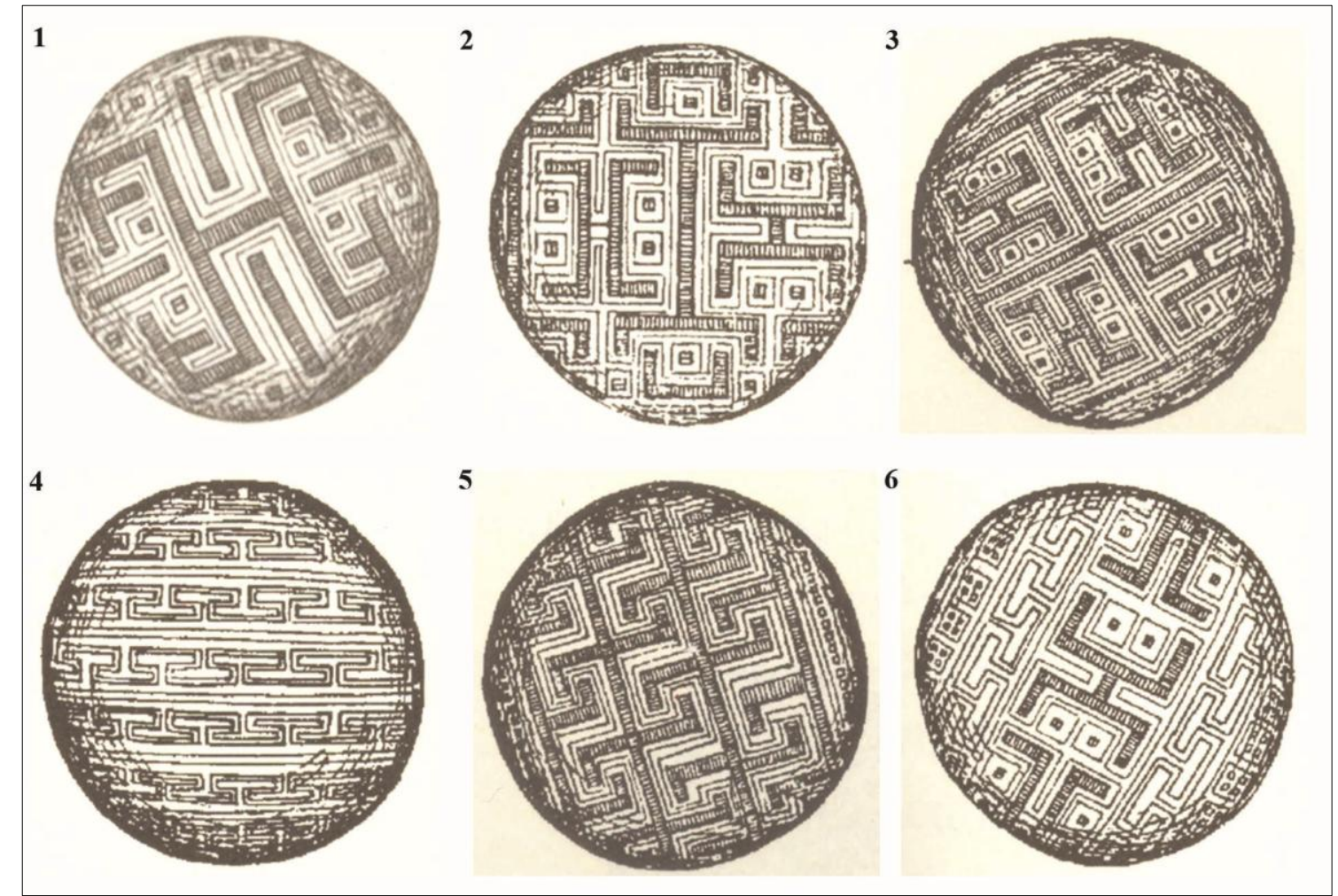

Figura 79: Grafismos na cestaria Kaiabi.1: motivo ifãe'ok; 2: Tanakuya, mulher-tanga e duas crianças-tanga; 3 : sapos kururu com os ea (olhos); 4: i/wirapui, fileiras de cipó; 5: kwatsiarapa, muitos braços; 6: sapo kururu e fileiras de cipó. (Cf: RIBEIRO, 1986: 267 e GRÜNBERG, 2004: 131-133). 


\subsubsection{Cerâmica Apiaká}

Um dos relatos para a cerâmica Apiaká é o de Nimuendaju ([1948] 1963: 316, que diz que consistia de potes, panelas e pratos, sendo que algumas vasilhas tinham forma bicônica, decoradas com uma série de ângulos retos paralelos na parte superior.

Florence (1941: 168) relata que as mulheres Apiaká seriam habilidosas ceramistas, utilizando uma argila de boa qualidade. Elas preparavam peixe em pratos de terracota e o camiú (milho socado e cozido) em uma panela de barro cozido cheia d'água. Esta última panela mede 3 palmos de altura e diâmetro, mas as paredes são finas, sendo a vasilha bastante leve. Os potes, vasos e panelas cerâmicas são descritos como tendo a forma de dois cones unidos pela base. $\mathrm{O}$ ornamento das vasilhas, apesar de ser variado, seria principalmente de ângulos retos e paralelos uns aos outros, como na pintura do rosto, peito e ventre. Vemos nas ilustrações de Florence os dois tipos de vasilhas descritos por ele (figuras 80 e 81): o prato, que seria um assador ou tostador; e a vasilha bicônica com decoração de ângulos retos e paralelos.

Como a própria descrição de Florence relaciona a pintura corporal à pintura das vasilhas, reproduzimos aqui algumas imagens da pintura corporal Apiaká (figura 82), tanto a de ângulos retos como outros motivos.

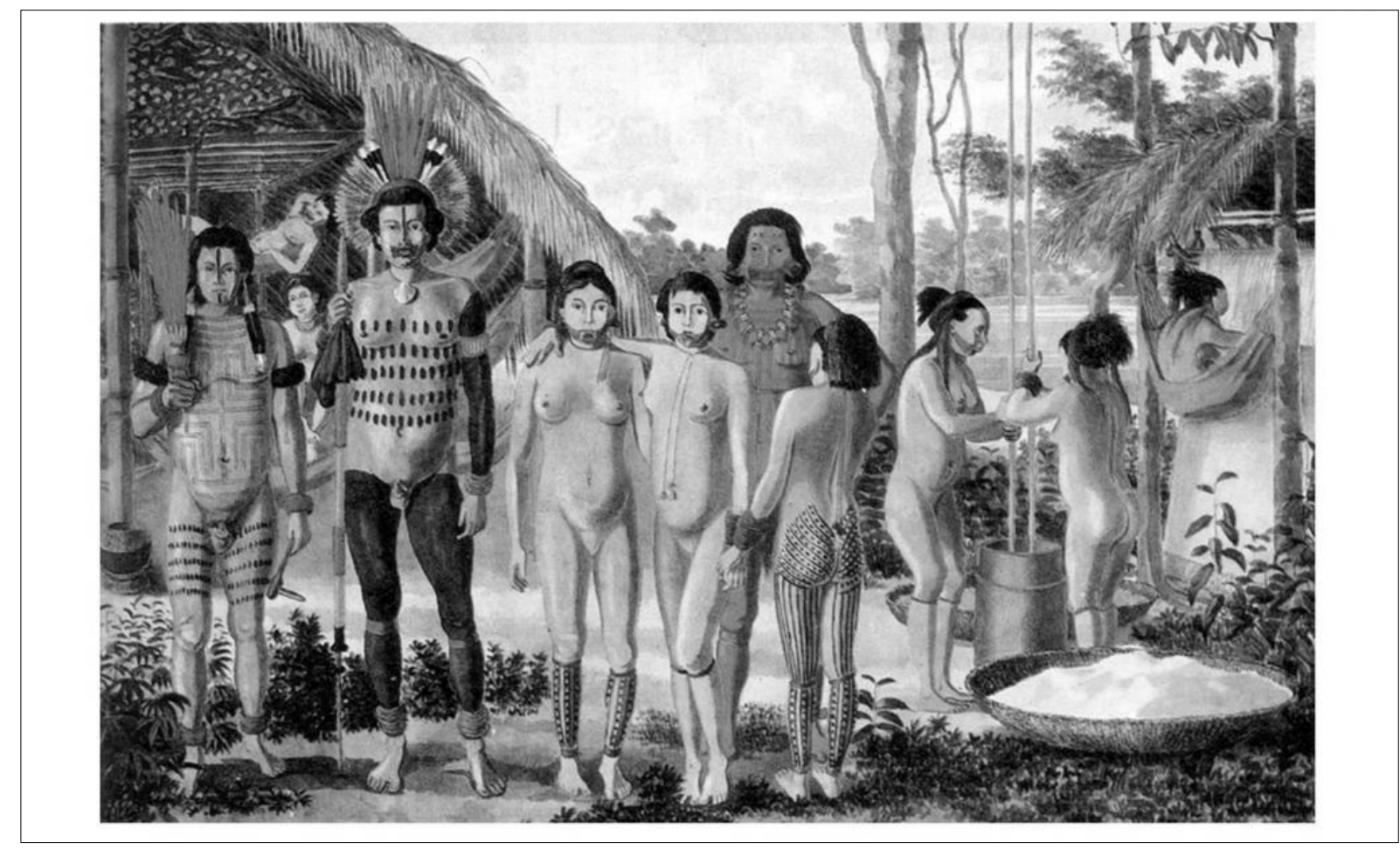

Figura 80: Maloca dos Apiaká, detalhes de vasilhas cerâmicas. (Cf: MONTEIRO, 1998: 338-339). 


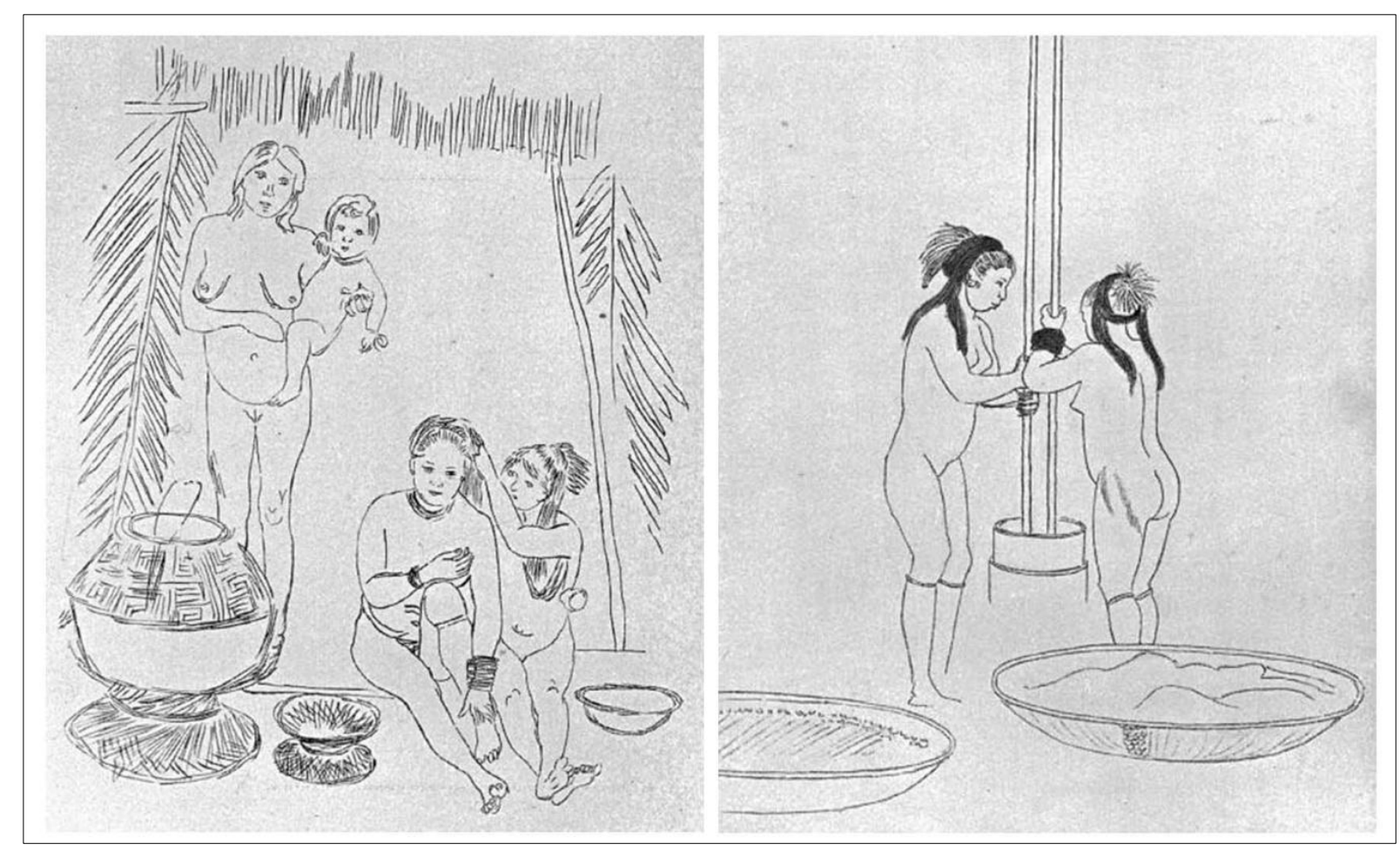

Figura 81: Os Apiaká e vasilhas cerâmicas. (Cf: FLORENCE, 1941).

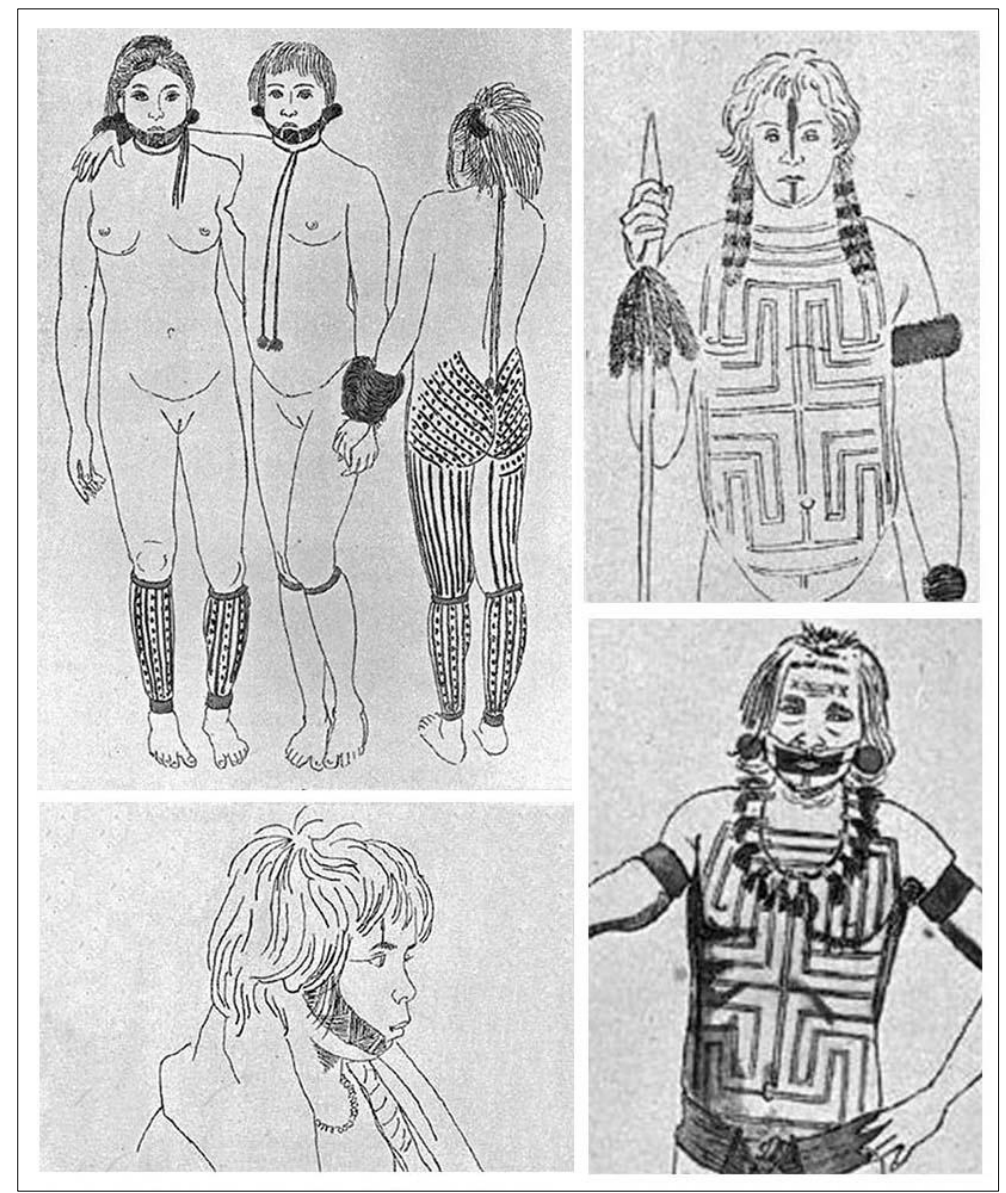

Figura 82: Pintura corporal Apiaká. (Cf: FLORENCE, 1941). 


\subsubsection{Cerâmica Munduruku}

Sobre a cerâmica Munduruku, há um breve parágrafo de Donald Horton ([1948] 1963: 276) dizendo que as mulheres modelam as vasilhas a partir de uma massa de argila, sendo uma cerâmica de baixa qualidade. Ele também menciona que as cinzas dos mortos (principalmente os homens altos) são depositadas em jarros. Murphy (1960: 67-68) relata que antes de começarem a tostar o beiju coletivamente em grandes panelas de cobre, as Munduruku utilizavam frigideiras de cerâmica, bem menores que as panelas, e que serviam somente a unidade doméstica. Florence (1825-1829) mostra em uma ilustração uma mulher cozinhando em um assador (figura 83).

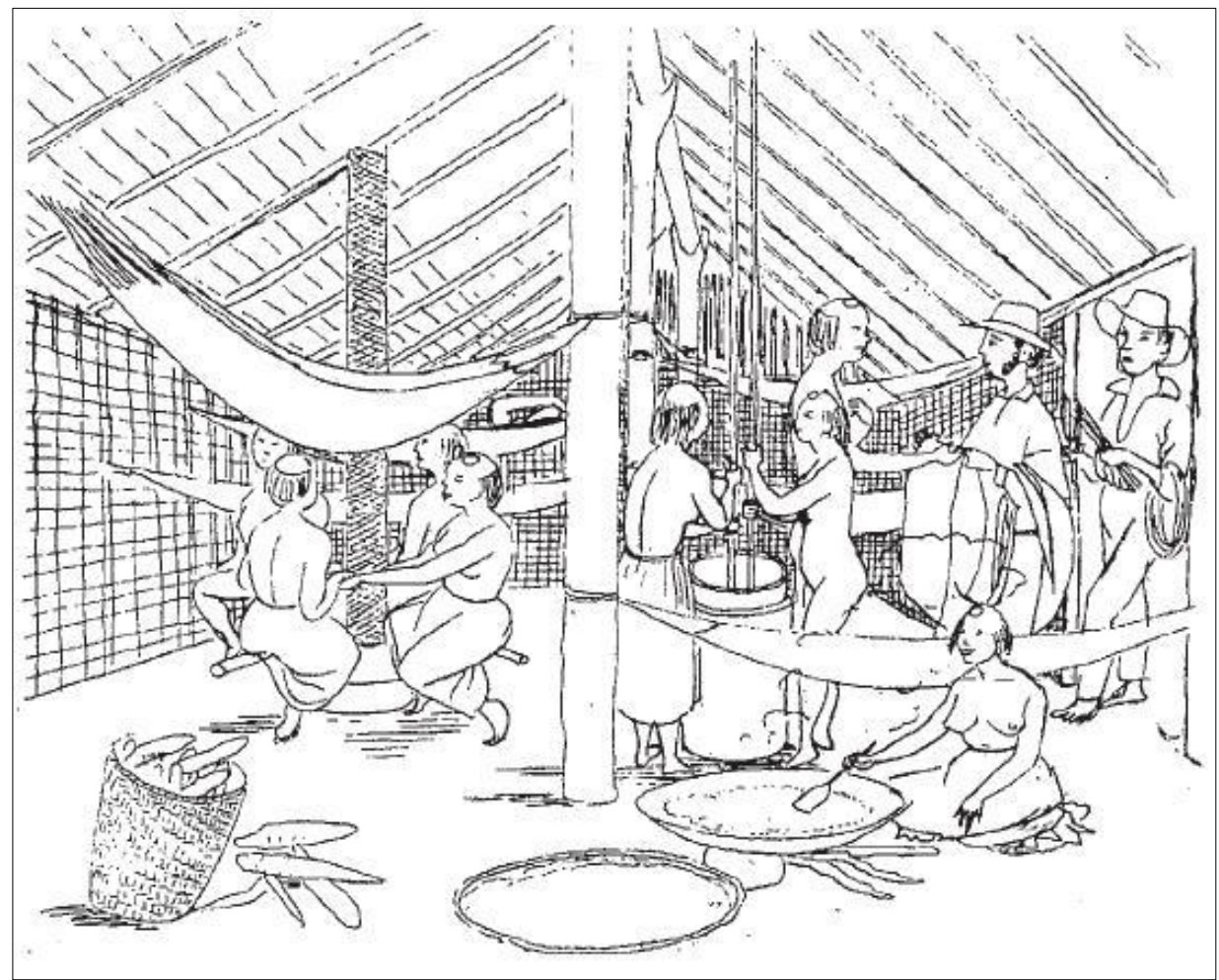

Figura 83: Interior de uma habitação Munduruku, com vasilhas cerâmicas. (Cf: FLORENCE, 1941).

Em seu mestrado, Bruna Rocha (2012) sugere que um tipo de cerâmica com motivos de losangos incisos poderia ser Munduruku, pois são motivos muito semelhantes aos da pintura corporal deste povo. Algumas ilustrações de Florence e Taunay nos mostram esse padrão de pintura corporal (figura 84), muito semelhante aos padrões dos fragmentos 
encontrados por Rocha, descritos na primeira parte deste capítulo. O próprio Florence relata que a cerâmica Munduruku é ornamentada com motivos de losangos (FLORENCE, 1941).

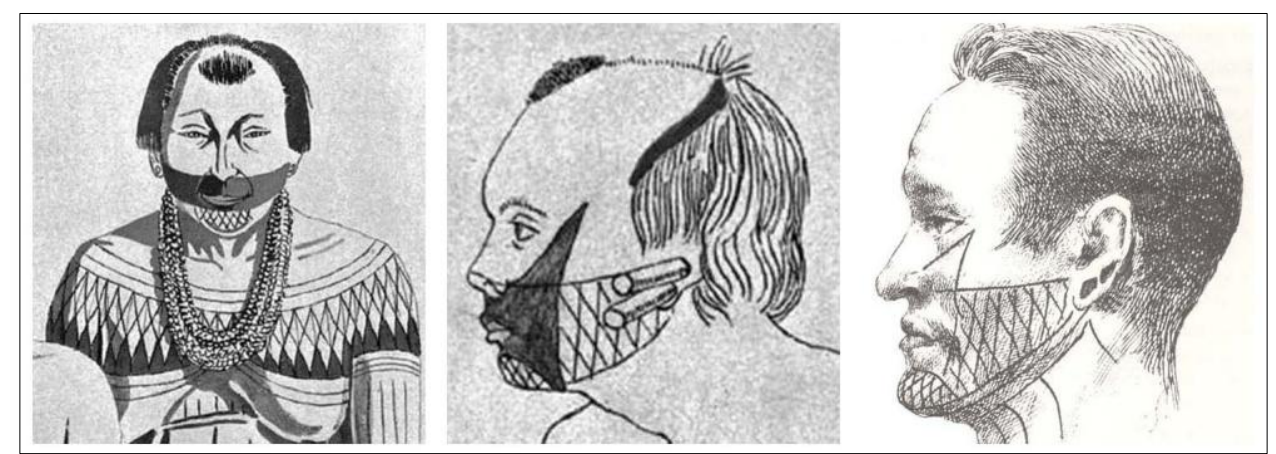

Figura 84: Pintura corporal Munduruku, com motivos losangulares. (Cf: FLORENCE, 1941 e COUDREAU, 1977:110).

Existem 2 vasilhas, de formas globulares e base plana, classificadas como Munduruku no Museu Nacional que são descritas por Andrade Lima (1986: 208): uma de contorno complexo, borda extrovertida, alisada, com resina em ambas as faces, $14 \mathrm{~cm}$ de altura e $23 \mathrm{~cm}$ de diâmetro da boca; a outra de contorno composto, base em pedestal, borda introvertida, duas linhas grossas vermelhas que se cruzam na parte interna, resina na face externa, $11 \mathrm{~cm}$ de altura e $18 \mathrm{~cm}$ de diâmetro da boca. No entanto, pode ser que essas vasilhas não sejam realmente Munduruku, mas sim Wajapi (com. pessoal Ângelo Correa, 2014).

Encontramos também algumas imagens de vasilhas Munduruku (em um museu de Alter do Chão e em uma loja que vende artesanato indígena em São Paulo) que são bastante diferentes dos fragmentos arqueológicos encontrados e sem os motivos da pintura corporal (figuras 85 e 86). São cerâmicas arqueológicas encontradas nas atuais terras Munduruku, sem mais informações específicas do contexto em que foram encontradas e da relação dos Munduruku com elas. É uma cerâmica alisada, de coloração escura, com apliques ondulados na borda e apêndices. Uma delas parece ter uma pintura vermelha sobre engobo branco, com motivos lineares. 


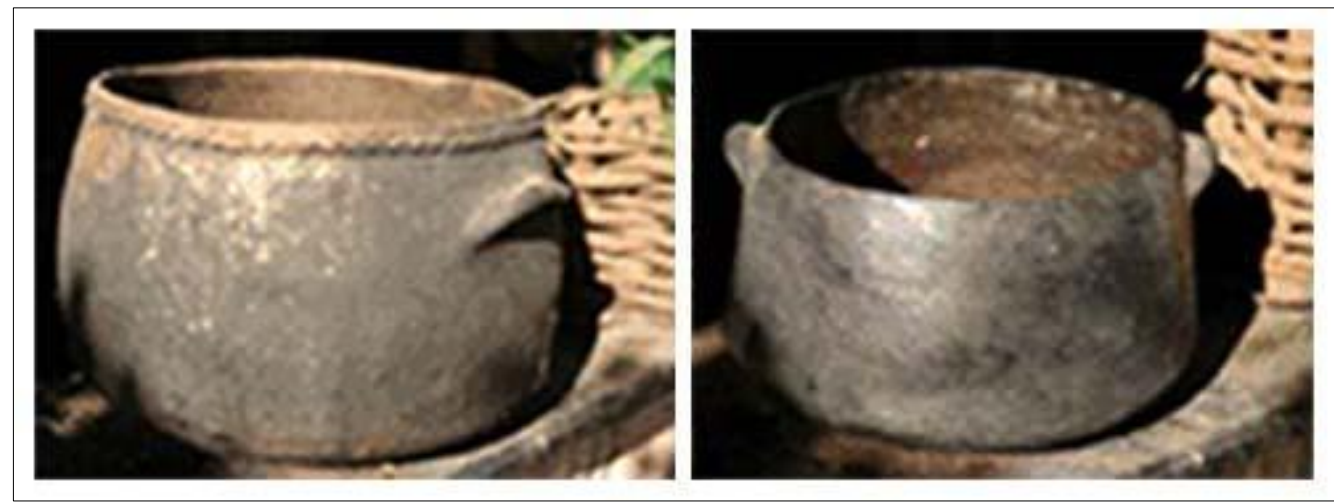

Figura 85: Vasilhas Munduruku. (Cf: ARARIBAH).

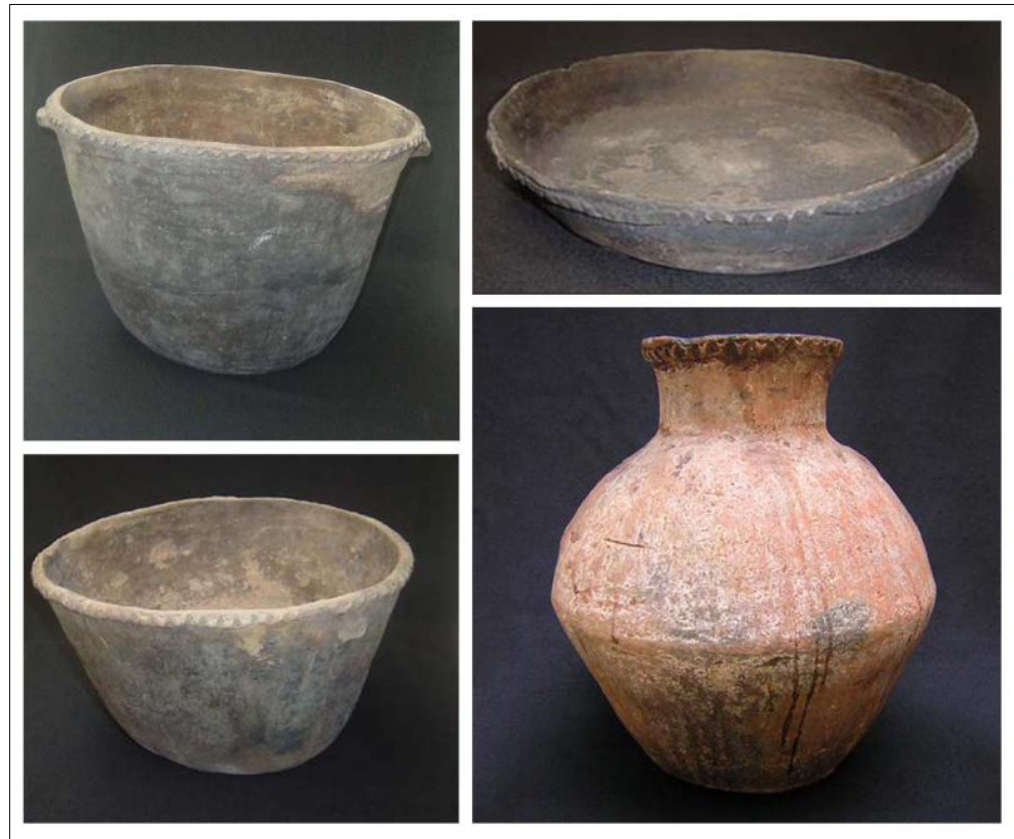

Figura 86: Vasilhas Munduruku. (Cf: IANDE).

Um último comentário em relação à cerâmica Munduruku vem de Hilbert (1958) que investigou as urnas arqueológicas escavadas pelo frei Protásio Frikel no rio Cururu, afluente do Tapajós. Estando localizadas em área Munduruku, o pesquisador procurou uma relação desse povo com a cerâmica arqueologica, sem resultados afirmativos. Segundo ele, as vasilhas Munduruku utilizariam caraipé como tempero, e não cauixi como nas urnas; seriam modeladas, e não roletadas; e os próprio Munduruku não reconheceram essas urnas como sendo deles, além de desconhecerem o enterramento secundário (HILBERT, 1958: 11). 


\subsubsection{Cerâmica Bakairi}

Os Bakairi são um povo de língua Karib, família linguística de origem no norte da América do Sul. Provavelmente os Bakairi chegaram à região onde se encontram atualmente (entre os rios Paranitinga e Arinos) percorrendo o Vale do Tapajós (BARROS, 2003).

Encontramos poucos relatos sobre o processo de produção da cerâmica entre os Bakairi, mas temos descrições de Karl von den Steinen e Max Schmidt, que passaram bastante tempo com esse povo no altos Teles Pires antes de irem ao Xingu. Segundo Schmidt (1947), os Bakairi do Posto de Simões Lopes importavam muitos objetos do Alto Xingu, principalmente vasilhas dos Mehinako, já que as mulheres diziam que o barro a que tinham acesso não era próprio para fabricar cerâmica. Andrade Lima (1986: 208) menciona que os Waujá, como grandes produtores de cerâmica, acabam exportando suas vasilhas para outros grupos próximos, muito mais do que os Mehinako.

Schmidt chega a descrever 3 vasilhas que levou para o Museu Etnológico de Berlin (figura 87). A primeira vasilha tem uma boca que representa um morcego, com diâmetro superior a $26,5 \mathrm{~cm}$ e altura $10,5 \mathrm{~cm}$; a coloração é escura e na parede exterior está aplicada uma pintura marrom de listras paralelas verticais, sendo que na base estas listras formam círculos concêntricos. A segunda vasilha tem altura $11,5 \mathrm{~cm}$ e diâmetro da boca superior a 26 $\mathrm{cm}$. A terceira vasilha tem altura $12,5 \mathrm{~cm}$ e diâmetro da boca superior a $20 \mathrm{~cm}$.

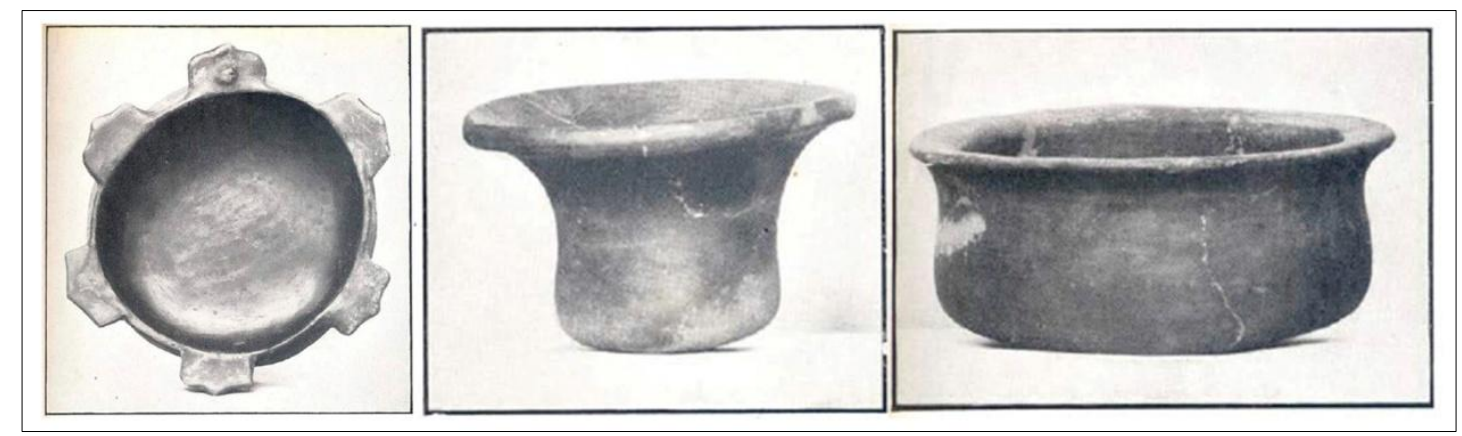

Figura 87: Vasilhas coletada entre os Bakairi de Simão Lopes. (Cf: SCHMIDT, 1947: 87).

Em uma ilustração da expedição de Karl von den Steinen (1942), podemos ver no chão algumas vasilhas simples, que talvez possam ser as vasilhas feitas pelos Bakairi (figura 88). 


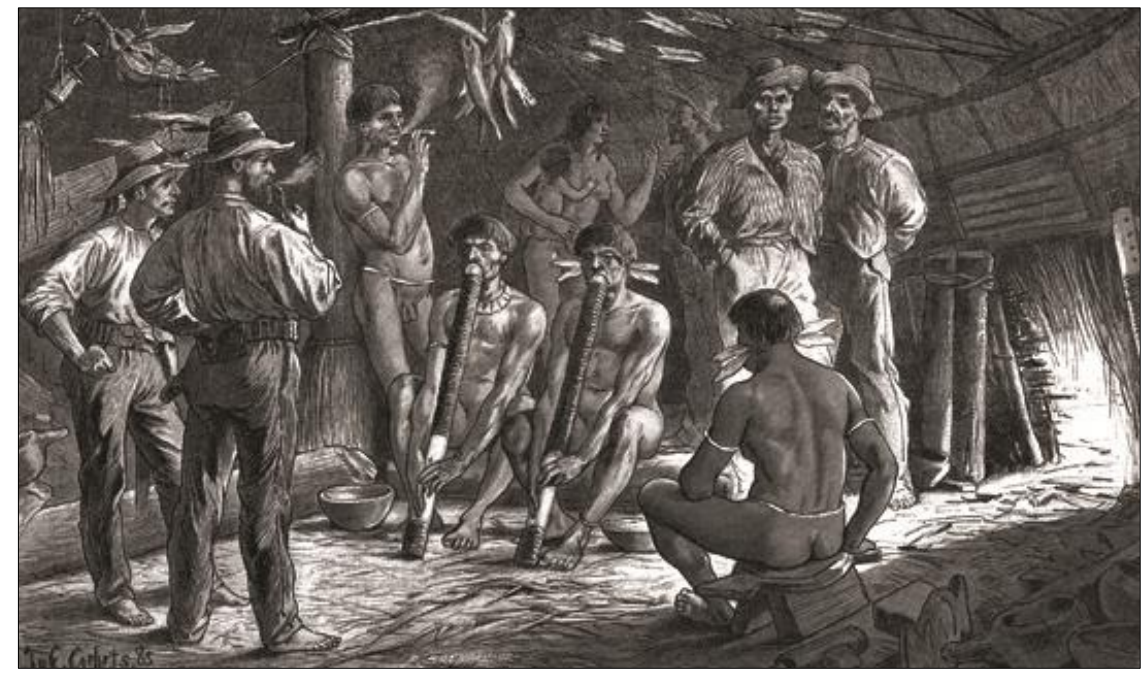

Figura 88: Ilustração de um dueto de flautas Bakairi, onde se observam vasilhas cerâmicas espalhadas pelo chão. (Cf: von den STEINEN, 1942: 202).

Por meio do catálogo online do Museu Etnológico de Berlin, conseguimos localizar uma foto de cerâmica Bakairi e algumas ilustrações de objetos Bakairi que incluem objetos cerâmicos (figura 89). Todas essas imagens mostram vasilhas muito semelhantes à cerâmica Waujá ou Mehinako. No entanto, em uma foto de uma família Bakairi conseguimos distinguir uma vasilha de formato simples, alisada, semelhante às vasilhas da ilustração acima.

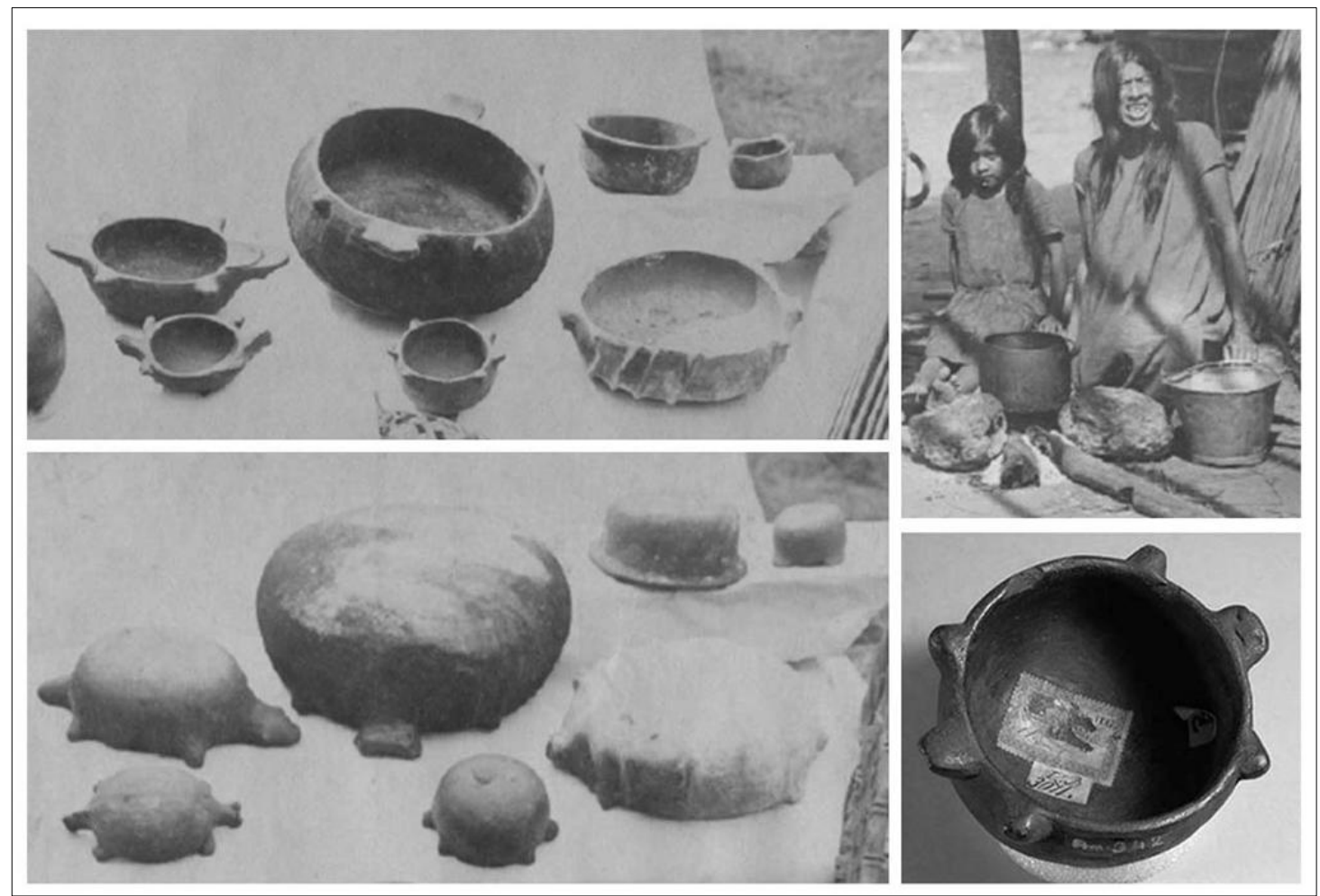

Figura 89: Vasilhas Bakairi, da coleção do Museu Etnográfico de Berlin. 
No MAE, existe um objeto fragmentado catalogado como uma vasilha Bakairi (figura 90), que poderia ser uma vasilha em miniatura, com características da cerâmica Waujá ou Mehinako.

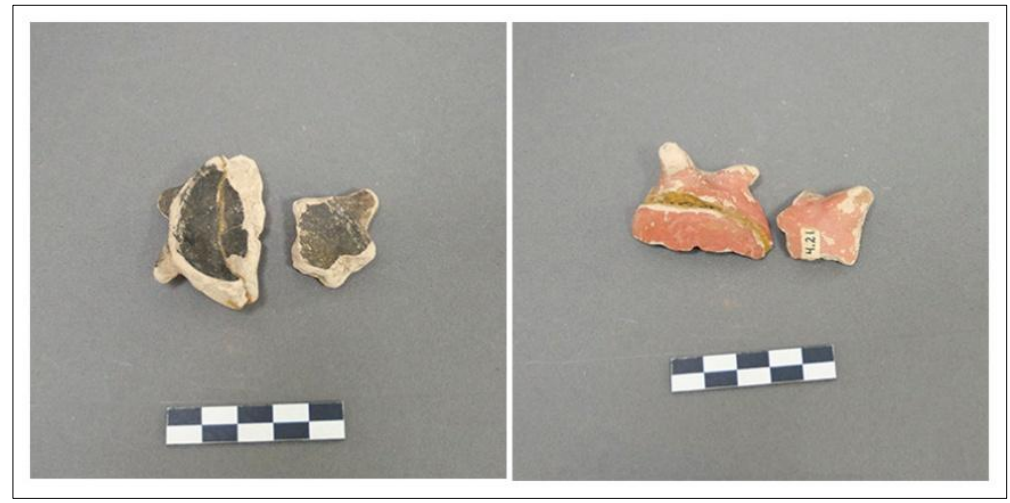

Figura 90: Vasilha fragmentada Bakairi, do acervo Plínio Ayrosa do MAE-USP. (Foto: Ader Gotardo).

\subsection{Reflexões comparativas}

Para organizar os dados etnográficos e arqueológicos relativos à fabricação da cerâmica, colocamos as informações em tabelas (tabelas 20, 21 e 22) de acordo com a cadeia operatória de produção de uma vasilha cerâmica (Cf. SILVA, 2000b), para também ser possível uma comparação com os conjuntos cerâmicos que identificamos na T. I. Kaiabi, resumidos na tabela 19 .

Estas comparações ainda são insuficientes e superficiais, no entanto esperamos que já apontem alguns caminhos para o aprofundamento das pesquisas com os conjuntos cerâmicos nesta área. 
Cerâmica Arqueológica - Brasil Central

\begin{tabular}{|c|c|c|c|c|c|}
\hline Classificação & Classificação & Tradição Una & Tradição Aratu & Tradição Uru & $\begin{array}{l}\text { Tradição Tupi- } \\
\text { guarani (no Mato } \\
\text { Grosso) }\end{array}$ \\
\hline \multirow[b]{2}{*}{$\begin{array}{l}\text { Preparação } \\
\text { da matéria- } \\
\text { prima }\end{array}$} & Argila & & & & \\
\hline & Antiplástico & $\begin{array}{l}\text { Mineral; pouco } \\
\text { caraipé e partículas } \\
\text { brancas de origem } \\
\text { animal não } \\
\text { identificadas }\end{array}$ & $\begin{array}{l}\text { Mineral; gradualmente } \\
\text { substituído por caraipé }\end{array}$ & Caraipé & $\begin{array}{l}\text { Caco moído, } \\
\text { mineral }\end{array}$ \\
\hline \multirow[b]{3}{*}{$\begin{array}{l}\text { Construção } \\
\text { da Vasilha }\end{array}$} & Manufatura & & & & Roletes \\
\hline & Espessura & 0,3 e $1 \mathrm{~cm}$ & 0,5 a $1,5 \mathrm{~cm}$; até $3 \mathrm{~cm}$ & entre 1 e $1,5 \mathrm{~cm}$ & \\
\hline & Morfologia & $\begin{array}{l}\text { Tamanho: pequeno } \\
\text { Contorno: simples ou } \\
\text { infletido } \\
\text { Forma: pratos rasos, } \\
\text { tigelas, panelas }\end{array}$ & $\begin{array}{l}\text { Base: arredondadas, } \\
\text { côncavas ou furadas } \\
\text { Borda: sem reforço, } \\
\text { diretas e extrovertidas } \\
\text { Apêndice: asa, aplique } \\
\text { mamilonar } \\
\text { Tamanho: grande } \\
\text { Forma: periformes, } \\
\text { esféricas ou elipsoides; } \\
\text { vasilha geminada; } \\
\text { cônicas, globulares e } \\
\text { semi-globulares }\end{array}$ & $\begin{array}{l}\text { Borda: acasteladas, } \\
\text { extrovertidas e } \\
\text { reforçadas Apêndice: } \\
\text { asa ou alça } \\
\text { Tamanho: grande } \\
\text { Forma: pratos e } \\
\text { assadores, tigelas rasas } \\
\text { de borda reforçada, } \\
\text { jarros, jarras com } \\
\text { pescoço e tijelas com } \\
\text { base plana }\end{array}$ & $\begin{array}{l}\text { Base: convexas ou } \\
\text { ovaladas; planas } \\
\text { Borda: reforçadas } \\
\text { Forma: vasos } \\
\text { compostos ou } \\
\text { complexos }\end{array}$ \\
\hline Queima & Coloração & $\begin{array}{l}\text { Cor: escura; preto, } \\
\text { marrom e cinza }\end{array}$ & & & \\
\hline $\begin{array}{l}\text { Acabamento } \\
\text { de superfície }\end{array}$ & $\begin{array}{l}\text { Acabamento } \\
\text { de superfície } \\
\text { fe }\end{array}$ & $\begin{array}{l}\text { Alisamento } \\
\text { Acabamento plástico: } \\
\text { raros inciso e } \\
\text { ponteado } \\
\text { Acabamento pintado: } \\
\text { engobo branco e } \\
\text { vermelho }\end{array}$ & $\begin{array}{l}\text { Acabamento plástico: } \\
\text { inciso, entalhe, ungulado, } \\
\text { ponteado, impressões } \\
\text { digitais, apliques } \\
\text { Acabamento pintado: } \\
\text { banho vermelho e pintura } \\
\text { preta } \\
\text { Base: impressão de folha } \\
\text { ou furos } \\
\text { Borda: acastelada }\end{array}$ & $\begin{array}{l}\text { Acabamento plástico: } \\
\text { apêndices ou apliques, } \\
\text { Acabamento pintado: } \\
\text { pintura preta sobre } \\
\text { vermelha Borda: } \\
\text { pequenas incisões, } \\
\text { ungulações ou entalhes }\end{array}$ & $\begin{array}{l}\text { Acabamento } \\
\text { plástico: } \\
\text { corrugado, } \\
\text { ungulado, digitado, } \\
\text { raspado, escovado } \\
\text { Acabamento } \\
\text { pintado: } \\
\text { policromia, banhos }\end{array}$ \\
\hline \multirow[t]{3}{*}{$\begin{array}{l}\text { Função e } \\
\text { Uso }\end{array}$} & Função e Uso & Cozinhar, servir. & $\begin{array}{l}\text { Cozinhar, servir, ritual: } \\
\text { urnas funerárias } \\
\text { Outros: rodelas de fuso, } \\
\text { carimbos, cachimbos } \\
\text { tubulares }\end{array}$ & $\begin{array}{l}\text { Cozinhar: } \\
\text { processamento de } \\
\text { mandioca, farinha } \\
\text { Líquidos: estocagem de } \\
\text { água, fermentação e } \\
\text { conservação de bebidas } \\
\text { Outros: carimbos, } \\
\text { suportes de panela } \\
\end{array}$ & $\begin{array}{l}\text { Cozinhar, servir, } \\
\text { líquidos, ritual. }\end{array}$ \\
\hline & Data & $\begin{array}{l}200 \text { a. C. - o início da } \\
\text { era Cristã } \\
\text { Mais antiga } 3.490 \text { AP }\end{array}$ & $\begin{array}{l}\text { início séc IX d. C. - } 1500 \\
\text { d. C. }\end{array}$ & séc VIII d. C. & séc XIII e XV dC \\
\hline & Fontes & $\begin{array}{l}\text { Wüst e Schmitz 1975, } \\
\text { Wüst e Barreto 1999, } \\
\text { Wüst (1990) }\end{array}$ & $\begin{array}{l}\text { Schmitz 1976-77 } \\
\text { Schmitz e Barbosa } 1985 \\
\text { Wüst e Barreto } 1999 \\
\text { Wüst (1990) }\end{array}$ & $\begin{array}{l}\text { Schmitz 1976-77 } \\
\text { Schmitz e Barbosa } 1985 \\
\text { Wüst e Barreto } 1999 \\
\text { Wüst (1990) }\end{array}$ & Wüst (1990) \\
\hline
\end{tabular}

Tabela 20: Características dos conjuntos cerâmicos arqueológicos no Brasil Central. 
Cerâmica Arqueológica - Mato Grosso e Amazônia Meridional

\begin{tabular}{|c|c|c|c|c|c|}
\hline Classificação & Classificação & $\begin{array}{l}\text { Tradição Borda } \\
\text { Incisa (Parauá) }\end{array}$ & $\begin{array}{c}\text { Tradição Inciso } \\
\text { Ponteado (Pajau e } \\
\text { Cocalino) } \\
\end{array}$ & $\begin{array}{c}\text { Terra Preta do } \\
\text { Mangabal }\end{array}$ & $\begin{array}{c}\text { Cerâmica Capão do } \\
\text { Canga }\end{array}$ \\
\hline \multirow[b]{2}{*}{$\begin{array}{l}\text { Preparação } \\
\text { da matéria- } \\
\text { prima }\end{array}$} & Argila & & & & \\
\hline & Antiplástico & $\begin{array}{ll}\text { Cauixi (pode } & \text { estar } \\
\text { combinado } & \text { com } \\
\text { quartzo, caco moído, } \\
\text { caraipé, saibro). }\end{array}$ & $\begin{array}{l}\text { Mineral (quartzo e } \\
\text { areia de quartzo), às } \\
\text { vezes associado com } \\
\text { cauixi. } \\
\end{array}$ & $\begin{array}{l}\text { Mineral (quartzo) e } \\
\text { cauixi. }\end{array}$ & $\begin{array}{l}\text { Mineral, às vezes } \\
\text { associado com cauixi } \\
\text { ou caco moído,pouco } \\
\text { caraipé. }\end{array}$ \\
\hline \multirow[b]{3}{*}{$\begin{array}{l}\text { Construção } \\
\text { da Vasilha }\end{array}$} & Manufatura & Acordelamento. & & & $\begin{array}{l}\text { Bases modeladas, } \\
\text { corpo acordelado. }\end{array}$ \\
\hline & Espessura & & 4 a $16 \mathrm{~mm}$. & 4 a $15 \mathrm{~mm}$. & 2 a $25 \mathrm{~mm}$. \\
\hline & Morfologia & $\begin{array}{l}\text { Forma: esférica, calota } \\
\text { esférica (tigelas rasas), } \\
\text { assadores. } \\
\text { plana. } \\
\text { Borda: } \\
\text { interna e externa, } \\
\text { diretas simples e } \\
\text { extrovertidas } \\
\text { reforçadas interna. } \\
\text { Lábio: arredondado ou } \\
\text { plano. }\end{array}$ & $\begin{array}{l}\text { Lábio: plano ou } \\
\text { arredondado. }\end{array}$ & & 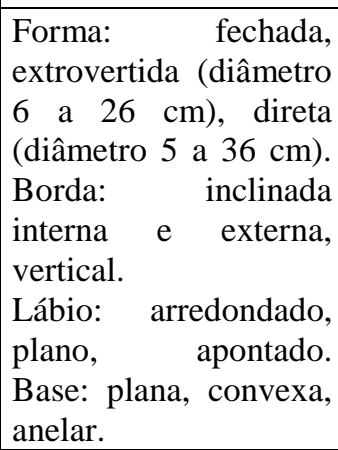 \\
\hline Queima & Coloração & & & & \\
\hline $\begin{array}{l}\text { Acabamento } \\
\text { de superfície }\end{array}$ & $\begin{array}{l}\text { Acabamento } \\
\text { de superfície } \\
\text { fe }\end{array}$ & $\begin{array}{l}\text { Acabamento plástico: } \\
\text { faixa de incisões } \\
\text { verticais } \\
\text { transversais sobre a } \\
\text { borda, raras bordas } \\
\text { com ponteado zonado } \\
\text { na face interna. } \\
\text { Acabamento pintado: } \\
\text { pintura vermelha. }\end{array}$ & $\begin{array}{l}\text { Alisado. } \\
\text { Acabamento plástico: } \\
\text { incisões com motivos } \\
\text { de espinha de peixe ou } \\
\text { linhas paralelas, de } \\
\text { triângulos isósceles ou } \\
\text { linhas cruzadas; } \\
\text { apliques de filetes de } \\
\text { argila com ponteado } \\
\text { em cima; lábios } \\
\text { entalhados (serrilhado) } \\
\text { ou com ponteado. }\end{array}$ & $\begin{array}{l}\text { Alisado. } \\
\text { Acabamento } \\
\text { plástico: incisos, } \\
\text { modelado, } \\
\text { ungulado, } \\
\text { apliques; motivo } \\
\text { inciso de linhas } \\
\text { incisas ruzadas } \\
\text { em r a r a r alos } \\
\text { agudos, formando } \\
\text { losangos r ou } \\
\text { diamantes. }\end{array}$ & $\begin{array}{l}\text { Alisado. } \\
\text { Acabamento plástico: } \\
\text { inciso, acordelado, } \\
\text { corrugado, escovado, } \\
\text { estocado, ponteado, } \\
\text { raspado, ungulado. } \\
\text { Acabamento pintado: } \\
\text { engobo vermelho, } \\
\text { enegrecimento, } \\
\text { brunidura. }\end{array}$ \\
\hline \multirow[t]{4}{*}{$\begin{array}{c}\text { Função e } \\
\text { Uso }\end{array}$} & $\begin{array}{l}\text { Função e } \\
\text { Uso }\end{array}$ & $\begin{array}{l}\text { Cozinhar:beiju, } \\
\text { farinha. } \\
\text { Servir. } \\
\text { Armazenar. } \\
\text { Líquidos: fermentação } \\
\text { de bebidas. } \\
\text { Ritual. } \\
\end{array}$ & & & \\
\hline & Localização & $\begin{array}{l}\text { Próximo à Santarém - } \\
\text { PA }\end{array}$ & $\begin{array}{l}\text { Próximo à Itaituba - } \\
\text { PA }\end{array}$ & $\begin{array}{l}\text { Próximo à Itaituba } \\
\text { - PA }\end{array}$ & Alto Guaporé - MT \\
\hline & Data & $\begin{array}{l}\text { A partir de } 3800-3600 \\
\text { AP a } 2740 \text { AP. }\end{array}$ & & & Entre 500 e $1400 \mathrm{AD}$ \\
\hline & Fontes & $\begin{array}{l}\text { Gomes 2005, 2008, } \\
2011\end{array}$ & Rocha 2012 & Rocha 2012 & Erig Lima 2012 \\
\hline
\end{tabular}

Tabela 21: Características dos conjuntos cerâmicos arqueológicos de outras regiões no Mato Grosso e Amazônia Meridional. 
Cerâmica Etnográfica - Vale do Tapajós

\begin{tabular}{|c|c|c|c|c|c|}
\hline Classificação & Classificação & Kaiabi & Apiaká & Munduruku & Bakairi \\
\hline \multirow{2}{*}{$\begin{array}{l}\text { Preparação } \\
\text { da matéria- } \\
\text { prima }\end{array}$} & Argila & $\begin{array}{l}\text { Obtida nas } \\
\text { margens do rio. }\end{array}$ & & & \\
\hline & Antiplástico & $\begin{array}{l}\text { Pó de carvão de } \\
\text { árvore (caraipé). }\end{array}$ & & Caraipé & \\
\hline \multirow[b]{3}{*}{$\begin{array}{l}\text { Construção } \\
\text { da Vasilha }\end{array}$} & Manufatura & $\begin{array}{l}\text { Base modelada, } \\
\text { corpo com roletes } \\
\text { sobrepostos. }\end{array}$ & & & \\
\hline & Espessura & & & & \\
\hline & Morfologia & $\begin{array}{l}\text { Panelas, assadores, } \\
\text { pratos. }\end{array}$ & $\begin{array}{l}\text { Assador, panela } \\
\text { bicônica. }\end{array}$ & Assador, jarro. & $\begin{array}{l}\text { Esféricas, } \\
\text { apêndices zoomorfos } \\
\text { na } \\
\text { Semi-esféricas } \\
\text { cônicas com boca. } \\
\text { extrovertidas. }\end{array}$ \\
\hline Queima & Coloração & $\begin{array}{l}\text { Preta com manchas } \\
\text { vermelhas. }\end{array}$ & & $\begin{array}{l}\text { Preta, marrom } \\
\text { avermelhado. }\end{array}$ & Escura. \\
\hline $\begin{array}{l}\text { Acabamento } \\
\text { de superfície }\end{array}$ & $\begin{array}{l}\text { Acabamento } \\
\text { de superfície fe }\end{array}$ & $\begin{array}{l}\text { Alisamento } \\
\text { polimento. } \\
\text { Impermeabilizada } \\
\text { com seiva. }\end{array}$ & 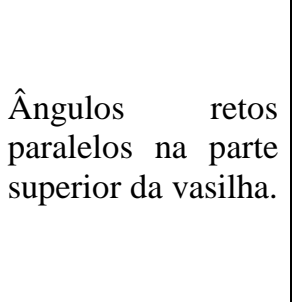 & $\begin{array}{l}\text { Borda com aplique } \\
\text { ondulado. } \\
\text { Ornamentos } \\
\text { losangos. }\end{array}$ & $\begin{array}{l}\text { Acabamento pintado: } \\
\text { pintura marrom de } \\
\text { listras paralelas } \\
\text { verticais e círculos } \\
\text { concêntricos; pintura } \\
\text { vermelha; } \\
\text { enegrecimento. }\end{array}$ \\
\hline \multirow[t]{4}{*}{$\begin{array}{l}\text { Função e } \\
\text { Uso }\end{array}$} & Função e Uso & $\begin{array}{l}\text { Cozinhar: } \\
\text { mingau, } r \text { beiju, } \\
\text { carne, } \\
\text { feijão, cogumelos, } \\
\text { etc; torrar farinha. } \\
\text { Líquidos: preparar } \\
\text { chicha. }\end{array}$ & Cozinhar. & $\begin{array}{l}\text { Cozinhar. Ritual: } \\
\text { urna funerária. }\end{array}$ & \\
\hline & Data & Meados séc XX. & Meados séc XX. & Meados séc XX. & Meados séc XX. \\
\hline & Fontes & $\begin{array}{ll}\text { Villas-Bôas } & 1999 ; \\
\text { Grünberg } & 2004 ; \\
\text { MAE } & \end{array}$ & $\begin{array}{l}\text { Nimuendaju } \\
{[1948] \quad 1963 ;} \\
\text { Florence } 1941\end{array}$ & $\begin{array}{lr}\text { Horton [1948] } 1963 ; \\
\text { Florence } & 1941 ; \text { Loja } \\
\text { Iande; } & \text { Museu } \\
\text { Araribah; } & \text { Hilbert } \\
1958 & \\
\end{array}$ & $\begin{array}{lr}\text { Schmidt 1947; von } \\
\text { den Steinen } & 1942 ; \\
\text { MAE; } & \text { Museu } \\
\text { Etnológico de Berlin }\end{array}$ \\
\hline & Observações & & & & $\begin{array}{l}\text { A cerâmica coletada } \\
\text { e descrita com os } \\
\text { Bakairi parece ser } \\
\text { toda de origem } \\
\text { Mehinako ou Waujá. }\end{array}$ \\
\hline
\end{tabular}

Tabela 22: Características dos conjuntos cerâmicos etnográficos na área da T. I. Kaiabi. 
Nosso Conjunto 1 pode ser comparado (figura 91), em muitos aspectos, com a cerâmica do Capão do Canga: o antiplástico mineral, as incisões entrecruzadas e losangulares. Também podemos fazer uma comparação do motivo inciso losangular com a cerâmica da Terra Preta do Mangabal (apesar de o cauixi também ter sido encontrado como material antiplástico neste conjunto) e a cerâmica Munduruku (descrita por ROCHA, 2012 e FLORENCE, 1941). A data de TL deste conjunto é alguns séculos posteriores à data de Erig Lima (2012).

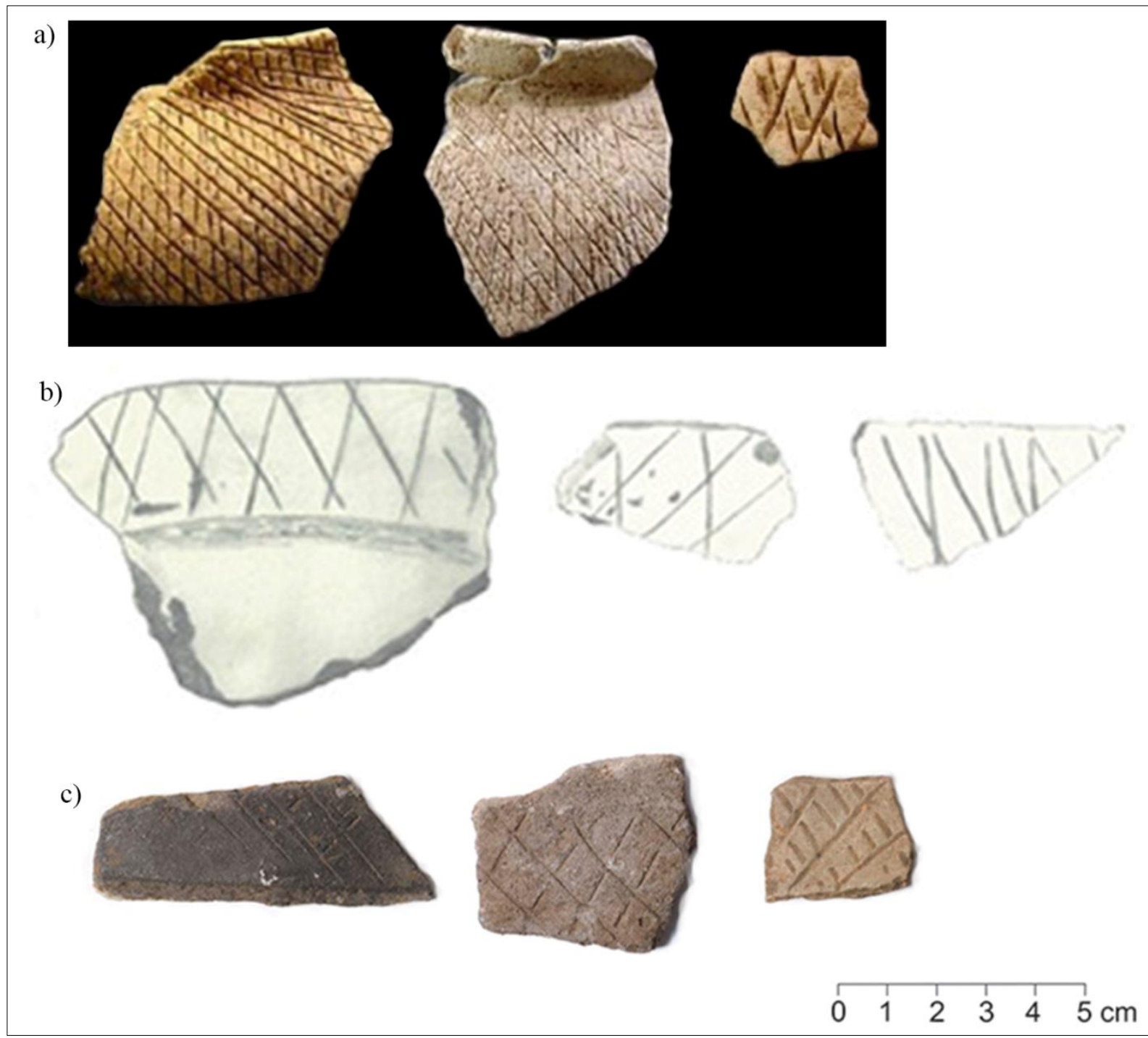

Figura 91: Comparação entre a) cerâmica do Capão do Canga (Cf. ERIG LIMA, 2012); b) cerâmica Terra Preta do Mandabal (Cf. ROCHA, 2012); c) cerâmica do Conjunto 1 (Foto: Ader Gotardo).

O Conjunto 2 apresenta características muito parecidas com a cerâmica de populações Tupi-Guarani (caco moído, formas carenadas), e um fragmento em especial se assemelha bastante à ilustração e descrição da cerâmica Apiaká (figura 92), sendo a relação 
entre este conjunto e a cerâmica Apiaká uma possibilidade. Sabendo da relação intrincada dos Kaiabi com este grupo, poderia tratar-se tanto de um grupo Apiaká como da presença de mulheres Apiaká entre os Kaiabi. A data para este conjunto é pré-colonial, muito antes das primeiras fontes históricas que mencionam os Apiaká na região, no entanto é coerente com o quadro geral de ocupações Tupi para a área se pensarmos que esses povos já estavam fixados ali neste período e não iniciando a ocupação (com. pessoal Ângelo Corrêa, 2014).

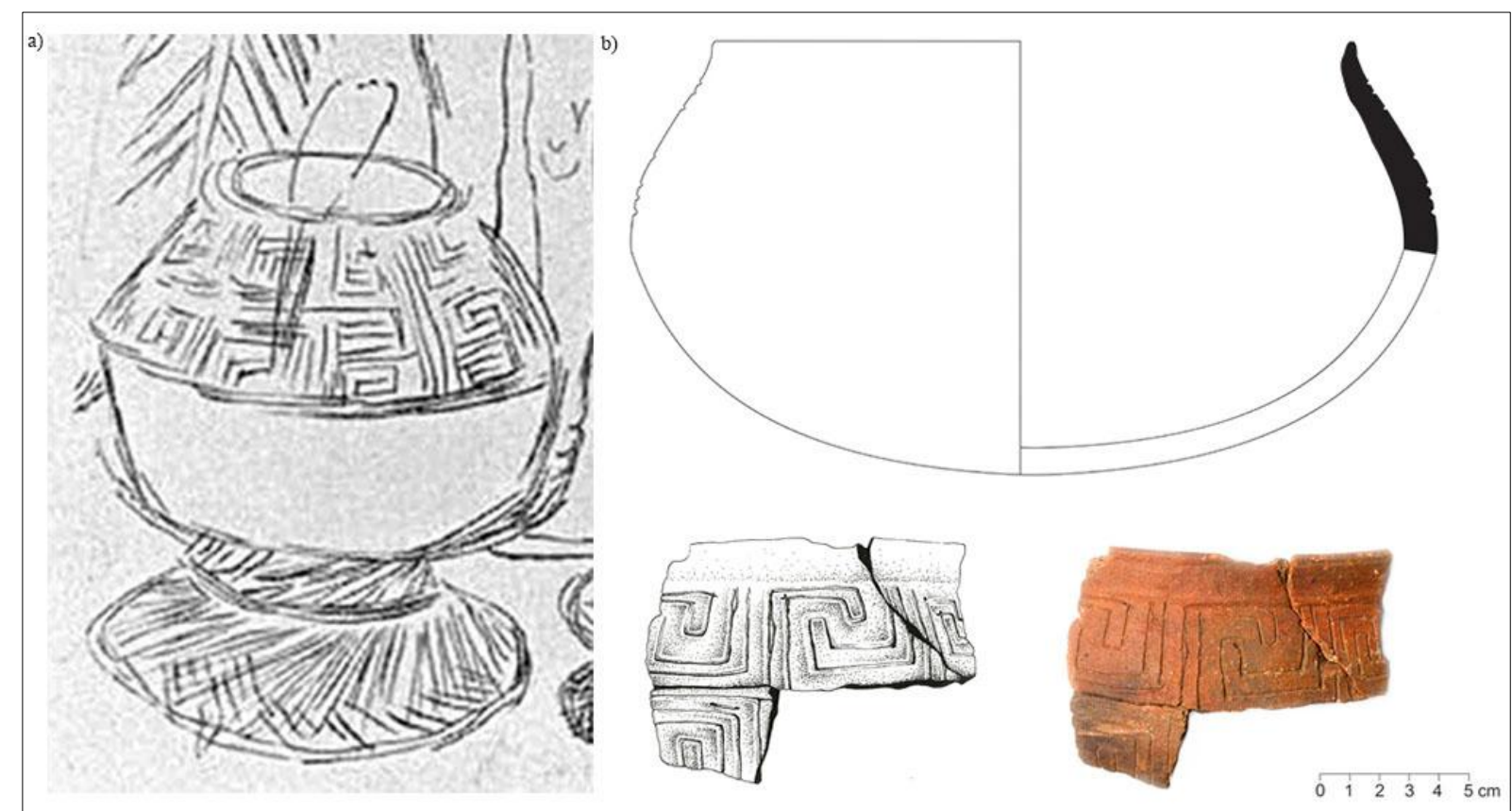

Figura 92: Comparação entre a) cerâmica Apiaká ilustrada por Florence (1941); b) cerâmica do Conjunto 2 (Desenho: Amanda Moraes. Foto: Ader Gotardo).

Os Kaiabi não reconheceram nenhum fragmento cerâmico como deles, no entanto pode ser que alguns fragmentos alisados e com antiplástico caraipé possam ter sido feitos por ceramistas Kaiabi.

Alguns fragmentos do sítio Dinossauro do Conjunto 3 possuem acabamentos semelhantes tanto aos descritos por Rocha (2012) em Pajau e Cocalino, da Tradição IncisoPonteado, e em Terra Preta do Mangabal, supostamente Munduruku; tanto como o descrito por Gomes (2005, 2008) em Parauá, da Tradição Borda Incisa (figura 93). Em ambos os casos, o cauixi está presente como antiplástico, mas não o caraipé ou caco moído. As datas de Gomes são anteriores a data do sítio Dinossauro, mas pode fazer sentido se pensarmos que as populações que produziam essa cerâmica vieram da foz Tapajós. 


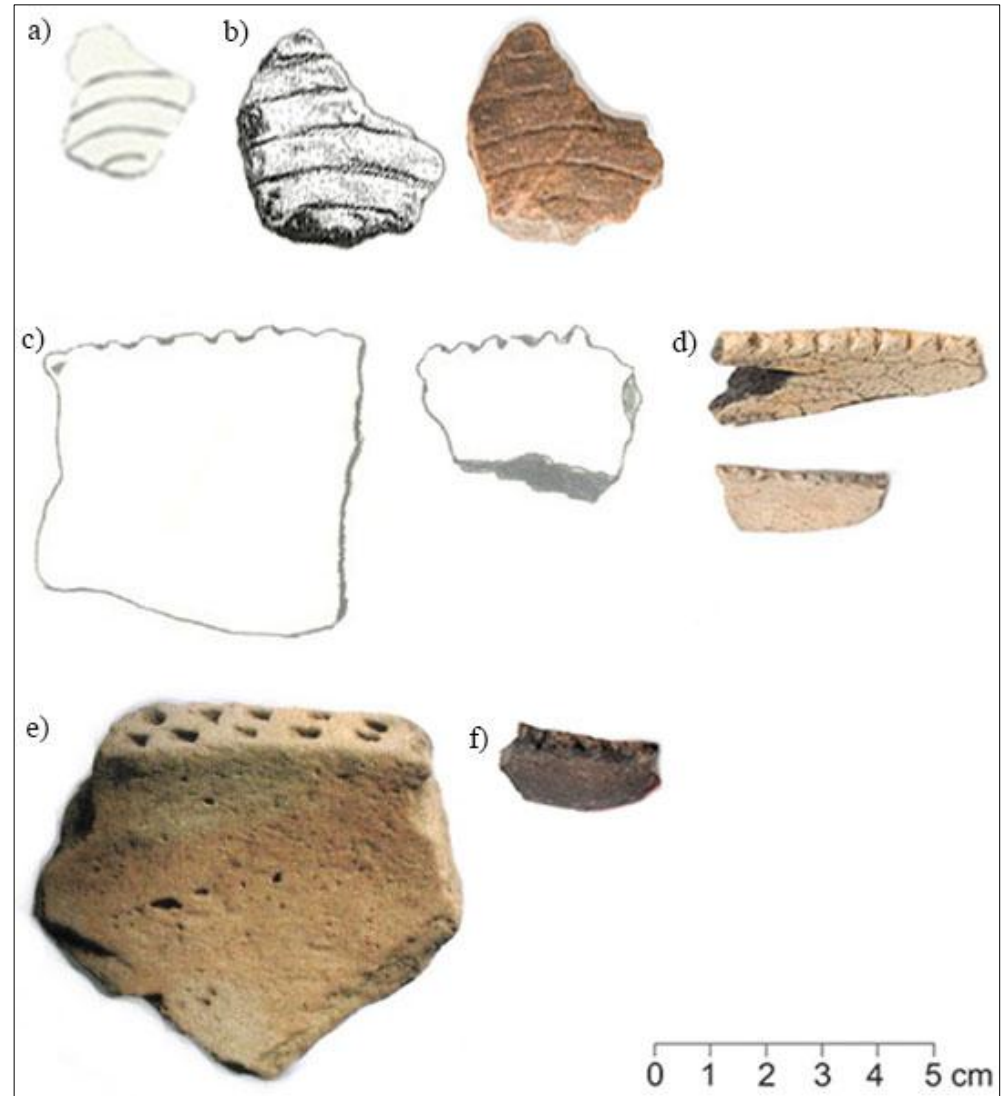

Figura 93: Comparação entre: a) cerâmica de Terra Preta do Mangabal (Cf. ROCHA, 2012); b) do sítio DR (Desenho: Amanda Moraes. Foto: Ader Gotardo). Comparação entre: c) cerâmica de Pajau e Cocalino (Cf. GOMES, 2005); d) cerâmica do sítio DR (Foto: Ader Gotardo). Comparação entre: e) cerâmica de Parauá (Cf. GOMES, 2005); f) cerâmica do sítio DR (Foto: Ader Gotardo).

Temos também um único fragmento do sítio Dinossauro do Conjunto 4 que se assemelha (figura 94), por seu acabamento de superfície e antiplástico cauixi, à fragmentos de Pajau e Cocalino, descritos por Rocha (2012), e de Parauá, descritos por Gomes (2005, 2008).

a)

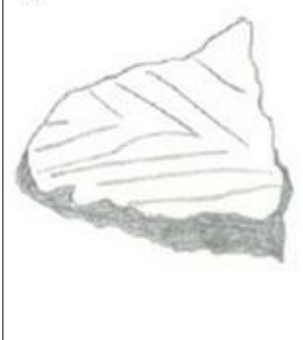

b)

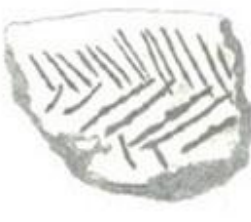

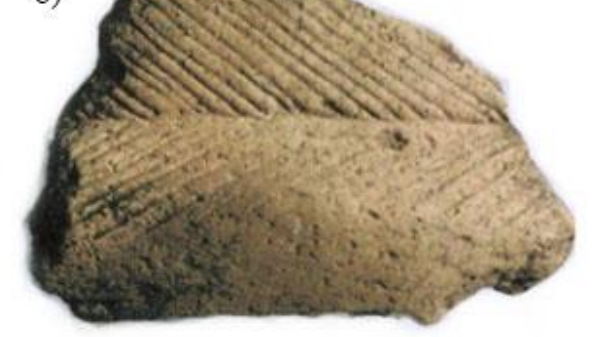

c)

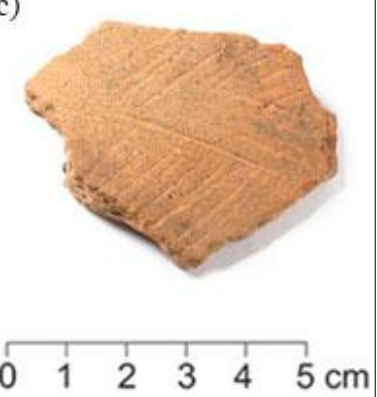

Figura 94: Comparação entre a) cerâmica de Pajau e Cocalino (Cf. ROCHA, 2012); b) de Parauá (Cf. GOMES, 2005; c) do sítio DR (Foto: Ader Gotardo).

Tanto o Conjunto 3 como o 4 possuem elementos similares aos descritos por essas duas pesquisadoras, apesar dos poucos fragmentos para realizar esta comparação. 


\section{CONSIDERAÇÕES FINAIS}

“A confecção de um artefato é o início de um processo de produção que concluído continua em fase de utilização e, ao quebrar-se, encerra uma sequência de funções não específicas mas presentes dentro de um contexto cultural que ao arqueólogo cabe explicar através da análise de seus fragmentos. É todo um ciclo, visível se se tentar refazer o sistema, invisível se se observar apenas seus efeitos e representações." (LA SALVIA e BROCHADO, 1989: 5)

Não existem mapas ou bússolas para nos explicar as complexas motivações do comportamento humano, no entanto podemos tentar compreender alguns aspectos dele através de seus efeitos no mundo material. Podemos estudar uma tecnologia por meio de análises, estatísticas e teorias, mas se perdermos de vista que ela faz parte de um contexto cultural maior, parte do modo de vida de um grupo de pessoas, teremos perdido a parte mais significativa de nosso próprio trabalho.

Os conjuntos propostos neste trabalho são resultado de uma primeira aproximação com o material cerâmico arqueológico na T. I. Kaiabi, no Vale do Tapajós, um material ainda pouco conhecido em uma área também pouco conhecida arqueologicamente. Assim, acreditamos que a abordagem que escolhemos utilizar neste trabalho (explicitada nos Capítulos 2 e 3) foi bastante interessante para pensar que a variabilidade deste material pode ser compreendida além de uma tipologia cerâmica. Os atributos desses conjuntos possuem uma dimensão significativa que não representa somente limitações físicas e químicas impostas pela matéria-prima, mas principalmente escolhas tecnológicas das ceramistas que pertenciam a um determinado grupo cultural e eram por ele influenciados. Outros trabalhos que utilizaram abordagens similares também obtiveram resultados interessantes em termos de interpretação da variabilidade artefatual cerâmica (p. ex.: SILVA, 2000; SILLAR e TITE, 2000; MACHADO, 2005-2006; RODRIGUES, 2011; CHILTON, 1998). 
Compreender que o objeto cerâmico pode ser analisado e interpretado por meio de diferentes metodologias foi fundamental para pensarmos no agrupamento dos fragmentos em conjuntos que constituíssem diferentes estilos tecnológicos (ver Capítulos 4 e 5). A organização dos dados da análise a partir da cadeia operatória de produção nos permitiu uma melhor visualização de quais escolhas foram feitas pelas ceramistas em algumas etapas deste processo. A análise estatística nos auxiliou na definição dos conjuntos, identificando as correlações entre alguns atributos e mostrando quais deles eram mais significativos para sua definição. Para entender as escolhas feitas durante o processo de produção, foram muito importantes os resultados de trabalhos de arqueologia experimental, que nos informaram sobre as características de performance de alguns atributos. Trabalhos de etnoarqueologia também auxiliaram da mesma maneira, além de nos dar exemplos para pensar nas motivações e significados das escolhas tecnológicas realizadas. Por fim, a arqueometria nos permitiu o aprofundamento de algumas questões relativas à composição da pasta e dos pigmentos, além do uso de fontes de argila.

É utilizando uma abordagem integrada que podemos pensar em modos de se fazer cerâmica que podem configurar tradições tecnológicas, como foi feito nos estudos sobre a cerâmica Guarani, iniciados por La Salvia e Brochado (1989). Ao invés de utilizarem somente alguns atributos de maneira isolada para classificar a cerâmica, esses pesquisadores procuraram relacionar todas as informações obtidas tanto pela análise dos fragmentos e vasilhas inteiras como pelo contexto arqueológico e cultural, pelas fontes históricas, etnográficas e linguísticas. Dessa maneira, foi possível visualizar as normas que orientavam a fabricação das vasilhas Guarani, demonstrando que determinadas morfologias e acabamentos não compunham diferentes sub-tradições, mas sim diferentes funcionalidades dentro de uma mesma tradição. Esta perspectiva foi muito importante para explicar o fato de encontrarmos vasilhas com "um estilo tecnológico padronizado sob regras rigosorosas" reproduzidas ao longo de 2 mil anos em uma grande região, como a reprodução de um modo de se fazer cerâmica dos povos Guarani (NOELLI, 2008: 35-37).

Este trabalho não teve como proposta todo o aprofundamento necessário para visualizar os conjuntos como modos de fazer cerâmica específicos de um determinado povo, uma tarefa para a qual ainda existem muitas lacunas. Porém acreditamos ter dado os passos iniciais nesta direção. Ainda é necessário um trabalho mais aprofundado de escavações arqueológicas, escolhendo alguns sítios para realizar escavações mais extensas, que permitam uma melhor visualização da estratigrafia do sítio e a escavação de materiais em contexto. Neste momento, seria mais proveitosa a coleta de fragmentos maiores, ou que remontem, 
possibilitando mais reconstituições das formas das vasilhas. Além disso, seria interessante um trabalho de prospecção e escavação em locais mais para o interior do Teles Pires, já que as informações sobre os Kaiabi (ver Capítulo 1) descrevem que seus assentamentos não eram localizados nas beiras dos rios, mas sim no interior. Além disso, pesquisas arqueológicas no território original dos Kaiabi (ver figura 2) podem encontrar a cerâmica que eles produziam. Outra possibilidade é investigar as fontes de argila mencionadas pelas Kaiabi (ver Capítulo 5), coletando amostras para comparação com os dados da arqueometria realizada neste trabalho.

Em relação à análise cerâmica, temos algumas sugestões para trabalhos futuros, já que neste trabalho priorizamos uma caracterização geral dos fragmentos (ver Capítulo 3). A pasta cerâmica também pode ser melhor caracterizada com descrições da distribuição, tamanho e quantidade de antiplásticos e outras inclusões nos fragmentos. Com base em nossa classificação inicial dos acabamentos de superfície, seria interessante descrevê-los melhor para compreender quais seriam os elementos diagnósticos e a relação deles entre si, e com formas e funções específicas. Uma análise arqueométrica dos pigmentos também seria interessante, principalmente no que diz respeito ao que classificamos como engobo rosa.

Alguns passos também foram dados para possibilitar a comparação da cerâmica na T. I. Kaiabi com conjuntos cerâmicos já descritos. Feito um levantamento bibliográfico inicial sobre os conjuntos cerâmicos arqueológicos e etnográficos na região do Vale do Tapajós, sugerimos algumas relações entre eles e a cerâmica na T. I. Kaiabi, comentada ainda de maneira muito superficial devido à falta de dados mais consistentes (ver Capítulo 6). Muitos dos povos citados nas fontes históricas já não existem mais e as informações sobre eles são muito escassas. No entanto, os relatos históricos nos mostram o Vale do Tapajós historicamente habitado por povos de língua Tupi (ver Capítulo 1), colocando essa região dentro de um debate maior que é o da origem e expansão desses povos pelo Brasil. Desde que surgiram as hipóteses iniciais sobre o tema, muitas pesquisas foram feitas e trabalhos recentes têm apresentado dados bastante interessantes nesta discussão ${ }^{17}$.

Na linguística (apesar de algumas divergências), a denominação Tupi é dada para o povo que falava o Proto-Tupi, língua que deu origem ao Tronco Tupi, dividido em 10 famílias: Tupí-Guaraní, Awetí, Mawé, Mundurukú, Jurúna, Arikém, Tuparí, Ramaráma, Mondé e Puruborá (CORRÊA-DA-SILVA, 2010: 63). Na arqueologia, determinados conjuntos cerâmicos foram classificados como pertencentes à Tradição Tupi-Guarani,

\footnotetext{
${ }^{17}$ O trabalho de doutorado de Ângelo Corrêa, em 2014, é a mais atual síntese sobre o assunto.
} 
diretamente relacionada a esses povos. A função deste termo era "descrever, datar, posicionar no espaço e classificar certos registros arqueológicos", contribuindo para comparar e mapear as rotas de difusão dessa cerâmica, presente em todo território nacional (NOELLI, 2008: 24).

A partir da relação entre Tradição e povo Tupi, procurou-se explicações para o fato do conjunto cerâmico Tupi-Guarani estar disperso por grande parte do território brasileiro em um intervalo de tempo tão grande. Contrariando uma ideia de origem exógena dos povos Tupi na Amazônia, proposta por Meggers e Evans, os pesquisadores Lathrap e Brochado (baseando-se em diversas fontes históricas, etnográficas, linguísticas e arqueológicas) propuseram o centro de origem desses povos na Amazônia Central, de onde teriam se expandido utilizando os cursos dos rios, devido à pressão demográfica (NOELLI, 2008: 26). As pesquisas de Brochado sempre procuraram estabelecer a continuidade entre o contexto arqueológico e cultural (NOELLI, 2008: 22), por isso também sua ideia da relação entre a cerâmica da Tradição Polícroma da Amazônia e povos de língua Tupi, além de sua preocupação em realizar uma caracterização mais consistente dos conjuntos cerâmicos, como fez para a cerâmica Guarani (LA SALVIA e BROCHADO, 1989).

É ainda necessário que sejam feitas mais pesquisas em diferentes ambientes e regiões da Amazônia para que novas informações possam preencher as lacunas sobre os processos históricos e culturais que estão relacionados a estas populações. Apesar de pesquisas recentes apontarem diferentes sequências cronológicas para as Tradições cerâmicas amazônicas e contrariarem a proposta do centro de origem na Amazônia Central (p. ex. HECKENBERGER, NEVES e PETERSEN, 1998), outros aspectos da hipótese de Brochado continuam atuais e ainda devem ser mais investigados, como a relação entre os Tupi e a cerâmica da Tradição Polícroma.

As sequências baseadas em dados etnolinguísticos continuam sendo mais confiáveis do que as sequências cerâmicas, que ainda não são muito consistentes, sendo a hipótese de Aryon Rodrigues de que a origem Tupi teria sido no sudoeste da Amazônia, no estado de Rondônia, bastante atual (NOELLI, 2008: 29-31). A ideia é de que esses povos se dividiram há mais ou menos 5 mil anos (CORRÊA-DA-SILVA, 2010: 73), sendo que nesta época eles já deviam compartilhar de um contexto cultural comum:

“O universo desse grupo indígena pré-histórico era a floresta, e sua cultura se afirmava na adaptação a esse meio, de onde extraíam seu sustento e muito provavelmente sua concepção de mundo. Utilizavam-se da caça e da pesca para obter os recursos 
proteicos necessários e praticavam algum tipo de agricultura, incipiente ou não, cultivando mandioca, batata-doce, cará, etc., proporcionando-lhes a abundância necessária ao aumento demográfico, que pode ser uma das diversas causas dos primeiros fracionamentos do grupo." (CORRÊA-DA-SILVA, 2010: 74-75)

Mais interessante ainda para este debate é a relação dos povos de língua Tupi com os povos de língua Karib, que aparece no Vale do Tapajós, historicamente habitado pelos Tupi, mas com a presença de uma cerâmica arqueológica classificada como Tradição IncisoPonteado, teoricamente associada aos povos de língua Karib (ROCHA, 2012). Ainda, temos a presença de uma cerâmica da Tradição Borda Incisa (GOMES, 2005, 2008), usualmente associada aos povos de língua Arawak (NEVES, 2011). Apesar de sabermos menos ainda sobre os processos de origem e expansão Karib e Arawak, os Bakairi que habitam próximo à T. I. Kaiabi podem ter chegado lá vindos do Tapajós (ver BARROS, 2003). Há muitos casos de empréstimos lexicais do Karib nas famílias Tupi-Guarani e Awetí, que sugerem uma separação dessas famílias na região do alto rio Arinos (CORRÊA-DA-SILVA, 2010: 76). Grünberg (2004) cita a confusão da classificação inicial da língua Kaiabi como Karib, sendo que só muito tempo depois ela foi corretamente classificada como Tupi-Guarani. Essa é uma das questões que poderia ser aprofundada em pesquisas futuras ${ }^{18}$.

Mesmo que existam muitas divergências no debate em torno dos povos Tupi e de sua expansão na América do Sul, existem dois consensos entre os pesquisadores: 1) existiu um centro comum de expansão, que teria sido em algum lugar da Amazônia; 2) mesmo diferenciando-se por distintos processos históricos e culturais, eles mantiveram diversas características em comum (NOELLI, 2008b: 659). Apesar de não temos uma imagem clara da história pré-colonial na Amazônia, fica cada vez mais evidente que ela é muito mais complexa do que as divergências de classificações tipológicas da cerâmica e outros materiais (NEVES, 2007: 360). São necessários trabalhos mais aprofundados na região, tanto de escavação como de análise de materiais, para se discutir o que realmente representam os conjuntos cerâmicos em relação aos povos que lá habitaram e habitam.

Para melhorar a imagem do quadro de conjuntos cerâmicos nesta região, aguardamos o resultado de mais pesquisas. Outros trabalhos arqueológicos, tanto acadêmicos como da

\footnotetext{
${ }^{18}$ Ver discussão em Corrêa (2014: 216 a 223) sobre a região que compreende o Vale do Tapajós, da importância da região para essa discussão dos povos Tupi e especificamente da área entre os rios Juruena e Arinos para a discussão da derivação da família Tupi-Guarani e seu contato com línguas Karib.
} 
arqueologia de contrato, estão sendo feitos na região do Vale do Tapajós. Seus resultados certamente serão interessantes para a continuidade do diálogo da cerâmica na T. I. Kaiabi com a cerâmica na região. Além disso, um trabalho mais aprofundado da cerâmica etnográfica da região seria muito interessante para pensarmos mais na relação entre nossos conjuntos e a cerâmica de diferentes etnias, especialmente Apiaká, Kaiabi e Munduruku.

Uma última sugestão para o aprofundamento das pesquisas é a análise dos materiais líticos já coletados, que não foram estudados neste trabalho. Seria interessante verificar se existe realmente alguma relação entre os líticos e a cerâmica, ou se tratam de ocupações diferentes. Outros tipos de materiais (solo, materiais históricos) também podem ser analisados e relacionados ou não com a cerâmica.

Aqui, então, finalizamos este trabalho, esperando ter contribuído para as discussões metodológicas de análise de conjuntos cerâmicos e também para que os modos de vida dos Kaiabi e outros povos da área possam ser realmente respeitados, respeitando-se toda a história ainda presente na terra em que habitam. 


\section{REFERÊNCIAS BIBLIOGRÁFICAS}

ALMEIDA, F. O. O complexo Tupi da Amazônia Oriental. Dissertação de mestrado, Museu de Arqueologia e Etnologia, Universidade de São Paulo, São Paulo. 2008

AlmeidA, F. O. A Tradição Poícroma no Alto Rio Madeira. Tese de doutorado, Museu de Arqueologia e Etnologia, Universidade de São Paulo, São Paulo. 2013

ALVES, M. A. Estudo de cerâmica pré-histórica no Brasil: das fontes de matéria-prima ao emprego de microscopia petrográfica, difratometria de raios $x$ e microscopia eletrônica. Recife: CLIO, Série Arqueológica (UFPE), v. 1 (12): 27-86. 1997

ALVES, M. A. Cadeia operatória, sistema tecnológico e análise arqueométrica nos assentamentos cerâmicos dos vales do Paranaíba, Minas Gerais e Turvo, São Paulo, Brasil. Cuadernos Del Instituto Nacional De Antropología y Pensamiento Latinoamericano - Series Especiales, v. 1: 46-60. 2013

AMARAL, D. M. Loiça de barro do Agreste: um estudo etnoarqueológico de cerâmica histórica pernambucana. Dissertação de mestrado, Museu de Arqueologia e Etnologia, Universidade de São Paulo, São Paulo. 2013

ANDRADE LIMA, T. A cerâmica indígena do Brasil. In: RIBEIRO, D. e RIBEIRO, B. (org.) Suma Etnológica Brasileira. Rio de Janeiro: Vozes/Finep, v. II: 173-229. 1986

APPOLONI, C. R. e PARREIRA, P. S. Doze anos de atividades em arte e arqueometria no Laboratório de Física Nuclear Aplicada da Universidade Estadual de Londrina. Revista Brasileira de Arqueometria, Restauração e Conservação, v. 1 (6): 301-304. 2007 ARARIBAH, <http://www.araribah.com.br/ceramica.htm> acessado em março de 2013

ARNOLD, D. E. Ceramic Theory and Cultural Process. Cambridge: Cambridge University Press. 1985

ARNOLD, D. Does the Standardization of Ceramic Pastes Really Mean Specialization? Journal of Archaeological Method and Theory, v. 7 (4): 333-375. 2000

BARReto, C. Arte e Arqueologia na Amazônia Antiga. Oxford: Center for Brazilian Studies, University of Oxford. 2005

BARROS, E. P. Os filhos do sol: história e cosmologia na organização social de um povo Karib, os Kurâ-Bakairi. São Paulo, SP: Edusp. 2003

BESPALEZ, E. Levantamento Arqueológico e Etnoarqueologia na Aldeia Lalima, Miranda/MS: Um Estudo sobre a Trajetória Histórica da Ocupação Indígena 
Regional. Dissertação de mestrado, Museu de Arqueologia e Etnologia, Universidade de São Paulo, São Paulo. 2009

BOWSER, B. J. e PATTON, J. Q. Learning and transmission of pottery style: women's life histories and communities of practice in the Ecuadorian Amazon. In: STARK, M. T.; BOWSER, B. J.; HORNE, L. Cultural Transmission and Material Culture: breaking down boundaries. Tucson: University of Arizona Press. 2008

BROCHADO, J. P.; MONTICELLI, G.; NEUMANN, E. Analogia etnográfica na reconstrução gráfica das vasilhas Guarani arqueológicas. Porto Alegre: Veritas, v. 35 (140): 727-743. 1990

BRONITSKY, G. e HAMER, R. Experiments in ceramic technology: The effects of various tempering materials on impact and thermal-shock resistance. American Antiquity, v. 51(1): 89-101. 1986

CAPDEPONT, I.; PUERTO, L. del; RAMÍREZ, A. Potenciales fuentes de aprovisionamiento para la manufactura cerámica: sitio Guayacas, Paysandú, Uruguay. Revista del Museo de La Plata, Sección Antropología, v. 13 (87):315-331. 2013

CARR, C. e NEITZEL, J. (orgs.) Style, Society and Person: Archaeological and Ethnological Perspectives. New York: Plenum. 1995

CHILTON, E. The cultural origins of technical choice: unraveling algonquian and iroquian ceramic traditions in the northeast. In: STARK, M. (ed.). The Archaeology of Social Boundaries. Washington/London: Smithsonian Institution Press. 1998

CHMYZ, I. (ed) Terminologia Arqueológica Brasileira para a Cerâmica. Curitiba: Centro de Ensino e Pesquisas Arqueológicas, Departamento de Antropologia, Faculdade de Filosofia, Ciências e Letras, Universidade Federal do Pará. 1966

CONKEy, M. e HASTORF, C. (eds.) The Uses of Style in Archaeology. Cambridge: Cambridge University Press. 1991

CORRÊA, A. A. Tetama nas matas mineiras: sítios Tupi na microrregião de Juiz de Fora - MG. Dissertação de mestrado, Museu de Arqueologia e Etnologia, Universidade de São Paulo, São Paulo. 2009

CORREAA-DA-SILVA, B. Etnolinguística e etno-história Tupi: desfragmentando o olhar. Revista de Estudos Linguísticos, Belo Horizonte, v. 18 (1): 61-86. 2010

COUDREAU, H. A. Viagem ao Tapajós. Belo Horizonte: Itatiaia São Paulo: Editora da Universidade de São Paulo. 1977 
CUOMO di CAPRIO, N. La ceramica in archeologia: antiche tecniche di lavorazione e moderni metodi d'indagine. Roma: "L’Erma" di Bretschneider. 1985

DAVID, N., STERNER, J. e GAVUA, K. Why pots are decorated? Current Anthropology, v. 29 (3): 365-389. 1988

DEGOY, L. Technical traditions and cultural identity: an ethnoarchaeological study of Andhra Pradesh potters. In: STARK, M., BOWSER, B. \& HORNE, L. (eds.) Cultural transmission and material culture. Breaking down boundaries. Tucson: The University of Arizona press. 2008

DIAS, A. S. Novas perguntas para um velho problema: escolhas tecnológicas como índices para o estudo de fronteiras e identidades sociais no registro arqueológico. Boletim do. Museu Paraense Emílio Goeldi. Ciências Humanas, Belém, v. 2 (1): 59-76, jan-abr. 2007

DIAS, A. S. e SILVA, F. A. Sistema Tecnológico e Estilo: as implicações desta interrelação no estudo das indústrias líticas do sul do Brasil. Revista do Museu de Arqueologia e Etnologia, v. 11: 95-108. 2001

DIETLER, M. e HERBICH, I. Tich Matek: The Technology of Luo Pottery Production and the Definition of Ceramic Style. World Archaeology, v. 21 (1): 148-164. 1989

DIETLER, M. e HERBICH, I. Ceramics and Ethnic Identity: Ethnoarchaeological observations on the distribution of pottery styles and the relationship between the social contexts of production and consumption. In: In BINDER, D. e AUDOUZE, F. (eds.) Terre Cuite et Socièté: La Céramique, document technique, économique, culturel. XIVe Rencontre Internationale d'Archéologie et d'Histoire d'Antibes. Juan-les-Pins: Editions APDCA. 1994

DORNAN, J. L. Agency and Archaeology: Past, Present, and Future Directions. Journal of Archaeological Method and Theory, v. 9 (4): 303-329. 2002

EREMITES DE OLIVEIRA, J. Guató: argonautas do Pantanal. Porto Alegre: EdiPUCRS. 1996

EREMITES DE OLIVEIRA, J.; VIANA, S. A. O Centro Oeste Antes de Cabral. Revista USP: São Paulo, v. 44 (1): 142-189. 1999-2000

ERICKSON, C. L. Amazonia: The Historical Ecology of a Domesticated Landscape. In: SILVERMAN, H. e ISBELl, W. H. Handbook of South American Archaeology. New York, NY: Springer. 2008

ERIG LIMA, L. F. A cerâmica Capão do Canga: Uma nova indústria cerâmica na bacia do Alto Guaporé, Mato Grosso, Brasil. Amazônica, v. 4 (1): 186-220. 2012 
FELICÍSSIMO, M. P.; PEIXOTO, J. L.; BARBOSA, M. S.; DEMORTIER, G.; PIREAUX, J. J. e RODRIGUES-FILHO, U. P. PIXE and PIGE analysis of pre-colonial pottery from Patanal - MS, Brazil. Journal of Radioanalytical and Nuclear Chemistry, v. 267 (1): 209-217. 2006

FERGUSON, J. R. (ed.) Designing Experimental Research in Archaeology: examining technology through production and use. Boulder: University Press of Colorado. 2010 FLORENCE, H. Viagem Fluvial do Tietê ao Amazonas, de 1825 a 1829. São Paulo: Melhoramentos. 1941

FRANKEL, D. Color Variation on Cypriot Red Polished Pottery. Journal of Field Archaeology, v. 21 (2): 205-219. 1994

GARCIA, L. L. W. G. Arqueologia na região dos interflúvios Xingu-Tocantins: a ocupação tupi no Cateté. Dissertação de mestrado, Museu de Arqueologia e Etnologia, Universidade de São Paulo, São Paulo. 2012

GOMES, D. M. C. Análise dos padrões de organização comunitária no Baixo Tapajós : o desenvolvimento do formativo na área de Santarém, PA. Tese de doutorado, Museu de Arqueologia e Etnologia, Universidade de São Paulo, São Paulo. 2005

GOMES, D. M. C. O Uso Social da Cerâmica de Parauá, Santarém, Baixo Amazonas: uma análise funcional. Arqueologia Suramericana/Arqueologia Sul-americana, v. 4 (1): 4-33. 2008

GOSSELAIN, O. P. Technology and style: potters and pottery among Bafia of Cameroon. London: Royal Anthropological Institute of Great Britain and Ireland. 1992 GOULD, R. A. Living Archaeology. Cambridge: Cambridge University Press. 1980

GRÜNBERG, G. Os Kaiabi do Brasil Central: História e Etnografia. São Paulo: ISA. 2004

HARRY, K. G. Understanding Ceramic Manufacturing Technology: the role of experimental archaeology. In: FERGUSON, J. R. (ed.) Designing Experimental Research in Archaeology: examining technology through production and use. Boulder: University Press of Colorado. 2010

HECKENBERGER, M. J. War and peace in the shadow of empire: sociopolitical change in the upper Xingu of Southeastern Amazonia, A.D. 1400-2000. Tese de Doutorado, Departamento de Antropologia, Universidade de Pittsburgh, EUA. 1996

HECKENBERGER, M. J. Estrutura, História e Transformação. In: FRANCHETTO, B. e HECKENBERGER, M. B. Os povos do alto Xingu: história e cultura. Rio de Janeiro: UFRJ. 2001 
HECKENBERGER, M. J.; NEVES, E. G.; PETERSEN, J. B. De onde surgem os modelos? As origens e expansões Tupi na Amazônia Central. Revista de Antropologia, v. 41 (1): 69-96. São Paulo. 1998

HEGMON, M. Archaeological Research on Style. Annual Review of Anthropology, v. 21: 517-536. 1992

HEGMON, M. Advances in ceramic ethnoarchaeology. Journal of Archaeological Method and Theory, v. 7 (3): 129-137. 2000

HERBICH, I. e DIETLER. M. The long arm of the mother-in-law: learning, postmarital resocialization of women, and material culture style. In: STARK, M. T.; BOWSER, B. J.; HORNE, L. Cultural Transmission and Material Culture: breaking down boundaries. Tucson: University of Arizona Press. 2008

HILBERT, P. P. Urnas Funerárias do rio Cururú, Alto Tapajós. Boletim do Museu Paraense Emílio Goeldi, Nova Série, n. 6. 1958

HODDER, I. (Ed.) The meaning of things: material culture and symbolic expression. London: Harper Collins Academic. 1991

HODDER, I. Symbols in action: ethnoarchaeological studies of material culture. Cambridge: Cambridge University. 2009

HORTON, D. The Mundurucú. In: STEWARD, J. H. (ed.) Handbook of South American Indians. New York: Cooper Square. 1963

HURCOMBE, L. Archaeological Artefacts as Material Culture. London: Routledge. 2007

IANDE. <http://www.iande.art.br/arteindigena.htm> acessado em março de 2013

INGOLD, T. Beyond art and technology: the anthropology of skill. In: SCHIFFER, M. B.

Anthropological Perspectives on Technology. Albuquerque: University of New Mexico Press. 2001

INSTITUTO SOCIOAMBIENTAL. Mapas. Disponível em <http://www.socioambiental.org/pt-br/mapas> 2012, acessado em: 15/04/2014

JÁCOME, C. Ayquatiá da Yapepó: Estudo dos Materiais Utilizados na Cerâmica Pintada Tupiguarani de Minas Gerais. Dissertação de mestrado, Escola de Belas Artes.Universidade Federal de Minas Gerais, Belo Horizonte. 2006

KRAMER, C. Ceramic Ethnoarchaeology. Annual Review of Anthropology, v. 14: 77-102. 1985

KRAMER, C. Pottery in Rajasthan: Ethnoarcaheology in Two Indian Cities. Washington \& London: Smithsonian Institution Press. 1997 
LA SAlVIA, F. e BROCHADO, J. P. Cerâmica Guarani. Porto Alegre: Posenato Arte e Cultura. 1989

LANE, P. Present to Past: Ethnoarchaeology. In: TILLEY, C. et al. (ed) Handbook of Material Culture. Los Angeles: SAGE London. 2010

LEMONNIER, P. Elements for an anthropology of technology. Ann Arbor, Mich.: Museum of Anthropology, University of Michigan. 1992

LEMONNIER, P. (ed) Technological Choices: Transformation in Material Cultures since the Neolithic. London: Routledge. 1993

LÉVI-STRAUSS, C. A oleira ciumenta. São Paulo: Editora Brasiliense. 1986

LIMA, H. P. História das Caretas: A Tradição Borda Incisa na Amazônia Central. Tese de doutorado, Museu de Arqueologia e Etnologia, Universidade de São Paulo, São Paulo. 2008

LIMA, H.; NEVES, E. G; PETERSEN, J. B. A Fase Açutuba: Um Novo Complexo Cerâmico na Amazônia Central. Arqueología Suramericana. Popayan - Colômbia, v. 2 (1): 26-52. 2006

LIMA, S. C. Tecnologia cerâmica chimu: estudo arqueométrico da coleção do MAE/USP. Tese de doutorado, Museu de Arqueologia e Etnologia, Universidade de São Paulo, São Paulo. 2010

LONGRACE, W. A. (Ed.) Ceramic Ethnoarchaeology. Tucson: University of Arizona Press. 1991

LONGRACE, W. A. e SKIBO, J. M. (Eds.) Kalinga Ethnoarcaheology: expanding archaeological method and theory. Washington: Smithsonian Institution Press. 1994

MACHADO, J. S. O Potencial Interpretativo das Análises Tecnológicas: um exemplo amazônico. Revista do Museu de Arqueologia e Etnologia, v. 15/16: 87-111. 20052006

MELIÁ, S. J. B. Os caiabis não-xinguanos. In: COELHO, V. P. (org) Karl von den Steinen: um século de antropologia no Xingu. São Paulo: Edusp/Fapesp. 1993

MIGLIACIO, M. C. A ocupação pré-colonial do Pantanal de Cáceres, Mato Grosso: uma leitura preliminar. Dissertação de mestrado, Museu de Arqueologia e Etnologia, Universidade de São Paulo, São Paulo. 2000

MILHEIRA, R. G.; APPOLONI, C. R. e PARREIRA, P. S. Arqueometria em cerâmicas Guarani no sul do Brasil. São Paulo: Revista do Museu de Arqueologia e Etnologia, v. 19: 355-364. 2009 
MONTEIRO, S. (org.) Expedição Langsdorff ao Brasil, 1821-1829. Iconografia do Arquivo da Academia de Ciências da Rússia. Rio de Janeiro: Alumbramento: Livroarte. 1998

MOSER, S. Archaeological representation: the visual conventions for constructing knowledge about the past. In: HODDER, I. (Ed.) Archaeological Theory Today. Cambridge, UK : Polity Press Malden, MA : Blackwell Publishers. 2002

MUNSELL. Munsell Soil Color Chart. New York: GretagMacbeth. 2000

MURPHY, R. F. Headhunter's heritage: social and economic change among the mundurucu indians. Berkeley: University of California Press. 1960

NEVES, E. G. Arqueologia, História Indígena e Registro Etnográfico: exemplos do Alto Rio Negro. Revista do MAE, v. 8: 319-330. 1998

NEVES, E. G. Ecology, Ceramic Chronology and Distribution, Long-term History, and Political Change in the Amazonian Floodplain. In: SILVERMAN, H. e ISBELL, W. H. Handbook of South American Archaeology. New York, NY: Springer. 2008

NEVES, E. G. Archaeological cultures and past identities in precolonial central Amazon. In: HORnBORG, A. e HILL, J. D. Ethnicity in Ancient Amazon: Reconstructing Past Identities from Archaeology, Linguistics, and Ethnohistory. Boulder, CO: University Press of Colorado. 2011

NIMUENDAJU, K. The Cayabi, Tapanyuna, and Apiaca. In: STEWARD, J. H. (ed.)

Handbook of South American Indians. New York: Cooper Square. 1963

NOELLI, F. S. As hipóteses sobre o centro de origem e as rotas de expansão dos Tupi. São Paulo: Revista de Antropologia - USP, v. 39 (2): 7-53. 1996

NOELLI, F. S. José Proenza Brochado: Vida Acadêmica e a Arqueologia Tupi. In: PROUS, A. e LIMA, T. A. (eds) Os Ceramistas Tupiguarani. Belo Horizonte: Sigma. 2008

NOELLI, F. S. The Tupi Expansion. In: SILVERMAN, H. e ISBELL, W. H. Handbook of South American Archaeology. New York, NY: Springer. 2008b

OLIVEIRA, F. C. B. de. Quando residir é habitar: lutas pela afirmação territorial Kaiabi no Baixo Teles Pires. Tese de doutorado, Instituto de Ciências Sociais Universidade Nacional de Brasília, Brasília. 2010

ORTON, C.; TYERS, P. e VINCE, A. Pottery in Archaeology. New York: Cambridge University Press. 1997

PAUKETAT, T. R. e EMERSON, T. E. The ideology of authority and the power of the pot. American Anthropologist, v. 93 (4): 919-941. 1991

PARDI, M. L. Frentes de Expansão. Seu Potencial e Impacto Sobre o Patrimônio 
Arqueológico - O Caso da Amazônia Mato-grossense e a Partir de um

Reconhecimento de 14 "CR/IPHAN". Coleção Arqueologia. Porto Alegre:

EDIPUCRS, v. 1 (1): 289-306. 1995-96

PEROTA, C. Relatório dos Trabalhos de Campo PRONAPABA. CNPq, IPHAN, UFES, SI. 1979

PEROTA, C. Relatório dos Trabalhos de Campo PRONAPABA. CNPq, SPHAN, INPA, UFES, SI. 1982

PETERSEN, J. et al. Gift from the past: Terra Preta and prehistoric occupation in Amazonia. In: McEWAN, C.; BARRETO, C.; NEVES, E. G. Unknown Amazon: culture and nature in ancient Brazil. Londres: British Museum Press. 2001

PFAFFENBERGER, B. Fetishised Objects and Humanised Nature: Towards an Anthropology of Technology. Man, v. 23 (2): 236-252. 1988

POLITIS, G. G. Tendencias de La Etnoarqueología em America Latina. Porto Alegre: Revista Horizontes Antropológicos, v. 8 (8). 2002

POUGET, F. M. C. Práticas Arqueológicas e Alteridades Indígenas. Dissertação de mestrado, Museu de Arqueologia e Etnologia, Universidade de São Paulo, São Paulo. 2010

PROUS, A. Arqueologia Brasileira. Brasília, DF: Editora Universidade de Brasília. 1992

RIBEIRO, B. Desenhos semânticos e identidade étnica: o caso Kayabí. In: RIBEIRO, D. e RIBEIRO, B. (org.) Suma Etnológica Brasileira. Rio de Janeiro: Vozes/Finep, v. II: 173-229. 1986

RICE, P. Pottery Analysis: a sourcebook. Chicago: University Press of Chicago. 1987

RICE, P. On the Origins of Pottery. Journal of Archaeological Method and Theory, v. 6 (1): 1-54. 1999

RIZZUTT, M. A.; CURADO, J. F.; MOTA, D. Relatório técnico das análises por Fluorescência de raios X por dispersão de energia (ED-XRF). 2014

ROBAZZINI, A. T. Dinâmica da ocupação territorial indígena no Vale do Rio Tapajós. Dissertação de mestrado, Museu de Arqueologia e Etnologia, Universidade de São Paulo, São Paulo. 2013

ROBRHAN-GONZÁLEZ, E. A ocupação ceramista pré-colonial no Brasil Central: origens e desenvolvimento. Tese de doutorado, Museu de Arqueologia e Etnologia, Universidade de São Paulo, São Paulo. 1996 
ROCHA, B. C. What can ceramic decoration tell us about the pre- and post- colonial past on the Upper Tapajós River? Dissertação de mestrado, Institute of Archaeology, University College London, London. 2012

RODRIGUES, I. M. Fora das grandes aldeias: A ocupação do recôndito sítio arqueológico Vereda III. Dissertação de mestrado, Faculdade de Filosofia e Ciências Humanas, Universidade Federal de Minas Gerais, Belo Horizonte. 2011

Roosevelt, A. C. Eighth Millennium Pottery from a Prehistoric Shell Midden in the Brazilian Amazon. Science 13, v. 254 (5038). 1991

RoOSEVElt, A. C.; LIMA DA COSTA, M.; LOPES MACHADO, C.; MICHAB, M.; MERCIER, N.; VALLADAS, H.; FEATHERS, J.; BARNETT, W.; IMAZIO DA SILVEIRA, M.; HENDERSON, A.; SILVA, J.; CHERNOFF, B.; REESE, D. S.; HOLMAN, J. A.; TOTH, N. e SCHICK, K. Paleoindian Cave Dwellers in the Amazon: The Peopling of the Americas. Science, v. 272: 373-384. 1996

RYE, O. Pottery Technology: principles and reconstruction. Washington, D.C.: Taraxacum. 1981

SACKETT, J. Style and ethnicity in archaeology: the case for isochrestism. In: CONKEY, M. e HASTORF, C. The Uses of Style in Archaeology. Cambridge: Cambridge University Press. 1991

SENRA, K. Os índios Kaiabi. Disponível em: < http://pib.socioambiental.org/pt/povo/kaiabi> Instituto Socioambiental - Povos Indígenas no Brasil. 1999, acessado em: 07/01/2013

SCHIFFER, M. B. Behavioral Archaeology: principles and practice. London: Equinox Pub.; Oakville (Conn). 2010

SCHIFFER, M. B. e SKIBO, J. M. The explanation of artifact variability. American Antiquity 62: 27-50. Washington: The Society. 1997

SCHMIDT, M. Los Bakairí. Revista do Museu Paulista, Nova Série, v 1. 1947

SHANKS, M. Post-processual archaeology and after. In: BENTLEY, R.A.; MASCHNER, H.

D. G. e CHIPPINDALE, C. Handbook of Archaeological Theories. Lanham, MD: AltaMira Press. 2008

SHANKS, M. e HODDER, I. Processual, Post-processual and Interpretive Archaeologies. In: WHITLEY, D. S. (ed) Reader in Archaeological Theory: post-processual and cognitive approaches. London and New York: Routledge. 1998

SHEPARD, A. O. Ceramics for the archaeologist. Washington: Carnegie Institution of Washington. 1971 
SILLAR, B. e TITE, M. S. The Challenge Of 'Technological Choices' For Materials Science Approaches In Archaeology. Archaeometry, v. 42 (1): 2-20. 2000

SILVA, F. A. As Tecnologias e Seus Significados: um estudo da cerâmica dos Asuriní do Xingu e da cestaria Kayapó-Xikrin sob uma perspectiva Etnoarqueológica. Tese de doutorado, Museu de Arqueologia e Etnologia, Universidade de São Paulo, São Paulo. 2000

SILVA, F. A. As cerâmicas dos Jês do Sul do Brasil e os seus estilos tecnológicos: elementos para uma etnoarqueologia Kaingang e Xokleng. In: MOTA, L. T.; NOELLI, F. S.; TOMMASINO, K. (eds.) Uri $\boldsymbol{e}$ Wãxi: estudos interdisciplinares dos Kaingang. Londrina: Editora UEL. 2000b

SILVA, F. A. As tecnologias e seus significados. São Paulo: Canindé, Xingo. 2002

SILVA, F. A. Ceramic technology of the Asurini do Xingu, Brazil: an ethnoarchaeological study of artifact variability. Journal of Archaeological Method and Theory, v. 15 (3): 217-265. 2008

SILVA, F. A. Arqueologia e Etnoarqueologia na Aldeia Lalima e na Terra Indígena Kayabi: Reflexões sobre Arqueologia Comunitária e Gestão do Patrimônio Arqueológico. In: Revista do Museu de Arqueologia e Etnologia 19: 1-15. São Paulo: Museu de Arqueologia e Etnologia. 2009

SILVA, F. A. Etnoarqueologia: uma perspectiva arqueológica para o estudo da cultura material. Métis (UCS), v. 8 (16): 121-139. 2009b

SILVA, F. A. O Patrimônio Arqueológico em Terras Indígenas: Algumas considerações sobre o tema no Brasil. In: FERREIRA, L. M.; FERREIRA, M. L. M.; ROTMAN, M. B. (Org.). Patrimônio Cultural no Brasil e na Argentina: estudos de caso. São Paulo: Annablume. 2011

SILVA, F. A. e STUCHI, F. F. Evidências e significados da mobilidade territorial: a Terra Indígena Kaiabi (Mato Grosso/Pará). Amazônica, 2 (1): 46-70. 2010

SILVA, F. A.; APPOLONI, C. R.; QUIÑNONES, F. R. E.; SANTOS, A. O.; SILVA, L. M. da; BARbieri, P. F. e NASCIMENTO FILHO, V. F. A Arqueometria e a Análise de Artefatos Cerâmicos: um estudo de fragmentos cerâmicos etnográficos e arqueológicos por Fluorescência de Raios X (EDXRF) e Transmissão Gama. Revista de Arqueologia, v. 17: 41-61. 2004

SILVA, F. A.; STUCHI, F. F.; BESPALEZ, E.; POUGET, F. C. Arqueologia, Etnoarqueologia e História Indígena: um estudo sobre a trajetória de ocupação 
indígena em territórios do Mato Grosso e Mato Grosso do Sul: a terra indígena Kayabi e a aldeia Lalima. Projeto FAPESP: Processo 2006/60241-8. 2006

SILVA, F. A.; STUCHI, F. F.; BESPALEZ, E.; POUGET, F. C. Arqueologia em terra indígena: uma reflexão teórico-metodológica sobre as experiências de pesquisa na Aldeia Lalima (MS) e na Terra Indígena Kaiabi (MT\PA). In: PEREIRA, E. e GUAPINDAIA, V. (Org.). Arqueologia Amazônica (2). Belém: MPEG; IPHAN; SECULT. 2010

SILVA, F. A.; BESPALEZ, E.; STUCHI, F. F. Arqueologia colaborativa na Amazônia: Terra Indígena Koatinemu, Rio Xingu, Pará. Amazônica, Revista de Antropologia, v. 3 (1): 32-59. 2011

SILVA, T. e FOSSAluZA, V. Relatório de Análise Estatística sobre o Projeto: "A Cerâmica Arqueológica na T. I. Kaiabi (MT/PA)". São Paulo, IME-USP. (RAECEA-13P22). 2013

SINOPOLI, C. Approaches to Archaeological Ceramics. New York: Plenum Press. 1991

SKIBO, J. M. Pottery Function: A Use-Alteration Perspective. New York: Plenum Press. 1992

SKIBO, J. M. Ethnoarchaeology, experimental archaeology and inference building in ceramic research. Archaeologia Polonia, v. 30: 27-38. 1992b

SKIBO, J. M. e BLINMAN, E. Exploring the Origins of pottery on the Colorado Plateau. In: SKIBO, J. M. e FEINMAN, G. M. Pottery and people: a dynamic interaction. Salt Lake City: University of Utah Press. 1999

SKIBO, J. M. e FEINMAN, G. M. Pottery and people: a dynamic interaction. Salt Lake City: University of Utah Press. 1999

SMITH, A. L. Processing Clay For Pottery In Northern Cameroon: Social And Technical Requirements. Archaeometry, v. 42 (1): 21-42. 2000

SMITH, C. e WOBST, H. M. (ed.) Indigenous archaeologies: decolonizing theory and practice. London: Routledge, New York. 2005

STAHL, A. B.; CRUZ, M. das D.; NEFF, H.; GLASCOCK, M. D.; SPEAKMANE, R. J.; GILES, B.; SMITH, L. Ceramic production, consumption and exchange in the Banda area, Ghana: Insights from compositional analyses. Journal of Anthropolgical Archaeology, v. 27 (3): 363-381. 2008

STARK, M. T. (Ed.) The Archaeology of Social Boundaries. Washington: Smithsonian Institution Press. 1998 
STARK, M.; BISHOP, R. L. e MIKSA, E. Ceramic Technology and Social Boundaries: Cultural Practices in Kalinga Clay Selection and Use. Journal of Archaeological Method and Theory, v. 7 (4): 295-331. 2000

STARK, M. T.; BOWSER, B. J.; HORNE, L. Cultural Transmission and Material Culture: breaking down boundaries. Tucson: University of Arizona Press. 2008

STUCHI, F. F. A Ocupação da Terra Indígena Kaiabi (MT/PA): História Indígena e Etnoarqueologia. Dissertação de mestrado, Museu de Arqueologia e Etnologia, Universidade de São Paulo, São Paulo. 2010

TITE, M. S. Pottery Production, Distribution, and Consumption - The Contribution of the Physical Sciences. Journal of Archaeological Method and Theory, v. 6 (3): 181-233. 1999

TRIGGER, B. História do Pensamento Arqueológico. São Paulo: Odysseus. 2004

TULLY, G. Community archaeology: general methods and standards of practice. Public Archaeology, v. 6 (3): 155-187. 2007

van der LEEUW, S. Variation, Variability and Explanation in Pottery Studies. In: LONGACRE, W. A. Ceramic Ethnoarchaeology. Tucson: University of Arizona Press. 1991

van der LEEUW, S. Giving the Potter a Choice. In: LEMONNIER, P. (ed.). Technological Choices. Transformation in Material Cultures since the Neolithic. London: Routledge. 1993

van VELTHEM, L. Mulheres de cera, argila e arumã: princípios criativos e fabricação materialentre os Wayana. MANA, v. 15 (1): 213-136. 2009

VIANA, S. A.; RIBEIRO, C. V.; OLIVEIRA, S. D. Cauixi em Cerâmica Arqueológica: uma Questão de Escolhas Culturais. Revista de Arqueologia da Sociedade de Arqueologia Brasileira, v. 24: 20-39. 2011

VIDAL, L. (org.) Grafismo indígena: estudos de antropologia estética. São Paulo, SP: Studio Nobel; FAPESP; Edusp. 1992

VILlAS BÔAS, O. e VILLAS BÔAS, C. Os Kayabi do Rio São Manuel. Porto Alegre: Kuarup. 1989

VITELLI, K. Looking up at early ceramics in Greece. In: SKIBO, J. M. \& FEINMAN, G. M. Pottery and people: a dynamic interaction. Salt Lake City: University of Utah Press. 1999

VOLKMER-RIBEIRO, C. e BATISTA, T. C. A. Levantamento de cauixi (Porifera, Demospongiae), provável agente etiológico da doença ocular em humanos, 
Araguantins, rio Araguaia, Estado do Tocantins, Brasil. Revista Brasileira de Zoologia, v. 24 (1): 133-143. 2007

von den STEINEN, K. O Brasil Central: expedição em 1884 para a exploração do rio

Xingú. São Paulo: Companhia Editora Nacional. 1942

WALLAERT, H. The way of the potter's mother : apprenticeship strategies among Dii potters from Cameroon, West Africa. In: STARK, M. T.; BOWSER, B. J.; HORNE, L. Cultural Transmission and Material Culture: breaking down boundaries. Tucson: University of Arizona Press. 2008

WEBSTER, G. S. Culture history: a culture-historical approach. In: BENTLEY, R.A.; MASCHNER, H. D. G. e CHIPPINDALE, C. Handbook of Archaeological Theories. Lanham, MD: AltaMira Press. 2008

WIESSENER, P. Is there a unity to style? In: CONKEY, M. e HASTORF, C. The Uses of Style in Archaeology. Cambridge: Cambridge University Press. 1991

WILLEY, G. R. e PHILLIPS, P. Method and theory in American Anchaeology. Chicago: Univ. of Chicago Press. 1958

WOBST, H. M. Stylistic behavior and information exchange. In: CLELAND, C. E. (ed.) For the Director: Research Essays in Honor of James B. Griffin. Anthropological Papers, v. 61: 317-342. Museum of Anthropology, University of Michigan: Ann Arbor. 1977

WÜST, I. Continuidade e mudança: para uma interpretação dos grupos ceramistas précoloniais da bacia do rio Vermelho, Mato Grosso. Tese de doutorado, Faculdade de Filosofia, Letras e Ciências Humanas, Universidade de São Paulo. 1990

WÜST, I. e BARRETO, C. The Ring Villages of Central Brasil: A Challenge for Amazonian Archaoelogy. Latin American Antiquity, v. 10 (1): 3-23. 1999

ZEDEÑO, M. N. Landscapes, Land Use, and the History of Territory Formation: an Example from the Puebloan Southwest. Journal of Archaeological Method and Theory, v. 4 (1): 67-103. 1997

ZUSE, S. Os Guarani e a Redução Jesuítica: tradição e mudança técnica na cadeia operatória de confecção dos artefatos cerâmicos do sítio Pedra Grande e entorno. Dissertação de mestrado, Museu de Arqueologia e Etnologia, Universidade de São Paulo, São Paulo. 2009 


\section{ANEXO A \\ CÓDIGOS DE ANÁLISE}

$\underline{\text { Análise preliminar da variabilidade artefatual da cerâmica na T. I. Kaiabi }}$

Códigos das variantes dos atributos analisados nos fragmentos cerâmicos, com ilustrações

Obs.: para todos os itens, código 0 = Ausente e código 99 = Não identificado.

\section{Identificação}

1. Sítio/Número do fragmento

2. Proveniência

3. Nível

\section{Preparação da Matéria-prima}

4. Antiplástico

$1=$ Mineral

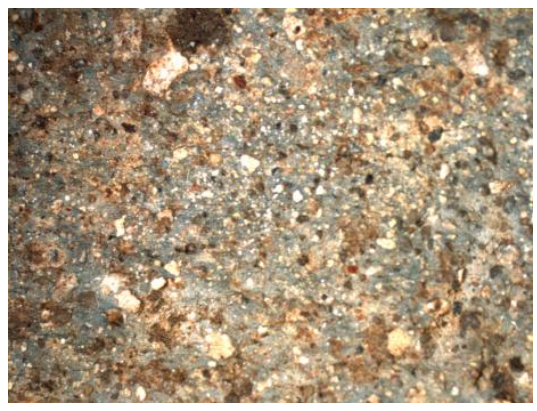

2 = Caco moído

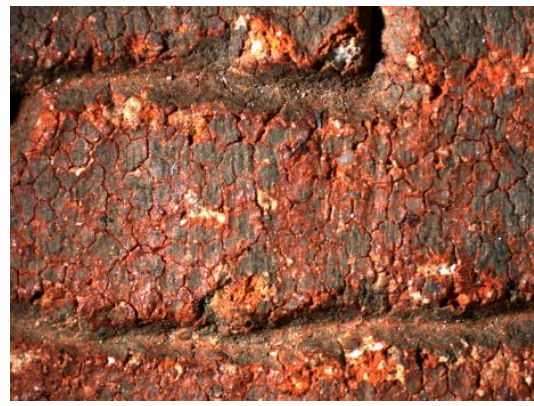

4 = Caraipé

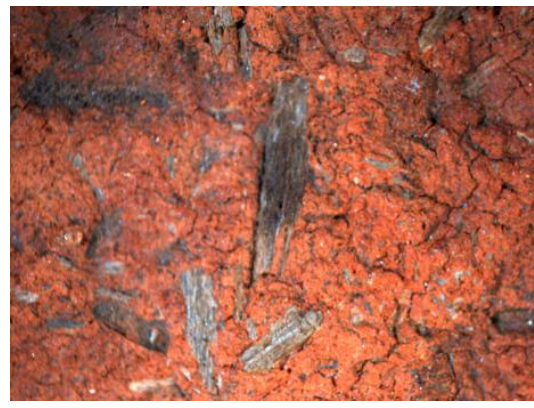

7 = Caco moído e caraipé

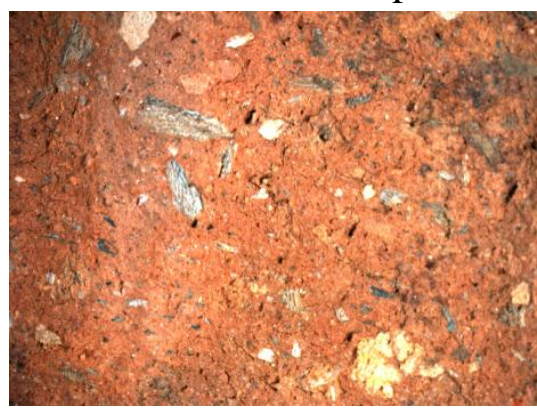

$8=$ Cauixi

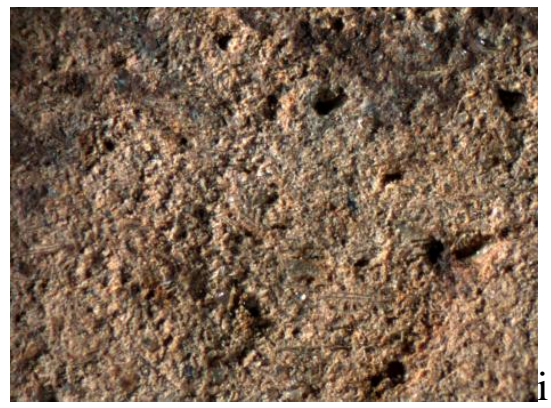

9 = Cauixi e caco moído

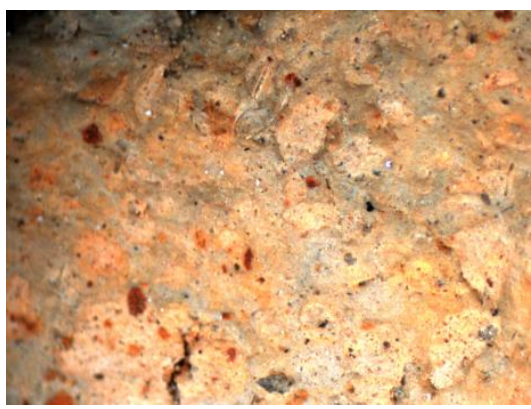


10 = Caco moído, caraipé e cauixi

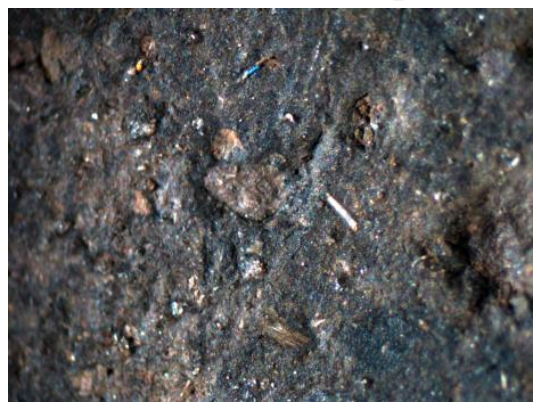

14 = Caco moído, cauixi, carvão

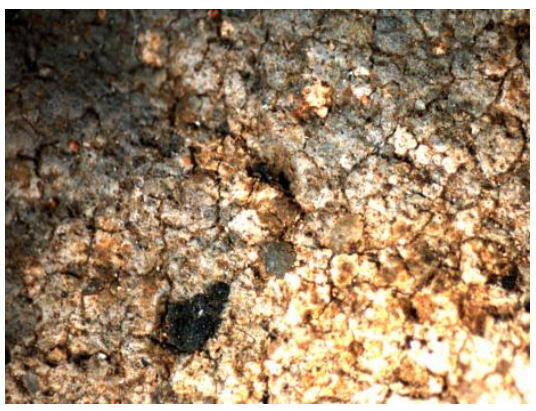

11 = Cauixi e caraipé

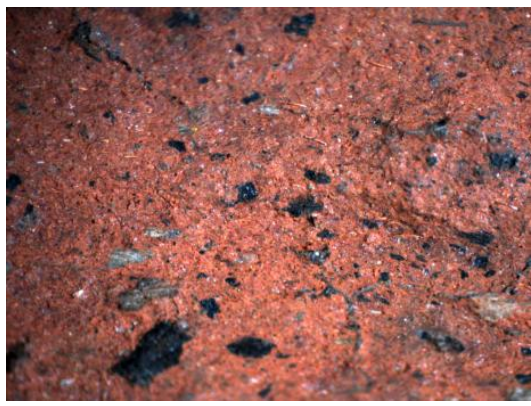

\section{Construção da Vasilha}

5. Técnica de manufatura

$1=$ Roletado

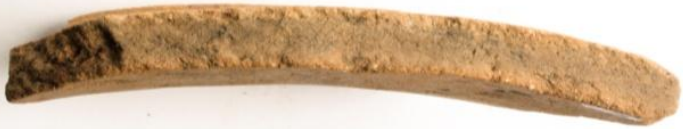

$2=$ Modelado

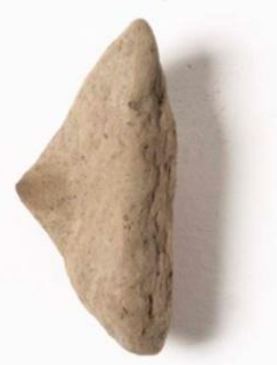

\section{Categoria estrutural}

$$
\begin{aligned}
& 1=\text { Base } \\
& 2=\text { Parede } \\
& 3=\text { Pescoço } \\
& 4=\text { Borda } \\
& 5=\text { Lábio } \\
& 6=\text { Apêndice } \\
& 7=\text { Bolota de argila } \\
& 8=\text { Outros }
\end{aligned}
$$




\section{Variante de Base}

$1=$ Circular plana

3 = Circular convexa

\section{Variante de Parede}

$1=$ Segmento inferior

$2=$ Segmento superior

$3=$ Ombro (ponto de tangência vertical)

$4=$ Parede infletida

$5=$ Parede carenada (ponto angular saliente)

$6=$ Parede angular (ponto angular reentrante)

$8=$ Parede cambada

\section{Variante de Borda}

$1=$ Direta vertical

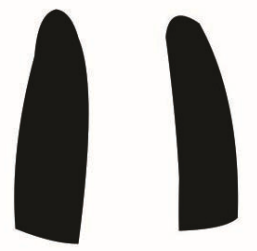

$2=$ Direta inclinada externa

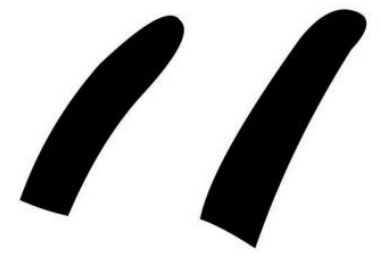

$3=$ Direta inclinada interna
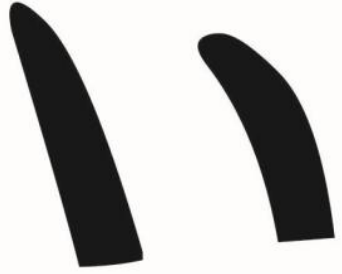

$4=$ Extrovertida

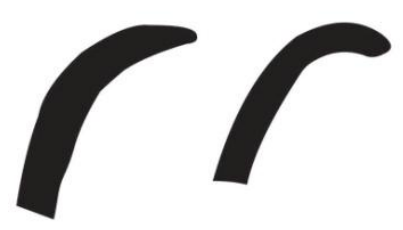

$8=$ Carenada

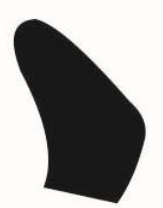

$10=$ Cambada

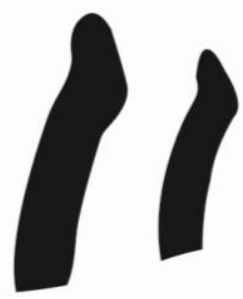


$12=$ Borda residual

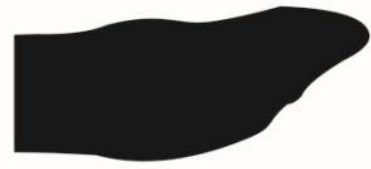

$13=$ Horizontal

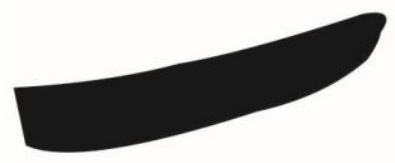

*Desenhos: Amanda Moraes
$1=$ Arredondado

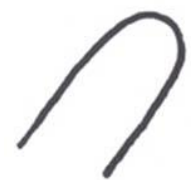

2 = Apontado

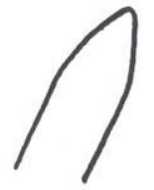

3 = Aplanado

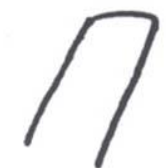

4 = Biselado

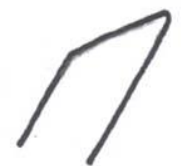

$8=$ Reforçado

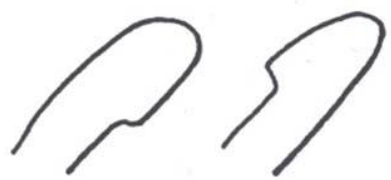

$10=$ Ondulado

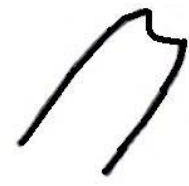

$11=$ Rebarbado

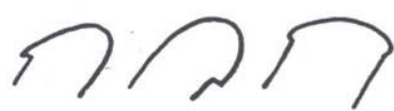

*Adaptado de: MIGLIACIO, 2000

11. Variante de Apêndice

3 = Mamilonar

*Foto: Ader Gotardo 


$$
\begin{aligned}
& 1=\leq 2 \mathrm{~cm} \\
& 2=\geq 2,1 \mathrm{~cm} \mathrm{e} \leq 4 \mathrm{~cm} \\
& 3=6 \mathrm{~cm} \\
& 4=8 \mathrm{~cm} \\
& 5=10 \mathrm{~cm} \\
& \ldots \\
& 29=58 \mathrm{~cm} \\
& 30=60 \mathrm{~cm} \\
& 31=\geq 60,1 \mathrm{~cm}
\end{aligned}
$$

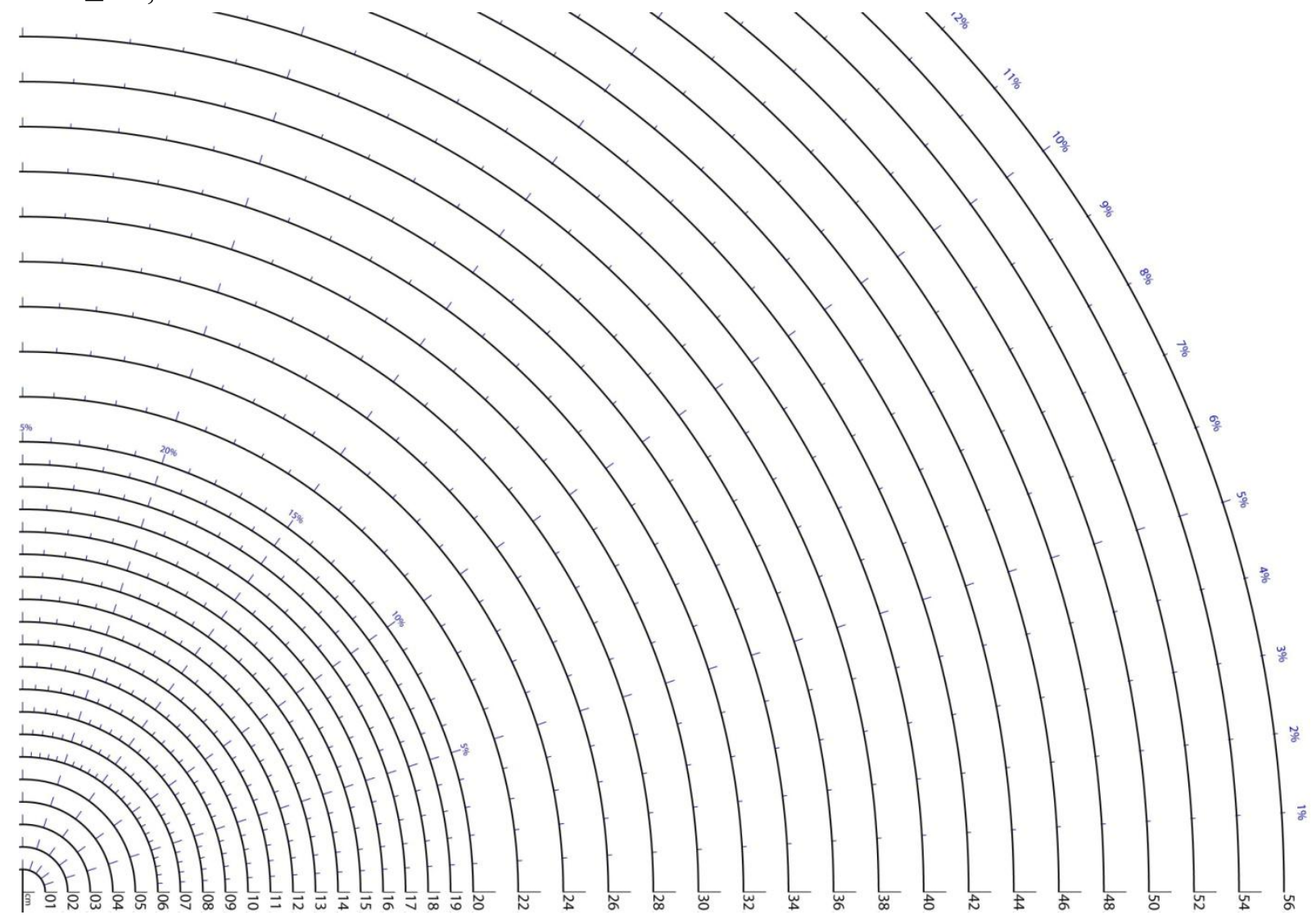

\section{Diâmetro da boca}

Idem item 12.

\section{Diâmetro máximo}

Idem item 12.

\section{Altura}

$1=\leq 1 \mathrm{~cm}$

$2=2 \mathrm{~cm}$

$3=3 \mathrm{~cm}$ 
$1=\leq 1 \mathrm{~mm}$

$2=2 \mathrm{~mm}$

$3=3 \mathrm{~mm}$

\section{Espessura (código)}

$1=$ Muito fino $(1 \mathrm{~mm}$ à $5 \mathrm{~mm})$

$2=$ Fino $(5 \mathrm{~mm}$ à $10 \mathrm{~mm})$

$3=$ Médio $(10 \mathrm{~mm}$ à $15 \mathrm{~mm})$

$4=$ Grosso $(15 \mathrm{~mm}$ à $20 \mathrm{~mm})$

5 = Muito Grosso (maior que $20 \mathrm{~mm}$ )

\section{Massa}

$1=\leq 1 \mathrm{~g}$

$2=2 \mathrm{~g}$

$3=3 \mathrm{~g}$

...

\section{Volume}

$1=\leq 1 \mathrm{~L}$

$2=2 \mathrm{~L}$

$3=3 \mathrm{~L}$

...

\section{0. Ângulo de inclinação}

$1=\operatorname{Vertical}\left(0^{\circ}\right.$ à $10^{\circ}$ positivos ou negativos $)$

$2=$ Ligeiramente aberto $\left(10^{\circ}\right.$ à $30^{\circ}$ positivos $)$

$3=$ Aberto $\left(30^{\circ}\right.$ à $50^{\circ}$ positivos $)$

4 = Ligeiramente fechada $\left(10^{\circ}\right.$ à $30^{\circ}$ negativos $)$

$5=$ Fechada $\left(30^{\circ}\right.$ à $50^{\circ}$ negativos $)$

$6=$ Muito fechada $\left(50^{\circ}\right.$ à $75^{\circ}$ negativos $)$

$7=$ Horizontal $\left(75^{\circ}\right.$ à $95^{\circ}$ positivos ou negativos $)$

$8=$ Muito aberto $\left(50^{\circ}\right.$ à $75^{\circ}$ positivos $)$ 


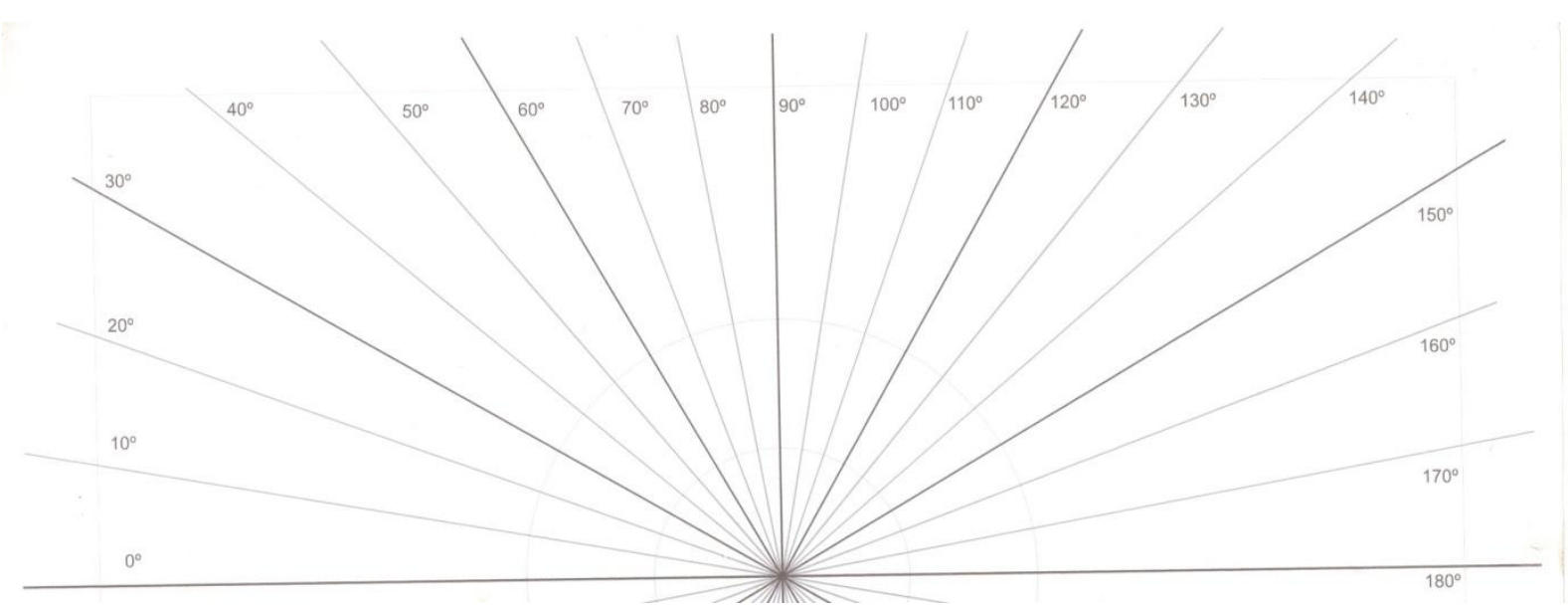

21. Relação boca/corpo

$1=$ Aberta

$2=$ Fechada

\section{Contorno específico}

$1=$ Simples

2 = Infletido

3 = Composto

4 = Complexo

\section{Classe estrutural}

$1=$ Não restringida

$2=$ Restringida

$3=$ Restringida independente

\section{Forma}

1 = Esférica
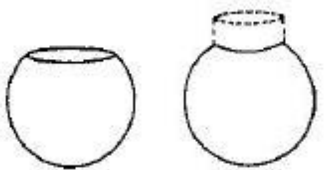

4 = Semi-elíptica vertical

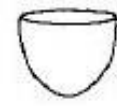

2 = Semi-esférica
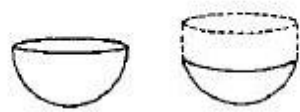

5 = Elíptica horizontal

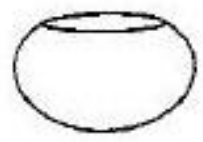

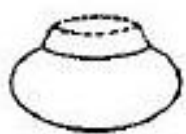

3 = Elíptica vertical
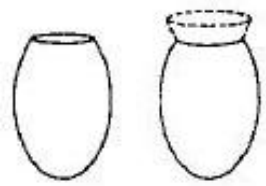

$6=$ Semi-elíptica

horizontal
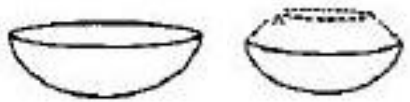
7 = Oval vertical

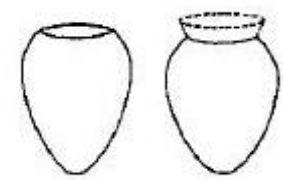

$10=$ Semi-oval invertido
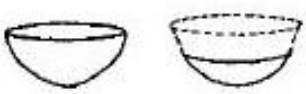

$8=$ Semi-oval vertical
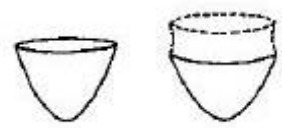

$9=$ Oval invertido

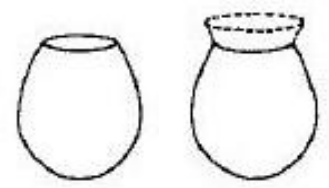

$11=$ Cilíndrica
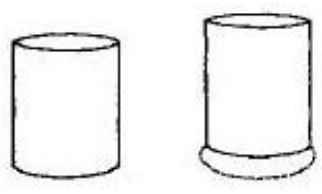

$\square$

12 = Cônica
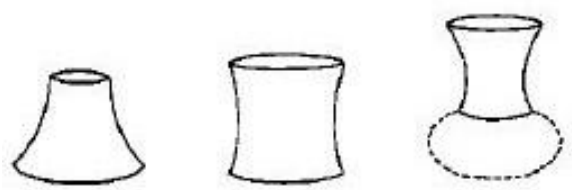<smiles>c1ccccc1</smiles>

13 = Hiperbólica
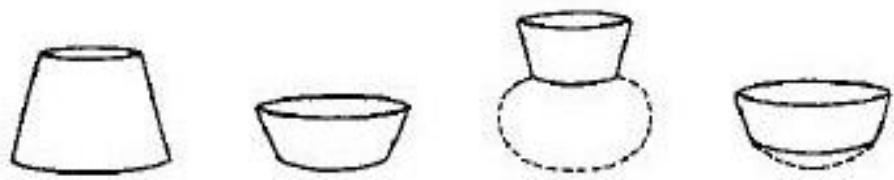

*Conforme: SHEPARD, 1971: 234

\section{Indicativos de Queima}

25. Configuração do Núcleo

$1=$

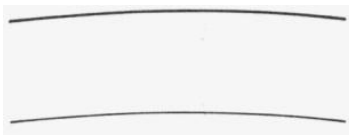

$4=$

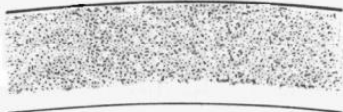

$2=$

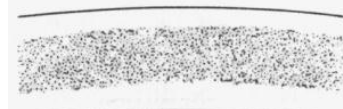

$5=$

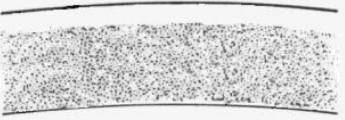

$3=$

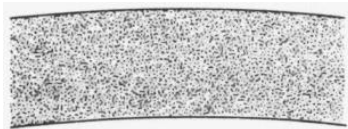

$6=$

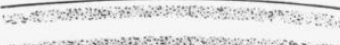

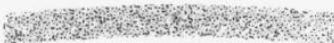

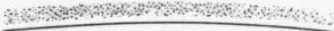

*Adaptado de: RYE, 1981: 116

26. Coloração da face externa

$1=\operatorname{Branco}(7.5$ YR 8/1, 7.5 YR 8/2, 7.5 YR 8/3) 
$2=$ Cinza Claro (7.5 YR 6/1, 7.5 YR 6/2, 7.5 YR 6/3, 7.5 YR 6/4, 7.5 YR 7/1, 7.5 YR 7/2, 7.5 YR 7/3, 7.5 YR 7/4, 7.5 YR 8/4, 7.5 YR 8/6, 10 YR 7/4)

$3=$ Cinza Escuro (7.5 YR 4/3, 7.5 YR 5/1, 7.5 YR 5/2, 7.5 YR 5/3, 7.5 YR 5/4)

4 = Marrom (7.5 YR 4/6, 7.5 YR 5/6, 7.5 YR 6/6, 7.5 YR 6/8, 7.5 YR 7/6)

5 = Marrom avermelhado (5 YR 4/2, 5 YR 4/3, 5 YR 4/4, 5 YR 4/6, 5 YR 5/3, 5 YR 5/4, 5 YR 5/6, 5 YR 6/4, 5 YR 6/6, 5 YR 6/8, 5 YR 7/6, 5YR 7/8, 5 YR 6/3)

$6=$ Vermelho (2.5 YR 4/4, 2.5 YR 4/6, 2.5 YR 5/4, 2.5 YR 5/6, 2.5 YR 5/8, 2.5 YR 6/4, 2.5 YR 6/6, 2.5 YR 6/8)

$7=\operatorname{Rosa}(5$ YR 7/4, 2.5 YR 7/4, 2.5 YR 7/6)

$8=$ Preto $(7.5$ YR $2.5 / 1,7.5$ YR 4/1)

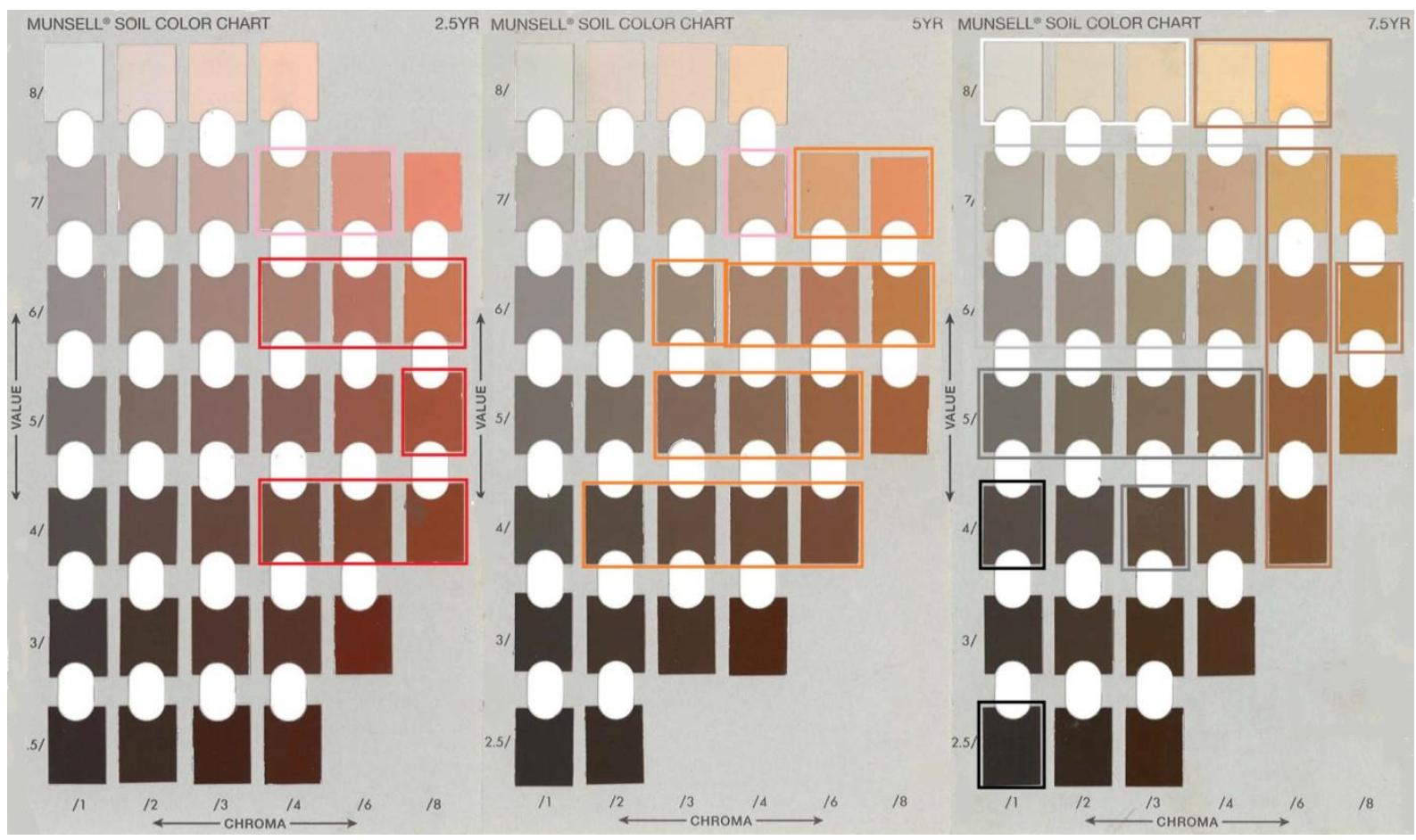

*Conforme: Munsell Soil Color Chart, 2000

27. Coloração da face interna

Idem item 26.

28. Marca de Queima

$1=$ Firecloud 


\section{Acabamento de superfície}

29. Face externa

\section{Acabamentos plásticos}

1 = Alisamento
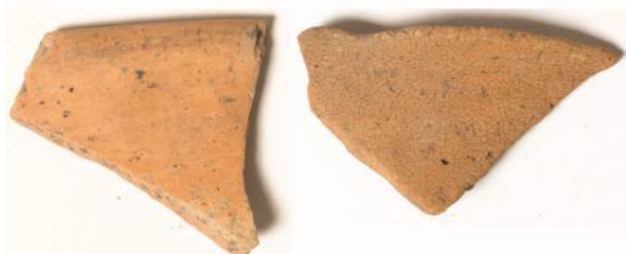

3 = Corrugado
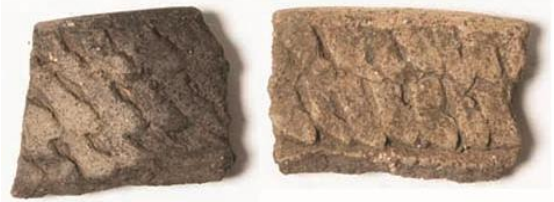

$5=$ Ungulado
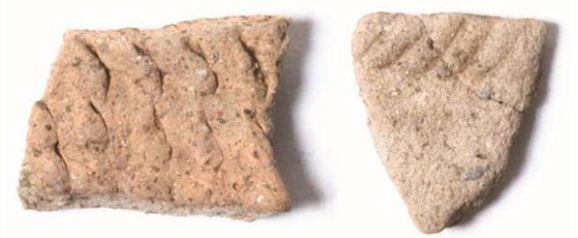

$6=$ Impressão de corda

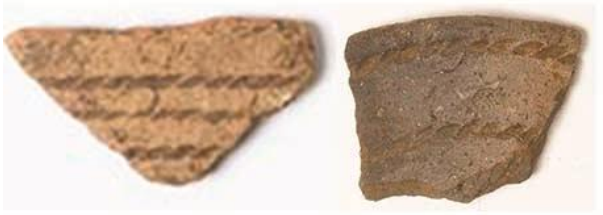

7 = Perfurado

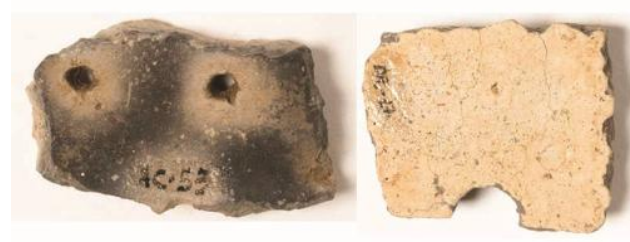

$8=$ Inciso

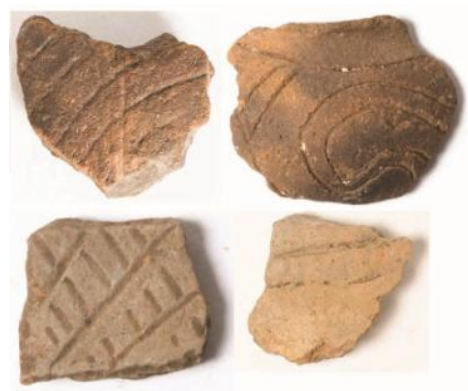

11 = Acanalado
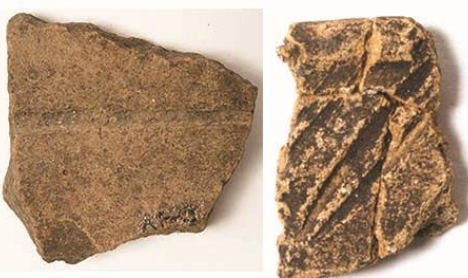

$14=$ Ponteado

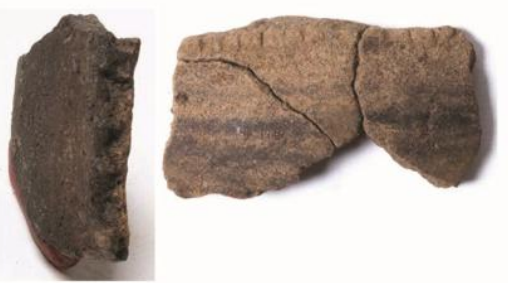


43 = Inciso e impressão de corda
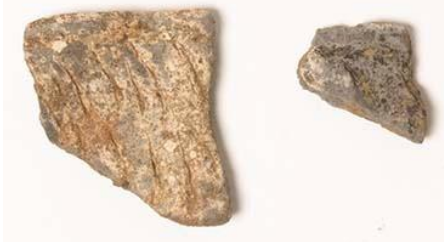

44 = Impressão de corda e beliscado

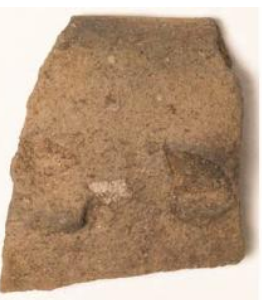

\section{Acabamentos pintados}

$22=$ Engobo branco

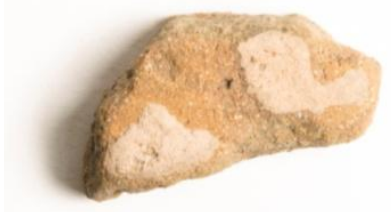

23 = Engobo vermelho
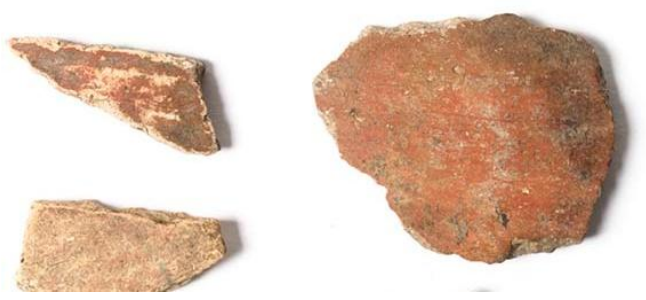

$24=$ Banho

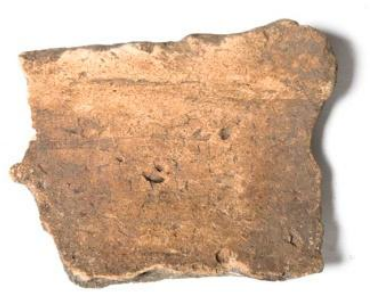

47 = Impressão de corda e acanalado

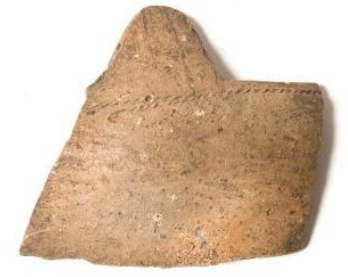

$48=$ Inciso e ponteado

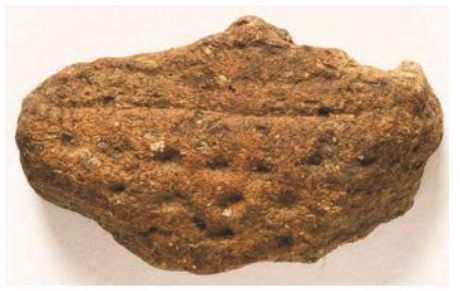

$25=$ Engobo rosa

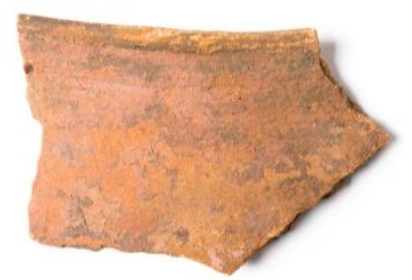

$33=$ Pintura branca sobre engobo vermelho

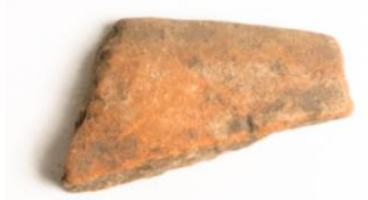

$35=$ Pintura branca sobre banho

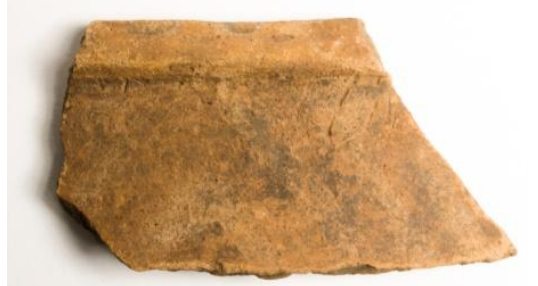


$40=$ Pintura vermelha sobre engobo branco

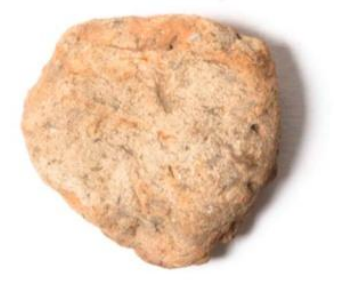

\section{Acabamentos mistos}

$30=$ Inciso e pintura branca

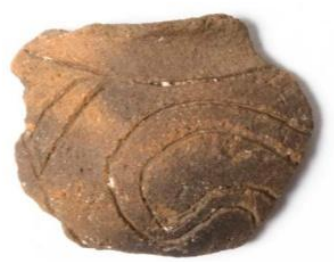

32 = Inciso sobre engobo vermelho

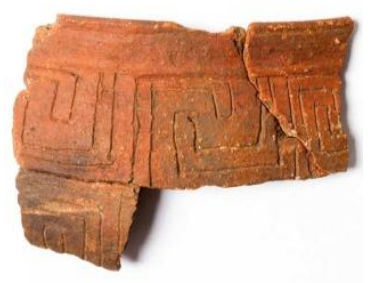

$46=$ Pintura branca sobre banho e faixa vermelha

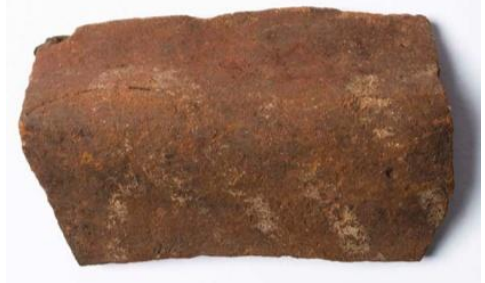

$36=$ Engobo rosa sobre inciso

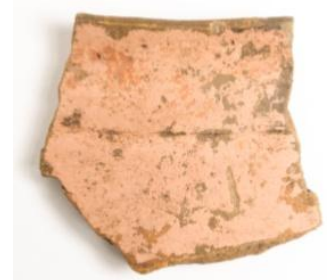

$38=$ Banho sobre inciso

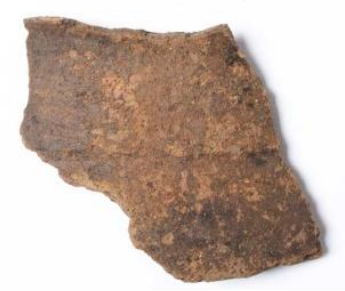

Idem item 29.

$$
\text { 31. Lábio }
$$

Idem item 29.

$$
\text { 32. Apêndice }
$$

Idem item 29.

\section{Posição do Grafismo}

$1=$ Parede face externa

$2=$ Parede face interna

3 = Borda face externa

4 = Borda face interna 
5 = Lábio

$6=$ Vasilha inteira

7 = Borda interna e externa

\section{Grafismos}

$1=$ Linhas

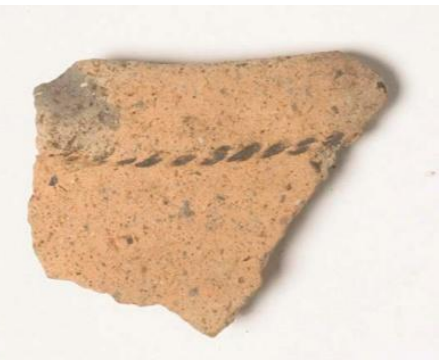

$4=$ Gregas

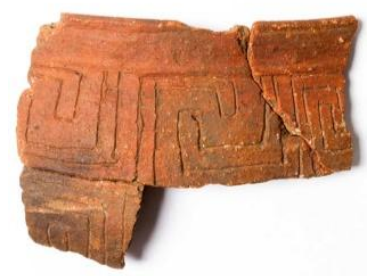

5 = Triângulos

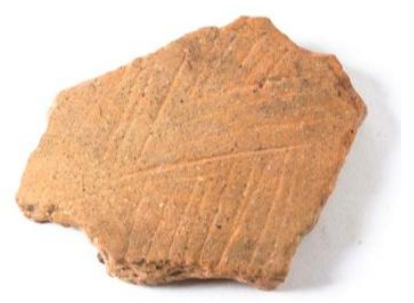

$6=$ Volutas e linha

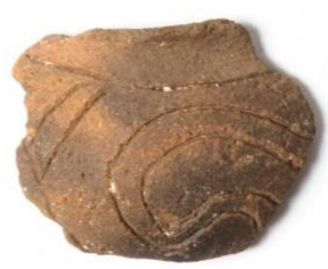

7 = Quadriculado

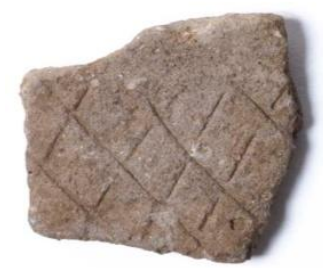

8 = Círculos

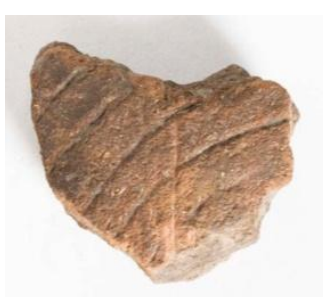

\section{Uso}

\section{Função}

$1=$ Vasilha para cozinhar

$2=$ Vasilha para servir

$3=$ Vasilha para consumir

$4=$ Vasilha para líquidos

$5=$ Ritual

$6=$ Decorativa

$7=$ Outros 
$1=$ Fuligem face externa

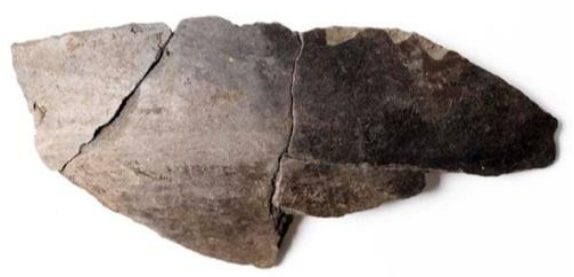

$2=$ Polidor sulco face externa

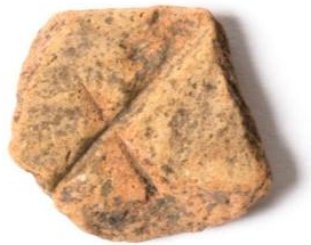

$3=$ Polidor sulco face interna

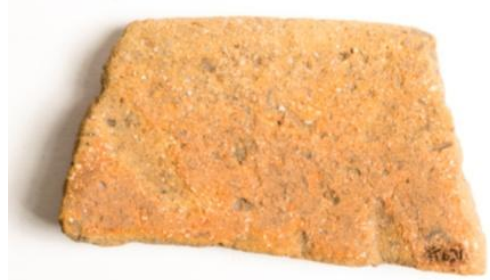

4 = Depósito de carbono face interna

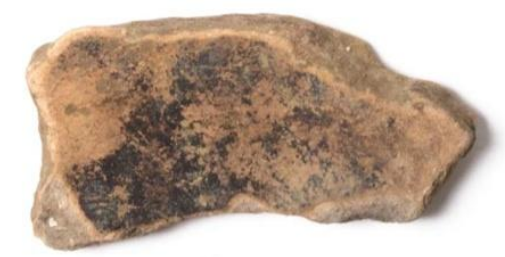

$6=$ Fuligem e polidor de sulco
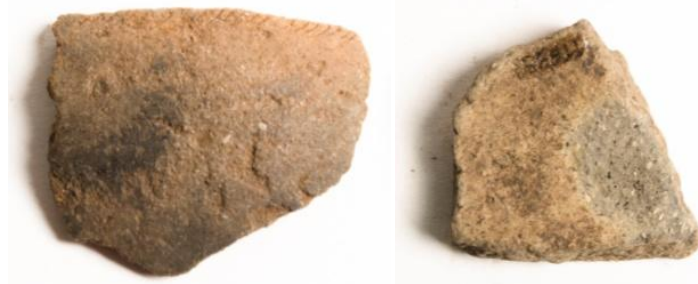

8 = Fuligem face externa e depósito de carbono face interna

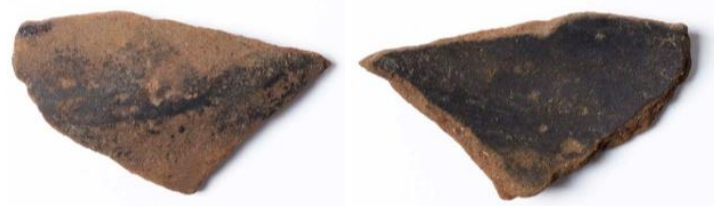

9 = Polidor núcleo
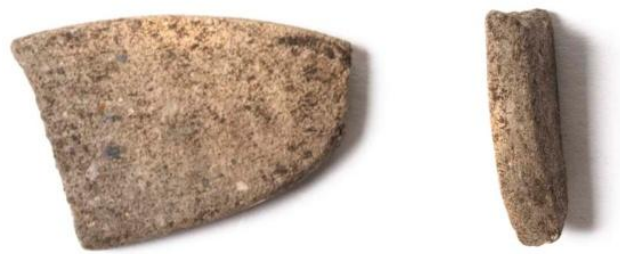

$10=$ Spalling

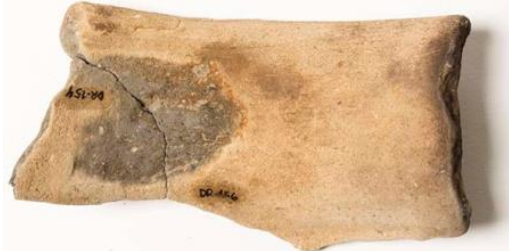

11 = Marca de líquido

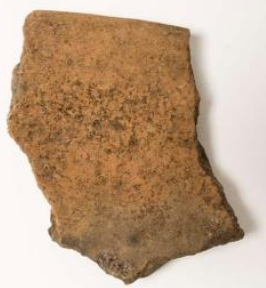

\section{Classificação}

37. Classificação

$1=$ Conjunto 1

$2=$ Conjunto 2

$3=$ Conjunto 3

$4=$ Conjunto 4 


\section{ANEXO B \\ LÍTICOS E OUTROS MATERIAIS}

Sítio Aldeia Coelho

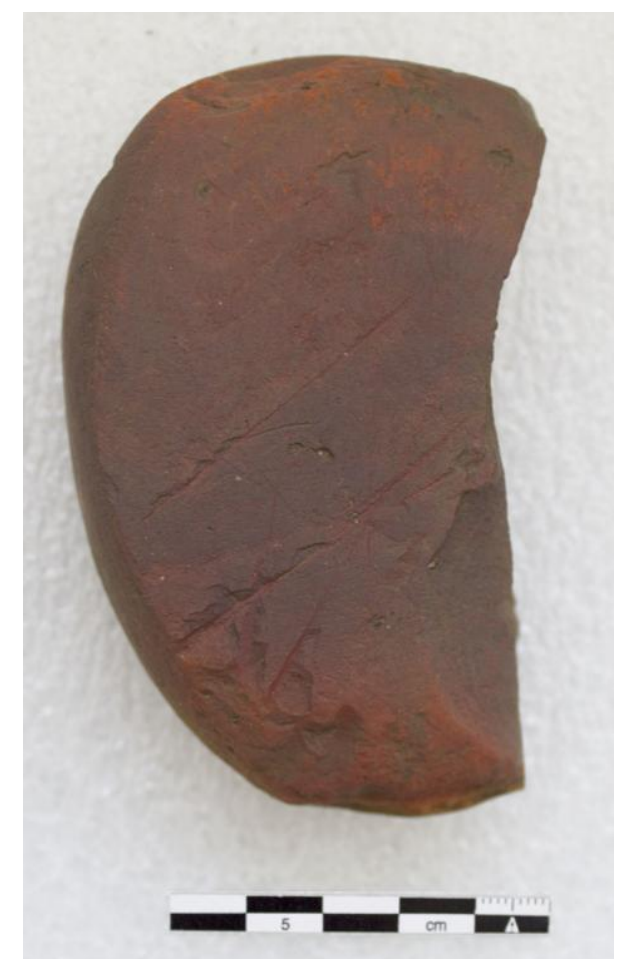

Lítico em superfície.

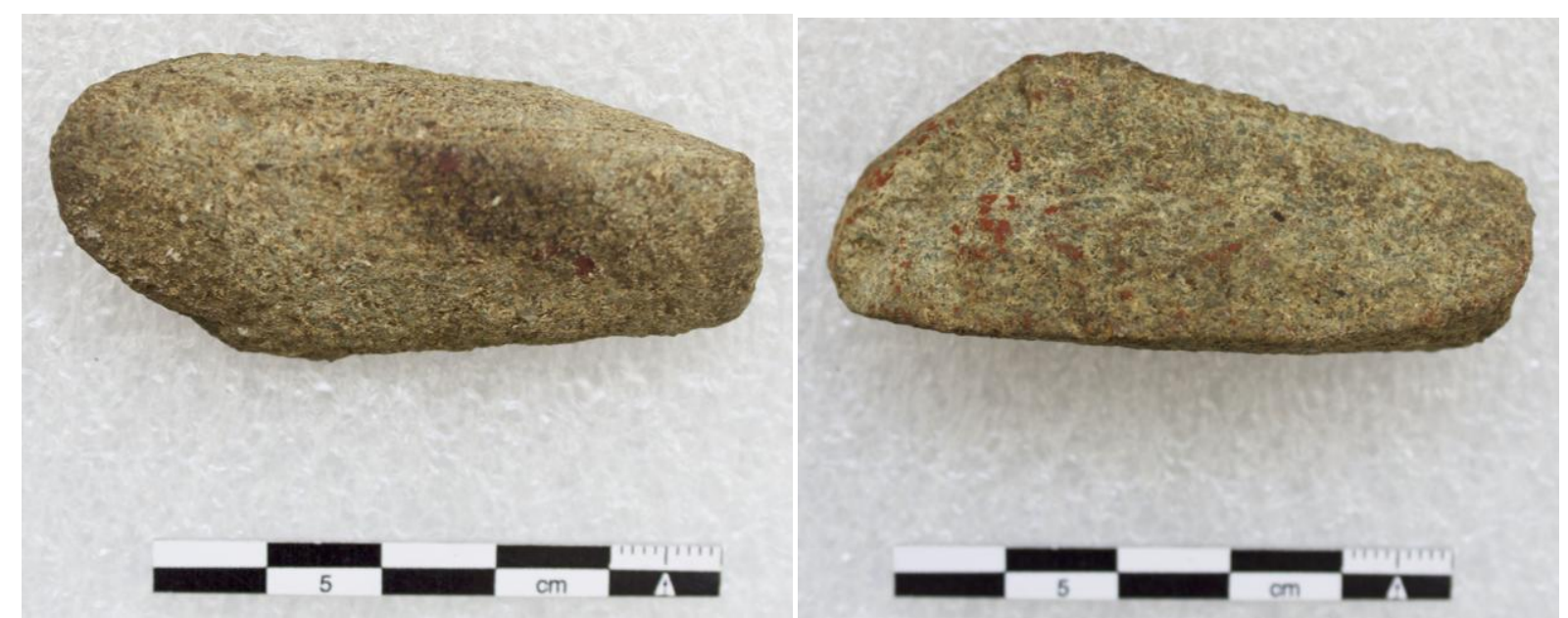

Lítico em superfície. 

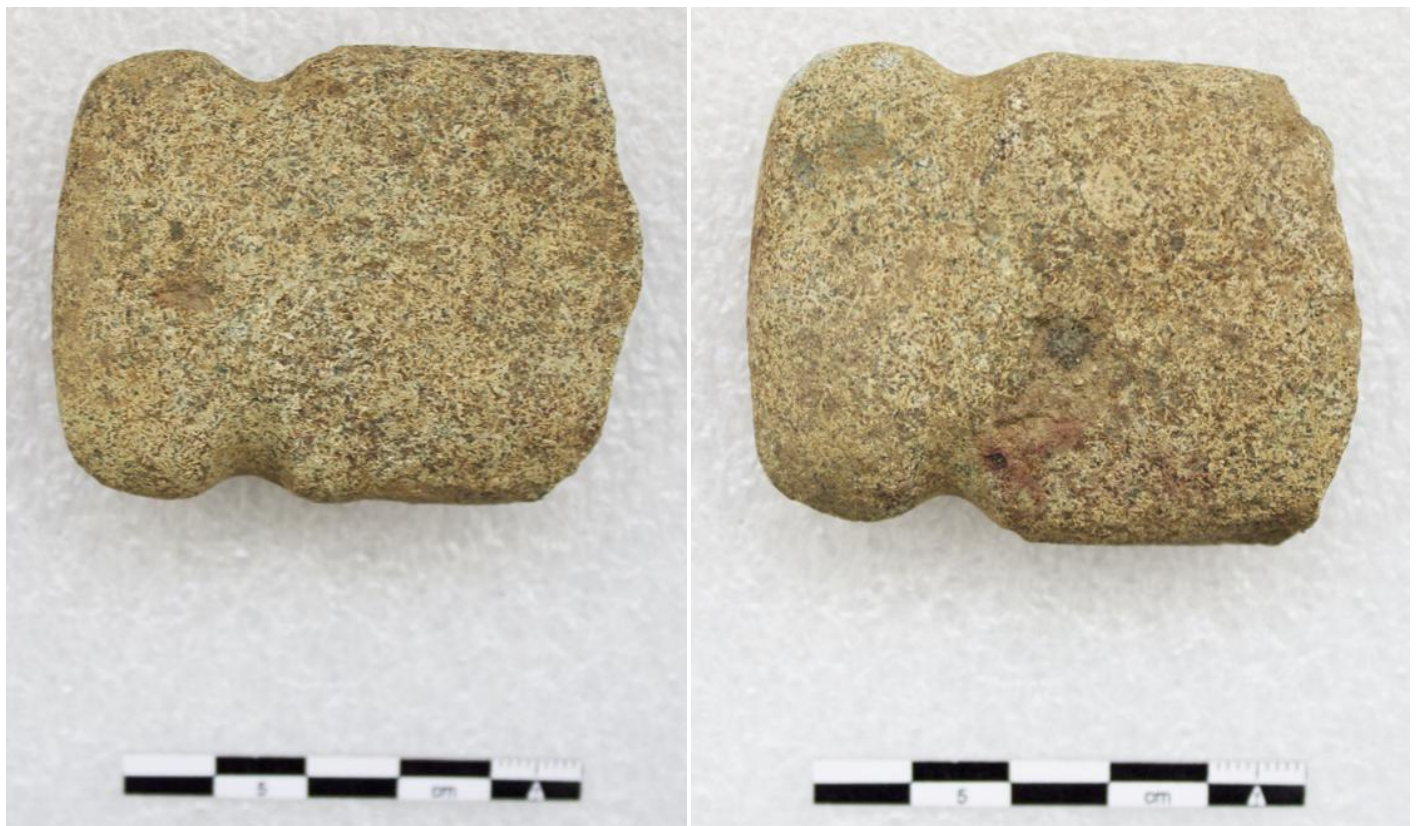

Lítico em superfície. Lâmina de machado.
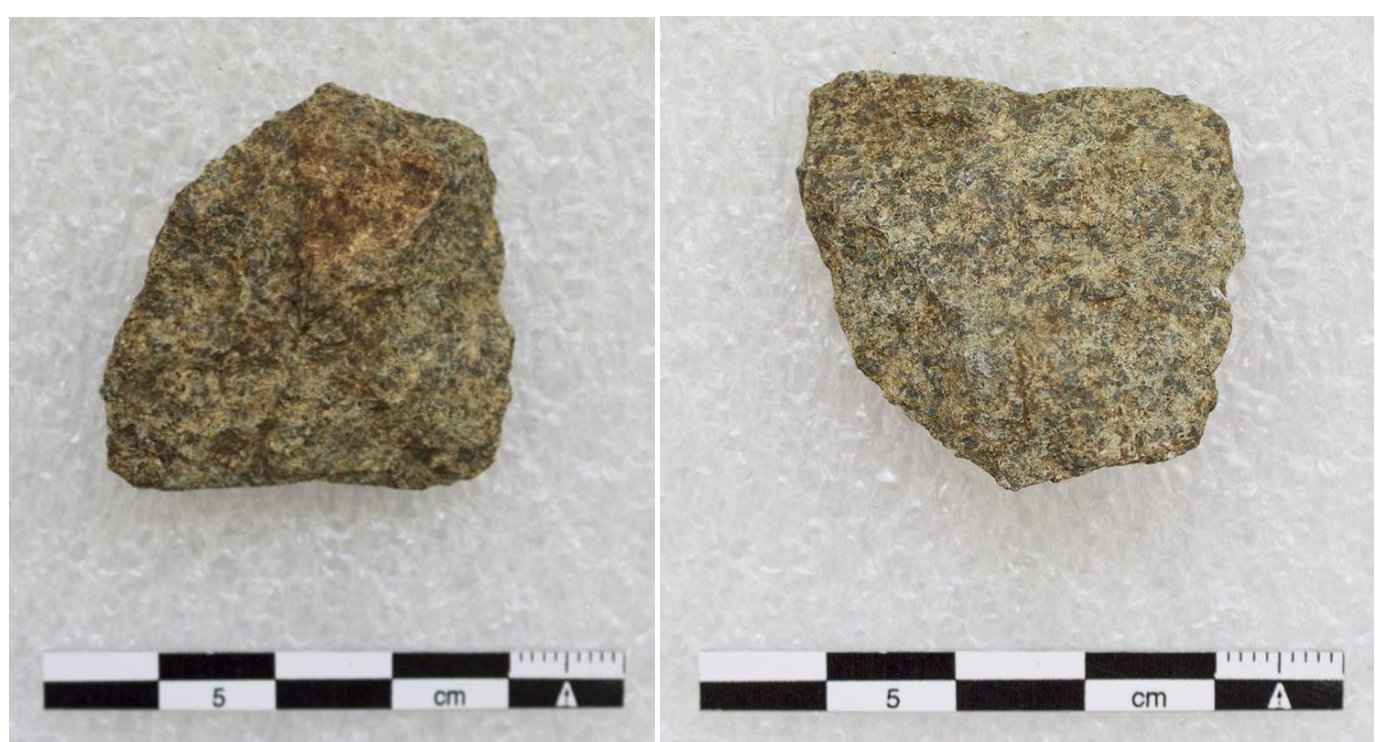

Lítico na sondagem 1, nível 4.

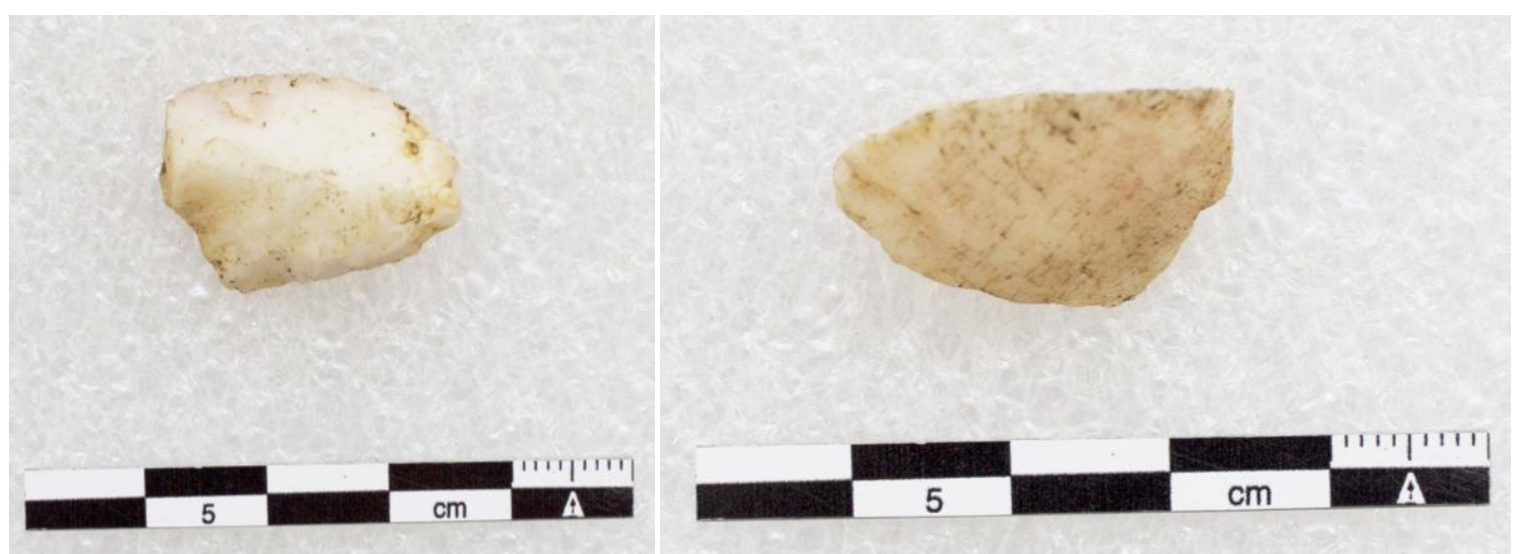

Lítico na sondagem 1, nível 4. 


\section{Aldeia São Benedito}
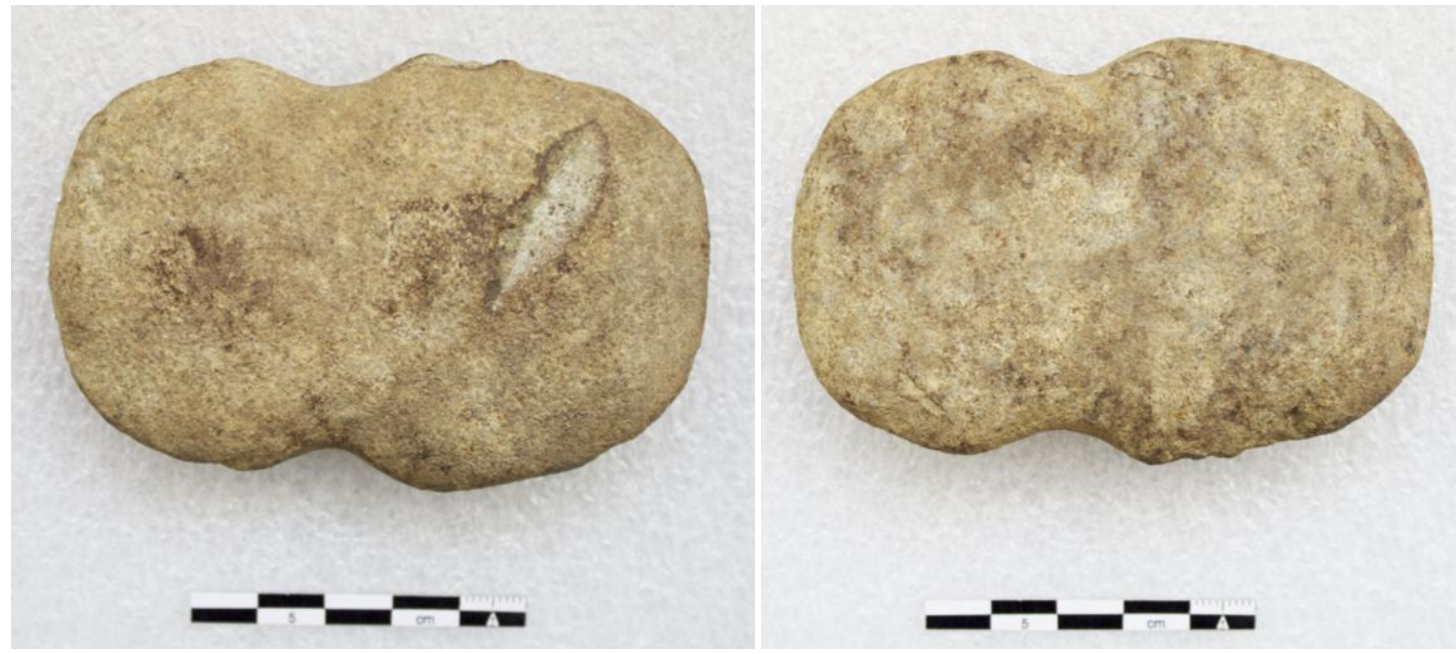

Lítico em superfície. Lâmina de machado.

\section{Sítio Aldeia Tukumã}

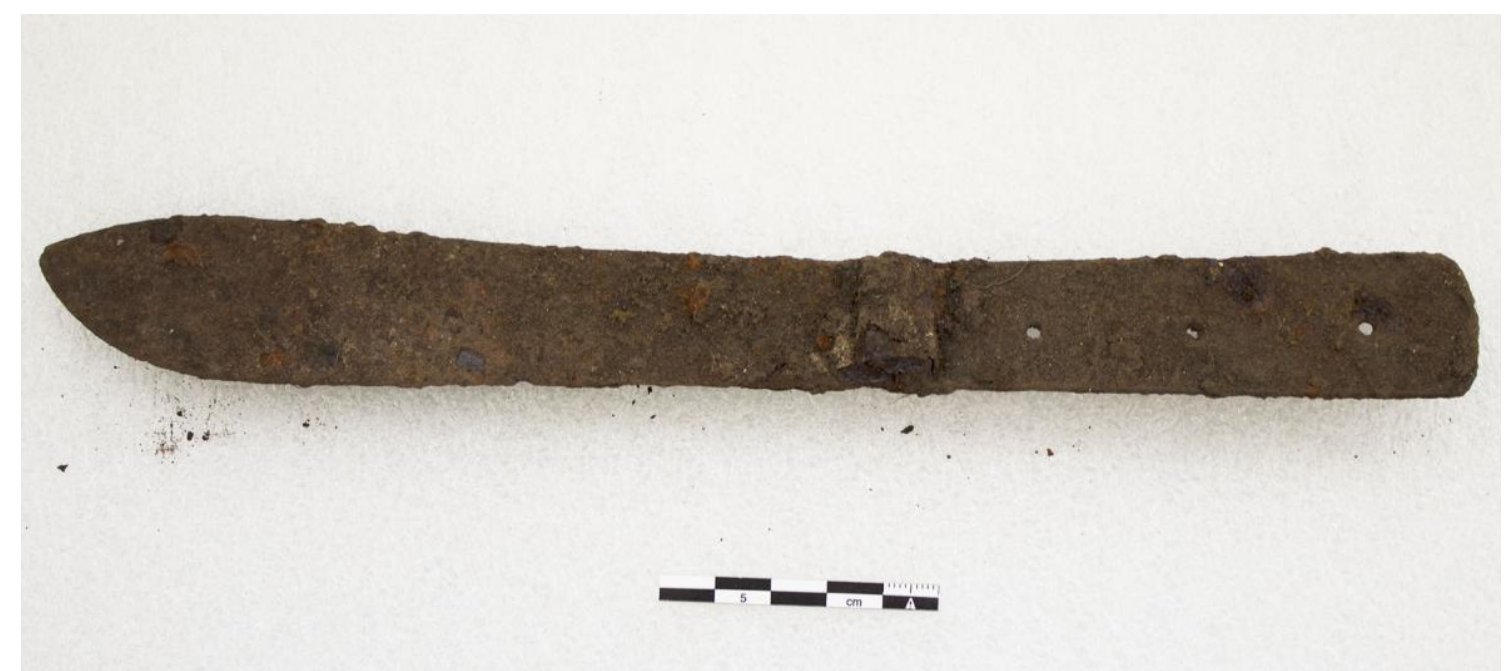

Facão de metal em superfície

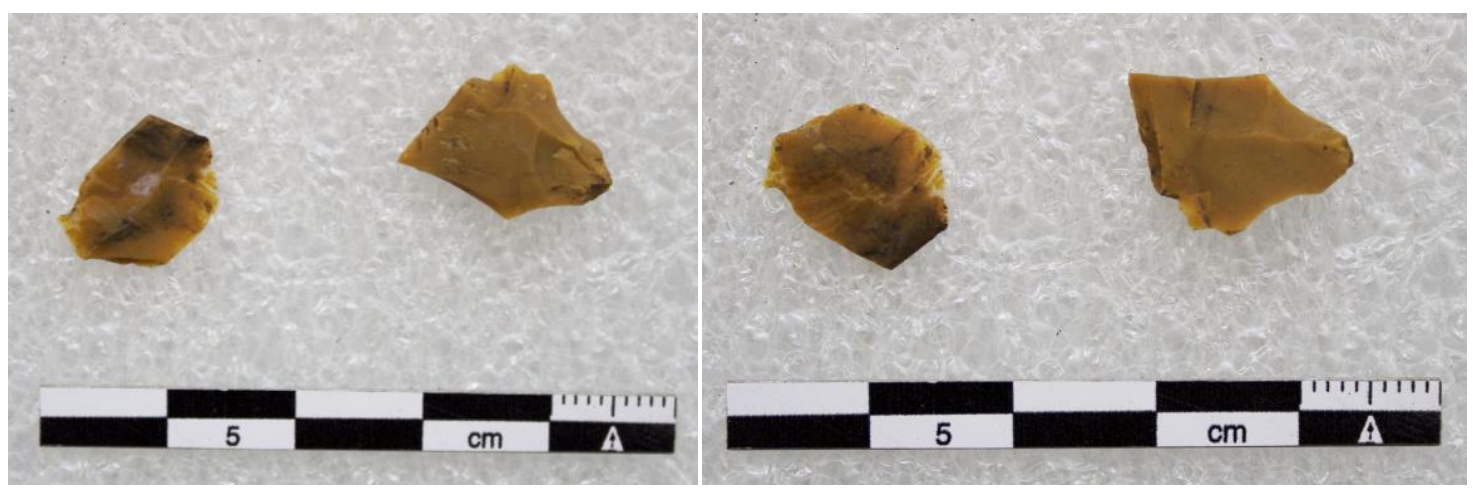

Lítico lascado na sondagem 1, nível 0 à $20 \mathrm{~cm}$. 


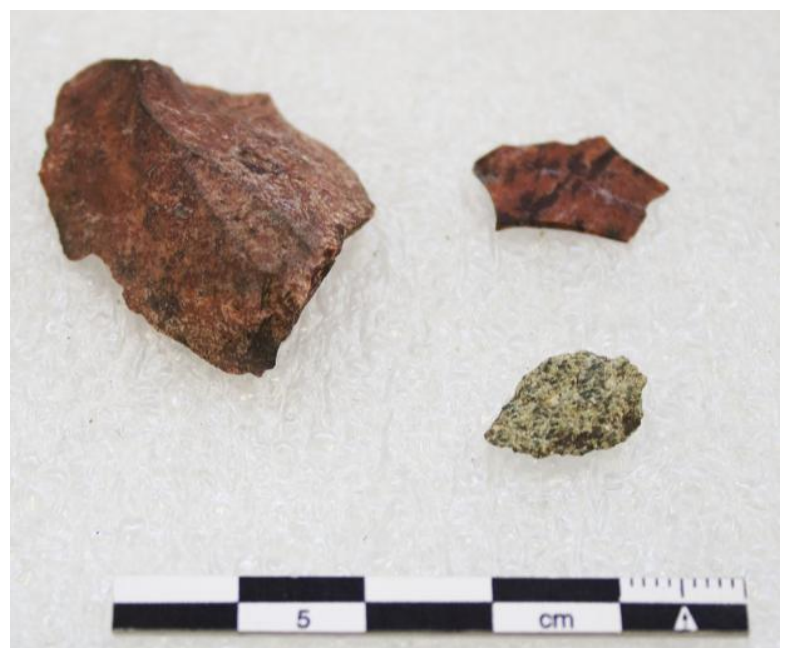

Lítico lascado na sondagem 3, nível 0 à $20 \mathrm{~cm}$.

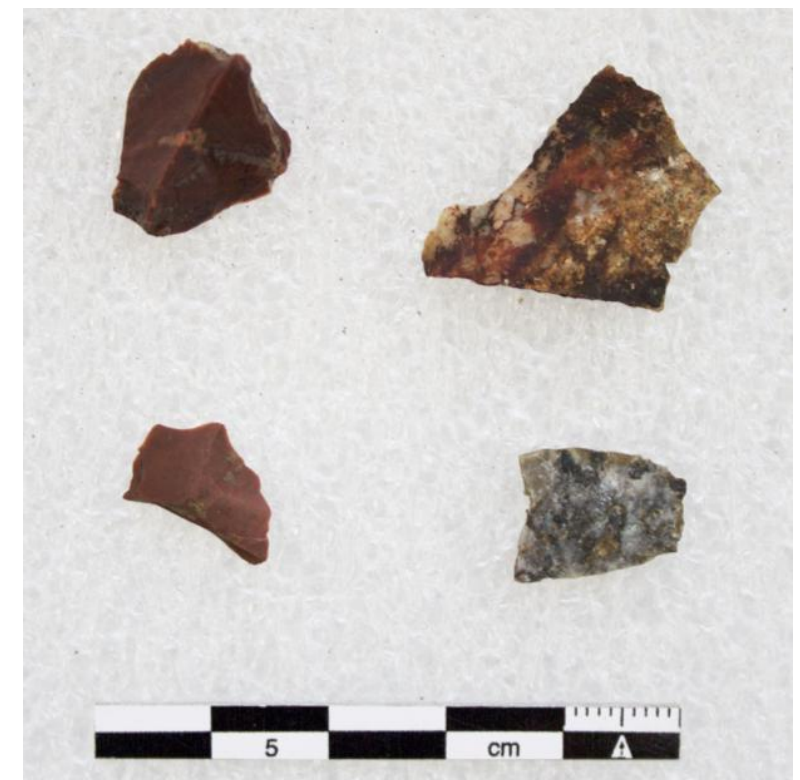

Lítico lascado na sondagem 5, nível 0 à $20 \mathrm{~cm}$.

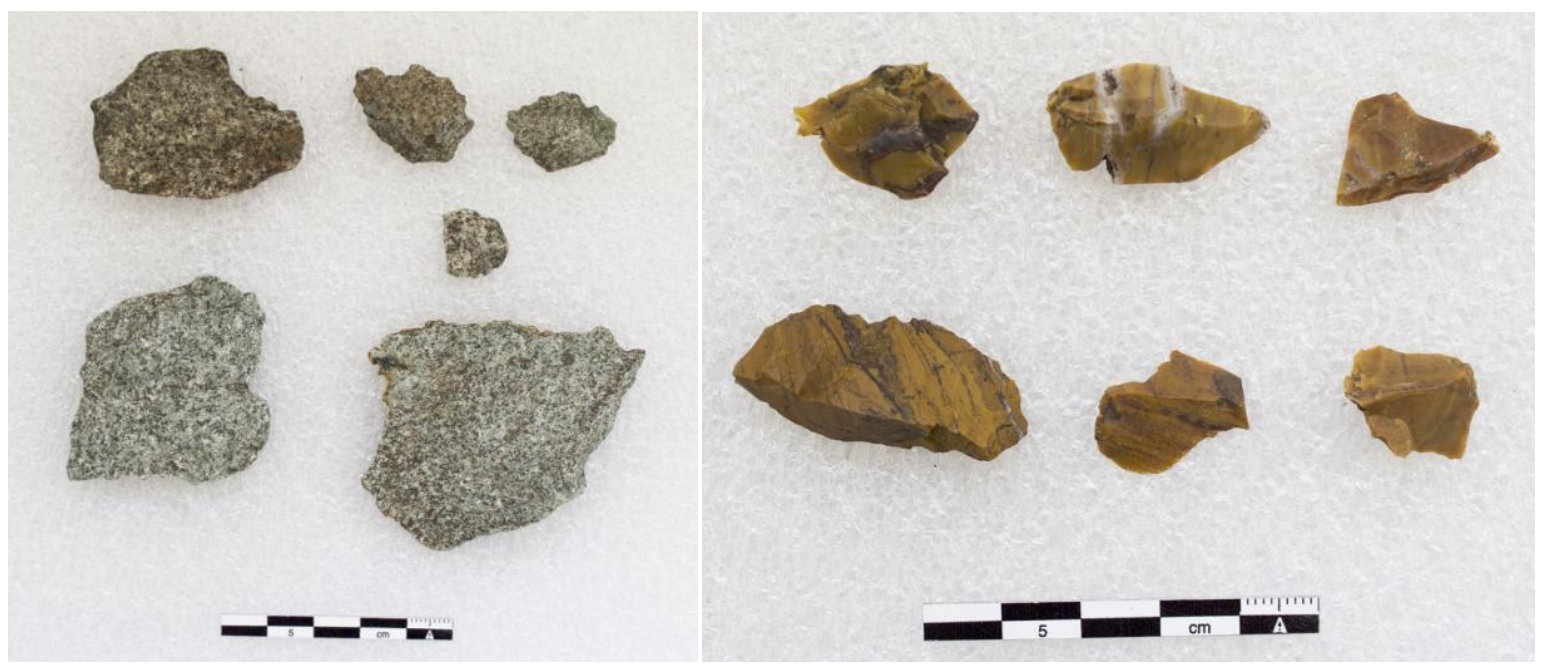

Lítico lascado no poço teste 1, nível 2. 

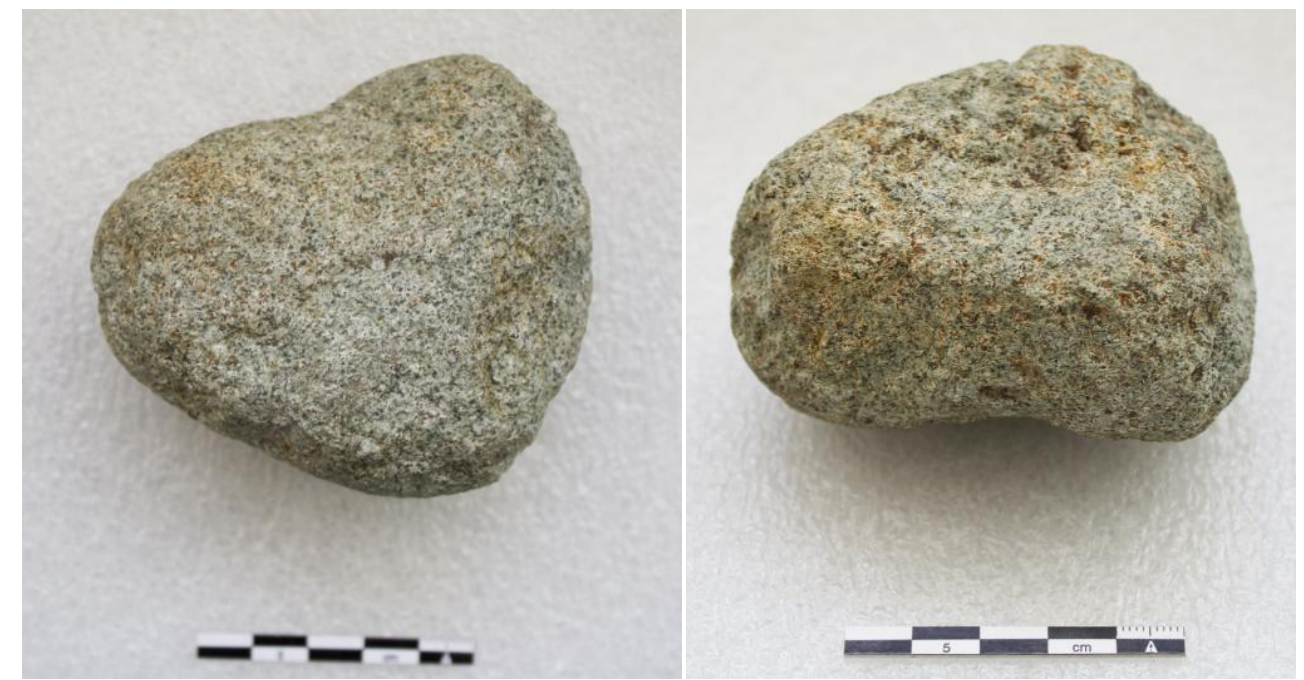

Lítico no poço teste 1 , nível 5

\section{Sítio Dinossauro}

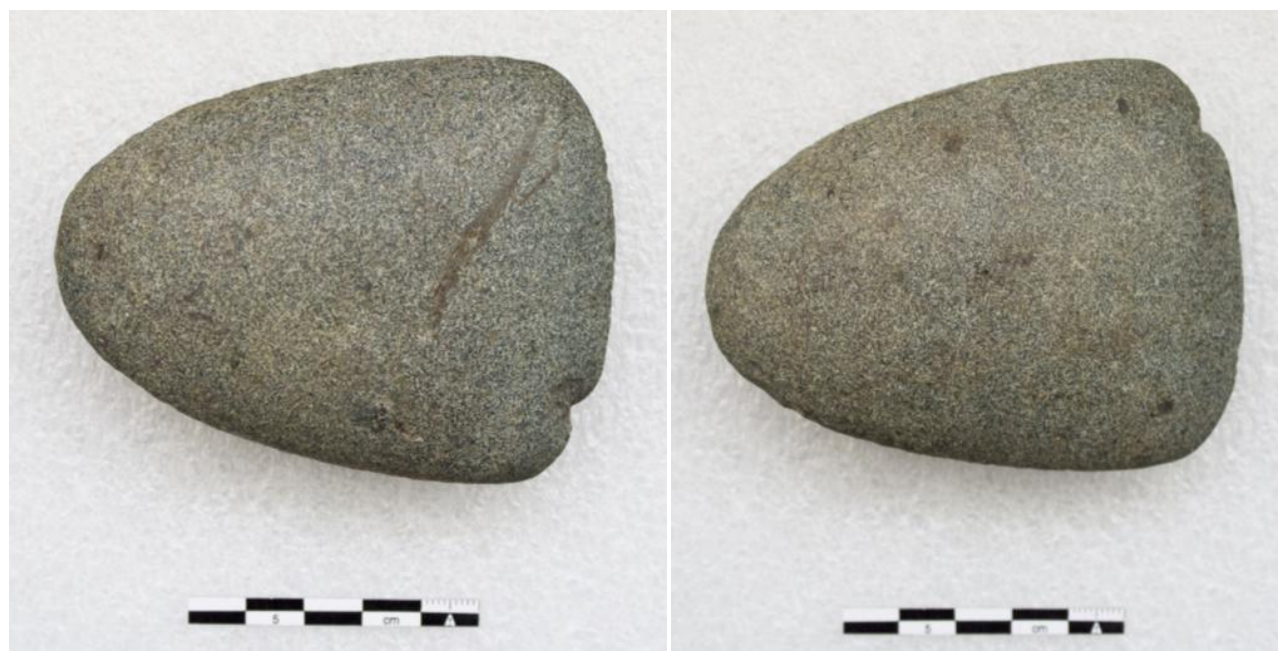

Lítico polido em superfície. Lâmina de machado.

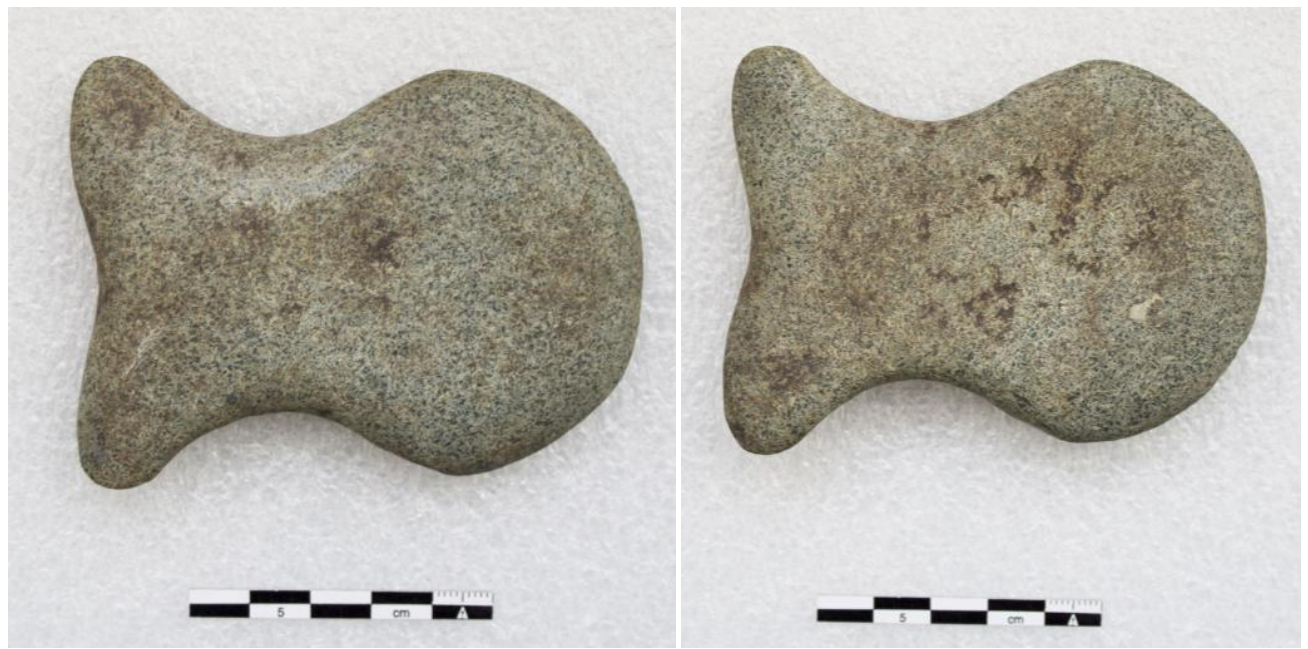

Lítico polido em superfície. Lâmina de machado. 


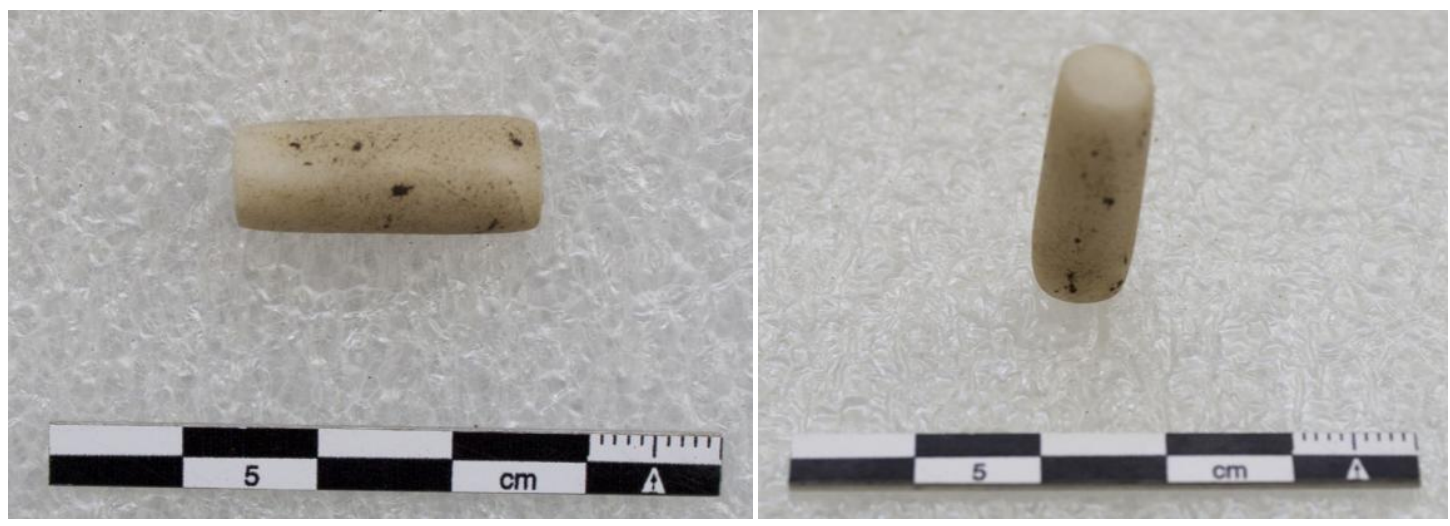

Lítico polido no poço teste 1, nível 2. Tembetá.

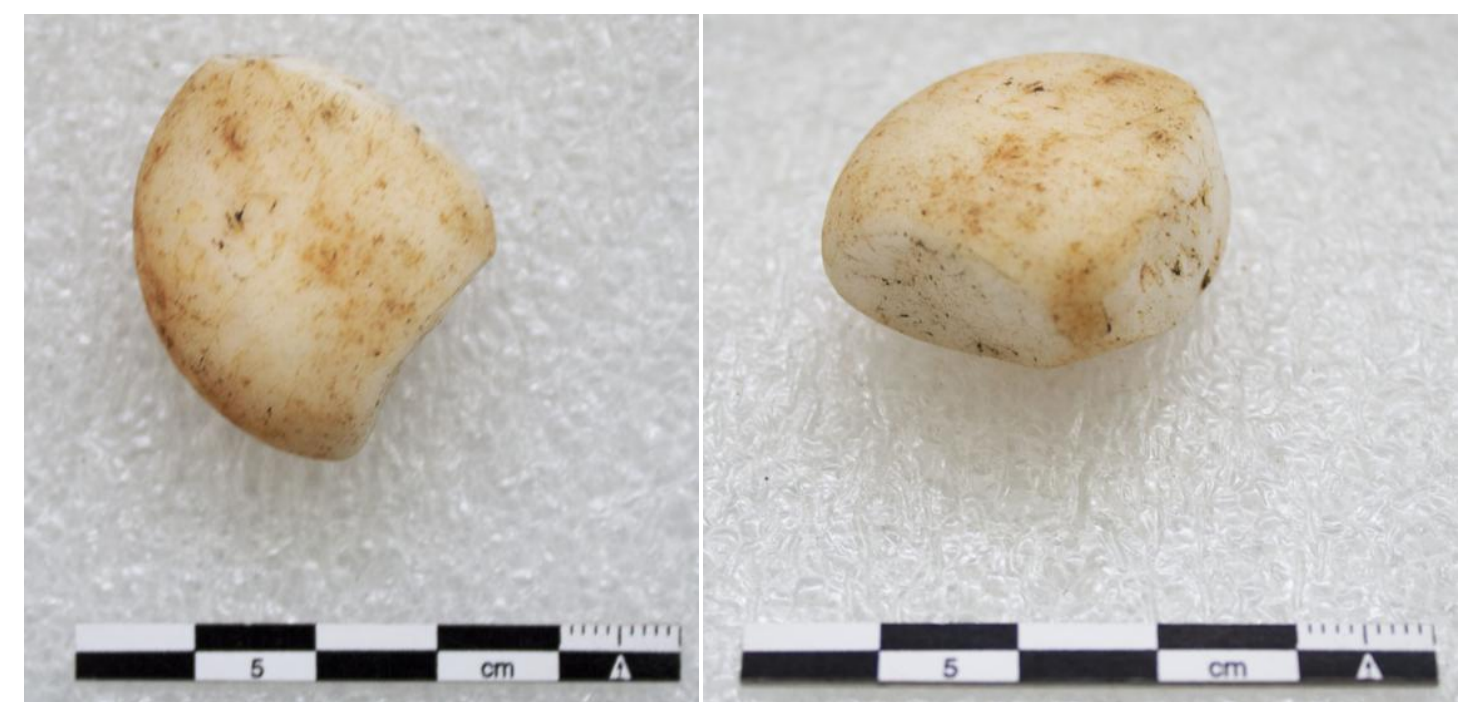

Lítico polido no poço teste 1 , nível 4. Polidor.

\section{Sítio Mukuin Caniné}

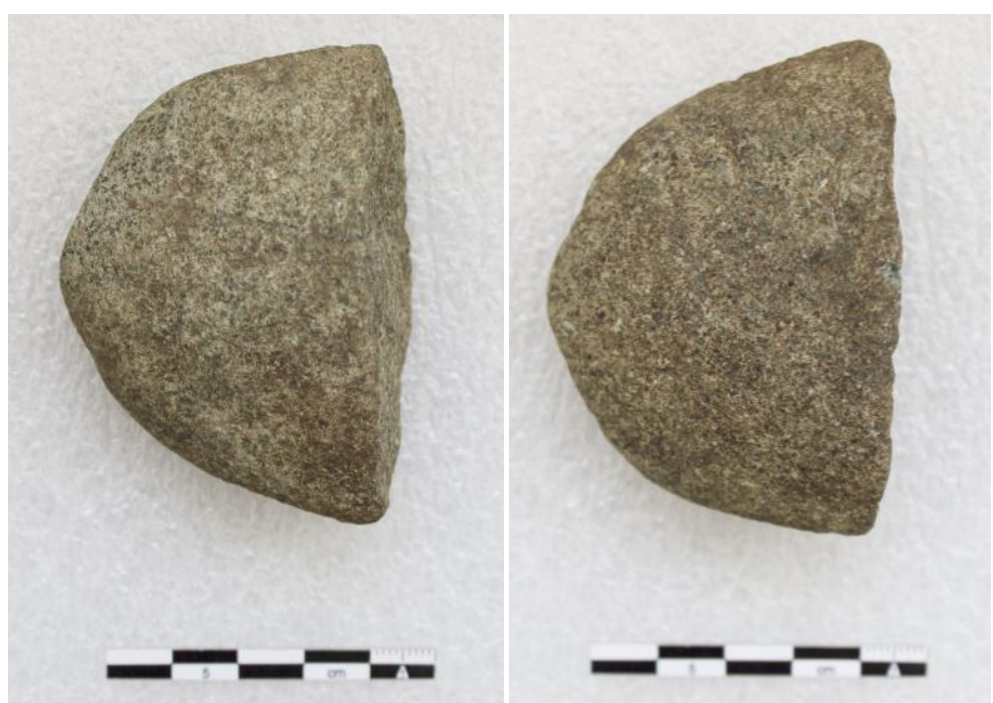

Lítico polido em superfície. 


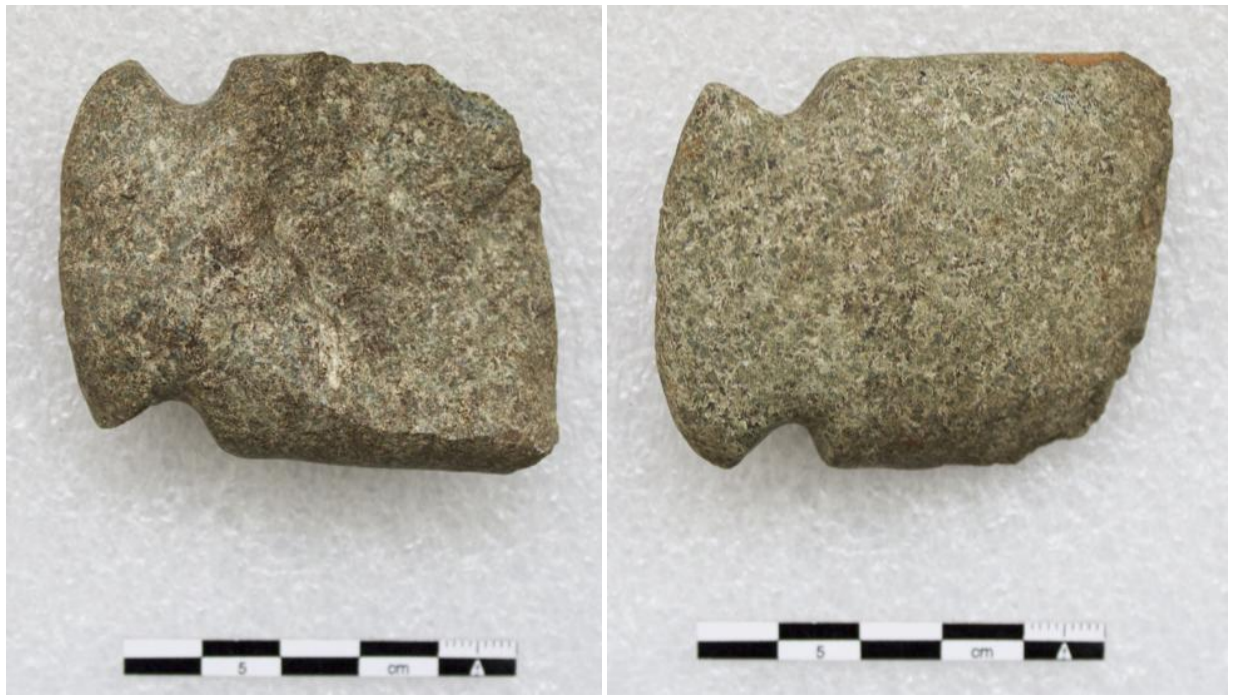

Lítico polido em superfície. Lâmina de machado.
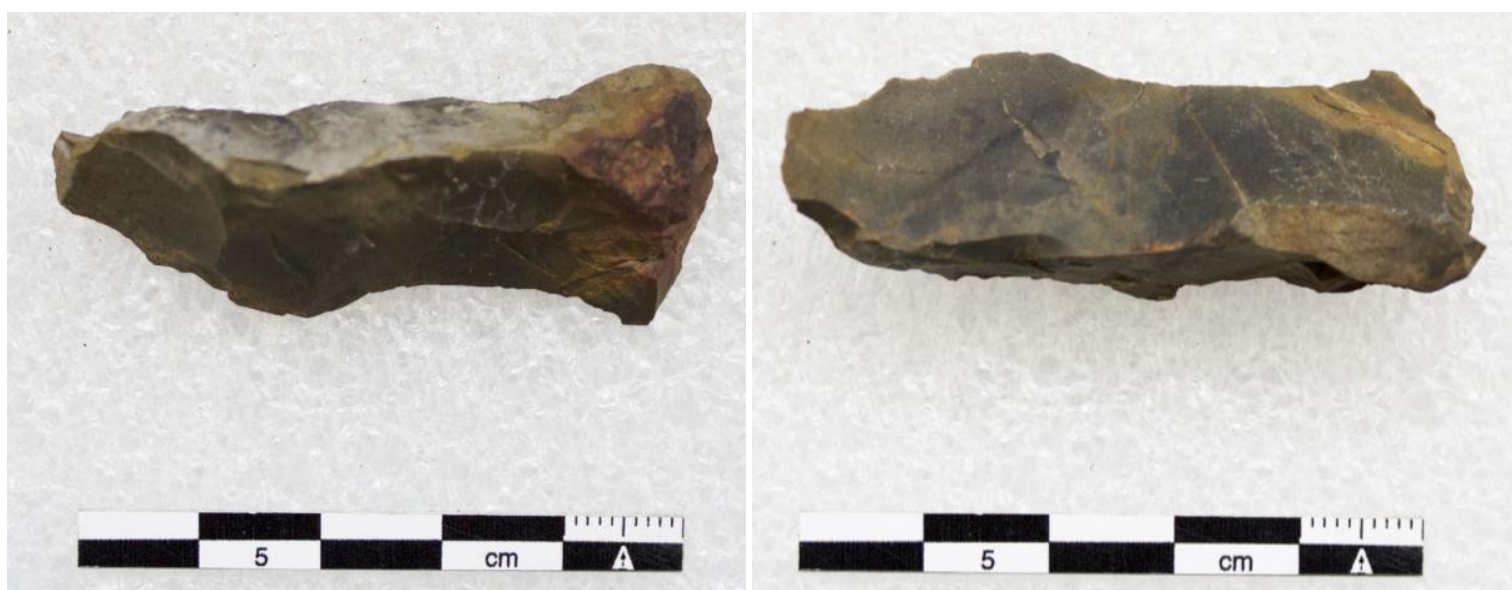

Lítico lascado em superfície.
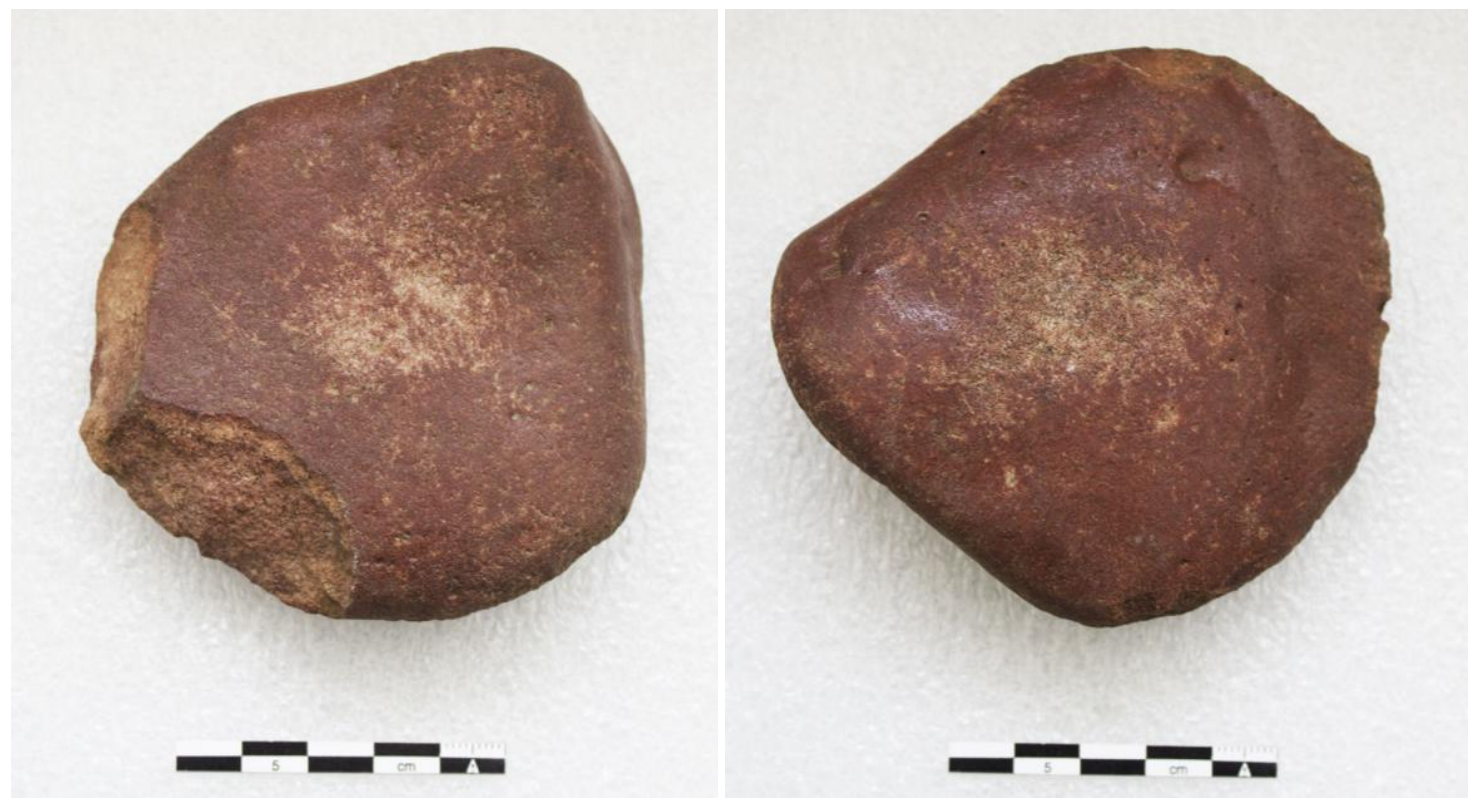

Lítico em superfície. 


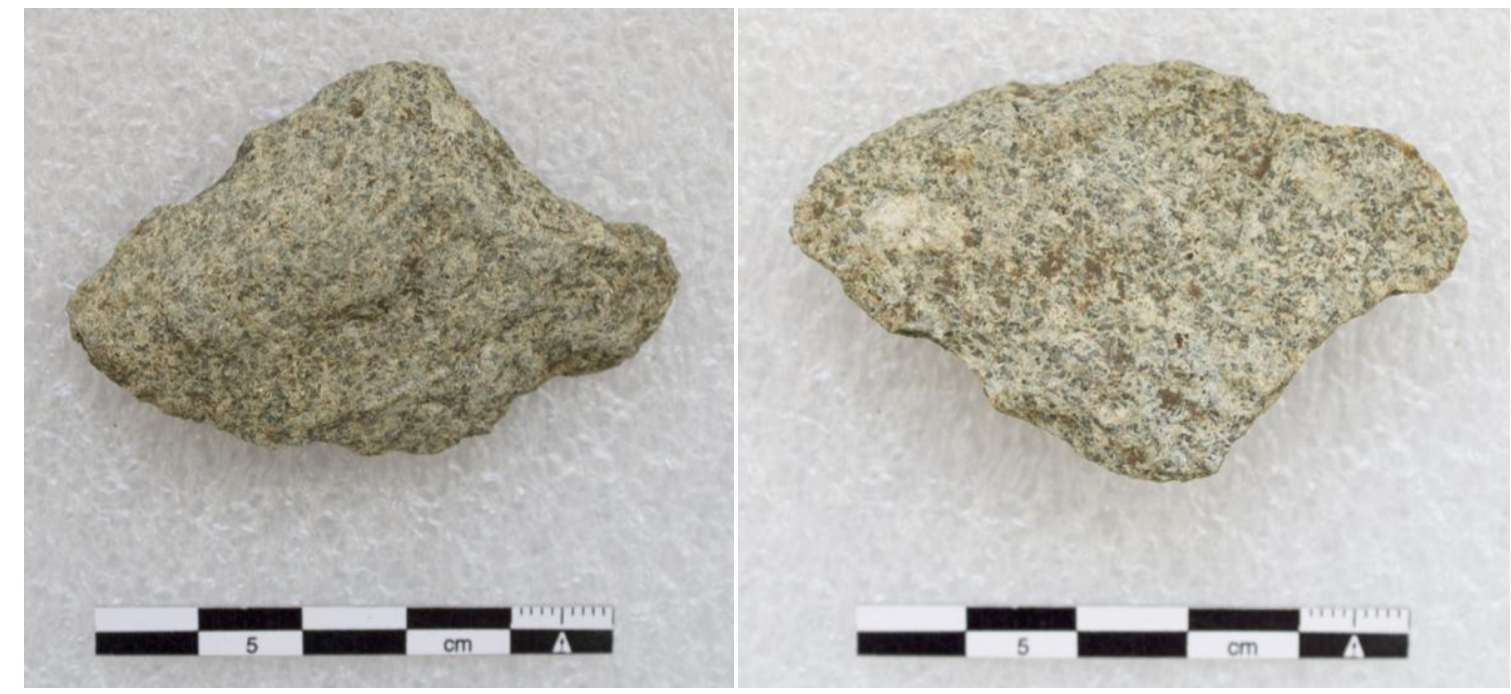

Lítico lascado na sondagem 7, nível 2.

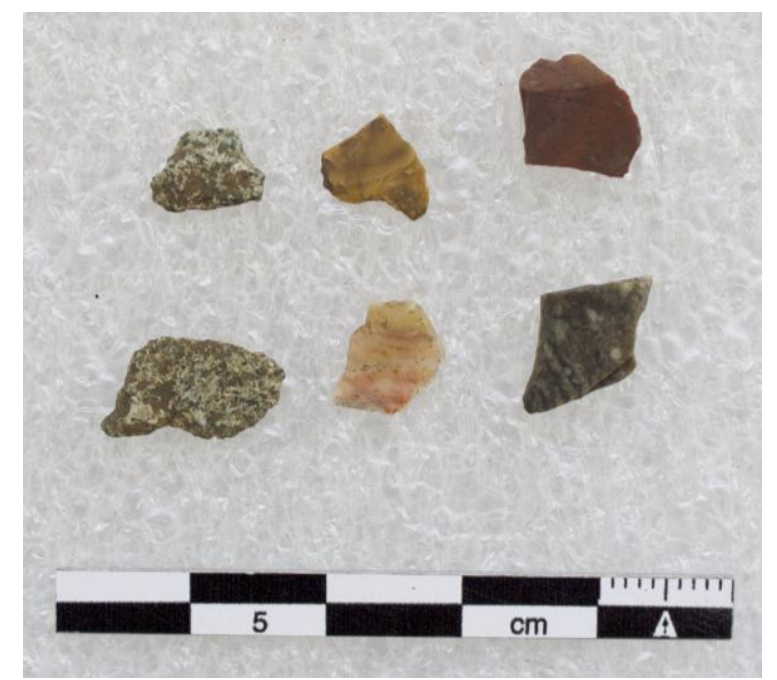

Lítico lascado na sondagem 8, nível 20 à $40 \mathrm{~cm}$.

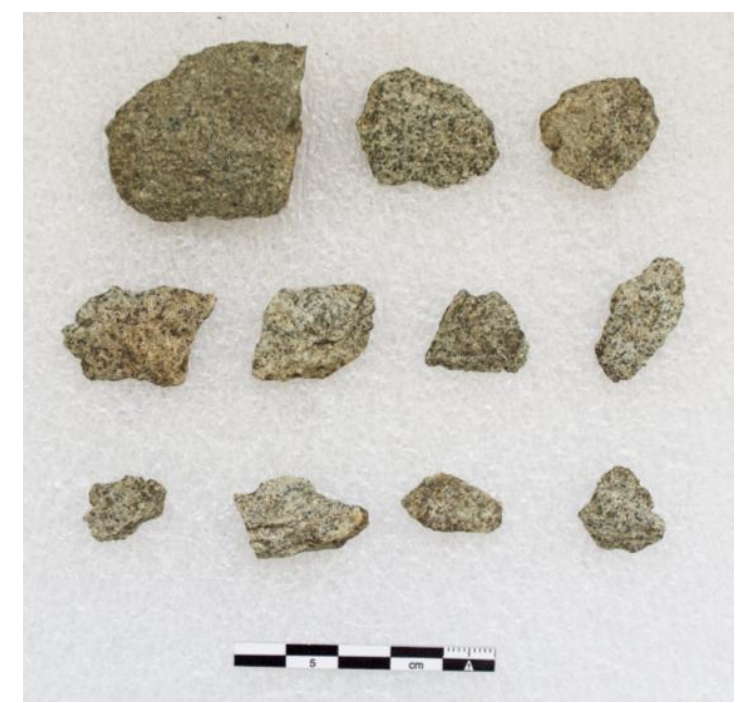

Lítico lascado no poço teste 1, nível 2. 


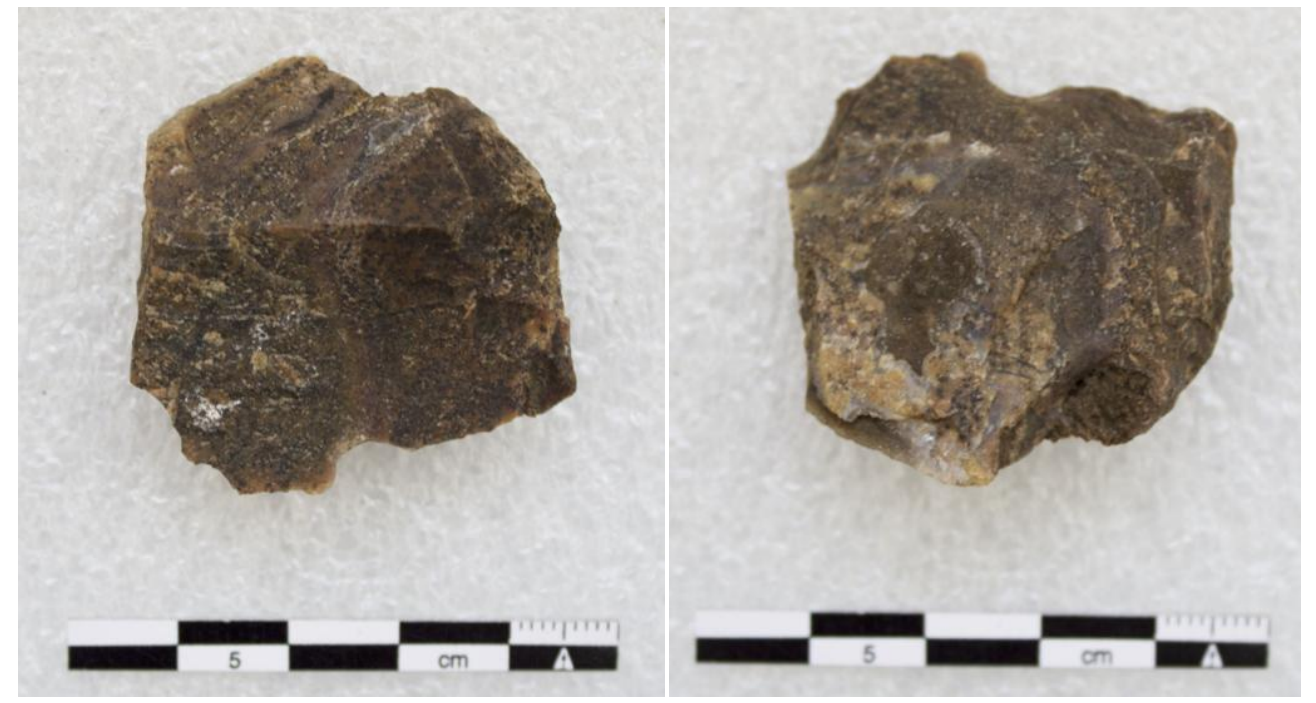

Lítico lascado no poço teste 1, nível 2.

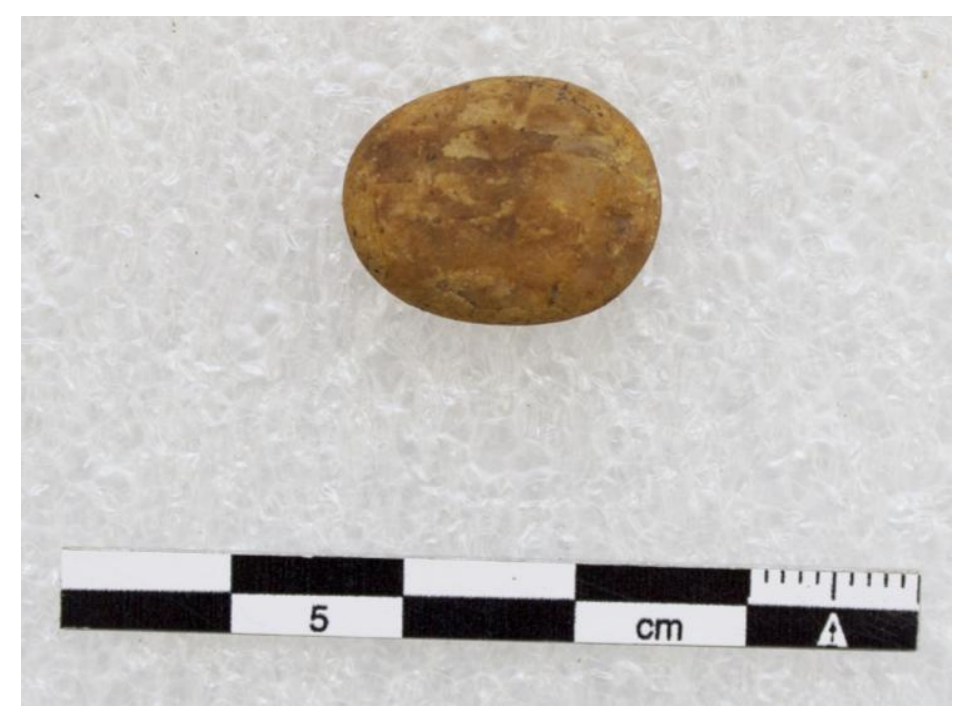

Lítico no poço teste 1, nível 2. Alisador.

Sítio Taitetu 


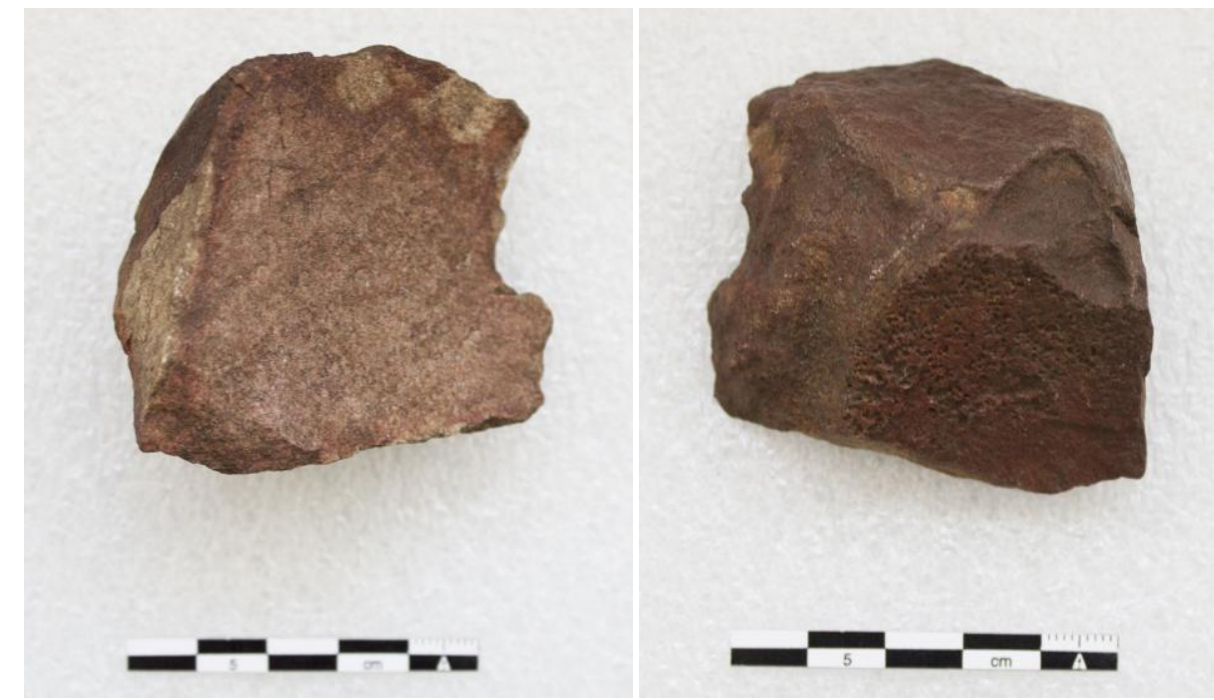

Lítico lascado em superfície.

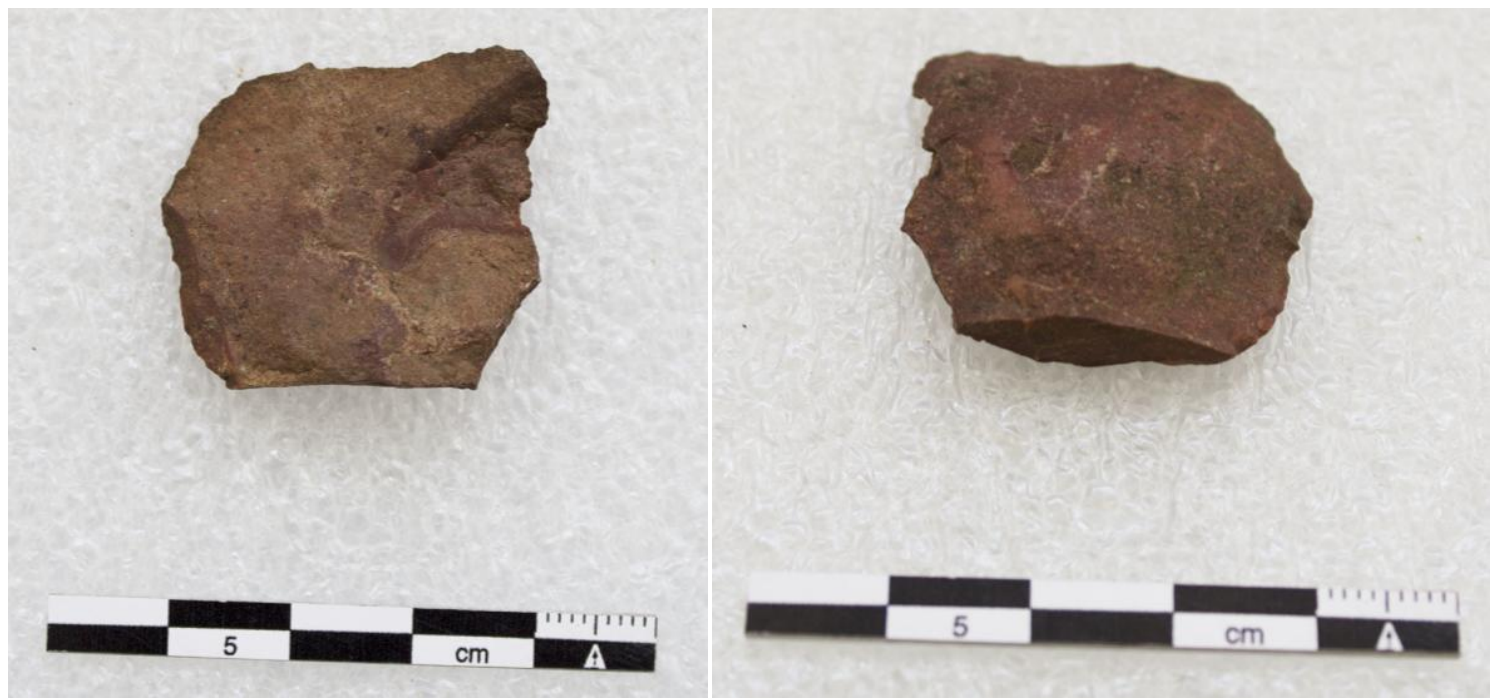

Lítico lascado em superfície.

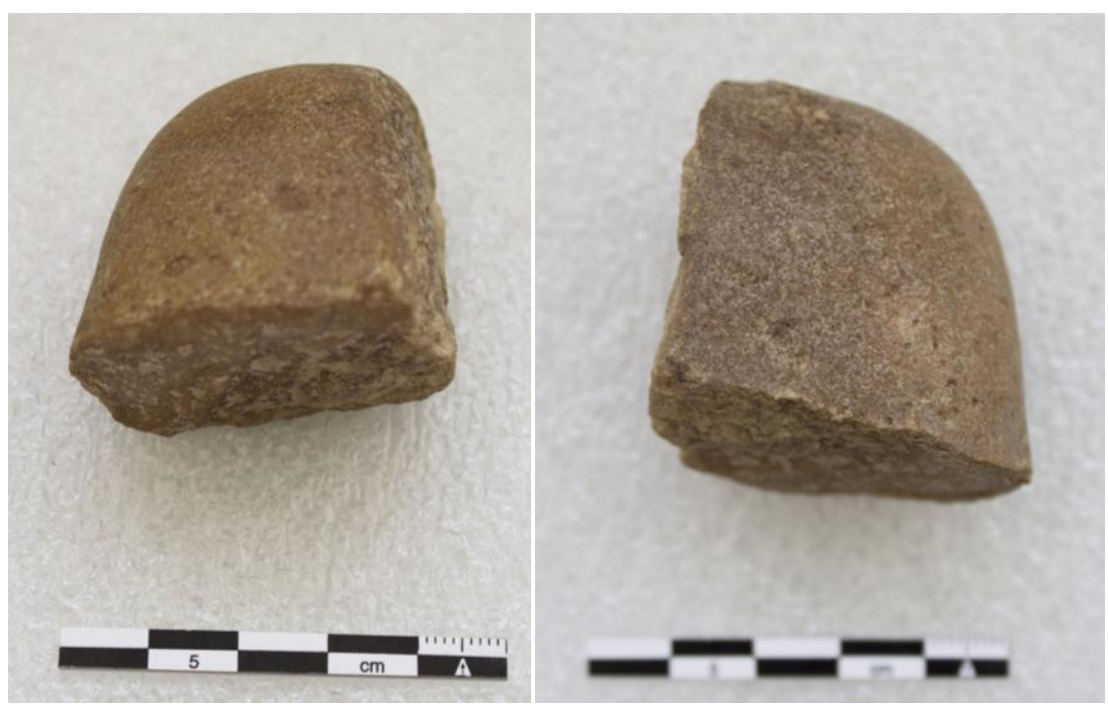

Lítico em superfície. 

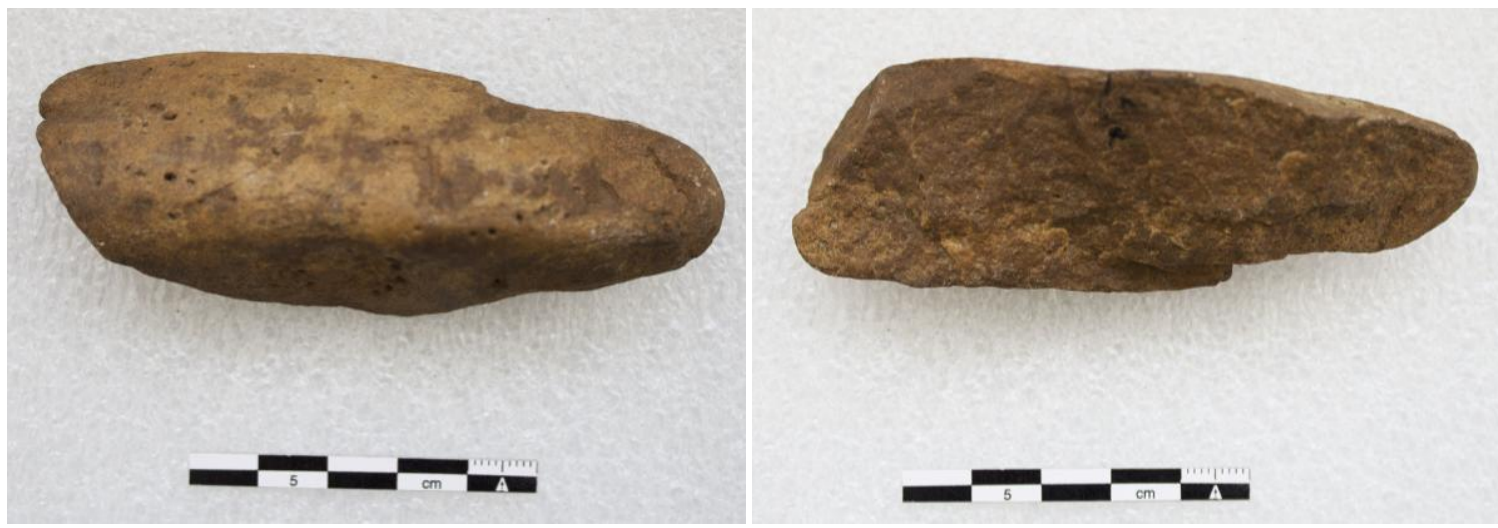

Lítico em superfície.
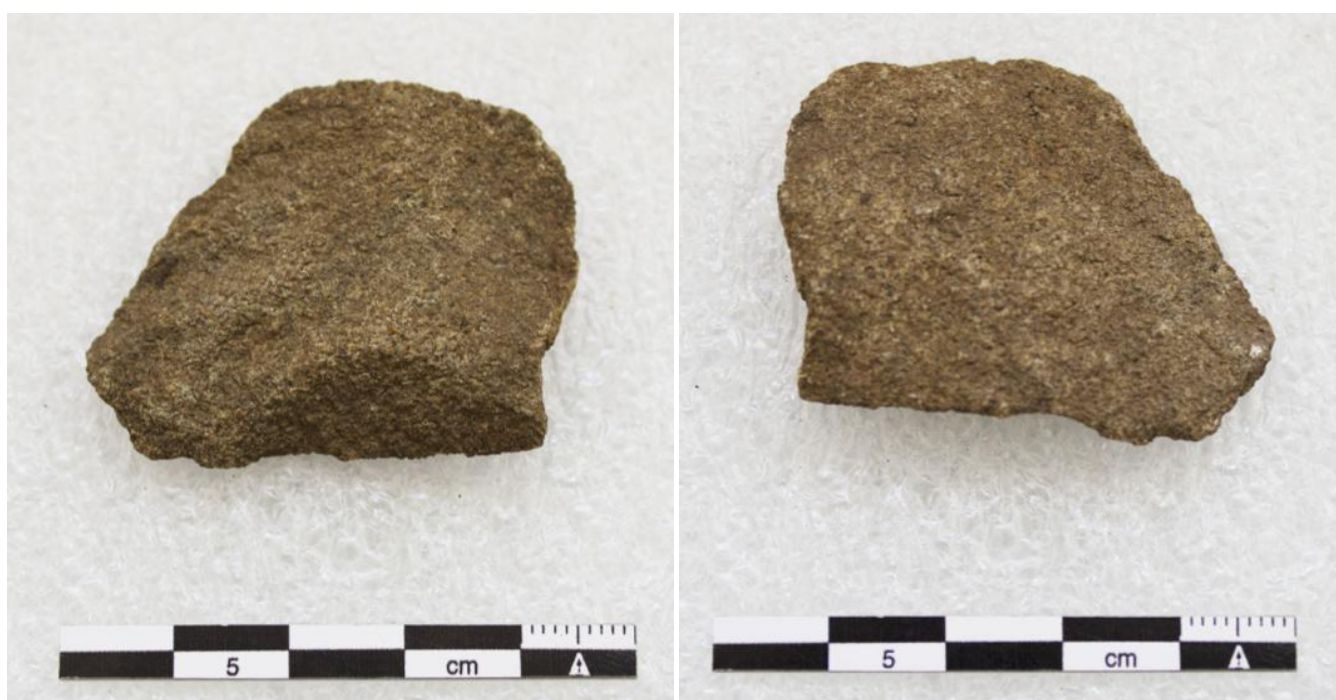

Lítico em superfície.
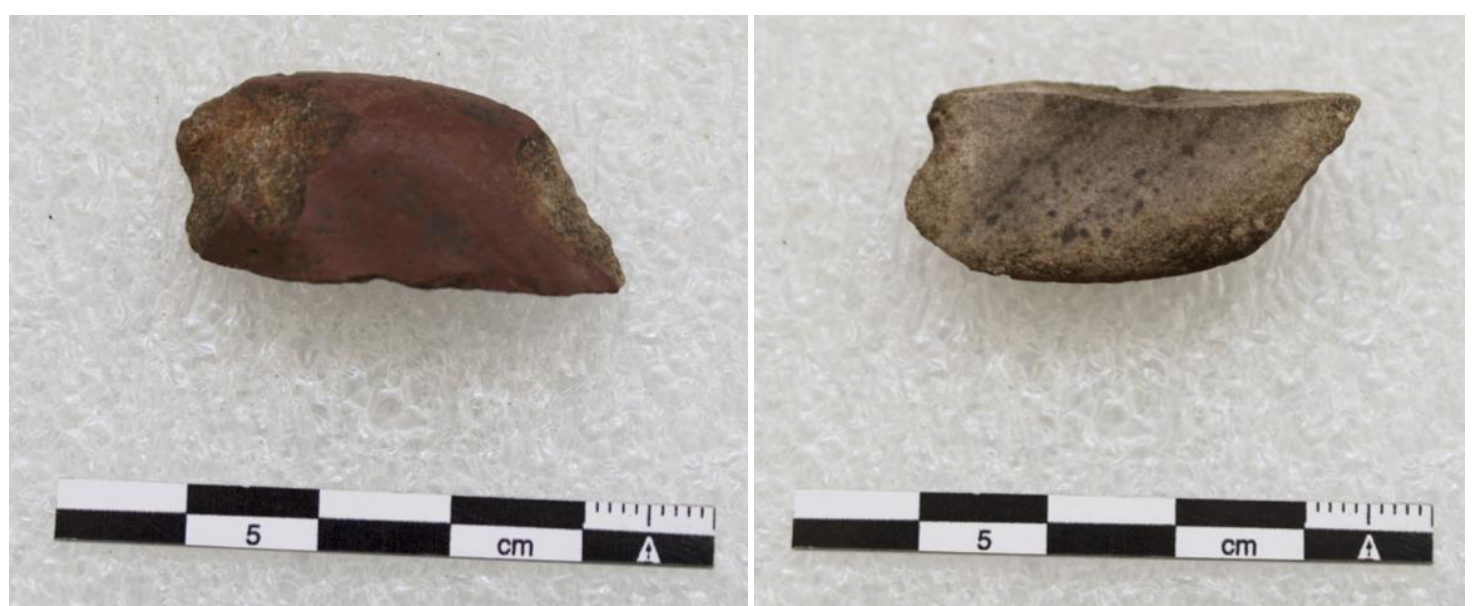

Lítico em superfície. 


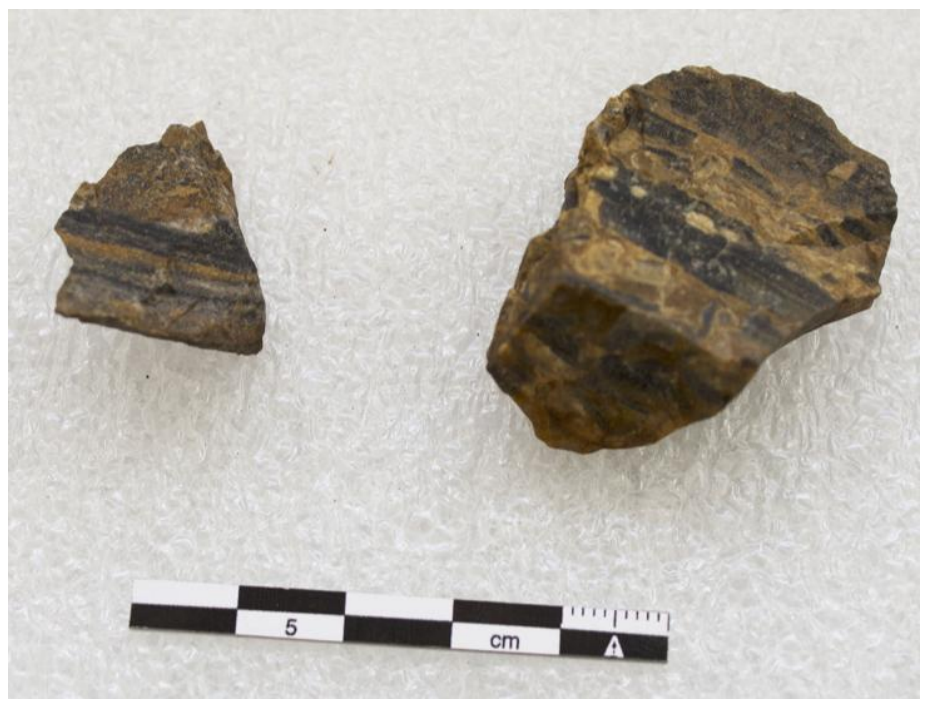

Lítico em superfície.

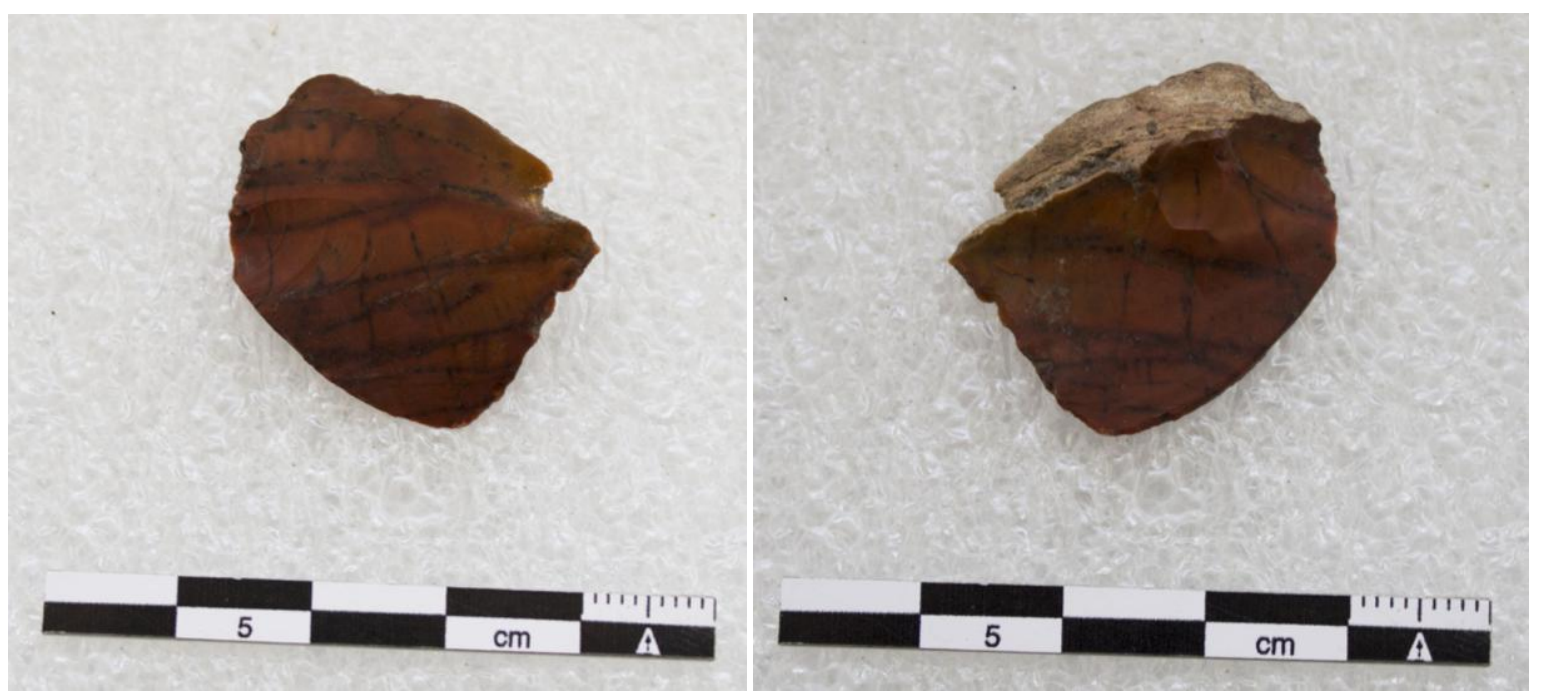

Lítico em superfície.

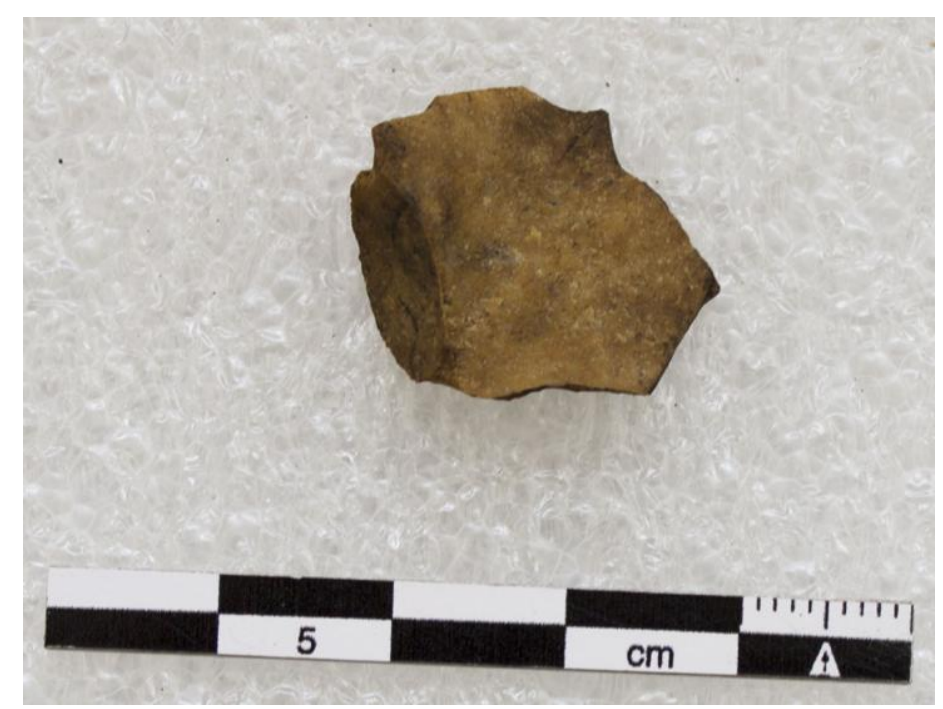

Lítico na sondagem 2, nível 3. 

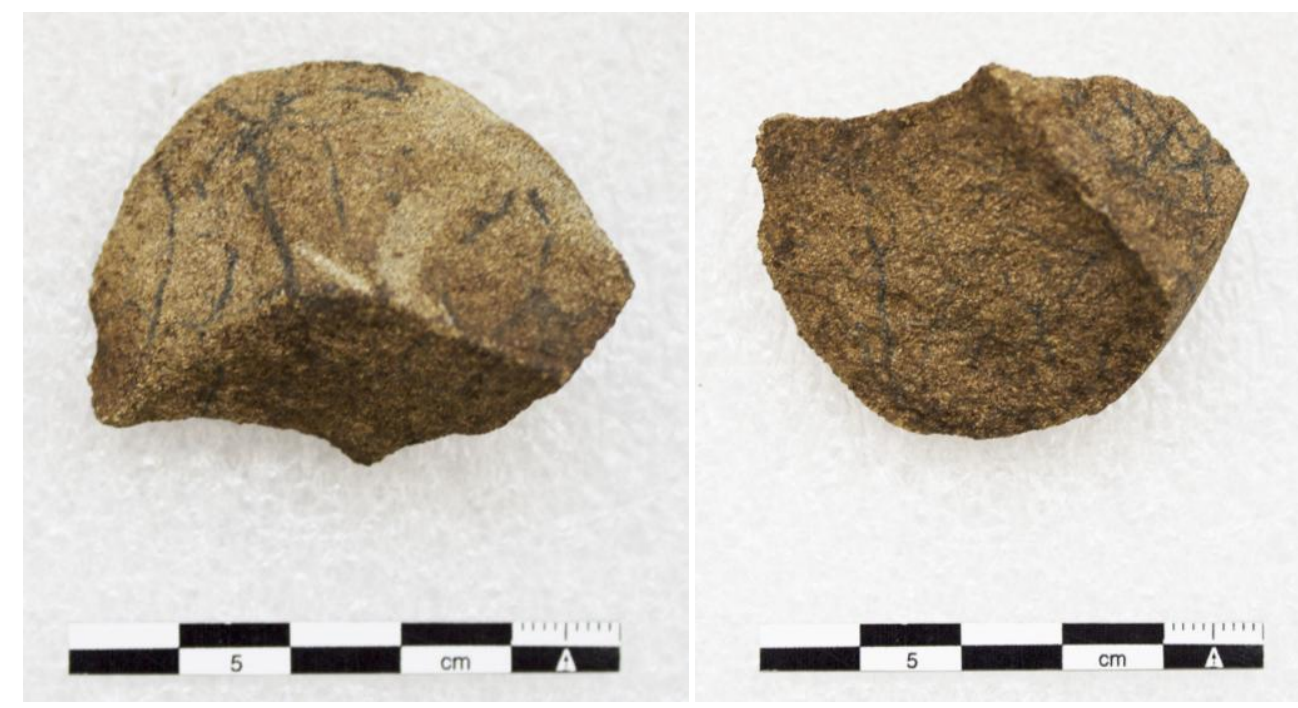

Lítico na sondagem 7.

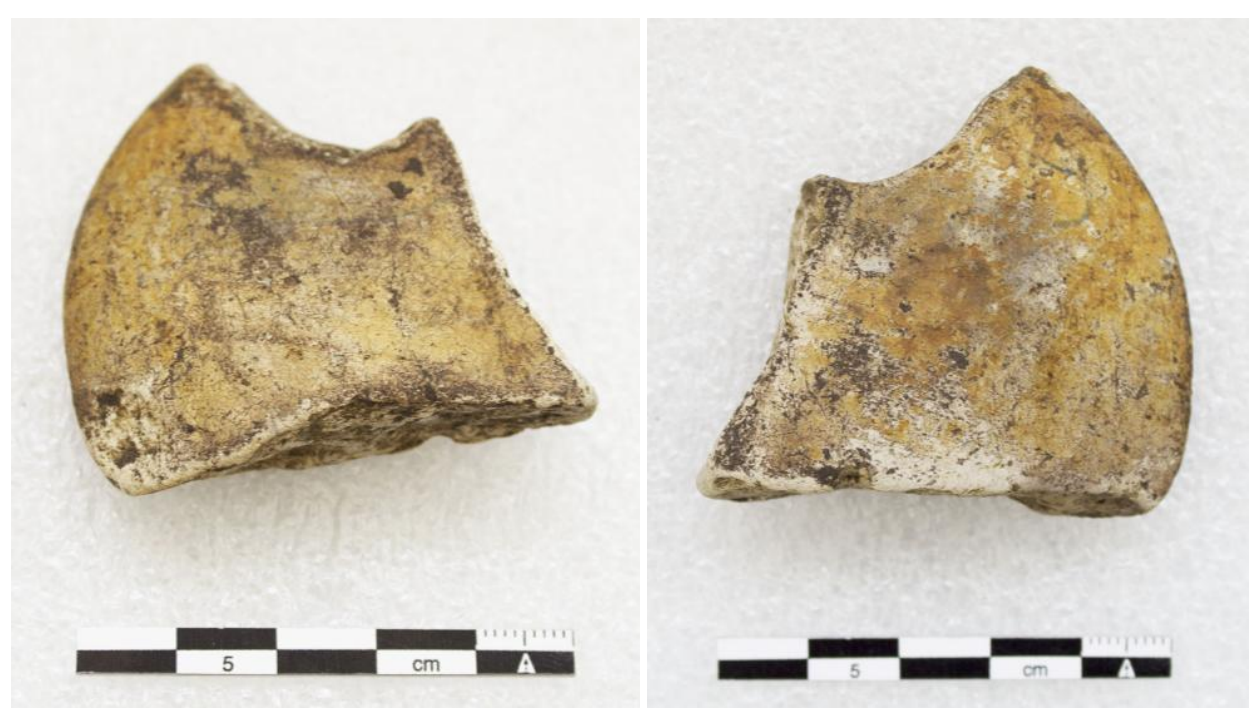

Lítico no poço teste 1, nível 9.

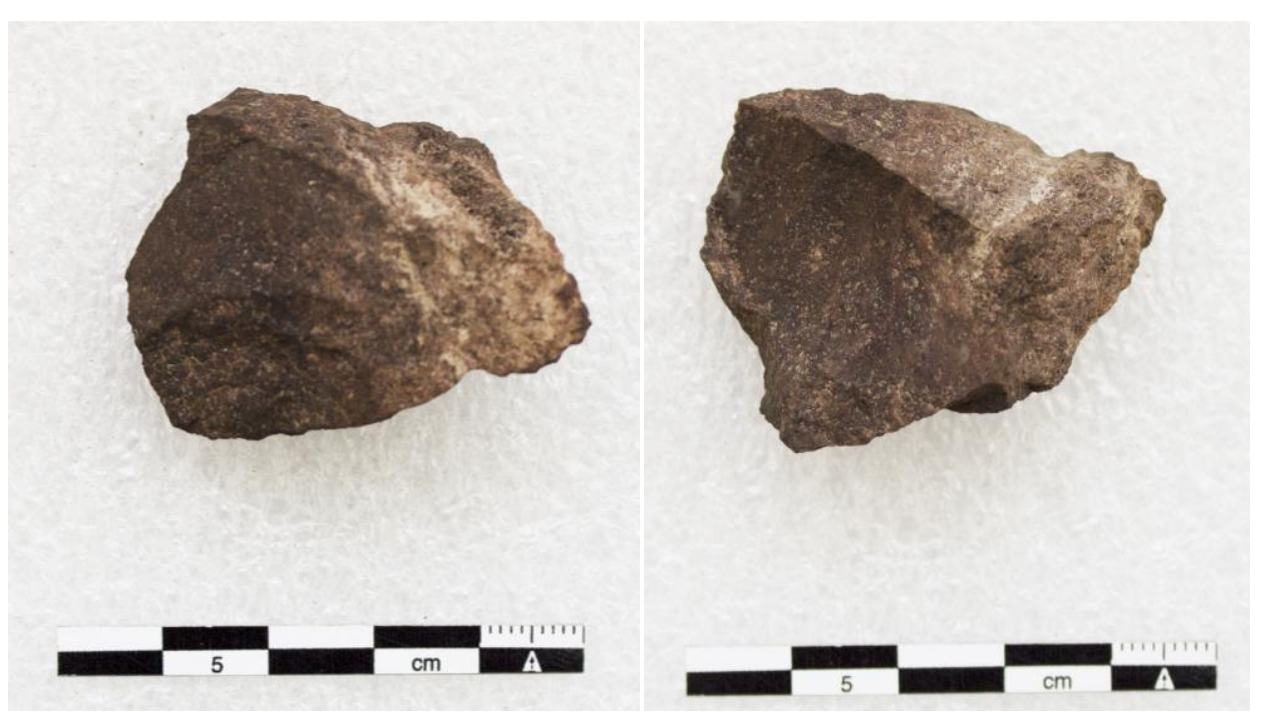

Lítico no poço teste 1, nível 9. 


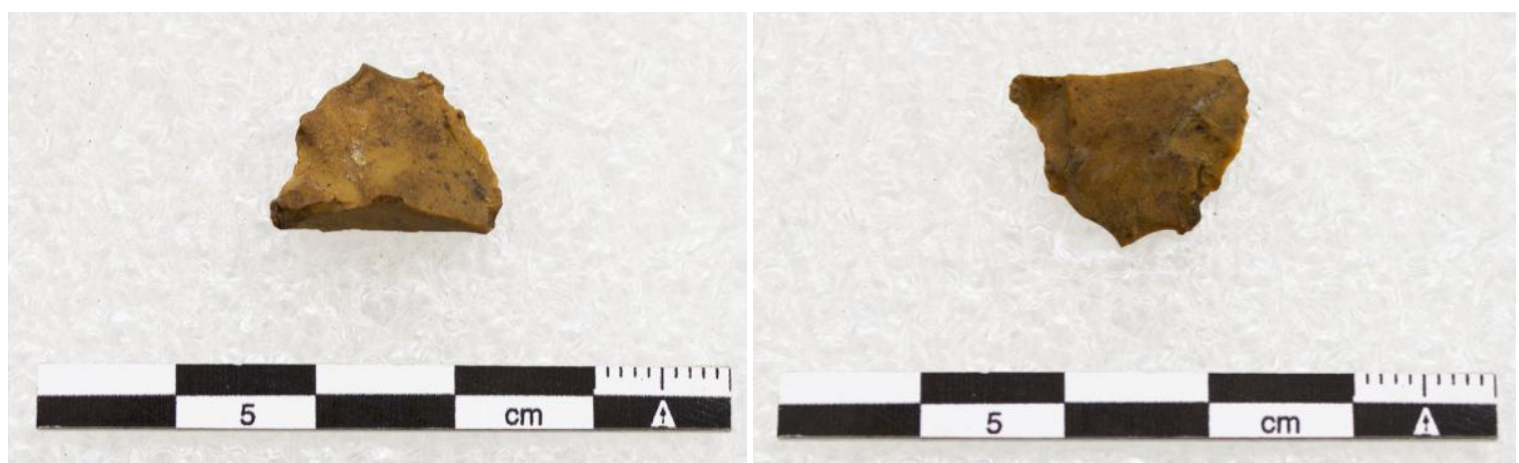

Lítico lascado no poço teste 1, nível 10.

\section{Ypiaowy}
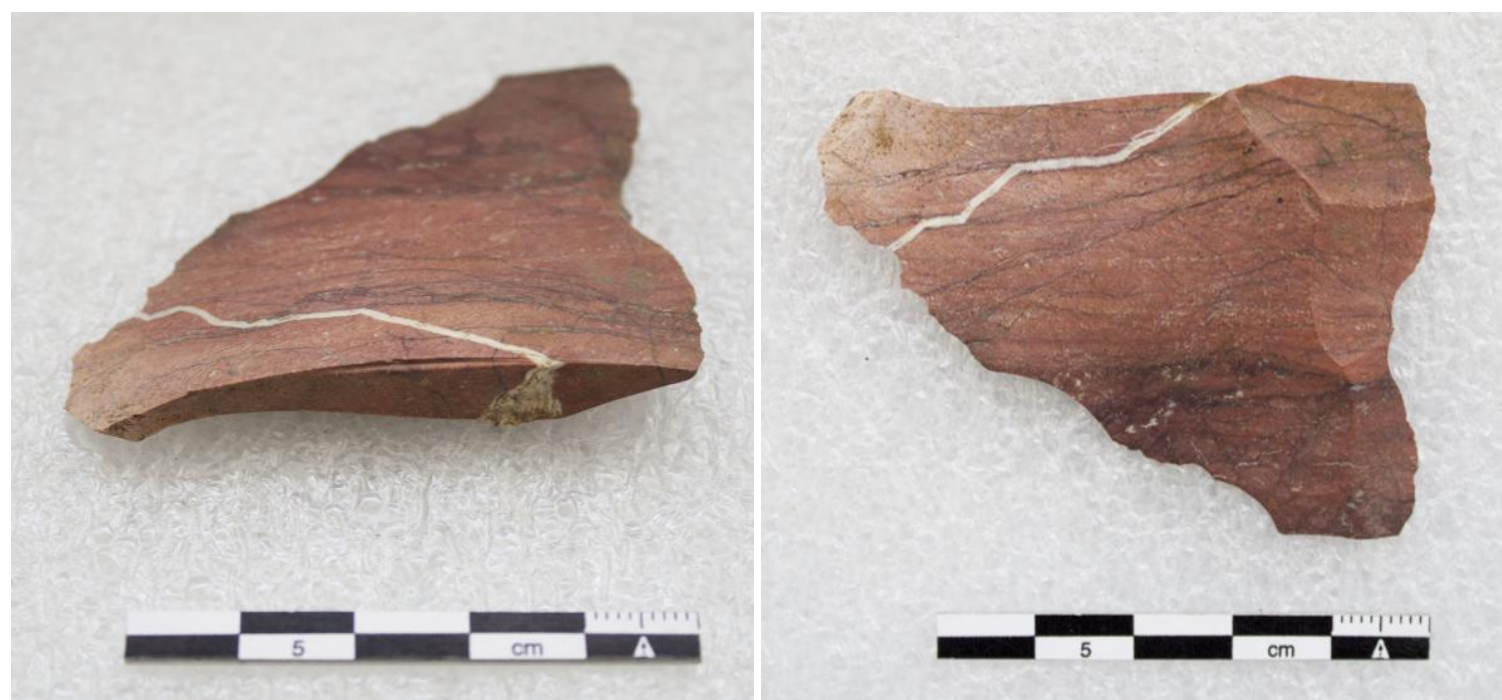

Lítico lascado em superfície.

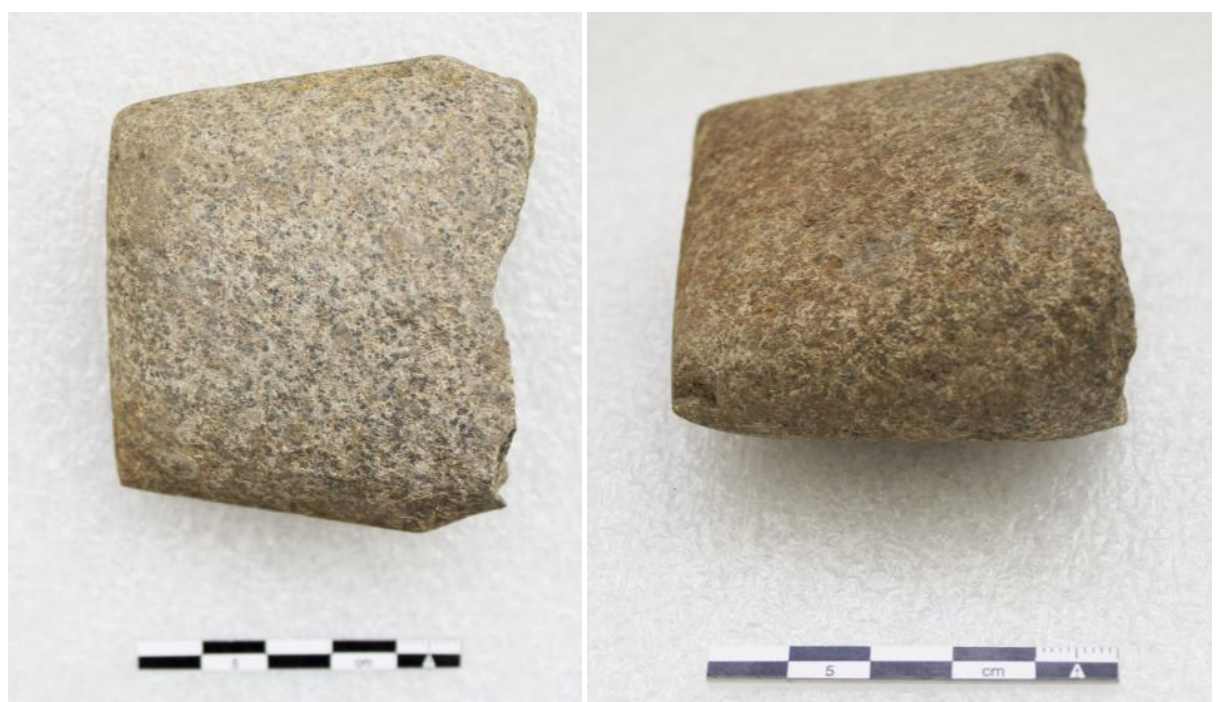

Lítico polido em superfície. Lâmina de machado. 


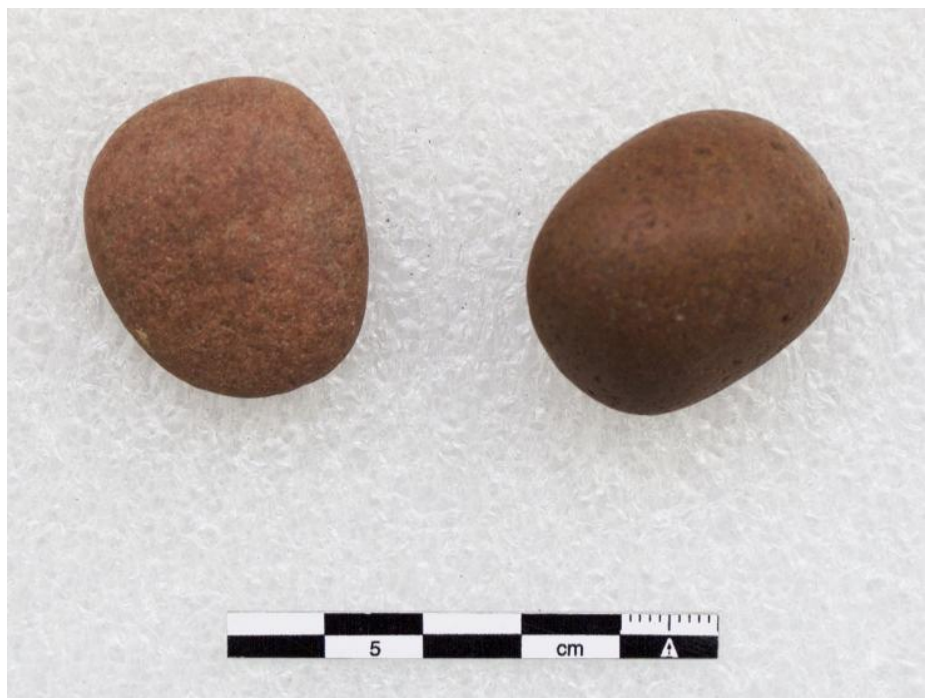

Lítico em superfície. Alisador.

Sítio Ywantã

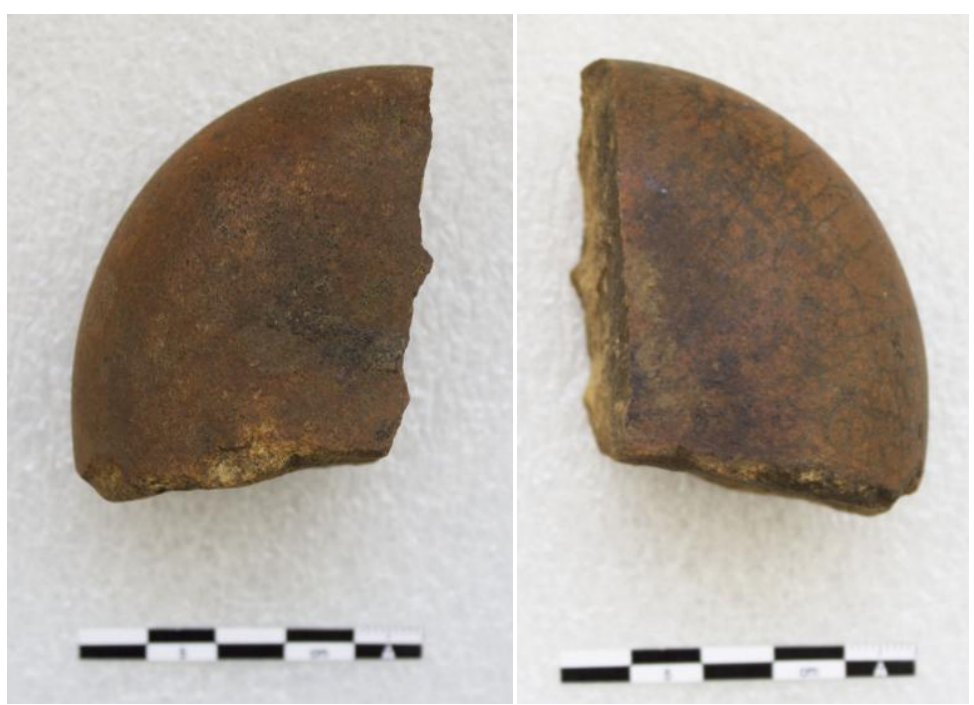

Lítico em superfície.

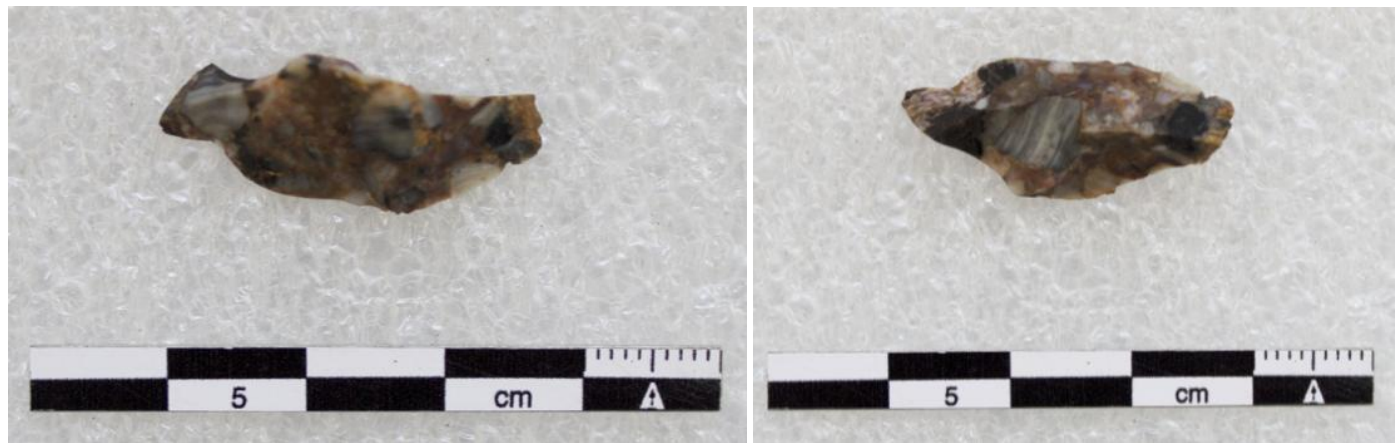

Lítico lascado na sondagem 15, nível 2. 


\section{$\underline{\text { ANEXO C }}$ \\ DATACÃO RADIOCARBÔNICA}

\section{BETR \\ BETA ANALYTIC INC.}

DR. M.A. TAMERS and MR. D.G. HOOD
4985 S.W. 74 COURT

MIAMI, FLORIDA, USA 33155

PH: 305-667-5167 FAX:305-663-0964

beta@radiocarbon.com

\section{REPORT OF RADIOCARBON DATING ANALYSES}

Dr. Fabiola Andrea Silva

Report Date: 11/8/2013

Universidade de Sao Paulo (MAE/USP)

Material Received: 10/21/2013

\begin{tabular}{lccc}
\hline \multicolumn{1}{c}{ Sample Data } & $\begin{array}{c}\text { Measured } \\
\text { Radiocarbon Age }\end{array}$ & $\begin{array}{c}\text { 13C/12C } \\
\text { Ratio }\end{array}$ & $\begin{array}{c}\text { Conventional } \\
\left.\text { Radiocarbon Age } *^{*}\right)\end{array}$ \\
\hline $\begin{array}{l}\text { Beta - 362386 } \\
\text { SAMPLE : DR-CAR-01 }\end{array}$ & $1710+/-30 \mathrm{BP}$ & $-26.8 \mathrm{o} / \mathrm{oo}$ & $1680+/-30 \mathrm{BP}$ \\
ANALYSIS : AMS-Standard delivery & & \\
MATERIAL/PRETREATMENT : (charred material): acid/alkali/acid \\
2 SIGMA CALIBRATION : $\quad$ Cal AD 260 to 300 (Cal BP 1690 to 1660) AND Cal AD 320 to 420 (Cal BP 1630 to 1530)
\end{tabular}

Beta -362389

$4950+/-30 \mathrm{BP}$

$-26.7 \mathrm{o} / \mathrm{oo}$

$4920+/-30$ BP

SAMPLE : YA-CAR-01

ANALYSIS : AMS-Standard delivery

MATERIAL/PRETREATMENT : (charred material): acid/alkali/acid

2 SIGMA CALIBRATION

Cal BC 3760 to 3720 (Cal BP 5710 to 5670) AND Cal BC 3720 to 3640 (Cal BP 5670 to 5600)

Dates are reported as RCYBP (radiocarbon years before present, "present" = AD 1950). By international convention, the modern reference standard was $95 \%$ the $14 \mathrm{C}$ activity of the National Institute of Standards and Technology (NIST) Oxalic Acid (SRM 4990C) and calculated using the Libby $14 \mathrm{C}$ half-life (5568 years). Quoted errors represent 1 relative standard deviation statistics (68\% probability) counting errors based on the combined measurements of the sample, background, and modern reference standards. Measured $13 \mathrm{C} / 12 \mathrm{C}$ ratios (delta $13 \mathrm{C}$ ) were calculated relative to the PDB-1 standard.
The Conventional Radiocarbon Age represents the Measured Radiocarbon Age corrected for isotopic fractionation, calculated using the delta 13C. On rare Radiocarbon Age was calculated using an assumed delta $13 \mathrm{C}$, the ratio and Age was calculated using an assumed delta 13C, The Conventional Radiocarbon Age is not calendar calibrated. When available, the Calendar Calibrated result is calculated from the Conventional Radiocarbon Age and is listed as the "Two Sigma Calibrated Result" for each sample. 
Datacão de carvão do sítio Dinossauro (DR-CAR-01):

\section{CALIBRATION OF RADIOCARBON AGE TO CALENDAR YEARS}

(Variables: $\mathrm{C} 13 / \mathrm{C} 12=-26.8:$ lab. mult $=1$ )

Laboratory number: Beta-362386

Conventional radiocarbon age: $1680 \pm 30 \mathrm{BP}$

2 Sigma calibrated results: Cal AD 260 to 300 (Ca I BP 1690 to 1660) and (95\% probability) Cal AD 320 to 420 (Cal BP 1630 to 1530)

Intercept data

Intercept of radiocarbon age with calibration curve:

1 Sigma calibrated result: Cal AD 340 to 410 (Cal BP 1610 to 1540) (68\% probability)

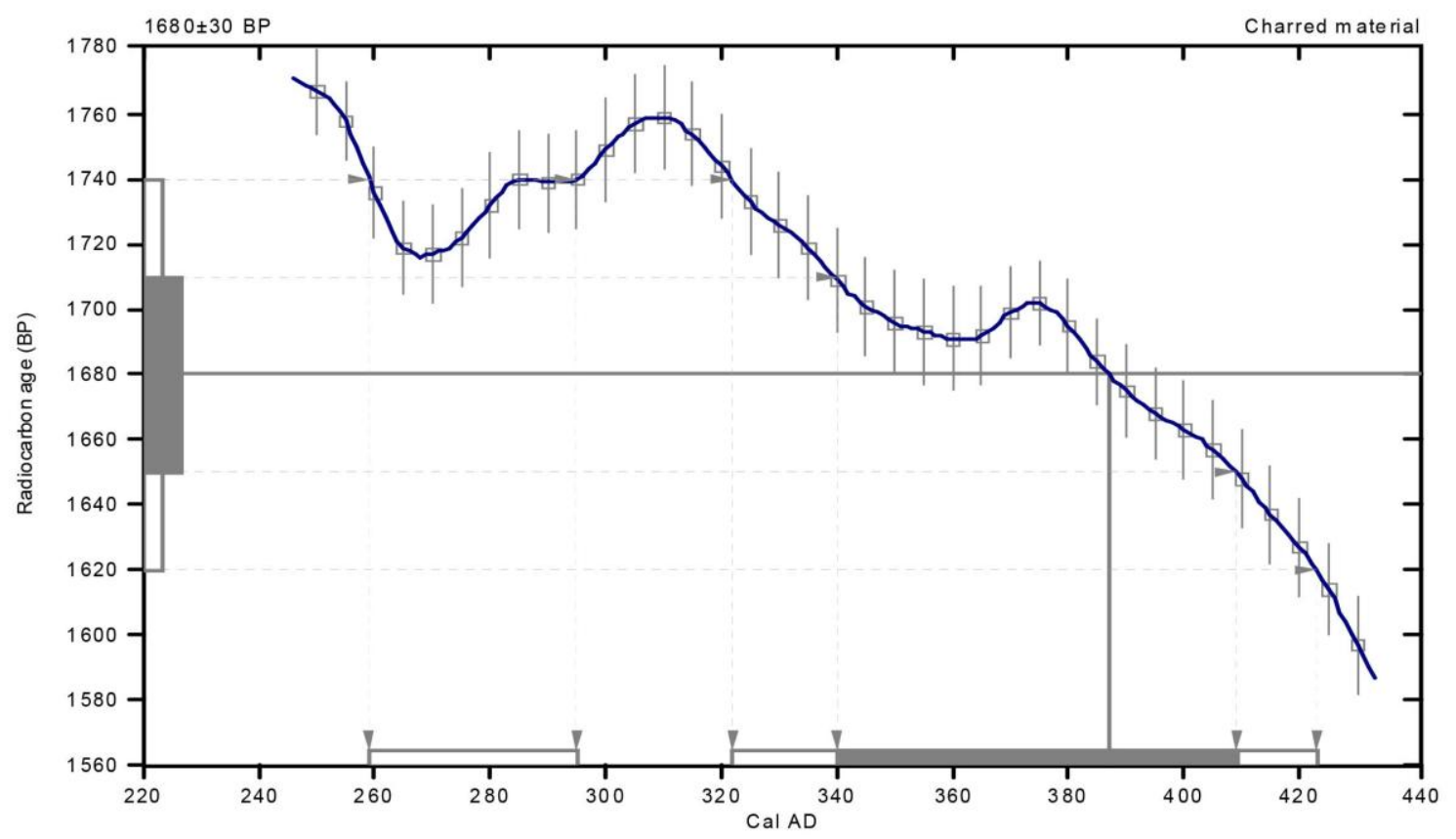

References:

Database used INTCALO9

References to INTCALO9 database

Heaton, et.al.,2009, Radiocarbon 51(4):1151-1164, Reimer,et.al, 2009, Radiocarbon 51(4):1111-1150, Stuiver, et.al,1993, Radiocarbon 35(1):13 7-189, Oesch ger,et.al., 1975, Tellus 27:168-192

Mathematics used for calibration scenario

A Simplified Approach to Calibrating C14 Dates

Talma, A. S., Vogel, J. C., 1993, Radiocarbon 35(2):317-322

\section{Beta Analytic Radiocarbon Dating Laboratory}

4985 S.W.74th Court, Miami, Florida 33155 Tel: (305)667-5167 -Fax: (305)663-0964 E-Mail: beta@ radiocarbon.com 
Datação de carvão do sítio Ywantã (YA-CAR-01)

\section{CALIBRATION OF RADIOCARBON AGE TO CALENDAR YEARS}

(Variables: $\mathrm{C} 13 / \mathrm{C} 12=-26.7:$ lab. mult $=1$ )

Laboratory number: Beta-362389

Conventional radiocarbon age: $4920 \pm 30 \mathrm{BP}$

2 Sigma calib ra ted results: Cal BC 3760 to 3720 (Cal BP 5710 to 5670) and (95\% probability) Cal BC 3720 to 3640 (Cal BP 5670 to 5600) Intercept data

Intercept of radiocarbon age with calibration curve:

1 Sigma calibrated result: Cal BC 3710 to 3650 (Cal BP 5660 to 5600) (68\% probability)

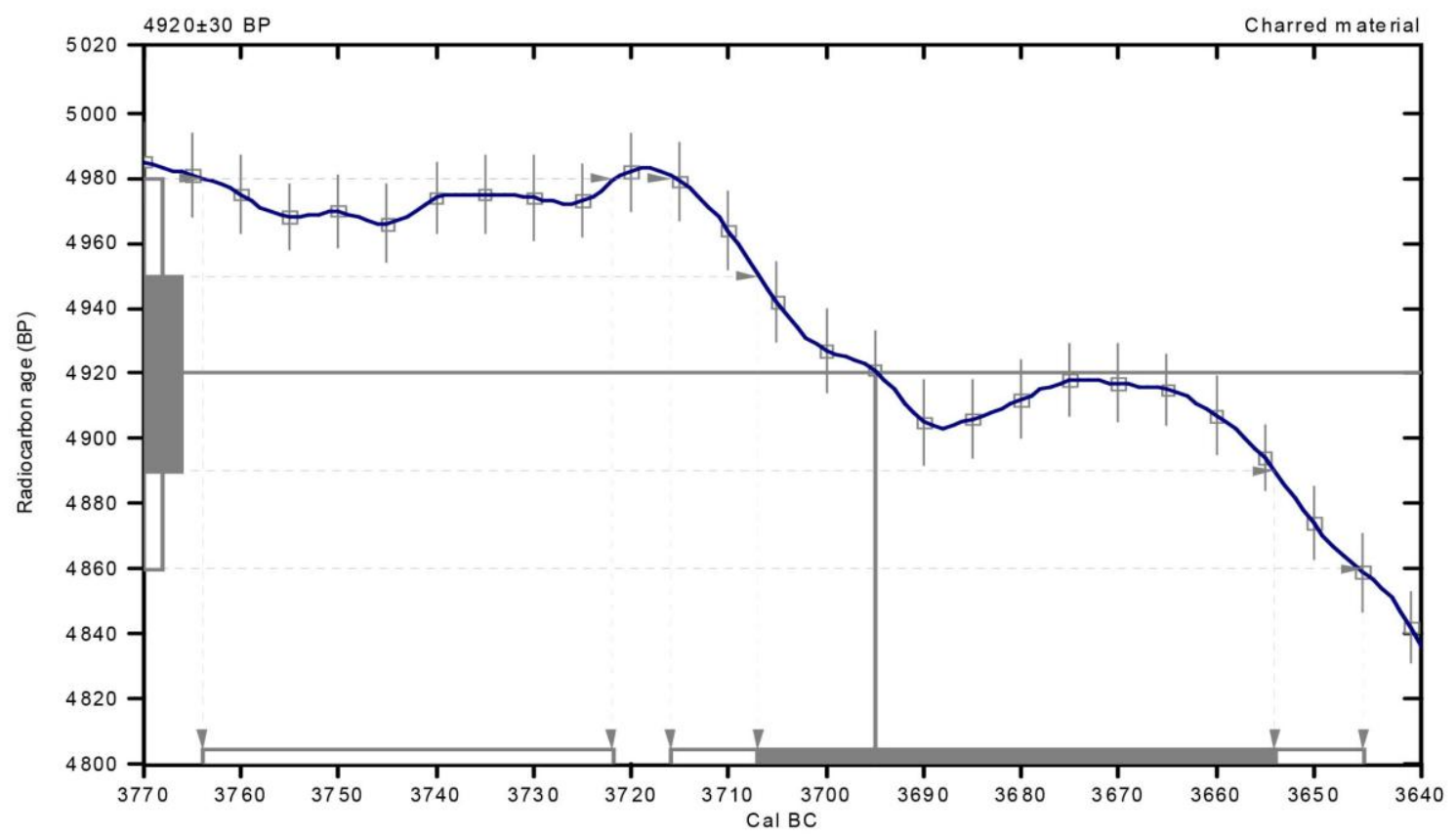

References:

Database used INTCALO9

References to INTCALO9 database

Heaton, et.al.,2009, Radiocarbon 51 (4):1151-1164, Reimer,et.al, 2009, Radiocarbon 51(4):1111-1150, Stuiver, et.al,1993, Radiocarbon 35(1):13 7-189, Oesch ger,et.al., 1975, Tellus 27:168-192

Mathematics used for calibration scenario

A Simplified Approach to Calibrating C14 Dates

Talma, A. S., Vogel, J. C., 1993, Radiocarbon 35(2):317-322

\section{Beta Analytic Radiocarbon Dating Laboratory}

4985 S.W.74th Court, Miami, Florida 33155 Tel: (305)667-5167 •Fax:(305)663-0964・E-Mail: beta@ radiocarbon.com 


\title{
DATACÃO TERMOLUMINESCÊNCIA
}

\section{D) \\ Datação, Comércio e Prestação de Serviços LTDA. \\ Datação: LOE e TL}

\author{
Relatório de Ensaio
}

\author{
CLIENTE: FABIOLA ANDREA SILVA \\ MELIAN VIGANO GASPAR \\ EMAIL: faandrea@usp.br, mmmeli@gmail.com
}

MATERIAL: Cerâmica Arqueológica.

NATUREZA DO TRABALHO: Preparação de Amostragem e Elaboração de Laudo de Datação de fragmentos cerâmicos pelo método da Termoluminescência (TL).

\section{REFERÊNCIA:}

\section{AMOSTRAS}

Foram fornecidas pelo cliente 4 (três) amostras com as designações indicadas na Tabela 1, acondicionada e devidamente embalada de forma que não tomou luz no envio. A amostra foi recebida e identificada no laboratório como 4106 até 4109.

\section{RESULTADOS}

Os resultados de dose acumulada, dose anual e da idade média das 5 alíquotas obtidas por TL são apresentados na Tabela 1, a seguir: 


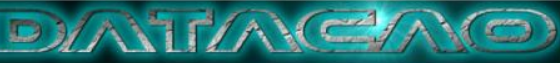 \\ Datação, Comércio e Prestação de Serviços LTDA. \\ Datação: LOE e TL}

Tabela 1: Código Datação, amostra, dose anual, dose acumulada e idade.

\begin{tabular}{|c|c|c|c|c|}
$\begin{array}{c}\text { Código } \\
\text { Datação }\end{array}$ & Amostra & $\begin{array}{c}\text { Dose Anual } \\
(\mu \mathrm{Gy} / \mathrm{ano})\end{array}$ & $\begin{array}{c}\text { Dose Acumulada } \\
(\mathrm{Gy})\end{array}$ & $\begin{array}{c}\text { Idade } \\
(\text { anos })\end{array}$ \\
\hline 4106 & YA-661 10 a $20 \mathrm{~cm}$ & $4.500 \pm 200$ & 1,87 & $420 \pm 40$ \\
\hline 4107 & MC-749 10 a $20 \mathrm{~cm}$ & $3.700 \pm 320$ & 3,23 & $870 \pm 120$ \\
\hline \multicolumn{5}{|r}{} \\
\hline 4109 & TT-1446 30 a $40 \mathrm{~cm}$ & $5.000 \pm 370$ & 1,90 & $380 \pm 50$
\end{tabular}

OBS - A idade obtida para os fragmentos cerâmicos estima o período decorrente a partir da última queima (acima de $450^{\circ} \mathrm{C}$ ) que a cerâmica foi submetida.

As concentrações medidas dos isótopos radioativos ${ }^{232} \mathrm{Th},{ }^{238} \mathrm{U}+235 \mathrm{U},{ }^{40} \mathrm{~K}$ utilizados para calcular a dose anual são apresentados na Tabela 2, a seguir:

Tabela 2: Amostra, Th (Tório), U (Urânio), K (Potássio).

\begin{tabular}{|c|c|c|c|} 
Amostra & $\begin{array}{c}\text { Th } \\
(\mathrm{ppm})\end{array}$ & $\begin{array}{c}\mathrm{U} \\
(\mathrm{ppm})\end{array}$ & $\begin{array}{c}\mathrm{K} \\
(\%)\end{array}$ \\
\hline 4106 & $\mathbf{1 6 , 0 0 7} \pm \mathbf{0 , 5 7 6}$ & $\mathbf{8 , 6 3 5} \pm \mathbf{0 , 1 1 9}$ & $\mathbf{0 , 8 4 3} \pm \mathbf{0 , 1 2 2}$ \\
\hline 4107 & $\mathbf{1 4 , 6 6 1} \pm \mathbf{0 , 5 2 8}$ & $\mathbf{3 , 8 3 9} \pm \mathbf{0 , 2 7 8}$ & $\mathbf{1 , 3 8 0} \pm \mathbf{0 , 2 0 0}$ \\
\hline 4108 & $\mathbf{2 0 , 4 4 7} \pm \mathbf{0 , 7 3 6}$ & $\mathbf{5 , 8 2 5} \pm \mathbf{0 , 1 2 8}$ & $\mathbf{1 , 6 2 4} \pm \mathbf{0 , 2 3 5}$ \\
\hline 4109 & $\mathbf{1 8 , 9 1 0} \pm \mathbf{0 , 6 8 1}$ & $\mathbf{5 , 6 6 9} \pm \mathbf{0 , 1 3 5}$ & $\mathbf{1 , 8 8 9} \pm \mathbf{0 , 2 7 4}$ \\
\hline & & &
\end{tabular}

São Paulo, 24 de Julho de 2014.

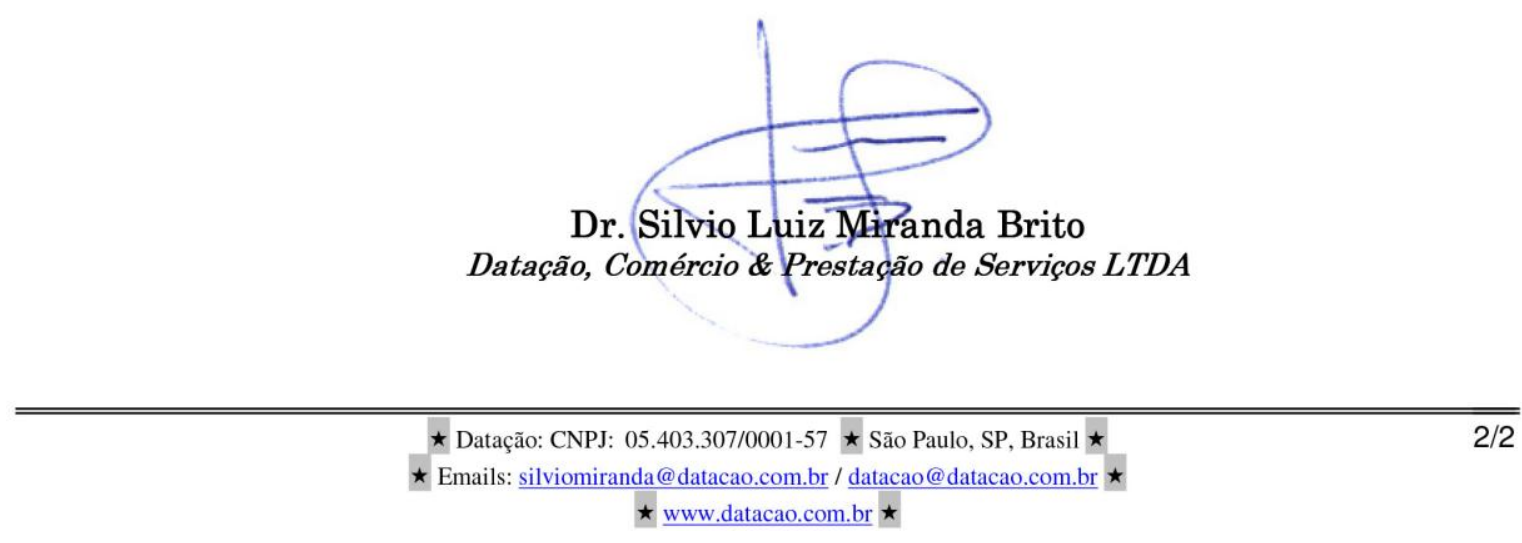




\section{ANEXO D \\ ESTATÍSTICA}

\section{Análise de associação entre as variáveis da análise cerâmica}

Do relatório final: SILVA, T.C.M. e FOSSALUZA, V. Relatório de Análise Estatística sobre o projeto: “A cerâmica arqueológica na T.I. Kaiabi (MT/PA)”. São Paulo, IME-USP, 2013 (RAE CEA - 13P22)

Gráfico 1: Densidade a posteriori para a medida de associação entre as variáveis Coloração de superfície face interna e Espessura (variável categorizada).

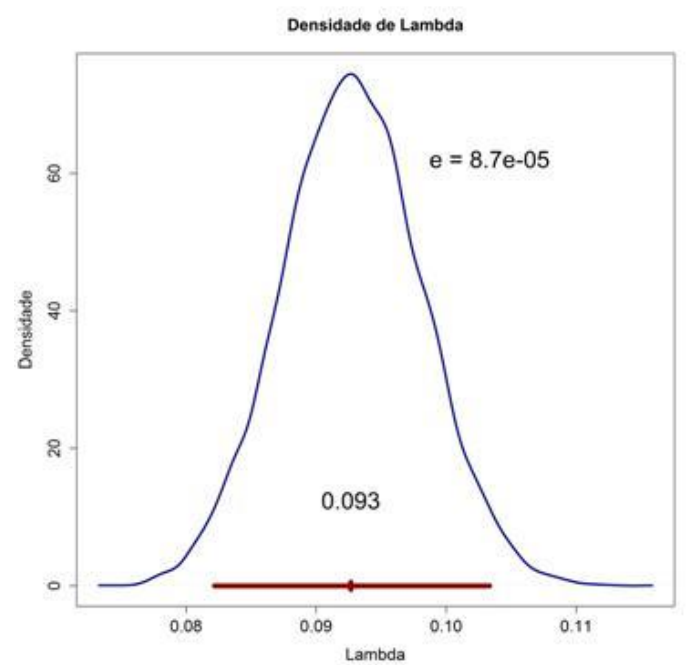

Gráfico 2: Densidade a posteriori para a medida de associação entre as variáveis Coloração de superfície face interna e Acabamento de superfície face interna.

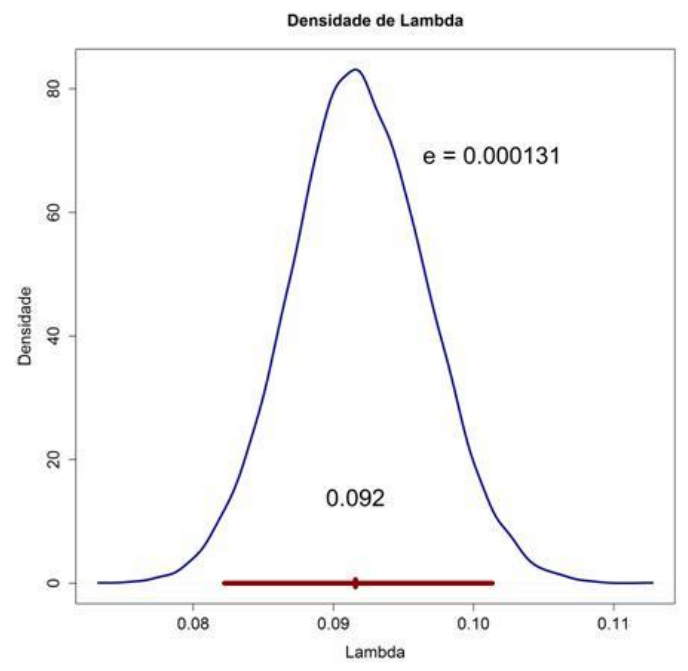

Gráfico 3: Densidade a posteriori para a medida de associação entre as variáveis Coloração de superfície face externa e Acabamento de superfície face externa.

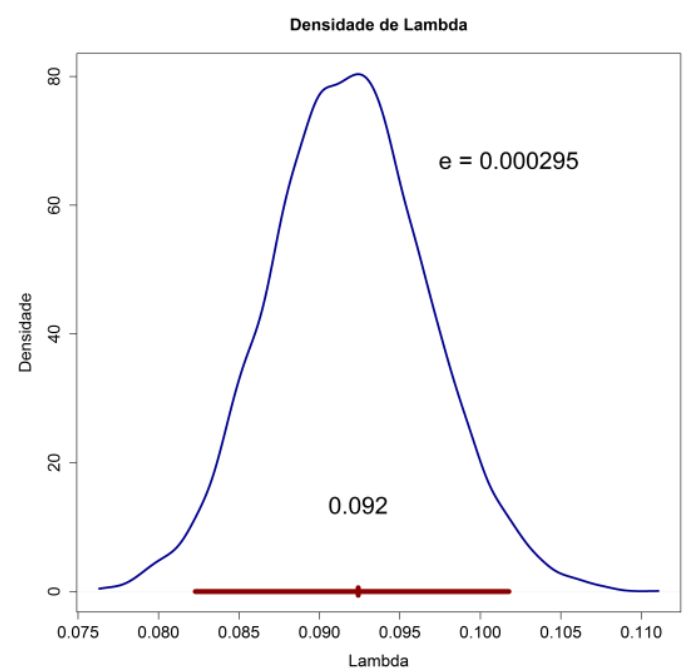

Gráfico 4: Densidade a posteriori para a medida de associação entre as variáveis Coloração de superfície face interna e Antiplástico.

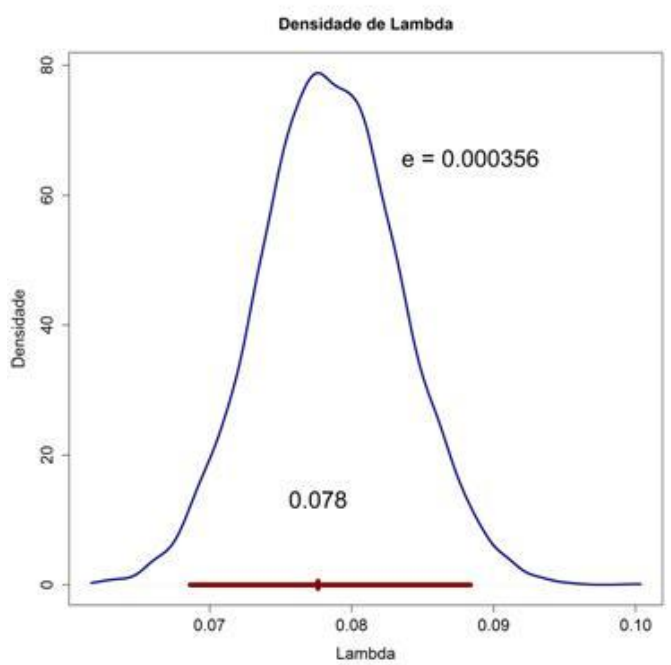


Gráfico 5: Densidade a posteriori para a medida de associação entre as variáveis Acabamento de superfície face externa e Sítio.

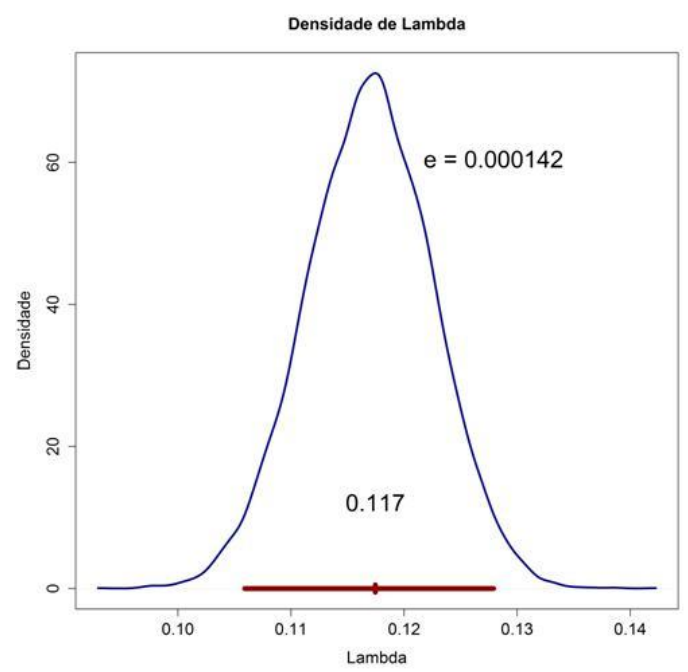

Gráfico 6: Densidade a posteriori para a medida de associação entre as variáveis Coloração de superfície face interna e Coloração de superfície face externa.

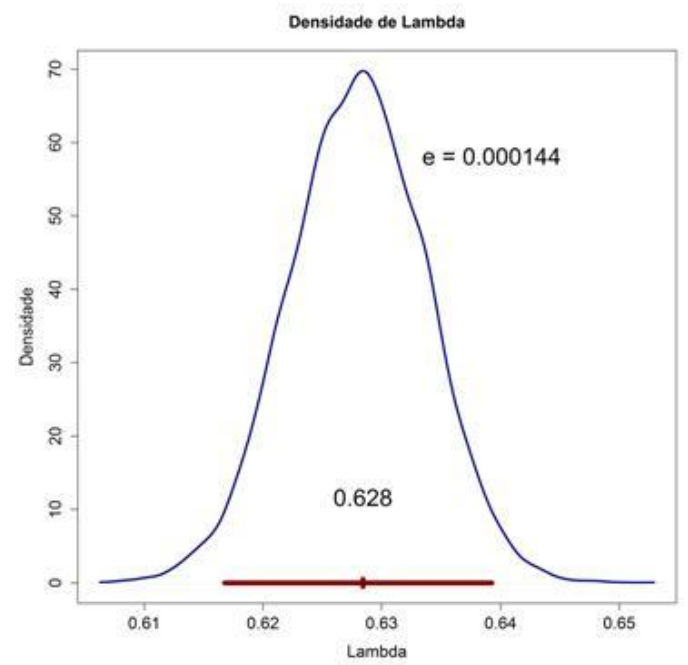

Gráfico 7: Densidade a posteriori para a medida de associação entre as variáveis Antiplástico e Sítio.

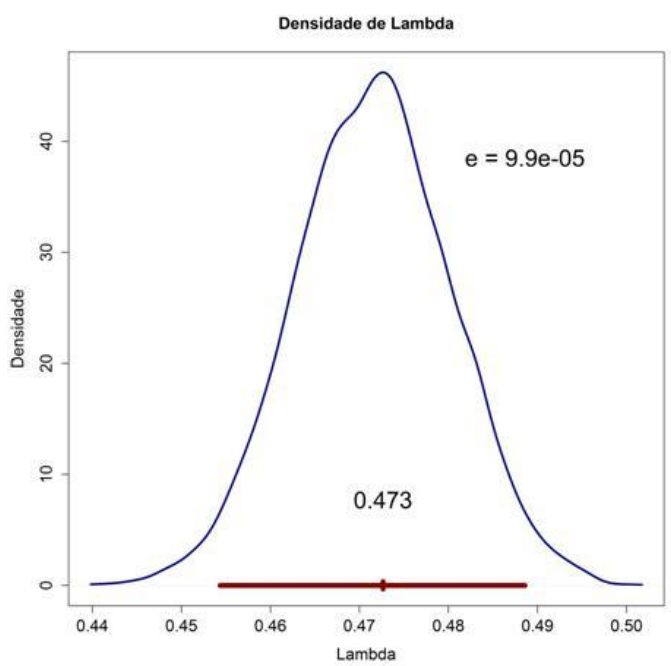

Gráfico 8: Densidade a posteriori para a medida de associação entre as variáveis Acabamento de superfície face interna e Acabamento de superfície face externa.

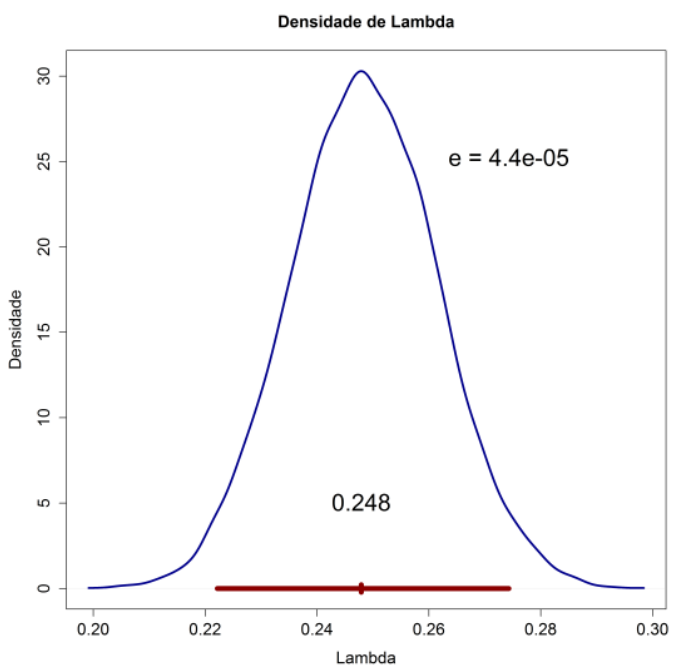




\section{Gráficos de distribuicão de variáveis nos 8 conjuntos estatísticos}

Do relatório final: SILVA, T.C.M. e FOSSALUZA, V. Relatório de Análise Estatística sobre o projeto: “A cerâmica arqueológica na T.I. Kaiabi (MT/PA)". São Paulo, IME-USP, 2013 (RAE CEA - 13P22)

Gráfico 26. Gráfico de barras da distribuição dos sítios nos diferentes grupos.

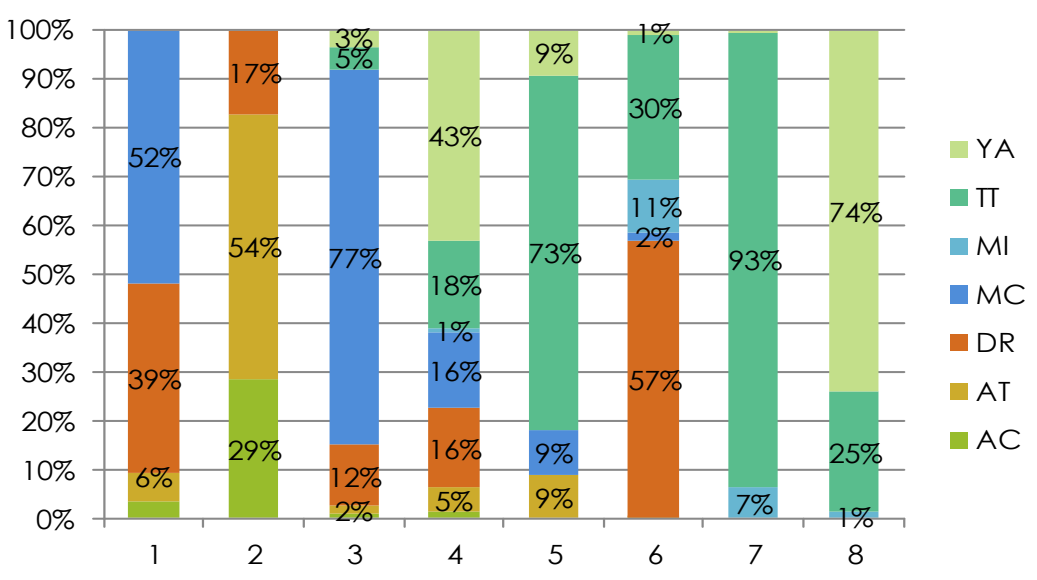

Gráfico 27. Gráfico de barras da distribuição dos grupos nos diferentes sítios.

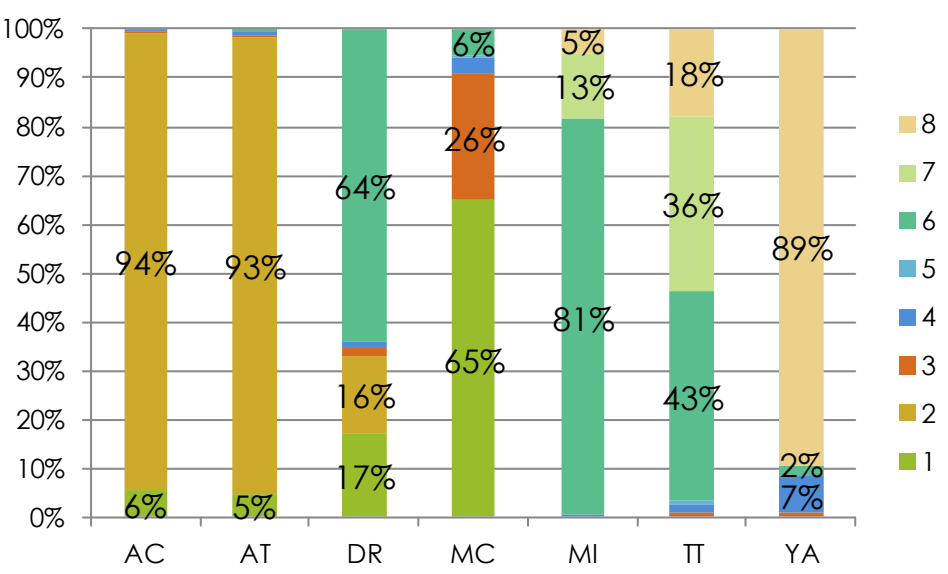

Gráfico28. Gráfico de barras da distribuição do antiplástico nos diferentes grupos.

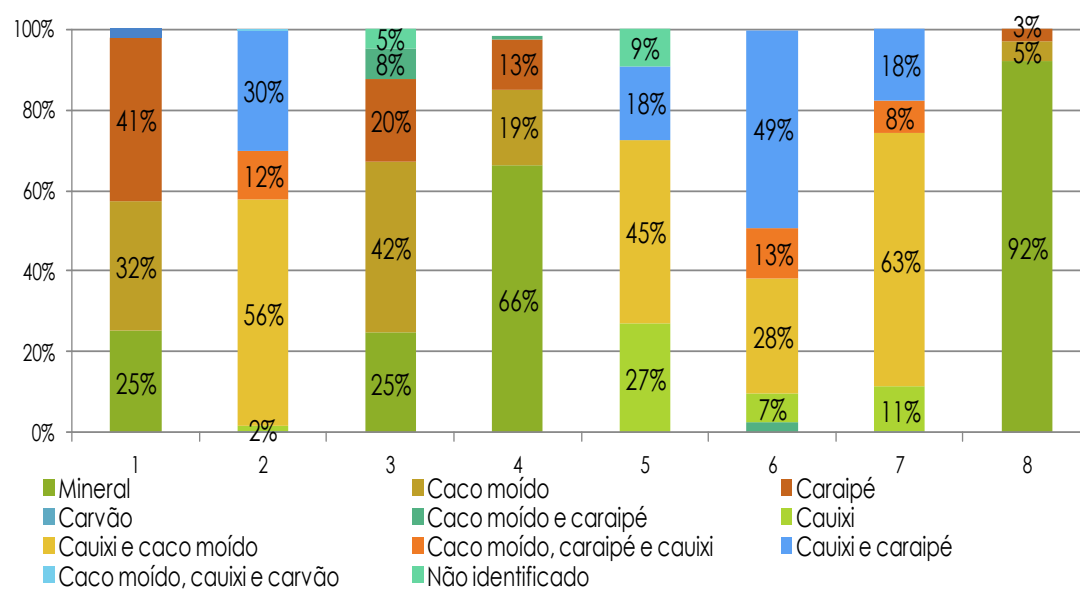


Gráfico 29. Gráfico de barras da distribuição da coloração de face externa nos diferentes grupos.

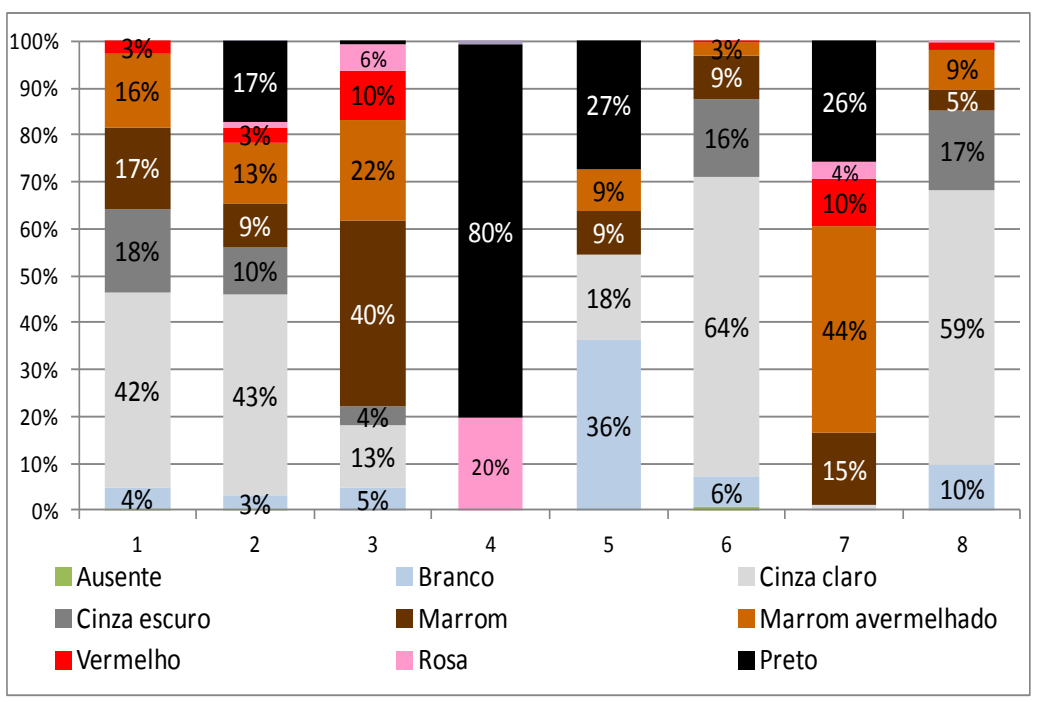

Gráfico 30. Gráfico de barras da distribuição da acabamento de face externa nos diferentes grupos.

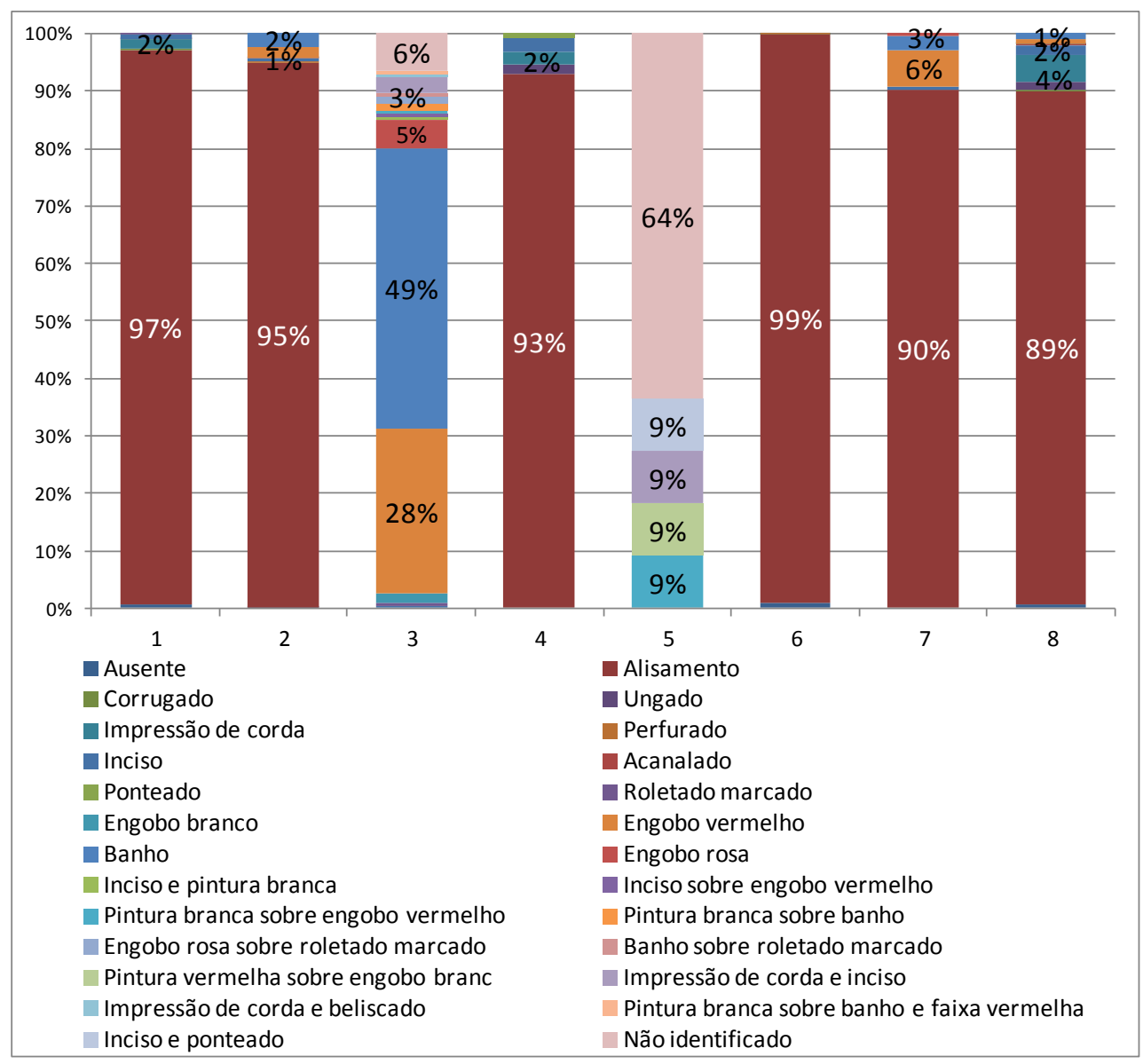




\section{Comparação dos Conjuntos com diferentes cortes no dendograma}

Observação: os conjuntos correspondentes em cada número de agrupamentos (da análise cerâmica e da estatística) estão marcados com a mesma coloração.

\begin{tabular}{|l|l|l|l|l|}
\hline $\begin{array}{c}\text { Análise } \\
\text { Cerâmica 4 } \\
\text { conjuntos }\end{array}$ & \multicolumn{1}{|c|}{ Conjunto 1 } & \multicolumn{1}{c|}{ Conjunto 2 } & \multicolumn{1}{c|}{ Conjunto 3 } & \multicolumn{1}{c|}{ Conjunto 4} \\
\hline Antiplástico & Mineral & $\begin{array}{l}\text { Caco moído e/ou } \\
\text { caraipé }\end{array}$ & $\begin{array}{l}\text { Caraipé e cauixi + } \\
\text { caco, caraipé, cauixi }\end{array}$ & $\begin{array}{l}\text { Caco moído e cauixi + } \\
\text { caco, caraipé, cauixi }\end{array}$ \\
\hline Sítios & YA, DR* & MC, DR* & DR, MI, AT**, AC & TT, AC, AT, DR \\
\hline $\begin{array}{l}\text { Acabamento } \\
\text { de superfície fe }\end{array}$ & $\begin{array}{l}\text { Plástica (impressão } \\
\text { de corda, ungulado, } \\
\text { inciso) } \\
\text { Pintura (banho, } \\
\text { engobo vermelho*) }\end{array}$ & $\begin{array}{l}\text { Pintada (banho, engobo } \\
\text { vermelho, rosa, } \\
\text { pinturas) Plástica } \\
\text { (inciso, roletado } \\
\text { marcado, impressão de } \\
\text { corda*, perfurado*) }\end{array}$ & $\begin{array}{l}\text { Liso } \\
\text { Poucos banho, engobo } \\
\text { vermelho, inciso } \\
\text { Raros impressão de } \\
\text { corda, inciso e } \\
\text { ponteado** }\end{array}$ & $\begin{array}{l}\text { Liso } \\
\text { Poucos engobo vermelho, } \\
\text { banho, pinturas } \\
\text { Raros impressão de corda, } \\
\text { inciso, perfurado }\end{array}$ \\
\hline Coloração fe & Cinza & $\begin{array}{l}\text { Cinza, marrom, } \\
\text { marrom avermelhado }\end{array}$ & $\begin{array}{l}\text { Cinza, marrom, marrom } \\
\text { avermelhado }\end{array}$ & $\begin{array}{l}\text { Cinza, marrom } \\
\text { avermelhado }\end{array}$ \\
\hline
\end{tabular}

\begin{tabular}{|c|c|c|c|c|c|}
\hline $\begin{array}{c}\text { Análise } \\
\text { Estatística } \\
5 \text { grupos }\end{array}$ & Conjunto 1 & Conjunto 2 & Conjunto 3 & Conjunto 4 & Conjunto 5 \\
\hline Antiplástico & $\begin{array}{l}\text { Mineral } \\
\text { (caraipé, caco) }\end{array}$ & $\begin{array}{l}\text { Caco e cauixi } \\
\text { (cauixi e caraipé) }\end{array}$ & $\begin{array}{l}\text { Caco } \\
\text { (mineral, caraipé) }\end{array}$ & $\begin{array}{l}\text { Caco e cauixi } \\
\text { (cauixi, cauixi e caraipé) }\end{array}$ & $\begin{array}{l}\text { Caraipé e cauixi } \\
\text { (caco e cauixi, } \\
\text { todos) }\end{array}$ \\
\hline Sítios & YA, MC, DR, TT & $\mathrm{AT}, \mathrm{AC}, \mathrm{DR}$ & $\mathrm{MC}, \mathrm{DR}$ & TT & DR, TT, MI \\
\hline $\begin{array}{l}\text { Acabamento } \\
\text { de superfície fe }\end{array}$ & $\begin{array}{l}\text { Liso } \\
\text { Impressão de } \\
\text { corda, inciso, } \\
\text { ungulado } \\
\text { Banho, engobo } \\
\text { vermelho }\end{array}$ & $\begin{array}{l}\text { Liso } \\
\text { Banho, engobo } \\
\text { vermelho, inciso }\end{array}$ & $\begin{array}{l}\text { Banho, engobo } \\
\text { vermelho/ rosa/branco, } \\
\text { pinturas, impresão de } \\
\text { corda e inciso }\end{array}$ & $\begin{array}{l}\text { NI, pinturas, inciso e } \\
\text { ponteado }\end{array}$ & $\begin{array}{l}\text { Liso } \\
\text { Engobo } \\
\text { vermelho, banho, } \\
\text { plásticos }\end{array}$ \\
\hline Coloração fe & $\begin{array}{l}\text { Cinza, marrom } \\
\text { avermelhado, } \\
\text { marrom }\end{array}$ & $\begin{array}{l}\text { Cinza, marrom } \\
\text { avermelhado, marrom }\end{array}$ & $\begin{array}{l}\text { Marrom, marrom } \\
\text { avermelhado, cinza }\end{array}$ & Cinza, preto & $\begin{array}{l}\text { Cinza, marrom } \\
\text { avermelhado, } \\
\text { marrom }\end{array}$ \\
\hline
\end{tabular}




\begin{tabular}{|c|c|c|c|c|c|c|c|c|}
\hline $\begin{array}{c}\text { Análise } \\
\text { Estatística } \\
8 \text { grupos } \\
\end{array}$ & Conjunto 1 & Conjunto 2 & Conjunto 3 & Conjunto 4 & Conjunto 5 & Conjunto 6 & Conjunto 7 & $\begin{array}{c}\text { Conjunto } \\
8\end{array}$ \\
\hline Antiplástico & $\begin{array}{l}\text { Caraipé, } \\
\text { caco, mineral }\end{array}$ & $\begin{array}{l}\text { Caco e cauixi, } \\
\text { cauixi e caraipé, } \\
\text { todos }\end{array}$ & $\begin{array}{l}\text { Caco, mineral, } \\
\text { caraipé }\end{array}$ & $\begin{array}{l}\text { Mineral, caco, } \\
\text { caraipé }\end{array}$ & $\begin{array}{l}\text { Caco e cauixi, } \\
\text { cauixi, cauixi e } \\
\text { caraipé }\end{array}$ & $\begin{array}{l}\text { Cauixi e } \\
\text { caraipé, caco e } \\
\text { cauixi, todos }\end{array}$ & $\begin{array}{l}\text { Caco e cauixi, } \\
\text { caraipé e } \\
\text { cauixi, cauixi }\end{array}$ & Mineral \\
\hline Sítios & $\mathrm{MC}, \mathrm{DR}$ & AT, AC, DR & $\mathrm{MC}, \mathrm{DR}$ & YA, TT, MC, DR & TT & DR, TT, MI & TT, MI & YA, TT \\
\hline $\begin{array}{l}\text { Acabamento } \\
\text { de superfície } \\
\text { fe }\end{array}$ & $\begin{array}{l}\text { Liso } \\
\text { Impressão de } \\
\text { corda, plásticos }\end{array}$ & $\begin{array}{l}\text { Liso } \\
\text { Banho, engobo } \\
\text { vermelho, plásticos }\end{array}$ & $\begin{array}{l}\text { Banho, engobo } \\
\text { vermelho pinturas, } \\
\text { mistos }\end{array}$ & $\begin{array}{l}\text { Liso } \\
\text { Inciso, impressão } \\
\text { de corda, ungulado }\end{array}$ & $\begin{array}{l}\text { NI } \\
\text { pinturas, mistos }\end{array}$ & $\begin{array}{l}\text { Liso } \\
\text { Plásticos }\end{array}$ & $\begin{array}{l}\text { Liso } \\
\text { Engobo } \\
\text { vermelho/rosa, } \\
\text { banho, inciso }\end{array}$ & $\begin{array}{l}\text { Liso } \\
\text { Inciso, } \\
\text { impressão } \\
\text { de corda, } \\
\text { ungulado, } \\
\text { banho }\end{array}$ \\
\hline Coloração fe & $\begin{array}{l}\text { Cinza, marrom, } \\
\text { marrom } \\
\text { avermelhado }\end{array}$ & $\begin{array}{l}\text { Cinza, preto, } \\
\text { marrom } \\
\text { avermelhado }\end{array}$ & $\begin{array}{l}\text { Marrom, marrom } \\
\text { avermelhado, } \\
\text { cinza }\end{array}$ & Preto, rosa & $\begin{array}{l}\text { Branco, preto, } \\
\text { cinza }\end{array}$ & Cinza & $\begin{array}{l}\text { Marrom } \\
\text { avermelhado, } \\
\text { preto, marrom }\end{array}$ & Cinza \\
\hline
\end{tabular}

\begin{tabular}{|c|c|c|c|c|c|c|c|c|c|c|}
\hline $\begin{array}{c}\text { Análise } \\
\text { Estatística } \\
10 \text { grupos }\end{array}$ & Conjunto 1 & Conjunto 2 & Conjunto 3 & Conjunto 4 & Conjunto 5 & Conjunto 6 & Conjunto 7 & Conjunto 8 & Conjunto 9 & $\begin{array}{c}\text { Conjunto } \\
10\end{array}$ \\
\hline Antiplástico & $\begin{array}{l}\text { Caraipé, } \\
\text { caco, } \\
\text { mineral }\end{array}$ & $\begin{array}{l}\text { Caco e cauixi, } \\
\text { cauixi e } \\
\text { caraipé, todos }\end{array}$ & $\begin{array}{l}\text { Caco, caraipé, } \\
\text { mineral }\end{array}$ & $\begin{array}{l}\text { Caraipé e } \\
\text { cauixi, caco e } \\
\text { cauixi, todos }\end{array}$ & $\begin{array}{l}\text { Mineral, caco, } \\
\text { caraipé }\end{array}$ & $\begin{array}{l}\text { Caco e } \\
\text { cauixi, } \\
\text { cauixi, } \\
\text { cauixi e } \\
\text { caraipé }\end{array}$ & $\begin{array}{l}\text { Cauixi e } \\
\text { caraipé, caco e } \\
\text { cauixi, todos }\end{array}$ & Mineral & $\begin{array}{l}\text { Caco e cauixi, } \\
\text { cauixi, cauixi } \\
\text { e caraipé }\end{array}$ & Mineral \\
\hline Sítios & $\mathrm{MC}, \mathrm{DR}$ & AT, AC, DR & $\mathrm{MC}, \mathrm{DR}$ & DR, AT, AC & $\begin{array}{l}\text { YA, TT, DR, } \\
\text { MC }\end{array}$ & TT & $\mathrm{DR}, \mathrm{TT}, \mathrm{MI}$ & TT, YA & TT & YA, TT \\
\hline $\begin{array}{l}\text { Acabamento } \\
\text { de } \\
\text { superfície fe }\end{array}$ & $\begin{array}{l}\text { Liso } \\
\text { Impressão de } \\
\text { corda, } \\
\text { inciso, } \\
\text { plásticos }\end{array}$ & $\begin{array}{l}\text { Liso } \\
\text { Banho, engobo } \\
\text { vermelho, } \\
\text { inciso, plásticos }\end{array}$ & $\begin{array}{l}\text { Banho, } \\
\text { engobo } \\
\text { vermelho, } \\
\text { pinturas }\end{array}$ & $\begin{array}{l}\text { Liso } \\
\text { Inciso }\end{array}$ & $\begin{array}{l}\text { Inciso, } \\
\text { impressão de } \\
\text { corda, } \\
\text { ungulado }\end{array}$ & $\begin{array}{l}\text { NI, pinturas, } \\
\text { mistos }\end{array}$ & $\begin{array}{l}\text { Liso } \\
\text { Plásticos }\end{array}$ & $\begin{array}{l}\text { NI, } \\
\text { impressão } \\
\text { de corda e } \\
\text { inciso, } \\
\text { pinturas }\end{array}$ & \begin{tabular}{|l} 
Liso \\
Engobo \\
vermelho/rosa, \\
banho, inciso
\end{tabular} & $\begin{array}{l}\text { Liso } \\
\text { Impressão } \\
\text { de corda, } \\
\text { inciso, } \\
\text { ungulado }\end{array}$ \\
\hline $\begin{array}{l}\text { Coloração } \\
\text { fe }\end{array}$ & $\begin{array}{l}\text { Cinza, } \\
\text { marrom, } \\
\text { marrom } \\
\text { avermelhado }\end{array}$ & $\begin{array}{l}\text { Cinza, marrom, } \\
\text { marrom } \\
\text { avermelhado }\end{array}$ & $\begin{array}{l}\text { Marrom, } \\
\text { marrom } \\
\text { avermelhado, } \\
\text { vermelho }\end{array}$ & $\begin{array}{l}\text { Preto, marrom } \\
\text { avermelhado }\end{array}$ & Preto, rosa & Cinza, preto & Cinza & $\begin{array}{l}\text { Cinza, } \\
\text { marrom } \\
\text { avermelhado }\end{array}$ & $\begin{array}{l}\text { Marrom } \\
\text { avermelhado, } \\
\text { preto, marrom }\end{array}$ & Cinza \\
\hline
\end{tabular}




\begin{tabular}{|c|c|c|c|c|c|c|}
\hline $\begin{array}{c}\text { Conjuntos em } \\
\text { cada sítio }\end{array}$ & AC & AT & DR & MC & MI & TT \\
\hline $\begin{array}{c}\text { Análise Cerâmica } \\
\text { 4 }\end{array}$ & 4,3 & 4,3 & $3,2,1$ & 2 & 3 & 5 \\
\hline $\begin{array}{c}\text { Análise } \\
\text { Estatística 5 }\end{array}$ & 2 & 2 & $5,1,2$ & 3,1 & 1 \\
\hline $\begin{array}{c}\text { Análise } \\
\text { Estatística 8 }\end{array}$ & 2 & 2 & $6,1,2$ & 1,3 & 6,7 & $7,6,8$ \\
\hline $\begin{array}{c}\text { Análise } \\
\text { Estatística 10 }\end{array}$ & 2,4 & 2,4 & $7,1,4$ & 1,3 & 7,9 & $7,9,10$ \\
\hline
\end{tabular}




\section{ANEXO E \\ ANÁLISES ARQUEOMÉTRICAS}

Do relatório final: CURADO, J. F.; RIZZUTT, M. A.; MOTA, D.. Relatório técnico das análises por Fluorescência de raios X por dispersão de energia (ED-XRF). Grupo de Física Aplicada com Aceleradores. Medidas Arqueométricas.

\section{Gráficos de barras para os elementos identificados}

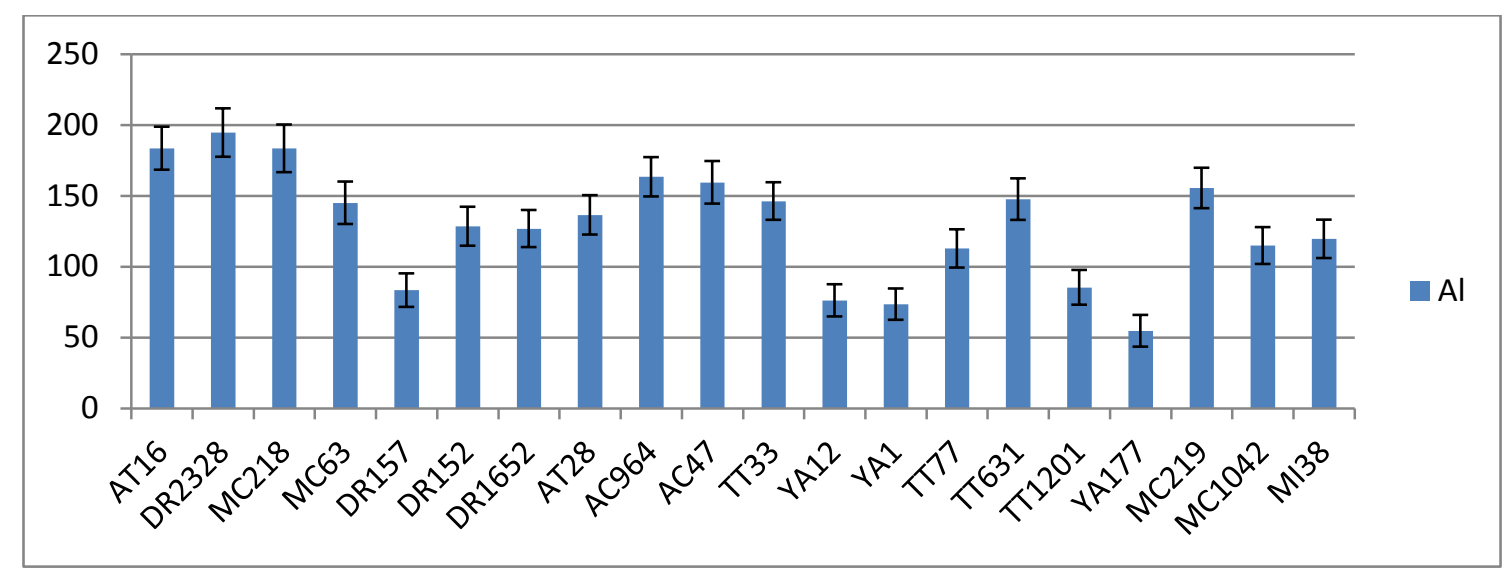

Figura 4. Gráficos de barras para o elemento Al.

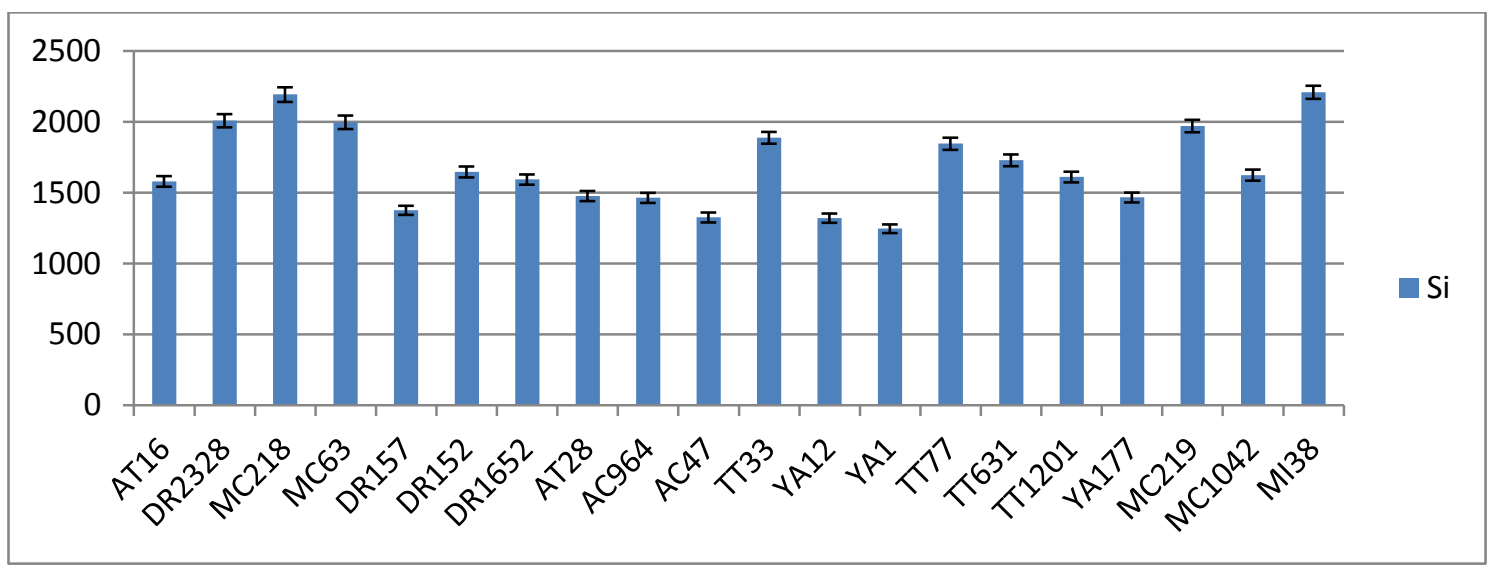

Figura 5. Gráficos de barras para o elemento Si.

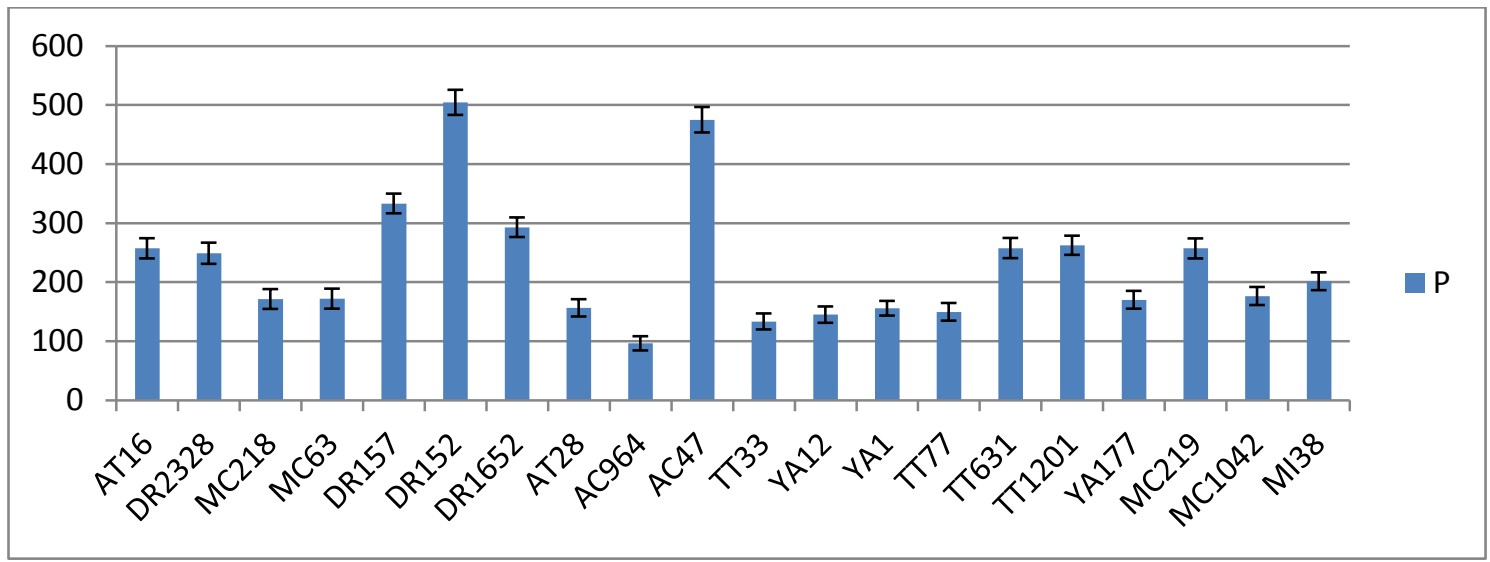

Figura 6. Gráficos de barras para o elemento $P$. 


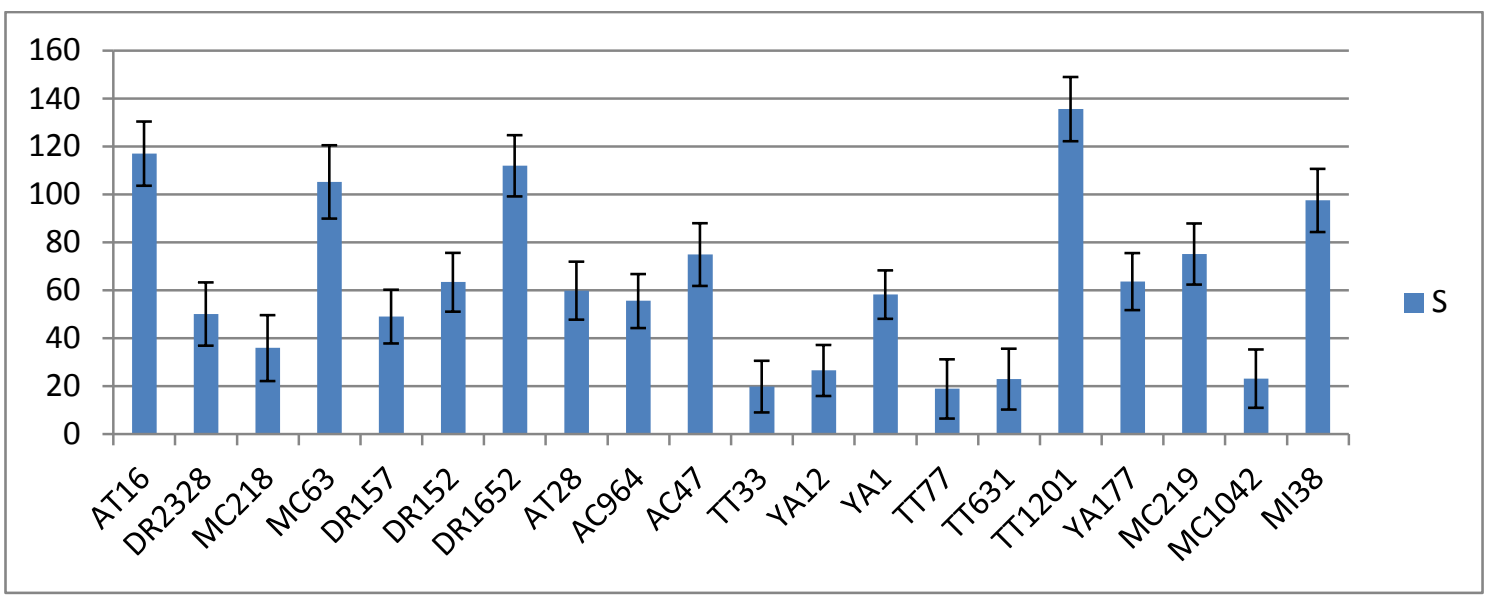

Figura 7. Gráficos de barras para o elemento $S$.

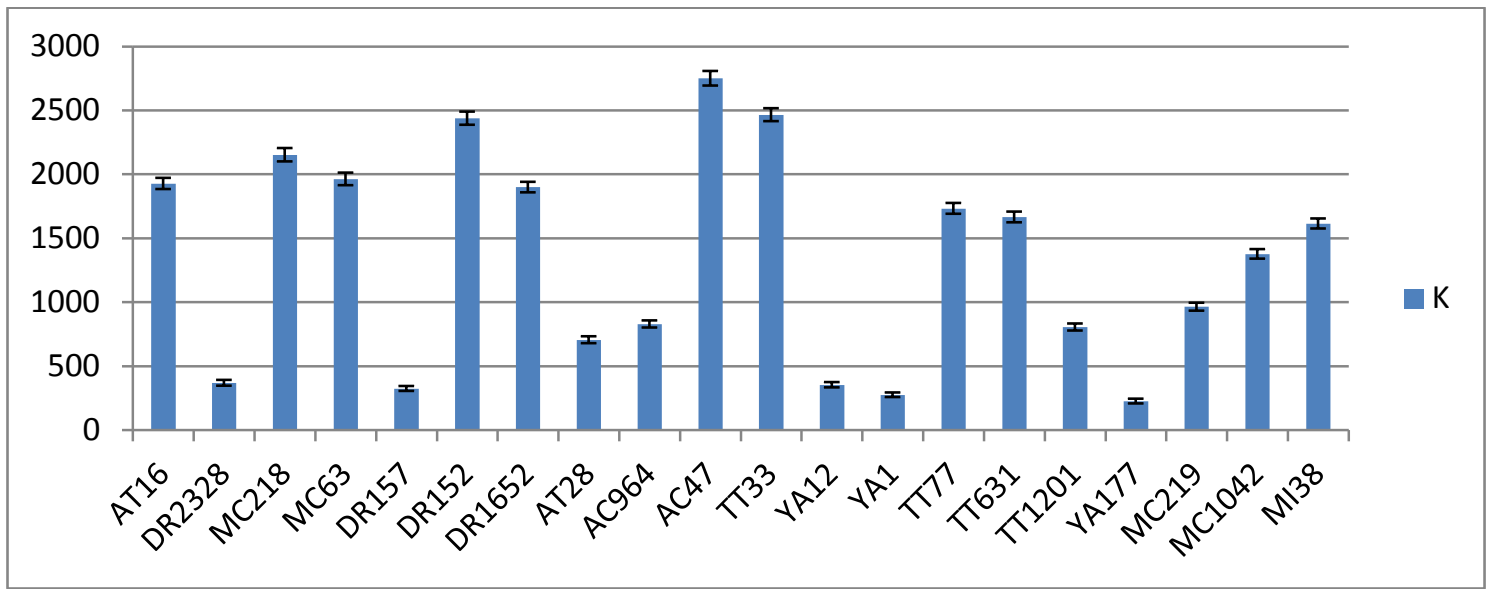

Figura 8. Gráficos de barras para o elemento $K$.

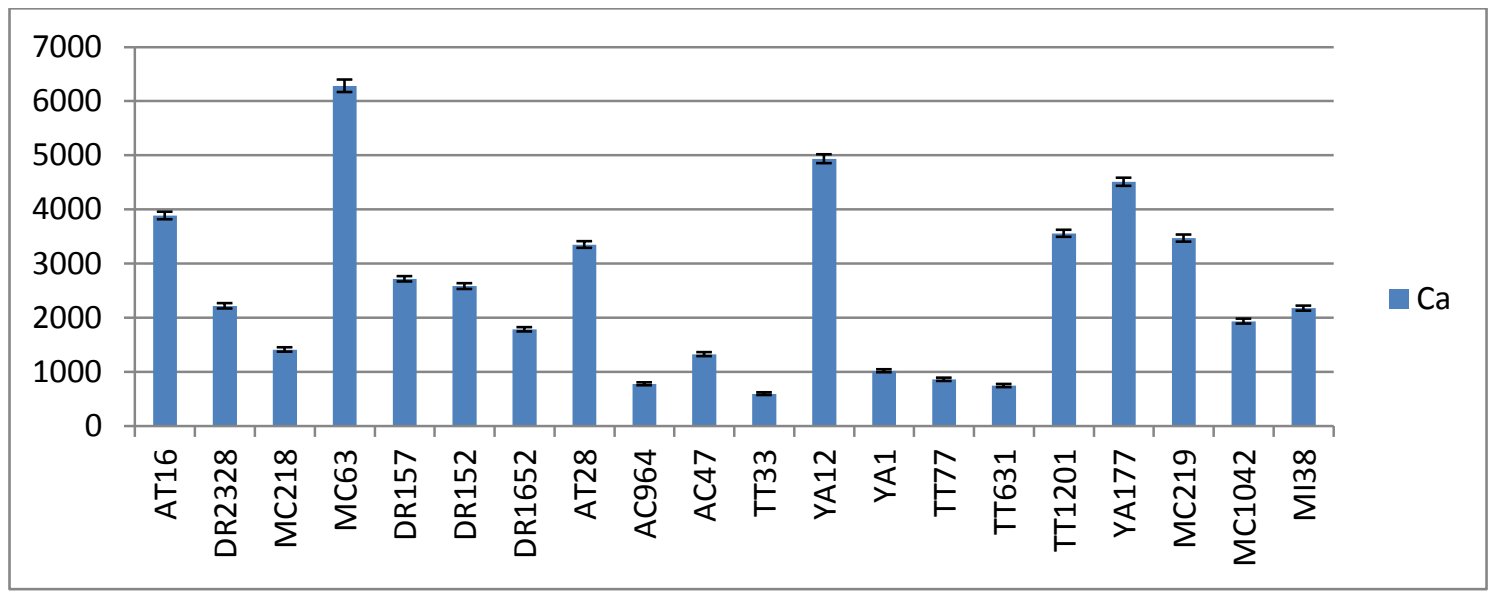

Figura 9. Gráficos de barras para o elemento Ca. 


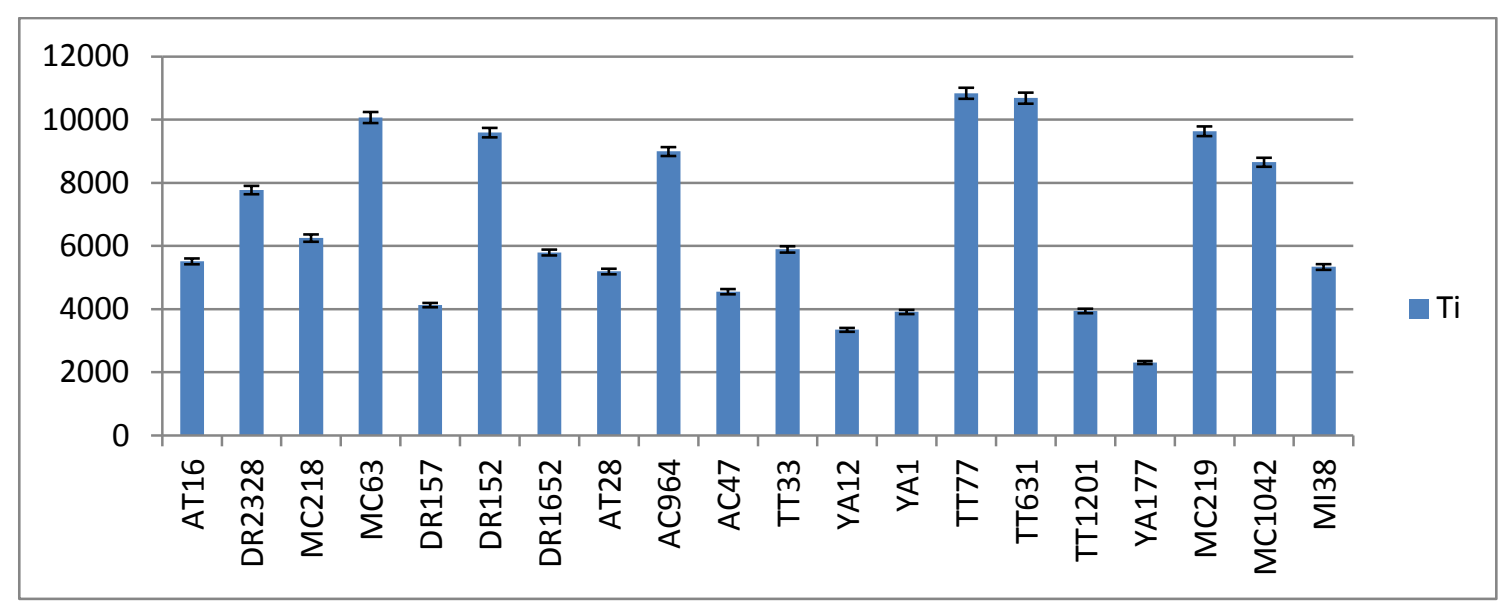

Figura 10. Gráficos de barras para o elemento Ti.

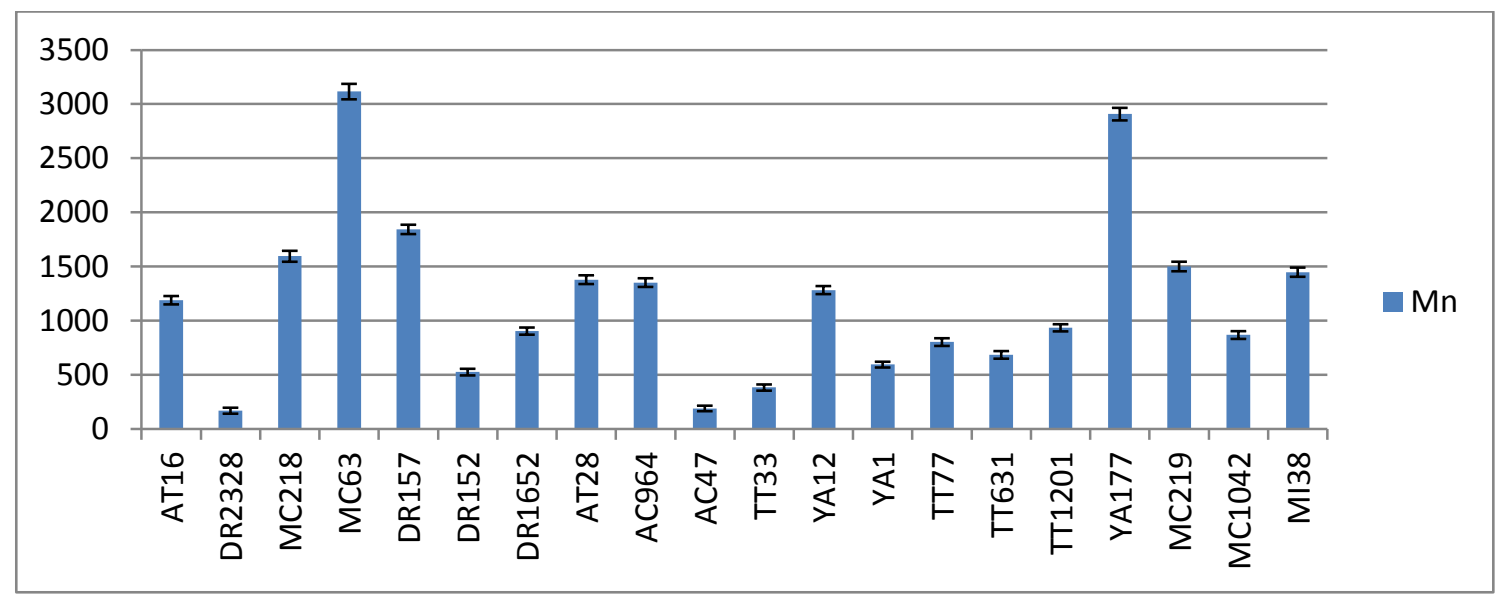

Figura 11. Gráficos de barras para o elemento $\mathrm{Mn}$.

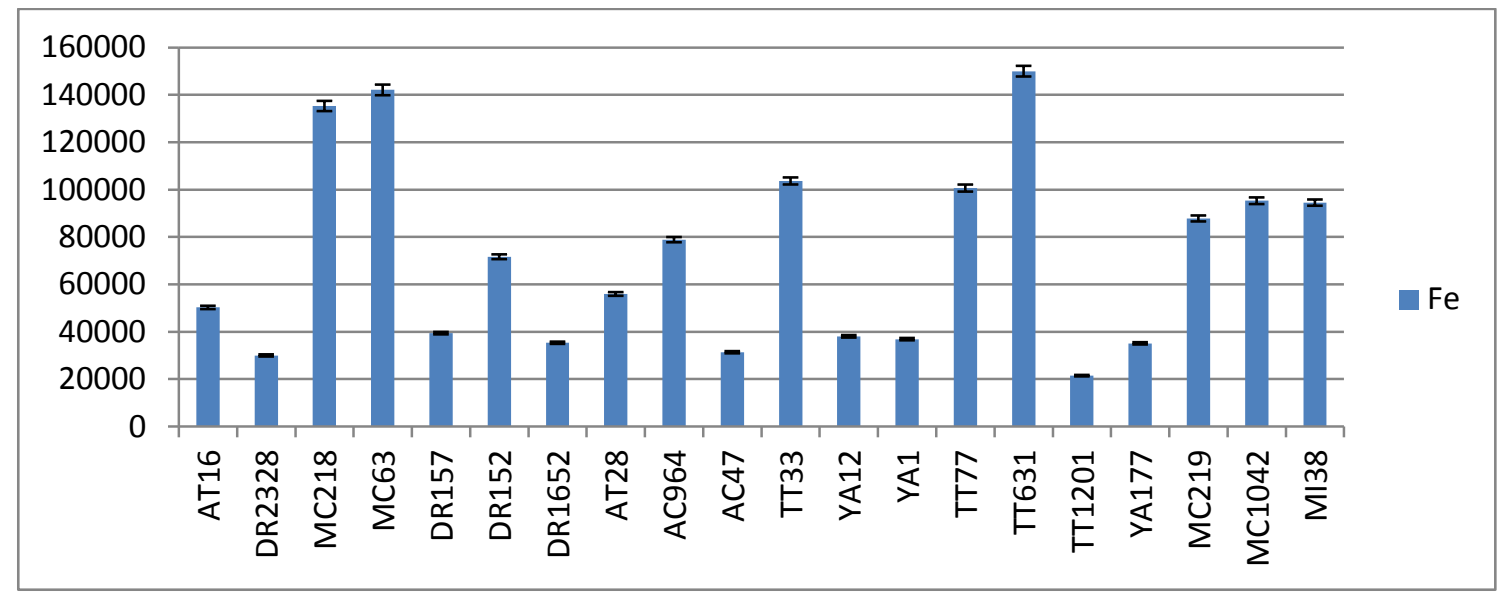

Figura 12. Gráficos de barras para o elemento Fe. 


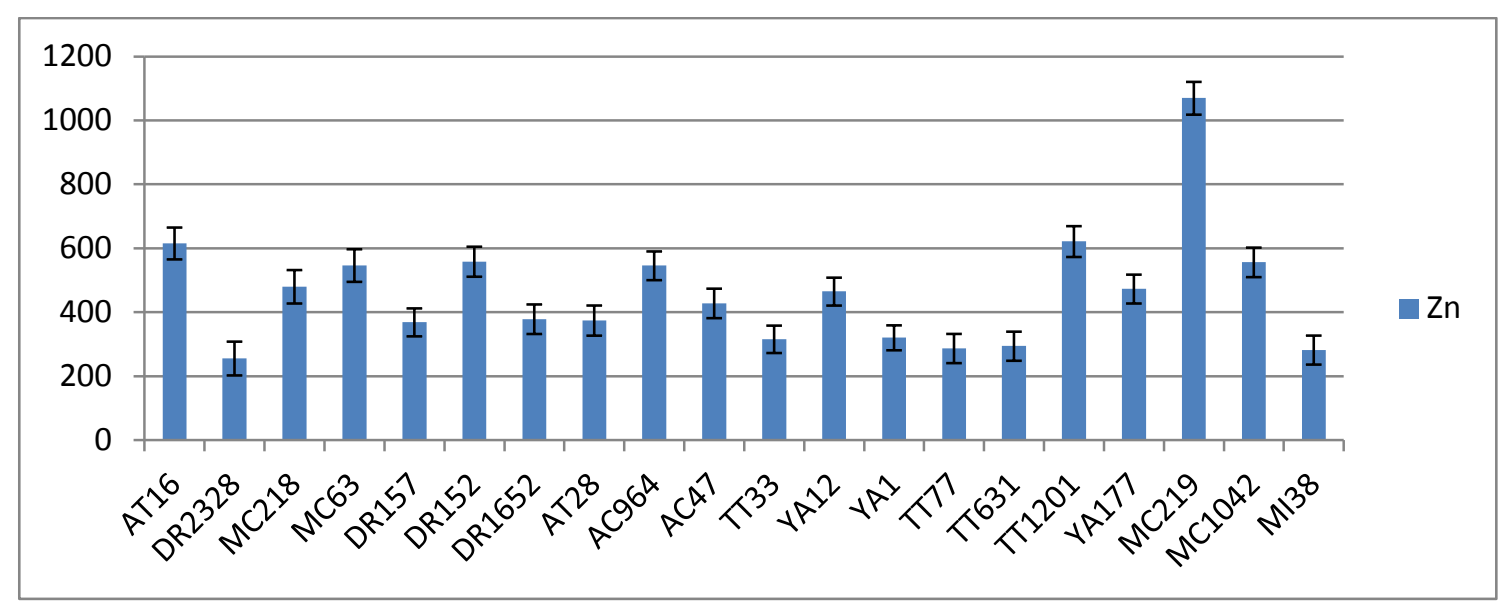

Figura 13. Gráficos de barras para o elemento Zn.

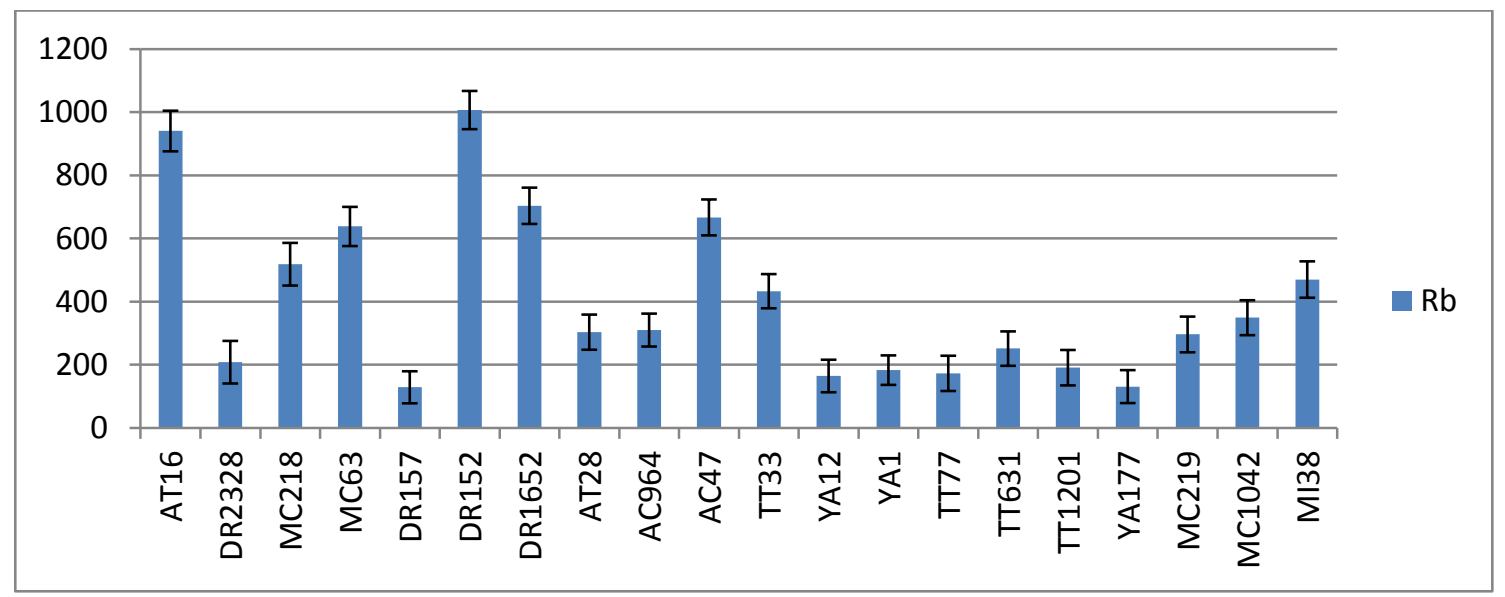

Figura 14. Gráficos de barras para o elemento Rb.

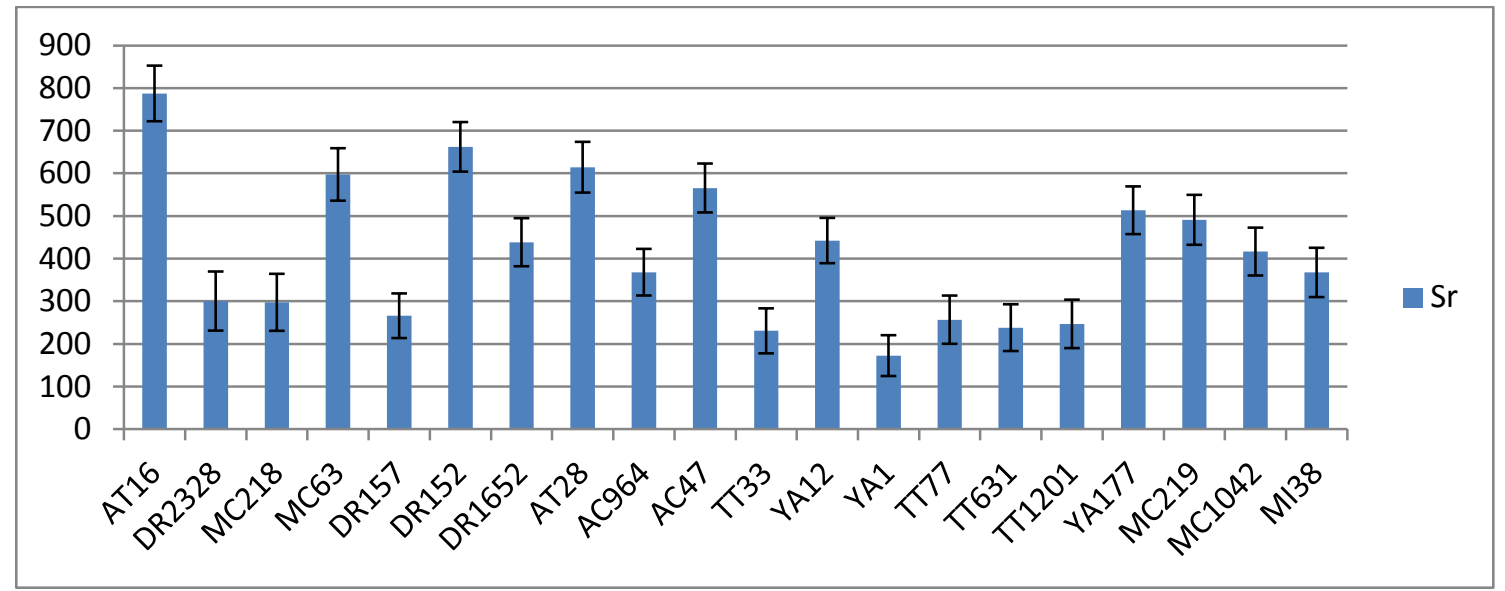

Figura 15. Gráficos de barras para o elemento $S r$. 


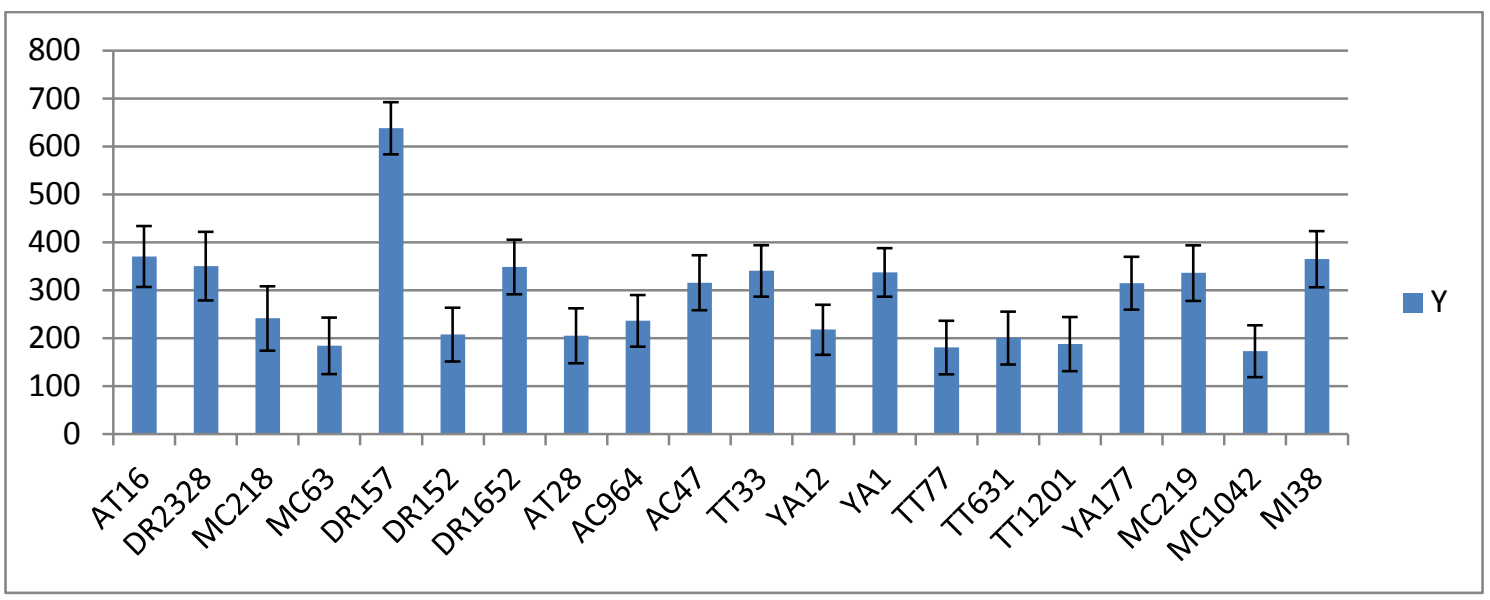

Figura 16. Gráficos de barras para o elemento Y.

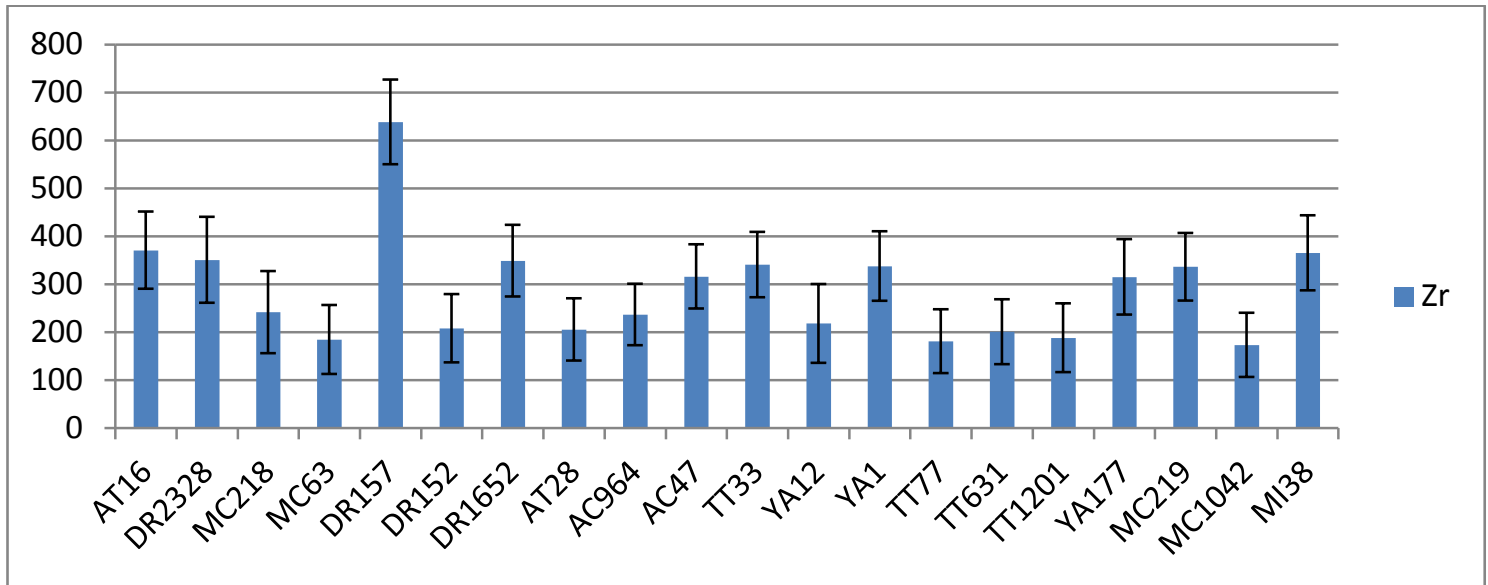

Figura 17. Gráficos de barras para o elemento Zr. 


\section{Gráficos para agrupamentos das pecas}

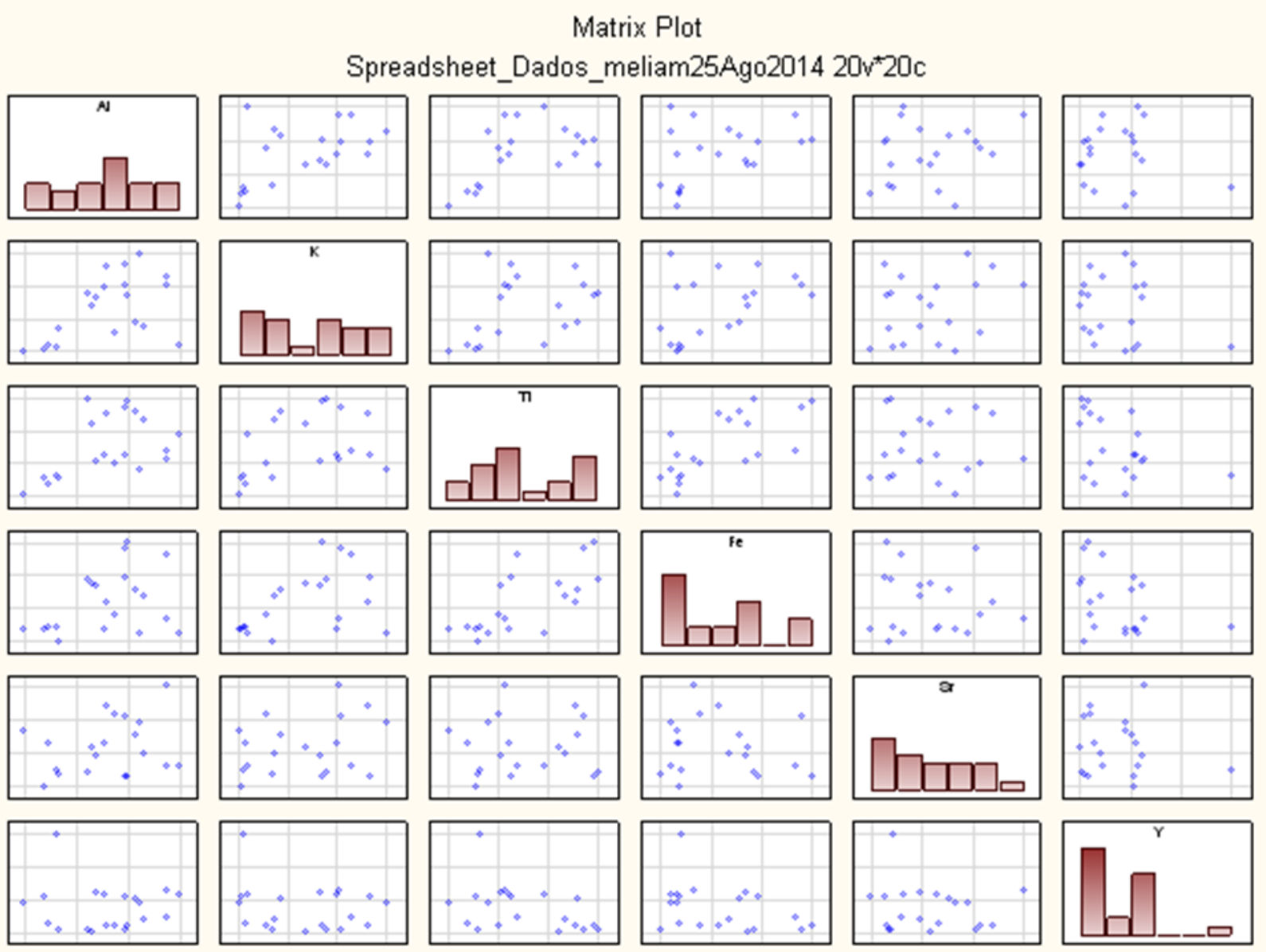

Figura 18. Matriz de combinação para os elementos Al, K, Ti, Fe, Sr e Y.

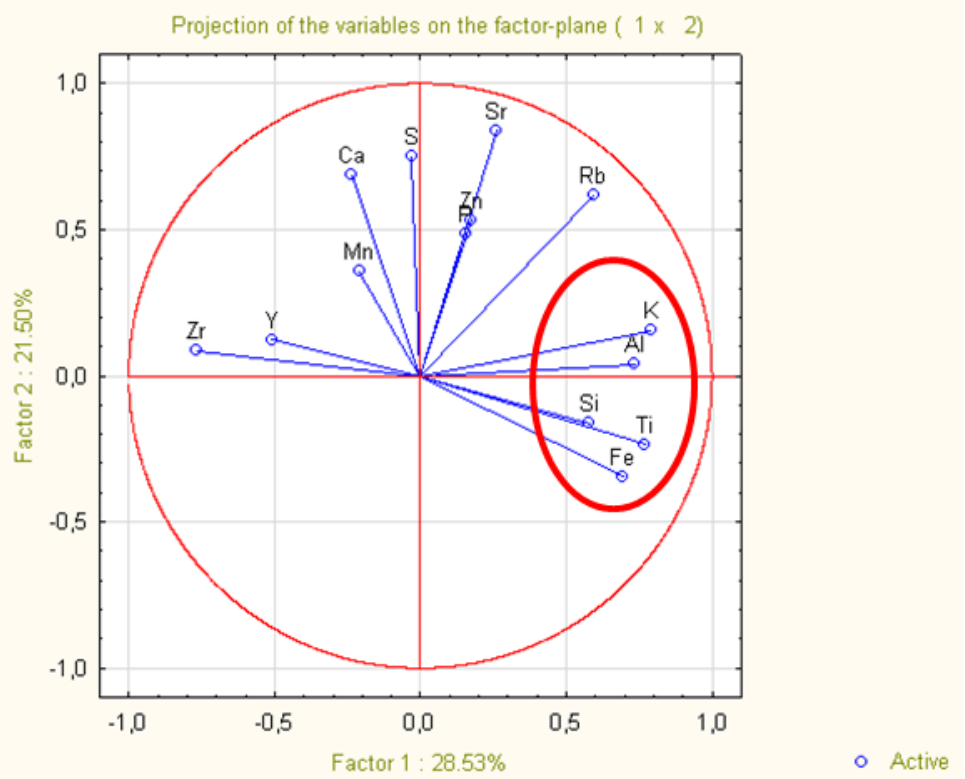

Figura 20. Círculo de correlçãoPCA entre as variáveis identificadas. Em destaque está o grupo de elementos utilizado para a análise PCA. 


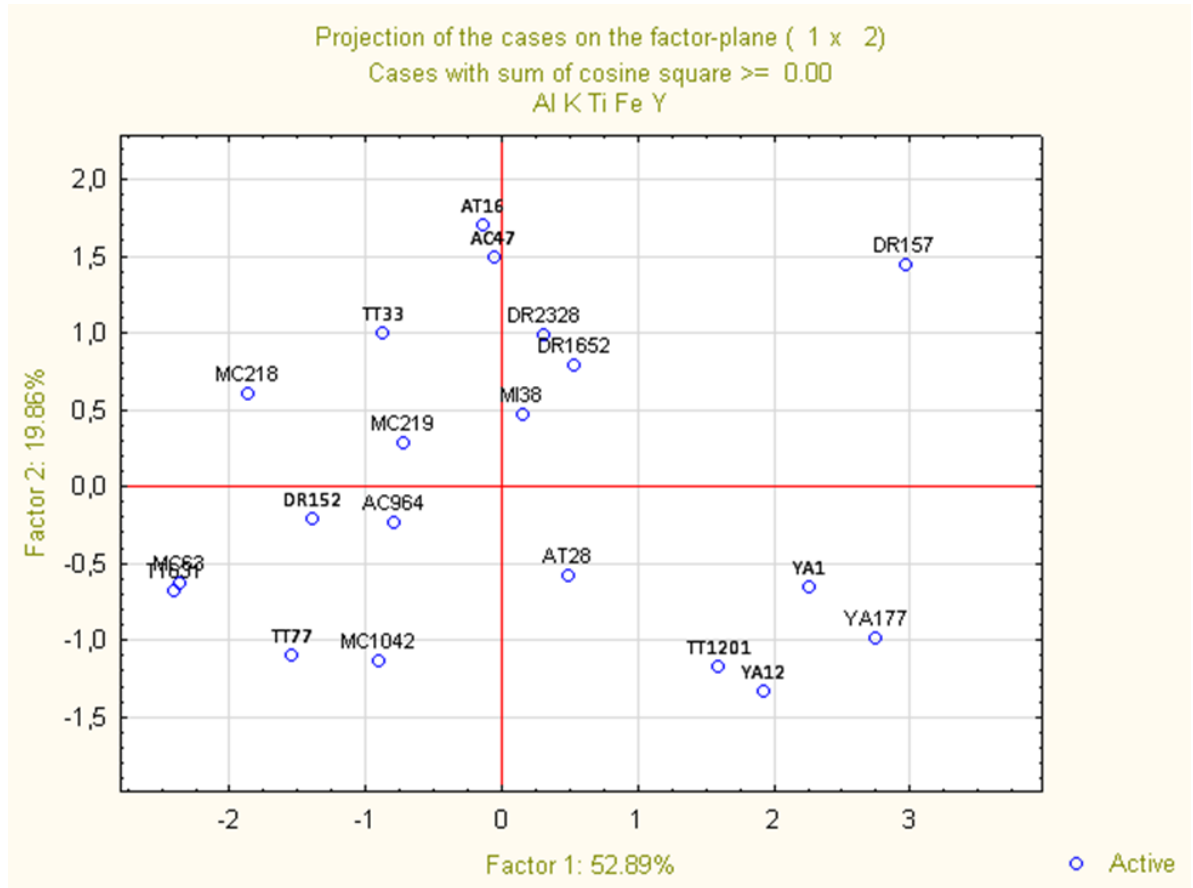

Figura 21. Gráfico de análise PCA para dados na análise XRF. Foram utilizados como parâmetros os elementos Al, K, Ti, Fe e Y.

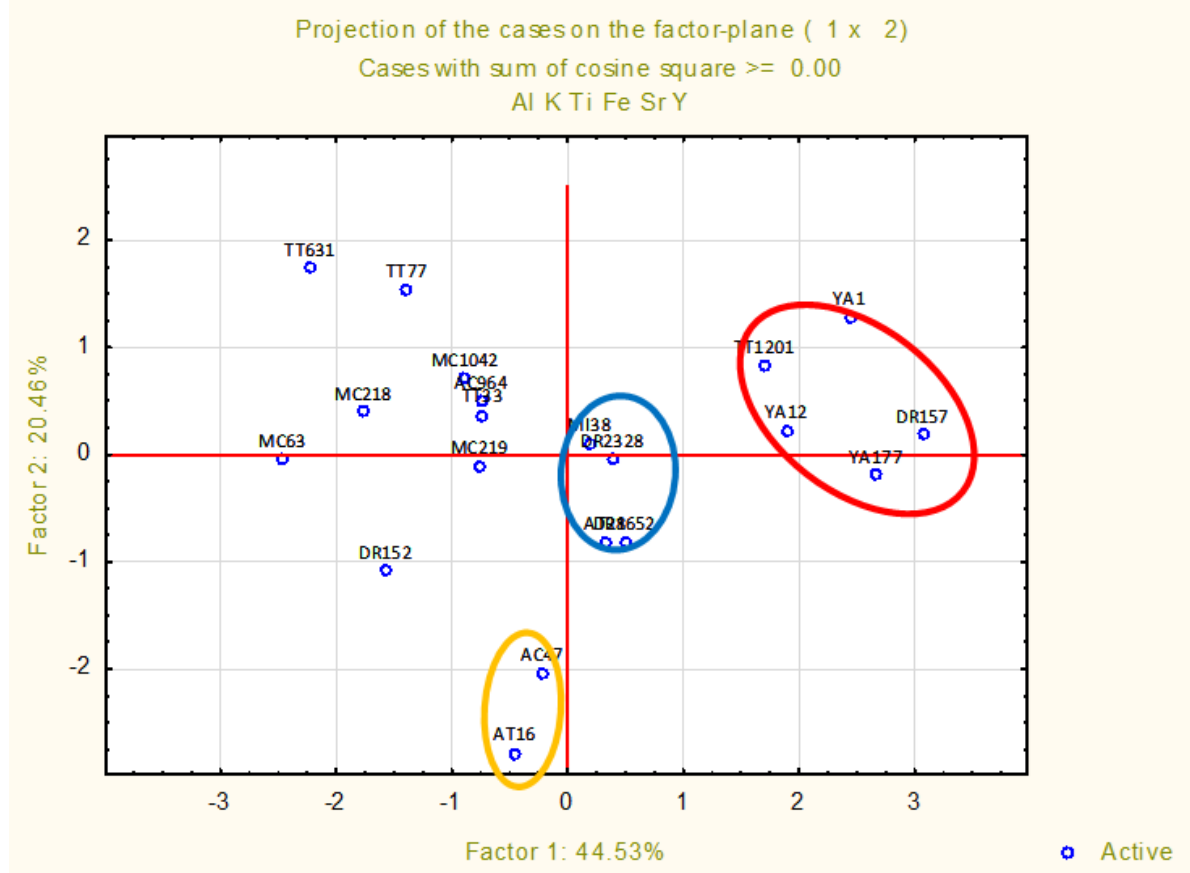

Figura 23. Gráfico de análise PCA para dados na análise XRF com sugestões de possível agrupamento. Foram utilizados como parâmetros os elementos $\mathrm{Al}, \mathrm{K}, \mathrm{Ti}, \mathrm{Fe}, \mathrm{Sr}$ e $\mathrm{Y}$. 